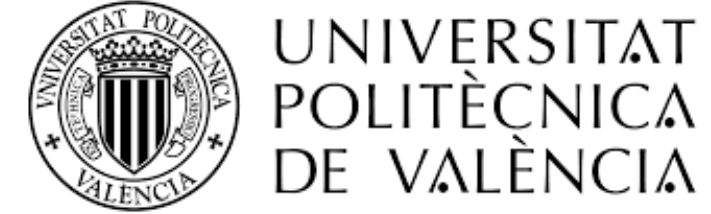

Faculty of Fine Arts San Carlos

Department of DCADHA

(Departamento de Comunicación Audiovisual, Documentación e Historia del Arte)

\section{DCA D HA}

\title{
Doctorate Program
}

Music

PhD Thesis:

\section{INCIPIT}

The search for a multidisciplinary language at the crossroads of Antiquity and Contemporaneity

\author{
Presented by: \\ Lobke Sprenkeling
}

\author{
Directed by: \\ Martina Botella Mestres \\ Carlos David Perales Cejudo
}

JANUARY 2016 


\section{INDEX}

CHAPTER 1 - EARLY MUSIC AND MEDIEVAL MUSIC THEORY

- 1.1 Early Music Research and its Problematics

- $\quad 1.2$ The Plainchant Repertoire and its "Restoration" History

- $\quad 1.3$ Music around 1300

- $\quad 1.4$ The Role of Plainchant in Liturgy

- 1.5 The Harmony of the Spheres and Pythagorean Tuning

- 1.6 Church Modes

- 1.7 The Medieval Voice and Instruments

- $\quad 1.8$ Notation and its Relationship with Rhythm, Improvisation and Polyphony

CHAPTER 2 - EXPERIMENTAL MUSIC THEATRE

- 2.1 Historical overview

- 2.2 Experimental Music Theatre: Definitions and Terms

p.86

- $\quad 2.3$ Strategies in Experimental Music Theatre

- 3.1 The context of Dante's Divina Commedia

- $\quad 3.2$ Structure of the Afterlife

- 3.3 Interpretations and Readings: Selection 
- 6.1 Concepts underlying Incipit

- 6.2 References

- 6.3 Creative process of composition and recording

- 6.4 Rehearsal process and dramaturgy

- Castellano

- Valencià

- Annex 1a: Table of scenic elements in Inferno

- Annex 1b: Table of scenic elements in Purgatory

- Annex 1c: Table of scenic elements in Paradise

- Annex 2: First "script" with selection of scenic elements

- Annex 3: Choreography of fight with self in Inferno

- Annex 4: Basic storyboard for Paradise before brainstorming with light designer p.421

- Annex 5a: Technical needs (translated) p. 422

- Annex 5b: Technical needs (original in Spanish) p. 424

- Annex 6: Program for the performance of Incipit p. 426

- Annex 7: Description of the mise-en-scene p. 428 


\section{INTRODUCTION}

This study is multidisciplinary in its inclusion of various research areas: it combines Experimental Music Theatre and Historically Informed Performance (HIP), the latter being a work process used by musicians trained in Early Music. It will take the Divina Commedia of Dante Alighieri (12651321) as a basis for this combination, involving the area of Literature Studies. The research is materialized into a music theatre work where the musical and extramusical references of the Divina Commedia have been approached with the methodology used in Early Music. This methodology aims to be as informed as possible about the original historical performance practice, context or sound of a musical composition.

\section{THEORETICAL CONTEXTS AND MOTIVATIONS}

In the Divina Commedia, the Medieval concept of music plays an important role. The Medieval theory of musica universalis deals with the perfection of God reflected in the harmonious proportions of the universe. The highest level of this type of music represents the relation between the planets (musica mundana). At an intermediate level it indicates harmonious proportions in body and soul (musica humana). The lowest level implies the only type of music audible for our imperfect ears, music as we understand it today (musica instrumentalis), which despite of its name includes vocal and instrumental music. Dante endorses his narrative of Afterlife with this theory of music, adapting it to Inferno, Purgatory and Paradise. In Inferno, the damned souls are denied any kind of music and are not even able to produce music themselves. There are also some non-musical parodies on liturgical music. Dante presents Inferno clearly as an anti-musical world. In Purgatory, the souls have to sing liturgical chants, which they do to cleanse their souls, gladly despite their tears, restoring their own musica humana through musica instrumentalis. Paradise is presented as a beautiful Divine theatre where music and dance are continuous but not always comprehensible for Dante the protagonist. This sonorous and hypersonorous aspect of the Divina Commedia has begun to be studied by some scholars but there has not been any historically informed musical setting of the chants of Dante's time.

The chants mentioned in the Divina Commedia are still present in the current church repertoire. Despite their appearance in a kind of pseudo-medieval notation, the chants forming part of the standard repertoire are not the same as the ones sung in the $13^{\text {th }}$ and $14^{\text {th }}$ centuries. At the end of the $19^{\text {th }}$ century, the monks of the French monastery of Solesmes tried to restore the $12^{\text {th }}$ century St. 
Gallen chants. These chants were written in a type of notation called neumes, not meant to indicate pitch but only performance details. By then, the entire chant repertoire had to be memorized by the singing clerics, who indeed must have had a remarkable memory. The $19^{\text {th }}$ century Solesmes monks based themselves on these chants because they were the oldest that survived. Their aim was to obtain one unified, "original" chant repertoire, which they presented in the form of square notation with neumes above it. However, Medieval reality was different. Although the Church always strived for a musical union throughout all their establishments, there were local differences and around 1300 there existed certainly varieties that were not in the St. Gallen repertoire due to developments in liturgical musical practice. We must not forget either that written music served as a basis for improvised organum - a kind of simple polyphony with one or two added voices - something not reflected in nowadays notation and practice. In addition, the Solesmes school interpreted the rhythm as a free flow which was assimilated into standard practice, while in the Middle Ages the chants were performed in a more measured manner. Due to the fact that they presented their work as being "authentic" while lacking a critical apparatus and being manipulated by their interpretation, the standard repertoire is not the same as the one in $13^{\text {th }}$ century Italy.

If we wish to approximate the music of the Divina Commedia in the form that Dante might have known it, we must avoid using the standard church repertoire and head directly to the historical sources. Ideally, this would be manuscripts of which we know that they were present in the Santa Reparata in Florence, the smaller cathedral previously existent to the current Santa Maria del Fiore. However, the Italian manuscripts have not been digitalized and it would be a musicological thesis in itself to digitalize, analyze and publish them. For this practice-based research, it has been decided to work with other so-called peripheral manuscripts (that is, non-Parisian) from Switzerland and Austria. We know that there was a difference between the Parisian new polyphonic genres and the general practices in the more "conservative" peripheral areas, which consisted of less complex improvised polyphony called organum. Although we will not be working with the manuscripts from Dante's exact location, we will study those of which we suppose that they were at least musically close to the chants that Dante might have heard. We will also "compose" additional voices according to the Medieval rules for organum. Furthermore, the non-musical sounds mentioned in the Divina Commedia will be listed and performed. In this way, the resulting composition of sounds and music is an approach to Dante's sonorous world. There are many mises-en-scene of the Divina Commedia, but none of them depart from a historical-musical research of the chants that are mentioned in the narrative. 
The combination of Early Music and Experimental Music Theatre is also one that has not been explored yet. This type of music theatre is an art form "between the arts": it is not purely theatre, it is not a concert, it is not a performance, it is not opera and it is certainly not a musical. It is an experimental, small-scale, multidisciplinary art form that combines drama with music and other art forms such as dance, physical theatre and visual arts. It has been described with other terms, such as Instrumental or Composed Theatre. Instrumental Theatre focusses more on musical interpretation, while Composed Theatre rather refers to the creative process. For the specific music theatre work that has been created for this thesis, Composed Theatre could be an appropriate term. Music, movement, light and colour have been used as elements within a dramatical composition, just as if they were notes in a musical composition. Music theatre normally includes newly composed music or sounds. Earlier "classical" music is certainly used as well, but normally this is not repertoire from before 1700 and it does not include historical-musical research. Experimental Music Theatre covers a relatively small part of international artistic activity but its combination with HIP of Early Music is even less frequent.

There are three reasons why this combination is interesting. First, the methodology of HIP can contribute to an original creative process for a music theatre work, due to its rigour and use of historical sources. Second, the sound of Medieval, Renaissance or Baroque music performed in a historically informed manner can lead to a different theatrical-musical language. Third, Early Music and Medieval liturgical chant in particular have a determined audience and bringing it to a different context opens it up to a broader audience. Removing a musical repertoire from its context means loosing part of its original experience. Perhaps it is much more ideal to perform Medieval liturgical chant in a church for a Catholic audience that knows the texts, their meanings and the current standard versions, so they can sincerely be surprised about the difference with the melodies they know and still be profoundly touched by these Medieval chants. The music theatre audience will certainly not have such an experience, but the combination of this music with a narrative in the form of theatre, dance and visual arts can reach the audience in a different manner.

Another aim of this research has been to communicate Dante's aesthetics and thoughts to a contemporary audience and has derived into an exploration of his metaphysics. Apparently, most of his ideas are linked specifically to his context and need formal adaptation in order to convey the same meaning to us. However, if we read between the lines, his metaphysical statements are much more universal than the text suggests. They are essential to our understanding of the Divina Commedia because without them, it is just a curious, historical and doctrinal narration. In reality, Dante's intention was exactly to transcend all doctrine, all history, all finite. The music theatre work 
created for this research aims to express this essential idea behind Dante's Commedia. It takes the sonorous level as a departure point for a journey through Dante's Afterworld, long after the protagonist Dante lived his own experience. Now, it will be our own journey, just as Dante proposed in his writing, through the same questions that Dante asked himself about the mystery of Life.

\section{STRUCTURE OF RESEARCH}

Chapter 1. As mentioned before, this study is on the crossroads of Early Music and Experimental Music Theatre, through a mise-en-scene of the Divina Commedia of Dante Alighieri. This chapter will be dedicated to the movement of Early Music and its motivations. The whole concept of Early Music brings along specific problematics, since it is a reinterpretation of something that was composed in very different circumstances, for a very different context, with different instruments or voices within a different aesthetics and framework of common understanding. This chapter also sketches an overview of the unique situation and problematics of the musical repertoire within the Church. The following sections deal with theoretical knowledge of Medieval music and in particular liturgical chant.

First, an overview is given for the musical historical background of the Divina Commedia. Then, we will discuss the role of plainchant in Medieval liturgy and the different forms in which plainchant can be sung. The chapter also describes the theoretical concept of the Harmony of the Spheres, musica universalis, and its relation with Pythagorean tuning based on perfect fifths, which are all basic to the functioning and performance of Medieval music. We will continue with a discussion of the church modes and the system of the hexachords described by Guido d'Arezzo (ca.992-after 1033). Then a section will follow on the Medieval voice and instruments. The voice was considered superior to musical instruments because it was a Divine creation, while instruments were created by man. We do not know how the voice sounded and there is very little evidence about it. Finally, the chapter ends with notation and its relationship with rhythm, improvisation and polyphony. This information is essential to obtain a basic idea of Medieval performance practice of liturgical chant, one of the major aspects of this study.

Chapter 2 defines the second underlying research area of this thesis, which is Experimental Music Theatre. This is a extensive form of art-between-the-arts whose borders are not always clear. It is characterized by a musical way of thinking in its structuring and expression, and includes various 
art disciplines. The chapter begins with an overview of its predecessors, which contributes to a better understanding of the nature and position of Experimental Music Theatre and gives an idea of its variety of forms. The second part of the chapter is focussed on defining the characteristics of the field that distinguish it from other disciplines. Sometimes it overlaps other artistic disciplines, such as dance theatre, performance or opera; its borders are not well-defined and other terms have been used as well to describe art works that include various disciplines, depending on the most accentuated artistic discipline or the way of presenting the work. This chapter discusses a possible definition of Experimental Music Theatre. It also centres on the creative processes within the field.

Chapter 3 deals with the narrative of Dante's Divina Commedia. It has been studied ever since it appeared in manuscripts because of its richness of ideas, knowledge and language. The chapter begins with an overview of the historical context of the work: the circumstances that led Dante to write it and the reception of the work. Dante was exiled for life from his city Florence when he wrote the Commedia. It gave him the freedom to write about society from an external perspective and to express his personal questions about concepts of city, identity, home and life itself while being an encyclopedic journey through academical matters. Chapter 3 subsequently gives an overview of the general structure of Dante's journey through Afterlife, the basic narrative and subject matter. Then, we will discuss some interpretations of the text that have formed the inspiration for the music theatre work created within this research. Finally, a separate section is dedicated to Dante's metaphysics, the central message of the Divina Commedia, and Dante's answer to universal questions that we still ask ourselves nowadays.

Chapter 4 deals with the sonorous events and references in the Divina Commedia. On a sonorous level, the journey leads from "Anti-Music" in Inferno to "Hyper-Music" in Paradise. In Inferno, the damned are denied any form of music and cannot even express themselves musically. Instead, it is a world of cacophony and parody on liturgical music. In Purgatory, the souls must sing liturgical chants in order to purge themselves, while an angel at the gate to each terrace sings one phrase from the Beatitudes with an inhumanly beautiful voice. The souls sing musica instrumentalis (audible music) in order to re-balance their own musica humana (the harmonic relations within themselves) and prepare them for Paradise. Paradise consists of a type of music that is incomprehensible for human imperfect ears. It is one great Divine representation filled with song and dance by the happy spirits.

Chapter 5 focusses on the historical musical sources that were selected for the performance of the Commedia's chants. Each chant's origin and transcription will be analyzed. Also, their performance 
practice will be discussed based on the information in Chapter 1. Part of this performance practice is the improvisation or "composition" of additional voices according to the rules of organum. The transcriptions and historical information on their performance will be used for the music theatre work Incipit.

Chapter 6 deals with the project for the mise-en-scene of the Commedia, a music theatre work which will be titled Incipit. It describes the concepts underlying Incipit and its various references from the different artistic disciplines: Experimental Music Theatre, Performance, Dance Theatre, Early Music and Film. It reports about the process of composition, rehearsals and recording for the soundtrack of Incipit, as well as the creative process in the physical-musical rehearsals for the final mise-en-scene.

Not only the sonorous references, but also all the fragments about movement, gesture, colour or light were collected and reflected in a table, serving as possible dramatical compositional elements. However, the sonorous references formed the cornerstone of Incipit and were maintained as intact as possible in their chronological order, whereas the references to visual elements were applied more freely, only when thought of as a contributive artistic element in the mise-en-scene. Incipit is a historically informed sonorous journey through Dante's Afterworld, in which the visual elements are contemporary without loss of contact with Dante's philosophical ideas as discussed in chapter 3.

The thesis will finish with the conclusions derived from the theoretical research in combination with the investigation through the creation and performance of Incipit.

\section{LIMITS OF THE RESEARCH}

\section{Nature of the research}

This study uses three kinds of research: bibliographical, musicological and practical. First of all, extensive bibliographical research is the basis for every $\mathrm{PhD}$ thesis. For this thesis, bibliography on Classical Philosophy, Medieval Philosophy, Medieval music, Medieval aesthetics, Dante, the Commedia, Music Theatre and other theatre forms has been studied. The bibliography on Medieval music combined with musicological analysis led to a transcription of the $14^{\text {th }}$ century musical sources and its historically informed performance, including the composition of additional voices according to the rules for improvised simple polyphony around 1300. The research through practice 
consists of creating an experimental music theatre work for one performer, in rehearsing it and performing it, observing how the methodology of Historically Informed Performance influences the mise-en-scene.

\section{Limits of the study area}

The study areas on which this research is based are Early Music, Experimental Music Theatre and Literature Studies. Literature Studies have served in order to obtain a comprehension of the Commedia's contents and underlying philosophy and determined the concepts behind the narrative of the music theatre work Incipit. Early Music is the collective name for both the movement of interprets working in a historically informed manner and the term for all music approximately before 1750-1800, although this limit is constantly shifted and will never cease to do so. In the end, all music that has not been composed today could be viewed as Early Music. Normally, Early Music stands for a combination of the two: music until approximately the second half of the $18^{\text {th }}$ century and performed in a historically informed manner. In the case of Incipit, its music is Medieval and the methodology that was chosen is historically informed. Since the standard ecclesiastic chants that are sung nowadays are not as old as they seem, nor their performance practice, the standard chant books have been avoided as much as possible for Incipit. Finally, Incipit is an Experimental Music Theatre work, where various artistic disciplines come together and musical thought underlies the creative process.

\section{Format of Incipit}

Incipit will be a music theatre work of approximately one hour. It will be performed in a black box theatre and recorded on video.

\section{Methodological and bibliographical limits}

Bibliographical study has been done for chapters 1, 2, 3 and 4. Composition and performance form the basis of Chapter 5, 6 and 7, with a specific focus on historical research of the Medieval chants. Chapter 6 centres around the creation of an experimental music theatre work. This implied reading the text of the Commedia, organizing and selecting fragments based on sound, movement, gesture, light and colour, of which the sonorous fragments formed the essence for Incipit. The bibliography for this study has been diverse due to the fact that different genres are mixed. The field of Literature Studies has provided the bibliography on the interpretation of the Commedia's narrative and its 
underlying philosophy. The group of bibliography on Early Music and its theoretical fundamentals is written by musicologists and musicians specialized in Early Music. The area of contemporary performance arts has provided the bibliography on the concepts of Experimental Music Theatre, Composed Theatre, but also on aspects of dramaturgy. Also, a general study about liturgy has been essential, such as the role of the chants within the services. There has been bibliographical study on the sonorous world in the Middle Ages. The metaphysics of Dante have been studied, and the relation between body and soul in the Middle Ages and specifically in Dante's Commedia. Contemporary mises-en-scene either in relation to the Commedia or in relation to the aesthetics of Incipit have been studied. Finally, the creation, rehearsals and performance of Incipit form an essential research route in which practice itself allows artistic research. They were the means of investigation of the question how Historically Informed Performance influences an experimental music theatre work.

\section{Actuality of the research}

Experimental music theatre, Composed Theatre or any other term that describes this genre-betweengenres is quite a young research field in itself. Moreover, its combination with Historically Informed Performance of Early Music probably does not have any existing research yet. Furthermore, the research and historically informed performance of Medieval versions of the chants mentioned in the Commedia - including the composition and performance of organum - within its mise-en-scene has not been done either, as far as the author of this study is aware.

\section{HYPOTHESIS}

Through a mise-en-scene of the Divina Commedia, the work methods taken from Historically Informed Performance will contribute to a music theatre performance and influence both its work process and dramatical language.

The research question is: How do the work methods taken from Historically Informed Performance practice contribute to the creation of a contemporary Music Theatre performance in a mise-en-scene of the Divina Commedia? 


\section{AIMS}

Our general aim is to merge a musical historicist rigour with contemporary experimental music theatre through a mise-en-scene based on the Commedia. Following this aim, specific aims were formulated:

- Location, transcription and performance of the chants mentioned in the Commedia.

- Creation of an overview of all its sonorous and visual elements.

- Analysis of its main concepts.

- Analysis of the role of musical and non-musical sounds in the Commedia.

- Procedure of applying sonorous and visual elements as compositional elements.

- Approach of the Medieval conceptual and sonorous world.

- Extension of Medieval chants performed historically informed to a non-specialist audience.

- Introduction of the Commedia to a wider audience, conveying its concepts.

\section{METHODOLOGY}

The methodology has included the following research areas :

- Musicology and Early Music Studies

- Medieval Literature Studies

- Contemporary Music Theatre Studies

The means in order to reach the aims have been:

- Search of musical sources and their study.

- Study of the principal text and glossary.

- Reading of bibliography on the Middle Ages, Medieval music and performance practice, Contemporary Music Theatre Studies, the Sonorous Medieval world, Classical and Medieval Philosophy, the relation between body and soul in Medieval life and afterlife, Medieval Aesthetics, projects of the Divina Commedia until now, Dramaturgy.

- Quantitative analysis of the text: isolation of fragments of sound, movement, gesture, color and light.

- Selection of pre-recorded sounds.

- Recording of noises, phrases and chants.

- Creation of a storyboard or timeline. 
- Theatrical and musical composition.

- Rehearsal and investigation through practice.

\section{RESEARCH STRATEGY}

The Commedia has served as the narrative framework for the combination of Early Music with Experimental Music Theatre. Therefore, thorough knowledge of the Commedia has been essential to this research. The Commedia itself and ample bibliography on its contents have been studied. The work has been scanned for all references to sound, movement, gestures, color and light, which were combined in a table. There was also a selection of specific phrases and events within the text. Subsequently, a basic outline for the dramaturgy was written.

The Medieval chants were found online in digital databases containing $14^{\text {th }}$ century manuscripts. First the type of chant was determined (such as hymn, psalm or Marian antiphon). Sometimes, psalms were performed in a special way, by two groups or by a soloist and a choir. These versions are existent in the surviving manuscripts. On the contrary, if a psalm was sung normally, it was set to music on a psalm tone, a fixed musical formula. There are eight psalm tones, one for each church mode. There is also the tonus peregrinus or "wandering tone", beginning on an A and ending on a G. The Medieval psalm tones were probably not the same as the present ones, but their melodies have not survived because they were known by heart. It was believed that each church mode expressed a different mood. For those psalms that have no version in a digitalized musical document, a modern psalm tone was chosen according to the mood of the particular scene in Dante's Commedia.

The selected digital sources were transcribed and additional voices were composed according to the late-Medieval rules of organum. The bibliographic reading was continued about Medieval aesthetics, the role of music in the Commedia, the Classical Greek and Roman authors, Medieval daily life and sounds, Medieval music theory, the Medieval voice, soul and body in the Commedia, Dante's metaphysics and Multidisciplinary Theatre. The writing process developed simultaneaously with the advances in the creation of Incipit. Non-musical sounds were selected at www.freesound.org, while other sounds, phrases and chants were recorded. The selected recordings were edited and combined into three sound files with the software Audacity. Inferno, Purgatory and Paradise each take between 15 and 25 minutes in this digital track, adding up to about an hour for 
the performance. Once the basic dramaturgy was fixed and the sound files were ready to be used, the physical rehearsals started. In combination with the soundtrack there was experimentation through live sounds and chants, the body, the space and the lighting.

This creative process - from the composition to the performance - set into work the essential research process centred around the question how the methodology of Early Music influenced the creation of an experimental music theatre work. It was thus much more than a result or side-product of the research: it was the origin of the research question. This concords with several other contributions on practice-based research, such as the one by philosopher and pianist Marcel Cobussen, who states that "the art work is not a practical aid which rushes in to help the discursively presented conclusions; it is itself the statement and the conclusion" ${ }^{1}$. Östersjö in his $\mathrm{PhD}$ thesis argues that in the case of his own practice-based project, "the research takes its deepest motivation from the artistic quest, rather than from a theoretical discussion." " He continues noting that his artistic practice "should function as a primary methodological tool, with the characteristic ambition of action research to not only study a certain process but also to attempt at achieving change in the existing practice.” (Östersjö 2008, 11). Also Falk Hübner observes that his artistic questions form the basis of his research. He presents the relation between the artistic practice and the theory around it as a feedback loop, where both influence, reinforce and inspire each other: "my artistic practice builds the foundation and motivation for the research questions and theoretical studies, which in turn feed back into the artistic work." 3 Indeed, for our practice-based research, the concept of Incipit also formed the motivation and orientation for the research question. However, since Incipit departs from historical versions of the chants mentioned in Dante's Commedia, as well as all the other sounds, movements, gestures, colours and light, it was first necessary to do a thorough analysis of the Commedia as well as a thorough search of historical musical scores. In this sense, the combination of the methodological of Historical Informed Performance with Experimental Music Theatre shows that the creative act is not the start of the research, because it necessarily has to be preceded by documental research. The interaction of practice and theory is set into motion once the creative act takes place in the form of composition, recording and rehearsal. The art work supplies an other type of knowledge than theory does, as Marcel Cobussen well explains. He argues that art does not only provide a metaphysical experience, but also makes us "wonder at the inexhaustibility of reality". It gives us other perspectives on the world in which we live: "in or through art we can perhaps arrive at another kind of knowledge, another kind of

1 Cobussen, M., “The Trojan Horse. Epistemological Explorations Concerning Practice Based Research.” Dutch Journal of Music Theory 12/1 (2007), p.18

2 Östersjö, S., "SHUT UP 'N' PLAY! Negotiating the Musical Work", PhD Thesis, (Lund University, 2008)

3 Hübner, F., Shifting Identities: the Musician as Theatrical Performer, PhD thesis (University of Leiden, 2013) 
thinking, a thinking beyond opining, representing, reasoning, and conceiving, that is, beyond 'ordinary' thinking." (Cobussen 2008, 26). Thus, if art provides new ways of unconcealing knowledge about the world we live in, then artistic research opens up a new ways of obtaining knowledge, questioning the traditional meaning of truth in the academic world until recently. (Cobussen 2008, 32).

Östersjo in his thesis distinguished two types of research: one in which the researcher takes part as researcher and the participators are the research objects, called "emancipatory action research", and one in which the researcher is also the practicioner, called "practicioner research" (Östersjö 2008, 12). The research through and around Incipit was clearly "practicioner research", where the researcher took on composition, recording, direction and performance. In this way, control over the entire creative process was maintained by one and the same person. The term "action research" was coined in 1944 by social-psychologist Kurt Lewin. It is a strategy in which there is an eternal circle of planning, action, reflexion and observation of the result in order to adapt the original plan and go through the entire process again. In practice-based research there is indeed an ongoing chain of these circles, just as Falk Hübner also made clear. Theoretical concepts are brought into practice, where some do not function the way they were thought to do, leading to a reformulation of some of these concepts, which again can provoke changes in the practice. 


\section{CHAPTER 1 - EARLY MUSIC AND MEDIEVAL MUSIC THEORY}

\subsection{Early Music Research and its Problematics}

Within the creation of the music theatre work Incipit, we shall make use of Historically Informed Performance for the Medieval chants referred to in the Divina Commedia. This working method, often abbreviated to HIP, is used for historical music with which we have lost a direct relationship because of the passing of time. Even tradition represents a fluid timeline of ever-changing perspectives and does not guarantee an unchanged performance practice. HIP consists of studying not only the historical musical sources themselves but also treatises, surviving musical instruments, archival documents, iconography, etc. The wish to approach historical music through knowledge of its context and practice came about at the end of the $19^{\text {th }}$ and beginning of the $20^{\text {th }}$ century, known as the Early Music movement. In this chapter we will discuss the development of the Early Music movement and its problematics, so that we can come to a better understanding about what Early Music actually is, why we should use a special approach for it and which specific problematics we encounter. We will also observe that the performance of liturgical chants has its own specific history, with its own obstacles.

Until the last decades of the $20^{\text {th }}$ century, the term "Early Music" referred only to the study of Baroque music and earlier styles, but by then it was extended toward Romantic music as well. Nowadays, it applies rather to "any music for which a historically appropriate style of performance must be reconstructed on the basis of surviving scores, treatises, instruments and other contemporary evidence". ${ }^{4}$ The discussion has revolved around the question of what would be exactly "historically appropriate", but the existence of the Early Music movement clearly reflects the wish to come closer to the historical composition and to its possible historical sound. Such an interest has not always existed. In fact, until the end of the $19^{\text {th }}$ century, it was more common to perform contemporary music, while older music was generally seen as "outdated". As a consequence, earlier music was substituted or fell into oblivion, while the newly composed music had a living contact with its audience; a situation similar to pop music culture nowadays. Music until the end of the $18^{\text {th }}$ century was generally composed for a specific occasion, mostly on a benefactor's demand, making it a functional art form rather than an independent art work. Only at the end of the $19^{\text {th }}$ century, when the figure of the composer was well established as an inspired and special artist, the idea of a composition being an independent work of art definitively replaced the idea of music as a functional product without any individual value.

4 Harry Haskell. "Early music." Grove Music Online. Oxford Music Online. Oxford University Press http://www.oxfordmusiconline.com/subscriber/article/grove/music/46003 [accessed 19-10-2014] 
Nonetheless, already from the early $18^{\text {th }}$ century, in England, France and Prussia there were in fact initiatives to perform what was Early Music for them, but it would be with the musical language and instrumentation of their own time. The Academy of Ancient Music in London was a first initiative. It was founded in 1726 with the aim of studying and performing music of more than 100 years old, but later it began to include more contemporary composers. Moreover, in the $19^{\text {th }}$ century the so-called Bach Revival took place, first in Germany but soon also in other countries. In fact, Mendelssohn got a copy of by then forgotten Bach's St Matthew Passion and would direct it in Berlin in 1829.

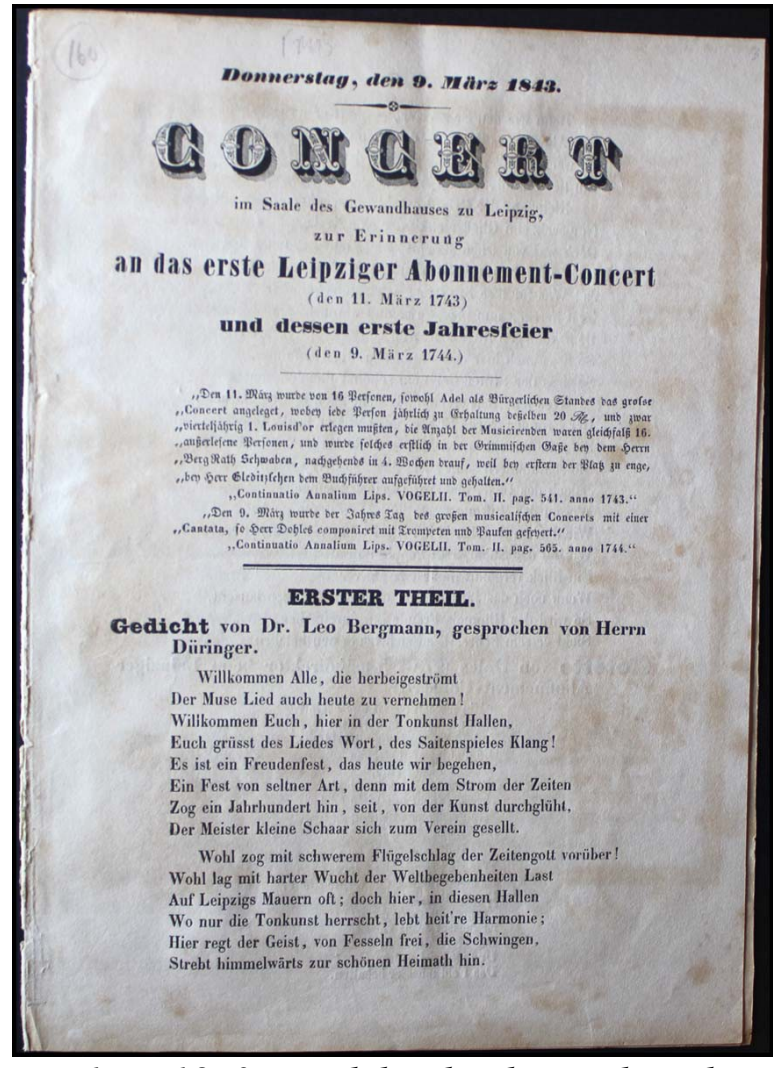

Fig.1. In 1843 Mendelssohn directed works of various composers, among them Bach, and finished the concert with the Ninth Symphony of Beethoven.
N. 2. $\quad\left(65^{\text {th }}\right.$ Sub. $)$

Academy of Ancient Mufic. THURSDAY, 3 t J JANUARY, 1793 . SEL.2CTLD $\mathrm{EY}$

$$
\text { Mr. L I V I E. }
$$

\section{ACT I.}

Overture. (Etther)

Air. What tho' I trace

Madrigal. When all alone

Duett. My faith and truth.

Recit. Thrice happy Ifracl.

Air. When the fun o'er.

Recit. Who quits the lilly.

Air. Balmy fweetnefs.

Recit. 'Tis done.

Recit. 'Tis done.
Air. Heart, thou feat of foft delight. $\}$ Handel.

Mottet. Gloris in excelfis.

Handel.

Ditto

Gia. Converfo.

Handel.

Ditto.

Dr. Borce.

Negri.

Fig. 2. Academy of Ancient Music, 1793

Early music became more and more popular among the European aristocracy and rich bourgeoisie. From 1890 onward, the "Early Music Movement" became more independent and stronger. Despite of being mainly an amateur movement, it brought a new development to musical culture by focussing on the possible intentions of the composer and the historical instruments he used for this. 
For this reason, historical research became an essential tool for the movement. The musician and instrument maker Arnold Dolmetsch was one of its main contributors, since the historical copies of instruments he built were much closer to the original ones and he was one of the first to use the term "authenticity". This term became important for the defense of the Early Music movement, but it would cause a considerable amount of discussion within the Early Music movement in the later half of the $20^{\text {th }}$ century. Dolmetsch himself argued that "we can no longer allow anyone to stand between us and the composer", which according to Haskell became a credo for the beginning historical performance movement". ${ }^{5}$ Beside instrumental music, there were also many initiatives in reviving the choral music and the baroque operas.

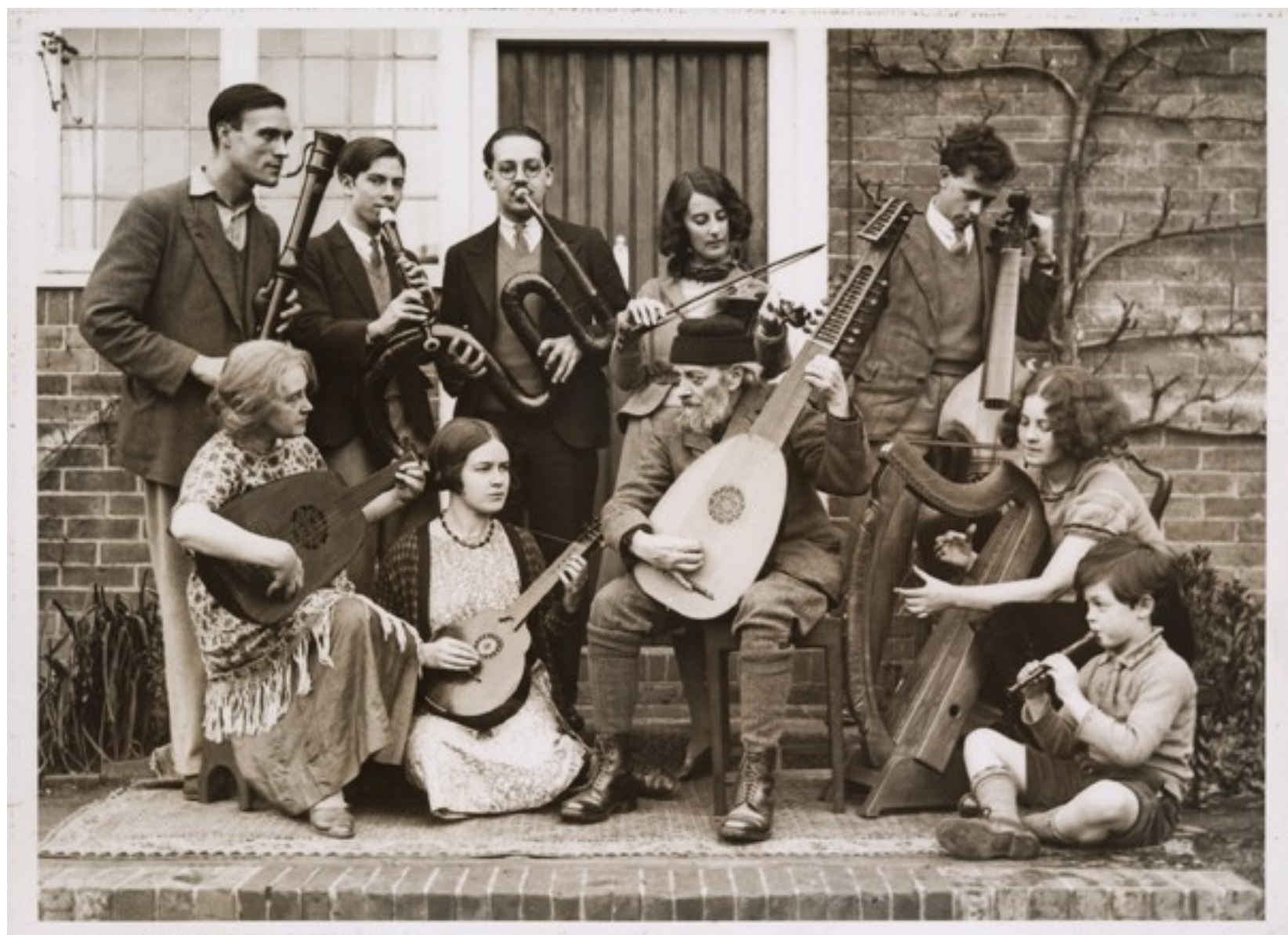

Fig. 3. Dolmetsch family and assistants, 1932. Arnold Dolmetsch is sitting in the centre.

After World War II, the Early Music movement grew especially strong in The Netherlands, England, Austria and the USA. Musicians like Nikolaus Harnoncourt, Gustav Leonhardt, René Clemencic, Alfred Deller and Paul Hindemith were important figures in this field. Although the 1920s had already witnessed the first recordings of Early Music performances, the 1940s brought the vinyl long-playing record and with it a broader distribution of historicist performances. This

5 Harry Haskell. "Early music." Grove Music Online. Oxford Music Online. Oxford University Press http://www.oxfordmusiconline.com/subscriber/article/grove/music/46003 [accessed 19-10-2014] 
larger distribution was not only due to the fact that the vinyl record became a popular medium but also, as Bernard D. Sherman states in his book Inside Early Music, because it "allowed period instruments, which often produce less volume than modern ones and can be harder to keep in tune, to come across more effectively to listeners than they might in a modern concert hall” ${ }^{\text {. In the }}$ 1960s, when the movement became more commercial, the leading performers in the early styles were, amongst others, Nikolaus Harnoncourt, Frans Brüggen and David Munrow. With these musicians, the movement became definitely a professional one, on the same virtuosic level as the "mainstream" tradition, the common performance practice of classical and romantic music. From this time on, Early Music instruments would be taught more and more at conservatories, causing an extensive growth of knowledge of the historic styles and virtuosity in their performance. While the 1960s still witnessed a considerable amount of experimentation, especially in medieval and renaissance music, in the 1980s and 1990s there was an increasing historically informed approach to this music. Since the 1970s, the impact of historicist performance on "mainstream" performance has been visible in the sense that it raised a certain awareness of historical performance aspects, such as ornaments, tone and articulation. Moreover, the Early Music area began to extend its borders toward the $19^{\text {th }}$ century - now also Romantic music was performed on period instruments by musicians trained in Early music - but not without critique from outside. ${ }^{7}$ Christopher Hogwood, Reinhard Goebel, William Christie, Jordi Savall, the Kuijken brothers, and Nikolaus Harnoncourt were among the main musicians from this time on.

The movement has experienced many points of discussion between the 1960s and 1990s, especially about the term "authenticity", which was gradually abandoned for others such as "historicist" or

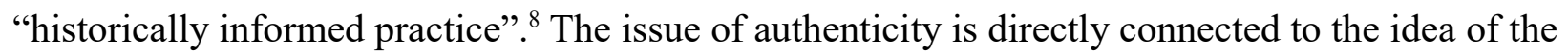
composition as an autonomous musical work of art. In the $19^{\text {th }}$ century the so-called Werktreue arose, the "fidelity" to the Work, as if it were an Object standing on its own (like a painting or stature) irregardless of the musical performer. ${ }^{9}$ However, in time it was discovered how a written musical composition on paper can never be a finished, independent work. Lydia Goehr, Professor of Philosophy at Columbia University and specialized in philosophy of music, aesthetics and philosophy of history, explains the reason behind this impossibility:

6 And adds the remark in parentheses: "That modern technology has been crucial to a historically oriented movement has often been called ironic." Sherman, B. D., "Authenticity in Musical Performance”, Pos. 49

7 Bernard D. Sherman borrows the term "disputes over turf” from Kerman, and says that recently the turf wars "have softened, giving rise increasingly to what Alfred Brendel calls "true cross-fertilization"”. Sherman, B.D., Inside Early Music: Conversations with Performers (Oxford, 1997), p. 4-7

8 As Bernard D. Sherman states, also the aesthetic basis for the Early Music movement. Sherman, B.D., Inside Early Music: Conversations with Performers (Oxford, 1997), p. 10

9 Goehr, L. The Imaginary Museum of Musical Works: An Essay in the Philosophy of Music (New York, 1992). She calls it the Werktreue ideal, regarding musical compositions as independent 'works'., Introduction. 
"Works cannot, in any straightforward sense, be physical, mental, or ideal objects. They do not exist as concrete, physical objects; they do not exist as private ideas existing in the mind of a composer, a performer, or a listener; neither do they exist in the eternally existing world of ideal, uncreated forms. They are not identical, furthermore, to any one of their performances. Performances take place in real time; their parts succeed one another. The temporal dimension of works is different; their parts exist simultaneously. Neither are works identical to their scores. There are properties of the former, say, expressive properties, that are not attributable to the latter. And if all copies of the score of a Beethoven Symphony are destroyed, the symphony itself does not thereby cease to exist, or so it has been argued." (Goehr 1992, pos. 70).

She continues stating that there is a close relationship between the written musical score, its performance and the identity of that work, and that it is not an easy question to tell what kind of existence or identity the compositions do have (Goehr 1992, pos 71). The fact is that there were times in which a composition was made for the occasion and performed once or a few times before being replaced by a newer composition. From the moment that a composition is seen as autonomous and integral, the question arises if the performer is being faithful to the composition or to the performance in its original context. Recently composed music does not present that much of a problem since it forms part of the current audible culture, but historical music does so, since it does not belong to the performer's tradition and culture in the same way. Some aspects are definitely recoverable through study of original instruments, historical treatises, documents, iconography etc., but other aspects are impossible to revive, simply because we will never know or because we cannot recreate the exact circumstances. There are even undesirable aspects within our culture, such as castrato singers. Most historical music was performed within a context that was completely different. How can the original meaning of a musical work be respected? What is that original meaning actually, can we ever know it? And if so, do we actually want to respect that original meaning? When the Early Music movement was still arising, the question of authenticity was used as a motivation for getting closer to the original sound of the historical music or the original intention of the composer. However, soon it became a defence against "mainstream" musicians and critics, advocating its own "superiority" in the performance of ancient music. As the movement grew, it became less necessary to defend itself. This was when the idea of authenticity became an interior dispute within the Early Music movement.

The term "authenticity" was taken from musicologists who applied it to describe the authorship of a manuscript. The word was used by the Early Music movement in order to claim that a performance was as the composer wanted it or heard it, unlike a "false" performance in the sense that it was modernized or changed and was not anymore the original work. Different kinds of problems arose 
with these statements, and through the years they were articulated stronger in the form of critiques within the Early Music movement itself. Bernard D. Sherman recognized in these critics fundamental doubts about three issues: the possibility of historical authenticity, its desirability and the performers' motivations. ${ }^{10}$

The first doubt is about the question if it is really possible to perform music exactly the way it was performed in its own time. Sherman comes with the example of the castrati but he states that in general the historical information we have at our disposal will never cover every aspect of its performance, there will always be something that has to be imagined. He refers to Richard Taruskin, an American musicologist who wrote the book Text and Act, where he analysed the premises of the concept of authenticity. Taruskin stated that modern musical imaginations by definition will be different from the historical ones. ${ }^{11}$ Furthermore, between the moment that a determined historical work was composed and now, many things have changed, such as the audience, the circumstances within which the work is performed and its function. Sherman bases himself on the book Early Recordings and Musical Style by Robert Philip when he argues that the era of the music recording has brought with it a high technical demand and precision in the performance of what is written. ${ }^{12}$ Taruskin wrote an interesting article about the historical audience for the opera seria, that was not being attentive at all to the performance, because the occasion was a social one and the music was performed during various nights. He compares it with the TV in our living room, which can be attended from time to time but for the rest it is just a background noise. ${ }^{13}$

The second doubt was about the desirability of historical accuracy. Much music was composed for next day's performance, the music was almost played at first sight and the musicians were not all as good as we expect them to be nowadays. As Sherman continues: "these critics argue that period performance cannot be assumed to have been better in any meaningful way than modern, unhistorical ones". ${ }^{14}$ Focussing not only on how it might have sounded originally but also at the intentions of the composer, we encounter even more problems because it might just be possible that a modern performance could serve the composer's intentions better (although we can never exactly know what his intentions were). In this group also falls the question if the performer should honour the historical accuracy or the audience's needs. Without the audience there is no performance but,

10 Sherman, B.D., Inside Early Music: Conversations with Performers (Oxford, 1997), p.8-20

11 Taruskin, Text and Act (New York, 1995), p.74

12 Philip, R. Early Recordings and Musical Style, Cambridge, 1991

13 Taruskin, R., "Performance Practice", The Oxford History of Western Music, Vol. 2 (Oxford, 2005)

14 Sherman, B.D.,"Authenticity in Musical Performance" from The Encyclopedia of Aesthetics, ed. Michael J. Kelly (New York, 1998), pos. 94 
on the other hand, it would not be good for such an art form to depend only on demand. Sherman also refers to the idea - commented by the philosopher and musicologist Peter Kivy in his book Authenticities - that, within our culture of posing the figure of the composer on a pedestal, performers are expected to take into account the composer's intentions but they can end up rejecting them if there are other options that work better for them (Sherman 1998, post 123). He mentions Taruskin's idea that many musicians, even if they think they are using all the relevant historical material, they are unconsciously selective anyway, being lead by their own taste within contemporary culture. In a way, historicist performance is in fact a contemporary form of expression. Over the majority of the historical repertoire there is no consensus about the desirability of its precise historical interpretation which, according to Sherman, suggests that this decision is not objective but rather dependent on the performer himself and the era in which he lives. The musicologist Howard Mayer Brown, one of the most influential analysts on historically performance practice, gives the example of the early recordings of singers at the beginning of the $20^{\text {th }}$ century, such as the recording of the last castrato singer. They do not fit our taste anymore, in spite of being historically very close to us. ${ }^{15}$

Concerning the performers' motivations, the most important one is the conviction that historicist performance will improve the interpretation of specific works, but there are also other motivations that can be simultaneously present within a performer, among which Bernard D. Sherman mentions the possibility of innovation or simply being distinct in the musical world where there is a lot of competition and a limited repertoire. Although contemporary music offers this possibility as well, it attracts only a small audience, while early music is more accessible to a wider audience. Therefore historicist performance and its music were an alternative to the already existing repertoire. A third motivation could be a wish for more personal freedom within performance which early music seems to give us but, on the other hand, a considerable amount of historical rules have to be studied and applied in order to call a performance a historicist one, so in a way it is only an apparent freedom. ${ }^{16}$

As we have seen, in historicist performance the perspective of the performer is the determining factor. No matter how historically precise we would like to be, unconsciously or consciously we always make selections, highlighting the aspects of the music that fit into our own world view and aesthetics. The issue here is that a written composition, unlike fine arts, is an unfinished work. It can only be completed when it is performed and consequently every time it will be a different work.

15 Howard Mayer Brown, et al. "Performing practice." Grove Music Online. Oxford Music Online. Oxford University Press, http://www.oxfordmusiconline.com/subscriber/article/grove/music/40272pg1. [accessed 3-11 2014]

16 Sherman refers to Perlman and Dreyfus about this point. Sherman, B.D., Inside Early Music: Conversations with Performers (Oxford, 1997), p. 19 
We could assume that the composer has the largest part in the creation of the work but, in cases such as Cage's aleatory works, the performer's role in creation is perhaps even larger than the composer's role.

Nowadays the discussion about authenticity has grown to an understanding that it is not a realistic value in performance because the composition is not a finished product and mostly there is no possibility or desirability of perfect reproductions of a historical product. The argument has moved toward the term Historical Informed Practice (HIP) which indicates that a musician is informed about the historical composition and its context. It does not indicate anything about the performance itself, only about the process. Nevertheless, as Howard Mayer Brown argues: "the means and style of performance imagined by a composer are so indissolubly bound up with the whole musical fabric that he or she has set down, that the communication and impact of the composition are seriously impaired if the sounds imagined are not at least kept in mind when preparing modern performances." $" 17$

Which are the aspects to be studied in order to reconstruct knowledge about a historical composition? Howard Mayer Brown names notation (including improvisation and ornaments), instruments, the way they were played, voice production, tuning (including pitch and temperament) and ensembles (including size, disposition and the manner in which they are directed). The path towards a comprehension of them is not only through study of the musical composition itself but also of treatises, critical writings, iconography, organology (the study of the historical instruments) and archival documents. ${ }^{18}$ Thus, in order to understand historical music, we must investigate further than the mere musical score. We need to include social history and examine extra-musical documents in order to come to an idea of how this music might have sounded and what could have been its meaning and function. The further we go back in history, the less information we can retrieve from the notation itself because there was no need to write down performance aspects that were part of the conventions. Through history there has been a growing wish to captivate all the performance elements within the musical score instead of the earlier "musical skeleton". Furthermore, there are less surviving documents and instruments as we go back in time. Until the invention of the art of book print, musical copies were much scarcer and mostly copied for and in the Church. Many documents have been destroyed in the meantime or they have become unreadable, although modern instruments can recover much of what the bare eye cannot perceive

17 Howard Mayer Brown, et al. "Performing practice." Grove Music Online. Oxford Music Online. Oxford University Press, http://www.oxfordmusiconline.com/subscriber/article/grove/music/40272pg1. [accessed 3-11 2014] 18 Ibid. 
anymore, even notes that were erased in palimpsests ${ }^{19}$. Also the indications about the way a musical composition was performed are scarcer or more difficult to understand for us.

Before the mensural system, there was the rhythmic modal system which is often ambiguous and complex. Before the tonal system, there was the modal system with its own logic of musica recta and musica ficta, the sharps and flats either entering the modal system (recta) or not (ficta), and many of them not notated but supposed at that time. Before the notes and their pentagram there were neumes, signs to mark the musical movement of a work. The earliest neumes were not even meant to indicate the intervals, only later they came closer to the concept of notes. The few surviving treatises were written in a culture whose conventions were lost through time, and some of them do not seem logical to us anymore. In some case a vocabulary for specific techniques did not exist yet, for example the way the voice should be used. These are the main reasons why we are without almost any information about major aspects of historical music we are performing today.

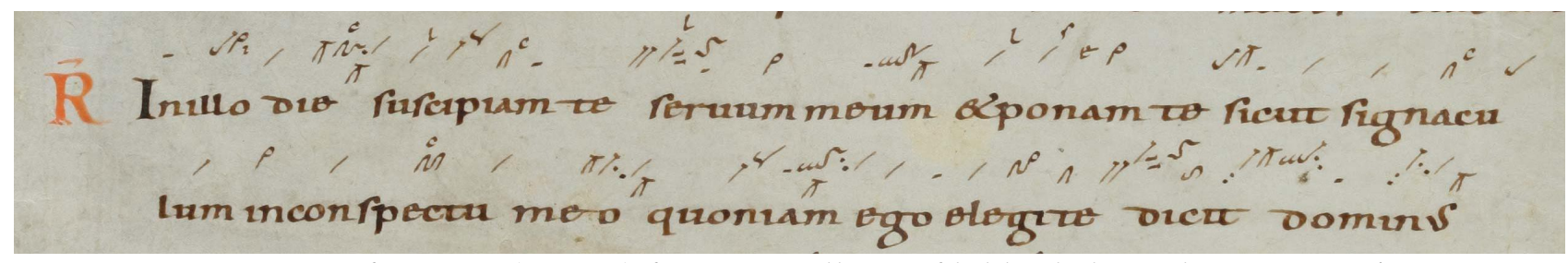

Fig. 4. Neumes, part of excerpt (c.1000) from St. Gallen Stiftbibliothek, Cod. Sang. 390 / 391

Taking into account all these considerations, we can make the following observations:

1. Historicist performance will never be exactly how it was originally due to the mere impossibility of reproducing the historical performance, the undesirability of reproducing certain aspects of the original practice, and the necessity of fitting the performance into today's taste. In this sense, the question would arise as follows: why should we strive for a historicist interpretation of the music?

2. On the other hand, as Howard Mayer Brown argues, "the means and style of performance imagined by a composer are so indissolubly bound up with the whole musical fabric that he or she has set down, that the communication and impact of the composition are seriously impaired if the sounds imagined are not at least kept in mind when preparing modern performances." 20

19 Palimpsest is the practice of scraping off or washing off a layer of a parchment, so whatever was written on it is erased and it can be used again. With modern ultraviolet light techniques the contents of the layers that were scraped away can be recovered.

20 Ibid. 
3. The synthesis of all these aspects is a performance which opens a small window to the perception by people who lived long ago of the world surrounding them, even though the performance is adapted to our habits and tastes. We can learn from it and it can form a musical language which can still surprise us.

In the music theatre work Incipit, the performance of the medieval liturgical chants will be the result of Historically Informed Performance but they will be taken out of their original context, into the theatre and through modern means like recorded sections on a computer which will be reproduced digitally. It is true that Dante's book can be considered as not being the original context either of these chants, but rather an imaginary world within a medieval man's mind. In Incipit, deliberate decisions have led to a partly non-historical treatment of these medieval chants, mixing historically informed practice with music theatre. Still, taking into account the earlier observations, the fact that these chants are Medieval versions interpreted on a basis of historical knowledge of their performance, they will provide us with a different perspective on Dante's world, in particular his sonorous world. 


\subsection{The Plainchant Repertoire and its "Restoration" History}

Why would we not use the standard versions of the liturgical chants mentioned in the Divina Commedia? Why go through such effort if we have the Graduale Triplex at hand? The answer lies in the fact that the standard chant repertoire is not as historical as it appears to be. The history of plainchant melodies is not quite the same as the history of Early Music, although there are certainly some similarities. First of all, the function of plainchant has always been different: in contrast to other music, the chant repertoire was not meant to be momentary, to be performed on one determined moment in time, but rather to be chanted every year, every week, or every day, depending on the type of chant. It was evolving within an ambience of "recycling" instead of substituting the old with the new: a circular way of thinking where everything returns periodically. This does not mean that chants have not undergone any change, on the contrary. Like within any other tradition, the chant repertory was organic, a living material that could be used as a basis for tropes $^{21}$ or that could be adapted to other liturgical texts. Some chants were eliminated while new ones were composed and others received a new treatment in the form of polyphony. Moreover, because of its geographical situation, a monastery or church would dedicate its worship to a certain (local) saint, so it could have a slightly different tradition than in other areas. At some points in history, for example in the Council of Trent (1545-63), which was a reaction on the activities of Luther, there was an initiative to reform or "purify" the chant repertoire. But, as musicologist John

A. Emerson writes,

"the process of standardization that began at Trent has, unfortunately, often been misunderstood. The Council was, in fact, a truly conservative movement. No new liturgy was set forth (the terms 'Tridentine Mass' and 'Tridentine Office' are misleading); religious establishments throughout Europe were required to follow prescribed customs and normative usage as well as to use 'corrected' liturgical books. Furthermore, the intended musical reforms were not realized, for despite the official imprimatur affixed to most chant books - Ex decreto Sacrosancti Concilii Tridentini restituti - a bewildering variety of chant melodies continued to flourish for another 300 years." 22

At the beginning of the $19^{\text {th }}$ century after the French Revolution, starting with the Concordat of 1801 between Napoleon and Pius VII, the Church regained civil status and it witnessed a thriving of theological study. Especially towards the half of the century there was a growing need to return to “original" practices: for some this meant focussing on Renaissance practices, for others it implied

21 Additions of new music or text to pre-existing chants

22 Emerson, J.A., “10. Developments between 1500 and 1800”, of Kenneth Levy, et al. "Plainchant." Grove Music Online. Oxford Music Online. Oxford University Press, http://www.oxfordmusiconline.com/subscriber/article/grove/music/40099pg5 [accessed 29-11, 2014] 
going back to the Late-Medieval chants between 1000 and 1300, while a third group wished to return to the older, neumatic chants, even if at that time they were hardly comprehensible. Especially the second half of the nineteenth century witnessed various initiatives and, as John A. Emerson rightfully states, "the fourty years between the publication of Félix Danjou's De l'état et de l'avenir du chant ecclésiastique en France (Paris, 1844) and the Liber gradualis (Tournai, 1883) prepared by Dom Joseph Pothier marked a significant period of chant reform."23

In 1851 the Reims-Cambrai Graduale romanum complectens missas was "the first serious attempt to restore medieval chant to modern books", based on an $11^{\text {th }}$-century French tonary ${ }^{24}$ discovered in 1847 which contained neumes doubled by alphabetic letters, thus giving a "translation" as to the pitch of the notes. Also the first important study on medieval notation was published: Histoire de l'harmonie au Moyen-Age by Coussemaker in 1852, which "set a standard for subsequent serious palaeographical investigations of chant neumes and rhythm". ${ }^{25}$

While the first initiatives were born in France, in Germany there was also an interest in restoring earlier chant practices, but it was the interest in Renaissance and Baroque styles within the liturgical repertoire that formalized into the so-called Cecilian movement, an organization with the aim of returning to the $16^{\text {th }}$-century polyphonic and vocal styles in all Europe. In 1868 the Vatican granted the privilege to the German Cecilian edition by Haberl in Regensburg to publish all the official chant books of the Church according to the editions of around 1600, and in 1871 they were declared by Pius IX as the "authentic" form of plainchant. ${ }^{26}$

It is interesting to observe that liturgical circles were already discussing about "authenticity" even before the "regular" Early Music movement, although they used the word "restoration" instead, while the term "decadent" referred to interpretations that would not fit into what was supposed to be authentic by the author. ${ }^{27}$ In the words of musicologist Kenneth Levy,

"dispute centered largely on the antiquity of the manuscripts used to prepare the editions. The 'archaeological school' (the monks of Solesmes) insisted that the readings be taken from the oldest

23 Emerson, J.A., "11. Restoration and reform in the 19th century", of Kenneth Levy, et al. "Plainchant." Grove Music Online. Oxford Music Online. Oxford University Press, http://www.oxfordmusiconline.com/subscriber/article/grove/music/40099pg5 [accessed 29-11, 2014]

24 A tonary is a liturgical book containing various chant incipits, organized according to the eight psalm tones of plainchant, which are fixed melodies used for the psalms.

25 Ibid.

26 Ibid.

27 “'restoration' (Fr. 'restauration'), used to characterize efforts to restore plainchant to its proper place in the Roman liturgy.” Emerson, J.A., “11. Restoration and reform in the 19th century”, of Kenneth Levy, et al. "Plainchant." Grove Music Online. Oxford Music Online. Oxford University Press, http://www.oxfordmusiconline.com/subscriber/article/grove/music/40099pg5 [accessed 29-11, 2014] 
accessible sources, whereas the 'traditionalists' (such as Pothier, Gastoué and Peter Wagner), considered it important that the choral tradition of the late Middle Ages also be represented. Since the criteria adopted by the commission favoured the traditionalist position and inclined more to practical wisdom than to abstract theory, manuscripts representing various national practices were used, some dating from as late as the $14^{\text {th }}$ and $15^{\text {th }}$ centuries. The diversity allowed in the Vatican edition exposed the commission to criticism on the most fundamental aesthetic level." 28

In spite of these first intents to restore earlier practices in Germany and France, it was with the work of the Benedictine monks of Solesmes headed by Abbot Pothier that the first rigorous historical research was done, resulting in publications between 1883 and the end of World War I. The origin of their work lies some decades earlier, when Don Prosper Guéranger, the previous abbot of Solesmes, intended to restore the monastic tradition in Solesmes and discovered that for the reestablishment of the Divine Office he needed the proper chant-books for it so the monks of Solesmes were sent to libraries in all Europe to search for early Chant manuscripts and do research on them. In 1889, their Paléographie Musicale was published, with the intention of showing the "authenticity" of their research based on photographies they had made of the $10^{\text {th }}$ century musical documents. This was a quite new technical invention that was not available before the late $1850 \mathrm{~s}$, even if it could not yet produce the sharp images of later photography. ${ }^{29}$ Nevertheless, these photographs added a more serious and "authentic" impression to their research, reinforced by the title ("paleography") they had chosen. Their edition was a reaction to the Pustet edition: instead of $16^{\text {th }}$-century or late-medieval chant, their aim was to restore the earliest chant melodies, directly from the neume notation. Pothier chose to transform its notation into the perfectly readable $13^{\text {th }}$ and $14^{\text {th }}$ century French type of notation while, as Emerson writes, "special ornamental signs representing the quilisma, cephalicus and epiphonus were adapted from pre- $13^{\text {th }}$-century Guidonian practice (see Schmidt, U1895-6)." ${ }^{30}$

At the beginning of the $20^{\text {th }}$ century the privilege to publish the official chant books was not longer given to the German firm of Pustet. Moreover, the new pope Pius X enunciated in 1903 his motu proprio "Tra le sollecitudini" in which the various aspects of church music were defined and the importance of plainchant was reestablished ${ }^{31}$, mentioning the restoration practice of "the most recent studies", referring to the Solesmes studies. It also gave priority to Renaissance and Baroque polyphony rather than later music ${ }^{32}$. Other instruments than the organ were only allowed if given a

28 Kenneth Levy, et al. "Plainchant." Grove Music Online. Oxford Music Online. Oxford University Press, http://www.oxfordmusiconline.com/subscriber/article/grove/music/40099pg12 [accessed 1-5 2015]

29 http://www.solesmes.com/GB/gregorien/hist.php [accessed 18-4 2015]

30 Emerson, J.A., Op.cit., http://www.oxfordmusiconline.com/subscriber/article/grove/music/40099pg5

31 Pius X, "Tra le sollecitudini” (1903), Rule 3, http://www.adoremus.org/MotuProprio.html [accessed 18-4, 2015]

32 Ibid., Rule 4 
special permission. ${ }^{33}$ Women were prohibited to sing in mixed choir: “(...) singers in church have a real liturgical office, and that therefore women, being incapable of exercising such office, cannot be admitted to form part of the choir. Whenever, then, it is desired to employ the acute voices of sopranos and contraltos, these parts must be taken by boys, according to the most ancient usage of the Church." ${ }^{34}$ It was prohibited to sing in vernacular ${ }^{35}$. Clearly, it was an initiative, just as the Solesmes studies, to return to earlier forms of music within the Church.

Edition of such early manuscripts with a notation that does not supply any reliable information about rhythm nor about exact pitch, always involves an inevitable number of personal choices where there is no objective evidence. Pothier made the choice of not assigning any rhythmic value to the notes since, according to him, it was not specifically reflected in them. His conclusion was that performance should be in a natural, freely flowing rhythm, depending on the natural accents and divisions in the Latin text. Thus, his version ignores the original letter indications for rhythm, tempo and articulation in his sources, while it adds phrasing marks, episemas (horizontal line above the note in order to lengthen it) and mora markings (dots which also lengthen the notes they accompany). The editions of Solesmes were not critical editions, as there are no commentaries in them and they do not mention the manuscript sources of each melody. There are several problems that have arisen from the choices of Pothier and the influence of Solesmes on the standardization of the chant repertoire. First, Pothier's proposition of free rhythm became imbedded into standard practice and gradually regarded as a historical fact, while in reality it was an invention of Pothier. Second, it took the repertoire from several sources but did not mention the source of each chant, so that it gave an image of an authoritative historical and unified repertoire, while in reality there was a variety in the repertoire all over Europe and through history. Third, it changed the original order of the chants within the liturgy. And fourth, other historical practices such as singing additive voices (polyphony) or the use of tropes are also not reflected in the work of Solesmes. The problem with the work of Solesmes is that it was presented as a historical "restoration", because it was believed to be so, but in reality it was not that historical at all. As a consequence, this "restored historical chant" ended up being a standardized church repertoire and certain traditional and historical knowledge became lost. As Kenneth Levy wrote,

"Special collections, such as the Solesmes Variae preces (1896) and Carl Ott's Offertoriale (1935) (see Steiner, K1966, p.164), provide some clues to the sources. However, the modern chant books are by and large functional compilations. To the inexperienced student, these books can easily seem to possess an

33 Ibid., Rule 15; Rule 17; Rule 19; Rule 15 
absolute authority, both musically and liturgically, and can stand as formidable barriers to a true understanding and appreciation of the immense diversity of medieval chant. Such an understanding may be further impeded by the widespread use of textbooks based almost entirely on these publications (for example, Apel's Gregorian Chant, C1958)." ${ }^{36}$

In 1904, the Vatican appointed a commission, lead by Pothier, who did not reside in Solesmes anymore, to supervise the preparation of official Vatican editions of the Graduale and Antiphonale. The members of the commission could not agree on several choices that the Solesmes monks had made in their musical transcriptions. But, according to Levy, "despite repeated clashes within the commission over editorial policies and the loss of editorship by Solesmes, three major Vatican chant books were published: the Kyriale seu ordinarium missae (1905), the Graduale sacrosanctae romanae ecclesiae (1908) and the Antiphonale sacrosanctae romanae ecclesiae (1912)."37

The issue of the antiquity of musical sources continued to be a reason for dispute, as well as the issue of rhythm. According to Levy,
"between 1895 and 1914, just as the Vatican editions were being prepared, argument among scholars on this matter was at its most intense. The early mensuralists, among whom were Hugo Riemann, Antoine Dechevrens, Ludwig Bonvin, Georges Houdard, Oskar Fleischer, Eduard Bernoulli and Peter Wagner, conjectured that chant was sung to notes of unequal value that usually bore a proportional 2:1 relationship. The results of their rhythmic interpretations, however, were widely divergent. In the editions of Dechevrens, a large number of notes are reduced to the status of rapid ornaments (U1902/R). Many of the rhythmic interpretations rely to a greater or lesser extent on the sophisticated detail in the notation of the early manuscripts from St Gallen (CH-SGs 359, 339), Einsiedeln (E 121) and Laon (F- LA 239), which indicate rhythmic, dynamic or agogic aspects of performance." ${ }^{38}$

Later in the $20^{\text {th }}$ century the Solesmes line of research developed with the palaeographic theories of Dom Eugène Cardine (1905-88). This so-called Gregorian semiology amplified and revised the rhythmic aspects of the earlier Solesmes works. Now the original letter indications for rhythm, tempo and dynamics were included, as well as the original episemata in the St Gallen manuscripts. They also changed neume shapes in order to indicate certain ways of performance and the grouping of notes. As Levy writes, "the new investigation of these rhythmic signs is important in two respects: firstly, it has stimulated considerable interest in close reading of primary sources; second,

\footnotetext{
36 Kenneth Levy, et al. "Plainchant." Grove Music Online. Oxford Music Online. Oxford University Press, http://www.oxfordmusiconline.com/subscriber/article/grove/music/40099pg12 [accessed 1-5 2015]

37 Ibid.

38 Ibid.
} 
and perhaps more fundamentally, it may contribute to a better historical and musicological understanding of early chant." 39 He continues on the Acta apostolicae sedis, issued by the Second Vatican Council in 1963:

"Faced with an increasingly secularized society, the Council sought to retain the allegiance of the faithful by endorsing a new pastoral theology of 'active participation' ('actuosa participatio'; see Articles 14, 21, 30 etc.). Unlike the reforms brought about by the Council of Trent, which were conservative in that they sought to standardize and retain existing liturgical practice throughout Europe, the reforms of the Second Council have been regarded by many as essentially contrary to any form of liturgical development known in the past. Fundamental changes have taken place that have profoundly affected the nature and function of traditional Gregorian chant: vernacular languages have largely replaced Latin (Articles 36, 54), completely new liturgical formularies have been introduced, and the structures of the Mass, Office and the liturgical year have been revised (Articles 50, 107 etc.). ${ }^{40}$

Such a great reform has not put an end to the discussion about the use of music in the church, but rather added another point of possible disagreement. Not only the discussion about the historical accuracy of the plainchant books continues, but also a discord has arisen about the question if the Roman gradual of 1974 and the Graduale triplex of 1979 - both revised visions of the older Vatican books - should be in the liturgy rather than the new vernacular chants. Thus, the discussion is about a historical interest versus an interest of modernization. Furthermore, new issues emerged, such as the type of vernacular chants and texts, the extent of its popularization and simplification. Levy gives a thought about the possible future development of this movement:

"Given the periodic nature of liturgical reform - approximately every 60 years since the Council of Trent - one might predict that in about the year 2025 another Council will have to be called to deal with, among other things, the liturgical and musical chaos resulting from too liberal an interpretation of 'actuosa participatio' and from the virtual abandonment by the Church of its traditional musical patrimony. At that time it might be well to return some semblance of orthodoxy to the celebration of the liturgy and to restore cantus planus to its central place within the Roman rite."${ }^{41}$

Summarizing, not only in the Early Music movement but also in the repertoire choices within the Church we have observed an original idea of "authenticity" or "restoration", and in both movements this turned out to be an impossible task: there is not enough historical knowledge, it would sometimes even be undesirable and we would not know whether to focus on the composer's 
intentions or on how it actually sounded. As Bernard D. Sherman stated already back in 1997, "even if we embed a Dufay mass in its liturgy, we probably won't feel, as Dufay's listeners did, emotional associations between the chants and specific religious holidays". ${ }^{42}$ Additionally, in the case of the Church, a choice had to be made for a specific historical period as the basis for the newly recovered standard liturgical repertoire. We have seen that the dispute about choosing between $12^{\text {th }}$ century neumatic sources, $13^{\text {th }}$ - and $14^{\text {th }}$-century sources containing more information about exact pitch, or Renaissance sources, was at its peak in the second half of the $19^{\text {th }}$ century. Then, the Vatican chose the oldest sources which meant the loss of other trends that based themselves on later periods and choosing an erroneous interpretation of several aspects of these early neumatic sources. Solesmes' free interpretation of certain details without any critical apparatus has caused a general believe that the plainchants and their indications in the Vatican books are according to the "original" sources, but in reality they are partially a late $19^{\text {th }}$ century invention. Nowadays, musicologists specialized in plainchant are conscious of this and are working with the original historical sources. Besides, musicological research has been done on the performance practice throughout the Middle Ages which has led to new insights. As our discussion on the basics of Medieval music theory will show, one of these developments is the knowledge that in the later Middle Ages it was common to improvise polyphony in oblique and counter-movement to the principal voice of plainchant. Such polyphony changes the sonority of plainchant considerably, especially for the modern listener who is used to hearing plainchant monophonically or at most with a drone. The basic rules for this counterpoint are known and musicians, mostly those already trained in Historically Informed Performance Practice, are beginning to work with them. Some do this in the form of a concert, others aim to include them in liturgical services. The proposal of Incipit is a third way of working with this repertoire, which consists of bringing it to a music theatre audience. These three ways are all examples of initiatives to revive this historical repertoire and performance practice.

42 Sherman, B.D., Inside Early Music: Conversations with Performers (Oxford, 1997), p.9 


\subsection{Music around 1300}

If we wish to understand the music that is present in the Divina Commedia and the way people might have experienced and performed that music in their daily life, first of all we should have a look at its historical context. The Commedia was written in the first decades of the fourteenth century in Florence, Italy. The musical references are almost all related to liturgical music, while only two references are about secular music.

The methods of Historically Informed Performance not only include consulting historical musical sources but also other information about performance, musical theory and circumstances in which the music was performed. Simply transcribing a piece of medieval music is not enough in order to call it historically informed. In addition, we should come to a certain idea about how it was performed, for which reasons and for whom it was performed. Also, the surviving historical instruments must be studied so that we can get an idea of how the music might have sounded. In the case of the voice, treatises or other historical documents that mention the voice can provide us with some clues about its sound in the Middle Ages. Historical treatises about music theory can give us a comprehension of the tuning, polyphony, tonal structures and interpretations of the musical notations, both in pitch and in rhythm. Furthermore, getting an idea of the cultural context can provide information about tastes and conventions. Historically Informed Practice is about understanding the music and the thought or system behind it, trying to get into that historical context as much as possible through the study of contextual documents and the music itself.

In the narrative of the Divina Commedia there are liturgical chants well known to Dante and his contemporaries. Below, we will give an overview of the relevant historical information that is necessary for at least a partial comprehension of their historical performance and of the Medieval sonorous world in general.

Dante wrote his Commedia about a century later than the heyday of the Nôtre Dame School in Paris, but its influence was so strong that it became the foundation of a main international style until the 1330s, just including Dante's lifetime..$^{43}$ One of its major musical developments was the invention of the rhythmic modes, in which for the first time rhythmic values could be deduced directly from the notes themselves, although still in a complex and ambiguous way. This important development created the possibility of more complex polyphonic compositions than just note-tonote or melismatic polyphony in which one voice holds one long note while the other one fills up 
with an extended series of notes. One of the consequences was that compositions for three or even four voices with a certain rhythmic independence could be notated and performed. However, the notation of plainchant did not take these rhythmic modes into account and assigned the same value to each note, with the exception of some basic rules for the prolongation of certain notes within the musical phrases. This means that the modern style did not enter the regular plainchant within liturgy, but rather that the more ancient techniques of polyphonic improvisation were kept in use, especially in the areas further away from Paris.

How about rhythm in plainchant? If we have a look at its history, very little historical documentation about the matter exists, but David Fenwick Wilson in his Music of the Middle Ages argues that "there is evidence that plainchant was performed in some kind of a measured manner in the ninth and tenth centuries, although there is disagreement about the specific rhythms. The shift to chant performance in equal note lengths apparently came about in the eleventh century, probably becoming general by around 1050 . The reason for this shift is unknown, but seems paralleled by a change in notational style from one emphasizing performance nuance to one giving greater indication of precise pitch. Both phenomena seem to indicate a definite shift in taste in performance." (Wilson 1990, 219). Wilson is referring here to the transition from neumes to notes. Neumes represented musical gestures and were meant as a support for memorizing the thousands of chants that had to be learnt by heart. Notes, on the other hand, indicated pitch, which meant that less melodies had to be memorized and that early polyphony could be developed through its notation. In the section about rhythm we will discuss the issue of rhythm for plainchant around 1300.

The monophonic troubadour style also reached Italy. After the Albigensian Crusades in the first half of the thirteenth century, Occitania was only a shadow of the richly coloured culture it used to be. Many troubadours had fled to Catalonia, Italy or the north of France, and with their art they influenced poetry and music. It is assumed that the lauda, a sacred genre with vernacular text, was one of those Italian genres influenced by their music because there are similarities in rhythm, melodic style and notation. Dante was a great admirer of some troubadours and in the Divina Commedia a few of them are present. In Inferno, Bertran de Born is placed as a sower of schism between Henry II and his sons. In Purgatorio we encounter Sordello as an example of patriotic pride and Arnaut Daniel is doing penance for lust. In Paradiso another soul influenced by lust resides in the sphere of Venus: Folco, whose name literally means "I shine" or "I burn" is an example of the word game that Dante uses repeatedly in his choices of characters.

Returning to sacred music, another musical genre was the motet, whose origins were in the Nôtre 
Dame school. Wilson defines it as following: "the motet consists of one or more texted voices above a tenor drawn from a melismatic segment of plainchant, all preceding in a measured rhythm." (Wilson 1990, 231). Melismas are extended series of notes on one syllable. In the late Middle Ages there were melismatic, florid and syllabic styles of music. The motet was the leading international musical form in the $13^{\text {th }}$ and $14^{\text {th }}$ centuries in Western Christianity. Wilson writes about the Italian motet that,

\begin{abstract}
"although the chief thrust of continental motet composition was in France, Italy played a significant role as well, although the evidence indicates that most of the repertoire has been lost. French polyphonic concepts and theory were known in northern Italy and Rome in the $13^{\text {th }}$ century, but we have no trace of Italian motet composition until the beginning of the following century. Then the repertoire varies from re-creations of $13^{\text {th }}$ century idioms to pieces in conservative $14^{\text {th }}$ century style. Of those datable to the first half of the century on the basis of manuscript transmission, 4 appear in lauda manuscripts along with a few motets of late $13^{\text {th }}$ century style." (Wilson 1990, 314).
\end{abstract}

In the 1330s most of the new polyphonic national styles began to arise, just after Dante finished his book. These were the French Virelai, Rondeau, Ballade and Chace, as well as the Italian Madrigal, Ballata and Caccia. In the 1360s, in Italy, the Ballata would be the last one to become a polyphonic form and from then on would become more popular than the Madrigal. The $14^{\text {th }}$-century Madrigal is not to be confused with the Renaissance Madrigal, even if they bear the same name.

Their more complex rhythms are possible due to the writings of Marchettus of Padua, who wrote two treatises on music theory between 1315 and 1320; he might even have influenced the developments within the French Ars Nova. His Lucidarium is about plainchant and his slightly later Pomerium deals with rhythmic notation. As a major innovation he offered the addition of various new binary rhythmical modes to the already ternary existing ones, forming the base for the new binary Italian music. ${ }^{44}$ These new developments were just taking place when the Divina Commedia was already finished but, even so, plainchant continued to be written in its own way which did not include the indication of any specific rhythm.

How about instrumental music? Definitely, instrumental music has always existed, mostly dances or popular songs, both of which were not notated. Until the $13^{\text {th }}$ century, book production was a costly and time-consuming procedure, and consisted solely of handmade copies produced by monks. When the Christian universities arose in the $13^{\text {th }}$ century, an increasing number of books were 
needed and the copying process was divided into different stages, each executed by different copyists, but books were still relatively rare and expensive. This is the reason why notated music would not just be any music, but mainly the so highly esteemed liturgical repertoire. Until 1250 all surviving music is vocal and there is very little secular music from 1100 on where instruments are being specified. Still, in Medieval literature and iconography there are many references to instruments, which does suggest the importance of instruments in musical culture. As to their use, Wilson writes the following:

"It seems that all were considered instruments of the professional music-making class, the minstrels and jongleurs, the trumpet alone standing apart as a signalling instrument. Certainly, they were also played by amateurs, but no amateur is spoken of as excelling at instrument playing. The art of the noble amateur, lord or lady, was singing. Instrumental skill was a pleasant but unnecessary adjunct. For those nobles who did play, the bowed and plucked strings are most named. Winds and simpler instruments were for peasants: bagpipe, flute, pipe and tabor, hurdy-gurdy. Important was the division of instruments into the categories haut and bas, loud and soft, those suitable for indoor playing and those for outdoor." (Wilson 1990, 380).

The music played by these minstrels and jongleurs was certainly dance music that was mostly improvised.

Despite the fact that there are two references to secular music in the Divina Commedia - a troubadour song by his friend Casella on a text by Dante himself and the singing siren in Dante's dream - only the references to liturgical chant have been used in this research. The reason for this is the fact that Incipit is not a re-enactment of Dante's visit to his Afterworld but instead a journey on a more abstract level, which takes place on a more general time level where all the characters with a specific significance for Dante are not present. Thus, we will not meet the character Casella, and we will not experience any personal dreams Dante the pilgrim had at that moment. Since we only focus on the liturgical chants, we will now explain what plainchant is, as well as its relation to liturgy. 


\subsection{The Role of Plainchant in Liturgy}

In the words of conductor and researcher Jeremy Summerly, "plainchant is the backbone of medieval music. Like cantillation (its Jewish precursor), plainchant is a singularly vocal medium, which exists to lend gravitas and audibility to the texts that it decorates." 45 Plainchant is not an independent musical genre, in the sense that chant and Catholic liturgy are two sides of the same coin. Wilson argues that

"plainchant, the music of the medieval church, is thus music for worship. Shorn of its liturgical ambience, it loses much of its inner meaning. Performed in isolation it may have great beauty, as an isolated opera aria may have great beauty, but neither, in isolation, can adequately convey the larger totality from which it was removed. It was the intimacy of plainchant to the lives of the Carolingian clergy in fact that made them so concerned with its development and preservation." (Wilson 1990, 11).

Maintaining such a huge repertoire intact that is learnt completely by memory is an impossible task and some of the exact melodies mutated to slightly different versions. The aim of the Church, however, has always been to maintain a unified repertoire in all its settlements. It is "the public expression of spirituality that drives a group", as written by Medieval chant specialist Marcel Pérès, and the Church was well aware of this. ${ }^{46}$ The unification of the Christian plainchant repertoire was facilitated by notation. The notation of neumes served only as a mnemonic for singers, but notes indicated exact pitch and thus were a more reliable means of transmission and conservation of the exact repertoire.

In the Middle Ages, Christianity was central to daily life and so were the rituals of offering praise to God. These rituals consisted on the one hand of public Masses which focused on the celebration of the Lord's Supper, and on the other hand of the Divine Offices or Canonical Hours only for the ecclesiastical clerics. The Divine Offices consisted of eight daily services: Matins, Lauds, Prime, Terce, Sext, None, Vespers and Compline. Their musical repertoire consisted mainly of Psalms, although many other chants were also being sung. Vespers and Matins were musically the most interesting because they were the longest and most complex of the Offices and thus had some space for complex musical settings of the chants. The Mass consisted of two types of chants: the recurring texts in each service (the Ordinary) and texts that change every day (the Proper). Wilson notes that Medieval composers focussed rather on the chants of the Proper, like the Introit, Gradual, Alleluya

45 Summerly, J. "Vocal Performance before c. 1430”, The Cambridge History of Musical Performance, ed. Lawson, C. and Stowell, R. (Cambridge, 2012), p. 248

46 Pérès, M., Les Voix du Plain-chant (Paris, 2001), p. 58 
or Offertory, while Renaissance composers concentrated more on the Ordinary, like the Kyrie, Gloria, Credo, Sanctus or Agnus Dei (Wilson 1990, 40).

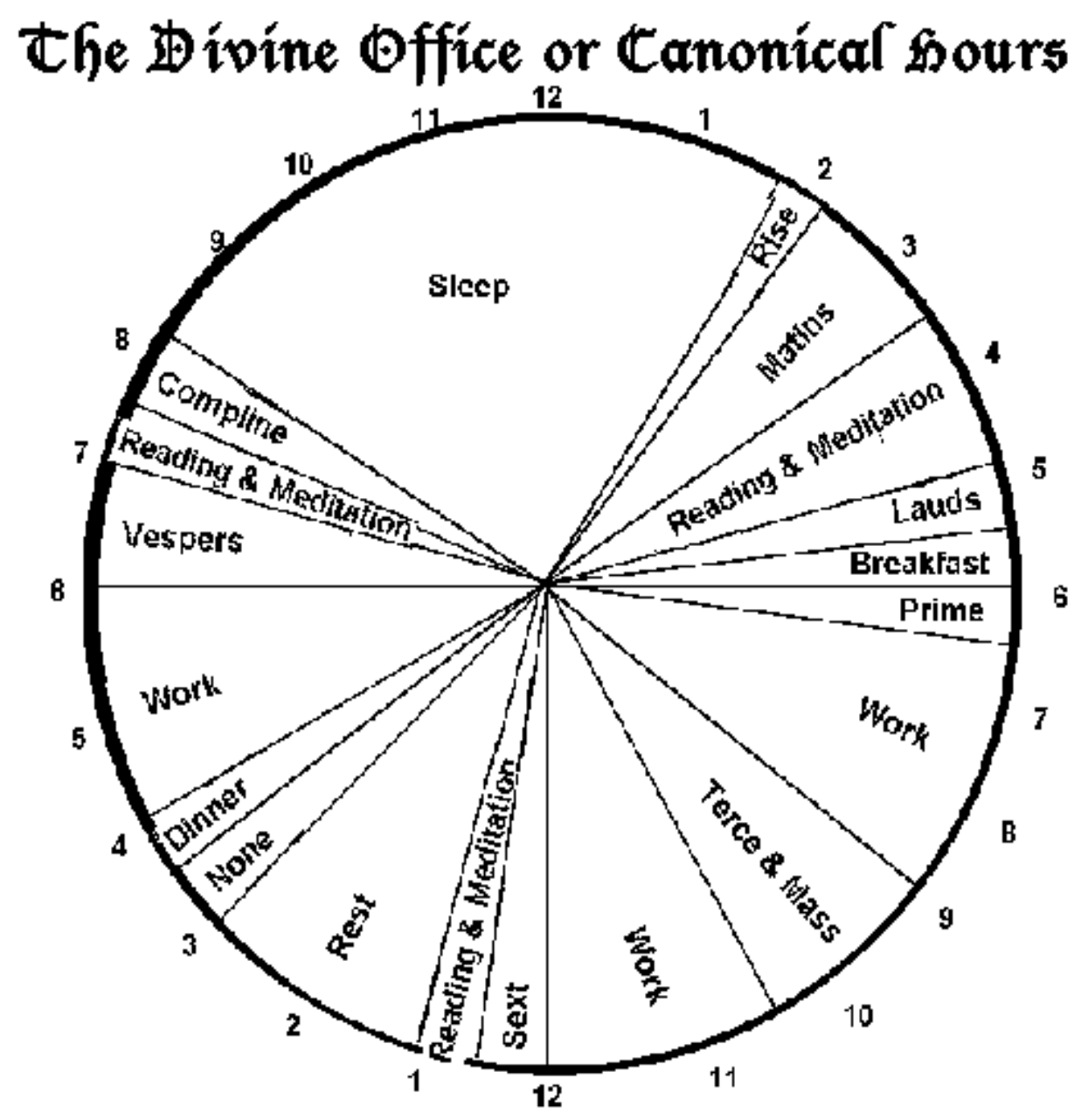

Fig. 5. The Divine Office or Canonical Hours by Brian Jones

(http://www.thebeckoning.com/art/limbourg/divine-office.html)

The chants in the Office and Mass can be divided musically into different types: Psalmody, Antiphonal Chants, Responsorial Chants, special Antiphons (Marian Antiphons, processional Antiphons), Hymns, and chants of the Ordinary.

The psalms were recited or chanted in psalm tones, fixed melodic formulas in each of the church modes. ${ }^{47}$ Additionally, there was a ninth psalm tone called tonus peregrinus, "wandering tone", because of its changing final from the first half of the verse to the second. Mostly, the psalm settings end with a so-called Doxology: Gloria Patri et Filio, et Spiritui Sancto. Sicut erat in principio, et nunc et semper, et in saecula seculorum, Amen. ${ }^{48}$

47 The church modes were the tonalities used by then, instead of our major and minor tonalities: Dorian, Phrygian, Lydian, Mixolydian, their authentic and plagal versions, the latter with a lower range from a fourth below to a fifth above the final. These were the eight modes used for the psalm tones.

48 Translation: "Glory to the Father and the Son and the Holy Spirit. As it was in the beginning, is now and ever shall be, world without end, Amen." 
There are different ways of singing the psalms. They can either be sung throughout or by two choirs in alternation. The latter is called an antiphonal chant. The antiphon is a free melodic refrain which precedes and concludes the psalm. An antiphonal chant thus can be the alternating of two choirs or between antiphon and psalm verses. It was used for the Introit and the Communion in the Mass (Wilson 1990, 45). In the Offices, the cycle of psalms is repeated every week but the antiphons change as the year progresses, so every week a psalm had another antiphon. The text of the antiphon emphasizes a specific aspect of the psalm. As Wilson states, "musically, the connection between antiphon and psalm tone is made by letting the antiphon determine that of the psalm." (Wilson 1990, 46). Another way of singing the psalms would be as a responsorial chant. This consists of a soloist singing the psalm verses and a choir that responds. In the Mass, it was used for the Gradual and Alleluia, while in the Office it was applied in the Great Responsories (Matins) and Short Responsories (Prime, Terce, Sext, None, and Compline).

Special Antiphons include the Marian Antiphons and processional Antiphons. According to Wilson, "the Marian antiphons, in honour of the Virgin Mary, [were] added in the thirteenth century to the office of Compline. Some, such as Salve regina, Alma redemptoris mater, Ave regina coelorum, and Regina coeli became favourite texts throughout the Renaissance and later." (Wilson 1990, 54). As we will see, the Divina Commedia contains references to both Salve regina and Regina coeli. As for the processional antiphons, they could be regular office chants for simpler marches from and to the church but they could also be specific antiphons for major processions on special feast days.

Hymns were of common use from the ninth century on. In the Offices they were sung by all attendants. A hymn uses a non-biblical poetic text, and each stanza is sung to the same melody. Thomas Aquinas (1225-1274) has nothing but praise for this genre: "Hymnus est laus Dei cum cantico; canticum autem exultatio mentis de aeternis habita, prorumpens in vocem." ("A hymn is the praise of God with song; a song is the exultation of the mind dwelling on eternal things, bursting forth in the voice." $)^{49}$ Hymns could be for a specific occasion within each year or for a specific saint.

The last genre here are the chants of the Ordinary. Their musical style is newer than the other chants because the old congregational ones were replaced by these choral chants during the Carolingian period, when the chants of the Proper were already formalized (Wilson 1990, 55).

49 Thomas Aquinas, Introduction to his Exposition of the Psalms of David, http://www4.desales.edu/ philtheo/loughlin/ATP/Proemium.html [accessed 13-6 2015] 
The following is a list of all the references to chants in the Divina Commedia and their categorization. Some of the psalms were simply sung in a psalm tone, while others existed in special settings for an antiphon. For this research only digitalized scores have been used, which means that existing settings that have not been digitalized are not included. This is the case of Beati quorum in Purgatory, for which a psalm tone has been chosen, even if we know that antiphon settings for it exist.

\section{Purgatory:}

- Purg. 2.46: In exitu israel

- Purg. 5.24: Miserere

- Purg. 7.82: Salve Regina

- Purg. 8.13: Te lucis ante

- Purg. 9.140: Te Deum

- Purg. 12.110: Beati pauperes spiritu

- Purg. 13.51: Litany of all saints

- Purg. 15.39: Beati misericordi

- Purg. 15.40: Gaudate et Exsultate

- Purg. 16.19: Agnus Dei

- Purg. 17.68: Beati pacifici

- Purg. 19.50: Beati qui lugent

- Purg. 19.73: Adhaesit pavimento anima mea

- Purg. 20.136: Gloria in excelsis Deo

- Purg. 22.6: Beati qui sitiunt

- Purg. 23.10: Labia mea, Domine

- Purg. 23.64: Beati qui esuriunt

- Purg. 25.121: Summae Deus Clementiae

- Purg. 27.8: Beati mundo corde

- Purg. 27.58: Venite, benedicti Patris mei

- Purg. 28.80: Delectasti

- Purg. 29.3: Beati quorum

- Purg. 29.51: Hosanna

- Purg. 29.85: Ave Maria gratia plena dominus

- Purg. 30.11: Veni, sponsa
Psalm, Tonus Peregrinus

Psalm Antiphon

Marian Antiphon

Hymn

Hymn

Antiphon (Beatitude)

Miscellaneous

Antiphon (Beatitude)

Antiphon (Beatitude)

Agnus Dei (Mass Ordinary)

Antiphon (Beatitude)

Antiphon (Beatitude)

Psalm

Gloria (Mass Ordinary)

Antiphon (Beatitude)

Psalm Antiphon / Responsory verse

Antiphon (Beatitude)

Hymn

Antiphon/Responsorial verse (Beatitude)

Introit (Antiphonal chant)

Psalm Antiphon / Responsory verse

Psalm (Beatitude)

Antiphon

Marian Antiphon

Psalm Antiphon 
- Purg. 30.83: In te Domine speravi

- Purg. 31.98: Asperges me

- Purg. 33.1: Deus venerunt gentes

Paradise:

- Par. 3.121: Ave Maria

- Par. 7, 1: Sanctus

- Par. 8.29: Hosanna

- Par. 23.103: Regina caeli

- Par. 24.113: Te Deum

- Par. 25.73-98: Sperent in te

- Par. 26.69: Sanctus sanctus sanctus

- Par. 27.1: Gloria Patri

- Par. 28.118: Hosanna

- Par. 32.95: Ave Maria
Psalm

Psalm Antiphon (Mass Ordinary)

Psalm
Responsory Verse (Marian Antiphon)

Sanctus (Mass Ordinary)

Antiphon

Marian Antiphon

Hymn

Psalm

Antiphon

Doxology

Antiphon

Marian Antiphon

In Chapter 5 we will come back on these chants and their categorization, on the choices made for a particular historical version of them and finally on the motivation behind the selection of the chants for the music theatre work Incipit.

If the chants are not independent from the liturgy, why remove them from their context? Indeed, a part of their identity and meaning are being taken away, and they are placed in another context (a music theatre work) which gives them another identity. To use Wilson's analogy with an isolated opera aria, if you take it out of its opera and insert it in another narrative, it could take on a different meaning or perspective. Even if we would leave them in their liturgical context, solely the fact that we are $21^{\text {st }}$-century performers and listeners implies a modification in the meaning of these chants. We must also keep in mind that the chants themselves in the narrative of the Divina Commedia do not appear within a liturgical context either. The music theatre work Incipit is based upon this narrative and not upon a specific type of liturgical service. The interest of taking these chants out of their original context is based upon minimum three reasons. First of all, these historical chants and their performance practice are conveyed to a different audience than the attendants of a Mass or other services. Secondly, together with the anti-music of Inferno and the "unearthly" music of Paradise, they form a sonorous world which approaches Dante's musical world and thus opens a window to an aspect of the Medieval inner world in Dante's time and place. And thirdly, their 
combination with a modern mise-en-scene gives way to a compound language in which - with the words of Gestalt psychologist Kurt Koffka (1886-1941) - the whole is other than the sum of the parts ("das Ganze ist anders als die Summe seiner Teile"). ${ }^{50}$ The contribution of these historical chants through historically informed performance to a mise-en-scene of Dante can be indeed very interesting and may lead to a different musical-theatrical language.

50 Later on he commented on the common mistranslation of anders (different) into more. "It has been said: The whole is more than the sum of its parts. It is more correct to say that the whole is something else than the sum of its parts, because summing up is a meaningless procedure, whereas the whole-part relationship is meaningful." Koffka, K., Principles of Gestalt Psychology (New York, 1935), p. 176 


\subsection{The Harmony of the Spheres and Pythagorean Tuning}

If we wish to understand the harmonic dissonances and consonances of the music in the Middle Ages, which operated differently from what our $21^{\text {st }}$ century ears are used to, we must understand the tuning system they are embedded in. In the equal temperament that is commonly used nowadays, an octave is divided into 12 equal parts, the 12 semitones of the octave. Although the human hearing grows accustomed to it, none of the intervals within the octave are perfect intervals. In other words, all intervals in the equal temperament are slightly out of tune. Western music has not always been in equal temperament. In the Baroque era, temperaments were still unequal but there was certainly a search for a temperament that could host modulations to keys with more sharps or flats. A famous example is The Well-Tempered Clavier of Johann Sebastian Bach (16851750), where he applied such a temperament in order to show that one can modulate to almost any tonality. In the Renaissance, the temperament was meantone. It was based on perfect major thirds, which are smaller than in equal temperament but the fifths were slightly too small. These perfect major thirds give the major chords in Renaissance work their beautiful sound. Even further back in time, the Middle Ages saw the Pythagorean temperament, in which the fifths and fourths are perfect but the major thirds are too wide. In a C-scale, both $\mathrm{E}$ and $\mathrm{B}$ are very high, transmitting an urgency to resolve into $\mathrm{F}$ and $\mathrm{C}$ respectively. Within a chord, they normally sound dissonant. Thus, listening to a Medieval work in Pythagorean temperament reveals the dissonants which equal temperament brings forth as consonants.

The basis of Pythagorean temperament is based on the mathematically elegant division of a monochord, with simple ratios. The monochord already existed in the $5^{\text {th }}$ century $\mathrm{BC}$ and was supposed to be an invention of Pythagoras. It was used for teaching and tuning. ${ }^{51}$ Dividing the string into two parts and playing it, would give exactly an octave higher than the original note, with a ratio of $2: 1$. The ratio $3: 2$ gives the fifth, while $4: 3$ stands for the fourth. Tuning fifths upward will lead to complex ratios for thirds: by the time we have tuned fifth on fifth beginning on C (C-G-D-A-E) we arrive at a ratio of 81:64 for a major third, while tuning fifths downward (C-F-Bb-Eb) will result in 32:27 for a minor third, two complex ratios. ${ }^{52}$ While the major seconds and thirds were larger than perfect intervals, pulling toward the note above them, the minor seconds and thirds are smaller and pulling toward the note below. Probably, the major third was gradually being adapted in the $15^{\text {th }}$ century to a smaller one, and in the Renaissance it was standard with a ratio of 5:4.

51 Cecil Adkins. "Monochord." Grove Music Online. Oxford Music Online. Oxford University Press, http://www.oxfordmusiconline.com/subscriber/article/grove/music/18973 [accessed June 14, 2015]

52 Mark Lindley. "Pythagorean intonation." Grove Music Online. Oxford Music Online. Oxford University Press, http://www.oxfordmusiconline.com/subscriber/article/grove/music/22604 [accessed June 14, 2015] 
In the Middle Ages and Renaissance, these numbers were not just some mathematical aesthetics. They were embedded within a philosophical system called Musica universalis ("Harmony of the Spheres"), a theory about the perfect proportions of the circling speed of the planets and their distance from the Earth. These perfect proportions can be expressed in numbers and, in Medieval Christian interpretation, express the perfection of God, the Creator of this universe. Instead of being audible music, musica is a mathematical-spiritual concept of perfect proportions. Claudius Ptolemy (ca.90-ca.168) had already made a distinction between cosmic and psychic harmony in his Harmonics. ${ }^{53}$ In addition, in the $6^{\text {th }}$ century, the philosopher Boethius in his De musica distinguished three categories: not only Musica mundana and Musica humana, the Latin versions of Ptolemy's categories, but also Musica instrumentalis, the only type of musica that the human ear can perceive. Boethius explains that the first type is referring to the planets, the second to the human being and the third to audible music, in which instrumental music is inferior to vocal music. ${ }^{54}$ Thus, musica mundana comprises the perfect proportions among the planets, musica humana is about the perfect proportions in the human soul and body, and musica instrumentalis is the expression of the perfect proportions through audible music. The latter term refers to the music the human being can produce and discern with his imperfect hearing. In the first place it is about vocal music because musical instruments were made by humans while the voice was made by God. The concept of the musician was different to ours: the musicus was the music theorist, while the cantor was the composer or interpreter who translated the perfection of the proportions into a less perfect form which is the music that humans can hear. In the words of Umberto Eco, "the name of musician belonged primarily to people who judged music in the light of reason. ${ }^{" 55}$ In Medieval theory all creation by God, according to the orderly principles of measure, number and weight, is connected through proportions, from macro-cosmos to micro-cosmos.

For these reasons, music had its place among the numerical sciences instead of the rhetorical sciences within the seven liberal arts. These were called liberal because only a free man could study them, as opposed to the working class and slaves that had to do work craft. These artes liberales were divided into the rhetorical sciences (the trivium) and the numerical ones (the quadrivium). The trivium contained Grammatica, Rhetorica and Dialectica. The quadrivium comprised Aritmetica, Geometria, Astronomia and Musica. Only toward the Baroque era, music gradually became considered as a rhetorical art. In musica instrumentalis, proportions really start to play a role when

53 James Haar. "Music of the spheres." Grove Music Online. Oxford Music Online. Oxford University Press, http://www.oxfordmusiconline.com/subscriber/article/grove/music/1944 [accessed June 14, 2015]

54 "II. Principio igitur de musica disserenti illud interim dicendum videtur, quot musicae genera ab eius studiosis conprehensa esse noverimus. Sunt autem tria. Et prima quidem mundana est, secunda vero humana, tertia, quae in quibusdam constituta est instrumentis, ut in cithara vel tibiis ceterisque, quae cantilenae famulantur.", Boethius, De institutione musica, http://www.chmtl.indiana.edu/tml/6th-8th/BOEMUS1 TEXT.html [accessed June 14, 2015]

55 Eco, U., Art and Beauty in the Middle Ages (Yale University, 1986), p. 30 
there are at least two different voices sounding simultaneously. Final harmonies consist of consonant intervals: octaves, fifths and in a minor degree fourths. We also have to bear in mind that for the Medieval mind, the concept of inverted harmonies did not exist. Sixths were not seen as inverted thirds, fourths were not thought of as inverted fifths. In general, unisons and octaves were perfect consonances, fifths and fourth intermediate consonances (although the fourth has moved in and out of this category). The third was accepted in English music as an imperfect consonant, while on the continent it was often regarded, together with the sixth, as an imperfect dissonance. Perfect dissonances were the second, the seventh and the tritone (augmented fourth or diminished fifth). Imperfect dissonances were often used to resolve into a final chord, like the sixth to the octave. The seventh became regarded as an imperfect dissonance after 1250, when a minor seventh was commonly resolved into a fifth.

Thus, perfection for a Medieval ear is completely different from what it is for ours. Our tonal perception is much stronger based on thirds than on the open-sounding fifths. As one of the consequences, our cadential hearing is different: we are accustomed to hearing a tritone like $f-b$ resolving into the sixth e-c and understand this progression as a progression of the dominantseventh G7 (g-b-d-f) to the tonic C (c-e-g-c). For Medieval ears this would be full of dissonance and would not feel as a resolution at all. They would rather have the sixth $d-b$ (with the Pythagorean $b$ higher than $\mathrm{a} b$ in equal temperament) resolving into $\mathrm{c}-\mathrm{c}$, or after 1250 , the minor seventh $\mathrm{b}$ - $\mathrm{a}$ resolving into c-g. This is a great change in our listening attitude, but once the ear is used to Pythagorean tuning and these progressions, it is a musical experience that is quite different from our usual one in "classical" music. The b in Pythagorean tuning, due to being higher than the $b$ we are used to, has a much stronger pulling force toward the $\mathrm{c}$, and makes obvious why these cadences function much more naturally than in equal temperament.

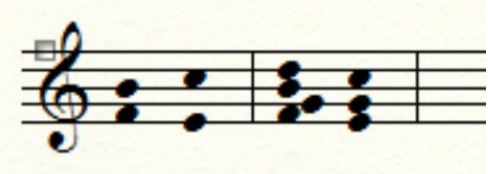

Fig. 6. A resolution that sounds natural to us.

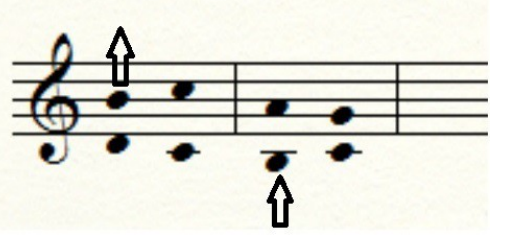

Fig. 7. Medieval resolutions with the heightened $b$ in Pythagorean tuning. 


\subsection{Church Modes}

In the Carolingian era, for the first time, liturgical chants were being combined with a modal system based on Byzantine practice, but it would only be from about 900 on that it was attempted to recover the ancient Greek modes, according to their description in Boethius' De institutione musica. Exact knowledge of these modes had been lost, so the new Medieval modes had little similarity with the original modes, except for their names. While the Carolingian modes were still melodic formulas, these later liturgical modes had become scale structures, which was a crucial development in Western music. It is important to understand, though, that our concept of the scale as a series of seven notes plus the octave (c-d-e-f-g-a-b-c, for example) did not exist in the Middle Ages. Rather, they thought in structures of pentachords (series of 5 notes) and tetrachords (series of 4 notes) and their combination. In the $11^{\text {th }}$ century, the final form of modal theory was created, due to the additions to the existing theories by authors like Guido of Arezzo and John of Affleghem.

In modal theory, the pentachord is the nucleus of the mode. There are four modes:

1. In mode I, also called dorian, it would consist of the notes d-e-f-g-a.

2. In mode II, phrygian, it would be e-f-g-a-b.

3. Mode III, lydian, would consist of f-g-a-b-c.

4. Mode IV, mixolydian, has g-a-b-c-d.

It is the placement of the tetrachord above or below the pentachord that determines if it is an authentic or a plagal mode. The plagal modes have the preposition hypo-: hypodorian, hypophrygian, hypolydian and hypomixolydian. The result are the following modes:

- Mode I authentic, dorian, d-e-f-g-a + a-b-c-d

- Mode I plagal, hypodorian, a-b-c-d + d-e-f-g-a

- Mode II authentic, phrygian, e-f-g-a-b + b-c-d-e

- Mode II plagal, hypophrygian, b-c-d-e + e-f-g-a-b

- Mode III authentic, lydian, f-g-a-b-c + c-d-e-f

- Mode III plagal, hypolydian, c-d-e-f + f-g-a-b-c

- Mode IV authentic, mixolydian, g-a-b-c-d + d-e-f-g

- Mode IV plagal, hypomixolydian, d-e-f-g + g-a-b-c-d

As we see, there is always one overlapping tone, whose importance indicates the exact church mode. It is sometimes called the reciting tone. These modes could also be transposed. Although they 
are an comprehensive framework for the melodic organization, Wilson comments that "there is some evidence to suggest that medieval musicians tended to organize and hear music in relatively short segments without the long-term tonal awareness we take for granted." (Wilson 1990, 55). This is especially notable in earlier Medieval works.

Apart from the modes as a theoretical framework, Guido of Arezzo also invented a teaching aid which became a very influential system. For the learning and memorizing of melodies, he used a hymn to Saint John, ut queant laxis, in which each phrase starts on the next note in an ascending scale:

\section{Ut queant laxis}
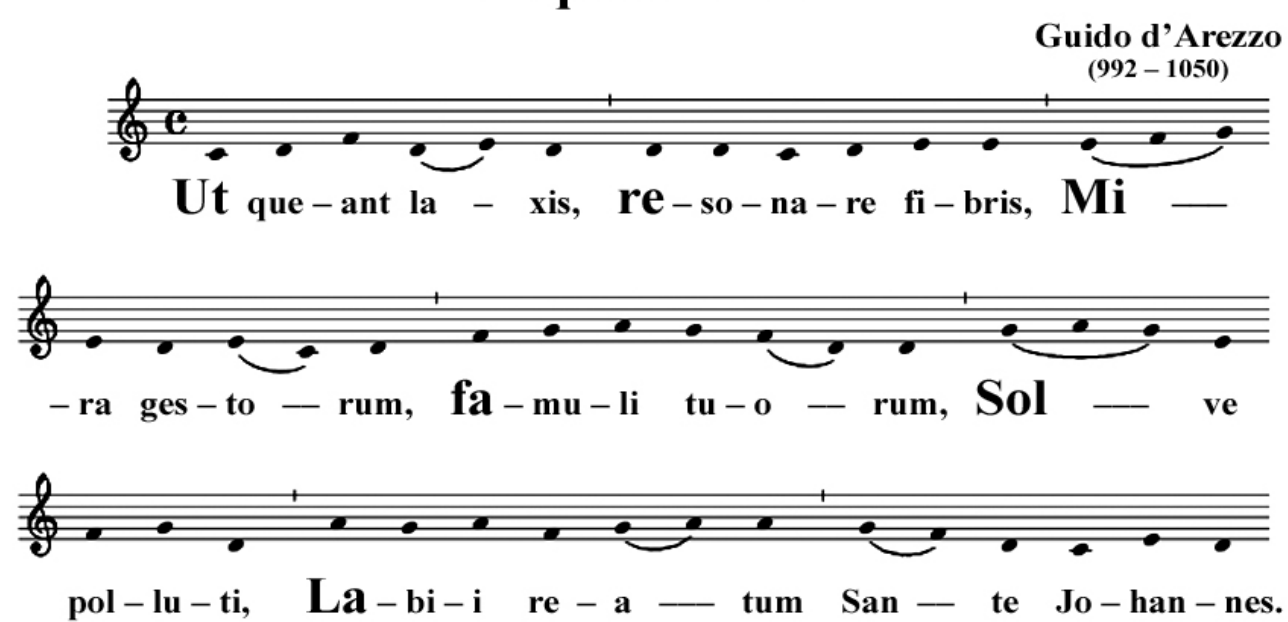

Fig. 8. Ut queant laxis

The first syllables of every phrase became the names of the notes of what was called a hexachord, a scale of six notes: ut, re, mi, fa, sol, la. Ut would be converted into Do in the $17^{\text {th }}$ century by the musicologist Giovanni Baptista Doni, using the first syllable of his own surname for it. The seventh note, si, did not form part of the hexachord but would later on be added from the initials of "Sancte Ioannes". In Guido's system, the natural hexachord starting on C could be transposed into two different hexachords: the "soft" hexachord called hexacordium mollum on F with a b flat, and the "hard" hexachord called hexacordium durum on G. Thus, in his system the only possible note alteration could be a b flat, and the larger part of the Middle Ages only knew this accidental in notation. All that did not enter the Guidonian system, named musica recta, including written or unwritten e flat or f sharp, would be called musica ficta or "false music".

Guido's system covers two octaves and a sixth. He called its lowest note Gamma ut, and as a 
consequence the entire span was called the Gamut. To each note, he gave the same fixed alphabet letter names as the one we still use nowadays, and its possible position within one of the three types of hexachords. The low G, Gamma ut, could only be ut because there was no lower note. Then A re, and B mi would follow. C could both be the fourth note in the G hexachord (fa) and the first note of the $\mathrm{C}$ hexachord (ut): C fa ut. Then D sol re and E la mi would follow. F would extend beyond the six notes of the $G$ hexachord. F would be fa, as well as ut of its own hexachord, and would thus be called Fa fa ut. Now $\mathrm{g}$ would fall into all three hexachords and thus would be $\mathrm{g}$ sol re ut, followed by a la mi re. If the next note were to be a $b$ flat, this would be fa; but in case of being a b, it would be mi. Thus, it is important to know in which hexachord one would like to continue: in the hexacordium mollum it would be with $\mathrm{b}$ flat, in a hexacordium durum it would be with $\mathrm{b}$ natural. It seems like a difficult system, but personal experience with this solmization method has led to the conclusion that it can even result a more practical tool than our regular system to understand and perform Medieval and Renaissance music. A major difference is that in Guido's system, the names ut, re, mi, fa, sol and la refer to functions within hexachords and not to absolute notes. Also, the mutation to another hexachord requires practice.

The Guidonian hand is a system of solmization with the visual aid of specific areas on the hand, where every note of the Gamut has its own spot, as shown in the illustration below.

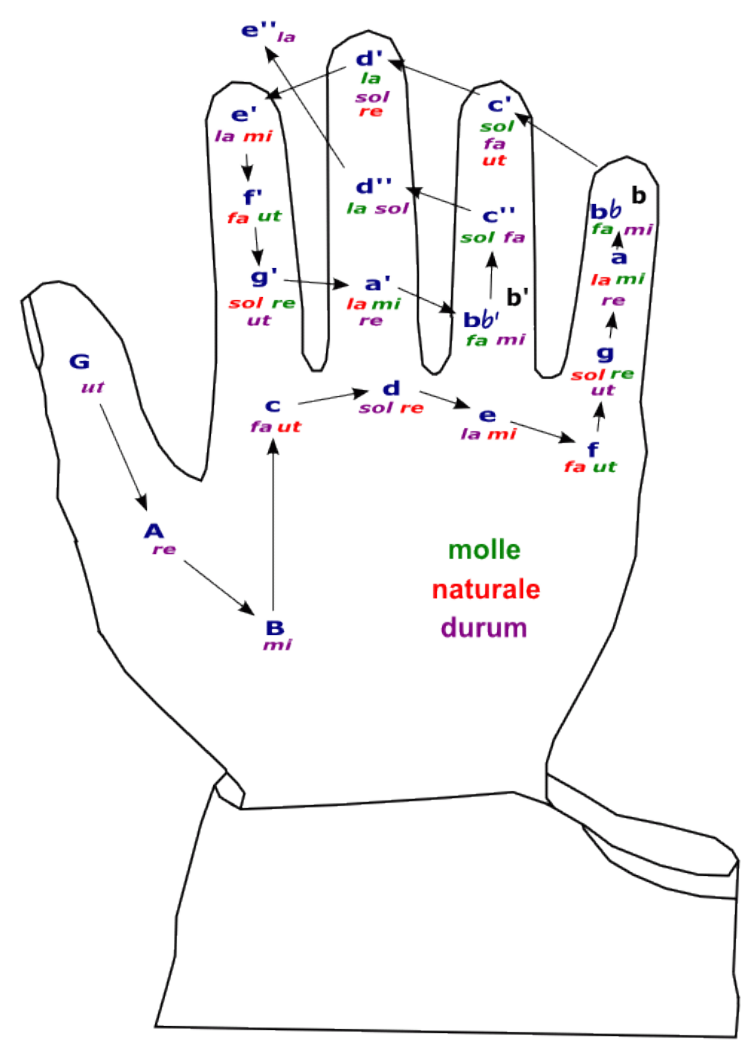

Fig. 9. The Guidonian hand 


\subsection{The Medieval Voice and Instruments}

Within the concept of the Harmony of the Spheres, the human voice is superior to musical instruments, because the former is created by God while the latter is created by human beings. The human voice can sing praises to God while the musical instrument only brings pleasure with its sound. There is a duality between body and soul, as noted by Medieval music historian Eduardo Aubert $^{56}$. In this duality, the body is being seduced by the pleasure of the sounds and the soul is being saved by the transcending aspect of the combination of liturgical music and text. This may be one of the reasons why liturgical chant had to be performed entirely vocally; musical instruments were prohibited in liturgy. The church organ was an exception, but in the time of Dante there were very few church organs and they were still in a primitive state. If we wish to perform the chants in a historically informed manner, we must thus sing them without using any musical instruments.

The idea that music could have a great influence on human beings had already been expressed by Augustine (354-430), one of the so-called "Church Fathers". ${ }^{57}$ In Book 9, Chapter 6, he exclaims:

"How freely did I weep in thy hymns and canticles; how deeply was I moved by the voices of thy sweet-speaking Church! The voices flowed into my ears; and the truth was poured forth into my heart, where the tide of my devotion overflowed, and my tears ran down, and I was happy in all these things." 58

In Book 10, Chapter 33, he ponders about the benefits and dangers of the music sung in church:

"In those melodies which thy words inspire when sung with a sweet and trained voice, I still find repose; yet not so as to cling to them, but always so as to be able to free myself as I wish. (...)

Sometimes, I seem to myself to give them more respect than is fitting, when I see that our minds are more devoutly and earnestly inflamed in piety by the holy words when they are sung than when they are not. And I recognize that all the diverse affections of our spirits have their appropriate measures in the voice and song, to which they are stimulated by I know not what secret correlation. (...) Thus I vacillate between dangerous pleasure and healthful exercise. I am inclined - though I pronounce no irrevocable

56 Aubert, E., "Locating the Sound of the Medieval Voice - an Analytical Framework", In Search of the Medieval Voice: Expressions of Identity in the Middle Ages, ed. Bleach, L; Närä, K.; Prosser, S. (Newcastle, 2009) p. 23

57 The Church Fathers were "early Christian theologians (in particular of the first five centuries) whose writings are regarded as especially authoritative.", http://www.oxforddictionaries.com/definition/english/father? $\mathrm{q}=$ church + father\#father 16 [accessed 12-7 2015]

58 "Quantum flevi in hymnis et canticis tuis, suave sonantis ecclesiae tuae vocibus commotus acriter! voces illae influebant auribus meis, et eliquabatur veritas in cor meum, et exaestuabat inde affectus pietatis, et currebant lacrimae, et bene mihi erat cum eis.", Augustine of Hippo, Confessions, Book 9, Chapter 6.

http://faculty.georgetown.edu/jod/latinconf/latinconf.html and English translation: http://faculty.georgetown.edu/jod/augustine/conf.pdf 
opinion on the subject - to approve of the use of singing in the church, so that by the delights of the ear the weaker minds may be stimulated to a devotional mood. Yet when it happens that I am more moved by the singing than by what is sung, I confess myself to have sinned wickedly, and then I would rather not have heard the singing." 59

Through history, elaboration and ornamentation of the existing plainchant has always been sought, making the text less comprehensible and shifting the attention from the meaning to the beauty of the music. This was not always appreciated by the leaders of the Church. An example is the papal bull Docta Sanctorum Patrum (1324) by Pope John XXII in which he warns against the seduction and distraction of polyphonic music in church. His warning did not achieve its aim: polyphony kept on developing within liturgy.

So how did the Medieval voice sound? This is a very difficult question to answer because the Medieval treatises that mention something about it are vague enough to leave room for many different vocal sounds. Jeremy Summerly in his article "Vocal Performance before c.1430" summarizes the more comprehensible Medieval indications: "Do not force the high notes. Sing sweetly, elegantly, and with fluidity - neither harshly nor nasally. Be rhythmically flexible where appropriate. Tune chords from the lowest voice upwards. Avoid singing wrong notes, respect natural word stress, and make the text clearly audible." (Summerly 2012, 248). This has not changed so much for us and they still do not give a clue about the actual sound but rather about the way how to perform the musical material. He continues: "The organisation of a fluid melody and attention to appropriate word stress were evidently the most important features of correct performance practice - these were the two areas in which a novice needed most guidance." (Summerly 2012, 249). The novices learnt the Latin texts of the 150 psalms by heart and only later they would completely comprehend their meaning. Summerly also recommends reading the words aloud before singing them, "not least because reading aloud was more common in the Middle Ages than it is now." (Summerly 2012, 249).

59 "Nunc in sonis, quos animant eloquia tua, cum suavi et artificosa voce cantantur, fateor, aliquantulum adquiesco, non quidem ut haeream, sed ut surgam, cum volo. (...) aliquando enim plus mihi videor honoris eis tribuere, quam decet, dum ipsis sanctis dictis religiosius et ardentius sentio moveri animos nostros in flammam pietatis, cum ita cantantur, quam si non ita cantarentur, et omnes affectus spiritus nostri pro sui diversitate habere proprios modos in voce atque cantu, quorum nescio qua occulta familiaritate excitentur. (...) ita fluctuo inter periculum voluptatis et experimentum salubritatis magisque, adducor; non quidem inretractabilem sententiam proferens, cantandi consuetudinem approbare in ecclesia, ut per oblectamenta aurium infirmior animus in affectum pietatis adsurgat. tamen cum mihi accidit, ut me amplius cantus quam res, quae canitur, moveat, poenaliter me peccare confiteor, et tunc mallem non audire cantantem.", Augustine of Hippo, Confessions, Book 10, Chapter 33.

http://faculty.georgetown.edu/jod/latinconf/latinconf.html and English translation:

http://faculty.georgetown.edu/jod/augustine/conf.pdf 
Another clue for performance of these chants lies in the fact that on solemn occasions the music would be sung slower. In fact, this is exactly the liturgical context of the first Parisian polyphonic compositions in which faster voices were written against the longer notes of the original chant. The repertoire was not always sung the same way: "the liturgical day, week and year revolved around lightness and darkness, high and low, ferial and festal; singing that did not reflect the perennially changing liturgical colours would have been as inappropriate as an immutably well-mannered vocal style.” (Summerly 2012, 251).

Somewhere in between speaking and singing, there was a kind of "song-speech", called cantillation. Aubert argues that the verbs mentioned in liturgical contexts indicate different uses of the voice:

- dicere (to speak)

- decante (to praise), psallere (to chant), recitare (to recite)

- cantare or canere (to sing) $)^{60}$

He also states that, in order to have an idea of how the singing voice sounded, it is fundamental to have some knowledge about the sound of the spoken voice (Aubert 2009, 19). We are not aware of the fact that our sound system could be completely different from the one in 1300, but "if upon hearing a recording made even half a century ago, we are often struck by how differently people spoke or sung, what scale of difference should we expect to encounter when placing ourselves a millennium in the past?" (Aubert 2009, 21). Aubert refers to the concept of the "soundscape" invented by musicologist Raymond Murray Schafer in 1977 for his book The Tuning of the World, as a broader sonorous context including all sounds in daily life. Jean-Pierre Gutton in his book Bruits et sons dans notre histoire (2000) applied this concept to a more historical context. Here, he contrasts the noisy street life with the silent monastic context. "From the Middle Ages on (...), noise is everywhere and foremost in the cities." ${ }^{\prime 61}$ After having mentioned the loud festivities on special days, he comments:

"On more ordinary days, the city is still very sonorous. Its many towers, churches or convents, change it into a 'ringing' city. (...) However, it is the small street traders who work without shop (...) that mostly animate the streets. (...) The seasonal merchants, the water carriers, milkmen, 'waferers' selling cakes, many more mingle their cries. The rurals also bring into town loaves of bread, butter, cheese." ${ }^{62}$

60 Aubert, E., "Locating the Sound of the Medieval Voice - an Analytical Framework", In Search of the Medieval Voice: Expressions of Identity in the Middle Ages, ed. Bleach, L; Närä, K.; Prosser, S. (Newcastle, 2009), p. 23

61 Original: "Dès le Moyen Age (...), le bruit est partout et d'abord dans les villes." Gutton, J.-P., Bruits et sons dans notre histoire (Paris, 2000), p. 19

62 "Dans des jours plus ordinaires, la ville demeure encore très sonore. Ses multiples clochers, d'églises ou de couvents, en font une ville "sonnante". (...) Ce sont cependant les petits métiers de la rue qui travaillent sans boutique (...) qui animent surtout les rues. (...) Les marchands des quatre saisons, les porteurs d'eau, les laitiers, les "oublieurs" qui 
The town criers announced important novelties, like proclamations, local decrees, royal births, but also the names of the deceased that day. Also the mourning expressed themselves loudly, not always welcomed, as this peculiar example demonstrates: "In the late thirteenth century, the statutes of Valréas prohibit those who follow the (dead) body in the street, the church or the cemetery screaming and whining because they "terrify the people", hinder the service and "are not useful in any way."63

Which role did the Church play in this? Gutton proposes the idea that the Church substitutes the cries of mourning with psalms, little procession bells and the tower bells. These same bells also are a call to prayer. "The bell covers thus disorderly manifestations that the Church condemns." ${ }^{64}$ The claims in favor of silence reside in the Church, and before anything else are expressed through the monastic rules. The rules that St. Benedict had set up recommend taciturnity or "restraint in words. ${ }^{" 65}$ While speech can be done with moderation, laughter was more conflictive, not only because it could be an expression of mockery or frivolity, but also because it "is a phenomenon that is expressed through the body and expressing the body. This is for monks, and clerics in general, a dangerous liaison.(...) It is presented as the most virulent and most vulgar to break the silence." ${ }^{\prime 66}$ Of course, singing is the only expression of the voice that is really valued by the Church, as a way of offering praise to God.

Within this sonorous historical context, we can imagine that the voices of monks and nuns were more polished than the voices of most common people. They spoke little and shouted less, while their voices were trained by daily singing. We do not have any certain knowledge about their singing technique and their ideal vocal sound, so this will be subject to our own imagination. For example, singing with our speaking voice or "chest voice" is not the same as singing with a more "classical" head-projected voice, the type of voice that professional classical singers use nowadays.

The American musicologist Timothee McGee has some specific thoughts on the subject. He departs from what is stated in the surviving treatises but also from the Medieval music and its demands on

vendent des gâteaux, beaucoup d'autres encore mêlent leurs cris. Les ruraux apportent aussi en ville miches de pain, beurre, fromage." Gutton, J.-P., Bruits et sons dans notre histoire (Paris, 2000), p. 20-21

63 "A la fin du XIIIe siècle, les statuts de Valréas interdisent à ceux qui suivent le corps dans la rue, l'église ou au cimetière de crier et de se lamenter car ils "terrifient le peuple", gênent l'office et "ne sont utiles en aucune façon"." Gutton, J.-P., Bruits et sons dans notre histoire (Paris, 2000), p. 22

64 "Le glas couvre ainsi les manifestations désordonnées que l'Église réprouve.”, Gutton, J.-P., Bruits et sons dans notre histoire (Paris, 2000), p. 23

65 "Celle de saint Benoît recommande la taciturnité ou «retenue dans les paroles»." Gutton, J.-P., Bruits et sons dans notre histoire (Paris, 2000), p. 23

66 “'C'est que le rire est un phénomène qui s'exprime par le corps et qui exprime le corps. C'est pour les moines, les clercs plus généralement, une liaison dangereuse. (...) Il est alors présenté comme la manière la plus virulente et la plus vulgaire de rompre le silence.”, Gutton, J.-P., Bruits et sons dans notre histoire (Paris, 2000), p. 26 
the voice. He comes to the conclusion that "the rapid articulation, pulsating notes, sliding pitches, and non-diatonic tones were a part of the basic technique, and not just unusual and colourful sounds that were introduced into a vocal style that was otherwise similar to the modern practice."67 However, some of his statements are more based upon generalizing speculation than facts:

"the obvious conclusion is that the entire medieval singing practice was a unified style in which flexible sounds and pitches had a basic and constant presence even outside the specific ornaments discussed in the treatises" and "a small amount of help can be found by investigating the vocal practices of later centuries, where some techniques are clearly related to the earlier practices and probably descended from them. In this regard it is surprising to note that a number of medieval techniques were still a part of the vocal practices as late as the Baroque period. (...) These later vocal practices probably can be accepted as evidence that once the Roman vocal style was learned, certain components of the performance technique were retained in all regions of Europe throughout the Renaissance and beyond" (McGee 1998, 118 and 126).

Both geographically and temporally, McGee overgeneralises vocal style and sound. If sound recording of classical singers from the beginning of the $20^{\text {th }}$ century are so alien to us, how can we expect that there was so much unity over more than a thousand years in the Middle Ages? The idea of a continuum of vocal practices from the Middle Ages to the Baroque is not very realistic. We can imagine that, with the slow connections within Europe, even local styles varied greatly. In fact, McGee himself quotes two Medieval sources which speak of the northerners having difficulty in performing nuances that formed part of the Roman practice: John the Deacon ( $9^{\text {th }}$ century) and Adhémar de Chabannes ( $11^{\text {th }}$ century). Both seem to express differences in the performance of the same repertoire by the people that lived more to the north than they did, although McGee's opinion is that, despite the adaption to the local practices, "the notation in the manuscripts and the theoretical treatises reflect the European-wide adoption of a common basic vocal style, whatever the local variants may have been" (McGee 1998, 122). However, neumatic notation changed into square notation in the $13^{\text {th }}$ century, and this notation did not convey any information anymore about vocal style, only about the specific notes of chant melodies.

67 McGee, T. J. The Sound of Medieval Song. Ornamentation and vocal style according to the treatises (Oxford, 1998), p. 118 


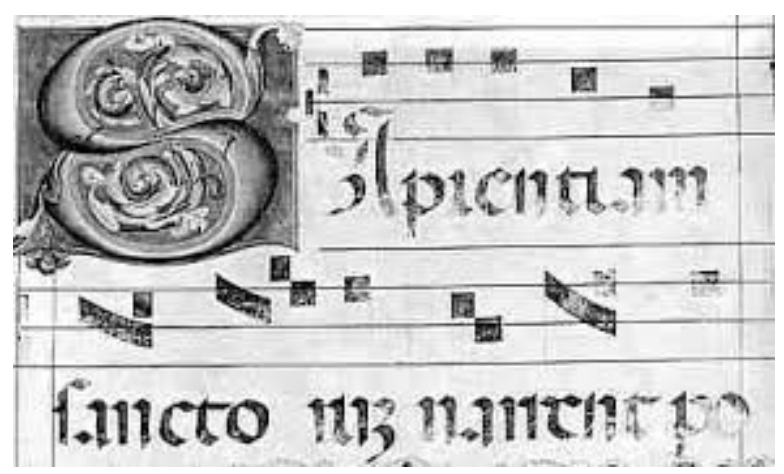

Fig. 10. An example of Medieval square

notation.

McGee continues:

"The treatises demonstrate that the Roman technique was still being taught in the early fourteenth century. Perhaps, however, the relatively large number of treatises treating the matter from c.1300 are evidence of decline rather than strength - of a need to reinforce a tradition that was no longer as well known or well observed as it had been. It is at the turn of the fourteenth century that we find contradictory opinions in France concerning the suitability of applying the chromatic and enharmonic genera to ecclesiastical music: Jerome [de Moravia, died after 1271] and [John de] Garlandia [c.1190 to c.1270] in favour, [Johannes] de Muris [c.1290 - c.1355] against. This may well be a sign of the decline of one aspect of the older practice in that region [Paris]" (McGee 1998, 126).

Paris was one of the more innovating European centres, so that would imply that in Tuscany, where Dante lived, the Roman vocal style could certainly still be active. So what is this Roman style exactly? McGee describes it as such:

\footnotetext{
"The technique involves the ability to sing with a clear (vibratoless) voice, rapid throat articulation and pulsation, slow, fast, and accelerating vibrato at variable intervals, and voice placement that alternates between a bright sound made in the front of the mouth and a dark tone from the throat. The sounds include fixed and sliding tones, diatonic and non-diatonic pitches, aspirated, gargled, and sibilant sounds, and both clear and covered tone qualities" (McGee 1998, 120).
}

He encounters these same voice qualities in the music of Eastern Mediterranean countries and India and adds that "in the absence of a better model, therefore, any and all of the Eastern vocal practices can be used to assist the modern reader to conceptualize the kind of sound that would have resulted from applying what is described in the theoretical treatises and required by the ornaments" (McGee $1998,120)$. It is indeed an interesting thought, at least for artistic purposes rather than for musicological ones. 
Another musicologist and musician, Marcel Pérès, found his examples closer to Europe: in Byzantine and in Corsican catholic chant.

\begin{abstract}
"Sometimes, focussing on some still living liturgical traditions can be profoundly beneficial. The study of Corsican religious chant, preserved by oral tradition, is valuable because it is one of the best preserved remains of the chant traditions of Post-Tridentine Catholicism. Byzantine chant can also enlighten us in a fruitful way to understand the vocal manners referred to by the first notations of Roman chant and some medieval theorists." ${ }^{, 68}$
\end{abstract}

Still, we must bear in mind that traditions are organic developments in which practices gradually keep on changing. The performance practice within a tradition will not be the same in the $20^{\text {th }}$ century as it was in the $13^{\text {th }}$ century, most probably not even as it was in the $19^{\text {th }}$ century. However, just as the Indian and Persian techniques can give us artistic ideas, so can Corsican, Byzantine and Mozarabic chant, and it must be said that, at least geographically, they are closer. As to the voice projection, he argues that "the spiritual can not be considered solely as a combination of a text and a melody. The act of liturgical chant is primarily a vocal conduct, that is to say, a particular manner of conducting the voice, to enter the sound and inhabit the space and time of celebration. The melodic contours are only the result of this attitude." ${ }^{69}$ He believes that the singers sang with a deeper voice than nowadays, with "a strong, resonant voice extensively using all the resources of art of the ornamentation". It is quite the opposite of the ideal that Solesmes sought in their "restoration" of Medieval chant, a voice "characterized by its high-implied-height angelic softness, lack of tone colour and its rejection of any ornamentation seen as futile and superfluous". ${ }^{70}$ His assumption that voices were lower, because "the pitch of ecclesiastical chant was, in France, one tone lower than the current pitch" ${ }^{71}$, might not be correct: historically, almost each location had its own pitch, witnessed by the historical instruments that have survived. Indeed, French courtly instruments from the $18^{\text {th }}$ century are in $\mathrm{a}=\mathrm{Hz} 392$, one tone lower than our $\mathrm{a}=\mathrm{Hz} 440$, but that was just one place at one moment in time. Many instruments from the earlier centuries are even in a higher pitch than

68 "Parfois, l'attention portée à certaines traditions liturgiques encore vivantes peut être profondément bénéfique. L'étude du chant religieux corse, conservé par la tradition orale, est précieuse car il représente l'un des vestiges les mieux conservés des traditions cantorales du catholicisme posttridentin. Le chant byzantin peut également nous éclairer de manière féconde pour comprendre les manières vocales auxquelles font référence les premières notations du chant romain et certains théoriciens médiévaux.”, Pérès, M., Les Voix du Plain-chant (Paris, 2001), p. 162

69 "Le chant religieux ne peut être considéré uniquement comme l'association d'un texte et d'une mélodie. L'acte du chant liturgique est d'abord une conduite vocale, c'est-à-dire une manière particulière de conduire la voix, d'entrer dans le son et d'habiter l'espace et le temps de la célébration. Les contours mélodiques ne sont que la résultante de cette attitude.", Pérès, M., Les Voix du Plain-chant (Paris, 2001), p. 163

70 “(...) une voix forte et timbrée utilisant abondamment toutes les ressources de l'art de l'ornementation.", "Dans la pensée de Solesmes, la voix parfaite se caractérise par sa hauteur élevée-sous-entendu angélique-sa douceur, son absence de timbre et son refus de toute ornementation considérée comme futile et superfétatoire.”, Pérès, M., Les Voix du Plain-chant (Paris, 2001), p. 163

71 "le diapason du chant ecclésiastique était, en France, un ton plus bas que le diapason actuel”, Pérès, M., Les Voix du Plain-chant (Paris, 2001), p. 163 
$\mathrm{a}=\mathrm{Hz} 440$. Thus, we do not know if chant was lower or higher in the Middle Ages, at any specific time or place. We must also keep in mind that Medieval notation only shows relative pitch, not absolute pitch, so any chant can be sung at a pitch that is comfortable for the singers (Wilson 1990, $88)$.

Why did the Solesmes monks search for this high-pitched, non-ornamented sound ideal that is still in vigour today? It was not the sound they were used to, in fact, their own living tradition was one of adding ornaments:

"It must be said that in the $19^{\text {th }}$ century the traditional chant was still very ornamented, the singers had preserved this knowledge. But it was considered that these ornaments were superfluous additions of the $17^{\text {th }}$ and $18^{\text {th }}$ centuries, which were considered the worst periods of the decadence of liturgical chant. How to explain then that the Roman manuscripts of the $11^{\text {th }}$ century offered an even more developed ornamentation? (...) These scholars of the late $19^{\text {th }}$ century could not understand how a repertoire being unanimous in its written versions could present differences in their interpretations. Because in their mind, formed by the theory of their time, everything that is written corresponds to a sound event. This was the basic principle of the theory of the $19^{\text {th }}$ century. But when we go back in time, from the $18^{\text {th }}$ century, it appears that the use was common among musicians to consider the written word as a frame around which all kinds of fireworks could be developed, designed to enhance the melodies." ${ }^{72}$

Indeed, from the $19^{\text {th }}$ century on, musical scores have been perceived as performance scores, in which indications on dynamics, speed, pitch and articulation are precisely annotated, while early scores were frameworks or skeleton scores which only gave the basics of the musical piece, supposing that the performer knew the stylistic and conceptual conventions, such as ornamentation, added sharps or flats, articulation, and so on.

We are not sure about the specific ornaments that might have been applied to plainchant in Florence around 1300 but according to the findings of McGee, "we can be fairly sure that the neumes that were retained in graphic style in the later manuscripts (quilisma, oriscus, plica) were still performed in the earlier ornamental style. For those ornamental neumes that were translated into stable pitches

72 "Il faut dire qu'au XIX' siècle le plain-chant traditionnel était encore très orné, les chantres avaient conservé ce savoir-faire. Mais on considérait que ces ornements étaient des ajouts superfétatoires des XVII' et XVIII' siècles, alors considérés comme les pires moments de la décadence du chant liturgique. Comment alors expliquer que les manuscrits romains du XI' siècle offraient une ornementation encore plus développée? (...) Ces chercheurs de la fin du XIX' siècle ne pouvaient comprendre comment un répertoire unanime dans ses versions écrites pouvait présenter des divergences dans l'interprétation. Car dans leur esprit, formé par le solfège de l'époque, tout ce qui est écrit correspond à un événement sonore. C'était le principe de base du solfège du XIX' siècle. Or, lorsque l'on remonte dans le temps, dès le XVIII' siècle, il apparaît que l'usage était commun chez les musiciens de considérer la chose écrite comme une trame autour de laquelle il était possible de développer toutes sortes d'artifices destinés à agrémenter les mélodies.", Pérès, M., Les Voix du Plain-chant (Paris, 2001), p. 37-38 
(the stropha neumes, pressus, etc.) we cannot be sure." (McGee 1998, 126). Scholars are not sure about the exact meaning of the ornaments that remained intact within square notation.

Let us see what musicologist and chant expert David Hiley can tell us about these ornaments. First of all, the quilisma ("rolling" in Greek) is a serrated note form, normally found between an ascending third.

\footnotetext{
"Aurelian of Réôme (fl ?840-50) spoke of it as a trembling and rising sound (GerbertS, i, 47), and most modern writers have not ventured beyond this. Tack suggested that it concerns a method of voice production no longer practised. Other studies (Wiesli, Cardine) have concentrated on the degrees of the scale on which it is most commonly found, suggesting that it may have been used for tonal orientation." ${ }^{.73}$
}

The second ornament, the oriscus, is a note shape with a kind of comma-like appendix. It is not sure if it involves micro-tones, a stress on the following note or something else, an uncertainty that Hiley indeed confirms. ${ }^{74}$ The last ornament, the plica ("fold" in Latin) is a note with two stems, like a U or an inverted U. In the words of David Hiley,

"the plica is a two-note neume, containing the pitch where the plica was placed on the staff plus a higher ('U' shape) or lower (inverted ' $U$ ') note. The second note was semi-vocalized to provide a passing or anticipatory note before the next pitch. The semi-vocalization was most commonly practised on the consonants ' 1 ', 'm', 'n' and 'r', before another consonant (2452 out of 3500 cases in the study in PalMus, 1st ser., ii, 1891), sometimes when they were the only consonant between vowels; on the second vowel of diphthongs; on the consonant pair 'gn'; sometimes on ' $d$ ' and ' $t$ ' at the ends of words (particularly et, sed, ut); sometimes on soft 'c' and soft ' $\mathrm{g}$ ' (before 'e' and 'i'); sometimes also on ' $d$ ', 's', 't' and ' $x$ ', before other consonants; and on ' $i$ ' or ' $j$ ' when used as a consonant."'75

73 Hiley, D., "Quilisma." Grove Music Online. Oxford Music Online. Oxford University Press, http://www.oxfordmusiconline.com/subscriber/article/grove/music/22699 [accessed June 18, 2015]

74 Ibid., "Oriscus." Ibid http://www.oxfordmusiconline.com/subscriber/article/grove/music/20467 [accessed June 18, 2015]

75 Ibid. "Plica." Ibid. http://www.oxfordmusiconline.com/subscriber/article/grove/music/21942 [accessed June 18, 2015] 


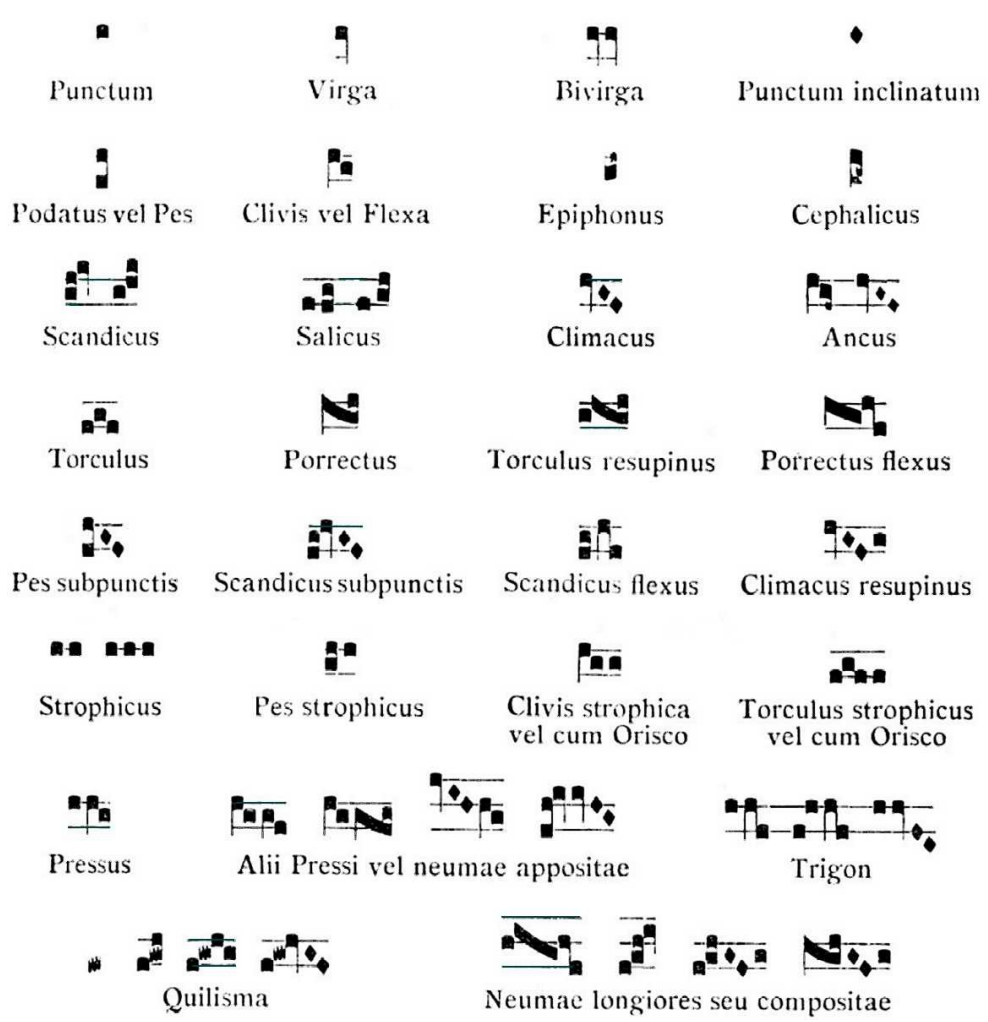

Fig. 11. An overview of various neumes.

Now that we have observed that Medieval voice techniques and ornamentations were apparently very different from the way most singers approach Medieval repertoires nowadays, there is still another important aspect of performance, pointed out by Marcel Pérès: the change from singing from the choir book on the lectern to smaller books supported by the singers themselves.

"From the late twelfth century, the Catholics, previously singing by heart, took the habit of singing from books, large enough so that everyone could simultaneously read the contents. These books were placed on a lectern (...). These large books were replaced at the beginning of the $20^{\text {th }}$ century by small books, eminently practical, but provoking a different way of standing during the act of singing. The books placed on a lectern forced the singers to lift their heads and therefore to stand upright and open their rib cages, and so to project their voices with a vigorous blast upwards. Wearing capes, in the exercise of the most solemn liturgies would reinforce this attitude. Conversely, the little book brings the choir to head down to read a tiny notation, back bent completely closes the rib cage, and the voice, supported by a 
compressed breath, is directed downward."

Connecting this to a voice which contains more harmonics, a somewhat more metallic voice like in Indian music would make sense for sparing the voice and projecting it toward the audience. In modern Western singing, there is a technique called "twang" which searches for a more metallic quality and does not put so much strain on the voice and which might also be taken into consideration for performance of the Medieval chant repertoire.

We have seen that we possess very little knowledge about the actual sound of the Medieval types of voices. We cannot generalize the singing style for the whole of Europe. It should not be forgotten that the native language of a singer also has considerable influence on his singing and pronunciation. Neither can we assume that the Medieval voice has been the same throughout more than a millennium. We can assume that ornaments did play a role in plainchant, although we are not very sure about what kind of ornaments were used around 1300 in Italy. As McGee stated, some of the Medieval music demands some specific voice qualities: a clear, vibratoless voice which is agile enough in its throat articulation and pulsation, while being able to produce a very controlled kind of vibrato on specific notes. We must keep in mind that this is not necessarily all Medieval music but it is at least a little bit of information that can help us to come closer to the sound of the singing voice around 1300 in Toscane. This city was close to Rome and it is probable that its singing style was much more similar to the Roman style than to the French one. Furthermore, we could think of a slightly metallic voice rich in overtones that would project well and not put too much strain on the voice during the many hours of singing. We certainly have to try to let go of the stereotype of the Medieval voice that was created by Solesmes monks at the end of the $19^{\text {th }}$ century. We do not necessarily have to abandon it entirely (although it seems that historical evidence points that way), but at least we should step out of our unconscious presuppositions and make an artistic decision based on the informations we do have access to.

76 "Depuis la fin du XII' siècle, les catholiques, qui auparavant chantaient par cœur, prirent l'habitude de chanter sur des livres, nécessairement de grande dimension, afin que plusieurs puissent en lire simultanément le contenu. Ces livres étaient posés sur un lutrin (...). Ces grands livres furent remplacés, au début du XX' siècle, par des petits livres, éminemment pratiques, mais qui induisirent une tout autre manière de se tenir pendant l'acte du chant. Les grands livres posés sur un lutrin obligeaient les chantres à lever la tête, et donc à se tenir droits et à ouvrir leurs cages thoraciques, et ainsi à projeter leur voix d'un souffle vigoureux vers le haut. (...) A l'inverse, le petit livre amène les choristes à baisser la tête pour pouvoir lire une notation minuscule, le dos courbé ferme complètement la cage thoracique, et la voix, soutenue par un souffle comprimé, est dirigée vers le bas.", Pérès, M., Les Voix du Plainchant (Paris, 2001), p. 165 


\subsection{Notation and its Relationship with Rhythm, Improvisation and Polyphony}

In the $8^{\text {th }}$ century Pippin the Younger (c.714-768) was the first Carolingian to become Frankish king thanks to the help of the Pope, to whom he had made the promise to support him in his power. This Frankish-Papal alliance was to be reinforced through faith, and so the Roman ritual with its music was imposed on the Gallican, although in reality the two became merged into what we call Roman-Gallican chant. His son Charlemagne, who became Holy Emperor in 800, reinforced the establishment of this liturgical repertoire. Because of his good relation with the Byzantine Empire, under his reign there was also an interchange of music and musicians with Byzantium (Wilson 1998, 11). Meanwhile, the Roman chant - not having been in contact with the Gallican chant would continue to exist as an oral tradition.

While Greek letter notation had been used in the earlier Roman Empire, the transmission of these early Christian chants was completely oral. Greek letter notation had been a notation of separate notes, just like in our system, but the first Christian notation focussed on contours of melodic lines. It was meant as a mnemonic for learning the great amount of chants by heart. According to Wilson,

"this accords well with the medieval concept of melodic transmission. To the medieval mind, melodic identity meant identity of contour, not a literal identity of notes. An ascent of a fifth and a descent of a third in one performance could be matched by the ascent of a fourth and the descent of a second in another. This identity of generalized contour rather than exact pitched content continues throughout the medieval era, and later precisely pitched manuscripts seldom match each other exactly and may display a bewildering variety of incidental and unimportant variants" (Wilson 1998, 24).

We have seen earlier that, as a mnemonic for these melodic lines, neumatic notation was used from the $9^{\text {th }}$ century on. The first neumes, called non-diastematic neumes, did not indicate any difference in pitch between the tones. Later on, diastematic neumes appeared, and when lines were added to these neumes, they could be associated with real intervals. At the beginning of the $11^{\text {th }}$ century, Guido of Arezzo proposed a red line for the $\mathrm{F}$ and a yellow one for the $\mathrm{C}$. Through time two more lines were added to the F-line and $\mathrm{C}$-line, and the $\mathrm{C}$ and $\mathrm{F}$ became clefs. By the $12^{\text {th }}$ century, square notation began to replace the neume notation, which implied a change from performance-oriented notation to pitch-oriented notation. As we have seen before, of all the special performance indications, only the quilisma, the oriscus and the plica or liquescent appeared in the square notation. The transition from neumes to notes took a long time, Wilson states that "most eleventhand twelfth-century manuscripts still use staffless diastematic neumes, indicative of the continued reliance on memory in medieval musical life" (Wilson 1990, 88). 


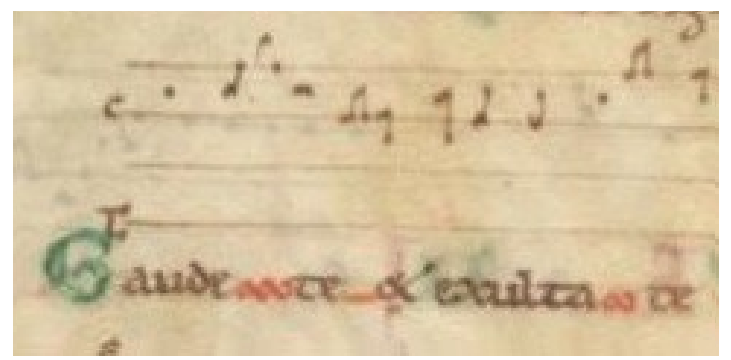

Fig. 12. Fragment from Gaudete et exsulate, Antiphonary from Saint-Maurdes-Fossés (12th century), 200v
Here we see $12^{\text {th }}$ century diastematic neumes with four lines, where the F-line and C-line are still indicated.

The appearance of reading from a book on a lectern is connected to the transition to square notation, which had to be clear and big enough to be read by everyone from a distance. Pérès comments that the first written testimony of the use of a lectern is about the Magnus liber organi in the Nôtre Dame, and it might very well be that square notation originated at that same place, spreading in the $13^{\text {th }}$ century throughout Europe (Pérès 2001, 50-51). The fact that the chants did not have to be memorized anymore secured the stability of the repertoire because it would not be altered due to faulty memory. Also, the repertoire could be extended without difficulty because it did not have to be taught by heart anymore. Finally, the precision in pitch and later on in rhythm gave way to more complex forms of polyphony.

The first testimonies of polyphony, treatises dating from the $9^{\text {th }}$ century, indicate that there was a practice of singing in parallel fifths, fourths and octaves. This is called parallel organum. They also mention so-called oblique organum, where both voices move in parallel and oblique intervals and come together in a unison at the last note (Wilson 1990, 98-99). These practices might have existed already in the $8^{\text {th }}$ century or before. Parallel organum would exist until the $16^{\text {th }}$ century as an improvised organum practice within liturgy. In the $13^{\text {th }}$ and $14^{\text {th }}$ centuries this practice would consist of parallel movement in fifths, and in the $15^{\text {th }}$ century the so-called "fauxbourdon" would consist of parallel sixths and fourths below the melody. This is the easiest form that could be performed by beginners. As Wilson argues,

"its effect to us may seem a bit sterile, but its effect within a liturgical service otherwise sung unison and heard by listeners not conditioned by a millennium of harmonic complexities, was great. Performed slowly, as the Scholia enchiriadis specifies, in the resonance of a stone church, the result can be impressive. Sonorous doubling can enrich a chant through pure chant. Besides, there was spontaneous ornamentation of one or more of the upper lines, a practice specifically discussed by 13th- and 14thcentury theorists and undoubtedly used long before" (Wilson 1990, 99). 
This is essential information for a possible interpretation of the chants mentioned in the Divina Commedia. However, contrary motion was probably used within the organum practices in the Santa Reparata, the former cathedral of Florence, where Dante would have heard the chants. It appeared for the first time at the end of the $11^{\text {th }}$ century, in the so-called free organum of Southern France or Aquitaine, being a thriving culture by then. Aquitanian culture, known for its art of courtly love, fomented the music and poetry of the troubadours. Simultaneously, in the sacred repertoire it witnessed some major developments, with contrary motion as its essential concept. Contrary motion was the basis for all later Western music, because it led to melodic independence of the different voices. But again, Wilson tells us that "there is every evidence that the earlier simple forms of organum continued throughout the succeeding centuries as an improvised form, seldom committed to writing" (Wilson 1990, 116). Until now, all these early polyphonic notated versions would be neume-to-neume or note-to-note organum: the parallel, oblique or contrary motion was always from one note to the other. The main reason for this is that rhythmic notation did not exist yet, so the different voices could not be rhythmically independent from each other. Still, in the Aquitanian sacred repertoire from 1100 on, we already encounter groups of faster notes against one note in the other voice: flourishes or even melismas, longer groups of more than six notes. They do not have any rhythmic notation, so the most logical rhythm would be giving the syllables the same length as in natural speech. Wilson quotes the Medieval music theorist John of Affleghem (Johannes Afflighemensis, fl. c.1100): “Although I have set a syllabic organum against syllabic motion, it is allowable for anyone making organum to double or triple the notes over the syllabic progression, or to expand then suitably in any way whatsoever" (Wilson 1990,149). His remark shows that the Aquitanian florid and melismatic notated compositions record a practice derived from improvisation. This is, again, relevant information about the practices in plainchant that could have been present around 1300, a more "conservative" practice by then which could perfectly have survived in the improvised organum practice.

Aquitaine also saw the first cantus firmus settings, where the notes of the original chant are stretched to tremendously long notes, above which the other voice is moving in rapid florid or melismatic movement, sometimes with a new text. Adding new music to a pre-existing chant is called a trope and was applied as early as in the $9^{\text {th }}$ century. This can refer to new melismas without text, adding a new text to a pre-existing melisma, or adding both new text and music. Wilson describes the motivation behind this work method when he argues that

"the great medieval inclination was not to discard but to improve - not to challenge received learning but to explain or 'gloss' it, even if that gloss subtly changed the received meaning. So it was with the 
service of the worship of God, a desire not to change but to embellish and thus make even more meaningful the texts of the Mass and Office" (Wilson 1990, 88).

The Parisian Nôtre Dame school was the place where eventually the rhythmic modes were created. Around the 1160s and 1170s, Leoninus composed the works of the Magnus liber organi, while Perotinus wrote his compositions at the end of the $12^{\text {th }}$ century, just at a time when Gothic architecture arose. If we are to make a connection between Gothic architecture and the "Ars nova" music of that time - aware of the fact that Gothic architecture was never fully accepted in Italy - we could imagine that the Parisian musical style did not find acceptance there either. In Florence, the Santa Reparata was a relatively small cathedral, and in 1296 the first cornerstone was laid for the current Cattedrale di Santa Maria del Fiore. This would take 140 years to be built, so Dante has never seen the larger building.

In Paris, simple ternary rhythmic formulas developed, mostly in trochaic rhythm (long-short). At the beginning of the $13^{\text {th }}$ century also other kinds of rhythms arose, which resulted around 1240 in the codification of the rhythmic modes, the first systematic rhythmic notation. There were six modes:

1. A long and a short (trochaic)

2. A short and a long (iambic)

3. A long and two shorts (the last short is a bit longer)

4. Two shorts and a long (the second short is a bit long; mode that was seldomly used)

5. All longs (the beat itself)

6. All shorts (three within one beat)

All these rhythmic modes were ternary. In Italy in the $14^{\text {th }}$ century binary modes were designed, which made the later $14^{\text {th }}$ century Italian music possible. The problem with the rhythmical modes was that the length of each note depended on the notes surrounding it, and thus it could be ambivalent. 


\begin{tabular}{|c|c|c|c|c|c|}
\hline Mode & Original Notation & Meaning & & nbols & Modern Equivalent \\
\hline Mode I & 70 & long-short & $\longrightarrow \smile$ & Trochaic & p \\
\hline Mode II & - 7 & short-long & & lambic & $D P$ \\
\hline Mode III & 70 & long-short-short & & Dactylic & Pp \\
\hline Mode IV & $\mathbf{\square}$ & short-short-long & & Anapaestic & DPP \\
\hline Mode V & 79 & long-long-long & - & Spondaic & pp \\
\hline Mode VI & a $\mathbf{\square}$ & short-short-short & & Tribrachic & $D D D$ \\
\hline
\end{tabular}

Fig. 13. The rhythmic modes.

The Parisian rhythmic notation adopted the square notation that was already in use for plainchant since the $11^{\text {th }}$ century. Thus, it seems as if plainchant from the $13^{\text {th }}$ and $14^{\text {th }}$ centuries contains rhythmic modes, but only in the new French polyphonic style a rhythmic meaning was given to patterns that in plainchant did not have any specific rhythmic significance. In plainchant, apparently already since 1050 the rhythm was one of equal note values (Wilson 1990, 156).

Nevertheless, according to Jerome de Moravia, there were certainly traditional rules for rhythmic performance of plainchant. He indicates that all notes are brief, except five exceptions that are long:

1. The first note of the chant, on the condition that this note is the finalis of the mode, its tonic or keynote.

2. The second note of a syllable which has more than one note (except if it is next to another of these five exceptions)

3. the plica longa, a plica with a longer tail at its right:

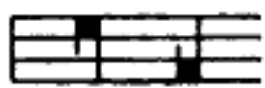

It can also appear in combination with other notes:

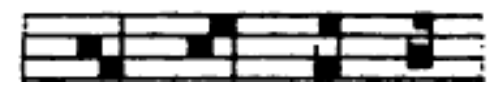

When the longer tail is on the left, it is short:

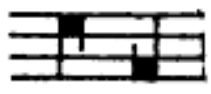

4. the penultimate note.

5. the last note before a break, lasting longer or shorter depending on its position at the end of a word or at the end of a sentence. 
He also wrote that each of these long notes "receives preceded reverberation, that is to say a sort of port-de-voix" (or apoggiatura). ${ }^{77}$ Jerome also wrote about the "French way" of rhythm, which basically consists of dividing the notes into a ternary rhythm according to the accents of the music, and which according to himself "many nations find agreeable", although he specifies that the other way is the more traditional way of singing (Pérès 2001, 64). He also argued that in France the "organum modes" could be used as well for plainchant, referring to the new rhythmic modes used for French polyphony, although it is not sure if this has been done in practice. All these ways of singing have different tempos according to the degree of solemnity of the liturgical service. On Sundays and feast days the tempo would be slower in order to create more solemnity than on normal days (Pérès 2001, 65). We can now imagine that in the context of this solemnity, the original chant took on the role of slow cantus firmus above which another fast voice was being improvised or composed. An interesting detail is that Jerome separates the French from "all other nations" in their use of the enharmonic quarter tone (there would be a difference of a quarter-tone between a D flat and the higher $\mathrm{C}$ sharp, for example) and their frequent changing of whole tones into semitones and the other way around (Pérès 2001, 65). This shows practices that were not written down in the music. It is probable that in Italy there were different unwritten conventions.

Liturgical musical practice in Italy around 1300 was probably relatively "conservative" from a Parisian point of view, just as its churches would not be as Gothic as the Parisian ones. The architectural style in Italy was actually a compromise between Roman and Gothic style, influenced by the simple fact that, in Italian summers, large windows would make the temperatures impossible inside of the church. The possibility exists that in Florence the influence of the Roman chant was considerable and that the Parisian style was too foreign to them to be really appreciated, although this is just another speculation. The kind of rhythm described by Jerome of Moravia is a useful indication for the possible practice in Florence: a regularly flowing rhythm with some longer notes. The polyphony that Dante might have heard would be an improvised one in either parallel movement with small ornaments in the different voices or in simple contrary movement.

77 Pérès, M., Les Voix du Plain-chant (Paris, 2001), p. 64; and http://remacle.org/bloodwolf/eglise/jeromemoravie/musique.htm [accessed 20-6 2015] 


\section{CHAPTER 2 - EXPERIMENTAL MUSIC THEATRE}

\subsection{Historical overview}

After the survey of the research areas of Early Music (Historically Informed Performance) in chapter 1, the field of experimental music theatre is discussed in chapter 2. Our research centres on how Historically Informed Performance practice influences a music theatre creation and performance, based on Dante's Commedia. Therefore, it is essential to define contemporary music theatre and study its predecessors. We have also mentioned some general initiatives within this field, but it must be noted that the field is too large for a discussion encompassing all its various forms. In chapter 6 we will discuss the primary musical-theatrical references that were relevant to the creation of Incipit.

Incipit is an experimental music theatre work, an art form "between the arts" where many art forms can interact and merge. We shall briefly discuss the historical initiatives of musical-theatrical genres which finally led to its rise, in order to get a more complete view of its background and development. The combination of theatre and music is certainly not new: they were inseparable in the Ancient Greek drama, the words being sung and acted in the plays by the same person, who sang, acted and danced. In the Middle Ages the Roman theatres had been closed, but theatre and music continued to be combined - although in a less integrated manner than in the Greek drama - in religious dramas and in the art of the travelling minstrels. From the late $16^{\text {th }}$ century on, the opera became the main genre to combine theatre, music and sometimes even dance. The $20^{\text {th }}$ century would generate genres like the musical, performance, chamber opera, and other genres in between the established arts. While the musical, upcoming in the sixties, became a commercial form with a fixed framework, the other interdisciplinary genres have always been more experimental, flexible and rather small-scale.

\section{Wagner and his Gesamtkunstwerk (Total Artwork)}

With Richard Wagner (1813-1883) a new concept of the union of all the arts was born: the Gesamtkunstwerk, as he defined it. The inspiration was the Ancient Greek drama where music, dance and theatre were combined. Instead of being separate genres, they were all united into one Total Artwork. ${ }^{78}$

78 Barry Millington. "Gesamtkunstwerk." The New Grove Dictionary of Opera. Grove Music Online. Oxford Music Online. Oxford University Press, http://www.oxfordmusiconline.com/subscriber/article/grove/music/O011027 [accessed April 19, 2015] 


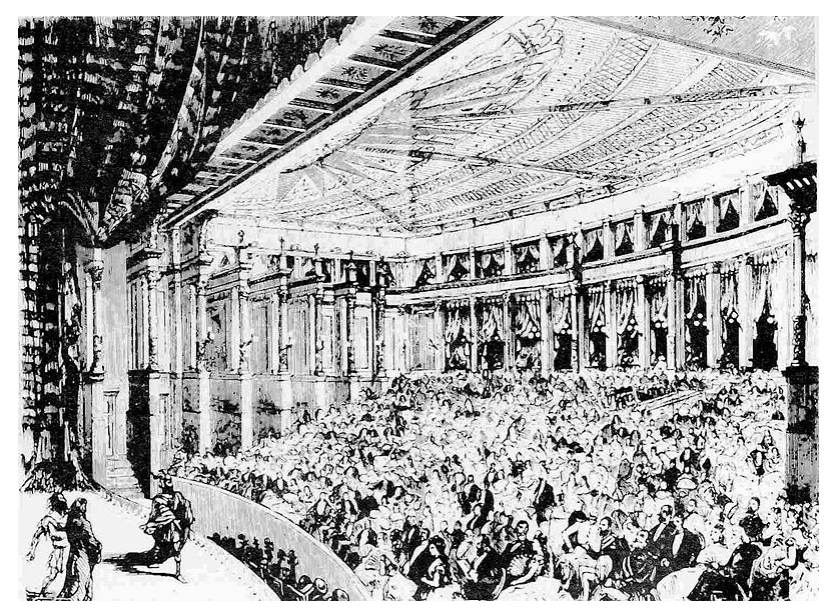

Fig. 14. The first performance of Wagner's

Rheingold in 1876.

This meant that all the disciplines had to express the same concept: they should not contrast but reinforce each other. Wagner was interesting in the middle ground between speech and song, which is the reason why his operas are not divided into recitatives and arias, like in the traditional opera, but are a continuous totality in uninterrupted progression. The Leitmotiv is also an invention of Wagner: a melody which always accompanies the same character or the same situation, thus creating a kind of symbolism. The audience had to be completely immersed in the story and the ambience, so Wagner chose to situate the orchestra under the stage, invisible to the audience. He did not only write his operas but he also staged them himself. On a musical level, there are so many subsequent modulations in his works that one cannot speak of tonality in the traditional sense of the word, but rather of pan-tonality. ${ }^{79}$ Although the composer Arnold Schönberg (1874-1951) by then had not yet implemented his sharp rupture with tonality right into atonality, both Wagner and other contemporaries were already moving away from tonality. His use of the Leitmotiv, a particular melody accompanying a determined character in the opera, was a way of creating an intimate link between the music and drama. The ideas of Wagner about the Total Artwork had a profound impact on the world of theatre and opera. It motivated the rise of some very interesting and innovating theatrical ideas.

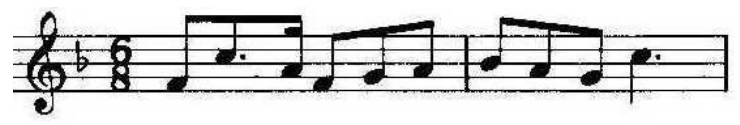

Fig. 15. Leitmotive associated with the hero Siegfried in Wagner's opera.

79 Pantonality: “A term coined by Rudolph Réti (...). Pantonality is characterized chiefly by the notion of "movable tonics'; that is, it recognizes and makes use of tonal relationships in intervals, melodic figures and chord progressions without defining, or even implying, a key centre in any large-scale sense.”, William Drabkin. "Pantonality." Grove Music Online. Oxford Music Online. Oxford University Press, http://www.oxfordmusiconline.com/subscriber/article/grove/music/20835 [ accessed April 20, 2015] 


\section{Adolphe Appia and his rhythmic spaces}

The stage designer and musician Adolphe Appia (1862-1928) designed several innovative stagings for Wagner's works and had a great influence due to his concepts of space and lighting. For Appia, the base of the representation was not the text but the rhythm of the music. The rhythm could be the base of the actor's movements and gestures and it could also determine the design and the lighting. This was how, according to Appia, all disciplines would be merged in a natural way. ${ }^{80}$ As art scholar Manfred Boetzkes notes, "Appia is the father of non-illusionist musical theatre. All anti-realistic tendencies of the moderns can more or less be traced back to him." ${ }^{\prime 1}$

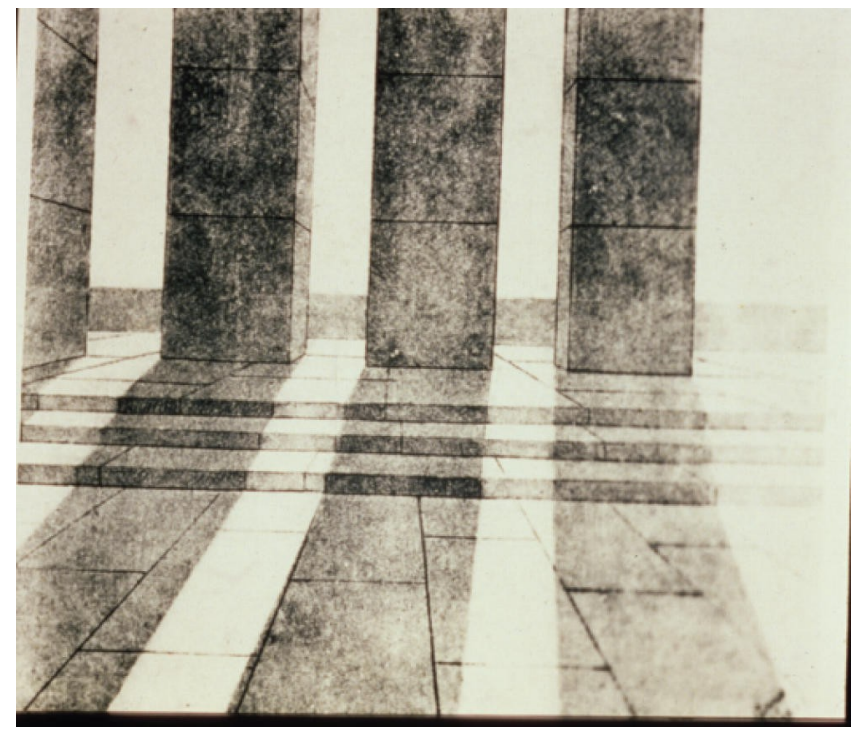

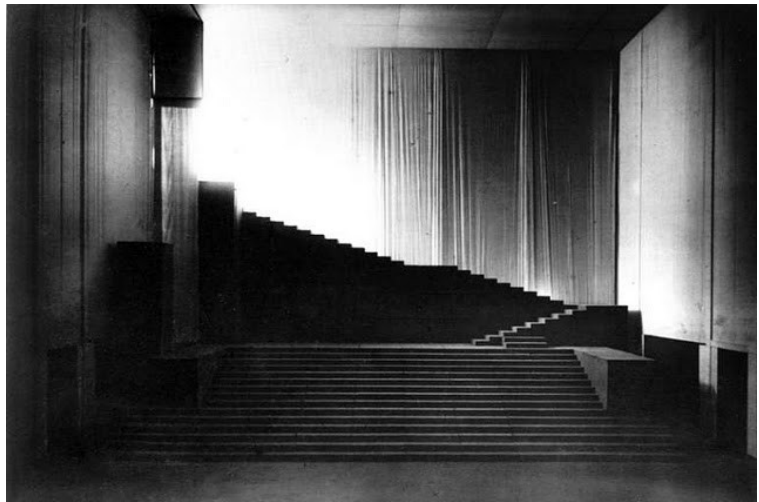

Fig. 17. Another of Appia's design for his rhythmic spaces

Fig. 16. Appia's design

\section{Meyerhold and the musical use of language}

The stage director Vsevolod Meyerhold (1874-1940) thought that it was not the rhythm of the music which had to be the basis of the work but the rhythm of the text. The musical use of language resulted into an emphasis on the theatricality and artificiality of a theatre work. ${ }^{82}$ The ideas of Appia and Meyerhold opened the possibility that musicality could also play a role on other levels of the theatrical performance, thus amplifying the theatrical possibilities of music, for example, a musical use of the dramatic text, a theatrical work based on musical rhythm or a movement of the actor based on the rhythm of a text.

80 Coppens, E. De balans tussen vorm en inhoud (The balance between form and contents) (University of Amsterdam, 1998)

81 Manfred Boetzkes. "Appia, Adolphe." Grove Music Online. Oxford Music Online. Oxford University Press, accessed October 1, 2015, http://www.oxfordmusiconline.com/subscriber/article/grove/music/01110.

82 Beacham, R. Adolphe Appia: Artist and Visionary of the Modern Theatre (London: Routledge, 1994), p.294 


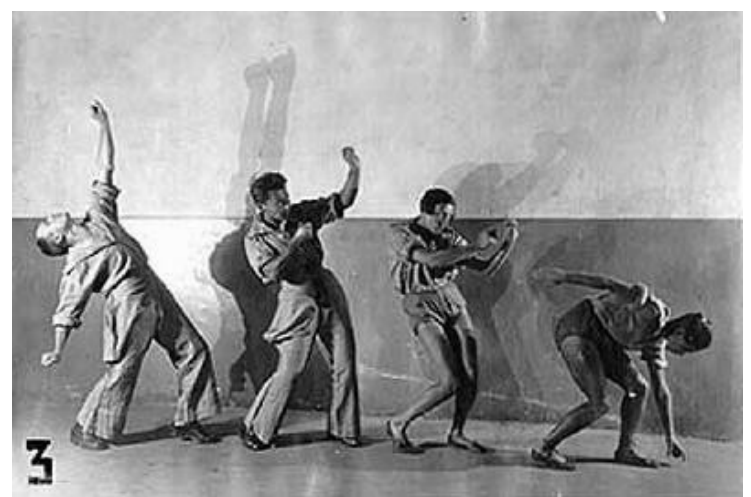

Fig.18 Study of a bow shot: sequence presented by Meyerhold's students

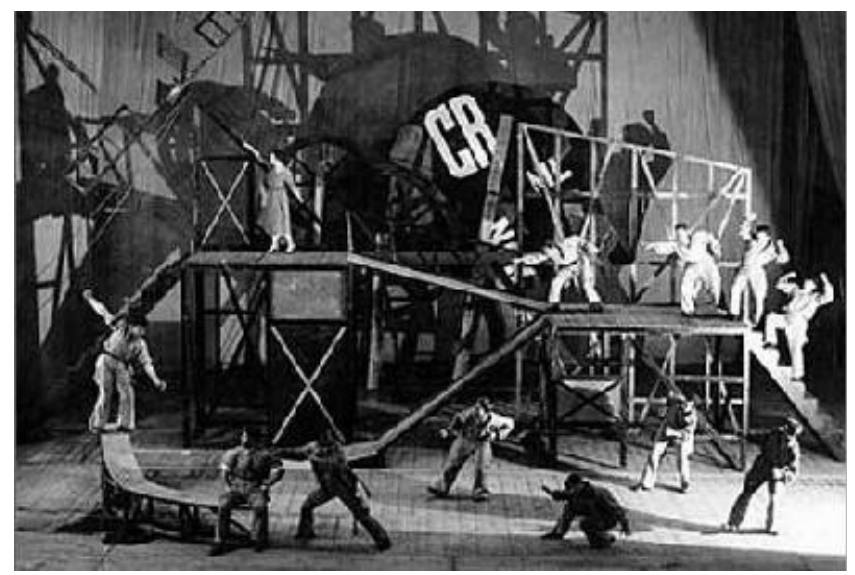

Fig. 19. Meyerhold: Le cocu magnifique (1928)

\section{Kandinsky and the "Monumental Artwork"}

At the beginning of the $20^{\text {th }}$ century, the interest of painters and sculptors in theatre, who approached the idea of the Total Artwork from the perspective of the visual arts, were another factor in the extension of the limits of theatre. The artists "seek autonomy of the scenic aspect through the very plasticity of the theatrical elements (light, movement, sound, costumes, decor). These experiences aim for the achievement of the 'Total Artwork', a heritage from the Romantic tradition, which only end when the idea of a 'total theatre' is no longer seen as a tool for major social transformations or as a reflection of an integrated society. ${ }^{" 83}$ The visual artists who entered the discipline of theatre especially Futurists and Dadaists - proposed theatrical experiences in which the text was not the dominant discipline. They gave priority to the visual components of theatre such as light and colour, or the musical components. In order to break with the chronological structure, they turned to scenic references like circus, acrobatics, variété and film. Their performances usually had the structure of a show consisting of separate scenes. They organized soirées where they theatricalized actions of daily life and sought direct contact with the audience. This was the first time in history that artists of different disciplines worked together and influenced each other, reaching a new interdisciplinary art form.

83 "buscan la autonomía de lo escénico a través de la plasticidad propia de los elementos teatrales (luz, movimiento, sonido, vestuario, decorado). Estas experiencias pretenden la consecución de la obra de "arte total", herencia de la tradición romántica, que sólo se terminará cuando se abandone la idea de un "teatro total" como instrumento para las grandes transformaciones sociales o como reflejo de una sociedad integrada.", Botella Mestres, M., De la escultura al teatro, del teatro a la escultura: influencias y confluencias (Valencia, 2005), p. 118 


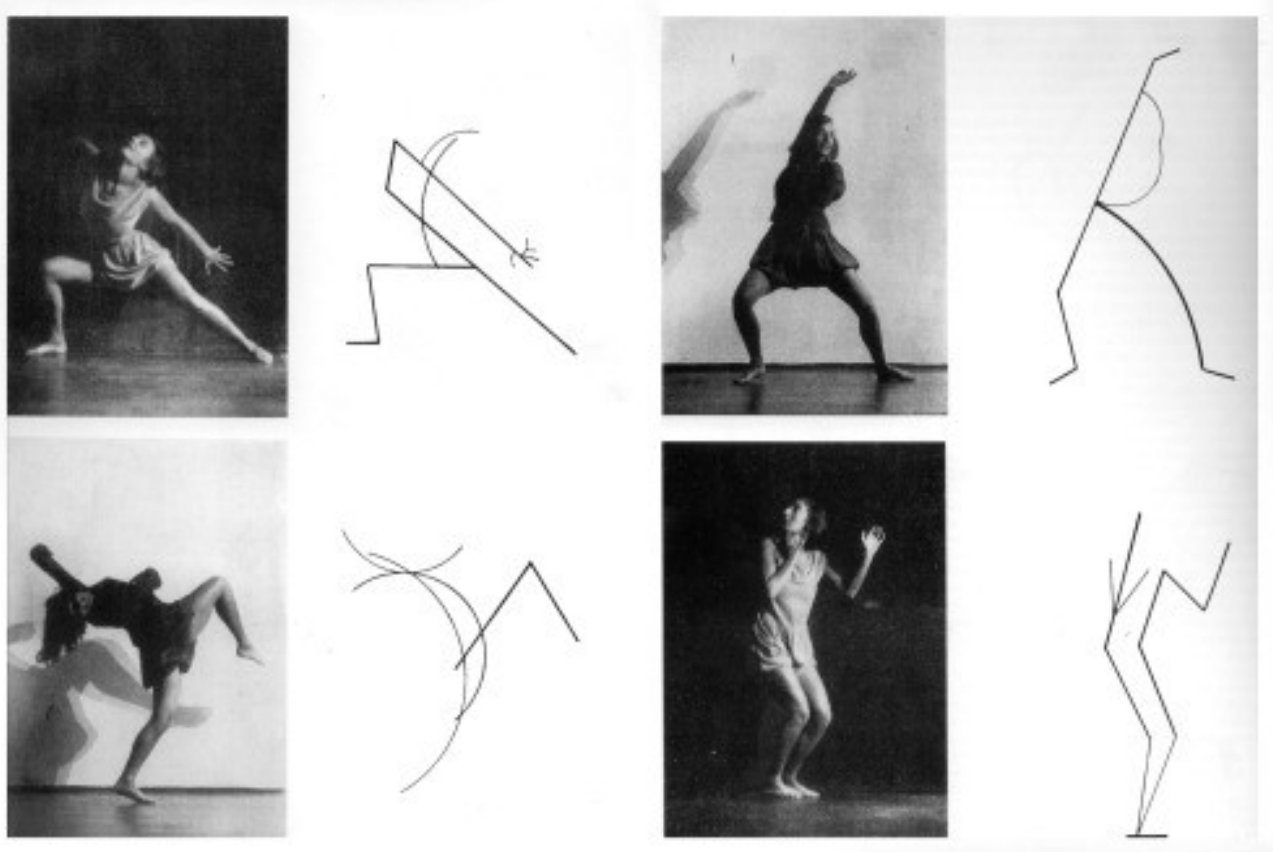

Fig. 20. Kandinsky: Dance Curves (with Gret Palucca, 1926)

The painter and art theorist Wassiliy Kandinsky (1866-1944) was interested in the Wagnerian concept of Total Artwork, which led to his concept of "monumental Artwork" from 1908 on. He was inspired by music, in particular by Schönberg's atonal music. In his Über das Geistige in der Kunst ("About Spirituality in Art"), Kandinsky wrote that colour and sound have psychological effects on the soul, a phenomenon he called "interior sound" or "mental vibration" ${ }^{84}$ According to Kandinsky, theatre consists of three artistic disciplines and their means of expression:

- Painting, with colour as its means of expression.

- Music, with sound as its means.

- Dance, with movement as its means.

Kandinsky suggested that these three disciplines could be merged within a fourth one:

architecture. ${ }^{85}$ Kandinsky, unlike Wagner, did not search for a "synaesthetic composition" in which the disciplines reinforce each other to reach a "monophonic" effect, but he searched for "a polyphonic effect in which the aimed effect is based on a composed movement of voices and counter-voices in different modalities. The role of music in the utopia of the unity of the arts is not just a question of parallel and similar movements and images, but rather a game or battle, based on both opposition and fusion: a unity originating from a composed parallel contrast. ${ }^{" 86}$ Kandinsky

84 Kandinsky, W. Über das Geistige in der Kunst insbesondere in der Malerei (München, 1912)

85 Coppens, E. De balans tussen vorm en inhoud (Amsterdam, 1998), p. 26

86 "een polyfoon effect waarbij het beoogde effect berust op een gecomponeerde beweging van stemmen en tegenstemmen in verschillende modaliteiten. De rol van muziek in de utopie van de eenheid van de kunsten is niet louter een kwestie van parallelle en overeenkomstige bewegingen en beelden, maar veel meer een spel of strijd, gebaseerd op tegenstellingen én versmelting: een eenheid voortkomend uit een gecomponeerd parallel contrast.", 
suggested that each discipline had its own means of expression and that the different disciplines were irreplaceable. Although each one can express the same concept in its own way, it is impossible to translate a meaning from one discipline to another. Therefore, expressions of specific disciplines can be dissociated from each other, and for each concept it should be explored which discipline best expresses it. The result is a theatre work in which there is a continuous interaction between the different art forms that are involved.

\section{L'Histoire du Soldat of Igor Stravinsky (1882-1971)}

The orchestra had been moved under the stage with Wagner's Gesamtkunstwerk, thus being invisible for the stage. However, with Stravinsky's Histoire du Soldat the musical ensemble is placed visibly on the stage and included as a scenic element next to the narrator, actors and dancers. While in Wagner's operas all elements fused into one single language, Stravinsky separated the scenic elements visually and structurally, so that the audience had to make the connection between them and thus come out of its passive attitude. The narrator does not sing but his speech is musical due to its strong rhythm, a character also inherent to the music played by the ensemble. The musical ensemble intercalates with the narrated text, which creates the idea of a dialogue between narrator and musicians. The characters are not realistic but rather representations and the music includes elements of folk music isolated from its original context, which gives the piece an abstract character and at the same time makes it very accessible to the audience.
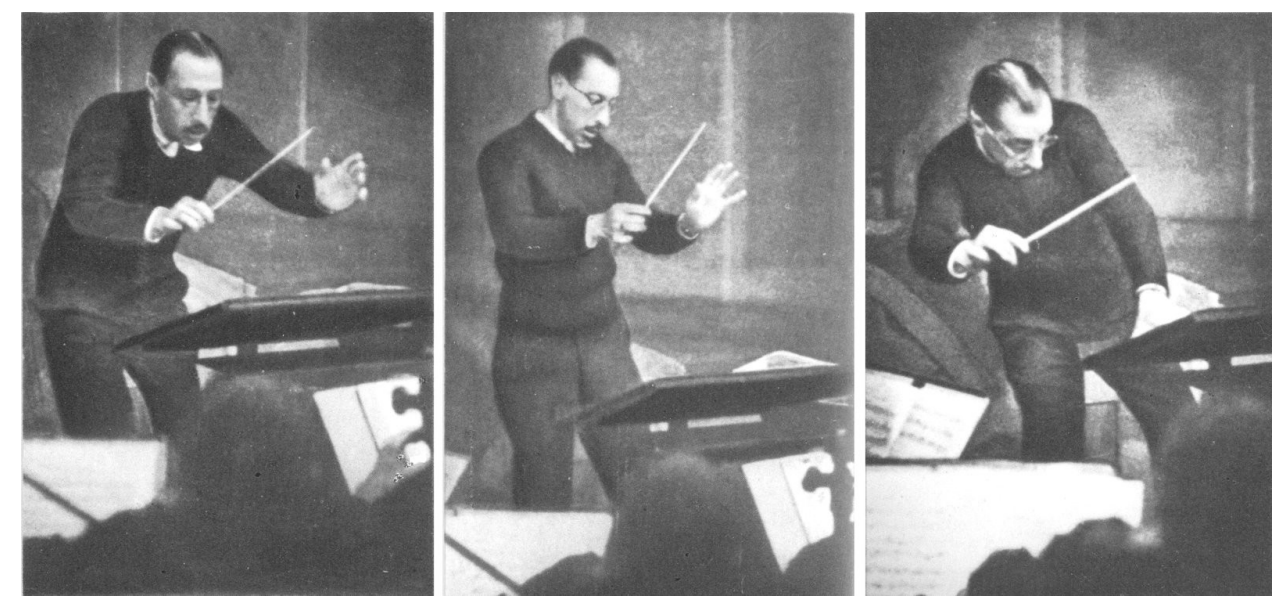

Fig 21. Stravinsky conducting in 1929 


\section{The epic theatre of Bertold Brecht}

Bertold Brecht (1898-1956) has been another important predecessor of the current interdisciplinary theatrical initiatives. Like Meyerhold, Brecht gave a political orientation to theatre, but he combined it with the characteristics that we have already seen in Stravinsky's Histoire du Soldat. Brecht wanted his audience to be capable of thinking and interpreting critically the scenic images and situations. He had a didactic aim: his audience would come to understand that human beings can change society and their own lives. In order for his audience to come to this conclusion, Brecht devised the "epic theatre". His intention was to break with the naturalistic theatre by applying effects of estrangement. This critical distance consisted of using different scenic resources to avoid that the spectator could identify himself with the dramatical fiction. Brecht broke with the illusion of reality on the stage so as to remind the audience that it was looking at a theatrical representation and not reality itself. For this reason the actors did not have to transform themselves into characters but instead had to show the characters to the audience, think about their characters in third person and make commentaries about them. Brecht's intention was that the audience would observe the actions as something alien to them and thus would reflect critically about them. One of the estrangement effects that Brecht used was based on music that interrupted the dramatical plot. In this way the audience, instead of attending passively the performance, would reflect about what happened on stage. Therefore, it must not be interpreted in a skilled and emotive way, but by nontrained voices. He sometimes used choirs like the ancient Greek ones, which commented on the action. In order to avoid any creation of illusion, the orchestra had to be visible for the audience and was therefore placed on the stage, an idea already observed with Stravinsky's L'Histoire du Soldat but for a different reason.

Brecht assimilated Kandinsky's concept in which each discipline had to express independently the theme of the work and its specific point of view. Accordingly, every work showed three points of view on the theme, from the text, the music and the image. The difference with Kandinsky is that Brecht politicizes his theatre, something already present in the theatre of Piscator (1893-1966). Piscator not only thought that each discipline had to provide its point of view on the theme, but also that the disciplines could even contradict each other. 


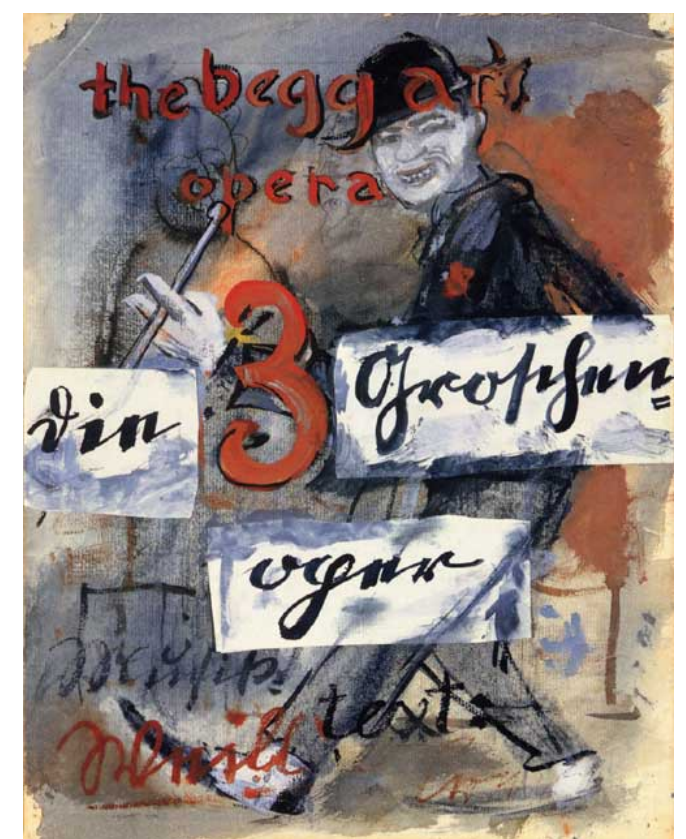

Fig. 22. A German poster for Brecht's

Dreigroschenoper ("Three-penny opera") from 1928, with music by Kurt Weill.

\section{John Cage, happening, Fluxus and performance}

We could state that the happening started with John Cage. Because of his interest in Zen philosophy, where non-desire is an essential concept, he came in the 1950s to aleatoric music (also called chance music). This was a counter-movement to composers' search for total control over musical components such as dynamics, time, or rhythm, which was the root of electronic music. Its countermovement arose in the 1950s, searching for freedom in the performance of a piece. Cage used aleatoric strategies to obtain this freedom, but there were also other ways like graphical notation, scores with an open form where the performer can decide the order, and works that leave place for improvisation. In this way, the work is not one fixed form but rather a set of uncountable possibilities. The performer decides the final form and as such becomes the co-creator of the work that is heard, therefore each performance of the score results in a different "musical work". The main consequence of this development was a change in the understanding of musical composition. The concept of musical authorship was not so clear anymore as the final composition was a creation of both the composer of the score and the performer. The score in itself did no longer equal the musical "work". Now, the final product was different with every performance, depending on the musician. Moreover, if the composer of the musical score had been guided by his choice of applying the concept of indetermination, like John Cage in some of his works, then the performer determined such a considerable part of the final result that he could be surpassing the composer's own share in it. Since the creative role of the performer considerably increased and the final result 
could only be something ephemeral, the artistic process itself became more important than the product. Simultaneously, in the field of theatre the same development ocurred, moving away from a product-centred concept toward a process-centred one ${ }^{87}$, as a reaction to the consumer-based society and its system of "merchandizing wishes" (Botella Mestres 2010, 144). In both music and theatre it meant letting go of conventions in order to obtain greater liberty in experimenting with forms and meanings. Theatre and music met each other again in expanding their limits (Botella Mestres 2010, 145-146).

In 1952 Cage took part in the first happening at Black Mountain College, although the genre did not bear that name yet. There he developed his Theatre Piece $n^{\circ} 1$, a performance where he was standing on a ladder, reading poetry and conferences. Meanwhile, the poet Charles Olson did the same from another ladder and visual artist Robert Rauschenberg showed some of his paintings and played some scratched gramophone records. Musician David Tudor played a prepared piano and Merce Cunningham danced. All of this happened simultaneously and in the middle of the audience. The word Happening comes from visual artist Allan Kaprow, who used it for the first time in spring 1957 for describing the works of art that were being made in an artistic picnic at the farm of painter and sculptor George Segal. In 1959 Kaprow created 18 Happenings in 6 parts. The form was used by others and its name was adopted by artists not only in the United States, but also in Europe and Japan.

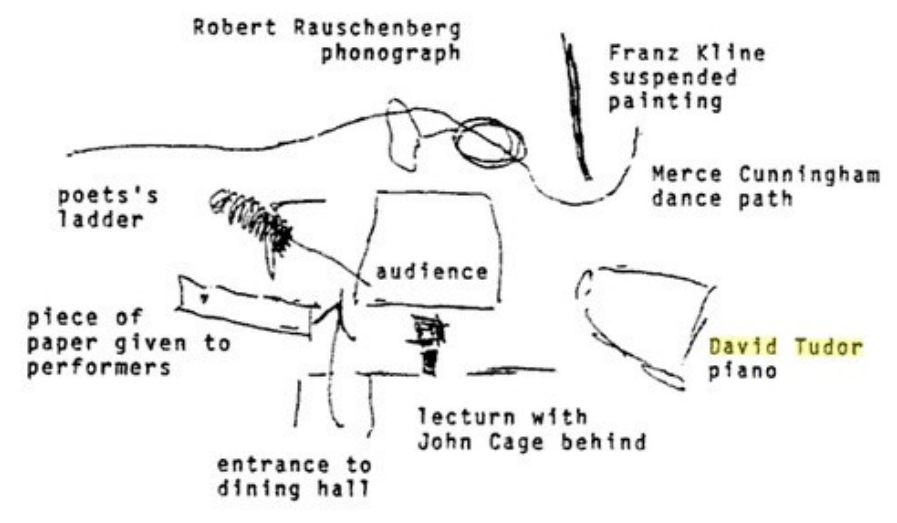

Fig.23. Floorplan of the happening in 1952 
As Julia Robinson notes,

"an important catalyst for Happenings was Jackson Pollock, or perhaps more accurately, the idea of Pollock created by the spectacular images of his practice: from Hans Namuth's film and photographs, to the interpretations of his painterly 'performance' by the Gutai group in Japan and Georges Mathieu (b 1921) in Paris. In the year of Pollock's death (1956) Kaprow wrote an essay: 'The Legacy of Jackson Pollock' (published in ARTnews in 1958). There he spoke of the scale of Pollock's work, leadingalmost logically — out into the real world. In addition to that apt prognosis, Kaprow programmatically listed many new materials that would appear in the 1960s — in performance as much as Pop art—and actually named the forms that he and George Brecht would soon develop: 'Happenings', and 'Events'. As such, Kaprow's 'Legacy' essay was a kind of manifesto addressed to the next generation, and perhaps also a means of clarifying the scope of his own future strategies." ${ }^{.8}$

She clearly links the Happening with visual art: "Happenings can be understood as the extension of the painterly, the sculptural and the 'environmental' into a temporal register." ${ }^{" 89}$ In musical-theatrical terms, it has a strong relation with John Cage's indeterminacy principle, where outcomes are unpredictable.

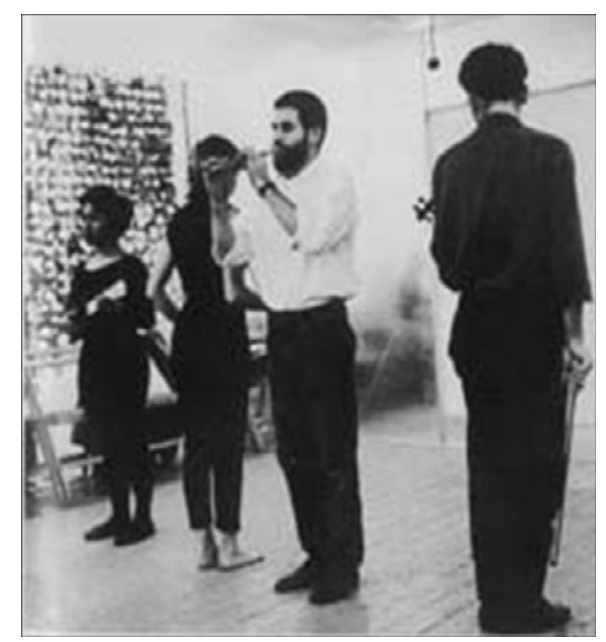

Fig. 24. Kaprow: 18 Happenings

in Six Parts (1959), which took place in the Reuben Gallery in New York

It is not easy to explain what happenings are exactly, since each of them is unique and totally different from the other ones. Performance specialist Martina Botella Mestres enumerates the following characteristics:

88 Julia Robinson. "Happening." Grove Art Online. Oxford Art Online. Oxford University Press, accessed October 12, 2015, http://www.oxfordartonline.com/subscriber/article/grove/art/T2213908

89 Ibid. 
- the work as a process and not as a result or product

- the overcoming of a theatre of representation and interpretation

- the critics towards stage directing as a centre of total aesthetic power

- the extension of the actor's functions

- the negation of an audience as something undifferentiated and passive

- the search of contact and interaction with the audience

- the use of theatre for the purpose of cultural promotion, intercommunication and mutual knowledge

- the use of theatre for the purpose of self satisfaction of social and individual needs. ${ }^{90}$

In a happening there is no plot since the work is not based on a dramatic text or a story. It is an interdisciplinary experience that is not about representation of an idea or narrative but the fact that something "happens" in the moment, the creation in situ. The various disciplines are not searching for a collective logic. In fact, the works were rather collages of images, texts and sounds. The aim consisted of bringing art closer to life, based on Antonin Artaud's statement that art is life ${ }^{91}$. The happenings were a form of resistance against the idea of art as an object, a product, in the middle of a consumer society. They criticized institutionalized art and intended to make art more accessible, bringing it to more common and known spaces, instead of theatres, museums and music halls. This would eventually lead to the development of site-specific theatre.

The happenings changed the passive position of the audience into an active one, which also had a great influence on theatre. Often the "fourth wall" (the "invisible wall" that separates the audience from the artists) would be eliminated. The happenings were a type of collage in which simultaneously various things happened. No longer it was tried to convey a single meaning but the spectator himself had to form his opinion and assign a meaning to the work. The fact that the happening was a multidisciplinary experience had also a great deal of influence on the theatre world, where multidisciplinary forms were already encouraged by its assimilation of the new multimedia technologies.

90 Botella Mestres, M., De la escultura al teatro, del teatro a la escultura: influencias y confluencias (Valencia, 2005), p. $145-146$

91 Antonin Artaud (1986-1948), in his "theatre of cruelty" (Théâtre de la Cruauté) sought for a truth-showing theatre form, a " "communion between actor and audience in a magic exorcism; gestures, sounds, unusual scenery, and lighting combine to form a language, superior to words, that can be used to subvert thought and logic and to shock the spectator into seeing the baseness of his world.", http://www.britannica.com/EBchecked/topic/36724/AntoninArtaud [accessed 2 Oct 2015] He manifested his ideas in his book The Theatre and Its Double (Le Théâtre et son Double, 1938). 
In the early 1960s the movement of Fluxus arose. Just like the happening, it had its origins in the non-determinative music of John Cage and in the work of the Lithuanian artist George Maciunas (1931-1978). The latter organized the first Fluxus event in 1961 in New York and the first Fluxus festivals in 1962. The movement gradually spread internationally. Fluxus fomented amateur aesthetics and valued simplicity more than complexity. It was anti-commercial and anti-art, and a pro-artist movement of social orientation. Fluxus artists preferred working with the materials at hand and created their own works or collaborated with their colleagues. Fluxus used interdisciplinarity for their no-art, resulting in a new type of "total art". In the Fluxus concerts, where the intention was to bring the visual arts closer to music, any object was converted into a musical instrument. Even the simple action of polishing a violin was understood as a concert, like George Brecht did in his Solo for Violin Polishing (1964). Life and actions of the individual artists were already considered artworks in themselves.

$$
\text { Manifesto: }
$$
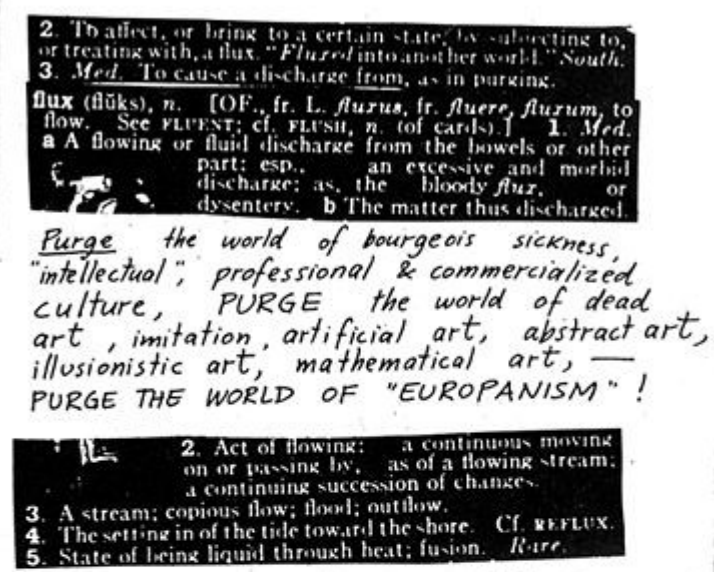

PROMOTE A REVOLUTIONARY FLOOD AND TIDE IN ART,

Promote living art, anti-art, promote NON ART REALITY to be fotty grasped by all peoples, not only critics, dilettantes and professionals.

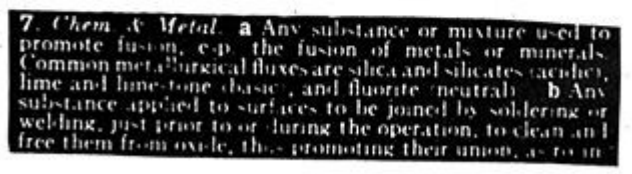

$$
\begin{aligned}
& \text { FUSE the cadres of cultural, } \\
& \text { social \& political revolutionaries } \\
& \text { into united front \& action. }
\end{aligned}
$$

Fig.25. Fluxus manifest written in 1963 by George Maciunas

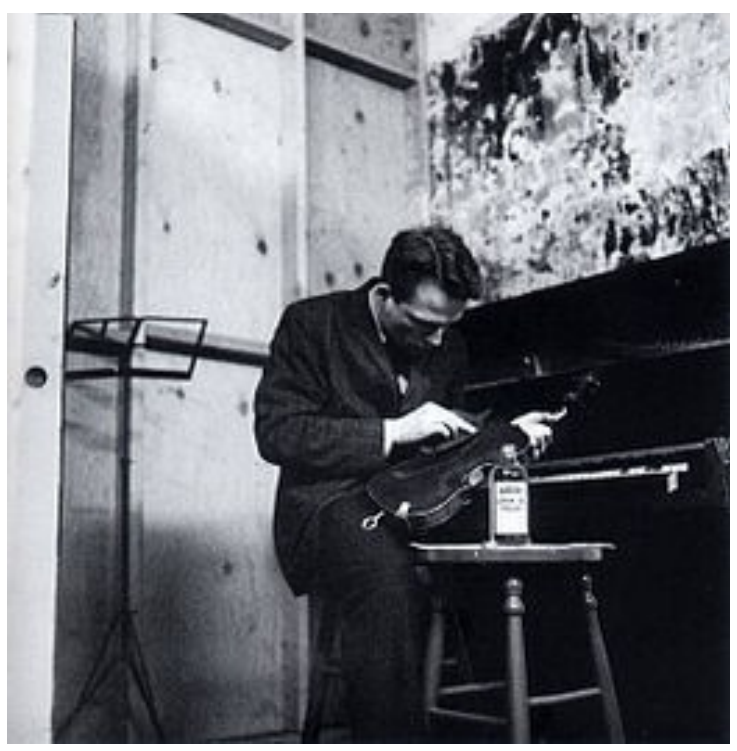

Fig.26 George Brecht: Solo for Violin Polishing (1964) 
From the sixties on, the concept of space obtained gradually more importance in theatrical experiments, which was another trigger for site-specific theatre: the artists began looking for alternative space for the theatrical creations. The creative process became more important than the result, thus focussing on space, the human body and multidisciplinarity. Fluxus artists experimented with the spacial distribution of the mise-en-scene, which augmented the communication with the audience and their participation. ${ }^{92}$

In the seventies Performance Art substituted the happenings and the Fluxus activities. This art form had a more structured chronological form. Performances were often created by one single artist, while happenings were normally a collective process, although Fluxus was already moving between collective and individual work. A performance consisted of four elements: time, space, the artist's body or its presence in a medium, and the relationship between the artist and his or her audience.

The performances could take on highly extreme forms. Chris Burden, in his work Shoot, was intentionally hit in his arm by a bullet, and in his work Trans-fixed he had himself crucified on a car. Another example is Marina Abramović, who also experimented with the limits of the human body. In her famous work Rhythm 0 she took a passive role and gave to the audience the active role. While she was passively sitting at a table with 72 objects, the audience could freely use the objects on her. At first, the audience acted carefully, but the spectators became increasingly aggressive towards her. While her other performances were a search for the limits of the body, this one was an experiment in which the bestial or dark side of human being is revealed.

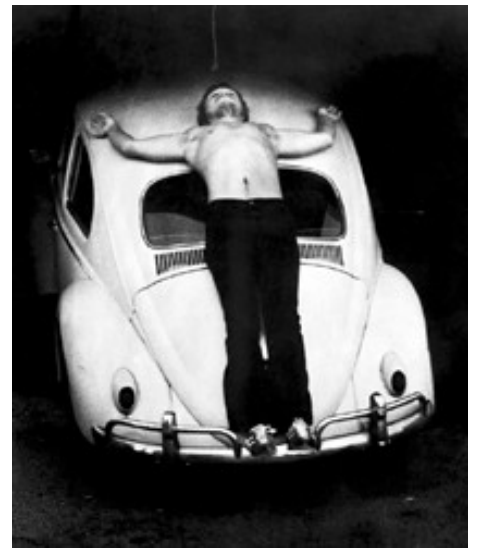

Fig.27 Chris Burden: Trans-fixed (1974)

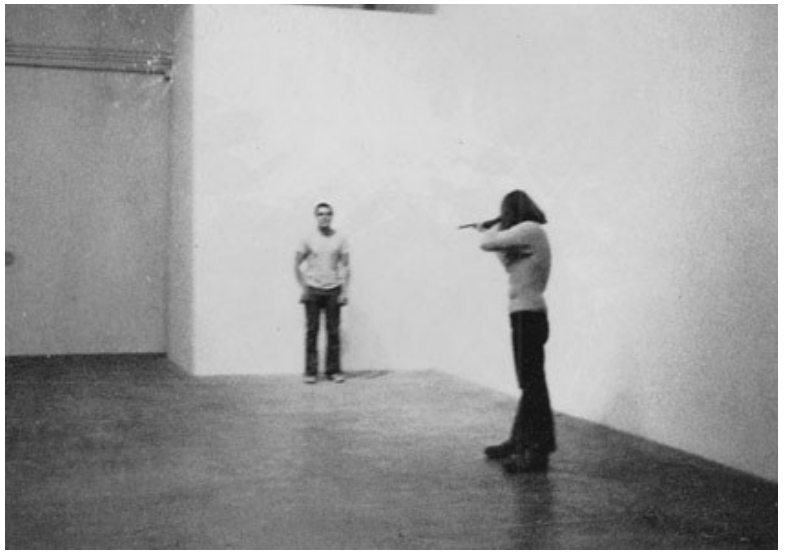

Fig.28. Chris Burden: Shoot (1971) 


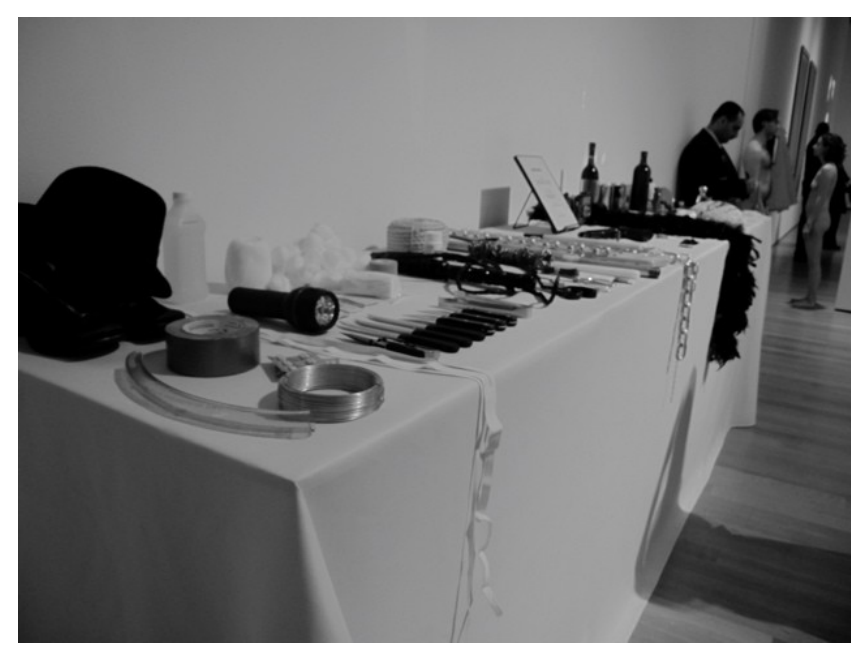

Fig. 29. 38 Objects from Marina Abramovic's performance piece "Rhythm-0" (1974)

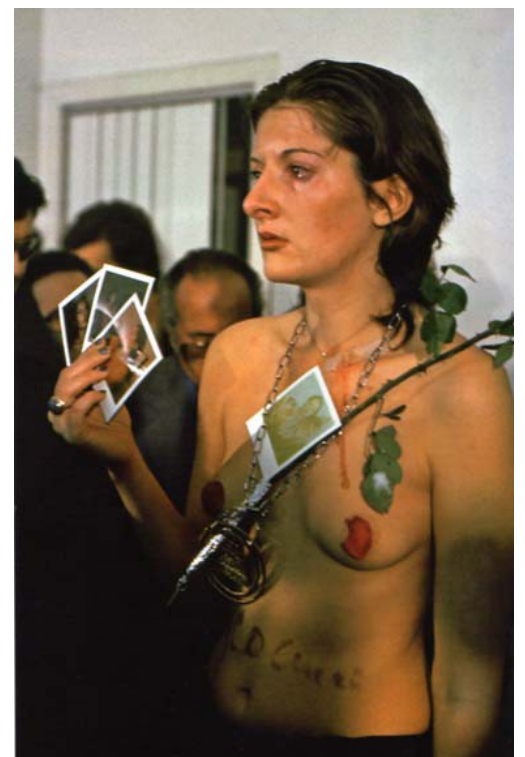

Fig. 30. Marina Abramovic after her "Rhythm-0" (1974)

From the 1970s on, video as an art form (video art) became gradually more common within performance and theatre. Another new developments were performances of a feminist and anthropological orientation. From the 1980s on, technology became gradually more important in performance, attracting a broader audience. Laurie Anderson, with her musical orientation of performance, quickly moved into the world of pop and experimental music with a theatrical touch. In one of her best known performances called Duet on Ice (1975), she played the violin accompanied by a recording, while she was standing on ice skates whose blades were stuck in a block of ice: the performance ended when the ice melted.

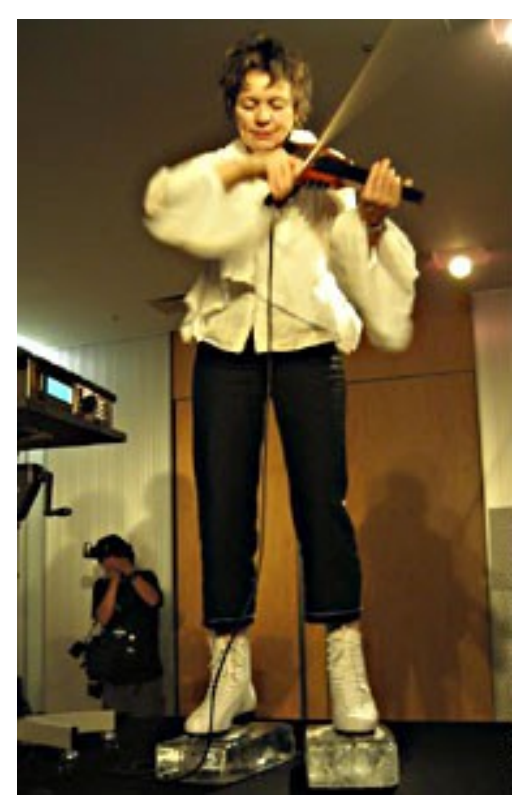

Fig.31. Laurie Anderson:

Duet on Ice (1975) 
Performance became gradually accepted by the art establishment, losing its original provocative rupture with conventional ideas about the question "what is art". Theatre itself became less provocative as well: it returned to limits that had previously been torn down, for instance the fourth wall that divides the actors and action from the audience. From the 1980s on, theatre approached performance, and the techniques and strategies of performance were taken in by the theatre field. Botella writes that theatre makers are interested in the aesthetic contributions of performance, transforming the individual ideas of the seventies into collective stage work. From its beginning, performance always sought to break down the boundaries between art and reality and opened the way to a multidisciplinary language. Now, theatre took in performance art in order to definitely break down the representational form imitating reality and use presentification and literalism rather than interpretation and symbolism. ${ }^{93}$

Art historian José Sánchez enumerates the elements of performance that were assimilated by theatre:

- no separation between actor and character, and the importance of physical presence;

- the identification of time on stage with the real time of the presentation instead of the dramatic time of the representation;

- the blurring of the limits between reality and fiction;

- the abandonment of an instrumental relationship between objects and space;

- the importance of isolated details that do not connect necessarily with the show

- certain ways of associative structuring and composition, which emerge from the combination of various overlapping languages

- the application of cross-disciplinary procedures in creating multimedia shows. ${ }^{94}$

This period also saw the introduction of rapidly advancing audiovisual technologies. The new techniques led to a new type of interaction, which again strengthened the relational character of theatre. Theatre incorporated elements of multimedia creation and installation art. The latter, according to Botella, "allows the integration of environmental characteristics in the staging and, in turn, adapt the stage elements or objects to the architectural space." ${ }^{\circ 5}$

93 Botella Mestres, M., De la escultura al teatro, del teatro a la escultura: influencias y confluencias (Valencia, 2005), p. 168-169, basing herself on Valentini, V. Després del teatre modern (Institut del Teatre, Barcelona, 1991). 94 Sánchez, J.A., Dramaturgias de la imagen (Cuenca, 1999), p.184

95 "permite integrar las características del entorno en el montaje, y, a su vez, adecuar los elementos u objetos escenográficos al espacio arquitectónico.", Botella Mestres, M., De la escultura al teatro, del teatro a la escultura: influencias y confluencias (Valencia, 2005), p. 207 


\section{The $20^{\text {th }}$ century version of the Gesamtkunstwerk from the musical world}

John Cage did not only have a great influence on the movement of the happening, but also on the world of music. Musicologists Donald Grout and Claude Palisca wrote about the developments of a kind of Gesamtkunstwerk in the 1960s outside of the happening. Examples of this type are Musicircus (1967) of John Cage, but also Staatstheater (1967-1970) of Mauricio Kagel, and the cosmic cycle Licht (from 1977 on) of Karlheinz Stockhausen (Grout and Palisca 2004, chapter 34). In Musicircus there are various musicians performing undetermined music simultaneously in a large space, based on chance operations within a bigger structured framework, while the audience can walk around.

In Staatstheater, described by Kagel himself as "not just the negation of opera, but of the whole tradition of music theatre", the normal performance hierarchy is overthrown: members of the chorus sing overlapping solos; soloists sing in ensemble; and non-dancers perform a ballet, while "antimusical sound" plays a substantial role. ${ }^{96}$ Also the Licht cycle ignored operatic norms, but, as musicologist Richard Toop states, because of "its tendency to ceremony and ritual: thus each work opens with a 'Greeting' (sometimes on tape) and concludes with a 'Farewell'.” Also, the main characters are multidisciplinary: they sing, play an instrument and dance or do mime. "Electroacoustic music has played an increasing and changing role in the Licht cycle. (...) Several parts of Licht deliberately venture outside the opera house, which Stockhausen regarded as a residue from the late Renaissance, still offering only a two-dimensional stage picture. At the première of Donnerstag the 'Farewell' was played from the rooftops of the square outside La Scala, Milan. Samstag, though produced under the auspices of La Scala, was performed in the Palazzo del Sport. The most drastic departure from standard operatic practice in the Licht cycle is the HelikopterStreichquartett in Mittwoch, whose airborne string quartet (in four helicopters) is naturally only conceivable out of doors, though transmitted into an auditorium via screens and loudspeakers." ${ }^{97}$

96 Paul Attinello. "Kagel, Mauricio." Grove Music Online. Oxford Music Online. Oxford University Press, http://www.oxfordmusiconline.com/subscriber/article/grove/music/14594 [accessed 1-5 2015]

97 Richard Toop. "Stockhausen, Karlheinz." Grove Music Online. Oxford Music Online. Oxford University Press, http://www.oxfordmusiconline.com/subscriber/article/grove/music/26808 [accessed 1-5 2015] 

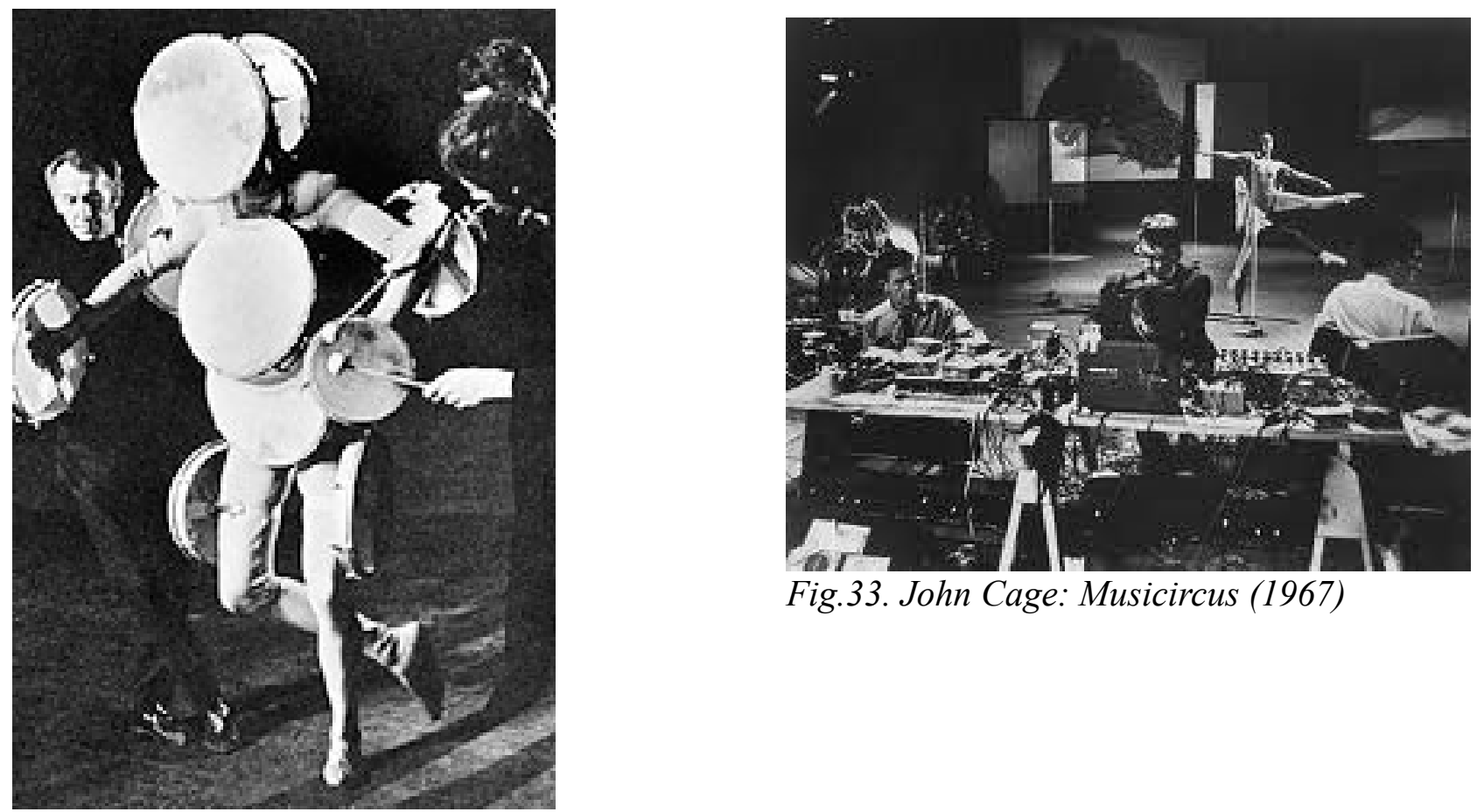

Fig.32. Debut performance of

Mauricio Kagel's "Staatstheater" (1971)

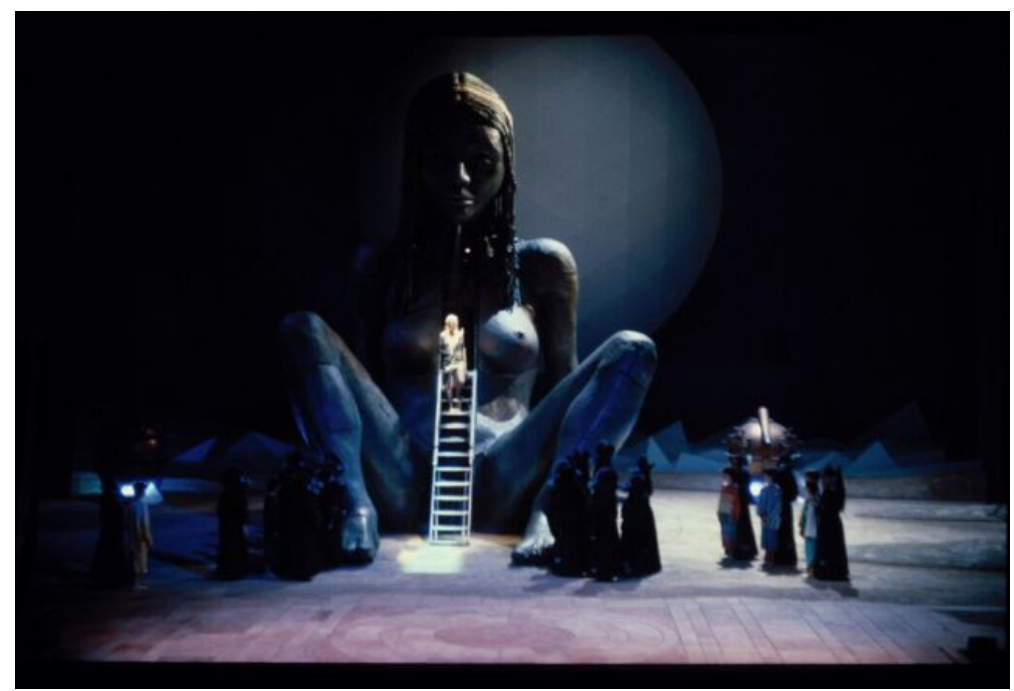

Fig. 34. Stockhausen: Licht (1988) in Scala, Milan

Composers such as Kagel and Stockhausen had a profound interest for the theatrical possibilities of music. Berio was so interested in the physical action of the musical performance that some works are not clearly definable as a concert or a theatrical work, for example his series of Sequenza (19581979), in which each Sequenza is a solo work for a different instrument. Kagel shows in almost all his work a sense of verbal or visual humour because of his ironic perspective on the conventions and strategies of musical performance. Similar to Cage's influence in the United States, Kagel's impact in Germany and Europe was considerable, especially on composers, in his use of all kinds of 
resources: voices, instruments, electronics, multimedia, visual arts. Kagel himself called his type of music theatre "Instrumental Theatre" and stated that "movement is the fundamental element of Instrumental Theatre and is taken therefore into account during musical composition. Movement on the stage becomes an essential feature for differentiating from the static character of a normal musical performance." 98

In Stockhausen's compositions, movement is also important. In Conversations with Stockhausen, he defined dance as any kind of musical movement of the body, even the smallest gesture.

"Every gesture of the body must be made consciously, since it connects with a musical layer, articulated rhythmically, which the instruments represent. (...) Music and dance are interdependent, and one notices the presence of the latter within the overall perception: while I hear the music, there's a part that dances continually within me. (...) Dance expresses musical structure in a fundamental way. It expresses it for the joy of the eyes." He also talks about the use of language as something musicalized and archetypal, in which "the secret meaning of the words surfaces at the level of consciousness, and music is made." 99

The composer and critic Sporck commented ironically on the works of Kagel:

"That which with Stockhausen could still be a profound issue (...), obtained absurdist and playful tendencies with composer like Kagel and Knaiffel. (...) The audience, intimidated by the dissonances of serial composers, post-serial composers, maximalists and new objectivists, is prepared for it. Miseen-espace is the name Audi ${ }^{100}$ gives to such a concept that in his eyes has to be a performance in the first place. And the composer has himself retrained as a stage director who does not write entire scores anymore, but invents scripts full of indications in order to disrupt a concert, put the audience on the wrong track and, if possible, have the audience take actively part of it. (...) The music stands barely on its own but illustrates; in fragments, with quotes and samples and has submitted to the technical gadgets that threaten to lead the entire show." 101

98 Kagel (1960), quoted in Rebstock, M. and Roesner, D, Composed Theatre: Aesthetics, Practices, Processes (Bristol, 2012), p. 37

99 Tannenbaum, M., Conversations with Stockhausen (Oxford, 1987)

100 Pierre Audi, stage director specialized in operas.

101 Sporck, J. Uit de doeken, uit de kleren - over de essentie van muziek (Budel, 2007), p. 116-117: "Wat bij Stockhausen nog als een diepzinnige aangelegenheid opgevat kan worden (...), krijgt bij componisten als Kagel en Knaiffel absurdistische en ludieke trekjes. (...) Het publiek, kopschuw gemaakt door de dissonanten van seriëlen, postseriëlen, maximalisten en nieuwe zakelijken, is er klaar voor. Mise-en-espace noemt Audi een dergelijk concept dat in zijn ogen vooral een voorstelling moet zijn. En de componist heeft zichzelf omgeschoold tot regisseur die geen partituren meer volschrijft, maar scripts bedenkt vol aanwijzingen om een concert te regelen, het publiek op het verkeerde been te zetten en waar mogelijk dat publiek er actief deel van uit te laten maken. (...) De muziek zelf staat nauwelijks nog op eigen benen maar illustreert; in flarden, met citaten en samples en heeft zich onderworpen aan de technische snufjes die het handelen volledig dreigen te bepalen." 
Sporck's scepticism towards the staging of music is an illustration of the difficulty that cross- and interdisciplinary forms encounter to obtain the delicate balance between music and theatre where both merge and still have a value on their own.

Despite such critics, composers continue to search for an integration with theatrical forms, especially in Northern Europe, where art politics have given support to these cross-disciplinary forms. Stage director Matthias Rebstock enumerates the leading artists in this field:

“composers like Heiner Goebbels, Georges Aperghis, Manos Tsangaris, Carola Bauckholt, Daniel Ott, Robert Ashley or Meredith Monk; theatre directors like Robert Wilson, Christoph Marthaler or Ruedi Häusermann; in dance, part of the work of Xavier le Roy, William Forsythe and Sasha Waltz, ensembles and theatre-collectives such as Theater der Klänge in Düsseldorf, Die Maulwerker and the LOSE СОМВO both in Berlin, Cryptic in Glasgow or the Post-Operativ Productions in Sussex". ${ }^{102}$

Some of these creators have been references for Incipit, as we shall discuss in Chapter 6 .

\section{The actor-musician: integrated music theatre}

In the 1970s, The Netherlands were the stage for various music theatre initiatives. Rudy Koopmans in his article "Het actuele muziektheater" ("The present-day/topical music theatre") distinguished three types of music theatre where composers and actors were the same people: the topical music theatre, music drama and visual music theatre. ${ }^{103}$ The first of the three was the earliest integrated type of music theatre, derived from improvised jazz and Fluxus performances, where in a humoristic way critics were given on the Dutch cultural politics. In 1972 Willem Breuker and Lodewijk de Boer had developed it into the first topical music theatre performance, Kaïn en Abel. This type of music theatre was mainly thought departing from the music, since its creators were musicians and added theatrical elements to their interpretations and improvisations, of which text was one among others.

The music drama ("muziekdrama") of the 1970s was a music theatre work based on a text, where music had an independent role. Unlike topical music theatre, there is a separation between creation and interpretation. First a text and composition score are written, upon which the mise-en-scene is

102 Rebstock, M., "Composed Theatre: Mapping the Field”, Roesner, D. and Rebstock, M., Composed Theatre: Aesthetics, Practices, Processes (Bristol, 2012), pos. 226 in e-book.

103 Koopmans, Rudy, 'Het actuele muziektheater'. Raster, Amsterdam, (1977) 3, p. 33. 
based. The work is not specifically written for the actors and/or musicians and there is no improvisation. One of the groups in this style was Baal, with Leonard Frank as their director. While in topical music theatre the music was the departure point, in music drama it is the text, while the music mainly has a supporting role. In comparison to topical theatre, the inner coherence of the work is stronger: there is a text which forms the plot in a narrative way.

The name of the third type, visual music theatre ("beeldend muziektheater"), was an invention of Janny Donker, referring to the theatrical creators in the 1970s for whom the visual aspect was highly important. ${ }^{104}$ Many of them came from Fine Arts and worked with space, form, colour, material and light. It was the type where music and theatre were most integrated. The main group in this genre was Hauser Orkater, founded by pop musicians and street actors. In 1980 the group split in two: De Horde ("The Horde", 1981-1984), which concentrated more on music, and De Mexicaanse Hond ("The Mexican Dog”, 1981-actualmente), which focussed more on theatre. Nowadays its ramifications function under the name of the association Orkater, which collaborates often with other groups and artists.

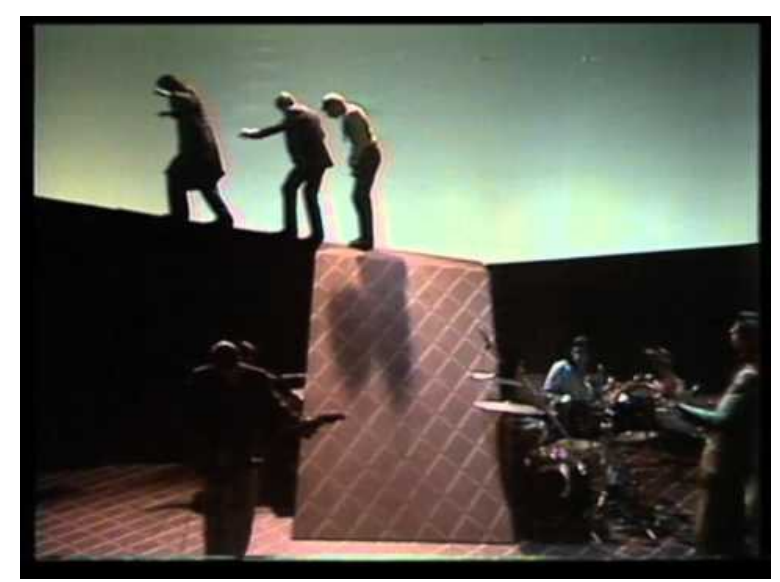

Fig. 35. Hauser Orkater: Zie de Mannen Vallen ("See the men fall", 1979)

This integrated type of music theatre became less popular in the 1980s and 1990s, because groups opted rather for a dominance of either music or text. It is possible that the position of music theatre, between theatre and opera, played a role in this development. Apart from the difficulty of the balance between music and text, the problem is that the theatre audience wants an understandable text while a music audience wants a musical performance with a considerable technical level, which is not always the case when actors sing. Theatre critics visited the music theatre performance, but music critics did not: since music theatre does not fit into the traditional genres, it has the danger to 
be left out, which is what happened in the 1980s and 1990s as well. And even in 2003, art historian José Antonio Sánchez noted that in Spanish cultural institutions there are three dimensions of experimentation which are not taken into account for their programmation: the "transdisciplinary", ${ }^{105}$ the performative and the relational. He meant to say that the cultural programmation commonly was - and still is - based on clearly defined categories, like music, dance, opera or theatre, and also on the idea of a theatre works as a product instead of a process. ${ }^{106}$

From the 1970s the genre of youth theatre had developed, where music, theatre, dance or other visual elements was assimilated in order to create a narrative in a more intuitive and emotive manner. After the 1990s, there was an increase again in the integrated type of music theatre where musicians are actors and vice versa. It is no coincidence that from that time on Conservatories in Holland and Germany have opened Master degrees in Experimental Music Theatre, and there has been a growth of trained actor-musicians in this genre. What began as a reaction to the demands of composers and theatre creators, in its turn has nourished even more composers' interest to work with professionals in the field of music theatre.

105 That which involves the total merging of various art disciplines. 


\subsection{Experimental Music Theatre: Definitions and Terms}

Music theatre covers an ample range between theatre on one side and strictly musical forms on the other, and is not to be confused with the more fixed-form disciplines of opera and the commercial musical. In order to separate music theatre from opera or musical, music historian Eric Salzman and stage director Thomas Dési call the more experimental and small-scale type "new music theatre". They describe it as "the wide and evolving territory that lies between opera and the musical" 107 and

"theatre that is music driven (i.e. decisively linked to musical timing and organization) where, at the very least, music, language, vocalization, and physical movement exist, interact, or stand side by side in some kind of equality but performed by different performers and in a different social ambiance than works normally categorized as operas (performed by opera singers in opera houses) or musical (performed by theatre singers in "legitimate" theatres)." 108

Musician, composer and music theatre scholar Falk Hübner, in his doctoral thesis on the musician as a theatrical performer, summarizes the basic characteristics of this genre-between-genres in two features: "music theatre is a) multimedial by definition, always staging more than one medium, and b) primarily music-driven, working with specifically musical structuring and musical thinking while creating a performance." ${ }^{109}$ Musical thinking does not necessarily imply musical performance; it is an approach of the scenic disciplines "according to musical principles and compositional techniques" 110 which can be applied to creative theatrical processes in general. It focusses on timing, sound and interaction of the different disciplines, which, according to the directors Heiner Goebbels and Christoph Marthaler, can be associated to the concept of polyphony. ${ }^{111}$

David Roesner and Matthias Rebstock, instead of defining the discipline, preferred to focus on the work process and included all the scenic art forms in which there is a musical treatment of the theatrical elements, calling it "Composed Theatre". They look at the process of creation rather than at the final result, which is marked by a non-hierarchic interaction between the different arts and the composition of a "theatrical" score.

107 Salzman, E. and Desi, T., The New Music Theater: Seeing the Voice, Hearing the Body (Oxford University Press: New York, 2008), "Introduction: What is Music Theater", e-book Pos. 61

108 Ibid., Pos. 61

109 Hübner, F., Shifting Identities: the Musician as Theatrical Performer, PhD thesis at University of Leiden, 2013, p.53

110 Roesner, D., "Introduction: Composed Theatre in Context”, Roesner, D. and Rebstock, M., Composed Theatre: Aesthetics, Practices, Processes (Bristol, 2012), pos. 62 in e-book.

111 As Roesner reports in his introduction: Rebstock, M. and Roesner, D., Composed Theatre: Aesthetics, Practices, Processes (Intellect Ldt: Bristol, 2012), p.8; and quoted by Falk Hübner, Hübner, F., Shifting Identities: the Musician as Theatrical Performer, PhD thesis at University of Leiden, 2013, p.53 
"Composing theatre suggests a shift in activity during the process of making theatre, a dramaturgical quality, a new perspective in creation. (...) Composed Theatre also brings music-theatre, dance, staged concerts, sound installations etc. into view. (...) Composed Theatre adds phenomena that would fall under the heading 'theatricalisation of music'. Composed Theatre is not a genre - it is more a frame or a lens that brings quite disparate phenomena into view and collocates them. At the centre of this frame, the focus is on creation processes that bring the musical notion of composing to the theatrical aspects of performing and staging" (Roesner and Rebstock 2012, pos. 106).

As Hübner reflects, "comparable to the musical score, a theatrical performance can be described in a kind of multimedial score that organizes not only music, but also performative events, dialogues, pitches of spoken text, video, light design, all of them interrelated and yet independent from one another." 112 About the exact boundaries of this field, Salzman and Dési note that

\begin{abstract}
"contemporary opera, music theatre in its various forms, and the modern musical coexist on a continuum and the lines between them are often blurred. But even though the boundaries between species are often fuzzy (an inevitable result of any evolutionary process), this does not mean that valid species do not exist (they clearly do) and should not lead us to deny that differences exist - differences of purpose, of category, of social setting, of casting, and of vocal type."113
\end{abstract}

The genre thrives especially in the Netherlands and Germany, where the programmation by theatre organizations allows for a genre that is not as defined as a concert, an opera performance or a theatre work, while in southern-European countries only more predefined disciplines are taken into account. Nonetheless, according to Rebstock, even in Germanic countries "there is no institutional infrastructure for New Music Theatre, and therefore we mainly encounter it at festivals or in independent productions." $" 114$ There are some institutions that promote music theatre. Furthermore, in Holland debates were organized between 2009 and 2011 about experimental music theatre and its future, in order to find a solution for this problem. As a result, an agreement was signed by almost 60 creators, theatre halls, and festivals, in order to foment several steady platforms where music theatre could be developed and performed. ${ }^{115}$

112 Hübner, F., Shifting Identities: the Musician as Theatrical Performer, PhD thesis at University of Leiden, 2013, p.55

113 Salzman, E. and Dési, T., The New Music Theater: Seeing the Voice, Hearing the Body, "Introduction: What is Music Theater", e-book Pos. 81

114 Rebstock, M., "Chapter 1, Composed Theatre: Mapping the Field”, Roesner, D. and Rebstock, M., Composed Theatre: Aesthetics, Practices, Processes (Bristol, 2012), pos. 823 in e-book.

115https://mcnforum.wordpress.com/2010/01/28/operatie-muziektheater-20-januari-2010-koninklijk-conservatoriumden-haag/ and https://mcnforum.wordpress.com/2010/01/28/operatie-muziektheater-20-januari-2010-koninklijkconservatorium-den-haag/\#comment-36 (Dutch only) 
Despite the difficulty of the cultural sector due to the crisis that began in 2008, the interest in this type of multidisciplinary theatre has remained. Roesner considers that this interest in an integration of sound, movement, gesture, light, image, and design is "reflected in recent developments towards post-dramatic forms that de-emphasise text, narrative and fictional characters, seeking alternative dramaturgies (visual, spatial, temporal, musical), and focussing on the sonic and visual materialities of the stage and the performativity of their material components."116 


\subsection{Strategies in Experimental Music Theatre}

Erin Coppens made an analysis of the characteristics of the Dutch integrated music theatre types of the 1970s. The work process of topical music theatre was departing from musical jazz improvisation and extending it to theatrical elements. There was no separation between composer/writer and actor, and the theatrical techniques were Brechtian: interrupting any text narrative by playing music; interrupting any "serious" music making by theatrical elements. In the second type, the music drama, the work process started with a text and a composition, on which further rehearsals were based. There was no improvisation and music was an independent discipline in the performance. Finally, the third type which was the visual music theatre, had a loose structure and was created collectively. There was no previously written text serving as the basis of the work and music, text and image were equal. Unlike the topical music theatre, there was a separation between composition and performance of the music. Its music was mainly based on pop music. ${ }^{117}$ Contemporary music theatre mostly combine the characteristics of these three types. In 2011 we analysed the works of three Dutch music theatre groups - De Veenfabriek, Susies Haarlok, Stella Theater - on basis of these characteristics and found that they seldom fit into one specific category. ${ }^{118}$ Our findings were that there is a tendency toward music drama, in which the music and acting stand next to each other and where music accompanies the narrative, and that the visual aspect seems to be more important in current music theatre than in the 1970s.

Thus, music theatre does not necessarily start with musical composition. As we saw before in the definition of music theatre, it is about musical thinking which underlies music theatre. As Falk Hübner notes, "music is essential in being an element providing structure to a performance. This could be musical timing and organisation of material, but also the way in which music theatre makers think" (Hübner 2013, 18). He gives as an example music theatre maker Paul Koek of De Veenfabriek ("The Peat Factory") who uses musical terminology when he speaks of his works. In our analysis of Paul Koek's works, we observed that he musicalizes the text and interrelates it with the music, in a musical-rhythmical way. ${ }^{119}$ For his location theatre work Machine Agricole at a farm he used songs by Darius Milhaud (1892-1974) and worked together with composer Martijn Padding. Despite the location and subject, the theatrical language transcends the piece toward an abstract aesthetics.

117 Coppens, E. De balans tussen vorm en inhoud (Amsterdam, 1998), p.9, 11-12, 16-17, 22

118 Sprenkeling, L., "El teatro musical experimental en Holanda", Thesis for Master of Advanced Master Studies (Universitat Politècnica de València, 2011), p.82

119 Ibid., p.82 


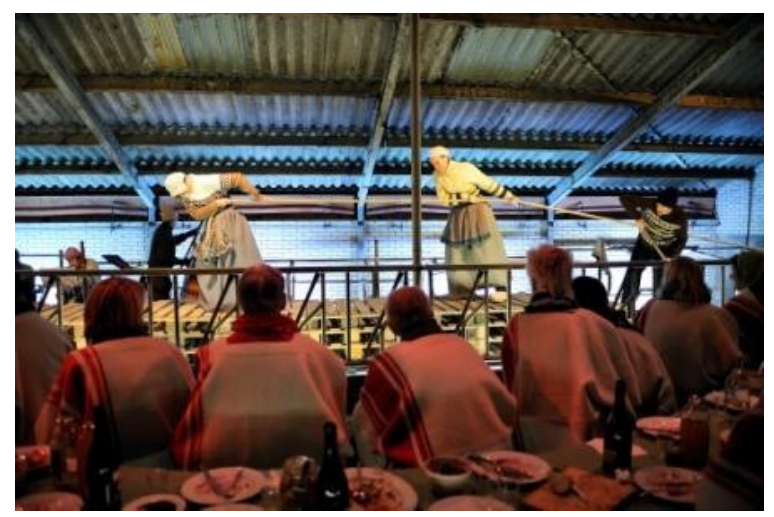

Fig. 36. Paul Koek: Machine Agricole (2011)

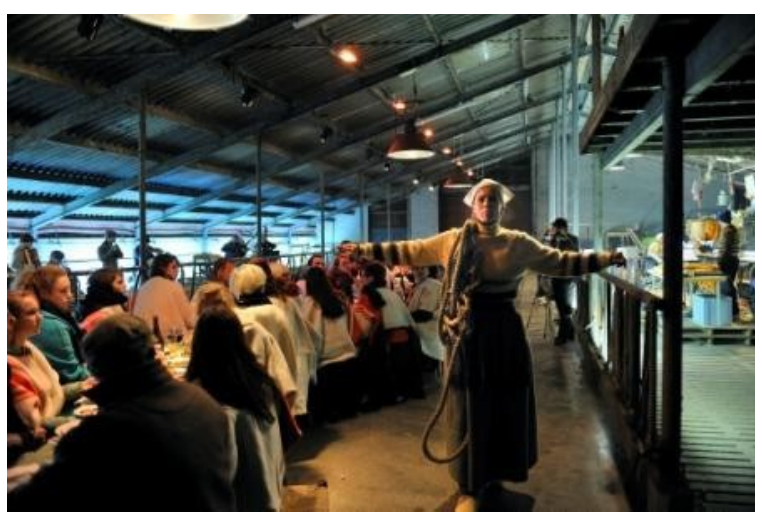

Fig. 37. Paul Koek: Machine Agricole (2011)

When departing from the music, there are four types of work strategy in music theatre according to Evelyne Coussens: interpretation, sampling, radical edit and creation. ${ }^{120}$ The first strategy is interpreting a finished score or presenting "counterpoint" in the mise-en-scene against it, but keeping "a strong relation with the structure, timing and tempo of the pre-existing music" (Hübner $2013,19)$. The second strategy, sampling is about using pre-existing music freely in the mise-enscene. In this sense, the sampling work of Fabrizio Cassol with the music from Johann Sebastian Bach's St Matthew Passion, for Alain Platel's Pitié! (2006) is an excellent example. The melody is still recognizable, but it is remixed and re-structured in a completely different way for the Belgian dance company Les ballets $\mathrm{C}$ de la B.

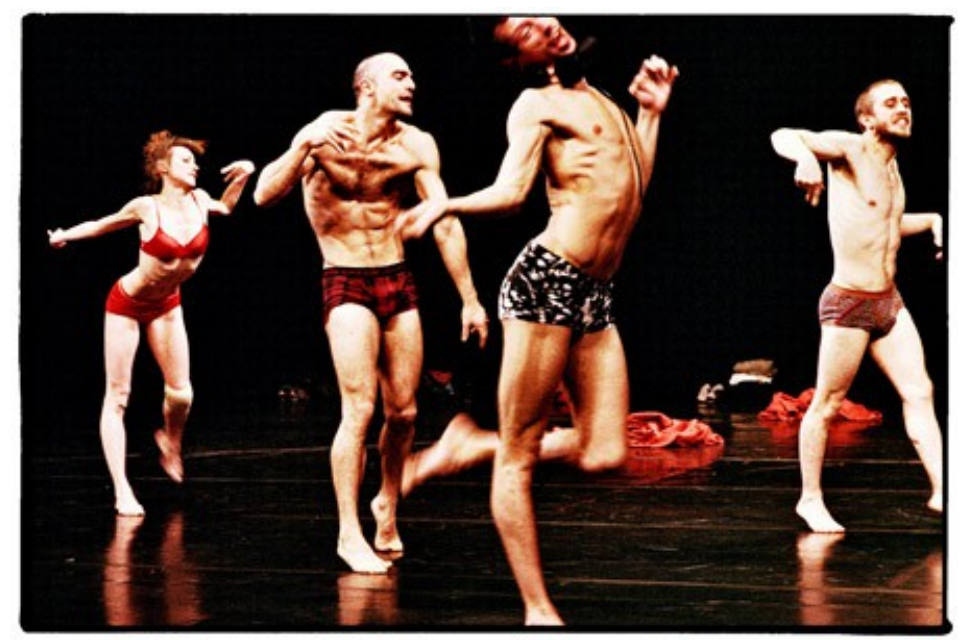

Fig. 38. Alain Platel: Pitié! (2008)

The third strategy, radical edits, takes this process even further toward a completely new creation. The final strategy is entirely new creation of the music, and often there is a simultaneous process of

120 Coussens, E., "Tweestromenland tussen repertoire en creatie - Muziektheater vanuit de blik van de regisseur", Courant 89, p.23-32, also quoted by Hübner 2012, 19. 
musical and theatrical composition. Coussens notes that music and theatre go together in the process: "Both components, music and direction, are impossible to separate from each other of course - there is a continuum where music and theatrical mise-en-scene merge to a greater or lesser extent" (Coussens 2009, 23).

In the case of Incipit, the strategy for Inferno is different than the one for Purgatory and Paradise. While the "repertoire" for Purgatory and Paradise mainly consists of notated historical versions of specific chants, Inferno's basic material comprises the sounds described by Dante: it is the only canticle that does not have any written music as its basis. As we can observe, the "libretto" and the "repertoire" for a music theatre work are not necessarily a script and a musical score. The "repertoire" of Inferno consisted of either recorded or pre-recorded copyright-free sounds. They were combined according to Dante's descriptions and a compositional process of the creator of Incipit. Although Inferno's constructive elements are mostly pre-existing recorded sounds, they were combined like notes in a written composition - either subsequently or simultaneously, like "melodies" and "clusters" - and thus added up to an entirely new composition. If we regard these sounds like musical notes or notes groups, then we can place the musical strategy for Inferno in the category of creation. However, these sounds represent actual sounds that Dante describes in his work and in a certain aspect there is also a sense of "re-creation" in it, although one must keep in mind that recreation should depart from the premise that something already sounded in the past in order to recreate, and in this case there is no such "original performance".

Contrariwise, the chants of Purgatory were regularly performed in Dante's time. In Incipit's Purgatory, pre-existing pieces were connected with each other through other sounds. It is true that in comparison to what Dante describes or supposes to be hearing, Incipit's versions are mostly shortened (with only a few verses of the entire chant, for example), and there is a possibility that Dante did not have the specific chant melodies in mind that have been selected for Incipit. Still, the chants of Purgatory are versions that have maintained relatively intact, and exactly in their chronological order. There is no libretto or entire composition that has been followed exactly, so Purgatory does not fall into the category of repertoire. The category of sampling is perhaps more precise, especially if we take into account that interpreting such ancient music includes a margin of guessing work, such as tempo, voice colour, exact rhythm, ornamentation and in this case even exact melody.

Finally, Paradise takes a step ahead to more editing and might be considered floating in between sampling and radical edit, depending on one's point of view. First of all, most chants described in 
Dante's Paradise are not specified enough to know what they are actually singing or are highly altered heavenly versions of chants (the Sanctus, for example). Secondly, for all these chants two additional voices were composed according to the rules of improvised organum around 1300, which could be called "creation" in Coussens' definition: even if it is done according to historical rules, we are not sure if we are close to the historical practice or if our application of these rules is too coloured by a 21 st century perspective. Finally, musical and conceptual decisions lead to a exclusion of a few chants described in the Commedia and to a slight change in the original order of the chants. While the mise-en-scene for Purgatory is still reminiscent of the Purgatory scenes in the Commedia, Incipit's Paradise is a completely different narrative form. Its underlying concept, however, is still based on the same idea of a Divine representation of a Paradise that no human can perceive, because it is not in space or time. Perhaps, in the case of Paradise, there is a multilayered treatment of the musical and creative material which could place it both in the categories of sampling and radical edits.

All three parts of Incipit have a pre-recorded musical track which had to be followed. The fact that historical works were used and had to be placed in a certain order with a certain performance practice determined the creative strategy and the rhythm of the mise-en-scene.

Also the relation between the actor and musician is an important part of the work process. Often, musicians are asked to play their music and be present on stage, but they do not have to act differently than they normally do. This kind of strategy is mostly present when Early Music is combined with Contemporary mise-en-scene: the musicians concentrate on their music apart from what happens around them. A much rarer situation is to see an Early Music performer being an actor at the same time, merging music making and acting completely. This could have a certain relation with the more archive-like work that is part of a historically informed musician's routine, and which makes the performance practice according to this knowledge an important part of his playing, also when he mixes it with a contemporary mise-en-scene. In Incipit, the performance merged acting and making music completely. This was especially visible in Purgatory, where dramatical acting was used. In Paradise, a more choreographic mise-en-scene was mixed with the singing, interacting with the lighting. Such physical movement and choreography can make the singing more of a challenge. It divides the attention of the musician, and Falk Hübner suggests that such divided attention "adds another layer to the performance of the musician, and contributes to a heightened attention and presence on stage" (Hübner 2013, 80). 


\section{CHAPTER 3 - THE DIVINA COMMEDIA}

\subsection{The context of Dante's Divina Commedia}

The Commedia, written by Dante Alighieri between c.1308 and 1320, is used as a basis for the music theatre work Incipit created within our research. In this chapter, the context of his work will be shortly discussed before continuing to its contents and interpretation. Bocaccio added the adjective divina to the original title in his Trattatello in laude di Dante ("Treatise in Praise of Dante") from 1373. ${ }^{121}$ Dante expert Zygmunt Baranski notes that it was only added in the Venetian edition of 1555 printed by Gabriele Giolito and supervised by Ludovico Dolce. ${ }^{122}$

Dante's original title referred to the literary genre of the comedy, a narrative with a positive ending as opposed to a tragedy. Although a comedy may also contain chaos and catastrophes, it will always end well. In a tragedy, however, the narrative moves from welfare toward catastrophe. Comedy was usually written in the "popular" vernacular, while tragedy was written in the more "academic" Latin language. Latin was considered a more "elevated" language, used for tragedy and matters of philosophy, contrary to the vernacular, used for love poetry and popular writings. Indeed, despite the philosophical and theological subject of his work, Dante chose to write in the vernacular Tuscan. This was a remarkable paradox for his time, even a provocation toward academic circles. Dante with his title not only indicated that his work is a narration with a good end, but it was also a stylistic decision. His reasons for this choice were various. First, his intention was that his work would be an educative narrative, accessible to everybody, not just those who could understand Latin $^{123}$. Second, his work was a means to give vernacular language a higher status, one worthy of such high subject matters. Third, Italy was in fact a collection of city-states, each with its own language, and Dante believed that a common vernacular language could unite Italy, even politically. This is also why he included in his Commedia (the title that we shall use from now on) different linguistic styles according to the language and origin of his characters. As Baranski notes, "the poet's desire to transcend Italy's dialectal fragmentation was, in part, born from the experience of his exile. It was expressed as a desire for linguistic unity to counter both the country's political factionalism and the widespread external interference in its affairs" (Baranski 2005, 572). It was not only Latin that the Tuscan would have to overcome, but also French and Provençal. By then, French was seen as the pre-eminent language for prose, while Provençal was the leading language for the lyric style (Baranski 2005, 571).

121 Lambdin, L.C. And Lambdin R.T., Arthurian Writers: A Biographical Encyclopedia (Greenwood Press: Westport 2008), p.117

122 Baranski, Z. "Experimentation and (self-)exegesis", p. 559-582, ed. Minnis, A. and Johnson I., The Cambridge History of Literary Criticism Volume 2: The Middle Ages (Cambridge University Press, 2005), p.577

123 Ibid., p.569. Baranski reports Dante's own explanations given in his Convivio. 
There is a possible fourth reason for his stylistic choice. The genre of the comedy was connected with Biblical and Christian narrations (Baranski 2005, 578). The Commedia is a spiritual journey, and it could be that Dante refers to the vernacular language in which the Bible was read. In his Yale lectures on Dante, professor Giuseppe Mazzotta says that the biblical story is a comedy in the sense that it has a positive end:

"He really has this idea of a comical vision, even of the divinity and certainly of the cosmos. Comical, in the sense that it is really the feast; in classical times, it would be the feast of the gods. Here it is the redemptive, happy, harmonious sense of the whole. (...) It is very difficult to locate the tragic: there is no such a thing as a Christian tragedy." 124

In the Biblical story, the most tragic part is the Crucifixion of Jesus, but it leads to the re-opening of heaven to humanity. Dante's Inferno is tragic, but he must descend into darkness in order to ascend to the light of Paradise. Baranski mentions fragments from the Commedia where Dante himself indicates that "both the journey and the poem were God's providential plan for humanity. (...) The Commedia turns to God for its legitimation" (Baranski 2005, 578). Dante scholar Andrew Frisardi notes that

\footnotetext{
"it is a commonplace that the Commedia reflects earthly events and people from two sourcebooks that were integral to medieval thought: the Book of God's Works, or the universe; and the Book of God's Words, or the Bible. In the Paradiso Dante often refers to the Creator's impronta o sugello - the imprint or seal of the Divine creative force - that leaves its traces in each successive level of creation" ${ }^{125}$
}

Dante was well aware of the possibilities of vernacular language, he knew various other dialects than Tuscan. Baranski argues that "basing himself not on a rhetorical construct such as the 'illustrious vernacular' but on his 'maternal Florentine', which he enriched with terms taken from all the languages and jargons with which he was familiar, Dante tried to find a register with which he could come to grips with the complexities of the world" (Baranski 2005, 574).

Dante began defending the vernacular already in his earlier works. His first work, the Vita Nova (c.1295), was an autobiographical type of vernacular love poetry in which he connected love with the intellect through the combination of religious and secular elements (Baranski 2005, 567). He began using the vernacular in his Convivio (1303-1306) for a discussion of a broad range of subjects 124 Giuseppe Mazzotta, Lecture 9 of Dante in Translation (September 4, 2008), Yale Online, http://oyc.yale.edu/italianlanguage-and-literature/ital-310 [accessed september 2014] 125 Frisardi, Andrew, “The Commedia as Cosmos”, Temenos Academy Review 14 (2011), p.49-79: p.50 
(Baranski 2005, 568-569). His De vulgari eloquentia (c.1304) was written in Latin but focussed on vernacular language, defending it for the Latin-reading audience. This linguistic development brought him to his specific use of the vernacular in his Commedia. However, as Baranski states,

"he always tried to maintain links with the tradition: this is the key critical tension which organizes his oeuvre. (...) The poet never forgot that he had to communicate in a society which, for centuries, had intimately associated certain forms with specific subjects and connotations. (...) Dante's aim was to innovate and challenge from within the tradition, rather than to reject this unconditionally. (...) If the poet had not created a dialectic between traditional forms and his own text, it is difficult to see how he could have underlined the newness of the Commedia" (Baranski 2005, 576).

Giuseppe Mazzotta is mentioning the Commedia not only as an epic, a romance, an autobiography, but also as an encyclopedia, referring to its etymologic meaning of "circle of knowledge" (Mazzotta

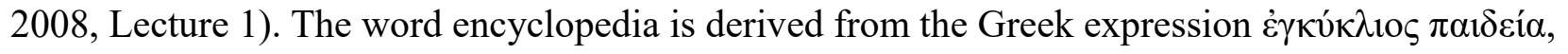
(enkyklios paideia, "encyclical education”), appearing as the erroneous form $\gamma \kappa v \kappa \lambda о \pi \alpha 1 \delta \varepsilon i ́ \alpha$ (enkyklopaidia) in manuscripts by Quintilian, Pliny and Galen. ${ }^{126}$ Mazzotta explains this as a circle in which, from a point of departure, one will travel along all the liberal arts and will come back to that point, but now with another perspective. Dante's Commedia is therefore an educative journey along grammar, dialectics and rhetoric (the trivium of the liberal arts) encompassing poetry and history. The journey is also along arithmetic, geometry, music and astronomy (the quadrivium of the liberal arts) encompassing ethics, theology, metaphysics and theology (Mazzotta 2008, Lecture 1). The plot of the book is simple: the protagonist Dante is lost in a wild forest. His beloved Beatrice, whose spirit is in Paradise, has requested to the soul of Virgil to help Dante and guide him through Hell and Purgatory. At the end of Purgatory, Beatrice herself waits for him in order to be his guide through Paradise. The book consists of three cantiche or canticles: Inferno, Purgatory and Paradise, each containing 33 cantos $^{127}$, except Inferno where there are 34 . Together they add up to exactly a hundred cantos for the whole Commedia. The first canto, where Dante finds himself in a forest, could be read as an introduction to the other 33 cantos of Inferno. It is no coincidence that Inferno has 34 canticles, an imperfect number next to the number 33 which represents the Trinity. Also within the cantos, the number three is the cornerstone of the Commedia's poetic language. Dante is the first poet to use terza rima, a series of three-line stanzas in chain rhyme in the pattern of ABA, $\mathrm{BCB}, \mathrm{CDC}$, DED, etc.

126 "encyclopaedia | encyclopedia, n.". OED Online. September 2014. Oxford University Press. http://www.oed.com/view/Entry/61848?redirectedFrom=encyclopedia (accessed October 03, 2014).

127 According to Oxford English Dictionary a canto is "one of the divisions of a long poem; such a part as the minstrel might sing at one 'fit'.", "canto, n.". OED Online. June 2015. Oxford University Press. http://www.oed.com/view/Entry/27287?redirectedFrom=canto [accessed June 21, 2015] 
Beatrice had already appeared in Dante's Vita Nova, the "New Life". The title perhaps refers to youth but it can also refer to the new, surprising aliveness that he feels at the moment he sees her, already at the age of eight, falling in love with her:

"Nine times already since my birth the heaven of light had circled back to almost the same point, when there appeared before my eyes the now glorious lady of my mind, who was called Beatrice even by those who did not know what her name was." 128

It is a platonic love because he admires her from a distance. The Vita Nova is a search for the meaning of love, since it came to him without desiring it. His answer comes in chapter XIX, with the famous opening words "Donne ch'avete intelletto d'amore", "Ladies who have intellect of love.". Love is not the chaos that his friend and poet Guido Cavalcanti sees as contrary to the intellect and friendship; for Dante, love is the union of intellect and emotion and has the force to set personal growth in motion on a more spiritual level. It is an autobiographical, introspective work, focused only on his inner world and on the effects Beatrice has on him (Mazzotta 2008, Lecture 2). His poetry alternates with prose sections which are commentaries on the poems. They are literary criticism and auto-exegesis incorporated in the work itself (Baranski 2005, 566).

Beatrice died while Dante was still writing his Vita Nuova. From there on, the Vita Nova narrates about his wanderings after she has died. Already when she was alive, Beatrice was an idealized figure in his poems, but after her death she became even a saintly figure to Dante. One year later, when Dante met another woman for whom he started to feel passion, he expressed the conflict this was arousing in his mind with the memory of Beatrice. Nonetheless, in the last poem of the Vita Nova he wrote about a vision he had of Beatrice reappearing to him at the foot of God's throne. Full of remorse, he decided to stop writing about her until his words would be able to do her justice (Mazzotta 2008, Lecture 2). Thus he left the Vita Nova unfinished:

"After I wrote this sonnet there came to me a miraculous vision in which I saw things that made me resolve to say no more about this blessed one until I would be capable of writing about her in a nobler way. (...) And then may it please the One who is the Lord of graciousness that my soul ascend to behold the glory of its lady, that is, of that blessed Beatrice, who in glory contemplates the countenance of the One qui est per omnia secula benedictus." 129

128 "Nove fiate già appresso lo mio nascimento era tornato lo cielo de la luce quasi a uno medesimo punto, quanto a la sua propria girazione, quando a li miei occhi apparve prima la gloriosa donna de la mia mente, la quale fu chiamata da molti Beatrice li quali non sapeano che si chiamare.”, Dante Alighieri, Vita Nuova, II,1. Ed. Michele Barbi, transl. Mark Musa, Testo critico della Società Dantesca Italiana (Florence, Società Dantesca Italiana, 1960). The name Beatrice comes from beatus, which means blessed.

129 "Appresso questo sonetto apparve a me una mirabile visione, ne la quale io vidi cose che mi fecero proporre di non 
The structure of poetry and narrative or reflective prose is probably based on that of the Biblical Song of Songs (Baranski 2005, 576), while the autobiographic aspect is modelled by Augustine's Confessions (Mazzotta 2008, Lecture 2). Both the Bible and Augustine's writings were essential works in the Middle Ages, commonly referred to and commented on. They served as a basic referential framework whose authority was not questioned, but rather used as a point of departure. ${ }^{130}$ Dante would continue to write poems that would be collected after his death in the book Le Rime, but in these poems he did not write about Beatrice. They do show a growth towards more complex forms and subjects, as well as variety and experimentation. ${ }^{131}$

Another crucial event in Dante's life had a great influence on his writing of the Commedia: in 1308 he was sentenced to perpetual exile by pope Boniface VIII, due to his political activities as a White Guelph. The Guelphs and Ghibellines in central and northern Italy were factions supporting respectively the Pope and the Holy Roman Emperor. When the Guelphs defeated the Ghibellines in 1289, they began to fight among themselves and by 1300 ended up being divided into Black and White Guelphs. While the Black faction continued to support the Pope, the White one disapproved of Papal influence on worldly matters, especially during the reign of Boniface VIII. In Florence, the White Guelphs had seized the power and expelled many Black Guelphs, among them Dante's friend Guido Cavalcanti, who died in exile very soon afterwards. In 1302, Boniface VIII planned a military occupation of Florence by restoring the leader of the Black Guelphs, just when a delegation of the Florentine council was in Rome. From this delegation Dante was the only one who was asked to stay in Rome with Boniface. It was actually a trap for Dante: he was sentenced to two years of exile, the payment of a large sum of money and a permanent ban from public functions. He refused to do so and was then sentenced to perpetual exile from his city, one of the most severe punishments a man could receive, since citizenship was an essential part of Medieval man's identity in society. Now that the Black Guelphs had the power in Florence, Dante took part in attempts by a group of White Guelphs to regain power. However, he grew disappointed with the divisiveness of his own allies and decided to leave them. From then on, Dante was travelling from court to court, from Bologna to Padua, Treviso, the district Lunigiana, the valley of Casentino, Verona and finally Ravenna where he would die of malaria in 1321.

dire più di questa benedetta infino a tanto che io potesse più degnamente trattare di lei.", Dante Alighieri, Vita Nuova, XLII,1 and 3. Ed. Michele Barbi, transl. Mark Musa, Testo critico della Società Dantesca Italiana; Florence: Società Dantesca Italiana, 1960. [Accessed online version availabe at http://http://etcweb.princeton.edu/dante/pdp/ on 4 October 2014]

130 Van Deusen, N., "They All Read the Same Books": A Book-Bag from Antiquity”, The Cultural Context of Medieval Music, p.105-122

131 Pertile, L., "Dante”, Ed. P. Brand and L. Pertile, The Cambridge History of Italian Literature, 2nd Edition (Cambridge, 1999), p. 37-69 
Despite those unstable circumstances he could manage to write several works, like De vulgari eloquentia ("About eloquence in the vernacular", ca.1304), the Convivio ("Banquet", ca.13031306), and the Commedia. In the words of Lino Pertile,

“(...) with these works Dante intended to assert his authority far beyond the field of love poetry (...) What, therefore, may seem like a slow and hesitant transition, was in fact a period of intense activity and of rapid, almost irresistible, intellectual evolution for the poet. After his recent misfortune, Dante was radically reviewing his past, seeking to restore his battered self-confidence and reputation, and to find new and more solid grounds upon which to base his future. (...) When he undertook his two projects, Dante consciously aimed as high as he could: the Convivio was to bring his philosophical canzoni within reach of a wide Italian audience; the De vulgari was to demonstrate in Latin the formal dignity of his vernacular poetry in the context of a universal theory and history of language and literature. Dante hoped that works of such significance would compel Florence to recognize his merits and revoke his exile" (Pertile 1996, 47).

Dante would not finish the Convivio either: of the fifteen planned treatises, he only completed four. They are not just literary criticism, they also discuss the subjects of ethics, metaphysics, cosmology and politics. The ideas he exposed in the Convivio were resumed in a less contradictory and more solidified form in his Commedia. ${ }^{132}$

De vulgari eloquentia was intended to consist of at least four books, dealing with the origins and history of language and the complete range of styles and forms used in vernacular literature, but he could complete no more than two books, both written in Latin, the formal language of science and philosophy. The work begins with an enumeration of the reasons why the vernacular is more noble than Latin: "Of these two kinds of language, the more noble is the vernacular: first, because it was the language originally used by the human race; second, because the whole world employs it, though with different pronunciations and using different words; and third because it is natural to us, while the other is, in contrast, artificial. And this more noble kind of language is what I intend to discuss." $" 133$

Another interesting argument that Dante presents in De vulgari eloquentia is the fact that language is only used by human beings, while the angels have other ways to communicate:

132 Pertile argues that the ideas in the Convivio are still "in a state of fluctuation, confusion and even contradiction". Pertile, L. "Dante", Ed. P. Brand and L. Pertile, The Cambridge History of Italian Literature (Cambridge, 1996) p.48 133 "Harum quoque duarum nobilior est vulgaris: tum quia prima fuit humano generi usitata; tum quia totus orbis ipsa perfruitur, licet in diversas prolationes et vocabula sit divisa; tum quia naturalis est nobis, cum illa potius artificialis existat. Et de hac nobiliori nostra est intentio pertractare.", Dante Alighieri, De vulgari Eloquentia, Ed. Rajna, P., Testo critico della Società Dantesca Italiana (Florence, Società Dantesca Italiana, 1960), I, i, 1-4 [Accessed online version availabe at http://http://etcweb.princeton.edu/dante/pdp/ on 4 October 2014] 
"This, in truth, is our primary language. I do not, though, say 'our' because there is or could be any other kind of language than that of human beings; for, of all creatures that exist, only human beings were given the power of speech, because only to them was it necessary. It was not necessary that either angels or the lower animals should be able to speak; rather, this power would have been wasted on them, and nature, of course, hates to do anything superfluous. (...) since the angels possess, in order to communicate their own glorious conceptions, a ready and ineffable sufficiency of intellect - through which either they make themselves, in themselves, completely known to each other, or, at least, are reflected, in the fullness of their beauty and ardour, by that resplendent mirror which retains an image of all of them - they seem not to have needed signs to represent speech. And if it be objected that some angels have fallen from heaven, a twofold answer may be made. First, that when we are discussing things that are necessary for a rightly ordered life, we should leave the fallen angels aside, since, in their perversity, they chose not to wait on God's care; second, and better, that these demons, in order to demonstrate their corruption to each other, need only to know, of anyone of their number, the nature and the degree of his fallen condition. And this they already know, for they knew each other before their ruin." 134

Dante would also write De Monarchia (ca.1312), a discussion on the relationship between Church and Empire in which he argues that the Pope should not hold any worldly power. This argument reappears in his Commedia. Interestingly enough, in the third book he states that, in human beings, the mind is not corruptible but the body is. That is why, according to Dante, human beings have a worldly part and a divine part. For this reason nor the Pope nor the Emperor should reign over each other. Remarkable in De Monarchia is the fact that Dante dares to speak very boldly about the role of the Church, speaking against the Donation of Constantine, which was believed to be authentic. ${ }^{135}$ In the Commedia he went even further and situated various monks and popes in the Inferno, where one of the damned souls predicts that Pope Boniface VIII himself is doomed for Hell.

134 'Hec est nostra vera prima locutio. Non dico autem 'nostra', ut et aliam sit esse locutionem quam hominis; nam eorum que sunt omnium soli homini datum est loqui, cum solum sibi necessarium fuerit. Non angelis, non inferioribus animalibus necessarium fuit loqui: sed nequicquam datum fuisset eis; quod nempe facere natura abhorret. (...) Cum igitur angeli ad pandendas gloriosas eorum conceptiones habeant promptissimam atque ineffabilem sufficientiam intellectus, qua vel alter alteri totaliter innotescit per se, vel saltim per illud fulgentissimum speculum in quo cuncti representantur pulcerrimi atque avidissimi speculantur, nullo signo locutionis indiguisse videntur. Et si obiciatur de hiis qui corruerunt spiritibus, dupliciter responderi potest. Primo, quod cum de hiis que necessaria sunt ad bene esse tractamus, eos preterire debemus, cum divinam curam perversi expectare noluerunt. Vel secundo et melius, quod ipsi demones ad manifestandam inter se perfidiam suam non indigent nisi ut sciant quilibet de quolibet quia est et quantus est: quod quidem sciunt; cognoverunt enim se invicem ante ruinam suam.” Dante Alighieri, De vulgari Eloquentia, Ed. Rajna, P., Testo critico della Società Dantesca Italiana (Florence, Società Dantesca Italiana, 1960), I, i, 1-4 [Accessed online version availabe at http://http://etcweb.princeton.edu/dante/pdp/ on 4 October 2014]

135 The Donation of Constantine was a decree supposedly written by Constantine I in order to give authority over the Western Roman Empire to the pope, probably written in the 8th century and discovered in the 15th century to be a falsification. 
Between c. 1313-1318 Dante was invited to stay at the court of the Ghibelline Cangrande in Verona, the longest and probably quietest period he stayed at any court. In 1315 Florence was forced by a Ghibelline military leader to give amnesty to their exiled citizens, including Dante. Florence accepted to do so but added as a requisite a public penance and a fine. Dante refused to return in such disgraceful circumstances to Florence. According to Pertile, he must have been finishing the Purgatorio already. Accepting the requisites would contradict his own convictions and everything he had written until then (Pertile 1996, 54). Dante's exile allowed him to speak freely about political, social and moral matters, thus providing us with quite a unique perspective on the events of his time. Just as Boethius had written The Consolation of Philosophy (ca. 523) as a way to understand his situation while he was waiting for his death sentence, in the Commedia Dante tried to find answers to the existential doubts about his unfair exile.

But the Commedia is more than that: it is an educational voyage for himself and his readers. In fact, throughout all his works there is a learning path, an exploration through the self and the world around it. The autobiographic aspect in his writing was not completely new either. It was already present in his Vita Nova, where he focussed on his personal thoughts and emotions. The Commedia brings that focus outward to the public space of his life, to what happens around him (Ciabattoni 2004, Lecture 2). His main predecessors in the genre of autobiography are Augustine in the Confessions and Abelard in Historia Calamitatum. In Chapter 1 we discussed Augustine's Confessions where he describes the great effect of sacred music on his body and soul. Finally, the idea of a journey to heaven had already been written about by Alain de Lille's in Anticlaudianus (12th century) where Nature travels to Heaven in a chariot made by the seven Liberal Arts, in order to obtain a soul for the body she had created. ${ }^{136}$ In these aspects, Dante is a writer of his time, and not a Renaissance humanist yet. Medieval writers did indeed focus on human emotions, although they tended to represent them through human characters, a technique that Dante also applied. It is true, nonetheless, that Dante made innovations but always respecting the existing traditions by trying to expand the existing limits rather than to ignore them. His exile gave him the possibility to look at society as an outsider (Baranski 2005, 576).

Apart from its vernacular language and terza rima, the Commedia was also a novelty in presenting an imaginary journey as if he really went to Hell, Purgatory and Heaven. No author before him dared to undertake something similar because it could be perceived as heretic. Pertile wrote about the Inferno, when it was brought out around 1313:

136 Baranski refers to the Anticlaudianus in his article, "Epistle to Cangrande", p.589. The description of the narrative has been based on Sheridan, James J. (1980). Introduction to The Plaint of Nature, (Toronto, 1980) 
"The Inferno was the first instalment of a three-part account in which the author claimed to have been on a journey among the dead, where he had met and talked to, among others, many of his friends and foes, especially from Florence. Even apart from the question of credibility, the work broke all the rules: literary, political, religious. Its subject was deeply serious, but its language vernacular ${ }^{137}$; its stylistic range was unprecedented, mixing the low and base with the lofty and abstract, the comic with the tragic, the lyric with the epic, the Christian with the pagan. Politically, it condemned to eternal damnation Guelphs (both Black and White) as well as Ghibellines, ecclesiastical as well as secular rulers. (...) Finally, although its theology appeared to be broadly orthodox, the poem was in many ways a veritable scandal: it denounced the Popes and the customs of the Holy Roman Church, calling for the surrender of all the wealth and power accumulated over a thousand years. What was worse, indeed intolerable, its author claimed to speak with the voice of God, to be a new Christian prophet, sent to reform the world before its impending end." 138

The Commedia was read throughout Italy. By 1315, the Inferno and Purgatorio were already circulating, while the Paradiso would be finished in 1321, the year of his death. No manuscripts from Dante's hand survived, only later ones from the $14^{\text {th }}$ and $15^{\text {th }}$ centuries. As Christian Moevs writes in his book about Dante's metaphysics,

“philosophically, and perhaps temperamentally too, Dante's nearest kinsman may be [the German mystic] Meister Eckhart, his exact contemporary (1260-1327). (...) In the fourteenth century Eckhart was condemned; the Comedy was banned by the Dominicans and escaped the Monarchia's inquisitorial condemnation only because it was written in the vernacular and could disguise itself as a poetic fiction. (...) Dante's son Pietro, like other early commentators, sought to (...) convince readers that a poem whose world they could not help treating as real, as historia, was really all a fiction. This was intended to save Dante from charges of heresy (which by law would have ruined Pietro too), for it was only too evident that the claim that he had penetrated the secrets of God, that he was another writer of the Holy Spirit, was implicit (when not explicit) in Dante's enterprise."139

With the invention of printing, the Commedia was one of the first books to be printed massively and distributed throughout Italy, contributing strongly to the nationalization of vernacular Tuscan as the standard Italian language. ${ }^{140}$ The $14^{\text {th }}$ century would generate hundreds of copies mostly of either Inferno, Purgatory or Paradise. In 1322 appeared the first commentaries on the Inferno and by 1330

137 Baranski writes about the negative commentary of the Bolognese magister Giovanni del Virgilio about the use of the vernacular for such intellectual issues and refers for this to Dante's Egloche I, 1-34, where Dante responds. Baranski, Z., "Dante Alighieri: experimentation and (self-)exegesis", Minnis, A. and Johnson, I., The Cambridge History of Literary Criticism (Cambridge,1993), p. 559-582

138 Pertile, L. "Dante”, Ed. P. Brand and L. Pertile, The Cambridge History of Italian Literature (Cambridge, 1996) p.39-40

139 Moevs, C., The Metaphysics of Dante's Comedy (New York, 2005), p. 175-177

140 Christopher Kleinhenz, Medieval Italy: An Encyclopedia, Vol. 1 (Routledge, 2004), p. 360. 
on the whole Commedia. Although we would expect Dante's contemporaries to understand his work better than we do after so many centuries, the $14^{\text {th }}$ century explanations of the Commedia are highly diverse and do not agree on the levels of its allegory. Dante himself indicated four levels of lecture in his Convivio:

"The first is called the literal (...). The next is called the allegorical, and this is the one that is hidden beneath the cloak of these fables, and is a truth hidden beneath a beautiful fiction. (...) The third sense is called moral, and this is the sense that teachers should intently seek to discover throughout the scriptures, for their own profit and that of their pupils (...). The fourth sense is called anagogical, that is to say, beyond the senses; and this occurs when a scripture is expounded in a spiritual sense (...). ${ }^{141}$

He distinguishes two subtypes of allegory but does not explain them:

"Indeed the theologians take this sense otherwise than do the poets; but since it is my intention here to follow the method of the poets, I shall take the allegorical sense according to the usage of the poets." ${ }^{142}$

Robert Hollander, Professor in European Literature at Princeton, explained that all imaginative secular literature was treated as something fictional and not historical because the only for religious literature was considered historical: the Bible, for example, was understood as a historical document which also had a symbolical meaning. The letter to Cangrande ${ }^{143}$, not sure to have been written by Dante $^{144}$, advices the reader to apply the fourfold interpretation of religious texts (literal, allegoric, moral and anagogical level) on the Commedia, as if it were a religious text itself and not mere fiction:

"For the elucidation, therefore, of what we have to say, it must be understood that the meaning of this work is not of one kind only; rather the work may be described as 'polysemous', that is, having several meanings; for the first meaning is that which is conveyed by the letter, and the next is that which is conveyed by what the letter signifies; the former of which is called literal, while the latter is called

141 Dante Alighieri, Convivio (II, i, 3-41), Edizione Nazionale (Florence, 1995), online available at http://etcweb.princeton.edu/dante/pdp/convivio.html [accessed 7-10 2014], with translation of Lansing, Richard, Dante's "Il Convivio" (New York: Garland, 1990).

142 Dante Alighieri, Convivio (II, i, 3-4), http://etcweb.princeton.edu/dante/pdp/convivio.html [accessed 7-10 2014] 143 Cangrande was his patron and protector in Verona.

144 Its authenticity has been disputed for over a century. Baranski argues against Dante being the author of the letter. Baranski, Z., "The Epistle to Can Grande", p.583-589, Edd. Minnis, A. and Johnson, I., The Cambridge History of Literary Criticism (Cambridge, 1996). Another well-known scholar on Dante, Robert Hollander, does think it is authentic. Hollander, R., Dante's Epistle to Cangrande (Ann Arbor, 1993). Also Christian Moevs in The Metaphysics of Dante's Comedy (New York, 2005) is quite convinced of its authenticity, because "the Letter conceives the Comedy's aim as the redemption of all humanity, by leading it to conclusion the direct experience of the divine. (Who but the author of the Comedy would make such a claim for it?)", p.175 
allegorical, or mystical [or moral, or anagogical]."145

Since we are not sure if Dante is the author of this letter, we cannot really make any sure conclusion. Hollander, as one of the scholars that do believe so, suggests that

\begin{abstract}
"Dante, faced with the strong opposition of theologians to the idea that secular literature had any meaningful claim to purvey truth, made a bold decision. Rather than employ the allegory of the poets, which admitted, even insisted, that the literal sense of a work was untrue, he chose to employ the allegory of the theologians, with the consequence that everything recounted in the poem as having actually occurred is to be treated as "historical," since the poet insistently claims that what he relates is nothing less than literally true."146
\end{abstract}

If this is true, then indeed the characters in the Commedia can be seen as real persons instead of being personifications of human aspects. Hollander points out that a genre of "realistic" fiction did exist beside the fabula ("unrealistic" fiction) and historia (non-fiction): the argumentum. ${ }^{147}$ Hollander adds that Dante makes use of prophetic expressions. ${ }^{148}$ In his own time, these were taken seriously, but as Moevs notes, it took only 'the arrival of the Renaissance, to defuse the 'prophetic' urgency of the Comedy and reduce it to poetic fancy." 149 Since the Renaissance it was understood as such, but in 1941 the Italian philosopher Bruno Nardi wrote an essay called "Dante profeta". As Moevs notes, according to Nardi
"Dante considered the Comedy not 'poetic fiction' or 'literary artifice', but the account of a 'true prophetic vision', and that to refuse or fail to accept this is to misunderstand Dante's poema sacro. Nardi concludes that Dante 'treats the objects of his vision as reality', not as a bella menzogna, not as a beautiful lie to 'represent a moral idea': Dante believed he saw Hell, Purgatory, and Paradise 'as they truly are in reality'." (Moevs 2005, 178).

From this moment on there was renewed discussion on Dante's metaphysics.

\footnotetext{
145 "Ad evidentiam itaque dicendorum sciendum est quod istius operis non est simplex sensus, ymo dici potest polysemos, hoc est plurium sensuum; nam primus sensus est qui habetur per litteram, alius est qui habetur per significata per litteram. Et primus dicitur litteralis, secundus vero allegoricus, sive moralis, sive anagogicus." Dante Alighieri, Epistle to Cangrande, Ed. Ermenegildo Pistelli, Testo critico della Societa' Dantesca Italiana (Florence, 1960).

146 Hollander, R., "Allegory in Dante”, http://etcweb.princeton.edu/dante/pdp/allegory.html [accessed 7-10-2014]

147 Ibid., footnote 3: "Argumenta are things that, while not having actually ocurred, could have done so." Hollander refers for general discussion to Curtius (Curt.1948.1), pp.452-455 and for discussion with reference to Dante to Hollander (Holl.1969.1), pp.256-258.

148 Ibid., footnote 4: "The main technique he borrows from the theologians centers on the relationship between the two first senses, historical/literal and allegorical. (...) In addition, historical events are sometimes referred to as "shadows" of things to come."

149 Moevs, C., The Metaphysics of Dante's Comedy (New York, 2005), p.178
} 


\section{Role of the Commedia in this investigation}

This short overview of Dante's life and works gives us a comprehensive framework for further analysis of the Commedia's narrative. For the contemporary reader, the Commedia has a great value as a fascinating scenery coming from a medieval mind, which can both surprise and teach us. In the field of music, Historically Informed Performance shares this fascination for the historical mentality. The Commedia was not only chosen as a departure point for our music theatre work Incipit because of its historical-philosophical value, but also because it provides sonorous, choreographic and visual elements for a multidisciplinary theatrical creation.

The Commedia contains many references to sound. In Inferno, there are only non-musical sounds, at least at a first glance. When we read more carefully, we can discover various references to chants and music, but only to reinforce the fact that all sonorous experience in Inferno is anti-musical. Francesco Ciabattoni, Associate Professor of Italian at Georgetown University, argues that this is part of the punishment in Hell: the damned souls and those who once were angels (the neutral angels and the disobedient devils) are denied any form of music. Ciabattoni calls it a perverted musical experience. ${ }^{150}$ In Purgatorio and Paradiso, there are many references to chants, as an important part of the Afterlife experience. Although the chants have already been listed and performed ${ }^{151}$, this performance was based on the $20^{\text {th }}$ century standard versions of the Church, which are different from the Late-Medieval repertoire (see Chapter 1). We must go back to manuscripts from around 1300 and, if this is not possible, at least try to find a version before the Council of Trent (1545-1563) and certainly before the reform of the monks of Solesmes at the end of the $19^{\text {th }}$ century. So far known by the author of this investigation, this research has not been undertaken yet, and as such it already contributes to knowledge of Dante's Commedia. Furthermore, there will be composition of additional voices to the plainchant melody according to the rules that were valid at the beginning of the $14^{\text {th }}$ century.

Not only sonorous allusions but also references to movements form the basis of the visual-sonorous concept of Incipit. The idea of creating a theatrical work as if it were a musical composition is suggested by the idea of Composed Theatre by Matthias Rebstock and David Roesner. ${ }^{152}$ In this case, the text itself has served as a resource of literal elements for this visual-sonorous composition of Incipit.

150 Ciabattoni, F., Dante's Journey to Polyphony (Toronto, 2010), p.43-84

151 This is the only setting known to the author at this point: http://www.worldofdante.org/music.html [accessed 19-102014], a monophonic choice of the Liber Usualis chants

152 Roesner, D. and Rebstock, M. Composed Theatre: Aesthetics, Practices, Processes (Bristol, 2012). 


\subsection{Structure of the Afterlife}

The cosmological model in Dante's time was the Ptolemaic universe, also called Geocentric model, in which all the planets and stars revolve around the Earth. Already from the $4^{\text {th }}$ century BC on, most educated Greeks believed in a round centric Earth. In the $2^{\text {nd }}$ century Claudius Ptolemaeus (c.90-c.168), a Greco-Egyptian mathematician, astronomer, geographer and astrologer of Alexandria, informed himself on a wide range of writings by different astronomers and devised a theoretical model that would form the basis of astronomy for many centuries. His theory describes the order of planets in relation to the Earth, where the moon is the closest to the Earth, then comes Mercury, Venus, the Sun, Mars, Jupiter, Saturn, the Fixed Stars and the Primum Mobile ("First Moved"). Medieval Christianity added the Empyrean, the firmament which is above all others. The

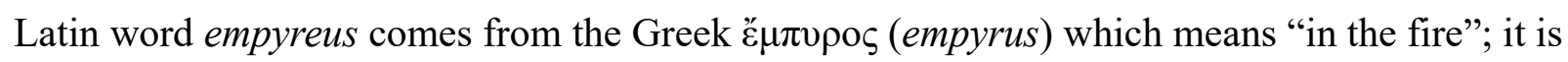
where the element of fire resided in various ancient cosmologies. The Empyrean, for Dante, is not a physical place but rather the spiritual universe, the mind of God, as Professor Mazzotta in his Yale lectures on Dante notes. Mazzotta calls the Empyrean "the heaven of fire, from which all motion begins, from which time starts. That is really where the roots of time are found and they stretch out into the finite world." (Mazzotta 2008, Lecture 11). The Medieval model dominated for centuries, shown by figure 39, dating from 1539. Nicolaus Copernicus came up in 1543 with the heliocentric system in his treatise De revolutionibus orbium coelestium ("On the Revolutions of the Heavenly Spheres"). It was still not a perfect model and would not find many followers until the $17^{\text {th }}$ century. Johannes Kepler corrected the theory in 1609 suggesting that the orbits of the planets were not circular but elliptical, which was supported by the gravity theory of Isaac Newton in 1687 . The Catholic Church was against the idea that the universe would not turn around God's creation of human being and maintained this position until the $19^{\text {th }}$ century.

In his Commedia, Dante follows the Ptolemaic model but with the peculiarity that the Sun casts a shadow over the Moon, Mercury and partly Venus. Its shadow has the form of a cone and comes to a point at Venus. Of course, this is rather allegorical-theological than scientific. For the Earth he also added an original story: when Lucifer fell out of Heaven, his body made a hole in the Earth by which the mount of Purgatory was created (Inferno 34). Purgatory arose from the middle of the ocean in the Southern Hemisphere, which was thought to be only water, exactly on the opposite side of Jerusalem. It is a remarkable connexion Dante makes between the creation of evil and simultaneously the possibility of redemption. 


\section{Schema huius pramuffa diuifionis Sphararum.}

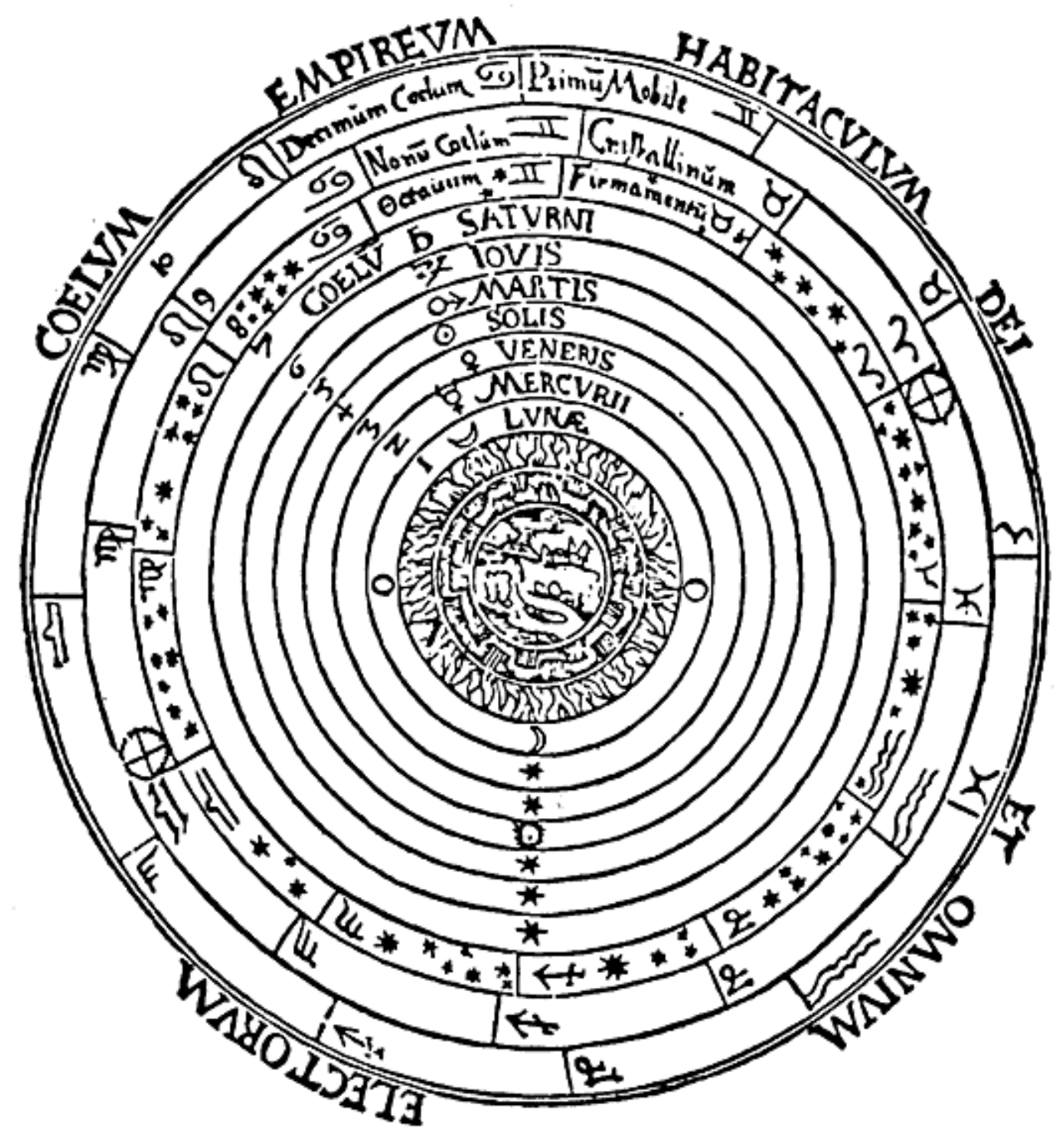

Fig. 39. Ptolemaic Model, (Petrus Apianus: Cosmographia, 1539). The Earth is in the middle with the other planets circling around it.

It must be noted, though, that at the time of Christ's Descent into Hell ${ }^{153}$, Limbo already existed, but Earthly Paradise on top of the mount of Purgatory as well as the immaterial Paradise were still inaccessible to humanity. In Dante's Commedia, the Greek hero Ulysses apparently saw Purgatory just before his death. In Dante's time, Ulysses was only known through later adaptations of Homer's

153 Also called Harrowing of Hell. According to the Bible, Christ had reopened Paradise with his Crucifixion. Before his resurrection, he descended to hell in order to free the righteous souls and bring them with him to heaven. Virgil tells Dante about Christ's descent to Limbo, where he was not one of the chosen. As Guy P. Raffa notes, "Only suggested in the Bible, the story of Christ's post-mortem journey to hell appears in apocrypha--books related to but not included in the Bible--such as the Gospel of Nicodemus. So prominent was this story in the popular and theological imaginations that it was proclaimed as church dogma in 1215 and 1274.", Raffa, G.P., Danteworlds, http://danteworlds.laits.utexas.edu/circle1.html\#harrowing [accessed 13-09 2015] 
Illiad and the Odyssey which did not include the original story of his death. Thus, it seems that in Dante's imagination Ulysses saw Purgatory from far away when he crashed with his vessel into the depth of Hell:

"a lone mountain loomed ahead, dark
in the dim distance, and it looked to me
the highest peak that I had ever seen.

We leaped for joy — it quickly turned to grief,

for from the new land a whirlwind surging up

struck the foredeck of our ship head on. (...)

Until the sea once more closed over us." 154

Dante's Afterlife is divided into three parts: Inferno, Purgatory and Paradise. Dante encounters himself in a wilderness before Virgil takes him to the entrance of Inferno. Inferno has the form of a funnel divided into 9 circles. The number 9 is not only present in Inferno but is repeated in all three canticles: the mount of Purgatory consists of 9 levels and Paradise encompasses 9 spheres. The number 9 is the total of $3 \times 3$, which is no coincidence either: 3 is the number of the Trinity, just as the Commedia has three canticles and each consists of 33 cantos - except Inferno with the number 34 - adding up to a total of 100 cantos. Such a symmetrical and theological construction is characteristic for the Middle Ages, when numerical symbolism was a way to manifest the Divine and symmetry reflected the perfection of God's creation. ${ }^{155}$ This is exactly why the Pythagorean system was so important, expressing the Music of the Spheres. The perfection of God was thought to be revealed through the proportions of the universe in all its levels (see Chapter 1 on the Music of the Spheres). Each of the three canticles in the Commedia ends with the word stelle ("stars").

\footnotetext{
154 “n'apparve una montagna, bruna / per la distanza, e parvemi alta tanto / quanto veduta non avëa alcuna. / Noi ci allegrammo, e tosto tornò in pianto; / ché de la nova terra un turbo nacque / e percosse del legno il primo canto. (...) infin che 'l mar fu sovra noi richiuso", Dante Alighieri, Commedia, Inferno 26.133. Original text:

https://it.wikisource.org/wiki/Divina_Commedia and English translation:

http://www.italianstudies.org/comedy/index.htm

155 Eco, U. Art and Beauty in the Middle Ages (Yale University Press, 1986), Chapter 2
} 


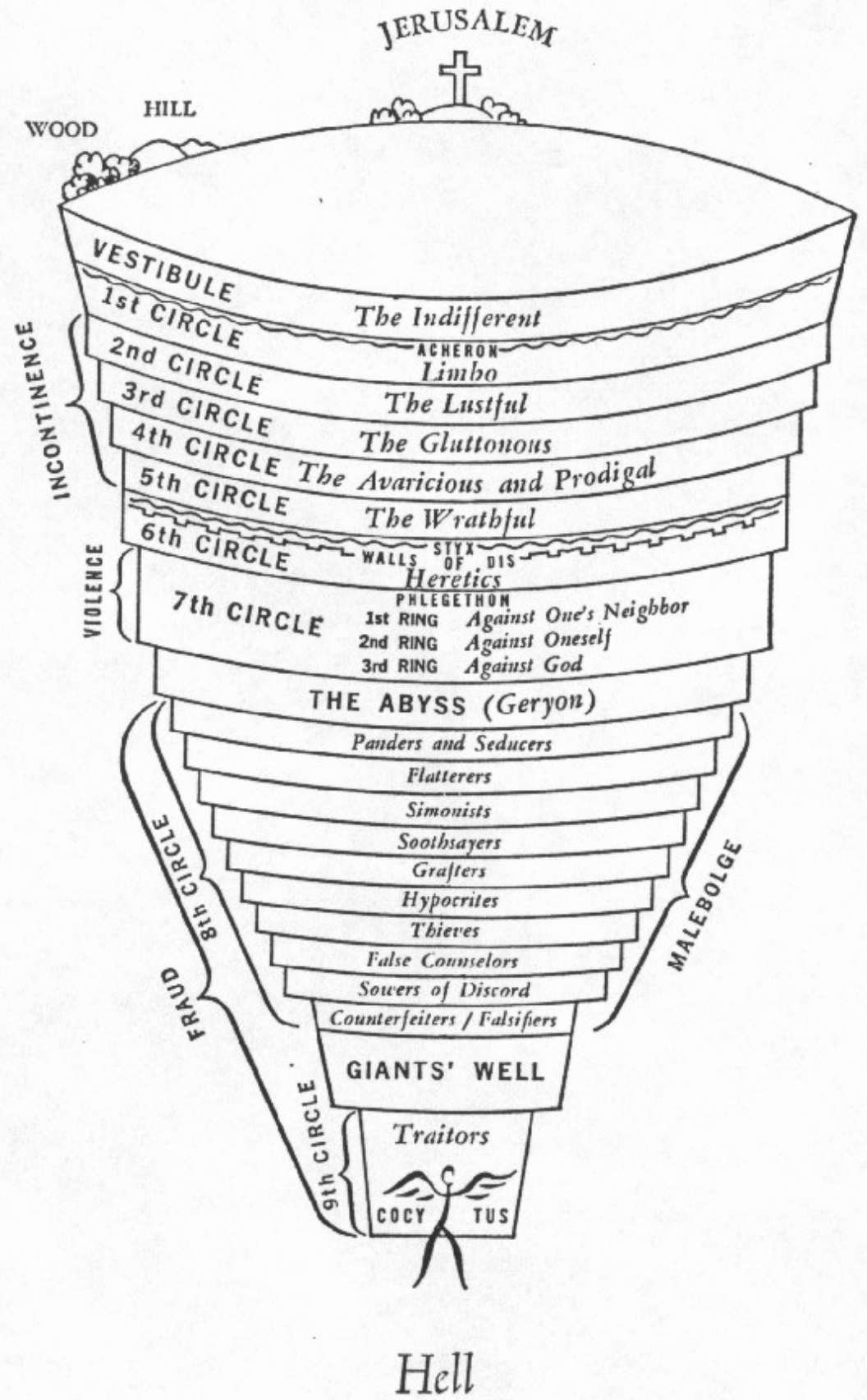

Fig. 40. Dante's Inferno. 


\section{Inferno}

In Dante's narrative, Dante encounters himself lost in the wilderness, with no idea about how he entered there or when he got off the straight path:

\begin{tabular}{|l|l|}
\hline $\begin{array}{l}\text { Nel mezzo del cammin di nostra vita } \\
\text { mi ritrovai per una selva oscura, } \\
\text { ché la diritta via era smarrita. (...) }\end{array}$ & $\begin{array}{l}\text { Halfway through the journey we are living } \\
\text { I found myself deep in a darkened forest, } \\
\text { For I had lost all trace of the straight path. (...) }\end{array}$ \\
$\begin{array}{l}\text { Io non so ben ridir com'i' v'intrai, } \\
\text { tant'era pien di sonno a quel punto } \\
\text { che la verace via abbandonai. }\end{array}$ & $\begin{array}{l}\text { I cannot say clearly how I entered there } \\
\text { So drowsy with sleep had I grown at that hour } \\
\text { When first I wandered off from the true way. }{ }^{156}\end{array}$ \\
\hline
\end{tabular}

This dark forest, not only poetical but also literal in Dante's narrative, is situated within a valley close to Jerusalem. When trying to get out of it, his way is blocked by three beasts. Their characteristics are explained later in the Commedia: a leopard which is fast and not easy to detect, a lion with an intimidating presence and a she-wolf with an insatiable hunger. It is said that they represent three vices but there is no agreement on their exact meaning.

The soul of Virgil appears just in time and offers to guide him through the Afterworld, explaining that he was sent by Beatrice. Dante feels that he is not worthy enough for such a journey but Virgil insists and tells him that Beatrice descended from her place in Paradise to visit Virgil in Limbo and ask him to help Dante. Dante then follows Virgil.

Dante and Virgil reach the entrance gate of Inferno, with the following inscription:

\begin{tabular}{|l|l}
\hline $\begin{array}{l}\text { Per me si va ne la città dolente, } \\
\text { per me si va ne l'etterno dolore, } \\
\text { per me si va tra la perduta gente. }\end{array}$ & $\begin{array}{l}\text { Through me pass into the painful city, } \\
\text { through me pass into eternal grief, } \\
\text { through me pass among the lost people. } \\
\text { Giustizia mosse il mio alto fattore; } \\
\text { fecemi la divina podestate, }\end{array}$ \\
\hline
\end{tabular}


la somma sapïenza e 'l primo amore.

with highest wisdom and with primal love.

Dinanzi a me non fuor cose create

Before me nothing was created that

se non etterne, e io etterna duro.

was not eternal, and I last eternally.

Lasciate ogne speranza, voi ch'intrate

All hope abandon, you who enter here

The last phrase of this inscription, Lasciate ogne speranza, voi ch'intrate, was used by Claudio Monteverdi at the beginning of the $17^{\text {th }}$ century in one of the first operas in Western music and has become a widely known phrase among Early Music practitioners and listeners. The inscription shows that it was not Lucifer who created Inferno but God.

The nine circles of Inferno are organized by type of sins. We will discuss shortly its organization ${ }^{157}$. They are numbered according to the number of their circle.

0. Past the entrance gate but outside of Inferno itself are the Neutral Angels and souls, those who did not make a choice between God or Lucifer. The words Che visser sanza 'nfamia e sanza lodo (Inf. 3.36), "those who lived without infamy and praise", remained an expression in Italian up to today ${ }^{158}$, not surprisingly representing mediocrity. These souls were the spectators of the world, the ones that only stood by and watched from what they thought to be a neutral perspective. The angels here did not take sides when Lucifer rebelled against God. Now, they are not welcome in Heaven nor in Hell, so they have to stay on the threshold of Hell, stung by insects while running eternally behind a banner. Their punishment is Dante's own invention. They are separated from Inferno by Acheron, one of the four infernal rivers. The boatman Charon brings the other souls to Hell.

1. Limbo. The unbaptized and those previous to Jesus' birth who did not believe in the Divine within the human, "they did not worship God in the right way" 159 . It is a place inhabited by good and wise spirits, protected from the rest of Inferno by seven walls. Here is where Virgil resides, together with Homer, Ovid, Lucan, Horace amongst others, all sighing. The souls are not entirely happy because they are not touched with God's light (they chose not to recognize the Divine within themselves), despite the fact that Limbo seems to be an agreeable place: “an open clearing, bright and high up"160. Christ's Descent into Hell was in

157 From now on, James Finn Cotter's translation will be used for the English quotes from Dante's Commedia, because it is more comprehensible than the traditional Longfellow translation and some translations are more accurate, although less poetic. http://www.italianstudies.org/comedy/index.htm

158 Nowadays it is "senza infamia e senza lode".

159 "non adorar debitamente a Dio" (Inferno 4.37)

160 "in loco aperto, luminoso e alto" (Inferno 4.116) 
Limbo, when Paradise was still not accessible to humanity, to save many righteous souls and bring them to the newly opened Heaven.

Dante's Hell is divided into sins of Incontinence, Violence and Fraud. Each sin has its own contrapasso, a punishment that suits the sin either in form or meaning. Prof. Mazzotta regards it as "the extension of what one has chosen to do in this life." He speaks of a counterpart or countersuffering, because passo comes from passion (from the Greek verb $\pi \alpha \sigma \chi \omega$ meaning "to suffer"). "You suffer equally for what you have done" (Mazzotta 2008, Lecture 8). Interestingly, some scholars like Manuele Gragnolati, Kenneth Gross, Anthony Cassell and Leonard Barkan, believe that the contrapasso is "more a manifestation of the damned souls' corruption than an antithetical retribution for their sin". ${ }^{161}$ Gragnolati quotes Barkan: "the living sinner, through his death but more particularly through the fate of his special damnation, is transformed into an eternal objectification of his sin" (Gragnolati 2005, 217).

The sins of incontinence, meaning that the will is not controlled by reason, comprise circles 2 to 6 (Lust, Gluttony, Avarice/Prodigality, and Wrath). At the edge of Circle 2, King Minos is judging the newly arrived souls and sentences them to their place in Hell. This infernal version of King Minos is the judge of Inferno, sentencing each soul to a circle. He owns a tail, which he coils around him as many times as the number of the circle apt for the soul in front of him. He can speak but also growls. He is one of the first hybrid creatures that inhabit Hell: half man, half beast, a reflection of the damned souls.

2. Lust. The lustful are flung by wind blasts that never stop. Their contrapasso consists of being out of control just like their actions when they were still alive. They did not take responsibility for their actions. Among these souls are Francesca da Rimini (1255-c.1285) and her lover Paolo, the brother of her husband who killed them when he caught them kissing each other. These two are in the circle of lust and incontinence as an example of people who entangled themselves in their own illusions of courtly love.

3. Gluttony. These souls are lying under a sour rain and snow, constantly flipping over to the other side of their bodies and howling because of the pain. The three-headed dog Cerberus barks so loud that the souls "wish that they were deaf"162. The souls are described as empty and lie on the ground like living dead: they cannot communicate and do not seem to have much conscience.

161 Gragnolati, M., Experiencing the Afterlife: Soul and Body in Dante and Medieval Culture (Indiana, 2005), p.217 162 "esser vorrebber sorde", Inferno 6.33 
4. Avarice and Prodigality. Avarice is the sin of holding on too much on worldly goods, while prodigality is the sin of wasting money. They are not only a sign of incontinence and lack of measure, but also for an obsession for material goods. The guard here is Plutus, the Roman god of wealth, who says "with clacking voice": "Pape Satan, pape satan, aleppe!""163, which are words with no specific meaning. He is yet another example of a hybrid creature, half human, half beastly. There are no individual characters in this circle, yet Virgil tells Dante that "these were the clergy who have no crown of hair / on their heads, both popes and cardinals, / within whom avarice runs to its extreme". ${ }^{164}$

5. Wrath and Sullenness. They are two sides of fury: expressed fury (wrath) and unexpressed fury (sullenness). The wrathful souls are fighting each other at the surface of the muddy river Styx, while the sullen ones are below the surface gurgling their sighs and laments. This river, with its boatman Phlegyas, surrounds the city of Hell, with the name of Dis. The word Dis comes from Dis Pater who was the Roman god of the Underworld. The entrance of the city is guarded by demons and fallen angels.

6. Heresy. As Virgil informs Dante, "In this section is found the cemetery / of Epicurus and his followers / all those who claim the soul dies with the body." 165 The contrapasso is clear: they are condemned to be dead (Mazotta 2008, Lecture 5). They must stay in mass graves surrounded by flames. The two Epicureans with whom Dante speaks show no empathy or interest for each other at all, they are only focussed on themselves and their own family members.

Circles 1 until 6 formed the upper part of Hell. The deepest three circles 7, 8 and 9 represent Lower Hell. Their sins are graver because these do not have their roots in passion but in the intellect.

7. Violence and Bestiality. The Minotaur, another hybrid creature, is its guardian. This circle consists of three rings, each with a different group of sinners according to their relation with their victims:

163 “"Pape Satàn, pape Satàn aleppe!", / cominciò Pluto con la voce chioccia”, Inferno 7.1

164 "Questi fuor cherci, che non han coperchio / piloso al capo, e papi e cardinali, / in cui usa avarizia il suo soperchio", Inferno. 7.46

165 "Suo cimitero da questa parte hanno / con Epicuro tutti suoi seguaci, / che l'anima col corpo morta fanno.", Inferno 10.13 
- Tyrants and Robbers: violence to other people. These have to stand in a river of boiling blood. The more severe are their sins, the deeper they will be submerged. There are Centaurs, half-human, half-horse, pointing arrows on those who try to exit the river.

- Suicides and Spendthrifts: violence to oneself. The spendthrifts are more violent to themselves than the prodigals in Circle 4, taking away their own means of survival. The suicides robbed themselves from their own bodies when they were alive. When they died, their souls did not have any more the shape of these God-given bodies they had willingly rejected. Instead, they fell down into Hell as little seeds and grew into trees. In this black forest, harpies - winged creatures with faces of women - are sitting in the trees and hurting them: "The harpies, feeding on its foliage, / cause pain and then an outlet for the pain." 166 They can only speak when they bleed. It must be noted that there are suicides in other places in Dante's Afterlife, because the motives for their suicide were more important than their act. The spendthrifts are chased and devoured by dogs, just as they themselves "devoured" their own means of survival.

- Blasphemers, Sodomites and Usurers. Blasphemy represents violence against God. Sodomy stands for violence against Nature, which Dante describes as God's direct offspring. Usury is violence to economy, offspring of nature and therefore grandchild of God $^{167}$. They reside in a sandy plain surrounded by the dead forest. Dante uses a curious example for sodomy, his teacher Brunetto Latini, who was not particularly known for sodomy, and it is thought that he interpreted the sin on a more metaphorical level. Brunetto speaks of glory as being personal fame, instead of glory as Christian grace enlightened by Divinity. The usurers are the only souls that Dante visits unaccompanied by Virgil which might be related to the fact that Dante's father was said to be a usurer.

The last two circles 8 and 9 represent the sins of Fraud. Circle 8 lies much lower than circle 7. The Geryon, a colourful creature which Dante calls "that repugnant picture of pure fraud" 168 , has the face of an honest man, with a reptilian body, hairy paws and a scorpion's tail. It flies and brings Dante and Virgil to the eighth circle. Circle 8 contains the souls who committed fraud to people they did not have any special relationship with. The souls of circle 9 betrayed those with whom there was a bond of trust.

166 "l'Arpie, pascendo poi de le sue foglie, / fanno dolore, e al dolor fenestra.", Inferno 13.101

167 Danteworlds, University of Texas, http://danteworlds.laits.utexas.edu/circle7.html\#violence, or Inferno 11.100-111 168 "quella sozza imagine di froda", Inferno 17.10 
8. Simple Fraud. This circle is called Malebolge ("Evil Pouches"). Although it is one circle, it contains 10 subdivisions in the form of ditches. Almost all of their separating platforms are connected by a bridge, except the one over the hypocrites.

- Seducers and Pimps. They are whipped from behind by devils and they are forced to walk or even dance: "how they forced them to lift up their heels / at the first strokes!"169

- Flatterers. These are dipped in excrement while they hit and scratch themselves.

- Simoniacs. Simony is presented by Dante as the abuse by clerics of their ecclesiastical position to make themselves rich and powerful. Simony is called after Simon Magus. According to Acts 8:9-24 (fifth book of the New Testament), Simon Magus was a sorcerer converted to Christianity who wanted to buy the apostles' powers. The souls who are sent to this place in Hell apparently fall upside down into a hole, pushing further down the others that are below them. The soles of their feet are on fire, so this ditch is full of wiggling and kicking legs with fire on their feet. Dante comments about the holes from which the legs arise: "No smaller or no larger they seemed to me / than are those booths for the baptismal fonts / built in my beautiful San Giovanni” (the Bapistry of Saint John in Florence). ${ }^{170}$ These souls are upside down in what seem baptismal fonts, with their feet dipped in oil: their contrapasso is a parody on baptism.

- Diviners. Their contrapasso is to walk around with their heads $180^{\circ}$ twisted, "so that they were compelled to walk backwards / since they could not possibly see ahead." ${ }^{171}$

- Grafters. ${ }^{172}$ These souls were involved in political corruption. Now they are completely submerged in sticky tar. If they come to the surface, they run the risk of being stabbed by the forks of black devils. These have strange names, such as Malacoda ("Bad tail"), Alichino (derived from arlecchino, "Harlequin”), Barbariccia (“Curly Beard”), Cagnazzo (“Nasty Dog”), Draghignazzo (“Sneering Dragon”), Ciriatto (“Wild Hog”), or Graffiacane ("Dog Scratcher"). ${ }^{173}$ The devils are anticipatory for the circle of the

169 “come facean lor levar le berze / a le prime percosse!", Inferno 18.37

170 “Non mi parean men ampi né maggiori / che que' che son nel mio bel San Giovanni, / fatti per loco d'i battezzatori”, Inferno 19.16

171 "e in dietro venir li convenia, / perché 'l veder dinanzi era lor tolto", Inferno 20.14

172 Graft is "bribery and other corrupt practices used to secure illicit advantages or gains in politics or business", Oxford Dictionary, http:/www.oxforddictionaries.com/definition/english/graft?q=grafter\#graft-2 16 [accessed 286 2015]

173 Lansing, R.H. and Barolini, T., "Devils”, The Dante Encyclopedia (New York and London, 2000), p. 301-303 
Hypocrites because they tell Dante where the next bridge is without mentioning that it is broken. Dante and Virgil have to slide down to the next ditch in order to escape. The devils form the humoristic part of the Commedia, a farse.

- Hypocrites. These souls walk around very slowly in beautifully ornamented cloaks, which are made of lead inside. Their contrapasso reflects perfectly the great difference between their inner part from their shining appearance when they were still alive. Caiaphas is crucified on the ground, with the others trampling him.

- Thieves. According to Guy P. Raffa, specialized in medieval Italian literature, "the contrapasso for the thieves (...) is arguably the most conceptually sophisticated of the poem. The tenuous hold on one's identity - with dramatic transformations of human and reptilian forms - suggests that no possession, no matter how personal, is safe in the realm of theft." 174 In this case, even the identity of the thieves and their bodily form are stolen from them. Dante observes one that is bitten by snakes, falling down into ashes and then arising alive again, just like the mythological figure of the phoenix. Dante also witnesses the metamorphosis of souls into the form of a reptile.

- Evil Counselors. These used fraudulent rhetoric for not so honourable motives. Rhetoric had already been regarded in Greek Antiquity as a persuasive means in politics that should be handled with wisdom. ${ }^{175}$ Here, we find the souls captured within tongues of fire, hidden from Dante's view. Ulysses and his companion Diomedes are together within a double flame. Dante's Ulysses used fraudulent rhetoric for convincing his men to sail further than the inhabited world, telling them: "You were not born to live like animals / but to pursue virtue and possess knowledge". ${ }^{176}$ As we have seen earlier in this chapter, in Dante's version they approached an island which seemed to be Purgatory. They drowned because of a wind that came from the island itself. Behind Ulysses' persuasion prevailed his wish to transgress borders in order to obtain knowledge, which is comparable to Dante's own journey. Ulysses keeps returning to Dante's mind throughout his voyage through Afterlife.

- Schismatics. The contrapasso consists of the souls literally being divided: their aerial bodies are cut into pieces. Mohammed, the founder of Islam and Ali, his cousin and son-

174 Raffa, G.P., Danteworlds webpage, http://danteworlds.laits.utexas.edu/circle8b.html\#fraud [accessed 28-6 2015] 175 Held, K., Treffpunkt Platon (Stuttgard, 1990), Chapter 8

176 "fatti non foste a viver come bruti, / ma per seguir virtute e canoscenza", Inferno 26.119 
in-law, reside in this section as sowers of religious divisiveness. As Guy P. Raffa comments, "one popular view held that Mohammed had himself been a cardinal who, his papal ambitions thwarted, caused a great schism within Christianity when he and his followers splintered off into a new religious community." ${ }^{177}$ Also, the troubadour Bertran de Born is here, with his head cut off, carried by his hand like a lantern. The separation of his head reflects the divisiveness that he caused between King Henry II of England and his son, because together they form one metaphorical royal body.

- Falsifiers. Here are alchemists, counterfeiters, imposters and liars. As Guy P. Raffa notes, their "corrupting influence - on metals (alchemists), money (counterfeiters), identity (imposters), and truth (liars) - is reflected in their diseased bodies and minds"178

Giants are standing on the ground of the ninth circle, bound by metal chains and arising from their middle at the rim of the eighth circle. They are thus forming the bridge between the eighth and ninth circles.

9. We arrive at the lowest level: an extensive lake of ice, the place where souls reside who committed treachery to people with whom there was a bond of trust. There are four regions, divided according to the soul's type of relationship with the victim:

- Caina: treachery to family. They are stuck in the ice and only their heads stick out, just as the inhabitants of Antenora.

- Antenora: treachery to country. Among these souls there are two heads stuck together in the ice: it is Count Ugolino della Gherardesca (c.1220-1289) eating from the skull of Archbishop Ruggieri degli Ubaldini (1271-1295). Ugolino had betrayed the leaders of Pisa and Ruggieri had him imprisioned together with two sons and two grandsons. After eight months of imprisonment, it was decided that the key of the door was thrown away and all his sons and grandsons starved to death. Ugolini at the end of his story utters the ambiguous words "Then fasting was stronger than grief". ${ }^{179}$

177 Op.cit, http://danteworlds.laits.utexas.edu/circle8b.html\#fraud

178 Op.cit, http://danteworlds.laits.utexas.edu/circle8b.html\#fraud [accessed 28-6 2015]

179 "Poscia, più che 'l dolor, poté 'l digiuno", Inferno 33.75. Here, I have preferred the translation by Henry F. Cary (1772-1844). The translation by Cotter is "Then fasting did what grief had failed to do". Wadsworth's translation is "Then hunger did what sorrow could not do". 
- Ptolomea: treachery to hospitality. One of the souls here is Fra Alberigo, who invited a political opponent and his son to dine as a gesture of peace but had them murdered when it was time for desert. At the moment such malignant treachery has been committed, a demon inhabits the living body while the soul goes directly to Hell.

- Judecca: treachery to lords and benefactors. These souls are completely locked in the ice in diverse postures: "where the shades were wholly sealed / and yet showed through below like straws in glass." $" 180$

In the centre, Lucifer is stuck at his waistline. He fell down to Earth on the Southern Hemisphere, head down, and pierced the Earth until its centre. Now, his upright torso sticks out on the bottom of the Northern Hemisphere, while his legs stick out at the part of the Southern Hemisphere. His three heads are crying and he is chewing on the most thorough sinners of Treachery: Brutus and Cassius, the two assassins of Julius Caesar and Judas. Julius Caesar was the founder of the Roman Empire which Dante considered "an essential part of God's plan for human happiness." ${ }^{181}$ Lucifer is filthy and covered with muck and his own tears. He is not able to speak. Since he is exactly at the centre of the Earth, Dante and Virgil can use his body as an instrument to climb "upside-down" to the bottom of the Southern Hemisphere. They arrive at a cave which leads upward to the shore of Purgatory.

\section{Purgatory}

As we can observe in the following illustration of Purgatory, its terraces have the inverted order of sins, since the highest terraces are closer to redemption. Purgatory consists of Ante-Purgatory and Purgatory Proper. Ante-Purgatory is a kind of waiting room for Purgatory Proper where the real purgation takes place. Here are the late repentants, those who turned to God on an advanced moment in their lives. They have to stay there the number of years they delayed their faith multiplied by 100 , before they can go up to Purgatory Proper. There is a special place reserved for the princes or rulers in general, a beautiful valley. 
Interestingly, Purgatory is measured by love. The first three terraces of Purgatory Proper are characterized by misdirected love, for the wrong kind of things. The fourth is about deficient love, which is good by nature but just not enough of it: the slothful. And finally, the highest three terraces are marked by excessive love.

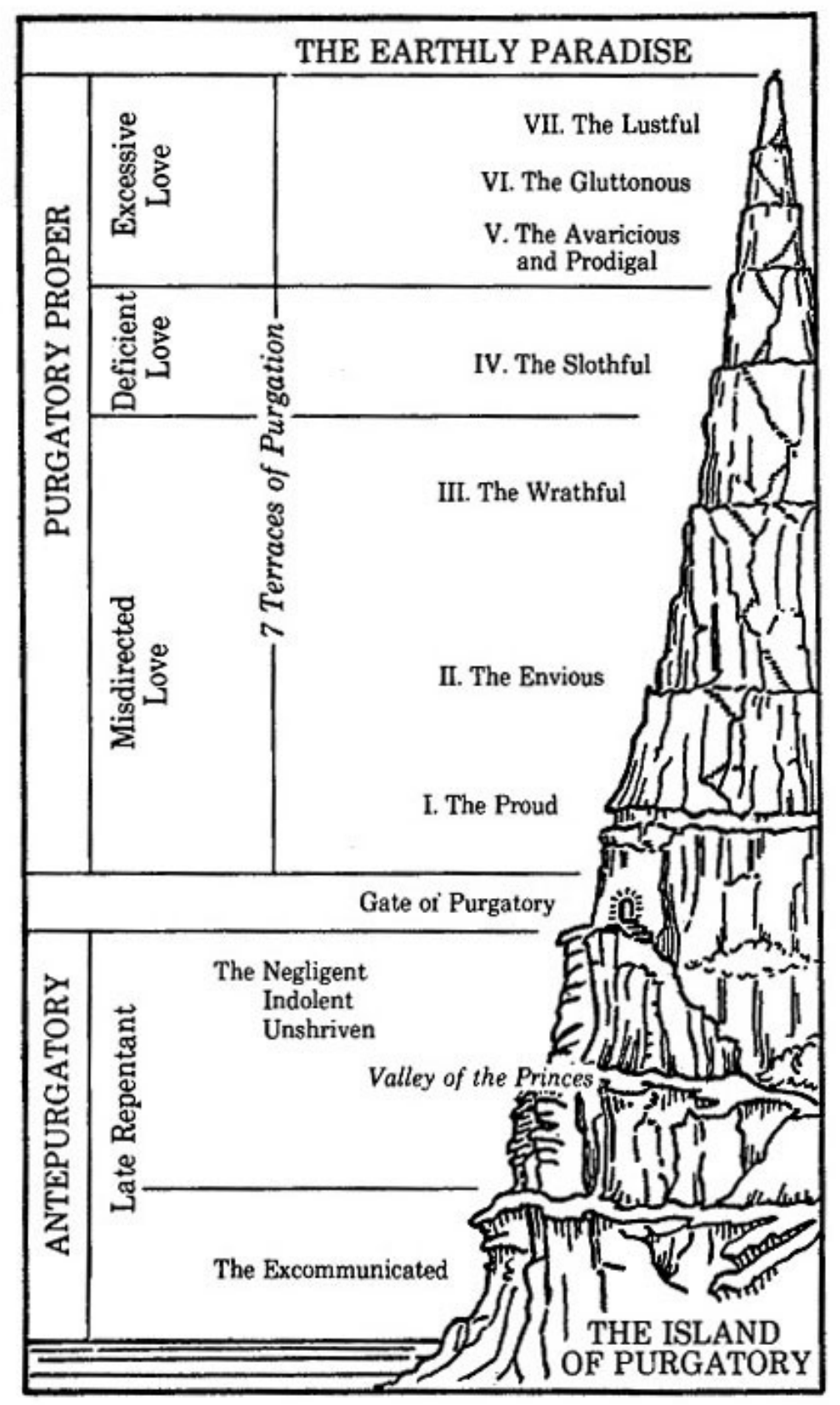

Fig. 41. Dante's Purgatory 
At the shore, the souls destined for Purgatory arrive in a boat steered by an angel while they are singing In exitu israel ("when Israel went out [of Egypt]"). This is the psalm of Exodus ${ }^{182}$. The guardian at the shore is Cato of Utica (95-46 B.C.), a Roman military leader and statesman. As Guy P. Raffa argues,

"Dante seems to have assigned this prominent role to Cato because he so valued freedom that he gave his life for it (1.71-2): the historical Cato chose suicide over submission to tyranny after he was defeated (along with Pompey) in the civil war against Julius Caesar." 183

Dante has to be cleansed after his stay in Hell: Virgil washes his face with dew and makes him a girdle from a special plant that grows there. Dante finds his old friend Casella among the newly arrived but they are not able to embrace each other: Casella's soul is only the imprint that his body made on the air. ${ }^{184}$ Casella is a troubadour and sings a secular song on the text of one of Dante's poems, which is immediately prohibited by Cato because in Purgatory only praise to God can be sung. In Ante-Purgatory there are three types of sinners:

- The excommunicated. These souls must wait in Ante-Purgatory thirty times the length of the years of their excommunication. Prayers by the living for these souls can shorten that time.

- The lazy spirits, the ones who repented at the last moment in their lives. They will have to wait the number of years they delayed their repentance before they can go up to Purgatory Proper. Here are also the souls that died by violence and just repented on time. They sing a Miserere.

- The late repentants that were noble rulers on Earth have their own "Valley of the Princes" reserved for them, a beautiful valley with many flowers. There resides Sordello, a $13^{\text {th }}$ century poet from Mantua, the birth place of Virgil. He warns that at night, one cannot travel through Purgatory. Salve Regina and Te lucis ante are sung. The latter is a prayer to ask God to protect against the dangers of the night. At evening, before sunset,

182 Exodus is the departure of the Israelites from Egypt. The second book of the Bible carries this name and is about the departure of the Israelites from slavery in Egypt, their journey across the Red Sea and through the wilderness led by Moses, and the giving of the Ten Commandments. http://www.oxforddictionaries.com/definition/english/exodus? q=Exodus\#exodus [accessed 13-7 2015]. It is thus closely related to the issue of exile.

183 Raffa, G.P., Danteworlds, http://danteworlds.laits.utexas.edu/purgatory/01 antepurgatory.html\#cato [accessed 28-6 2015]

184 Explained by Statius in Purgatory 25 and analysed by Gragnolati, M., Experiencing the Afterlife: Soul and Body in Dante and Medieval Culture (Indiana, 2005). In Hell this seems to be different, where the souls are clearly heavier and some are even able to touch Dante, like Virgil, who embraces Dante various times. 
two angels descend while a snake appears, chasing it away. This short divine representation repeats itself every night like a ritual.

On a higher terrace lies the entrance of Purgatory Proper. The gate is unreachable from AntePurgatory by foot. Saint Lucia carries Dante in his sleep through the air and leaves him in front of it. At the entrance gate of each terrace has a guardian angel, singing one of the beatitudes (the eight blessings in the Sermon on the Mount in the Gospel of Matthew). This first gate has to be opened with a silver and a golden key. The angel carves seven times the letter P on Dante's front, representing either peccata (sins) or poenae (punishments). With every terrace, one $\mathrm{P}$ will disappear from his front and he will be a bit lighter than before, therefore climbing the mountain will gradually be easier. The three steps to the gate are in three colours: clear white marble, black and cracked, and blood red, which apparently represent three stages of penance: recognition of one's sins, heartfelt contrition and satisfaction. ${ }^{185}$ When the gates close behind Dante, he seems to hear a sung Te Deum.

The first three levels of Purgatory Proper represent misdirected love:

1. The proud. Their contrapasso exists of carrying heavy rocks on their backs that weigh them down, so they are forced to walk bent low to the ground. There are examples of pride and humility carved in the rock, works of God's art that are so realistic that the images seem to become alive. At the gate to the next terrace, the first of the Beatitudes is sung: Beati pauperes spiritu ("Blessed are the poor in spirit").

2. The envious. When alive, they found pleasure in seeing others doing worse than themselves, now their eyelids are sewn with iron thread so that they cannot see. They sit together like blind people in cloaks with the same colour of the rocks. Bodiless voices fly past them shouting opposed examples of kindness and envy. They cry out the Litany of all Saints in vernacular. ${ }^{186}$ At the gate Dante hears Beati misericordi ("Blessed are the merciful") and Godi tu che vinci! $!^{187}$.

3. The wrathful. Dante does not mention the sullen. Since wrath and sullenness are both sides of the same sin (deep anger), they could be present here as well even if they are not

185Raffa, G.P., Danteworlds, http://danteworlds.laits.utexas.edu/purgatory/02valleyofrulers.html\#gate [accessed 13-7 2015]

186 “udia gridar: 'Maria òra per noi': / gridar 'Michele' e 'Pietro' e 'Tutti santi'.,, Purgatory 13.50

187 "Gaudete et Exultate", Matthew 5:12, the text just after the Beatitudes ("Rejoice and be glad, because great is your reward in Heaven" etc.) 
referred to specifically. The souls have to have walk around within a thick black cloud. They experience hallucinations of images of gentleness and wrath. They also sing Agnus Dei. At the gate an angel says the Beatitude Beati pacifici ("Blessed are the peacemakers").

The central terrace is about deficient love:

4. The slothful. Guy P. Raffa notes that "sloth (technically called accidia) describes a lax (or tepid) love and pursuit of what is good and virtuous." ${ }^{188}$ Now, the slothful have to run around the terrace in high tempo while shouting examples of sloth and its opposite diligence. At the gate, they hear the Beati qui lugent quoniam ipsi consolabuntur from an angel ("Blessed are the mournful, for they will be comforted").

Next are the terraces of excessive love, either for worldly goods (terraces 5 and 6) or for other human beings (terrace 7). Material matters as such are not considered sinful - and these souls are devoted sufficiently to God - but if there is excessive love for the worldly goods, it takes the attention away from their love for God.

5. The avaricious and prodigals. These souls have to lie on the ground facing down and sing Adhaesit pavimento anima mea ("My soul has cleaved to the pavement"), Psalm $118 / 119^{189}$. Among them is the first pope that Dante saves from Hell, Adrian V (c.1210/1220 - 1276). Since they were so attached to worldly goods and neglected spiritual matters, they have to remain in the most sober of circumstances. They have to recite examples of avarice during the night and during the day declaim those of contentment with little. Statius, a Roman poet (A.D. 45-96) who converted to Christianity, is just liberated from his punishment at the moment that Dante and Virgil are there. When a soul is ready to go to Heaven, the mount of Purgatory shakes and Gloria in excelsis Deo sounds all over. At the gate, the angel anticipates the sin of the next level with his Beatitude: Beati qui sitiunt ("Blessed are those who thirst"). ${ }^{190}$

188 Raffa, G.P., Danteworlds, http://danteworlds.laits.utexas.edu/purgatory/06sloth.html [accessed 29-6 2015] 189 The Vulgate and most Catholic translations are based on the Septuagint (a translation of the Hebrew Bible and some related texts into Koine Greek), while other translations are based on the Hebrew text. They have a slightly different numbering (mostly the translations from Hebrew are one number ahead) because of the division of some psalm that the Septuagint did not make. The first number is the Septuagint numbering, the second the Hebrew one.

190 This Beatitude is in fact Beati qui esuriunt et sitiunt, 'Blessed are those who hunger and thirst'. The esuriunt will be sung at the gate at the end of the terrace of the gluttonous. 
6. The gluttonous. They have to dwell in a place with fruit trees and fresh water falling on the leaves from the rocks above, while they cannot eat or drink from these trees. Voices come from them, reciting phrases about gluttony and temperance. The souls' shades are so meagre that their faces, with the eyes in their hollow sockets, form the word OMO, meaning "man". They sing psalm 50/51 Domine labia mea aperies et os meum adnuntiabit laudem tuam ("O Lord, thou wilt open my lips: and my mouth shall declare thy praise"). At the gate, the angel sings Beati qui esuriunt ("Blessed are those who hunger"), the missing part of the Beatitude sung at the previous gate.

7. The lustful. They walk inside fire, shouting examples of lust and chastity, while singing the hymn Summae Deus Clementiae in between. There are different groups walking around and when they meet, they kiss the others affectionately before continuing their way. At the end of this terrace, there is a wall of fire that has to be traversed by anyone who wants to reach the Terrestrial Paradise on top of the mount. Here, an angel sings Beati mundo corde, ("Blessed are the pure of heart"). It suggests that this gate is a little cleansing moment for all souls in Purgatory. Once Dante is in the fire, a voice guides him out of it into the Terrestrial Paradise, singing Venite, benedicti Patris mei ("Come, blessed of my Father").

Behind the fire lies a beautiful, calm forest, with little singing birds and trees with gently rustling leaves in the soft breeze. This is the Terrestrial Paradise where Adam and Eve lived before their fall. In this Paradise there are the two rivers Lethe and Eunoe, which have to be crossed in order to be ready for the immaterial Heaven. The river Eunoe is an invention of Dante, probably derived from Greek eu meaning "good" and noe meaning "mind." Matelda, a beautiful young woman and also an invention of Dante, washes the souls first in the river Lethe, where sinful memories are forgotten, and then in the river Eunoe, where memories of their good deeds in life are strengthened. In Greek mythology, once in the afterworld called Hades, drinking from the river Lethe caused complete forgetfulness of one's life and was suitable for the dead who would reincarnate. The other river, the one of memory, was called Mnemosyne, after the Titaness Mnemosyne who bore the nine muses from Zeus and who presided over this river.

In the Commedia's Terrestrial Paradise Dante meets with an allegorical procession of many Biblical figures and virtues following banners in the form of flying candlesticks and singing religious chants. It is the second Divine representation that Dante encounters in the Afterworld but this time it is much more extensive, impressive and metaphoric. There is a chariot pulled by a Griffin, a hybrid 
animal with the wings and head of an eagle and the body of a lion. In the chariot is Beatrice; she will be the guide for Dante from now on because Virgil cannot pass beyond the Terrestrial Paradise and has to return to Limbo.

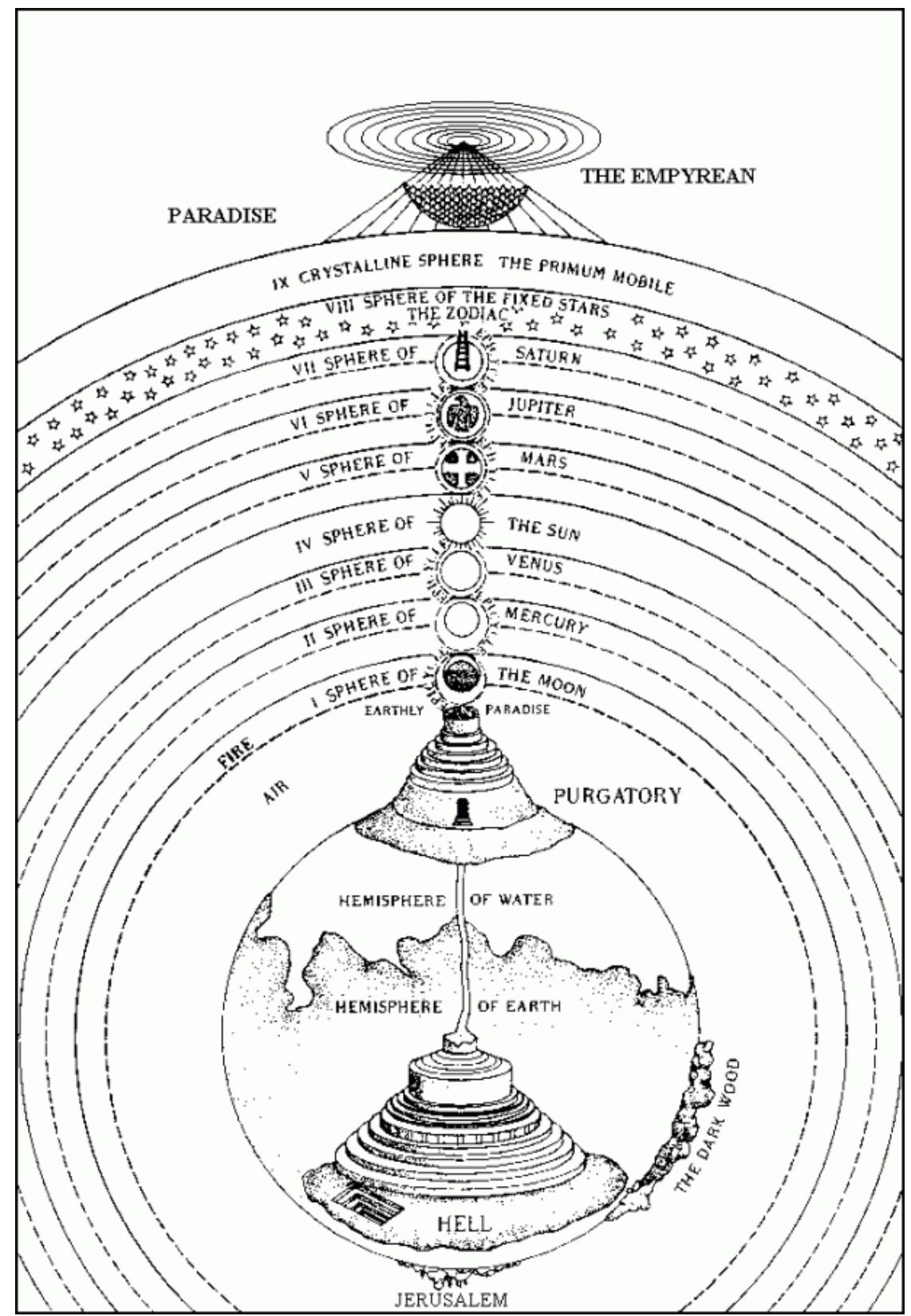

Fig. 42. Dante's Paradise

\section{Paradise}

Paradise is a Divine dramatical representation of the immaterial Paradise, adapted to Dante's mortal senses. It is supposed that the souls are in Abraham's bosom but God shows the souls as if they were living on the planets within the Ptolemaic universe. Dante will travel so fast from planet to planet 
that he arrives at each one before even being aware of it. Beyond the seven planets are the Fixed Stars and the Primum Mobile (the "First-Moved", the place from where the universe is set into motion), adding up to a total of nine spheres. Even beyond is the Empyrean, the spiritual universe, the mind of God. Dante argues in his Convivio (Book II, chapter 13), that each planet has its association with one of the seven artes liberales, the arts and sciences which were considered necessary in Antiquity for a free man's education. These artes are divided into the trivium and quadrivium. The trivium consists of grammatica, dialectica and rhetorica and are associated with the Moon, Mercury and Venus, the first three planets. The quadrivium comprises arithmetica, musica, geometria and astronomia and pair up with the Sun, Mars, Jupiter and Saturn. The Fixed Stars, the Primum Mobile and the Empyrean are connected to higher sciences: physica and metaphysica, ethica, and theologia. ${ }^{191}$

1. Moon: grammatica. This is the sphere of those who broke their vow. They were forced to leave the monastery and from there on lived a secular life. As the soul of Piccarda Donati says, "God knows what my life became thereafter". ${ }^{192}$ They appear like reflected images and they are still shades, but more beautiful than when they were alive. After she speaks, Piccarda disappears singing Ave Maria, "just like a solid weight down through deep water". ${ }^{193}$ The souls here are happy despite the fact that they appear to be in a lower sphere; after speaking with the bright, happy Piccarda, Dante understands that "every place in heaven is paradise". ${ }^{194}$ In his Convivio Dante links the moon with grammar: just as different parts of the moon's surface are lit by the sun, reason illuminates grammar "now on one side, now the other". ${ }^{195} \mathrm{He}$ discusses the question if he is in a real universe here: are the souls really living on the planets, or are they only images? (Mazzotta 2008, Lecture 17). He finds out that they are only images so that a human being like himself can perceive them.

2. Mercury: dialectica, logic speech. In the Convivio Dante compares Mercury to dialectics in two aspects. He claims that both are less substancial than the other planets and sciences and that Mercury's course is more veiled by the sun than they other planets while the course of dialectics is veiled by "a more sophistical and polemical mode of

191 Dante Alighieri, Il Convivio, Book 2, Chapter 13: http://digitaldante.columbia.edu/library/dantes-works/theconvivio/book-02/\#13 [accessed 30-6 2015]

192 "iddio si sa qual poi mia vita fusi.", Paradise 3.108

193 “(...) vanio / come per acqua cupa cosa grave”, Paradise 3.122

194 "ogne dove / in cielo è paradiso", Paradise 3.88

195 Dante Alighieri, Il Convivio, translation in English by T. Kline,

http://www.poetryintranslation.com/PITBR/Italian/ConvivioII.htm [accessed 14-7 2015], Chapter 13 
argument." 196 The souls here were righteous, but their actions on Earth were motivated by personal fame. Among them is Justinian (527-565), the Byzantine emperor who reformed Roman law. From here on the souls are lights instead of shades, so their physical characteristics are not visible anymore. Gladness causes the lights to glow even brighter. The lights come closer when they see Dante, and one of them rejoices: "Look, someone comes who shall augment our love!"197, an expression that shows clearly how all the souls in Paradise are bright with Divine love and experience no gap between reason and will anymore.

3. Venus: rhetorica. Venus and rhetorics share a brightness, "sweeter to view than any other". ${ }^{198}$ These souls were lustful, but unlike the spirits in Purgatory they managed to control it. According to Dante, the conical shape of the shadow that the Earth casts on the first three planets comes here to its point. Scientifically not very correct, but metaphorically it does suggest their inferiority to the souls on the higher planets. One of the souls on Venus is the biblical prostitute Rahab who helped the Israelites in capturing the city of Jericho in the Promised Land. Guy P. Raffa comments that "Rahab is the first spirit to adorn Venus following Christ's Harrowing of Hell. Rahab is viewed in Christian scripture as an ancestor of Jesus (Matt. 1:5) and as an example of salvation by faith (Heb. 11:31) and justification by works (James 2:25)." ${ }^{199}$ On Venus resides also the noble Cunizza da Romano who lived in the $13^{\text {th }}$ century and had various subsequent lovers, among them the troubadour Sordella who had actually abducted her. She is an interesting illustration of the connection between rhetoric and love.

4. Sun: arithmetica. Dante makes the association of arithmetic with the Sun claiming that all the other planets and sciences "are illuminated by its light" and "the eye cannot gaze on it". ${ }^{200}$ The Sun hosts the wise spirits, forming two circles dancing around the Sun.

Each light makes an entire circle in order to come back to its starting point: Mazzotta describes it as an illustration of the circle of knowledge (Mazzotta 2008, Lecture 17). Here, the Dominicans (headed by Thomas Aquinas) and Franciscans (headed by Bonaventure) are together as brothers and talk highly of each other, unlike their

196 Dante Alighieri, Il Convivio, translation in English by T. Kline, http://www.poetryintranslation.com/PITBR/Italian/ConvivioII.htm [accessed 14-7 2015], Chapter 13 197 "Ecco chi crescerà li nostri amori", Paradise 5.105 198 Dante Alighieri, Il Convivio, translation in English by T. Kline, http://www.poetryintranslation.com/PITBR/Italian/ConvivioII.htm [accessed 14-7 2015], Chapter 13 199 Raffa, G.P., Danteworlds, http://danteworlds.laits.utexas.edu/paradiso/03venus.html [accessed 29-6 2015] 200 Dante Alighieri, Il Convivio, translation in English by T. Kline, http://www.poetryintranslation.com/PITBR/Italian/ConvivioII.htm [accessed 14-7 2015], Chapter 13 
conflictive situation on Earth. In this sphere of arithmetic, the form of the circle is regularly referred to.

5. Mars: musica. In this red sphere, the warriors' souls have formed an image of a cross of equal length vertically and horizontally, along which they move while singing. It flashes forth an image of Christ: "Christ flamed from that cross with such a flash / that I can find no pattern fit for it." ${ }^{201}$ Here, an ancestor of Dante descends from the cross and foretells Dante's exile, which in his narrative has not happened yet because the story is situated in 1300 , before his exile in 1302. The relation between Mars and music is essentially an issue of proportions, but Mazzotta gives the following hypothesis about the relation between both:

"Dante links Mars and music out of the belief that harmony is the meeting point or the result of discordant elements, a kind of concordia, a concord, an attuning of hearts reached through discordant elements. The discordant elements can be different sounds; it can be the passions within us that need tempering and so on."202

However, musica mundana is about perfect proportions rather than discordant elements in sounding music, so his argument can be disputed. Dante in his Convivio, written more than a decade before the Commedia, wrote the following:

"Music may be compared to the sphere of Mars because of two properties: one is the planet's beautiful relationship with the other heavens, since in counting the moving spheres, wherever we begin, whether with the nearest or the farthest, the sphere of Mars is the fifth and most central, that is of the first, second, third and fourth pairs. The second is, (...) that Mars dries and incinerates things because of its burning heat; and this is why it appears fiery in colour, to a varying extent, according to the density or rarity of its accompanying vapours (...). These two properties are also found in Music; for it consists wholly of relationships between sounds, as we hear in harmonised words and songs, where the harmony is sweeter the more beautiful the relationship, and these relationships are the principal beauty of the science, being its chief aim. Moreover, Music attracts the human spirits within us, which are, as it were, in the main, vapours of the heart, so that the heart almost ceases its activity; this happens to the entire soul, likewise, when it hears music." 203

201 "quella croce lampeggiava Cristo, / sì ch'io non so trovare essempro degno;”, Paradise 14.104

202 Yale Online lectures "Dante in Translation", Prof. Giuseppe Mazzotta (2008), Lecture 19

203 Dante Alighieri, Il Convivio, translation in English by T. Kline, 
We may smile at his ideas on the vapours of Mars and his logic that seems awkward to us, but indeed he mentions the perfect proportions in music just as Mars is perfectly related to the other spheres.

6. Jupiter: geometria. Just as Jupiter "turns between two heavens antithetical to its sweet temperance", so geometry "operates between two things antithetical to it, namely the point and the circle". ${ }^{204}$ This is a white planet lodging the righteous rulers, who first spell out the words Diligite iustitiam, qui iudicatis terram ("Love justice, you who judge the earth") and then assemble into the form of an eagle. The Eagle presents itself as a single being and with one voice, although it is composed by many souls. It explains Divine Justice to Dante and then flies around just as a real eagle would do. God employs the souls as letters to speak directly to Dante in his aesthetical-didactical representation. Furthermore, Mazzotta connects qui iudicatis terram with the "ultimate measurement of geometry, the Earth" (Mazzotta 2008, Lecture 20).

7. Saturn: astronomia. Just as Saturn moves very slowly through the twelve zodiacal signs in order to master astronomy, "a very large span of time must pass". Furthermore, both are far above the other planets and sciences. ${ }^{205}$ In this sphere reside the contemplatives. It is the first planet where Dante hears no singing at all, which is because his imperfect mortal ears cannot cope with the singing at this stage yet. This is also the reason why Beatrice does not smile, she would turn Dante into ashes. Dante's body gradually becomes more perfect, closer to a resurrected body so he will be able to capture the perfect sounds and visions while ascending, as suggested by Manuele Gragnolati, expert in Medieval Italian literature. ${ }^{206}$ Saturn is just below the Fixed Stars and inhabited by the contemplatives, therefore it has a natural relation with astronomy. In this sphere there is a golden ladder upwards along which many souls travel, just like the one that appeared in a dream to the biblical Jacob.

8. Fixed Stars: physica and metaphysica. Dante in the Convivio connects these two sciences with the heaven of the fixed stars. He tells us about what seems to be the Milky Way,

204 Dante Alighieri, Il Convivio, translation in English by T. Kline,

http://www.poetryintranslation.com/PITBR/Italian/ConvivioII.htm [accessed 14-7 2015], Chapter 13

205 Ibid., Chapter 13

206 Gragnolati, M., Experiencing the Afterlife: Soul and Body in Dante and Medieval Culture (Indiana, 2005) 
"the white band that the populace call St Jacob's Way (...) it reveals one pole to us while the other is hidden (...) the pole which we see signifies material things, which Physics treats of, taken as a whole; while the pole we cannot see signifies non-material things, which are not visible, of which Metaphysics treats; and therefore the two sciences individually resemble aspects of that sphere." 207

This sphere surpasses the seven planets and is connected with the science of what is above nature, metaphysics, which means "the branch of philosophy that deals with the first principles of things, including abstract concepts such as being, knowing, identity, time, and space" ${ }^{208}$, comprising ontology $y^{209}$ and cosmology ${ }^{210}$. The lights represent the coronation and re-ascension of Mary and Christ into the Empyrean. Dante receives an exam on faith by St. Peter, on hope by St. James and on charity and love by St. John. Here resides Adam too, and he speaks about his transgression of the boundaries that God had set for him. Now Adam himself has surpassed the Earthly Paradise.

9. Primum Mobile: ethica (moral philosophy). Dante in his Convivio argues that: "the Crystalline Heaven, or Primum Mobile, is analogous to Moral Philosophy; since Moral Philosophy, as Saint Thomas says in commenting on the second book of the Ethics, directs us towards the other sciences." 211 It is literally called the "first moving (sphere)" and is, what Guy P. Raffa calls "the physical origin of life, motion, and time in the Aristotelian-Ptolemaic universe.”212 The Empyrean sets the Primum Mobile in motion with its Divine love, and from there on it determines the movement of the universe around the Earth. When Dante is in the Primum Mobile, he is able to see a representation of the Empyrean in the form of an tremendously bright Point with nine circles of angels around it. This sphere has a crystalline air, it is of a thinner material than the spheres below.

207 Dante Alighieri, Il Convivio, translation in English by T. Kline, http://www.poetryintranslation.com/PITBR/Italian/ConvivioII.htm [accessed 14-7 2015], Chapter 13

208 Oxford Dictionary, http://www.oxforddictionaries.com/es/definicion/ingles/metaphysics [accessed 30-6 2015]

209 "The branch of metaphysics dealing with the nature of being.", Oxford Dictionary, http://www.oxforddictionaries.com/es/definicion/ingles/ontology [accessed 30-6 2015]

210 "The science of the origin and development of the universe.", Oxford Dictionary, http://www.oxforddictionaries.com/es/definicion/ingles/cosmology [accessed 30-6 2015]

211 Dante Alighieri, Il Convivio, translation in English by T. Kline, http://www.poetryintranslation.com/PITBR/Italian/ConvivioII.htm [accessed 14-7 2015], Chapter 13

212 Raffa, G.P., Danteworlds, http://danteworlds.laits.utexas.edu/paradiso/09primum.html\#primum [accessed 30-6 2015] 
The Empyrean is the spiritual universe, the origin of the physical universe, the mind of God. It is connected with theologia, considered as the highest of all sciences. From the Primum Mobile, it is shown as a Point with nine circles of angels dancing around it. Then it transforms into a city-garden of light. First, he sees a river of light, where lights jump in and out, surrounded by spring-like nature made out of light. Subsequently, it changes into an immense white rose, associated with the mystical rose, while at the same time it is presented as a theatre ("lowest rank", "its row"213). The Empyrean is made visible to Dante but in reality it has no location, its centre is everywhere and nowhere at the same time. The mystical rose is a name for Mary herself, and the Medieval interpretation of Solomon's Song of Songs views Mary as the enclosed garden of God, the virgin new Paradise of God.

The souls are presented having their places on the petals of the Rose, according to belief, age and gender. Here are the main biblical figures and the Church Fathers. Maria is here with archangel Gabriel re-enacting the Annunciation and with Eve at her feet. Adam is here too, so apparently he descended to the Fixed Stars especially for Dante's education. Beatrice returns to her place on the Rose and St. Bernard replaces her as Dante's guide. St. Bernard prays to Mary, asking her to plead to God on Dante's behalf to grant him a beatific vision. In writing down his journey, Dante's human memory and language fail to recall and to express his experiences in the Empyrean, and this worsens toward his final vision. What Dante sees, within a penetrating Light, are three circles "of one dimension and three different colours". Two of them seem reflected by each other, "rainbow by rainbow", and the third seems fire, "breathed equally from one and from the other." In the middle of the three circles, he sees an image of God within humankind: "that middle circle (...) / within itself and in its colouring / seemed to be painted with our human likeness."214

He does not remember more than this image. It is an open end which invites others to make their own journey.

213 “l'infimo grado (...) sé raccoglie”, Paradise 30.115-116

214 "di tre colori e d'una contenenza", "l'un da l'altro come iri da iri / parea reflesso, e 'l terzo parea foco / che quinci e quindi igualmente si spiri”, "Quella circulazion (...) / dentro da sé, del suo colore stesso, / mi parve pinta de la nostra effige”, Paradise 33.117-131 


\subsection{Interpretations and Readings: Selection}

In the description of the Commedia's structure we have discussed the organization of sins and virtues, as well as the main characters that Dante encounters in his journey through Afterlife. What has not been reflected yet are the underlying meanings below the surface of the literal events. It is a complex work comprising many issues and it goes beyond this study to review all of them. This section of chapter 3 will focus on their interpretations. Of course there are many possible readings but below we have followed some of them that formed the basis for the artistic inspiration of the music theatre work Incipit.

One of the main decisions has been situating the voyage of Incipit through Dante's Afterworld in another moment than the year 1300 which is the narrative moment of Dante's journey where he met characters known to him and to his contemporaries. We do not have the contextual knowledge anymore of the political happenings and main figures in his lifetime. If we would re-enact his journey, each of these characters should first be explained to our audience, at least some of their biographies and their significance in Medieval society. Beatrice, Virgil, St. Bernhard, Francesca da Rimini, Boniface VIII, Cacciaguida or Farinata: they do not have the same importance for a contemporary audience as they had in the late Middle Ages. Dante chose them because they represented certain values or sins for him, but if someone from the $21^{\text {st }}$ century were to make the same journey, it would not be as logical to meet the same characters. Thus, Incipit's visit to Dante's Afterworld happens at an unspecified moment in time when Dante is not there anymore. Beatrice has not descended to ask Virgil to guide us because neither of them has a particular connection with us.

Another essential decision has been focussing on the universal questions and not so much on the particularly Christian issues that Dante reviews. His image of God and the universe goes beyond a specific Christian explanation, as we will see later when we will discuss Paradise. It is not our aim to make a Christian music theatre work but rather one that poses universal questions which may appeal to all of us. On the other hand we must understand that the Commedia's historical reference framework was a Christian one which has its own historical interest. The particularity of Dante's Commedia is that he manages to transcend orthodox thoughts and look through the formal aspects.

The main interpretation that we have followed in this research is the one by Yale University professor Giuseppe Mazzotta. His 24 lectures on Dante were recorded in 2008 and are now fully 
available on Yale Online in video and audio formats. ${ }^{215}$ For the information on the relationship between soul and body in the Afterlife, we will use Manuele Gragnolati's Experiencing the Afterlife: Soul and Body in Dante and Medieval Culture. ${ }^{216}$ For the metaphysical interpretation we will refer to the book The Metaphysics of Dante's Comedy by Christian Moevs. ${ }^{217}$

Dante's Commedia is an educational journey through practical experiences. It is an encyclopedia, a "circle of knowledge" and at the end of his poem he will indeed return to his point of departure but with a different perspective from when he started the journey. The poem arose from his condition as an exiled citizen and gave him the possibility to look at the city from the outside, providing a unique analysis of society and humankind but ultimately it is a journey into the metaphysical questions about the origin of life. As Mazzotta says,

"he wants us, at the end of the poem to adventure, to take our own journey and make our own discoveries about that which remains the essential point of the Divine Comedy, as is the essential point of all great texts about tradition: the encounter between the human and the Divine" (Mazzotta 2008, 24).

As we wrote before, his point of view is one that transcends literal Christian images and even has similarities with issues in modern cosmological theories. For now, we will travel along the issues and questions he discusses in his voyage.

\section{Inferno}

Inferno is about politics and ethics. It shows the vices of humankind within society, but often it is a self-confrontation where he encounters the same vices or temptations within himself. He learns that the history of Earth contains an ongoing violence which is often disguised as love. Dante has to admit that "violence lodges even within him" (Mazzotta 2008, Lecture 24), but he wishes to overcome it. As an imperfect human being, open to the worldly temptations on Earth, he will never be able to erase the roots of those temptations within him: he can only be conscious of them and try to resist them.

Aristotle in his De anima ("On the soul") wrote that the human soul, the most complete of all living beings, consists of three levels while the souls of animals comprise two and plants only one:

215 Yale Online, ITAL 310: Dante in Translation by Prof. Mazzotta, http://oyc.yale.edu/italian-language-andliterature/ital-310

216 Gragnolati, M., Experiencing the Afterlife: Soul and Body in Dante and Medieval Culture (Indiana, 2005)

217 Moevs, C., The Metaphysics of Dante's Comedy (New York, 2005) 
- Nutritive or vegetative soul (growth, reproduction)

- Sensitive soul (locomotion, perception)

- Rational soul (intellect, reason)

In the late Middle Ages his subdivision was used in the Scholastic discussion about the nature of the soul. ${ }^{218}$ The sins in Inferno are ordered corresponding to the three levels within the human soul:

- Incontinence (lust, gluttony, avarice and prodigality, wrath and sullenness, heresy)

- Violence (tyranny, suicide, spendthrift, blasphemy, sodomy, usury)

- Fraud (seduction, flattery, simony, foretelling, graft, hypocrisy, theft, fraudulent rhetoric, treachery)

Only humankind is capable of free will because "in free will you have a conjunction of both will and reason and that's the beginning of the moral life. Only when your will is free, you can start making decisions and getting engaged in the world around you" (Mazzotta 2008, Lecture 4). It implies individual responsibility, since man's "intellectual faculties of reason and will distinguish them from other animals and allow them to exert control over their appetites" (Gragnolati 2005, 78). Those who sinned are deprived of their rational and free nature from the moment they are in Hell, being reduced to a more beastly state. This is the reason, as we stated before, why there are hybrid creatures (half human, half beasts) guarding the different levels.

The narrative begins in medias res ${ }^{219}$ : Nel mezzo del cammin di nostra vita ("In the middle of our life's path", Inf. 1.1). Although it is an autobiography, he speaks of "our life" instead of "my life", thus indicating that it might concern all of us. Although it is not completely clear if he has gone off the straight path because of having sinned ${ }^{220}$, the essential point is that he begins his journey disorientated. He does not even know how he entered the forest: "I cannot say clearly how I entered there, / so drowsy with sleep had I grown at that hour / when first I wandered off from the true way." "221 The Latin word silva "wood", is a literal translation of the Greek word hyle (vँ $\lambda \eta)$, adopted by Aristotle to describe the raw matter of which different forms can be made. ${ }^{222}$ Another association of this silva is the wilderness to which Adam and Eve fell, which was the Earth.

218 See Gragnolati, M., Experiencing the Afterlife: Soul and Body in Dante and Medieval Culture (Indiana, 2005), p. 58-67

219 Literally "in the middle of things": a narrative that opens in the midst of action.

220 Retrospectively it is almost sure, though, that this was the reason. When Dante meets Beatrice in the Terrestrial Paradise, she reproaches him for having sinned from the moment she was dead and he confesses (Purgatory 31), and after his sinful memories are washed away in the river Lethe, he does not remember all of that time anymore (Purgatory 33.91-96).

221 "Io non so ben ridir com'i' v'intrai, / tant'era pien di sonno a quel punto / che la verace via abbandonai.", Inferno 1.10

222 Held, K., Treffpunkt Platon (Stuttgard, 1990), Chapter 11 
Dante wishes to leave the forest, ascending a hill toward the sunlight as a Platonist would do: knowledge alone would signify salvation. ${ }^{223}$ However, as Mazzotta says,

"Dante will find out very quickly that that is a false promise; (...) that his own realities are going to be a little bit more complex than what one can find in books, manuals of philosophy, about how we get saved and how we can save ourselves" (Mazzotta 2008, Lecture 3).

In his ascent he encounters three beasts that block his way and threaten to kill him. Knowledge alone will not save him: his initial Platonic journey fails. Then, the spirit of Virgil appears. The first words Dante uses is a prayer: Miserere di me, "Have pity on me", when he sees Virgil and does not know if he is a shade or a man. It is no coincidence that the last spoken words of the Commedia will also be a prayer: from St. Bernard to Maria so that Dante can have the beatific vision but he does not feel worthy:

Ma io, perché venirvi? o chi 'l concede?

Io non Enëa, io non Paulo sono

But I, why should I go? Who gives permission? I am not Aeneas, nor am I Paul (Inf. 2.31) $)^{224}$

The first question he has to answer is about who he is and what the purpose is of his journey (Mazotta 2008, Lecture 3).

They pass through the gate and see the "choir" of neutral souls and angels. For Dante, not taking sides is a very serious sin: it is about turning the world into a spectacle and only when the outcome is clear, choosing the side of the winning party. It is a sign of great cowardice to him. Virgil finishes his explanation about these souls with the following words: "Let us not discuss them, but look and pass on." ${ }^{25}$ Mazzotta comments on this scene: "he does not even name them, because to name then would be to bring them into reality and the neutrality is a sign for the way in which they de-realize the world. They reduce the world to a pure show for their own spectatorship." ${ }^{226}$ It is also a political commentary but Dante will actually have to redefine his judgement, because he will have to "become a party to (by) himself", as his ancestor Cacciaguida foretells him in Paradise about his

223 Plato believed that one could perceive the eternal world of Ideas only by looking further than the material temporal world, so by knowledge. In his Allegory of the Cave, human beings are chained and forced to look at the shadows on the wall a number of puppeteers cast due to a fire behind them, while the real sunlight is to be reached through another path. The sunlight stands for Truth, but at first it would be hard for a freed prisoner to handle it, and only gradually would he be able to discern reality. Only then would he be able to reason about it.

224 Aeneas travelled through the underworld in book 6 of Virgil Aeneid, and the apostle Paul had visited Paradise according to 2 Corinthians 12 .

225 "non ragioniam di lor, ma guarda e passa", Inferno 3.51

226 Yale Online lectures "Dante in Translation", Prof. Giuseppe Mazzotta (2008), Lecture 3 
exile. ${ }^{227}$ As we mentioned earlier in this chapter, Dante's description of these souls che visser sanza 'nfamia e sanza lodo, "who lived without infamy and without praise", entered the Italian language as an expression for mediocrity. ${ }^{228}$

The word Limbo comes from lembo, "edge" and it is literally situated on an edge. It is a garden, one of the three gardens throughout the Commedia (Limbo, Purgatory's Valley of Rulers, Terrestrial Paradise). Such a place is called a locus amoenus, "pleasant place", a beautiful place with trees, grass and water, which seems to be a refuge. Ovid in his Metamorphoses turns the apparent refuge into a dangerous place: just when the hero dismantles himself, the least expected danger appears. Dante in Limbo meets five writers from Antiquity that he greatly admires: apart from Virgil there are also Homer, Lucan, Ovid, and Horace. He has the honour that they invite him within their group "so that I was the sixth among those minds". ${ }^{229}$ His temptation is to stay there with them, feeling proud of his own status. Much later, in Purgatory's Valley of Rulers, Virgil will explain that he did not posses the three holy virtues (faith, hope, charity or Divine love), but did own the four cardinal virtues, also called the moral or classical virtues (fortitude, temperance, justice, and prudence). ${ }^{230}$ It is another way of saying that the souls in Limbo did not carry the Divine inside of them, because this is what the Incarnation represents: the Divine within the human. ${ }^{231}$ Sordello, a poet from Mantua just like Virgil, was allowed to go to Purgatory and resides in the Valley of Rulers. That Valley is a similar place to Limbo in Purgatory, only with more colours, light and, most important, hope to reach Paradise.

The lustful spirits are blown around by the wind and as such they are a parody on the choir of angels: "the angels are those who circle around the throne of God so that the circle implies the plenitude and perfection of movement." ${ }^{, 232}$ The lustful cannot sing, although they are compared to birds (starlings, cranes, and Francesca and her lover descend like doves). About the storm, Mazzotta remarks that "it is the externalizing of the storm inside, the inner storm, never resting" (Mazzotta 2008, Lecture 4).

Francesca da Rimini shows that she has also read work of Dante by paraphrasing him. He descends from his pride when he notices that the interpretation by readers can be completely different than

227 "Their own behaviour will prove their brutishness, / so that it shall enhance your reputation / to have become a party to yourself." - "Di sua bestialitate il suo processo / farà la prova; sì ch’a te fia bello / averti fatta parte per te stesso", Paradise 17.67

228 Nowadays it is: "Senza infamia e senza lode".

229 "sì ch'io fui sesto tra cotanto senno", Inferno 4.102

$230 \mathrm{http}: / /$ danteworlds.laits.utexas.edu/purgatory/02valleyofrulers.html\#virtues [accessed 6-7 2015]

231 This idea is based upon what Moevs says about the transcendent within oneself. Moevs, C., The Metaphysics of Dante's Comedy (New York, 2005), p. 174

232 Yale Online lectures “Dante in Translation", Prof. Giuseppe Mazzotta (2008), Lecture 4 
what the writer wishes to suggest, realizing that there is a responsibility in writing poetry. In this circle it is about the responsibility for one's own acts, something Francesca did not assume. He also asks himself if justice allows for pity or if there is a type of justice where there is no place for compassion (Mazzotta 2008, Lecture 4). Seemingly, in God's justice the latter is the answer since it was these souls' own choice to banish the divine from within themselves but Dante is still at the point where he feels some self-recognition. The question here is also about the relation between lust and love.

In the circle of the gluttonous, there are empty bodies incessantly flipping over to protect themselves from the sour rain. The stinky and acid rain seems to be an appropriate part of their punishment: "there are hints that this is really some kind of repulsive form of waste and food" (Mazzotta 2008, Leccture 4). The soul with whom Dante speaks, called Ciaccio (literally meaning "pig"), talks about Florence, the home-town of Dante. He makes the link between body and city: these gluttonous were thinking too much about the body and too little about the mind: "Politics are now reduced to the question of inexhaustible appetites of bodies", as Mazzotta suggests (Mazzotta 2008, Lecture 4). Their contrapasso is to be empty, mindless bodies. The civil war (between Black and White Ghuelphs) is also a theme appearing here: the city as a dispersed body. The image of the city as a corporate structure was already used in Roman times. No one can escape this reality, "the inner world is necessarily part of the outside world and the outside world will encroach upon it and it will enter one's own inner world" (Mazzotta 2008, Lecture 4).

In the circle of the Avaricious and Prodigals, Dante discusses distributive justice, the type of justice where the goods are divided over many people in a fair way. The term comes from Aristotle in the Nicomachean Ethics ( $4^{\text {th }}$ century B.C.). Dante uses the image of the Wheel of Fortune in order to express that all that goes up must come down at some moment. The souls here have no identity because they are too filthy to be recognizable. The only thing we know is that many among them are clerics, therefore avarice and prodigality are presented as common sins. Dante asks himself why we are so attached to the worldly goods. Here, the souls shout to each other: Perché tieni?, Perché burli?, (“Why do you hold?", "Why do you throw away?”). ${ }^{233}$ Mazzotta comments: "Dante is intimating that the only way to conquer Fortune is to really give up. It's a kind of mystical idea. Mystical in the sense of a spiritual idea, that is, give up the attachment to the things of this world." (Mazzotta 2008, Lecture 4). 
Dante then meets the wrathful and sullen. The sullen are not able to express themselves since they are lying under the surface. Dante shows the same anger as one of the souls that tries to get to him, showing that this violence resides within himself too.

We arrive at the city of Dis. It is like a real Medieval city with a swamp outside and ready for battle. The door is smashed in Virgil's face: they are in an impasse. It is a passage about failure and the weakness of the will. Just when they do not know what to do and the feared Medusa is announced to arrive soon, a Divine messenger comes walking over the water to open the gate.

Within the city there is a cemetery with many heretical souls in each tomb, the Epicureans, who did not belief in immortality of the soul. Epicureanism sought for the individual pleasure of the mind, aiming for happiness in moderation and balance so that suffering could be avoided. In the Middle Ages they were considered heretics because they did not believe in a Divine principle and thought that the soul would die together with the body. While in the circle of gluttony Dante suggested a relation between the city and the body, here there is a connection between city and soul. The souls here only worry for themselves and their own families but ignore completely each other's worry and pain. They do not listen to each other and only want to tell their own story, just like in a city where everybody just quarrels without listening. Here Dante learns that all the damned souls can look into the future but cannot see the present on Earth. As Guy P. Raffa states, "because there will no longer be a future when the world ends (...), souls of the damned will have no external awareness to distract them from their eternal suffering." ${ }^{, 234}$ The soul of Farinata, a noble Ghibelline, sticks out of the tomb up from his middle. There are two types of character in Inferno of whom only their upper bodies are visible. The first are the chained giants that connect circles 8 and 9 . The second is Lucifer, trapped in the centre of Earth. According to Mazzotta, they are a parody on the image of the resurrecting Christ shown from his middle up; there was a mosaic of it in the basement of a church in Rome, opened once a year in the Easter season for the public (Mazzotta 2008, Lecture 5). The circle of tyrants is anonymous, no one of these souls is named specifically, as if there are no great personalities among them. The irony here, according to Mazzotta, is that Dante places them next to figures of teachers, just after Virgil has been instructing him about usury. He treats here the tyranny of teaching, in which there is no freedom of choice in thought (Mazzotta 2008, Lecture 6). This has a direct relation with the doctrines of his time. According to Christian Moevs, the world that Dante portrays, is one in which doctrines are taught which are "familiar to all, but whose radical import is understood, experienced, and lived by almost none" (Moevs 2005, 173). Indirectly, at this point Dante is beginning to question some of the Christian doctrines that were taught. 
The question arises in the forest of the suicidals, why some of them, like Cato at the shore of Purgatory and Lucretia in Limbo, did not end up here. The souls in the forest of suicidals are marked by a false transcendence of themselves. The soul whom Dante encounters, Pier della Vigna $^{235}$, says: ingiusto fece me contra me gustio, ("it made me unjust against my just self", Inferno 13.72), as if there were two of him. This implies a loss of self. Cato, however, committed suicide because he did not wish to live without freedom, he was integer. Lucretia in Limbo was raped and then committed suicide out of shame. It was the "consequence of an excessive way of understanding virtue" (Mazzotta 2008, Lecture 6). Dido, who also committed suicide, is in the circle of the lustful because that was her principal sin. As Mazzotta argues, "whenever we sin, all sins are involved. (...) Dante highlights one specific aspect” (Mazzotta 2008, Lecture 6).

In the canto on violence against God, the blasphemer Capaneus is the perfect example of the state of the damned souls. He shouts: Qual io fui vivo, tal son morto, (“As I was in life, so I am in death", Inferno 14.51). It may seem to us as a sign of a strong personality, but as Gragnolati points out, in reality he is not only unforgiven but also unforgivable because he keeps on believing in his sin. He and all the other dammed souls "are forever stuck in the same sinful condition they had in life, without any possibility of repentance, change, or improvement" (Gragnolati 2005, 80). This is because

\footnotetext{
"sin unalterably damages reason and will, which are the faculties that define the souls as human and grant them the possibility to be free. Hence, the damned souls have lost the good of the intellect, and hell is a place where it is impossible to return to good will. The perverse will, which was in life the result of free decision and the cause of damnation, continues in hell, where it becomes an unchangeable state of being." 236
}

This also shows in the next canto about the sodomites, where his former teacher Brunetto Latini misunderstands Dante and speaks of glory in the Humanist sense - fame - and not in the Christian sense. The student Dante moves beyond his former teacher, although Brunetto thinks that Dante will follow in his footsteps. Sodomy here is not taken literally, as Mazzotta explains, it stands for rhetorical perversion, a failed theory of knowledge, a proto-humanist pursuit of immortality, and concludes that sodomy in this way also implies a confusion between the real and the imaginary (Mazzotta 2008, Lecture 6). Interestingly, Mazzotta draws a connection between the natural scenery 
(forest and sandy plain) and violence. The natural world that presents itself here is a violent one, "the idea is that the natural world can hardly be contained" (Mazzotta 2008, Lecture 6). In fact, Inferno is full of references to a hostile kind of nature, among them a loud thunderclap, a hurricane, acid rain, a muddy river, a dead forest, a river of blood, and a lake of ice. There is a natural violence within us that is difficult to cope with.

In Circle 8, called Malebolge ("Evil Pouches" referring to its ditches), Fraud is the central sin. As Virgil explains in Inferno 11.25, "Since fraud is man's peculiar vice, / it gives God more displeasure; the fraudulent, then, / lie lower down and more pain harries them." ${ }^{237}$ In the ditch of simony, placing a Pope upside down in a hole, Dante criticizes the Church. He also warns that worldly and spiritual powers should not be confused. The sorcerers who walk with their heads turned 180 degrees have a deformed aerial body. ${ }^{238}$ This is one of the many hints for the fact that the aerial bodies of the damned are deformed, their spiritual deformation has its direct impact on their aerial bodies. Gragnolati argues that,

"since sin permanently disrupts the order within the rational faculties of the damned soul, the aerial body that the soul radiates in hell can be greatly distorted and altered (...). Sin transforms the damned souls into monstrous hybrids that are both bestial and reminiscent of the humanity that they rejected on earth. Moreover, sin is also responsible for the heaviness and tangibility that often characterizes the shades in hell, especially in the second part of the Inferno" (Gragnolati 2005, 80).

Indeed, Virgil even takes Dante in his arms and carries him. The shades of Purgatory, on the other hand, seem to be made of air, which is exemplified by the moment that Dante three times in vain tries to embrace the shade of his friend Casello. Gragnolati adds that "the infernal souls' heaviness is a sign that they are not only unglorified but also unglorifiable: it represents both the lack of desire to move toward God and the impossibility of doing so" (Gragnolati 2005, 81). This is essential to our understanding of the structure of Dante's Afterlife and his idea of Divine justice.

The comic episode of the devils ends for Dante into a fall; Virgil takes him into his arms and slides down into the next ditch just in time before the devils catch them. It was a set-up by the devils who had told them there would be a bridge to cross the next ditch. The devils form a chaotic group and Dante compares them to a bizarre type of military unit. One could think of politics, imagining the

237 "Ma perché frode è de l'uom proprio male, / più spiace a Dio; e però stan di sotto / li frodolenti, e più dolor li assale"

238 Aerial body is a term used by Gragnolati for the shades' forms because they are an image of the body impressed on the air. Gragnolati, M., Experiencing the Afterlife: Soul and Body in Dante and Medieval Culture (Indiana, 2005), p.55 
association of the black devils with the Black Guelphs (Mazzotta 2008, Lecture 7). Indeed these devils guard and punish the political corrupt souls.

The canto on hypocrisy again refers to the Church. These sinners wear beautifully embroidered cloaks, "made in a similar style / as those that are made for monks in Cluny". ${ }^{239}$ But just like their shiny outward image did not match their dark insides, these cloaks "are so gilded outside that they dazzle, / but inside, solid lead, and so heavy that, compared to them, Frederick's capes were straw". ${ }^{240}$ Their contrapasso reflects perfectly how different their inner part was from their shining appearance when they were still alive. On the ground the high priest Caiaphas is crucified, who was thought to have organized the plot to kill Jesus. He has to endure all these heavy souls trampling him. Instead of being crucified straight upwards, as Jesus was, his is a "fallen" crucifixion and constitutes a parody on the Crucifixion.

The contrapasso for the thieves is a subtle one. Some are robbed of their "lives" over and over again, in the Phoenix-like cycle falling into ashes and being reconstructed into a human shape again. Others are robbed of their identity by metamorphoses. There is a parody on the Incarnation when a human shade changes form with a reptile and his fellow sinners tell him "Look how already you're neither two nor one"241 and "Then every former likeness was blotted out: that perverse image seemed both two and neither" ${ }^{242}$.

In the ditch of the evil counsellors and fraudulent rhetoricians, Dante begins with a self-reflective warning not to abuse his own talent. As Mazzotta comments, "It's always the temptation of the artist himself, it's Daedalus who builds the labyrinth and gets caught by it. It's the story of the artist who becomes a captive of that which he himself is constructed" (Mazzotta 2008, Lecture 8). This is the place where Dante examines transgression of boundaries and asks himself if he is not going beyond the boundary of knowledge. At this point he begins to worry about God's justice (Mazzotta 2008, Lecture 8). Justice is essential for Dante, not only within himself but also within society. This is one of the central issues of Inferno: throughout the Commedia he even goes further and searches for the possibility of a universal justice, "as opposed to Lucretian ideas of anarchy and chaos in the cosmos" (Mazzotta 2008, Lecture 8). While the Wheel of Fortune represents distributive justice, in Inferno it is retributive justice that rules in the form of the contrapasso. But let us keep Gragnolati's words in mind: "in hell the aerial body allows the soul to experience pain and to express its

239 "fatte de la taglia / che in Clugnì per li monaci fassi", Inferno 23.62

240 "Di fuor dorate son, sì ch'elli abbaglia; / ma dentro tutte piombo, e gravi tanto, / che Federigo le mettea di paglia.

241 "Vedi che già non se' né due né uno", Inferno 25.69

242 “Ogne primaio aspetto ivi era casso: due e nessun l'imagine perversa parea”, Inferno 25.76 
perverted self in a never-ending, repetitive way" (Gragnolati 2005, 82).

In the canto on divisiveness, Dante relates schism to tearing apart a metaphorical body: the political body of the king (Bertran de Born) or the mystical body of the Church (Mohammed and Ali). Again, it seems to be a reference to a parodic version of the Incarnation. The aerial body of Bertran de Born holds his head by the hair, "swinging it like a lantern in its hand (...). / Itself had made a lamp of its own self, / and they were two in one and one in two: / How can that be? He knows who so ordains it."243

In the ditch of the fraudulent rhetoricians Dante connected language and tragedy. In the ditch of falsification - full of sick aerial bodies and minds - he creates a relationship between madness and tragedy. The lower part of Hell is the tragic part of his Commedia. As Mazzotta says, "there is no such thing as a Christian tragedy" because it is a world of creation, redemption and love but it contains tragic moments as well, such as the Crucifixion of Christ (Mazzotta 2008, Lecture 9). For these spirits here below, it is an eternal tragedy. We must keep in mind, though, as Gragnolati argues, that they are trapped in their own perspectives and thus are incurable. They do not blame themselves for their damnation and do not seek repentance; instead they think of revenge (Gragnolati 2005, 80-81).

The giants, who seem to be towers from a distance, connect physically circle 8 and 9. It is another reference to the city, the public place of politics and inter-human connections. Here is Nimrod, who built the Tower of Babel. He wanted to reach Heaven by building high enough to reach it, instead of going down into humility. When the Tower of Babel fell, the confusion of tongues was God's punishment for such pride of humankind. Nimrod is now only able to babble and says: "Raphèl may amèch zabi almi". Mazzotta discovered in it an imperfect anagram ${ }^{244}$ of one of the Sayings of Jesus on the cross: “Eli, Eli, lama sabachthani?", "My God, why have you abandoned me?". Not only it is an imperfect parody on the Crucifixion, furthermore Nimrod is not able to communicate it. The theme here is human ascent instead of divine descent, which implies pride. Mazzotta also connects pride and perspective (Mazzotta 2008, Lecture 9).

In the icy circle of treachery, there is a development in Dante's expressions towards ineffability and silence, just like at the end of Paradise. It is the inverted sublime. The two heads that are stuck together in the ice are the political traitors Count Ugolino della Gherardesca and Archbishop

243 "pesol con mano a guisa di lanterna (...). / Di sé facea a sé stesso lucerna, / ed eran due in uno e uno in due; / com'esser può, quei sa che sì governa.", Inferno 28.122

244 Some letters do not concord. 
Ruggieri degli Ubaldini, on whose head Ugolino is gnawing out of deep hatred. Ruggieri locked Ugolino and some of his sons and grandsons in a tower and let them starve to death. Now, Ugolino cannot tell love and hatred apart, he does not have a perspective anymore. As Mazzotta argues,

"there is a way in which the violence inflicted on Ugolino's children seems to repeat or re-enact the great drama of the Christian sacrifice. (...) The tragic occurrence is in the very presence of the Christological language in this canto, because the sacrifice of the cross means one thing and one thing only: that now that all violence is finished and because we have found the voluntary scapegoat (...), that's why we are made innocent once again. The story here, re-enacting and echoing the story of the cross, seems to announce the futility of that sacrifice. Retrospectively, he says that that sacrifice too was just one of the senseless acts of violence that have happened in history and that punctuate human history. Of course, this is not the end of the poem, but it's the most desperate part of the poem, because Dante comes to believe that the law of history, that the law of the world is really a tragic law. And there is something absolute about it, and not quite escapable" (Mazzotta 2008, Lecture 9).

The ambiguous phrase Poscia, più che 'l dolor, poté 'l digiuno ("Then, stronger than grief was my hunger", Inferno 33.75) leaves in the middle if he died of hunger before he died of grief, or if his hunger was so strong that he reached cannibalism. We have reached nihilism at this point, there are no universal values anymore (Mazzotta 2008, Lecture 9).

Lucifer, once the most beautiful angel, is now crying and filthy. Although he is enormous, he seems quite helpless. He cannot even speak. Professor Mazzotta tells us: "as we remember from De vulgari eloquentia, he is not supposed to speak, because he is one of the angels who do not use the human language, but more importantly, because he represents evil defeated" (Mazzotta 2008, Lecture 9). Dante in De vulgari eloquentia argued that angels never had needed language because they were able to communicate in a more direct manner, and that language was a gift of God specifically to humanity. Lucifer is stuck there as a dumb object, an instrument for Dante's ascent to Purgatory. In Mazzotta's words: "The real defeat of evil is when that itself can become the stepping stone over the threshold of evil itself in order to reach the purgatorial island" (Mazzotta 2008, Lecture 9). Another interesting detail, as Mazzotta indicates, is that Inferno starts with neutral angels and ends with the fallen angel.

We have thus seen that Dante in Inferno focusses on psychological and socio-political questions, ethics and politics. It is the only part of the Commedia where one has to go down in order to go up; it is a descent into humility and seeing one's own faults. It is also about witnessing the horrible in order to learn to appreciate the good and beautiful. 


\section{Purgatory}

In Purgatory there are both time and light, two aspects that did not exist in Inferno. Where there is time, there is hope because there is a future for which plans can be made. Cato, who committed suicide in order to be free, represents political freedom. Being the guardian of the coast of Purgatory, he also represents a pagan form of new beginnings. For Dante there is another type of freedom which is spiritual freedom. This kind of freedom has a relation with future. The song of the newly arriving souls, In exitu israel, is precisely connected with spiritual freedom. This psalm is about the return of the exiled to the promised land. It is the Christian idea of a new beginning. As Mazzotta argues, "at the basis of Dante's own religious longing, there is the sense of displacement." Dante's poetry is one of exile, not only on a personal level but generalizing it for all human beings, who are exiled from the place that is their final home (Mazzotta 2008, Lecture 10). Dante believes that, in our exile, we cannot know God's ways and we should not try to as ourselves the reason behind the finite reality, like Plato and Aristotle did. According to Dante, their strategy did not succeed, as we have witnessed in his failed Platonic intent to exit the wilderness.

The message in Ante-Purgatory is that God forgives everyone who repents, even if that was at the last moment before death. Dante's shadow also becomes an essential element that differs him from the others, who do not have a shadow anymore. There are different reactions when they see he is alive. The excommunicated react like a flock of sheep, creeping together, while the souls in the Valley of the Princes interrupt their Miserere with a long, surprised "O". Others stare, or point at him, many come closer out of curiosity and some of them ask how it is possible. The souls here are very different from the ones in Inferno; they are polite and happy in their suffering because they are aware that they need to be purged from their sins, through purgation their souls will become pure enough to go to heaven. In their essence they are not too contaminated by their sins to be redeemed. Dante continues to recognize in these souls his own faults, and he will even admit that he will have to spend time on the terraces of Envy and Pride after his death: "My eyes", I said, "will here [on the terrace of Envy] be taken from me, / but not for very long, because they rarely / committed sin by casting looks of envy. / Far greater is the fear that keeps my soul / suspended, of the torment there below, / for even now that burden weighs me down." ${ }^{245}$. But also in Ante-Purgatory he projects the sin on his own person: when he passes the lazy spirits, Dante feels tired himself. He is aware of the difficult way up. Gragnolati argues that

245 “"Li occhi", diss'io, "mi fieno ancor qui tolti, / ma picciol tempo, ché poca è l'offesa / fatta per esser con invidia vòlti. / Troppa è più la paura ond'è sospesa / l'anima mia del tormento di sotto, / che già lo 'ncarco di là giù mi pesa."', Purgatory 13.133 
"through their wait, the souls of ante-purgatory are punished for delaying repentance until the end of their life on earth but do not experience any of the interior evolution that occurs through the curative and productive suffering of purgatory, which is physical. (...) Dante's invention of ante-purgatory indicates that interior grief does not cause any real progression of the soul and that the experience of physical suffering is necessary for the soul's expiation and healing. (...) Dante insists on the productivity of suffering in Purgatory, categorically contrasting it with the sterility of suffering in Hell. While Purgatory is the realm of improvement, Hell is the realm of stasis. The damned are stuck in the same psychological condition they had in life, without any possibility of repentance or change" (Gragnolati 2005, 115).

While Limbo in Inferno could be compared to a kind of Kafkaesque and eternal waiting room without exit, Ante-Purgatory is like a waiting room for real purgation of the soul.

One of the souls in Ante-Purgatory is the son of a damned soul. In this way Dante shows that there is "no necessary causality between past and present and future", which gives the way to individual freedom. Here it is not birth but death as a revelatory event about a soul's destination (Mazzotta 2008, Lecture 11). The human soul even has the freedom given by God, to choose not to love Him. As Mazzotta says, "Dante understands that the relationship between the soul and God is a relationship shaped by risk on both sides" (Mazzotta 2008, Lecture 11). On the other hand, Moevs argues that for Dante "Creator" and "creation" are not the same, yet creation is not separate from the Creator. A metaphor which partially covers this concept is the idea of us being His thoughts or dreams, in the sense that "dreams and thoughts have no existence apart from the intelligence in which they arise, but one cannot point to that intelligence because it is not a thing" (Moevs 2005, 5). This Creator does not exist in the way we exist, not in time or place, so we could not speak about Him, Her or It as if the Creator were a subject (Moevs 2005, 5).

In canto 6, Dante also speaks about politics, this time about the nation rather than the city as a place of suffering. The three cantos 6 of the Commedia (Inferno, Purgatory, Paradise) are all about politics, composing the symbolical Number of the Beast 666 .

The Valley of Rulers is the second locus amoenus in the Commedia. Here Dante learns that they cannot travel after sunset and one of the souls even draws a line on the ground indicating that they cannot go further than the line. A song about the dangers of the night Te lucis ante precedes a short Divine representation, repeated every night like a kind of ritual, to show the dangers of evil and the power of the Creator to defeat it. Mazzotta says that the song captures "the sense that the night is fraught with phantasms and that they will intrude on the powers of judgements of the various souls, 
Dante's own included" (Mazzotta 2008, Lecture 11). The angels are green, a colour that represents hope. Raffa tells us that white, green and red are the colours of respectively faith, hope and charity (Divine love), which are the three theological virtues. ${ }^{246}$

As mentioned before in this chapter, Purgatory is about degrees and types of love. It is the theme of the central canto of the entire Commedia, canto 17 of Purgatory. Also, according to Mazzotta, "the whole poetic mode of Purgatorio, unlike the poetic mode of Inferno, is played out in Purgatorio through the imagination, art images, memories, phantasms. In other words, we are really in a world which is in between that of bodies and souls, the world of the middle ground of the imagination" (Mazzotta 2008, Lecture 11). Indeed, the souls of Inferno are heavy and apparently flesh-like souls, while in Paradise the souls are made of Divine light. The mount of Purgatory is still on Earth but is reaching toward the heavens. It is the bridge between the physical and the spiritual, where corporal suffering is exactly a way to cleanse the soul. According to Gragnolati, these souls are joyful in their suffering because

"pain is an instrument of union with Christ, and the souls of purgatory become like Christ through the pain they experience with the sensitive faculties they keep and express with their aerial body. (...) Like Christ's torn body, the soul's body in purgatory is tortured and often distorted. But like Christ's body, it is never liable to any grotesque or parodic caricature. Rather, it has the dignity of productive suffering: the body of purgatory is always fully human and reflects the process of purgation and assimilation with the suffering Christ. Its deformation is never the monstrous expression of sin but rather the sign that pain is working to transform the soul into an image of Christ" (Gragnolati 2005, 137).

On the terrace of Pride, Dante receives an ethical education through God's art. He creates a relationship between virtue and art, and between an aesthetic and ethical education. Mazzotta links it to the question: "How do we look at art and what do we learn from it?" Dante is not a mere spectator of the world, just as the neutral souls wanted to be, so a safe perspective does not exist. As Mazzotta suggests, "if I think that I can take a safe distance, it is because I do not want to look within myself" (Mazzotta 2008, Lecture 11). Dante focusses on the Franciscan perspective: “the only way in which you can understand the creation is really to look from the bottom up and not from the top down." However, to know God, perspective is inadequate: God has no perspective. He is presented here as an infinite circle (Mazzotta 2008, Lecture 12). Art and pride are connected here by describing the painter Giotto - a contemporary of his whom he knew personally - as the one who surpassed the art of Cimabue (1240-1302) and took away his fame. The search for fame is

246 Raffa, G.P., Danteworlds, http://danteworlds.laits.utexas.edu/purgatory/02valleyofrulers.html\#angels [accessed 6-7 2015] 
something that characterizes some of the proud souls and Dante certainly is not innocent in this aspect either, as he expresses at the terrace of Envy. ${ }^{247}$ But fame, Dante tells us, comes and goes, just as one painter or poet replaces the other: "Earthly fame is but a breath of wind, / no more; huffing here and puffing there, / it changes name when it changes quarter."248

Dante inserts the acrostics VOM (uom, man $)^{249}$ in his poem as to indicate that pride is a sin common to mankind. But Dante redefines its concept: pride is not about a love for what is still above you and the wish to reach it, but it is essentially about feeling better than others, perhaps even having contempt for what is below you. As Mazzotta says, "humility and pride really have to go hand in hand and one attenuates and changes the meaning of the other" (Mazzotta 2008, Lecture 12). On every terrace one of the Ps on Dante's forehead is removed by an angel, which refers to the cleansing of his own soul throughout his journey up the mountain of Purgatory.

On the terrace of Envy - where the souls have their eyelids sown - Virgil is giving an ode to the Divine light. Contrasting sharply with his ode is the thick black cloud of the terrace of Wrath, associated to the cloud of anger (Mazzotta 2008, Lecture 12), which darkens all reasonable thought. The form of hallucinations in which examples of gentleness and wrath come to these souls refers even more to the loss of conscious reason. On this terrace, Dante makes a difference between worldly goods which lessen when shared by more people, and the Divine Good which doesn't. The Good is unlimited Divine love, a light that is available to everyone. However, the freedom to make our own choices implies moral responsibilities, if we wish that this light shines within us. These moral responsibilities imply certain limits within that freedom. Free will is not the same as free choice: "in fact, so many theologians go on asking if free will means that the will finally can be moved by an act of choice that follows on the prior act of knowledge" (Mazzotta 2008, Lecture 12). Here Dante presents the Creation as a free and playful act: "God creates the world in a moment of freedom and that freedom becomes the foundation for positing our own human freedom. We were born free. So it is a creation - but it's spontaneous and playful" (Mazzotta 2008, Lecture 12). The heavens do exert some influence over human desires, but because of free will, individuals are responsible for their actions. Here is where politics enter, since laws and leadership, if executed correctly, form a guidance for human beings. However, "misrule, due primarily to the Church's

247 “"My eyes," I said, "will here [on the terrace of Envy] be taken from me, / but not for very long, because they rarely / committed sin by casting looks of envy. / Far greater is the fear that keeps my soul / suspended, of the torment there below, / for even now that burden weighs me down."', “"Li occhi", diss'io, "mi fieno ancor qui tolti, / ma picciol tempo, ché poca è l'offesa / fatta per esser con invidia vòlti. / Troppa è più la paura ond'è sospesa / l'anima mia del tormento di sotto, / che già lo 'ncarco di là giù mi pesa."', Purgatory 13.133

248 "Non è il mondan romore altro ch'un fiato / di vento, ch'or vien quinci e or vien quindi, / e muta nome perché muta lato.", Purgatory 11.100

249 This is not the only time Dante uses the word "man" connected to a vice. At the terrace of gluttony the souls are so meagre that their faces show the word OMO, which also means "man". 
illegitimate claim to temporal authority, is the reason the world has fallen into corrupt ways and virtue is so rarely seen." ${ }^{250}$ Dante's solution to this common problem of his time is the equality of Church and Empire. Even in our contemporary secular society, misrule and corruption are still a common problem.

At the centre of the Commedia's poetic universe, canto 17 of Purgatory, Dante speaks of love. Virgil tells him that love is the "seed" of all human acts, whether these are sinful or virtuous, and that not all kinds of love are good. He examines the relation between love and our perception of the world. Virgil discusses free will in relation to love and the process of making judgements for which the individual is fully accountable. Dante also explores the relation between perception and imagination: our perception captures an impression from the reality outside of us and unfolds it within us, thus perception is the basis of imagination (Mazzotta 2008, Lecture 13). Here, for the first time, Dante realizes he needs a kind of inner imagination completely independent from the physical world to approach and comprehend the Divine. Indeed, as Moevs argues, the case in Dante's Metaphysics, being a heritage of Classical and Christian philosophy, is that "God, as the ultimate subject of all experience, cannot be an object of experience: to know God is to know oneself as God, or (if the expression seems troubling) as one 'with' God or 'in' God" (Moevs 2005, 5) and "for Dante the touchstone of salvation, and the resolution of the mystery of life, consists in the capacity to recognize Christ, which means either to be awake to (to expect), or to awaken to, the revelation of the infinite in the finite, the divine in the human, that is Christ. (...) It is to know Christ in and as oneself" (Moevs 2005, 174). "It is to know oneself not only as a thing in spacetime, but also as one with the source of space-time. It is to awaken to [the Divine within] oneself (...) by voluntarily sacrificing the attachment to, or obsessive identification with, the finite. It is to experience oneself as attributeless, extensionless, immune to all contingency: one with the ontological ground that spawns and knows all possible objects of experience as itself. It is to know oneself as everything, and as nothing, which is to love all things literally, and not just metaphorically, as oneself" (Moevs 2005, 7). Dante is not yet this far in his development, but he begins to find the Divine within himself and it seems that his first step is to abandon all finite experience and use the imagination to begin recognizing the infinite within himself. Now, retrospectively, we understand the difference between the damned and the saved: "If, hypnotized by their spatiotemporal form, humans experience themselves only as ephemeral bodies and identities, they are lost in eternal night and desire; if, following Christ, they turn their mind or awareness back on itself, surrendering all worldly attachment and greed (cupidigia), they can come to experience themselves as (one with) the reality that spawns all possible experience, immune to birth and death" 
(Moevs 2005, 6). If one defines Christ as the Divine within the human, instead of the person of Jesus Christ, respectively we also understand that the fact of having lived before or after Christ's human life does not make a difference for God's judgement of the soul in Dante's Afterlife. Furthermore, to understand Dante's metaphysics we do not need to be Christians, since it is not about the specific person of Christ but about what he represents. This is why Dante also encounters non-Christian souls in Purgatory and Paradise. The fact that Mohammed and Ali are in Inferno is not because they have another religion, but because they were believed originally to have been within the Christian Church and then to have caused a break in this spiritual corporal union (Mazzotta 2008, Lecture 8).

Here, at the centre of his poetic universe, Dante also understands that apparent opposites go together: limitations and transgression, pride and humility, subjection and freedom. In Mazzotta's words,

"each involves the other, (...) a paradox, the knot that joins these things together, the [Platonic] image of the mirror, the Celestial Hierarchy of the Pseudo-Dionysius. The Pseudo-Dionysius thinks of all creation being a kind of hall of mirrors where everything is reflected onto the other, a number of reflections that all give in different ways the light of God" (Mazzotta 2008, Lecture 12).

Mazzotta describes sloth, the theme of this terrace, as a crisis of desire because the mind finds itself indifferent to the object of desire. He adds that

\footnotetext{
"it is the so-called noonday devil, the temptation of the monks, that's why I call it a parody of contemplation. It's the temptation that the monks experienced in their cloisters when they find that the whole idea of turning their minds to the divine is no longer, or provisionally perhaps, appealing. It's the loss of appeal of anything outside of oneself and indicates a kind of both intellectual and dreamy sort of condition" (Mazzotta 2008, Lecture 13).
}

On the terrace of Avarice and Prodigality, the souls recite examples of avarice during the night and examples of contentment with little at daytime, while lying on the ground face down. Each time a soul is liberated from his punishment and ready to go up to the heavens, all sing Gloria, the hymn that the angel sung at Christ's birth. The mountain trembles, suggesting a connection with the earthquake just after Christ's death at the Cross. Moreover, Dante compares the liberated soul with the resurrected Christ. "Incarnation, Crucifixion and Resurrection are recapitulated and refer to the condition of the soul who has completed purgation", according to Gragnolati (Gragnolati 2005, 135). 
On the terrace of Gluttony, Dante connects gluttony with poetry. While in Inferno it was about empty cities because bodies were fed while minds were ignored, here it is about a form of art, "a worldly type of poetry that does not look beyond itself, beyond the concerns of the flesh" (Mazzotta 2008, Lecture 14) Dante refers to the Occitan love poetry that entered Italy through the art of the troubadours and found its way into Italian poetry. The mouth can be used for eating and for reciting poetry, which is the connection Dante establishes here. It is criticism on the lack of Divine inspiration in the written and recited arts. The gluttonous souls depart like birds but unlike Inferno 5 they do not move in a circle but straight on, which indicates progress instead of stagnation (Mazzotta 2008, Lecture 14).

On the terrace of Lust, Dante continues about the relation between Divine creation and inspiration with poetic creation. Here Dante's extended theory about the nature of the soul and body is explained. He merges the complex theories of unity of form (in which body and soul are one whole) and plurality of form (in which body and soul are separate unities) into a unique theory that allows the souls to be perfectly happy in Paradise. According to his idea, when the body dies, the soul "prints" the body's form on the surrounding air which results in a kind of holographic body that accompanies the spirit like a flame following fire. As Raffa confirms, "this new form therefore goes by the name of 'shade' / 'shadow' (ombra): as a 'shadow' follows a real body and repeats its form, so the 'shade' takes on all bodily parts and functions." ${ }^{251}$ Mazzotta adds that "the reality of his presence there in his body, [with his own shadow,] is the physical aspect that separates him from the others" (Mazzotta 2008, Lecture 14).

Dante himself has to pass through the fire that separates Purgatory from the Terrestrial Paradise in order to finish his own purgation. Once he is at the other side, he is a man free to go ahead, making his own decisions from this point on. As Mazzotta says, desire is the moving force but now pleasure can become his guide (Mazzotta 2008, Lecture 15). The first part of his journey began in a wilderness and ends in a garden, the Garden of Eden. Now his original failure in the wilderness is converted into a successful voyage in the Terrestrial Paradise because now he is purged and ready to go to the heavens, beyond the original human paradise. According to Mazzotta, "the Garden of Eden is exactly the wilderness that we left behind, seen from a different perspective; the supernatural world is the natural world through a different lens and different perspective" (Mazzotta 2008, Lecture 15). Dante still carries the stains of his own humanity which is why he is still separated from the heavenly spirits that are present at his arrival. Matelda, a Divine creature that apparently symbolizes the innocence of humankind before the fall, plunges him in the rivers Lethe 
(to forget his sins) and Eunoe (to recall his good acts). She tells him that the two rivers come from the same source - memory and forgetfulness are connected, which is exactly what we will see confirmed at the end of the Commedia.

Adam will explain later in Paradise that what caused the fall of mankind was not his wish to have knowledge but the fact that he transgressed the limits God had set for him. Professor Mazzotta comments that it was a happy fall, felix culpa, because it gave humankind the opportunity to even go beyond the Terrestrial Paradise (Mazzotta 2008, Lecture 15). In another lecture he comes back to this:

"The consequence of it or the flip-side of this quest for more knowledge is the violation of boundaries and that has to be re-established. The fall of man is only a re-establishment of the boundaries; it is not a way of mortifying the quest for knowledge" (Mazzotta 2008, Lecture 21).

The term felix culpa was first used by Augustine to express the fact that God made something good out of something evil instead of annihilating it, but it was Thomas Aquinas in his Summa Theologica who used the term to connect the fall of Adam with the Incarnation, arguing that God allowed evil to exist because it can lead to more goodness.

With Beatrice he has a great self-confrontation about his own life, while Virgil disappears.

Beatrice's arrival is described with the same words that were used for the entrance of Christ into the city. This is not so strange if we consider Christ as the Divine with the human; Beatrice represents the same. Her harsh language is natural for the Christian Medieval reader, who sees it as a just language for Dante's sins, while it seems cruel and unloving to a contemporary Western reader.

Here is the first and last time that Dante's name appears, as if the whole epic story at this moment becomes his autobiography (Mazzotta 2008, Lecture 15). Beatrice warns him to be stronger in the future when faced with temptations: Dante's conversion is not a definitive act, but an ever ongoing process. Despite his Divine journey, he will still be human and thus will have to keep on managing his impulses. 


\section{Paradise}

Moving out of Purgatory into Paradise the focus shifts from ethics to aesthetics: dance, music, visual and poetical aesthetic experiences. Paradise is the place where Dante can move beyond the psychological and sociological issues, asking questions about the universe through a continuous process of doubts and answers. Paradise is not a purgation anymore, it is a purely educational journey. From here on it is an exploration of what lies beyond that which we see, achieving the sublime, which is infinite, although but he still has to communicate them to his readers through his imperfect, finite senses. His first questions are about the universe of Paradise. Is it a real universe or a representational one? The souls appear to live on the planets of the Ptolemaic universe but they turn out to be a Divine representation for his human comprehension. Especially for Dante, the souls appear in the spheres only as a sign of their varying degrees of beatitude. According to Mazzotta, "the representation of Paradise is fictional and once the pilgrim disappears so will the souls vanish. They will return into the bosom of Abraham according to biblical accounts" (Mazzotta 2008, Lecture 17). Dante's whole Paradise is an accommodation of realities that far exceed the powers of our human mind. The souls condescend to Dante's level of comprehension.

This universe is a highly ordered one, just as we have seen with Pythagoras, one of numeric proportions. It is invaded by light. As Umberto Eco writes in his book on Medieval aesthetics, "the aesthetics of proportion always remained a quantitative aesthetics. It could never explain satisfactorily the medieval pleasure in light and colour, which was a qualitative experience." ${ }^{252} \mathrm{He}$ also states that Dante's Paradise is "a perfect exemplar of the love for light: in part an expression of medieval spontaneity - the medievals often conceived of God in terms of light, and regarded light as the original metaphor for spiritual realities - and in part influenced by a patristic Scholasticism" (Eco 1986, 46). Mazzotta tells us that "all of Paradiso is about the refinement of sight and the refinement of vision." But also the fear of transgression or blasphemy continues to be present in Dante. Paradise is about "limits and impossibility of establishing clear limits" (Mazzotta 2008, Lecture 16).

According to Mazzotta, Dante tells us here that God is cause and participation in creation (Mazzotta 2008, Lecture 16). In order to understand what that means, one should have an idea of the basic principles underlying this concept. Moevs summarizes them into five principles: 
- The spatiotemporal world as we know it does not exist within space and time: it exists in Intellect, which is pure conscious Being.

- Matter is not something "material". "Matter is ontologically dependent upon Intellect (consciousness or awareness), but Intellect is self-subsistent, because it is nothing in itself, it is the act of being" (Moevs 2005, 171).

- All creation is a self-qualification of Intellect or Being, and only exists insofar as it participates in it. "Intellect-Being is what is, unqualified, self-subsistent, attributeless, dimensionless. It has no extension in space or time; rather, it projects space-time "within" itself, as, analogously, a dreaming intelligence projects a dream-world, or a mind gives being to a thought." Moevs makes the analogy with the experience of a dreamer and his dreams, with the warning that this does not imply the idea that the finite world is a dream or unreal.

- Creator and creation are not two, since creation cannot exist independent of Creator, yet they are not the same. "Since creation exists only as a facet, or qualification, of the selfexperience of the creator, the two are not two, and yet the distinction between them could not be sharper: the creator is self-subsistent, attributeless, dimensionless, out of time; its creation is contingent, dependent, limited by attributes, ephemeral." In his analogy of the dreams or thoughts of someone with Creation, Moevs distinguishes three similarities: a. like dreams or thoughts, created things are contingent, and dependent on what or who is creating them,

b. being is not a "something" to make things out of, nor in thoughts, nor in the finite world, c. thoughts have no existence apart from the intelligence in which they arise, but one cannot point to that intelligence because it is not a thing.

- God, as the ultimate subject of all experience, cannot be an object of experience: to know God is to know oneself as God, or "in” God (Moevs 2005, 4-5).

The travel to the Moon, which is the first planet, is so fast that he does not comprehend it. As Gragnolati argues, the souls on the Moon "are still shades, but so pale that he mistakes them as “specchiati sembianti" or reflected images (Par. 3.19)" (Gragnolati 2005, 82). He continues: “The pilgrim (..) acknowledges that in the appearance of these shades, something divine makes them different from their earthly figures, but they are nonetheless recognizable" (Gragnolati 2005, 83). If we look back on Inferno and Purgatory, there is a clear development in their aerial bodies: from thick, dark, deformed and heavy shades in Inferno, through immaterial, lighter, sometimes slightly altered souls in Purgatory, to heavenly shades that are even more perfect than when they were still alive. In the higher spheres of Heaven, the souls will not be shades anymore but lights. Only in the 
Empyrean Dante will see the perfect bodies of the most virtuous souls. His own body also shows signs of improvement. At the beginning of Purgatory, the stains are washed off his face, then his body becomes lighter with each "P" that has been erased from his forehead. Throughout Paradise his senses will become more perfect so that he is able to withstand the Divine light and sound. In fact, Dante even invents a new word for it: trasumanar ("transhumanizing"). Gragnolati argues that Dante's body resembles more and more a resurrected body:

"the mortality that the pilgrim progressively casts off during his heavenly journey seems to correspond to the transformation of his body into a resurrected body, which is able to endure whatever can please him" (Gragnolati 2005, 176).

Gragnolati therefore proposes that the pilgrim's journey can also be read as a "journey of the body" (Gragnolati 2005, 168). The transformation of Dante's body reflects the paradigm "which emphasizes that the first human being was created immortal, that Christ's pain on the cross redeemed humankind from the consequences of the Fall, and that only resurrection will conclude and bring to a closure the experience of humankind" (Gragnolati 2005, 168).

Returning to the theme of representation, Mazzotta makes a statement which connects with Moevs' arguments on the metaphysics of Dante, in the sense that God himself does not exist in time and space and cannot be captured into our finite, dualistic language and imagery:

"representation has the power to make appearances (...) the only reality that we manage to see. (...) The journey of Dante is the journey between images and testing of what these images may mean, finding out whether behind these images there is some kind of substance, some kind of reality. Dante literally moves between the two worlds and things, images, or representations and in appearances and the world of essences, and tries to join the two of them" (Mazzotta 2008, Lecture 16).

This is the sphere of grammar because the allegorical discourse is a grammatical issue, as we saw before.

Canto 6 of Paradise is a political canto just like the other cantos 6 of the Commedia. Situated in the sphere of Mercury, it is related to dialectics and logic. This time the politics are not discussed at the level of the city (Inferno) or the nation (Purgatory) but of the Empire, and its making of laws. Dante speaks of political justice through laws and criticizes again the power of the Church on worldly matters. According to Dante, the Empire is necessary in order to stop civil war, a crucial theme for him because it led to his exile. He chooses the middle between the Virgilian positive model of the 
Empire that leaves no room for the individual internal life and the Augustinian anti-political model.

Here Dante discusses one of the fundamental questions of Christian theology: the Incarnation or "Why God Became a Man" [Cur Deus Homo], as the Benedictine monk Anselm of Canterbury (c.1033-1109) called his treatise. ${ }^{253}$ As Raffa states, "Dante (...) develops his argument within the context of Roman and medieval history, and he makes an important contribution by presenting the Incarnation as a paradoxical union not only of natures (human and divine) but of choices as well." Raffa tells us that Dante comes to a solution in which God was both human and divine at the same time. "Through the "magnificent process" (Par. 7.113) in which God chooses to become completely human while remaining completely divine, both God and humankind participate fully in the redemptive process (Par. 7.103-20)." Indeed this connects well with the interpretation by Moevs of Christ as the Divine within the human, when he states that

\begin{abstract}
"Incarnation is one with Crucifixion: what is eclipses itself at the very moment that it reveals itself in/as space-time by giving itself to finite experience. Crucifixion is one with salvation: the divine reveals, and awakens to, its own transcendence by its perfect self-sacrifice and surrender to and of the finite. This is the creation and redemption of the world, enacted within history as the Passion, Christ's and our own" (Moevs 2005, 7).
\end{abstract}

In the sphere of Venus, the planet of rhetoric, we encounter souls who indeed carried the Divine within themselves but had to live with a continuous ardour. The lustful in Purgatory had excessive love for things that were inherently good but still worldly matters. The souls on Venus experienced the Divine within themselves and through their worldly experiences. On Venus, the Earth's shadow comes to its point: these were the last souls of Dante's journey to be influenced by worldly matters.

In the sphere of the Sun, where arithmetic is central, there are two circles of wise spirits dancing around it. These circles are a representation of the circle of knowledge and indeed the lights are returning to their point of departure. The circle of knowledge implies travelling through the liberal arts and coming back to the starting point with a different perspective. Since Dante is moving beyond the sunlight, the question he poses is: what kind of knowledge is needed here? He reaches the insight that the journey of knowledge never ends due to "the circle of knowledge as one made of contradictory voices" coming together. ${ }^{254}$ There is a redefinition of the relationship between knowledge and error: through errors we extend our knowledge about the universe. Knowledge with

253 Raffa, G.P., Danteworlds, http://danteworlds.laits.utexas.edu/paradiso/02mercury.html\#incarnation [accessed 7-6 2015]

254 In the sphere of the Sun the Dominicans and Franciscans are the contrary voices coming together and even complementing each other. 
theology on one hand and playfulness with freedom on the other hand can go together; they are apparent opposite perspectives which are in fact interdependent (Mazzotta 2005, Lecture 17). Mazzotta says about this playfulness that it is "the notion that God plays, that creation itself is a spectacle, (...) a 'theodrama', the idea that it doesn't deprive the Divinity of its seriousness but makes that seriousness part of the world of joy. That is the new aesthetics [here] (...), this kind of playful idea of the world, a comedy." It reveals a new dimension to the title of Commedia:

\begin{abstract}
"Of course this is [also] about the happy ending because comedies are always the genre of happy endings. It is about the low level of experiences, about the vulgar language that Dante uses, but the real and substantial reason for Dante calling his poem a comedy, and for the readers using the attribute of divine, is exactly that; a way of responding to this sense of the joyful quality of creation. (...) the tragic vision is part of something larger" (Mazzotta 2008, Lecture 18).
\end{abstract}

Dante also moves away from violence and advocates tolerance between religions, which is a new step in his personal development, overcoming his innate violence with more transcendental values.

In this sphere he also compares God to the sun, being the inexhaustible source of light. The idea of Divine light is an image from long before Dante's time. Umberto Eco states that metaphysical symbolism had its roots in Antiquity. His quote of the $9^{\text {th }}$ century John Scotus Eriugena shows that the use of light as a metaphysical symbol was already well embedded in Christianity by then:
"one God, one Goodness, one Light, diffused in all things so that they may exist fully, shining in all things so that all people may know and love His beauty, dominating all things so that they may flourish in their full perfection, and so that all may be one in Him. Thus the light of all lights comes from the Father" (Eco 1986, 57).

The sphere of Mars stands for the Holy Warriors and is connected to music. It begins with a musical metaphor: "Gracious will (...) / hushed to silence the sweet-sounding lyre / and stilled the sacred strings that the right hand / of heaven either slackens or sets tight." ${ }^{255}$ Music is about Divine proportions and here we encounter again a geometric figure: a resplendent cross made of light, both arms equally long.

In this sphere Dante focusses on the self and how it belongs in history. One option is that the self is a prolongation of the ancestors. Another is that the self forms part of the city. The city involves us

255 "Benigna volontade (...) / silenzio puose a quella dolce lira, / e fece quïetar le sante corde / che la destra del cielo allenta e tira.", Paradise 15.1 
because we construct its history. Even in exile Dante is still a part of the community. However, Dante asks himself: if families disappear and the city gradually decays, does this really stand for the self? He comes with a third option: taking into account that the self is based upon its family and its community, it also lies within one's personal projects, one's future. He understands that we cannot step outside of history, we inevitable belong to it. It is at this point where he transforms the idea of exile as a punishment into exile as a virtue. He proposes that exile - in the sense of dislocation - is also the root of our religious consciousness and that we are all in exile, being away from Heaven (Mazzotta 2005, Lecture 19). “An exile, which does not mean the random movement, but always a sense of the problematical qualities of a place in the world and the relationship that we have with ourselves and our own ideas" (Mazzotta 2005, Lecture 20).

We arrive at the sphere of Jupiter, related to geometry. As Mazzotta says, "geometry regulates idea of space and implies perspective." We saw that Dante in his Convivio described geometry as operating "between two things antithetical to it, namely the point and the circle". ${ }^{256}$ Dante continues:

"as Euclid says, the point is Geometry's beginning and the circle its most perfect figure, therefore to be thought of as its end. Geometry thus operates between the point and circle, its beginning and end, and these two are antithetical to its exactness; since the point cannot be measured because of its indivisibility, and the circle cannot be squared because of its arc, and so cannot be measured precisely."257

Curiously enough, in the Commedia it is not a circle but a Point that represents Divinity itself. This coincides with what Umberto Eco notes about the relation between the circle and the point. He reports that Augustine in his De Quantitate presents a theory based on geometrical regularity, considering the circle as the most beautiful of all geometrical figures, "which has no angles to disrupt the continuous equality of its circumference. Above all (...), however, is the point indivisible, centre and beginning and end of itself, the generating point of the circle, the most beautiful of all the figures" (Eco 1986, 43). Dante's Paradise presents many circles of motion and dance but it is Divinity itself who appears as a Point, towards the end of Paradise, with the circles of the angels turning around it.

Geometry and justice are also related here because the relationship between crime and punishment implies proportionality (the contrapasso), but also because, according to Mazzotta, it "always

256 Dante Alighieri, Il Convivio, translation in English by T. Kline, http://www.poetryintranslation.com/PITBR/Italian/ConvivioII.htm [accessed 14-7 2015], Chapter 13 257 Dante Alighieri, Il Convivio, translation in English by T. Kline, http://www.poetryintranslation.com/PITBR/Italian/ConvivioII.htm [accessed 14-7 2015], Chapter 13 
implies the existence of other points; it establishes relations therefore." Here, the souls form the letters DILIGITE IUSTITIAM, QUI IUDICATIS TERRAM (a verse from the Book of Wisdom ${ }^{258}$ : "love, justice, you who judge the Earth"). Then the souls transform into a the form of an eagle that can even fly and talk as if all these souls were one. This is "a divine spectacle, the heavens are a sacred theatre where God will go on speaking to human beings by using the souls of the blessed" (Mazzotta 2008, Lecture 20). Through the formation of these letters,

\begin{abstract}
"we really discover that the beauty of geometry underlies the rigour of the alphabet so to speak, but more importantly, we discover that these souls that dispose themselves in letters are really God's way of speaking to us. The language that God uses is the language of human beings. We are the syllables, we are the letters disposed in order to convey whatever God's message may be." (Mazzotta 2008, Lecture
\end{abstract} 20)

The essential issues here are thus Divine Justice and the idea that the shapes of the world are the representations of the perfection of God's geometry. However, this perfection can never be captured in shapes or language:

\footnotetext{
"The language of measure, the language of accounting, and the language of limits is set against this idea of something not finite, something that escapes the logic of geometry, the logic of measurement, an infinite and excess" (Mazzotta 2008, Lecture 20).
}

Dante poses the question if justice depends on where we live, and his answer is negative. As we saw before, there is no difference to have known Christ or not, since it is not about the person but about the Divine within oneself. Moevs bases himself on the arguments of theologian and philosopher David Burrell, professor at University of Notre Dame USA, when he outlines that,
"because God is not a thing, but the beginning and end of all things (Aquinas, ST 1a.2. Proem), any 'believer' who assumes that he or she believes in the existence of one more entity than the non-believer (i.e., the world 'plus something' — and quite an intrusive something!) is in fact an atheist or idol worshipper; one who considers himself an atheist because he rejects the God of such a believer may well be responding to Truth, and be a 'believer'" (Moevs 2005, 11).

About the issue of our location Mazzotta adds that "boundaries are political but they are not nor can they be thought of as being moral boundaries" (Mazzotta 2008, Lecture 20). Dante included another acrostic in his text, this time three lines beginning with L, V and E (lue), meaning "plague, 
pestilence". It is, as Mazzotta says, "fitting commentary on the pernicious effects of injustice and misrule, much as the acrostic in the Purgatory underscored the propensity of humankind (VOM) to fall victim to pride (Purg. 12.25-63)" (Mazzotta 2008, Lecture 20).

Dante also connects philosophy and theology here as interdependent. As Mazzotta says,

"philosophy without theology ends up in a sort of labyrinth of its own constructions and may lose the way. Theology, without philosophy, may end up in mere opinion which has no validity at all for people who believe in the power of reason" (Mazzotta 2008, Lecture 20).

Saturn is the sphere of contemplation, related to astronomy. The main theme here is the degeneracy of the Benedictine order. In Mazzotta's words, "the contemplatives are those who cut a space of time and privilege it, or a space in place, and cut it off from the flow of history. The danger of the contemplation though is that they can bypass and drive a wedge between the contemplative life and the active life" (Mazzotta 2008, Lecture 20). Here are the contemplatives that were

"desiring to see God, but accepted this longing as the sign of God's presence and gift to them. This is an extraordinary passage in terms of what Dante thinks of contemplation and clearly the danger of thinking of contemplation as the condition that would allow and bring about the vision of God. Such a vision, Dante is saying, is not going to be possible while we are here on Earth" (Mazzotta 2008, Lecture 20).

Thus, perhaps he is linking contemplation with humility; the idea that humankind should not try just like the giant Nimrod did - to ascend to the Divine, but rather have the humility to accept that the Divine descends and possibly not in the way we had wished for. The soul of Saint Benedict tells Dante that there is perfect happiness in the Empyrean and that it is no part of our physical universe: "that sphere is not in space, it has no pole, / and our bright ladder reaches up to it". ${ }^{259}$ For them, there is indeed a ladder by which they can ascend to God, who is not in space; a beautiful paradox.

The Fixed Stars are connected with ethics and focus on the three Holy Virtues: faith, hope and charity or Divine love. The first two virtues, faith and hope, only exist on Earth, including Purgatory. In Hell there is no hope because the souls will not be rescued and in Paradise there is no hope either because there is no need for anymore. Hope cannot exist without faith. A crisis of faith is not a denial, it is rather a dialectic movement, which implies there are different degrees of faith. It is compared to a coin, being

"something valuable, authentic, establishing the value of everything. (...) Dante wants us to think about 
this kind of the resonance of profanation that is in the language of money and link it with really this purity of faith. The distinction is really never quite between profanation and the purity of faith and that somehow the world of faith comes out of the world of profanation. That it belongs to the world of time, it can be profane and yet it still manages to put things into circulation" (Mazzotta 2008, Lecture 21).

Hope is a virtue of time and future. We all have to live our own Exodus: exile and hope are related.

Dante tries to see if St. John carries his body, just like Maria and Christ, as was speculated in his days, and becomes blind, just before his exam on love. When he passes the exam, his eyesight returns better than before: it is as if he had to become blind in order to see Divine Love. In fact, love is the most mystical of the three, the only one impossible to capture into words for Dante, just like God's name. Both love and God are ineffable. Here he asks himself how one can know God.

Language marks our distance to the Divine because it can only be used to describe the definable. As Mazzotta says: "language is part of our exilic longing". The three holy virtues are necessary to get to know God (Mazzotta 2008, Lecture 21).

The Primum mobile, linked to metaphysics, is a crystalline heaven with a very thin materiality, still physical but at the edge of the material universe. All motion begins from here. Moevs tells us that

"without the nexus or bridge of the Primo Mobile, there could be no "transhumanizing" (trasumanar), no Incarnation, no revelation, no redemption, no journey. There could be no translation of being into contingent or finite experience, and hence no space-time and no Comedy" (Moevs 2005, 8).

He explains later that "Dante conceives the Primo Mobile, the source of all being in space-time, as pure motion, ubi plotted against quando, conceptually inseparable from each other" (Moevs 2005, 189). Dante looks up to see a representation of the spiritual universe. There is a Point smaller than the smallest star and yet so bright that it illuminates the whole sky. Nine circles of angels are dancing and turning around it, representing the nine spheres, like an inverted Ptolemaic universe where the highest angels are closest to the centric Point and thus most illuminated by its Light.

"Beatrice tells Dante that when he realizes that all spatial extension is parvenza (appearance, not a selfsubsistent reality), he will see that the two opposing pictures of creation are perfectly equivalent. (...) In perfect self-knowledge, it knows itself as a dimensionless point of awareness spawning all experience, or as an infinite, spaceless, timeless reality encompassing all space and time.” (Moevs 2005, 6-7).

The Point is like an inverted singularity, very small, but emitting great amounts of light. ${ }^{260}$ Physics 
and metaphysics are connected; while the first searches for explanations for the physical world, the second seeks the general rules behind it. As we saw before, Dante in his Convivio linked physics to the visible and metaphysics to the invisible. Here, Dante focusses on the issue of the origin of space-time. Mazzotta tells us that "the real beginning, the real universe is in God's mind, so he distinguishes two worlds: the physical world we see and the spiritual world, which is in God's mind. In a way, and just to make it very simple, Dante is journeying into the mind of God" (Mazzotta 2008, Lecture 21). Moevs indeed confirms that the Empyrean

\begin{abstract}
"is nowhere at all. It does not exist in space or time; thus neither does the spatiotemporal world it 'contains'. The Empyrean is the subject of all experience, it is what does the experiencing. (...) It may be imagined as an infinite reality containing the entire universe of every possible object of experience (this cosmological picture is the framework of the Paradiso) or it may be conceived as a point with no extension in either space or time, which projects the world of space and time around itself, as a light paints a halo onto mist. (...) Dante takes both these tacks" (Moevs 2005, 6).
\end{abstract}

The shape of Dante's cosmos could be seen, according to Mazzotta, like a spiralled shell (Mazzotta 2008, Lecture 22). This is only a partial image; the spiritual universe does not exist in time or place, it is only a representation that Dante sees here. Ultimately, "language, thought, and propositions can all express the structure and articulation of reality, but they can say nothing about the subject of experience itself, because it is not part of that structure; there is nothing to say about it" (Moevs $2005,171)$. Dante also poses the analogy of time with a tree, whose roots are in the pot of eternity and only the shadow of the falling leaves is what we see. There is a ninefold hierarchy of angels. Their function is to move the spheres and to be the intermediary agents between the Divine and the human (Mazzotta 2008, Lecture 22).

Dante describes the Creation as something very peculiar: there was no time before creation, yet creation was like a tiny break in continuous speech. It is an act of love and he uses language of natural production and reproduction to describe it: love opening up within new loves. Moevs explains it the following way:

anymore, but quantum physics laws do. There is still very little known about them. A singularity can either be a black hole or a naked singularity. The latter has not been observed yet and is until the moment only a theoretical type, which would arise from a spinning black hole forming two event horizons that eventually merge and at that moment send out light or other information. The opposite of a black hole, however, would be a white hole, another theoretical possibility not observed yet. While a black hole can only be entered from the outside and nothing can escape from it, not even light, a white hole cannot be entered from the outside but matter and light can escape from it. The original universe must have been a kind of singularity, but with the behaviour similar to a white hole. 
"the ultimate ontological principle is a splendore, the reflexive self-awareness of pure consciousness; creation is its re-reflection as an apparently self-subsistent entity, a limitation of its unqualified selfexperience as something, as a determinate thing. This voluntary self-experience of self as "other" is love; thus Dante can say that creation is an unfolding of divine love" (Moevs 2005, 5).

Redemption is only possible until "the whole of evil is overcome and destroyed, so that even the world of hell now appears as part of what we get to know about the ultimate structure of the universe. (...) Redemption means that the cosmos can go back to its beginning and be restored in its original form" (Mazzotta 2008, Lecture 22).

Dante seems to be an Aristotelian but his thoughts on cosmology are rather Neo-Platonic. As Mazzotta states, they are ideas coming from the $12^{\text {th }}$ century School of Chartres. In the Empyrean, Dante centers this part around the Incarnation: the Divine within the human. In a way the Incarnation was a re-creation, a redemption in order to redirect the world towards order. Here Dante explores the relation between the finite and the infinite, only seemingly disjointed. Mazzotta tells us that

"the finite universe can only be part of the infinite universe and so [Dante] describes how the infinite enters the finite and the finite enters the infinite. This is the heart of the cantos of metaphysics which we can call the cantos of physics and metaphysics at the same time" (Mazzotta 2008, Lecture 23).

From here on, gradually his memory begins to fade, while starting to have problems to capture into words what he experiences. In the very end he is not sure even what he sees. He is still a mortal being trying to convey his experiences and visions through a limited language which cannot capture the ineffable. Now, the Empyrean is presented to him as a city-garden ${ }^{261}$ and a mystical white rose where the spiritual and the material come together. His journey has been from the wilderness, passing through the Garden of Eden, to reach the city-garden. As we indicated in our overview of the Commedia, Dante also describes it as a theatre using words such as "lowest rank" and "procession", referring again to the idea that Paradise as it appeared to him has been a theatrical performance. The special characteristic of this heavenly theatre is that Dante does not just have one, but all perspectives at the same time: he can see the whole universe, just like these souls can. At the same time he still belongs to the material universe; his poem is political, not only spiritual, and is his way of taking part in history. "The idea of city always implies some human contact, the polis"

261 Prof. Mazzotta mentiones the combination that Dante makes between city and garden already in his Lecture 15 when he speaks of the Terrestrial Paradise on top of the mount of Purgatory, and comes back to the term to describe the representation of the Empyrean in Lecture 23. Normally, the garden was an escape from the polis, the city, but for him the ideal heavenly polis is one where both are combined. Mazzotta, G., "Dante in Translation", Yale Online lectures (2008), http://oyc.yale.edu/italian-language-and-literature/ital-310, Lectures 15 and 23. 
(Mazzotta 2008, Lecture 23).

The souls are no longer mere lights, they appear with recognizable bodies. "There I saw faces given all to love, / bright with Another's light and their own smiles, / and gestures touched with grace and dignity." 262 Mazzotta comments that "these blessed are blessed because there is some other in them. They are themselves and there is another in them too" (Mazzotta 2008, Lecture 23). But Moevs argues that the Divine within human being is not "Other" because there is only "One" and we form a part of it. Moevs suggests that if the Commedia has a philosophical or theological message, it would be to make us comprehend that there is no duality, only One which is and of which everything forms a part or is an expression, even if we need dualistic imagery to speak about reality.

"To understand is not to grasp ideas or concepts: it is for Intellect, reflected in or as the human mind, to see and know itself as the basis of creation, which is to see truth, what alone is. It is to see that there is no where, no when, and no how in the creation of the world, no place, no time, and no manner in which the non-contingent One either does or does not experience itself as the contingent Many" (Moevs 2005, 7).

Dante focusses on images and reflections. "The journey of the Comedy is one between images and essences; here he wants to go beyond the images" (Mazzotta 2008, Lecture 23), or rather, he is ready to go beyond them, he now experiences the Divine within himself. He understands that, with the words of Moevs, "one may describe everything that is seen, but not what is ultimately doing the seeing. (...) The world itself cannot resolve the mystery of its own being, which is precisely why Dante travels from within to beyond space-time" (Moevs 2005, 169-170).

Symbolically, Eve sits at the feet of Maria, Eve being the one that caused the Fall while Maria being the one that gave birth to the re-opening of the Heavens and the possibility of going beyond the Earthly Paradise. The archangel Gabriel is re-enacting the Annunciation and the whole of heaven answers as a choir, which is again an example of theatrical representation.

Creation is a gift to us, and Mazzotta says that "therefore we are invited to have an aesthetic admiration of it." He continues: "The poem will end up with being a sort of registering the defeat, the unavoidable defeat of memory and importance of forgetfulness" (Mazzotta 2008, Lecture 23). This mystical rose represents Mary's womb, who became the feminine part of Divinity from the moment of Incarnation. Dante describes the Incarnation - the humanizing of the Divine - as her womb being an immense sphere. In this sphere, the finite and infinite converge. Its centre is at the 
same time nowhere and everywhere because its circumference is nowhere. Interestingly, Guy P. Raffa writes that, "like a hologram, a three-dimensional image, the rose is formed from a ray of light reflected off the outer surface of the Primum Mobile (30.106-17)."263

According to Mazzotta, there is the danger that the pilgrim looses his human mind at this level. His language becomes incantatory with repetitions and loss of words (Mazzotta 2008, Lecture 23). Incantatory language implies some kind of musicality in it. However, the final experience contains primarily light, color and image, and not sound. Mazzotta comments that here Dante "is in the presence of the eternal instant. First memory fails, then language fails: not everything is reducible to language" (Mazzotta 2008, Lecture 23). Dante writes it with the future in mind: "That it may leave behind a single spark / of [thy] glory for a people still to come." ${ }^{264} \mathrm{He}$ does not experience a beatific vision, instead he sees the Incarnation, the human image within God, "painted with our likeness". ${ }^{265}$ He sees the origin of the light but not God himself. According to Moevs, it is impossible for Dante to see God, since he is not in time or space. The eye that sees is outside of its own visual field. The telling of the journey and the journey itself are an unending circle: he comes back so that we can undertake the journey ourselves. Here is where Dante expresses what Mazzotta calls the "closed circularity of God" (Mazzotta 2008, Lecture 23): "O everlasting Light, you dwell alone / in yourself, know yourself alone, and known / and knowing, love and smile upon yourself"266

The fact that he uses the word "our" again in "painted with our likeness" reminds us of the beginning of the Commedia: "midway upon the journey of our life"267. His story is always written for all humanity, not only for himself. He has taken us with him on his journey, so it has become our own journey. Moevs writes that "the Comedy's aim is self-knowledge, the self-experience of what is" (Moevs 2005, 9). It “mirrors us to ourselves and places us where we place ourselves" (Moevs 2005,182 ), which means that it does not tell us what to think or do, but rather hands to us a journey through all-compassing finite forms and images, where it is not about what he writes but about what we ourselves experience while reading it. This is for Dante the way to awaken to Being within ourselves, to self-knowledge, while reading the Commedia. However, Moevs states that "we cannot know what we are until we surrender what we think we are" (Moevs 2005, 8).

263 Raffa, G.P., Danteworlds, http://danteworlds.laits.utexas.edu/paradiso/10empyrean.html\#rose [accessed 30-6 2015] 264 "ch'una favilla sol de la tua gloria / possa lasciare a la futura gente", Paradise 33.71

265 " pinta de la nostra effige", Paradise 33.131

266 "O luce etterna che sola in te sidi, / sola t'intendi, e da te intelletta / e intendente te ami e arridi!", Paradise 33.124

267 "Nel mezzo del cammin di nostra vita", Inferno 1.1 (I have used Henry Wadworth Longfellow's translation here: http://www.divinecomedy.org/divine_comedy.html) 


\subsection{Dante's Metaphysical Journey}

Medieval thought on non-dualistic Being has some resonances in modern quantum mechanics and is perhaps not as foreign to us as we think when we read the Commedia in a literal way rather than looking through its images. Moevs gives a number of philosophical and dialectical reasons against materialism and dualism, among which he states that "it is difficult for materialism to provide a non-arbitrary answer to the question, 'Why is there something rather than nothing?' In (nonmaterialistic) non-duality the distinction between something and nothing dissolves: they are not two." He also mentions that "the direct awareness of being conscious is the one non-contingent certainty of human experience" (Moevs 2005, 189).

But also in science, quantum physics show that on the smallest level of materiality it is precisely materiality that is not applicable anymore. The smallest elements act like waves and particles at the same time. Moevs quotes the physicist Werner Heisenberg (1901-1976) - known for his uncertainty principle ${ }^{268}$ within quantum mechanics - who observed that

"the smallest units of matter are, in fact, not physical objects in the ordinary sense of the word; they are forms, structures, or - in Plato's sense - Ideas, which can be unambiguously spoken of only in the language of mathematics" (Moevs 2005, 188).

Ideas, which can also be interpreted as bits of information. They can act in ways we would not expect them to do. For example, they can be in various places simultaneously and thus interact with themselves. Our observation interacts with them and causes them to be in a specific place at the moment of being monitored, but we can observe their behaviour at arriving at their end point and note that they have interacted with themselves. Furthermore, in an empty space, particles can appear and disappear "spontaneously". Also, the interaction within a system does not diminish together with distance between the several components of that system. The interaction can be direct, faster than the speed of light. So, certain places can be directly connected with each other regardless of the space between them. Moevs argues that

"the speed of light constitutes the limit of motion, and thus the boundary of space-time; it is the constant of conversion between matter and energy or electromagnetic radiation. The substance and limits of the physical universe seem in some sense to consist in the nature of light, broadly conceived, and its mysterious convertibility into spatiotemporal form, and thus into gravity. Bonaventure and other

268 The uncertainty principle states that certain pairs of variables of a particle cannot be known simultaneously: the more precisely one of the two variables is known, the less precisely the other one can be known. Examples of such pairs are energy and time, or impluse and position. 
proponents of the 'metaphysics of light' would not be surprised" (Moevs 2005, 189).

Dante, whose Paradise is all about Divine light, would probably not be surprised either. Moevs continues later on about this issue, stating that

"the fact that 'information gets around' superluminally, ignoring any constraints of spatiotemporal extension, would suggest that all experience is in some sense one and indivisible (it is not made of 'locally connecting separate parts'): it is coherent only if conceived as a whole. It also implies that 'what the world consists in', the ground of its being, is not subject to the constraints that operate within the world. In some sense, the very notion of locality — of position, distance, and separation in space-timeis an illusion. Reality is ultimately one, and ultimately dimensionless" (Moevs 2005, 191).

There is an alternative theory of multiple universes, which states that all possibilities an event could experience are developing simultaneously in an infinite number of universes. However, despite the fact that these theories go far beyond human logic and intuition, our study follows the idea of all possibilities within the same reality - whatever that reality might be - rather than within an infinite number of separate realities that will never communicate.

The idea of space-time is perhaps not as new either as we think. In his Primo Mobile, Dante links space to time as inseparable from each other. Moevs connects this to the concept of space-time in the theory of general relativity and adds that "mass is simply a 'condensation' of space-time, that is, of an energy field" (Moevs 2005, 189). He continues to observe that what not yet has been proven, is

"the convertability between light-energy-vacuum (or strings) and consciousness, what Dante calls luce intellettual. This is to be expected: to use Wittgenstein's image, the visual field does not include the eye itself $^{269}$; what alone is absent from any description of experience is the subject of experience, because nothing can be said about it, it is nothing" (Moevs 2005, 189).

In quantum mechanics it was found that the observance of a particle determines its behaviour; the observer and the observed are closely connected. The observer forms part of the reality he is trying to observe:

269 On pages 169-170 of his book Moevs already mentioned this image: "one may describe everything that is seen, but not what is ultimately doing the seeing. (...) The seeing eye is one with its visual field, and yet is not contained in that field but lies outside it.". 
"every description of reality is simply a picture that is in part determined by the act of observation itself. The observing subject's point of view as an entity within the world, its frame of reference, and the questions it asks are all factors that determine its picture of the reality it seeks to describe: they are part of that picture. The 'world in itself' may be approximated and imaged — but never grasped or communicated - by descriptions, concepts, or equations: reality lies beyond, beyond all concept, all description, all thought, [p.190] all image. That beyond, the architects of quantum physics unanimously concluded, lies in consciousness itself. There is no such thing as the world 'in itself' autonomous of consciousness" (Moevs 2005, 189).

Quantum mechanics seem to reinforce this concept. Indeed, even the physicist Erwin Schrödinger (1887-1961), known for his scepticism against the uncertainty principle, realized that the duality between the observer and the observed was an illusion: "Subject and object are only one. (...) The reason why our sentient, percipient, and thinking ego is met nowhere within our scientific world picture can easily be indicated in seven words: because it is itself that world picture." Moevs adds to Schrödinger's words that "the true subject cannot interact with its experience: it is nothing in itself, it is its experience. (...) Consciousness is ultimately one: the subject of all experience is singular and attributeless" (Moevs 2005, 190).

Finally, we would like to add some observations on the creation of the universe according to scientists. Stephen Hawking tells us that the very early universe was infinitely small, so small that only quantum mechanics can be applied for its explanation. There is no quantum theory of gravity yet, so there is no theory that correctly could describe the early universe yet. But what is known already is that,

\footnotetext{
"once we add the effects of quantum theory to the theory of relativity, in extreme cases warpage can occur to such a great extent that time behaves like another dimension of space. In the early universe when the universe was small enough to be governed by both general relativity and quantum theory there were effectively four dimensions of space and none of time. That means that when we speak of the "beginning" of the universe, we are skirting the subtle issue that as we look backwards towards the very early universe, time as we know it does not exist!"270
}

Time is so curled up that there was no beginning of time, like a starting point on a chronological straight line. He continues: 
"suppose the beginning of the universe was like the South Pole of the earth, with degrees of latitude playing the role of time. As one moves north, the circles of constant latitude, representing the size of the universe, would expand. The universe would start as a point at the South Pole, but the South Pole is much like any other point. To ask what happened before the beginning of the universe would become a meaningless question, because there is nothing south of the South Pole. In this picture space-time has no boundary - the same laws of nature hold at the South Pole as in other places. In an analogous manner, when one combines the general theory of relativity with quantum theory, the question of what happened before the beginning of the universe is rendered meaningless. This idea that histories should be closed surfaces without boundary is called the no-boundary condition" (Hawking and Mlodinow 2010, pos.1400).

He also states that the so-called Big Bang was an 'inflation': “the universe expanded by a factor of $1,000,000,000,000,000,000,000,000,000,000$ in 0.00000000000000000000000000000000001 second. It was as if a coin 1 centimetre in diameter suddenly blew up to ten million times the width of the Milky Way. That may seem to violate relativity, which dictates that nothing can move faster than light, but that speed limit does not apply to the expansion of space itself" (Hawking and Mlodinow 2010, pos.1344).

These ideas connect at least on an associative level to the image that Dante evokes about when and how Creation happened. And, as we stated before, the Point that Dante sees in the Primum Mobile makes us think of a kind of inverted singularity, a White Hole. We explained it in footnote 260 as follows: in modern astronomy, a singularity is a point with an infinitely small volume and an infinitely high density. Within it, space-time is so curled up, that space and time in a way cease to exist. The general physical laws do not apply here anymore, but quantum physics laws do. There is still very little known about them. A singularity can either be a black hole or a naked singularity. The latter has not been observed yet and is until the moment only a theoretical type, which would arise from a spinning black hole forming two event horizons that eventually merge and at that moment send out light or other information. The opposite of a black hole, however, would be a white hole, another theoretical possibility not observed yet. While a black hole can only be entered from the outside and nothing can escape from it, not even light, a white hole cannot be entered from the outside but matter and light can escape from it. The original universe must have been a kind of singularity, but with the behaviour similar to a white hole.

The early universe was in a highly ordered state: it had low entropy. The second law of thermodynamics regulates that the entropy in a system can increase, but not decrease along the arrow of time, in other words: the universe has developed from a highly ordered state to an 
increasingly "chaotic" state. The Medieval theory of musica mundana, the highly ordered universe with perfect proportions, is different to this theory because it is a static and ordered model. However, we have seen that the Fall of Adam and Eve did represent the beginning of dualistic thinking and of a growingly chaotic worlds. Inferno represents this chaos, while Paradise represents order. This scientific idea artistically can connect to a representation of Dante's Afterworld.

Not all scientists come to the conclusion that there is something "behind" or "inside" reality that is Consciousness or Being. Stephen Hawking is an example, stating that if the universe is finite, which still has to be proved, then "it will be a model of a universe that creates itself" (Hawking and Mlodinow 2010, pos.1875). However, in general there are indeed associative similarities between Dante's metaphysics and modern science. His metaphysics are much closer to non-dualistic thought in many contemporary religions and philosophies then we think when we read his text only on the literal level. This is important because it gives us the possibility to see through Dante's historical culturally bound expressions of thought. We can transcend his work to the level of universal questions that we still ask ourselves and try to answer either through science, philosophy or religion. 


\section{CHAPTER 4 - THE SONOROUS WORLD OF THE COMMEDIA}

While the previous chapter dealt with the general issues and questions Dante discusses or implies in the Commedia, this chapter focusses specifically on the aspect of musical and non-musical sounds in the text. The Commedia's many sonorous references often do not only have a literal interpretation but also a metaphorical one. Our music theatre work Incipit will be based upon the Commedia's sonorous landscape through a historically informed approach. The aim of this approach is "opening a window" to Dante's inner sonorous world as well as combining the specific methodology of Early Music with the multidisciplinary language of music theatre. Thus, the sonorous references of the Commedia and their interpretation are essential to this thesis.

In his book Dante's Journey to Polyhony ${ }^{271}$, Francesco Ciabattoni did considerable work by transmitting information from a great range of bibliography on Dante, among others works by Italian-writing authors that have not been translated into English. In this aspect it has served as a useful source of information for our study. Unfortunately his book is not precise in its reasoning and conclusions, rather based on wishful speculations than facts, sometimes even using erroneous data $^{272}$. Ciabattoni bases his hypothesis on the assumption made in a number of writings that Dante seems to be making a journey from Anti-Music in Inferno through monophonic music in Purgatory to polyphonic "hyper-music" in Paradise. ${ }^{273}$ However, the idea that music in Purgatory is monophonic and in Paradise polyphonic is not as evident as it may seem. Most references to music in the Commedia do not give any specified information about its performance. As we will see, Ciabattoni has interpreted certain poetical expressions as indications for either monophony or polyphony but they are not that obvious. First of all, improvised note-to-note organum could range from parallel movement in octaves and fifths to contrary movement. There was no break between monophony and polyphony but rather a continuum in everyday liturgical practice. Organum or cantus planus binatim was a colouring of the sound, not a polyphonic form with different rhythmic patterns. Thus, it is perfectly possible that Dante might have thought of organum in Purgatory at some points. On the other hand, in Paradise many musical descriptions are of an incomprehensible, supernatural type of music while polyphony is only clearly implied in a few cases. Perhaps we

271 Ciabattoni, F., Dante's Journey to Polyphony (Toronto, 2010)

272 Two notable erroneous statements in Ciabattoni, F., Dante's Journey to Polyphony (Toronto, 2010): p. 17: “ The Chapter Library of Padua preserves two early thirteenth-century manuscripts (signed C 55 and C 56)". These are the Padua Biblioteca Capitolare C 55 and C 56 and date from the early fourteenth century. p.48: "Although instruments often appear appear in similes or metaphors, they embody the first of Boethius's three categories: musica instrumentalis, musica humana and musica mundana". This is incorrect: musica instrumentalis is the audible music for the human ear and involves both vocal and instrumental music, while musica humana is about the proportions within the human soul and body.

273 Among the writings with this assumption are "Dante's musical progress through the Commedia" (2004) by William Peter Mahrt and “The Music of Dante's Purgatorio" (2005) by modern flutist Mimi Stillman. 
should not take for granted that Dante imagined anything like human musica instrumentalis, even if such vocal, audible music produced by humans was thought to be a creation of God. Just as Inferno hosts Anti-Music, Paradise hosts Hyper-Music.

Definitions and suggestions of musical forms and performance have changed considerably over time. In order to understand what Dante is really describing, a study of Medieval definitions is essential. Margaret Bent wrote an excellent article on how Dante defines poetical and musical terms in De Vulgari Eloquentia. Bent shows herself very critical on a number of these musical and nonmusical issues, confirming the problem of Medieval terminology. She poses the question why the bibliography on Dante and music is so scarce.

\footnotetext{
"One reason may be a disjunction between, on the one hand, Dante's apparent expectation of musical or at least oral performance of his work and, on the other, the total absence of any near-contemporary musical settings of his poetry. Dante seems to imply that canzoni from his own poetic output were musically composed and performed, but no such settings survive. A second reason why Dante's several striking reports of music in the Commedia have eluded comment could be that most do not inform us about music as such, but about its affective impact on listeners. However powerful in effect, the content of such reports is hard to pin down. Thirdly, there are serious problems of terminology, and ambiguities as to where the line falls between verbal poetry and what we would call musical settings or musical performance."274
}

As to the first reason given by Bent, none of the texts of Dante have been used for a $14^{\text {th }}$ century musical composition: "No musical settings of his poetry survive from the fourteenth century. This is the more surprising since polyphonic settings of other secular Italian poetry survive in large numbers from soon after Dante's death" (Bent 2004, 162). In Purgatory 2 of the Commedia, the troubadour Casella sings a song with the text of one of Dante's poems, but such a setting has never been found. Bent notes that the madrigal as a polyphonic musical form became only popular from around the 1340s. ${ }^{275}$ Indeed, Dante just mentions the poetic forms canzone, ballata and sonnet in his De vulgari eloquentia, adding that there are other forms that he has not yet discussed. Bent concludes that "there is thus a considerable disjunction between the surviving poetic genres and actual musical settings. Dante sets out a hierarchy which in no way correlates with whether forms were or were not set to music" (Bent 2004, 163). Nevertheless, the development of the new polyphonic genres probably came just at the end of Dante's lifetime, after the propositions of binary

274 Bent, M. "Songs without music in Dante's De vulgari eloquentia: cantio and related terms", in "Et facciam dolçi canti". Studi in onore di Agostino Ziino in occasione del suo $65^{\circ}$ compleanno. ed. Bianca Maria Antolini, Teresa M. Gialdroni, Annunziato Pugliese (Lucca: LIM- Libreria Italiana Musicale, 2004), vol. I, p. 161

275 This musical genre is not to be confused with the later Renaissance madrigal. 
rhythmic modes by Marchettus da Padova between 1317 and 1319. It is thus probable that Dante never knew the madrigal.

Bent mentions as a second reason the fact that the musical references in the Commedia are not informative about the actual music but rather its effect on Dante. She continues:

\begin{abstract}
"musical references in the Commedia take their identity largely from the words attached to them, and are reported for rhetorical effect, usually praised as sweet [dolce] (...), a performative quality to which we have no access and which permits no reconstruction, even in those cases where we can point to the chant melody Dante would have had in mind.” (Bent 2004, 164).
\end{abstract}

She questions the idea that Dante had any technical musical knowledge:

\begin{abstract}
"Such affective reporting of music has always been common for the great majority of music-lovers, of all degrees of culture, who are sensitive to its effects but who are not themselves musically trained. Isidore [of Seville, ca.560 - 636] attests to the universally moving effect of music, corresponding to Dante's Aristotelian understanding of passio or effect in De Vulgari Eloquentia II.viii. I find nothing in Dante's mentions of music to suggest that he was musically adept beyond an acquaintance with the somewhat abstract theory of Isidore and Boethius as the sources for his definitions of harmony." (Bent 2004, 165).
\end{abstract}

Bent points out that Dante's "impressionistic" way of describing the effects of music does not reveal any "authority of an ars or techne", a craftmanship, while specifying that "in addition to any aesthetic or emotional effect it produces, artful, composed music has its own inner logic or grammar, independent of words, hard but not impossible to hint at in verbal description" (Bent 2004, 166). This is a very interesting argument, although some caution is required, since the musical knowledge of Medieval professional and amateur musicians was very different from ours and we should get acquainted with their musical expressions. There is no certain knowledge of the musical education of Dante, even though modern flutist Mimi Stillman in her article suggests otherwise, basing herself on the musician Michele Croese, arguing that there two stages in Dante's musical education: in his early years his contact with music was through making music and working with musicians, and later on he explored the theory and philosophy of music. Croese bases this conclusion on the fact that high-born classes normally received practical musical training. However, there is no existent evidence for the suggestion that Dante made music himself. Stillman continues: "In this elegant, leisurely world described by Dante in his Vita nuova and by Boccaccio in the Decameron, aristocrats and intellectuals gathered to read poetry, perform music, and dance. In his 
Trattatello in laude di Dante, Boccaccio records that the young Dante played, sang, and composed skillfully". ${ }^{276}$ This work was one of the first biographies of Dante, written by someone who had not known him personally. We have to be aware again of the fact that Medieval society and manner of self-expression were very different from ours. It is likely that the stories on Dante's life that circulated in the $14^{\text {th }}$ century were embellished or changed slightly through time. Bocaccio did not do any historical research for his biography but rather mentioned the information and personal ideas he had about Dante's life and work.

As a third reason in Margaret Bent's article for so little bibliography on the Commedia's musical references she lists problems of terminology for verbal poetry versus musical performance. She specifies that

\begin{abstract}
"it is sometimes hard to determine which of three possible levels Dante might be talking about [in $D e$ Vulgari Eloquentia]: music as we understand it; musical terms as metaphors or analogies for poetry; undifferentiated terminology common to both and transferable between them. (...) Some apparently musical terms did not have uniquely 'musical' connotations in the middle ages but were borrowed from grammar, rhetoric and other word-based disciplines.” (Bent 2004, 166).
\end{abstract}

She continues stating that "'song' and 'music' are not necessarily 'sounding music' in our sense; there are also many overlaps and much interchangeability in the medieval vocabulary of speech and song." (Bent 2004, 171). To take the most obvious example, the three cantiche (canticles) and the hundred cantos are not referring to sounding music but to poetical definitions. Furthermore, Bent confirms that "the Commedia is full of apparently interchangeable words for saying and singing" and that "dicere and canere seem to be interchangeable as words for authorship, for saying and singing, just as facere is used both for making and doing, composition and performance." (Bent 2004, 178). She warns against an understanding of the word armonia solely as the modern concept of musical harmony:

"armonia relates to the science of harmonics, the proportions, ratios or numerical relationships (ratio) both between the heavenly bodies and between the components of musical intervals. (...) At another level armonia is a qualitative word expressing the proportioned joining of diverse components, and for music the definitions are parallel to those used by Dante for words. Armonia denotes relationships between people, between words, between musical sounds (consonant intervals) as well as silent mathematical relationships, but the word had no compositional musical meaning in Dante's time, and most certainly nothing like the idea of 'musical setting', 'musical accompaniment' or harmonising in the 
sense familiar to us from recent usage" (Bent 2004, 174).

She warns that terms such as "musical" or "song" in the Middle Ages "might apply to some kind of chanted monotone with inflections, more so to an actual melody applied to the words, spontaneous or composed, and finally and most clearly to a composed polyphonic setting of those words" (Bent 2004, 178). As examples she refers to the declamatory performances of Sarah Berhardt (1844-1923) and the Comédie Française of the early $20^{\text {th }}$ century, where speech and song are mingled into "a high, declamatory style of delivery inconceivable to modern theatre-goers." (Bent 2004, 179). Finally, Bent concludes that "music, as Dante understands it, consists of internal relationships perceived by the mind and potentially transmittable to the mind of another person via the sense of hearing, but not necessarily realised in sound" (Bent 2004, 180). She refers to a kind of mental, inner listening that does not have to sound in order to be musical.

Keeping Bent's statements in mind, we read Ciabattoni's book with some caution when he writes enthusiastically about the musical references, stating that Dante meant a monophonic performance in Purgatory and a polyphonic performance in Paradise. When Ciabattoni writes that "historical and musicological evidence tells us that Dante's exposure to polyphony was such that we should actually be surprised if he had not made polyphonic songs an important element in his poem", it should be noted that this polyphony was the simple, note-to-note, improvised organum, which was generally not perceived as polyphony but rather as adding a musical colour to the plainchant melody. Ciabattoni in his introduction quotes Margaret Bent's words on the matter:

"There are very few places in the Commedia that can be construed as referring to polyphonic music (...) Most of Dante's references to sounding music lend themselves most readily to interpretations either of monophonic music or, if polyphonic, in a relatively simple style, such as Dante doubtless heard in Tuscan churches." (Bent 2004, 162 and Ciabattoni 2010, 11).

We see that Medieval definitions of polyphony and monophony were quite different from ours, and it is wise to follow Margaret Bent's caution in this matter as we discuss the Commedia's musical and non-musical sonorous references. Thus, instead of polyphony in the modern sense, it is possible that Dante's "polyphonic" references in Paradise were principally metaphors for the Trinity (using expressions such as "triple melodies") and that a word such as armonia pointed to a poetical harmony rather than a musical one. 


\subsection{Inferno}

In Inferno there is no music. The souls are not only denied any form of music but they are also unable to express themselves musically. Their reason and will are so distorted that they are simply not capable of singing nor they wish to do so. They are stuck in their sinful perspective, as Gragnolati has shown in his book on the aerial body in Dante's Commedia ${ }^{277}$. We read in Chapter 1 that music in its Medieval understanding is in fact a reflexion of Divine order by means of perfect numeric proportions. Since Inferno is a place of disorder and the souls themselves are internally discomposed without any possibility to return to their natural inner harmony, music has no place down here. Ciabattoni states that,

"as the orderly structure of the heavens is expressed in musical terms by the choirs of the blessed, so the chaos of hell produces a cacophonic mockery of the sacred songs. Such mockery, however, turns uniquely against the wretched and reminds them that their eternal damnation cannot be alleviated" (Ciabattoni 2010, 83).

The sounds emitted by the damned are expressions of negative emotions, principally anger and pain. Mostly, the souls express themselves by shouting or other aggressive behaviour. Some are not even able to verbalize their emotions, either because they are submerged in some substance or because they are babbling nonsense. This does not mean that there are no references to music. The sounds of Inferno together form a kind of Anti-Music, a term coined by writer and academic Edoardo Sanguineti (1930-2010). ${ }^{278}$ Apart from a lack of any audible music, Dante even goes further and includes non-musical parodies on liturgical music. The main audible characteristic of the sounds in Inferno is their cacophonic nature. ${ }^{279}$ In Ciabattoni's words, "cacophony is a primary element of the landscape and an instrument of punishment" (Ciabattoni 2010, 78). Thus, musical disorder is not only a reflection of the damned souls' distortion but also their punishment.

At the beginning of Inferno, Virgil appears when Dante's path out of the wilderness is blocked by three beasts. Dante anxiously pleads to Virgil: "Miserere di me", a translation into Italian of the Latin miserere mei. These words are the incipit of Psalm 50, meaning literally "have pity on me"280. They are the first spoken words in the canticle of Inferno. In the whole Commedia, the Miserere

277 See Chapter 3. Gragnolati, M., Experiencing the Afterlife: Soul and Body in Dante and Medieval Culture (Indiana, 2005)

278 Mentioned in M. A. Roglieri, “La dolce Sinfonia di Paradiso: Can Mere Mortals Compose It?”, Braida, A. and Calè, L., Dante on View (Ashgate: Aldershot, 2007), p.66, referring to Sanguineti, E., "Infernal Acoustics: Sacred Song and Earthly Song", Lectura Dantis, 6 (1990), p.69-70.

279 Cacophony is a combination of dissonant or harsh sounds with no obvious relationship between them.

280 This is Psalm 50, translating as "Have mercy on me, o God, according to thy steadfast love; according to thy abundant mercy blot out my transgressions. Wash me thoroughly from my iniquity, and cleanse me from my sin." 
only appears two more times: in Purgatory 5.22, sung by the late repentants who have to wait in Ante-Purgatory, and in Paradise 32.12, only mentioned - but not sung - by Saint Bernard when he speaks about Ruth, the great-great-grandmother of David, "the singer who in remorse cried 'Miserere mei', ${ }^{281}$.

Ciabattoni tells us that

\begin{abstract}
"the invocation miserere, as Sapegno warns, was used in its original Latin form even by the common people in everyday situations, but in the Psalms it recurs in specific association with the recognition of the condition of sinfulness and the plea for divine help. It is an invocatio peccatorum, a desperate cry for help in the darkest time of trouble when the soul is so burdened with sin that it cannot be lifted without God's merciful intervention. It is a request to heal the soul and create a clean heart in the sinner. Such supplication for help can obviously only take place once the singer has become aware of his desperate condition and is alone before his sin" (Ciabattoni 2010, 67).
\end{abstract}

He argues that this is the reason why Dante himself is not singing: he cannot sing because he is in sin himself. However, Dante is a living man so he is still in time to change his destiny - at the moment of a man's death, the Divine judgement will be unchangeable for the rest of times. "There is a defect of the pilgrim's state that prevents him from singing it", as Ciabattoni formulates it (Ciabattoni 2010, 67), who sees it as the deciding moment where Dante the sinner, heading towards his damnation, realizes for the first time that he has to change. Ciabattoni remarks that "Dante's spoken word of desperation is a musicless anticipation of the reversal of sacred chants we shall find later on." (Ciabattoni 2010, 73).

Ciabattoni also tells us that "music is programmatically made the herald of infernal reality because it introduces the landscape and character of Hell before images are added." (Ciabattoni 2010, 76). Indeed, the choir of the neutral angels and souls is introduced by its sound rather than by its visual aspect (Inferno 3.22-30):

Quivi sospiri, pianti e alti guai risonavan per l'aere sanza stelle, per ch'io al cominciar ne lagrimai.

Diverse lingue, orribili favelle,
Here heartsick sighs and groanings and shrill cries re-echoed through the air devoid of stars, so that, but started, I broke down in tears.

Babbling tongues, terrible palaver, 
parole di dolore, accenti d'ira,

voci alte e fioche, e suon di man con elle

facevano un tumulto, il qual s'aggira

sempre in quell'aura sanza tempo tinta,

come la rena quando turbo spira. words of grief, inflections of deep anger,

strident and muffled speech, and clapping hands,

all made a tumult that whipped round and round forever in that colorless and timeless air, like clouds of sand caught up in a whirlwind.

The souls are not presented physically but audibly: "here he offers us only the sinners' disembodied voices and a handful of whirling sand. We are, therefore, presented with an array of ghosts. (...) It is the racket that whirls around, rather than their bodies." (Ciabattoni 2010, 77). Dante indicates the neutral angels with "wicked choir" (cattivo coro) in Inferno 3.37. This description and the sound of their eternal circular motion indicate a parodic version on the angelic choir. "A fitting form of symbolic retribution, their punishment is a lowly imitation of the angelic wheels: they are arrayed in a circle and must forever spin, fixing their attention on a meaningless and yet unreachable banner (...), instead of looking to God in whom all truth lies." (Ciabattoni 2010, 78). After a while, Dante is able to see them as well (Inferno 3.52-57):

E io, che riguardai, vidi una 'nsegna che girando correva tanto ratta, che d'ogne posa mi parea indegna;

e dietro le venìa sì lunga tratta di gente, ch'i' non averei creduto che morte tanta n'avesse disfatta.
And I, looking again, observed a banner which, as it circled, raced on with such speed it did not seem ever to want to stop;

and there, behind it, marched so long a file of people, I would never have believed that death could have undone so many souls.

Another aspect to this parody on the angelic choir are the cacophonic, bizarre and senseless sounds they produce. There is nothing harmonious in their utterances and nothing proportional in their intervals and rhythm. Ciabattoni argues that "the hidden musical datum of this passage is revealed in all its technical implications if we skip ahead to Paradiso 10.139, which stresses the importance of measuring time for polyphonic singing by envisioning a clock made of singing souls. (...) The infernal mockery of angelic music has no rhythm, no accordance of tempo." (Ciabattoni 2010, 78). The first commentator on the entire Commedia, Jacopo della Lana (1290-1365) wrote about the expression sanza tempo (Inferno 3.29):

"He says this because every sound that is musically attuned produces pleasure to the hearing, that tempo 
is the order in music, making the voices resound sweetly together. If that noise is without tempo, it means it lacks order, and, consequently, does not give any pleasure." ${ }^{282}$.

Ciabattoni also points out that "the neutral angels in Inferno are presented in a position that forms a mirror image of the angels at the end of the poem, where Dante employs the same rhyme words '(co)loro' / 'coro' / 'fuoro' (Inf. 3.35-9; Par. 28.92-6)." (Ciabattoni 2010, 79). In Paradise 28.118, all the angels sing a Hosanna, confirming the image of the choir of angels. Prof. Mazzotta suggests, as we saw in Chapter 3, that the "choir" of neutral souls and angels is linked to the end of Inferno, where the fallen angel Lucifer resides: "Inferno begins and ends with angels rejected from Paradise" (Mazzotta 2008, Lecture 9). Moreover, the neutral angels run eternally after a meaningless banner, while Lucifer is indicated by Virgil with the words Vexilla regis prodeunt inferni ("The Banners of the King of Hell Advance") - a parody on the $6^{\text {th }}$ century hymn Vexilla regis prodeunt ${ }^{283}$.

At the beginning of the circle of the lustful, it is again the sound rather than the image that introduces the scene (Inferno 5.25-27):

\section{Or incomincian le dolenti note a farmisi sentire; or son venuto là dove molto pianto mi percuote.}
Now the notes of suffering begin
to reach my hearing; now I am arrived
at where the widespread wailing hammers me.

The souls that inhabit this circle are compared to birds. First they are described as crying similar to the cranes' song. Curiously, Dante uses the musical-poetical term lai for their song (Inferno 5.4649):

\begin{tabular}{|l|l|}
\hline $\begin{array}{l}\text { E come i gru van cantando lor lai } \\
\text { faccendo in aere di sé lunga riga } \\
\text { così vid'io venir, traendo guai, }\end{array}$ & $\begin{array}{l}\text { And as the cranes fly over, chanting lays, } \\
\text { forming one long line across the sky, } \\
\text { so I saw come, uttering their cries, }\end{array}$ \\
ombre portate da la detta briga & shades wafted onward by these winds of strife \\
\hline
\end{tabular}

When Francesca and Paolo descend, they are describes as two pigeons (Inferno 5.82-87):

282 Quoted in Ciabattoni 2010, 79

283 The opening stance of this hymn is: "Vexilla regis prodeunt, fulget crucis mysterium, quo carne carnis conditor suspensus est patibulo" ("The banners of the king issue forth, the mystery of the cross does gleam, where the creator of flesh, in the flesh, by the cross-bar is hung.") 
Quali colombe dal disio chiamate

con l'ali alzate e ferme al dolce nido

vegnon per l'aere, dal voler portate;

cotali uscir de la schiera ov'è Dido, a noi venendo per l'aere maligno,

sì forte fu l'affettüoso grido.
Just as the doves when homing instinct calls them to their sweet nest, on steadily lifted wings glide through the air, guided by their longing,

so those souls left the covey where Dido lies, moving toward us through the malignant air, so strong was the loving-kindness in my cry.

The word lai refers to a poetical genre of which is known that it also appeared as a musical setting. There are no surviving Italian musical sources containing any lai. The lai was mostly a French form used in the $13^{\text {th }}$ and $14^{\text {th }}$ centuries. In the $12^{\text {th }}$ century it gained popularity in France because of the works by Marie de France who claimed that they were adaptations of Breton narrative lais. Descort was the Provençal name for lai, while in Italy it seems to have been translated into discordio (for example, a poem of Jacopo da Lentino was defined with this word). It is thus surprising that Dante uses the Northern French name lai. Musicologist David Fallows on his article on the lai writes that "the very irregularity of the poetic form led to large metrical and rhyming patterns that have caused the lai and its German equivalent the Leich to be described as the major showpieces of medieval lyric poetry; and there is much truth in Spanke's useful distinction (1938) between songs that are primarily metrical in their formal concept (i.e. nearly all medieval strophic song) and those that are primarily musical (the lai and the sequence), a distinction that almost inevitably brings with it the suggestion that the lai and related forms represent by far the earliest surviving attempts at continuous extended musical composition outside the liturgy." 284 Why would Dante use the NorthFrench lai instead of discordio or descort? Ciabattoni points out that the term returns in Purgatory 9.13-15:

Ne l'ora che comincia i tristi lai la rondinella presso a la mattina forse a memoria de 'suo' primi guai

At the hour nearing dawn when the swallow begins to sing her mournful melodies, perhaps remembering her former woes

This is a reference to the mythological story of the sisters Procne and Philomela who were turned into a swallow and a nightingale. Procne's husband Thereus had raped Philomela, cut her tongue off and hidden her from her sister, but Procne found out. She killed her own son, whom she cooked and served as food to her husband. When she told him whom he had just been eating, the outrageous Thereus wanted to kill the both of them but as a protection the gods turned all three into birds. 
Ciabattoni notes that "the lustful tinge of the story, the elements of aviary zoology, and the reference to the flesh in line 17 represent a thematic link to Inferno 5." (Ciabattoni 2010, 89). Lais could be set to music but were a poetical genre in the first place. Perhaps Dante used the term lai to reinforce his criticism against certain types of written secular poetry, such as the love poetry that had led his characters Francesca and Paolo to believe that they could live just like the protagonists in the book. Ciabattoni argues that, "by portraying the cranes while they are 'cantando lor lai', Dante introduces a musical element into his critique of French love lyrics" (Ciabattoni 2010, 89) but in reality these souls are emitting a sound similar to that of cranes, which is rather non-musical. It also reflects the somewhat beastly state the damned souls are in.

In the next circle, where the gluttonous are lying on the ground and continuously flipping over under the sour rain, we encounter "the demon Cerberus thundering loudly against the souls who wish that they were deaf." ${ }^{285}$ This is yet another indication that the chaotic and shrill non-musical sounds in Inferno are a punishment. Many of the unpleasant sounds in Inferno, though, are produced by the souls themselves. The yells in the circle of the avaricious and prodigals in Inferno 7.30 are a good example of those sounds, since they keep on screaming: "Perché tieni?" "Perché burli?" ("Why do you hoard?" "Why do you splurge?"). Their guard is Plutus, the Roman god of wealth, who can only try to warn Lucifer with a strange clacking voice and in a gibberish kind of language: "Pape Satan, pape Satan, aleppe!". The god of wealth has become a powerless creature that cannot express itself very well.

The expression "perché?" ("why?") reappears from time to time in Inferno, apparently expressing the confusion of these souls and at the same time showing that they are completely blind to their own accountability for the situation they are in. In the circle of heresy, the father of Dante's best friend and poet Guido Cavalcanti ${ }^{286}$ asks anxiously for his son: "Mio figlio ov'è? E perché non è teco?" ("Where is my son? Why is he not with you?", Inferno 10.60). The suicidal soul of Pier della Vigna $^{287}$ in the form of a tree puffs and cries: "Perché mi schiante? (...) Perché mi scerpi? ("Why do you break me? (...) Why do you rip me?”, Inferno 13.33-35). In the lowest circle of Hell, trapped inside the frozen lake except for his head, Bocca degli Abati ${ }^{288}$ screams through his tears when Dante kicks him by accident in the face: "Perché mi peste? (...) Perché mi moleste?" ("Why do you kick me? (...) Why do you pester me?”, Inferno 32.79-81).

285 “(...) lo demonio Cerbero, che 'ntrona / l'anime sì, ch'esser vorrebber sorde”, Inferno 6.32-33

286 Guido Cavalcanti was still alive in 1300 , but at the moment of writing he had already died in exile, as a consequence of a decision in which Dante had taken part.

287 The former chancellor to Emperor Frederick II in the $13^{\text {th }}$ century.

288 A Florentine nobleman from the $13^{\text {th }}$ century whom Dante regarded as a traitor. 
Most damned souls express themselves either with aggressiveness (shouting, screaming, yelling, hitting, biting) or with deep sadness (weeping, wailing, moaning). Yet there are some that simply cannot express themselves. We have already seen the choir of the babbling neutral angels and souls. From the ditch of thieves in circle 8 arises "a voice that seemed incapable of forming words." 289 The giant Nimrod, whose body is so large that it connects circles 8 and 9, "for which no sweeter psalm is better suited", can only babble with his beastly mouth the words "Raphèl maì amècche zabì almi" (Inferno 31.67-69):

\begin{tabular}{|l|l|}
\hline $\begin{array}{l}\text { "Raphèl maì amècche zabì almi", } \\
\text { cominciò a gridar la fiera bocca, } \\
\text { cui non si convenia più dolci salmi. }\end{array}$ & $\begin{array}{l}\text { "Raphèl maì amècche zabì almi" } \\
\text { began to shout the savage mouth, } \\
\text { for which no sweeter psalms were fit. }\end{array}$ \\
\hline
\end{tabular}

We saw already in chapter 3 that Mazzotta reads these words as an imperfect anagram of "Eli, Eli, lama sabachthani" ("My God, My God, why have you forsaken me?"), the fourth saying of Jesus on the Cross. Nimrod built the tower of Babel in order to ascend toward God through his own effort, instead of having the humility to wait for the Divine descent. God's punishment was the confusion of language, which is exactly what Nimrod is representing. Interpreting Nimrod's phraseas an imperfect anagram of the fourth saying of Jesus on the Cross, we understand the indication of "psalm" for Nimrod's intent to express himself as a most suitable description for a parodic version of a liturgical psalm. Nimrod's enormous physical size is not in balance with his powerless state, something that is also seen in Lucifer himself.

The souls that are below the surface of the mud are the sullen. ${ }^{291}$ They always carried around a great unexpressed internal anger and now their opportunity of self-expression has been taken away from them completely (Inferno 7.121-126):

Fitti nel limo dicon: "Tristi fummo ne l'aere dolce che dal sol s'allegra, portando dentro accidioso fummo:

or ci attristiam ne la belletta negra". Quest'inno si gorgoglian ne la strozza, ché dir nol posson con parola integra.
Mired in slime, they moan, "We were morose in the sweet air made cheerful by the sun; we bore within ourselves the torpid vapors:

now morbid we are made in this black mud."

This hymn they gurgle in their gullets

since they can't sound it with full syllables.

289 “una voce uscì de l'altro fosso, / a parole formar disconvenevole", Inferno 24.65-66 
Just like in the case of the ironic term of psalm for Nimrod's babbling, here the word hymn is used for the gurgling: "a hymn that enacts a reversal of the liturgy that cannot be performed in Hell but will properly celebrated in Purgatory by the penitents" (Ciabattoni 2010, 82). Ciabattoni argues that the plural verb indicates various souls gurgling this "hymn" and calls the result a "poly-cacophony". Cacophony in itself is already a multitude of sounds. It is what pervades all soundscape of Hell, except the soft sighs of Limbo and the silent processions we will discuss below. Other souls unable to express themselves are the ones in the lowest circle, captured within the ice like straws (Inferno 34.10-15):

Già era, e con paura il metto in metro, là dove l'ombre tutte eran coperte, e trasparien come festuca in vetro.

I was now - and with fear I set it down in verse - where the shades were wholly sealed and yet showed through like straws in glass.

Altre sono a giacere; altre stanno erte, quella col capo e quella con le piante; altra, com'arco, il volto a' piè rinverte.

Some of them lie flat, some stand upright, one on his head and one upon his soles; another, like a bow, bends face to foot.

The ultimate inhabitant of Inferno who cannot express himself is Lucifer. We also saw in chapter 3 the reason for his muteness: angels do not use language and he represents evil defeated in Dante's narration.

Silence also plays a special role in Inferno. Limbo is a relatively silent place but its air is filled with sighs. However, the way the sorcerers and foretellers walk - with their heads $180^{\circ}$ turned around so that they are forced to walk backwards - is compared to a "silent litany" (Inferno 20.7-9):

e vidi gente per lo vallon tondo venir, tacendo e lagrimando, al passo che fanno le letane in questo mondo.
When through the valley's circling I descried people coming hushed and weeping, at the pace followed by procession [litanies] in this world.

As Ciabattoni informs us, "letane are properly the supplications and chanted litanies intoned by the priests and the congregation during slow-paced processions" (Ciabattoni 2010, 80). In a further ditch of the same circle, the hypocrites walk very slowly under the weight of their lead-filled cloaks, similar to a procession, while their capes are compared to the shiny mantles of the monks of Cluny. They trample Caiaphas, crucified on the floor, a fallen version of the Crucifixion. These are 
parodies on liturgical events, just as Nimrod's "psalm" is a parody on a liturgical chant. Ciabattoni claims that,

"through the frequent quotations of, and hints at, liturgical songs, Dante constructs the first musical cantica as a musical parody of the other two. (...) In Dante's time certain parts of the sacred scriptures were commonly understood as inherently musical. Everybody, for example, would think of a hymn or a Psalm in conjunction with its manner of intonation." (Ciabattoni 2010, 44).

Also the silent litanies are clearly a parody on real litanies, where there would be chant accompanying the processions.

Before encountering the babbling Nimrod, there is the sound of a horn, much louder than Roland's Olifant ${ }^{292}$ when he was in danger. It might be the only musical note sounding in all Inferno, it is too loud so it is unpleasant to the ear. Furthermore, the horn can only produce one note, which makes it unsuitable for melodic use. ${ }^{293}$ Ciabattoni is correct in pointing out that the only real musical instrument in the whole Commedia precedes Nimrod's incomprehensible "psalm" (Ciabattoni 2010, $83)$.

Parodic "instruments" are found in the passage of the devils, for example in Inferno 21.136-139:

Per l'argine sinistro volta dienno; ma prima avea ciascun la lingua stretta coi denti, verso lor duca, per cenno; ed elli avea del cul fatto trombetta.
They turned around upon the left-face bank, But first each pressed a tongue between his teeth To sound a signal to their commandant,

And with his ass he blew a bugle-blast.

The trombetta that the devil Malacoda blows with his ass as a kind of signal, according to Ciabattoni, is the degraded imitation of the military trumpet, while cenno means a raspberry. ${ }^{294}$ (Ciabattoni 2010, 51) Indeed, in the subsequent canto (Inferno 22.1-12), the walking devils are compared to a chaotic and bizarre army:

Io vidi già cavalier muover campo, I have seen horsemen in the past break camp,

292 As narrated in the late $11^{\text {th }}$ century Chanson de Roland and mentioned by Dante in this part of his Commedia. 293 Mentioned by Ciabattoni (Ciabattoni 2010, 83). Commentary by Claudio Bacciagaluppi, "La 'dolce sinfonia di paradiso': Le funzioni delle immagini musicali nella Commedia", Rivista di studi danteschi 2, no 2 (July-December 2002), p.279-333, at. p.298.

294 The "rude" sound made by pushing one's tongue outside the lips and blowing air out of the mouth. 


\begin{tabular}{|l|l|}
\hline $\begin{array}{l}\text { e cominciare stormo e far lor mostra, } \\
\text { e talvolta partir per loro scampo; }\end{array}$ & $\begin{array}{l}\text { muster their army and open assault, } \\
\text { and at times even beat a quick retreat; }\end{array}$ \\
$\begin{array}{l}\text { corridor vidi per la terra vostra, } \\
\text { o Aretini, e vidi gir gualdane, } \\
\text { fedir torneamenti e correr giostra; }\end{array}$ & $\begin{array}{l}\text { I have seen outriders roam your countryside, } \\
\text { o Aretines, and seen raiding-parties charge, } \\
\text { tournaments clash and jousters galloping, }\end{array}$ \\
$\begin{array}{l}\text { quando con trombe, e quando con campane, } \\
\text { con tamburi e con cenni di castella, } \\
\text { e con cose nostrali e con istrane; }\end{array}$ & $\begin{array}{l}\text { some called by trumpets and some by bells, } \\
\text { by drumrolls and by flares from castle-walls, } \\
\text { by homemade and imported instruments; }\end{array}$ \\
$\begin{array}{l}\text { né già con sì diversa cennamella } \\
\text { cavalier vidi muover né pedoni, } \\
\text { né nave a segno di terra o di stella. }\end{array}$ & $\begin{array}{l}\text { but never before have I seen horsemen, } \\
\text { footsoldiers, or ships that sail by sighting } \\
\text { of land or stars move to a stranger bugle. }\end{array}$ \\
\hline
\end{tabular}

Ciabattoni comments on the specific symbolism of this scene that

"the entire scene employs musical and military elements to build a perfect mockery of a regular army: trumpets, bells, local and foreign customs, even the strangest behaviours to which the poet testified on real battle grounds are not as ridiculous as the team of improvised soldiers. And they will indeed prove incapable of discharging a soldier's most elementary duty when they disobey orders and start a fight among themselves", which will be in 22.91-151 (Ciabattoni 2010, 51-52).

Ciabattoni also points out that "the devil's trumpet and raspberries (...), most improper 'wind' instruments are a hybrid of musica artificialis and musica naturalis, as theorized by tenth-century chronicler Regino of Prüm" (Ciabattoni 2010, 53). Musica artificialis, instrumental music, represent the devises created by human beings instead of the voice, given by Divinity. The "bugle-blast" by Malacoda is a perverted and inverted version of the human voice, since it is produced by the human body. "A perverted quality of both types, artificialis and naturalis, this 'music' is the reversal of the breath employed in real singing and stands in sharp contrast to the melodious vocal harmony of heavenly music" (Ciabattoni 2010, 53). Thus the music of the devils is the opposite of the music of God, as suggested by Dante specialist Gian Sarolli. ${ }^{295}$

In the ditch of the fraudulent speakers, the voices within the flames are sputtered out when they

295 Mentioned in Ciabattoni 2010, 53: Saroll, G.R., "Musical Symbolism: Inferno XXI, 136-139, Exemplum of musica Diaboli versus musica Dei.” In Sarolli, Prolegomena alla 'Divina Commedia.', 363-380. (Florence: Olschki, 1971). 
wish to speak. They have difficulty expressing themselves, because their voices have to pass the obstacle of the flame itself. The sound of the flame is perfectly noticeable in the onomatopoetic speech of one of these souls, characterized by the repetitive use of the consonant " $s$ " (Inferno 27.5866):

\begin{tabular}{|l|l|}
\hline $\begin{array}{l}\text { Poscia che 'l foco alquanto ebbe rugghiato } \\
\text { al modo suo, l'aguta punta mosse }\end{array}$ & $\begin{array}{l}\text { After the flame had roared on for some time } \\
\text { in its unique way, the pointed tip swayed } \\
\text { di qua, di là, e poi diè cotal fiato: }\end{array}$ \\
$\begin{array}{l}\text { "S'i' credesse che mia risposta fosse } \\
\text { a persona che mai tornasse al mondo, } \\
\text { questa fiamma staria sanza più scosse; }\end{array}$ & $\begin{array}{l}\text { "If I thought that my answer was to someone } \\
\text { who might one day return up to the world, } \\
\text { this flame would never cease its flickering; }\end{array}$ \\
$\begin{array}{l}\text { ma però che già mai di questo fondo } \\
\text { non tornò vivo alcun, s'i' odo il vero, } \\
\text { sanza tema d'infamia ti rispondo. }\end{array}$ & $\begin{array}{l}\text { however, since no one ever turned back, alive, } \\
\text { from this abys - should what I hear be true - } \\
\text { undaunted by infamy, I answer you. }\end{array}$ \\
\hline
\end{tabular}

In the circle of the falsifiers resides Master Adam, distorted physically by dropsy which gives his body the shape of a lute (Inferno 33.49-51):

Io vidi un, fatto a guisa di lëuto, pur ch'elli avesse avuta l'anguinaia tronca da l'altro che l'uomo ha forcuto.
I saw one sinner there shaped like a lute if only he'd been cut off below the belt at the groin where the body forks in two.

The "false Sinon" (a pun on si/non, yes/no) lying next to him $^{296}$, reacts to this adjective given to him by punching Master Adam in the stomach. Surprisingly, the lute-shaped Master Adam sounds like a drum. The lute, a popular instrument with its origens in the Arabic culture as the $u d$, appears here as a corrupt version of the cithara, mentioned by Dante in his Paradise. The cithara, psaltery, lyre and zithern were all stringed instruments which were not always clearly easy to distinguish. As Ciabattoni writes, "given the salvific associations of the cithara with David's psaltery, the lute fittingly plays its comic dark-world counterpart." (Ciabattoni 2010, 61). Although instruments in general were considered worldly and man-made objects, with a certain danger of mundane seduction through wordless music, the cithara was an exception due to the following section from Samuel 16:

296 “l'altr'è 'l falso Sinon greco di Troia: / per febbre aguta gittan tanto leppo" ("The other is false Sinon, the Greek from Troy. Their burning fever makes their bodies reek.”), Inferno 30.98-99 


\begin{tabular}{|l|l|}
\hline $\begin{array}{l}6 \text { "iubeat dominus noster et servi tui qui coram } \\
\text { te sunt quaerant hominem scientem psallere } \\
\text { cithara ut quando arripuerit te spiritus Dei } \\
\text { malus psallat manu sua et levius feras" }\end{array}$ & $\begin{array}{l}16 \text { "Let our lord command his servants here to } \\
\text { search for someone who can play the harp } \\
\text { [cithara]. He will play when the evil spirit from } \\
\text { God comes upon you, and you will feel better." }\end{array}$ \\
$\begin{array}{l}\text { Saul tollebat David citharam et percutiebat } \\
\text { manu sua et refocilabatur Saul et levius habebat } \\
\text { recedebat enim ab eo spiritus malus }\end{array}$ & $\begin{array}{l}23 \text { Whenever the spirit from God came upon } \\
\text { Saul, David would take his harp [cithara] and } \\
\text { play. Then relief would come to Saul; he would } \\
\text { feel better, and the evil spirit would leave him. }\end{array}$ \\
\hline
\end{tabular}

The word cithara has been translated into harp ${ }^{297}$ or lyre ${ }^{298}$. In the Spanish Sagradas Escrituras of 1569 it is called arpa (harp) as well, but in the 1649 Italian version of Giovanni Diodati it surprisingly appears as cetera (cithara). In the 1907 Riveduta version it is arpa. We can assume that at a certain moment in history the term "cithara" fell out of use because the instrument itself was not known anymore. Ciabattoni uses the term "psaltery", and although this is not correct, he does mention the very similar historical descriptions of psaltery and cithara (Ciabattoni 2010, 60). The cithara existed in similar forms, both with or without neck, so a general confusion between the instruments is not surprising. Nevertheless, even if the lute could resemble the cithara, their symbolic meaning were very different.

The fact that the lute-body of Master Adam sounds like a drum when he is hit in the stomach, is an accentuation of the perverted musical symbolism. The drum is a martial instrument, and as Ciabattoni points out,
"it is no accident that a martial instrument underscores the fight. The dull sound is synaesthetically rendered by the rhymes tamburo / duro, all dark vowel, and, above all, by the word oscuro, in which the signifier itself expresses the acoustic obscurity of the signified. Thus, Master Adam's body undergoes a change in the rhetorical unfolding of the canto, and what was initially presented as resembling a lute gives out a much duller drum sound instead" (Ciabattoni 2010, 65-66).

The symbolic representation of falsifying money is double: "Not only is Adam's body altered to look like a lute, as repayment for altering coins, but its sound is altered as well! When hit, his body
297 For example in the New International Version and generally in American, Spanish, German, Dutch, French versions.
298 For example in the English Standard Version and generally in all British versions.


resonates like something else, the way a counterfeit coin would ring differently from an authentic one." (Ciabattoni 2010, 66).

Master Adam and Sinon continue arguing, to which Edoardo Sanguineti has attributed an "amoebaean character"299. Amoebaean singing was a kind of competition between two singers in Greek antiquity. One singer would choose a topic of his own election, and the other singer would contest with either an opposed view, a similar topic or additive information, trying to surpass his opponent. ${ }^{300}$ Virgil's Eclogue VII gives a good example of this genre. ${ }^{301}$

As we saw, Lucifer himself is a representation of the defeat of Evil. Additionally, he is a parody on the Crucifixion:

"Lucifer's threefold nature, his being stuck and planted at the middle of the earth, even his winged form with a disproportionate three-headed body, are the constitutive elements of a tragic parody of the Crucifixion as well as a parody of the Trinity. His tears, streaming down his three chins, and the dribble mixed with blood are a perpetual, distorted version of the weeping and bleeding of Christ on the cross. Lucifer's three mouths are busy chewing three sinners, and are therefore unfit for singing. Thus the hymn, here evoked in a merely verbal disguise, marks the frustrated desire for the liturgical songs that will appear in the following cantica. (...) Thus, the last of the songs of Hell (...) [the spoken Vexilla regis prodeunt Inferni,] crowns the underworld's unholy racket with a reversal of the kingly song of the Holy Cross (...)" (Ciabattoni 2010, 84-85).

Once having climbed Lucifer's body - the fact that he serves as an object for Dante's ascent is another aspect of his defeat - Dante and Virgil come in a subterranean cave. Ciabattoni suggests that there is a connection of this last step before Purgatory with the wall of fire which separates Purgatory from the Terrestrial Paradise: "the sound of a stream, not the sight of it, guides the pilgrim out of the tunnel that connects the Inferno to the shores of Purgatory, the same way as, in Purgatorio XXVII, the song of the guardian angel of Eden will lead a blinded Dante through the thick wall of flames into the Earthly Paradise." (Ciabattoni 2010, 46-47).

299 Mentioned in Ciabattoni 2010, 66: Sanguineti commented this during the convention called "Dante Studies in the Nineteen Hundreds", held in Turin on 18 May 2004.

300 Pearce, J.B., "Theocritus and Oral Tradition”, Oral Tradition, 8/1 (1993): 59-86, p.63, http://journal.oraltradition.org/files/articles/8i/4_pearce.pdf [accessed 11-8 2015]

301 As suggested by Ciabattoni (Ciabattoni 2010, 66). An English version can be found here: http://classics.mit.edu/Virgil/eclogue.7.vii.html [accessed 11-8 2015] 
In the poetic words of Sarolli,

"even the lowest words or ugliest lines, not ugly anymore but tragic, are indispensable and even central to the gigantic structure of the Divina Commedia, since they clearly belong to the Inferno as musica diabolica, to the tragic and disharmonic anti-Trinitarian kingdom of Lucifer, where everything is antithesis, reversed and opposed (...) to the Triune God." 302 


\title{
4.2 Purgatory
}

While in Inferno the sonorous disorder and the musical absence are both an expression of the souls' state and their punishment, music in Purgatory serves as an aid in cleansing or even healing the soul. This idea is a very ancient one and was already expressed in a Christian framework by St. Augustine:

\begin{abstract}
"With an appropriate voice and harmony in our hearts we seek a physician so as to be healed. Our salvation is not within our power, though it is within our power to wound ourselves. Our soul alone is capable of sinning, but we must pray for God's healing hand to cure the wound of sin. Whence it is said, in another Psalm: 'I said, Lord, be merciful unto me: heal my soul; for I have sinned against thee."303
\end{abstract}

Ciabattoni comments on St. Augustine's expression "the sick invokes the physician" 304 that the healer is God and the psalms are a cry for help." He adds that "Augustine proposes the Psalter as a way of treating the soul's sickness by invoking the help of Christ, because he associates healing with the Psalms as the most musical texts in the Bible." (Ciabattoni 2010, 113).

As we discussed at the beginning of this chapter, Ciabattoni's hypothesis is that all music sung by the penitent souls is monophonical, while polyphony is only reserved for celebration. This makes sense if we think of the rhythmically more complex Parisian polyphony: on feast days the plainchant melody was to be sung slower, more solemnly. There, the note-to-note practice changed into an extended plainchant melody with faster notes above it. The improvised note-to-note organum, however, was a kind of "polyphony" that was not specially saved for feast days. We can imagine that suffering souls in Purgatory do not take the trouble to improvise a second voice, since they are completely focussed on their pain or discomfort. Ciabattoni points out exactly this aspect, basing himself on the conclusions by Gianni Vinciguerra: "Here in Purgatory there is no time or place for joyful celebrations; all the musical effort is aimed at purging sins and repairing the dead poetry and the dead songs of Hell" (Ciabattoni 2010, 93). The churchgoers would not improvise organum, only some of the clerics. Ciabattoni's conclusion is that polyphony only exists in Paradise.

However, there are some moments in Purgatory that would allow for organum. All terraces are preceded by an angel at the gate, singing one of the Beatitudes monophonically. Sometimes, it is not the angel who sings, but "voices". They are angelic and according to Ciabattoni's reasoning, they

303 Psalm 40:5, Augustine, Sermones ad populum, classis prima: Sermo XX.1 (PL, vol. 38, col. 137), as found in Ciabattoni 2010, 112.

304 "Clamat aeger ad medicum" 
would thus sing in polyphony. Another possibility would be Ante-Purgatory, where the souls have plenty of time because they have to wait years before they can start their purging. On the other hand, the music in Paradise is clearly described by Dante as a kind of perfect music that he has difficulty to comprehend. We imagine that it is the musica mundana that is only comprehensible by the souls and angels that reside there. How would this music sound to them? As mere polyphony? There are thus various reasons that show the gaps of Ciabattoni's hypothesis. One could even state the opposite: going from polyphony to monophony because the Divine unity is translated into sound.

Beside the healing chants sung by the penitent souls and the angelic music in the Terrestrial Paradise, Ciabattoni indicates a third type of music present in Purgatory: the deceptive songs. In this category are the song of Casella on the words of a poem by Dante, "Amor che ne la menta mi ragiona" (Purgatory 2.112), and the siren's song in Dante's dream (Purgatory 19.19). Both of these will not appear in Incipit, because they are the protagonist's own personal experiences, thus we will not discuss them here. For the healing chants, specialist in Italian literature Erminia Ardissino identified two groups of chants. The first are penitential ones from the Easter liturgy and the others have a rejoicing character. ${ }^{305}$ Many of the penitential chants are psalms, which according to Ciabattoni represent "a particularly fitting aesthetic choice since the Book of Psalms has an inherently penitential connotation." (Ciabattoni 2010, 110).

Tthe Beatitudes that mark the transitions between the different terraces are the eight declarations of blessedness spoken by Jesus at the beginning of the Sermon on the Mount (Matthew 5). They describe the ideals of the teachings of Jesus in the form of a number of short phrases beginning with the word Beati, "Blessed are...". They illustrate those who have learnt the teachings of Jesus and their rewards. In Matthew 5 there are nine Beatitudes but Augustine acknowledged only eight of them and the scholastics just seven. Dante expert Chiavacci Leonardi suggests that Dante followed the scholastic ordering, but omitted Beati mites ("Blessed are the meek") so that he could split in two Beati qui esuriunt et sitiunt ("Blessed are those who hunger and thirst after justice"). ${ }^{306}$

Ciabattoni claims that "the musical and liturgical facets of the Beatitudes are less easy to evaluate than might be expected. All we know is that three of them were employed in the communion antiphon on All Saints' Day. There was probably no tune specifically associated with any of them,

305 Mentioned in Ciabattoni 2010, 110: Ardissino, E., "I canti liturgici nel Purgatorio dantesco", Dante Studies 108 (1990): 39-65.

306 Mentioned in Ciabattoni 2010, 138: Chiavacci Leonardi, A.M., "Le beatitudini e la struttura poetica del Purgatorio", Giornale storico della letteratura italiana 161, no.513 (1984): 1-29. 
but they must have been chanted on a psalm tone." ${ }^{307}$ Historical manuscripts suggest that Ciabattoni might be wrong: all six Beatitudes can be found in existing $14^{\text {th }}$ century chant books as antiphon or responsory verse.

Now that the general aspects of both the "healing" chants and the angelic chants have been discussed, all musical references of Purgatory in their chronological order of appearance shall be reviewed.

At the shore of Purgatory Dante observes over a hundred souls arriving in a boat, singing monophonically the psalm In exitu israel (Purgatory 2.46-48):

\begin{tabular}{|l|l}
\hline 'In exitu Isräel de Aegypto' \\
$\begin{array}{l}\text { cantavan tutti insieme ad una voce } \\
\text { con quanto di quel salmo è poscia scripto. }\end{array}$ & $\begin{array}{l}\text { 'From exile Israel came out of Egypt' } \\
\text { they all intoned together with one voice } \\
\text { right through the psalm as it had been } \\
\text { composed. }\end{array}$ \\
\hline
\end{tabular}

Basing himself on an article by Charles Singleton, Ciabattoni writes that "the penitential phase on the shore of Ante-Purgatory represents the transition from the age of darkness to the age of light. In fact, 'In exitu Israel de Aegypto' was sung in the Proprium for the Nativity, announcing the liberation of humankind from the captivity of sin." (Ciabattoni 2010, 116). Indeed, the commentaries by Prof. Mazzotta in his Yale lectures already showed us that the theme of exile is essential to Dante: not only his own exile but in its generalization into man's exile from Heaven. Furthermore, this psalm symbolizes their journey toward Paradise (Mazzotta 2004, Lecture 10). These souls sing psalm 113 (114) ${ }^{308}$ ad una voce (monophonically) and right through the psalm, without any antiphonal treatment of the chant.

In Purgatory 5.22-27 the Miserere sung by the late repentants is psalm 50 (51):

\begin{tabular}{|l|l|}
\hline $\begin{array}{l}\text { E 'ntanto per la costa di traverso } \\
\text { venivan genti innanzi a noi un poco, } \\
\text { cantando 'Miserere' a verso a verso. }\end{array}$ & $\begin{array}{l}\text { And meantime all across the mountainside } \\
\text { came people slightly ahead of us, singing } \\
\text { the Miserere, verse answering to verse. }\end{array}$ \\
\hline
\end{tabular}

$307 \mathrm{He}$ adds a bibliographic source to compare his findings with: Birge-Vitz, E., "The Liturgy and Vernacular Literature", in The Liturgy of the Medieval Church, ed. Heffernan, T. and Matter, A. (Kalamazoo: TEAMS, 2001), 551618 , at p.592

308 The first psalm number refers to the number in the Vulgate, the number in between brackets indicates versions that do not base themselves on the Vulgate but on the Hebrew version and thus have a slightly different numbering. 
Quando s'accorser ch'i' non dava loco

When they had noticed that the rays of light

per lo mio corpo al trapassar d'i raggi,

did not pass through my body, they soon

mutar lor canto in un "oh!" lungo e roco;

changed

their chant into a hoarse and drawn-out "Oh!"

Just like Dante in the first canto, they are asking for forgiveness:

Miserere mei deus

et a delicto meo mundame

quia tibi soli peccavi.
Have mercy on me, God

and cleanse me from my delict

because to you alone I have sinned.

Supposedly, they sing this during all the years they have to wait for their real cleansing. Ciabattoni directs our attention on verso a verso, asking himself if this means "line by line", suggested by the early commentators Benvenuto (ca.1320-1388) and the Anonymous Florentine (14 ${ }^{\text {th }}$ century), or "verse by verse" as Ottimo thought (first half of $14^{\text {th }}$ century). If it is the last case, then Dante refers to responsorial chant, in which two groups are singing the verses in alternatim, each group one verse. Ciabattoni comments that "other chants that had many verses were also performed this way, for the sake of variation and inclusion. (...) The most frequent practice was just two half-choirs singing monophonically in alternation." (Ciabattoni 2010, 117). He also informs us that there was a practice in which the congregation or one half of the choir sang a verse and then the soloists sang the next verse in polyphony : "responsories, in thirteenth-century ordinals, are often mentioned among the sections containing polyphony; see, por example, the ordinal of S. Maria Patavensis" (Ciabattoni 2010, 117 footnote). Ciabattoni sees the souls here as newcomers and concludes that therefore they can only sing monophonically, but this is a assumption that is not necessarily true: the souls have to wait the number of years they waited until they repented, which was almost the duration of their entire life. Surely, one can learn to sing organum in those years and embellish the praise to God; moreover, some of them could have been soloists when they were still alive.

As we saw in chapter 3, the Valley of Princes is a locus amoenus, a beautiful place such as a garden or a green valley which makes the visitor feel safe. The souls here have to wait for their cleansing but their "waiting room" is beautiful and pleasant. The Salve Regina is sung, apparently not by all souls (Purgatory 7.82-4):

'Salve, Regina' in sul verde e 'n su' fiori quindi seder cantando anime vidi,
'Salve Regina' - I saw the souls who sang this hymn seated on the flowering green: 
He then describes the souls: one sits highest and refuses to sing (lines 91-93), with a soul next to him comforting him. There is a snub-nosed one (nasetto) "thick in talk" (stretto a consiglio) with another (103). One beats his chest (106). There is also one that cradles his cheek in the palm of his hand while he sighs (107-108). Then there is a strong-built soul who chimes his singing ( $s^{\prime} a c c o r d a$, cantando) with the big-nosed shade (maschio naso, "male nose") (112-113). Finally, there is one gazing upward (115), who sits with them on lower ground. He depicts nine souls of which at least 3 to 5 are actually singing. We do not know if others are singing too (which would be probable) or if they are simply further away. Ciabattoni writes about this group of souls that "the general impression is of a Babel of different performances, in which each soul is singing on his own, or (...) in small groups. The 'Salve, Regina' prayer was adopted by the Cistercians as a daily processional chant as early as 1218 , and, shortly after, it became the ending hymn of Compline." (Ciabattoni 2010, 118). Its text is perfectly suitable to the situation, including both "exiled children of Eve" and "this valley of tears":

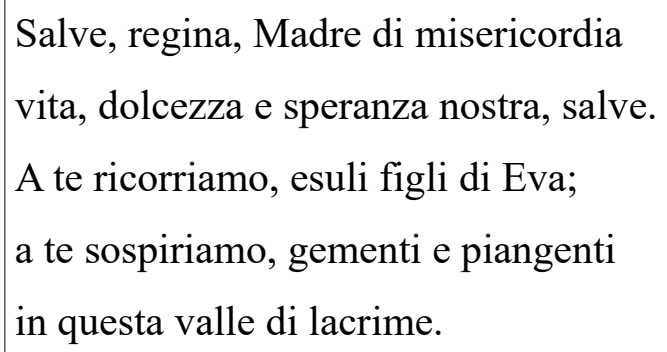

In this valley, every night just before sunset, the same song precedes a kind of angelic representation in which two angels come to chase away a serpent. The chant is the ancient hymn $T e$ lucis ante, a chant to ask for God's protection against the dangers of the night:

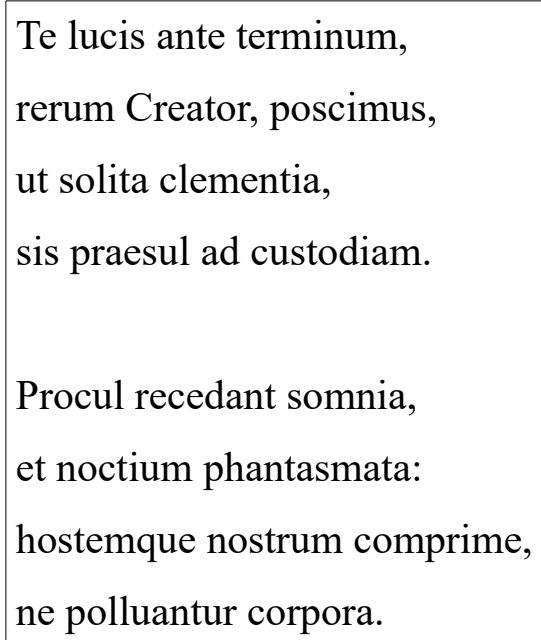

To thee before the close of day,

Creator of the world, we pray

That, with thy wonted favour, thou

Wouldst be our guard and keeper now.

From all ill dreams defend our sight,

From fears and terrors of the night;

Withhold from us our ghostly foe,

That spot of sin we may not know. 
Praesta, Pater omnipotens,

per Iesum Christum Dominum,

qui tecum in perpetuum

regnat cum Sancto Spiritu.
O Father, that we ask be done,

Through Jesus Christ, thine only Son,

Who, with the Holy Ghost and thee,

Doth live and reign eternally.

Amen.

Amen.

First it is sung by a solo singer who stands up, asks for attention with some gestures, and begins to sing as if he were leading a kind of liturgical service. Then, the choir joins him after his solo (Purgatory 8.8-18):

\section{(...) una de l'alme}

surta, che l'ascoltar chiedea con mano.

Ella giunse e levò ambo le palme, ficcando li occhi verso l'orïente, come dicesse a Dio: 'D'altro non calme'.

'Te lucis ante' sì devotamente le uscìo di bocca e con sì dolci note, che fece me a me uscir di mente;

e l'altre poi dolcemente e devote seguitar lei per tutto l'inno intero, avendo li occhi a le superne rote.
(...) one of the souls there who had stood up and gestured to be heard.

He folded his hands in prayer and lifted them, with his eyes fastened on the east, as if saying to God, "I care for nothing else".

"To You before the light is done" — devoutly came from his lips with such melodious tones that it made me step straight out of myself.

Then the rest with sweetness and devotion harmonized with him through the whole hymn, fixing their eyes on the spheres of heaven.

Ciabattoni writes about this scene: "in a reconciling climate that reminds us of the meeting with the Wise Men of limbo, their courteous conversation is intermingled with scenes from a full-fledged liturgical drama. The action of the play takes its direction from the inherently visual, theatrical nature of the gestures, as was custom of the time in many areas of Italy. Historian of liturgy Antonio Lovato notes how a 'strong dramatization of liturgy' characterized the celebrations of an 'ecclestiastical community which continuously prays through singing, accompanied by definite stage-direction.' " (Ciabattoni 2010, 119). Ciabattoni follows the commentarist Jacopo della Lana 
(1324-28) who interprets the word seguitar as "to follow", and he concludes that they sing in monophony. However, as we already stated, simple organum was not seen as an entirely polyphonic genre, it was rather still seen as singing the same song, only with adding a colour to the sound. In such a ceremony meant to ask for God'snocturnal protection, repeated at every sunset, one could imagine the use of organum just as well as monophony.

Precisely after this hymn and representation, Dante has his first dream. While he is asleep, Saint Lucia takes him up and put him in front of the entrance gate of Purgatory proper. When Dante enters through the entrance gate, a Te Deum sounds in a peculiar manner (Purgatory 9.133-145):

\begin{tabular}{|c|c|}
\hline $\begin{array}{l}\text { E quando fuor ne' cardini distorti } \\
\text { li spigoli di quella regge sacra, } \\
\text { che di metallo son sonanti e forti, }\end{array}$ & $\begin{array}{l}\text { And when the pivots of that holy entrance, } \\
\text { which were round rods of ringing and strong steel, } \\
\text { turned within the sockets of their hinges, }\end{array}$ \\
\hline $\begin{array}{l}\text { non rugghiò sì né si mostrò sì acra } \\
\text { Tarpëa, come tolto le fu il buono } \\
\text { Metello, per che poi rimase macra. }\end{array}$ & $\begin{array}{l}\text { they made a louder and more resonant clangor } \\
\text { than Tarpeia did, when the good Metellus } \\
\text { was snatched from it, the treasure gone forever. }\end{array}$ \\
\hline $\begin{array}{l}\text { Io mi rivolsi attento al primo tuono, } \\
\text { e 'Te Deum laudamus' mi parea } \\
\text { udire in voce mista al dolce suono. }\end{array}$ & $\begin{array}{l}\text { I turned around at the first thundering sound } \\
\text { and thought I heard "Te Deum: Praise to God" } \\
\text { chanted by voice(s) mixed with that sweet strain. }\end{array}$ \\
\hline $\begin{array}{l}\text { Tale imagine a punto mi rendea } \\
\text { ciò ch'io udiva, qual prender si suole } \\
\text { quando a cantar con organi si stea; }\end{array}$ & $\begin{array}{l}\text { The notes I heard conveyed to me the same } \\
\text { exact impression which we have at times } \\
\text { when people sing in concert with con organi }\end{array}$ \\
\hline ch'or sì or no s'intendon le parole. & and now and then we just make out the words. \\
\hline
\end{tabular}

The Te Deum is an early hymn of praise to God. It will return in Paradise 24 sung by "the saintly court on high". From the text in Purgatory there are some translations, like the one of James Finn Cotter who translates cantar con organi as "with an organ". However, the expression is more ambiguous than it seems. Ciabattoni indicates its three possible interpretations. The first is singing organum, which is a simple improvised polyphony. The second is singing it in alternatim with an organ. The third is "that some songs have sections of voice singing above the sound of the opening door, which to the pilgrim resembles the sound of an organ." (Ciabattoni 2010, 124). He does not 
believe that the first option is the correct one because

"everywhere else [Dante] describes polyphony as sweet and harmonious, so how can this thundering blast accompanied by screeches be interpreted as polyphonic? Moreover, (...) there is no explicit indication here that allows us to read this song as polyphonic." (Ciabattoni 2010, 124).

It is true that in organum the words would have been perfectly understandable. The incertitude about the meaning of Dante's words is amplified by the knowledge that organs were not used yet in service as in later centuries and they would certainly not be played simultaneously with the singers as an accompaniment. The organetto, a small hand-organ, was a much more common instrument which was played instead of a singer and could be used in alternatim with singers. Interestingly, Ciabattoni reports the discovery in 1931 by A.M. Vicentini of the first church organ brought to the Florence Church of Ss. Annunziata in 1299 (Ciabattoni 2010, 124 footnote), just in Dante's time. This raises several questions about its construction, sound and use. Ciabattoni states that "organmaking methods in Europe remained primitive in many ways until the fifteenth century, and the sound of these instruments was more disconcerting than uplifting." (Ciabattoni 2010, 124). He adds that some very large organs did exist, with pipes made of copper, "which were built for the purpose of grandiosity." We are not sure if Dante knew such an organ, if the Ss. Annunziata was such an organ and if he visited the church, but Ciabattoni has a point when he writes that the sound of the screeching hinges is reminiscent of these organs. It is not even necessary for Dante to have known these organs: he could have read descriptions of the early organs. The St. Gall monk Notker Balbulus (ca.840-887) described an organ that was a gift to Charlemagne by a Byzantine delegation in 812:

\footnotetext{
"An outstanding organum of the musicians which with vessels cast in bronze and bellows of bullhide blowing magnificently through the bronze pipes, matched the very roar of the crash of thunder, the chattering of the lyre, or the sweetness of bells" ${ }^{309}$
}

So even if these organs were not a usual practice in liturgical services, such a thundering organ would suit a Divine gate very well. Ciabattoni therefore proposes the option of voices together with the organ, not because it was a habitual practice or a practice at all, but because of its symbolical nature (Ciabattoni 2010, 127). All this information, however, does not take away the possibility that the voices sing in polyphony, except if it is only one voice. The expression in voce mista al dolce suono does not give us certainty about this issue. This is actually the only chant in the Commedia 
considered by Margaret Bent as an example of polyphony, but she adds that "it is unclear whether this refers to vocal polyphony, to organ or to other instruments, but the fact that the words are obscured may suggest some kind of elaboration" (Bent 2004, 162). Ciabattoni adds to his argument an interesting detail: "it is not inconceivable that a harsh sound is oxymoronically perceived as sweet: the creaking of the gate opens the way of suffering but also of hope" (Ciabattoni 2010, 123).

Not all prayers in Purgatory seem to be sung, an exception might be the following one (Purgatory 21.1-24):

"O Padre nostro, che ne' cieli stai, non circunscritto, ma per più amore ch'ai primi effetti di là sù tu hai,

laudato sia 'l tuo nome e '1 tuo valore da ogne creatura, com'è degno di render grazie al tuo dolce vapore.

Vegna ver' noi la pace del tuo regno, ché noi ad essa non potem da noi, s'ella non vien, con tutto nostro ingegno.

Come del suo voler li angeli tuoi fan sacrificio a te, cantando osanna, così facciano li uomini de' suoi.

Dà oggi a noi la cotidiana manna, sanza la qual per questo aspro diserto a retro va chi più di gir s'affanna.

E come noi lo mal ch'avem sofferto perdoniamo a ciascuno, e tu perdona benigno, e non guardar lo nostro merto.

Nostra virtù che di legger s'adona, non spermentar con l'antico avversaro,
"Our Father, who art in heaven, not bound there, but dwelling in it for the greater love

Thou bearest toward thy firstborn works on high,

hallowed be thy name and be thy worthiness through every creature, as it is most fitting to thank thee for the sweet breath of thy wisdom.

Thy kingdom come to us in peacefulness, because we cannot reach it by ourselves, unless it come, for all our striving effort.

And as the angels do thy will in heaven by sacrificing theirs, singing hosanna, so let the men on earth do with their wills.

Give us this day our daily manna, since without it, through this bitter wilderness he retreats who tries hardest to advance.

And as we pardon all for the trespasses that we have suffered, so in loving kindness forgive us: do not judge by our deserving.

Our strength so easily fails: lead us not into temptation through our ancient foe, 
ma libera da lui che sì la sprona.

Quest'ultima preghiera, segnor caro, già non si fa per noi, ché non bisogna, ma per color che dietro a noi restaro". but deliver us from the evil he provokes.

This last petition, dearest Lord, we make not for our sake, since now we have no need, but for those people who remain behind us."

It is an altered version of the Pater Noster, Our Father, adapted to these souls. The proud souls, weighed down under their stones, seem to say the prayer rather than singing it. This is logical because the Pater Noster was always said or murmured but not sung. Only at one other point in the Commedia there is such a spoken prayer: in Paradise 33.1-21 by Saint Bernard to Mary for Dante's beatific vision. We can imagine the proud souls lowered by the immense weight of the stones and only being able to murmur the prayer.

At the gate to the second terrace, the first Beatitude sounds (Purgatory 12.109-111):

Noi volgendo ivi le nostre persone,

'Beati pauperes spiritu!' voci

cantaron sì, che nol diria sermone.
When we turned ourselves to that direction, "Blessed are the poor in spirit" voices sang more sweetly than words ever could describe.

It is not the angel who sings Beati pauperes spiritu, but voci, "voices"; they could either sing monophonically or polyphonically. The text of the Beatitude is a comment on the proud:

Beati pauperes spiritu

quoniam ipsorum est regnum celorum.
Blessed are the poor in spirit

because theirs is the kingdom of Heaven.

On the terrace of the envious, there are flying bodiless voices crying out examples of gentleness to the envious, who have their eyelids sewn and cannot see. The souls themselves cry out - it is not sure if they sing - what seems to be the Litany of All Saints (Purgatory 13.49-51):

E poi che fummo un poco più avanti, udia gridar: 'Maria òra per noi':

gridar 'Michele' e 'Pietro' e 'Tutti santi'.
And when we went straight forward a short space, I heard cried out " Mary, pray for us!": cried out "Michael" and "Peter" and "All saints."

The melody of the Litany is very simple and repetitive, so it could well have been sung. The Litany is very long, invoking practically all holy beings. The selection of its text that is mentioned in the 
Commedia is shown below:

\begin{tabular}{|l|l|}
\hline (...) & $(\ldots)$ \\
V. Sancta Maria. & V. Holy Mary. \\
R. Ora pro nobis. & R. Pray for us. \\
V. Sancta Dei Genitrix. & V. Holy Mother of God. \\
R. Ora pro nobis. & R. Pray for us. \\
$\begin{array}{l}\text { V. Sancta Virgo vírginum. } \\
\text { R. Ora pro nobis. }\end{array}$ & V. Holy Virgin of virgins. \\
$\begin{array}{l}\text { V. Sancte Michael. } \\
\text { R. Ora pro nobis. }\end{array}$ & V. Pray for us. \\
(...) & R. Prayt Michael. \\
V. Sancte Petre. & (...) \\
R. Ora pro nobis. & V. Saint Peter. \\
(...) & R. Pray for us. \\
V. Omnes Sancti et Sanctæ Dei. & (...) \\
R. Intercédite pro nobis. & V. All Holy Saints. \\
\hline
\end{tabular}

The "V" stands for the verse sung by the soloist, while the " $\mathrm{R}$ " represents the responsory sung by the choir or congregation. We can well imagine that these souls have all day long to recite the entire text; Dante the pilgrim is just passing by so he only captures a part of the text. It seems that these souls are not reciting continuously, since they must be interrupted regularly by the disembodied voices that come hurtling again. After the fragment of the Litany, these ghostly voices are shouting examples of envy in a more aggressive manner.

When Dante crosses the gate to the next terrace, the second Beatitude sounds (Purgatory 15.34-39):

Poi giunti fummo a l'angel benedetto, con lieta voce disse: "Intrate quinci
When we had come up to the blessed angel, he said with a glad voice, "Enter here 
ad un scaleo vie men che li altri eretto".

to stairs that are less steep than were the others."

Noi montavam, già partiti di linci,

We left him there and we then climbed beyond,

e 'Beati misericordes!' fue

cantato retro, e 'Godi tu che vinci!'. until "Blessed are the merciful" rang out in song behind us, and "Conqueror, rejoice!"

"Beati misericordes" is sung behind Dante, and "Godi tu che vinci!" The latter probably refers to Gaudete et exultate ("rejoice and be glad"), the last phrase of the Beatitudes. Musical sources ${ }^{310}$ give almost the exact melody for both and it is logical that the voices sing one unified or similar melody rather than two completely different ones. The two texts are shown below:

\begin{tabular}{|l|l|}
\hline $\begin{array}{l}\text { Beati misericordes } \\
\text { quonim ipsi misericordiam consequentur }\end{array}$ & $\begin{array}{l}\text { Blessed are the merciful } \\
\text { for they shall obtain mercy }\end{array}$ \\
$(\ldots)$ & $(\ldots)$ \\
Gaudete et exultate & $\begin{array}{l}\text { Rejoice, and be exceeding glad } \\
\text { quoniam merces vestra copiosa est in caelis }\end{array}$ \\
\hline
\end{tabular}

The terrace of the envious is thus concluded with the Beatitude of the merciful followed by this expression which previews the reward of Paradise.

On the terrace of wrath, in the cloud of anger where the souls cannot see anything, they sing perfectly together Agnus Dei (Purgatory 16.16-21):

\begin{tabular}{|l|l|}
\hline $\begin{array}{l}\text { Io sentia voci, e ciascuna pareva } \\
\text { pregar per pace e per misericordia } \\
\text { l'Agnel di Dio che le peccata leva. }\end{array}$ & $\begin{array}{l}\text { Voices I heard and each one seemed to pray } \\
\text { the Lamb of God who takes away our sins } \\
\text { to grant his mercy to us and his peace. }\end{array}$ \\
Pur 'Agnus Dei' eran le loro essordia; & "Agnus Dei" their response began, \\
\hline
\end{tabular}

310 To give two very different examples, both an early $12^{\text {th }}$ century French manuscript as well as a late $16^{\text {th }}$ century German manuscripts contain the same melody for the Gaudete et exultate: Antiphonarium ad usum Sancti Mauri Fossatensis, 1101-1125 (France), http://gallica.bnf.fr/ark:/12148/btv1b6000531z/f404.image and DK-Kk 3449 8o XII, Date: 1580 c., Provenance: Augsburg, http://www.uniregensburg.de/Fakultaeten/phil_Fak_I/Musikwissenschaft/cantus/microfilm/copenhagen/vol12/images/210.jpg, while yet again $14^{\text {th }}$ century manuscripts give the same melody for Beati misericordes, like the $14^{\text {th }}$ century antiphoner in two volumes (29 and 30) from the Abbey of Sankt Lambrecht (Steiermark, Austria) or the 14thcentury antiphoner from the monastery of Einsiedeln, Switzerland. 
una parola in tutte era e un modo,

sì che parea tra esse ogne concordia. as if one word and measure were in all

so that full harmony appeared among them.

Ciabattoni interprets their way of singing as monophonic: "As Sapegno points out, 'modo' refers to the way they sing and therefore means 'intonazione', 'pitch' or 'intonation'. Hence every soul is singing the same words and the same melody." (Ciabattoni 2010, 129). We have already seen in the article of Margaret Bent that "concordia" does not mean polyphony, but rather "being harmoniously together" without any further specification. It does not tell anything about performance but, if combined with una parola in tutte era e un modo, it does seem to suggest monophony. The Agnus $D e i$, whose placement at this terrace "is a perfect example of the law of symbolic retribution", contrasts the sin of these wrathful by focussing on the lamb, symbol of humility and peacefulness (Ciabattoni 2010, 129):

Agnus Dei, qui tollis peccata mundi, miserere nobis. $(2 \mathrm{x})$

Agnus Dei, qui tollis peccata mundi, dona nobis pacem.
Lamb of God, you who take away the sins of the world, have mercy on us.

Lamb of God, you who take away the sins of the world, give us peace.

To reinforce this opposite of wrath, the angel at the gate to the next terrace "says" the Beati pacifici (Purgatory 17.67-69):

senti' mi presso quasi un muover d'ala e ventarmi nel viso e dir: 'Beati

pacifici, che son sanz'ira mala!'. near me I felt the brush as of a wing fanning my face, and I heard said, 'Blessed are the peacemakers, those free of wicked wrath.'

He declaims the following text:

Beati pacifici
quoniam filii Dei vocabuntur.

Although the word is "dire" (speak) and not "cantare" (sing), we read at the beginning of this chapter that both were used interchangeably for either singing, cantillating ${ }^{311}$ or speaking. It would be strange if this were the only Beatitude to be recited with a speaking voice. However, if it is sung, should the end of the text be changed? After all, this angel adds "those free of wicked wrath" to the 
first part of the Beatitude. We can imagine a Divine reign where total freedom of melodies and texts form part of a ludic theology $y^{312}$. We could even think of a Divine trope $\mathrm{e}^{313}$, where the angel inserts new text with its own melody (che son sanz'ira mala) behind the words Beati pacifici in order to continue with quoniam filli Dei vocabuntur afterwards.

At the end of the terrace of the slothful, who are running around and shouting examples of religious vigor in tears, the next angel "affirms" Beati qui lugent (Purgatory 19.49-51):

\begin{tabular}{|l|l|}
\hline $\begin{array}{l}\text { Mosse le penne poi e ventilonne, } \\
\text { 'Qui lugent'affermando esser beati, } \\
\text { ch'avran di consolar l'anime donne. }\end{array}$ & $\begin{array}{l}\text { Then he moved his feathers and he fanned us } \\
\text { as he affirmed that "they who mourn" are blessed } \\
\text { for they shall have their souls richly consoled. }\end{array}$ \\
\hline
\end{tabular}

The text of this Beatitude is:

Beati qui lugent

quoniam ipsi consolabuntur.
Blessed are those who mourn

for they will be comforted (consoled).

Although mourning and sloth apparently do not match, making this Beatitude seem a bit awkward in this moment, they correlate in two possible ways. The first was suggested by Federigo Tollemache based on Thomas Aquinas' definition of accidia (sloth) as tristitia de spirituali bono ("sadness over one's spiritual health") (Summa theologiae, IIa-IIae q.35 a.2). The second was pointed out by Nicola Fosca basing himself on Augustinian and Thomistic explanations of the Beatitude, where knowledge and weeping are associated with each other. Thomas Aquinas wrote that "omnia peccata quae ex ignorantia proveniunt, possunt reduci ad acediam" ("all the sins that are due to ignorance can be reduced to sloth") (Summa theologiae, Ia-IIae q.84 a.4). Augustine had stated that those who obtain knowledge, realize that the things and actions they thought to be good were actually a sin, and they mourn over it, which is a first step towards salvation (Augustine, De sermone Domini in monte, I.iv.11). The slothful were once ignorant but now they comprehend, so their mourning signifies their liberation from sloth and finally their salvation. (Ciabattoni 2010, 142).

The avaricious and prodigals on the next terrace murmur their psalm due to their posture (Purgatory 19.70-75):

312 Prof. Mazzotta speaks about the idea of the ludic theology (Mazzotta 2004, Lecture 12).

313 The insertion of new text on a melisma, or even of both text and melody, in a chant. 
Com'io nel quinto giro fui dischiuso,

vidi gente per esso che piangea,

giacendo a terra tutta volta in giuso.

'Adhaesit pavimento anima mea'

sentia dir lor con sì alti sospiri,

che la parola a pena s'intendea.
When I stepped out into the fifth circle,

I witnessed people on it who were weeping,

lying on the ground with faces downward.

'My soul cleaves to the dust,'

I heard them say with sighs so deep and gasping

that scarcely could the words be understood. ${ }^{314}$

These souls "are forced to stare at the ground as a punishment for not lifting their eyes to lofty matters during their lives on earth"( Ciabattoni 2010, 131). The psalm phrase they sing has associations with the tendency of the avaricious and prodigals to cling to earth and its worldly goods (Psalm 118 (119): 25):

Adhaesit pavimento anima mea;

My soul clings to the ground;

vivifica me secundum verbum tuum.

revive me according to thy word.

Dante witnesses the moment that one of the souls is liberated in order to go to Paradise. The mountain trembles and "Gloria in excelsis Deo!" is sung by all souls (Purgatory 20.136-138):

'Glorïa in excelsis' tutti 'Deo' dicean, per quel ch'io da' vicin compresi, onde intender lo grido si poteo.
"Glory to God in the highest" they all cried, by what I understood from those close by, where the crying could be comprehended.

Again the word "dicere" is used for what could be crying ("lo grido"). It could be loud singing or cantillating. It is the purging souls themselves who are pronouncing these words, apparently interrupting their purgation.

At the gate there is an angel singing a Beatitude, but not wholly (Purgatory 22.1-6):

Già era l'angel dietro a noi rimaso, l'angel che n'avea vòlti al sesto giro, avendomi dal viso un colpo raso;
By now the angel had been left behind us, the angel who'd turned us to the sixth circle, having erased a letter from my face,

314 I have followed the translation of Ciabattoni since the James Finn Cotter translation is not as precise (Ciabattoni 2010, 131). 
e quei c' hanno a giustizia lor disiro detto n'avea beati, e le sue voci con 'sitiunt', sanz'altro, ciò forniro. and he'd told us that those who crave for justice are blessed, and his words had accomplished this with "they that thirst" and no more of the text.

Sitiunt, thirst, forms part of the Beatitude of hunger and thirst for justice:

Beati qui esuriunt et sitiunt quoniam ipsi saturabuntur.
Blessed are those who hunger and thirst for justice for they will be filled.

The section of esuriunt, hunger, is sung after the terrace of the gluttonous. Ciabattoni connects the sitiunt part of the Beatitude to the avaricious because "thirst for justice is an exemplary virtue that the angel points to for those who must unshackle themselves from the thirst for gold and earthly wealth. (...) It is for justice that we should thirst" (Ciabattoni 2010, 143). The musical difficulty is that the word esuriunt comes before sitiunt in the Beatitude. A solution is simply skipping the esuriunt and going directly to sitiunt. If Divinity can add a trope, it can also move flexibly through its own musical and textual material.

The gluttonous sing while crying (Purgatory 23.10-12):

Ed ecco piangere e cantar s'udìe 'Labïa mëa, Domine' per modo tal, che diletto e doglia parturìe.
And suddenly in tears and song we heard "Open my lips, O Lord," sung in such tones that it gave birth to gladness and to grief.

Labia mea is a phrase in psalm 50 (51). The mouths of these souls were used as a instrument for their own gluttony, whether literal or metaphorical for gluttonous poetry as Prof. Mazzotta proposes (Mazzotta 2004, Lecture 14), but now they ask for it to be a means of praise to God:

Domine labia mea aperies et os meum adnuntiabit laudem tua
Lord, open my lips

and my mouth will declare your praise

The angel at the gate can now complete the Beatitude by quoting the first section of the Beatitude: "Beati qui esuriunt" (Purgatory 24.151-154): 
E senti' dir: "Beati cui alluma

tanto di grazia, che l'amor del gusto

nel petto lor troppo disir non fuma,

esurïendo sempre quanto è giusto!".
And I heard say: "Blessed are they whom grace enlightens so, the love of taste enkindles no overindulgent longings in their breasts,

hungering always only after justice!"

At the terrace of lust, "Summae Deus Clementiae" is sung by the souls within the fire (Purgatory 25.121-123):

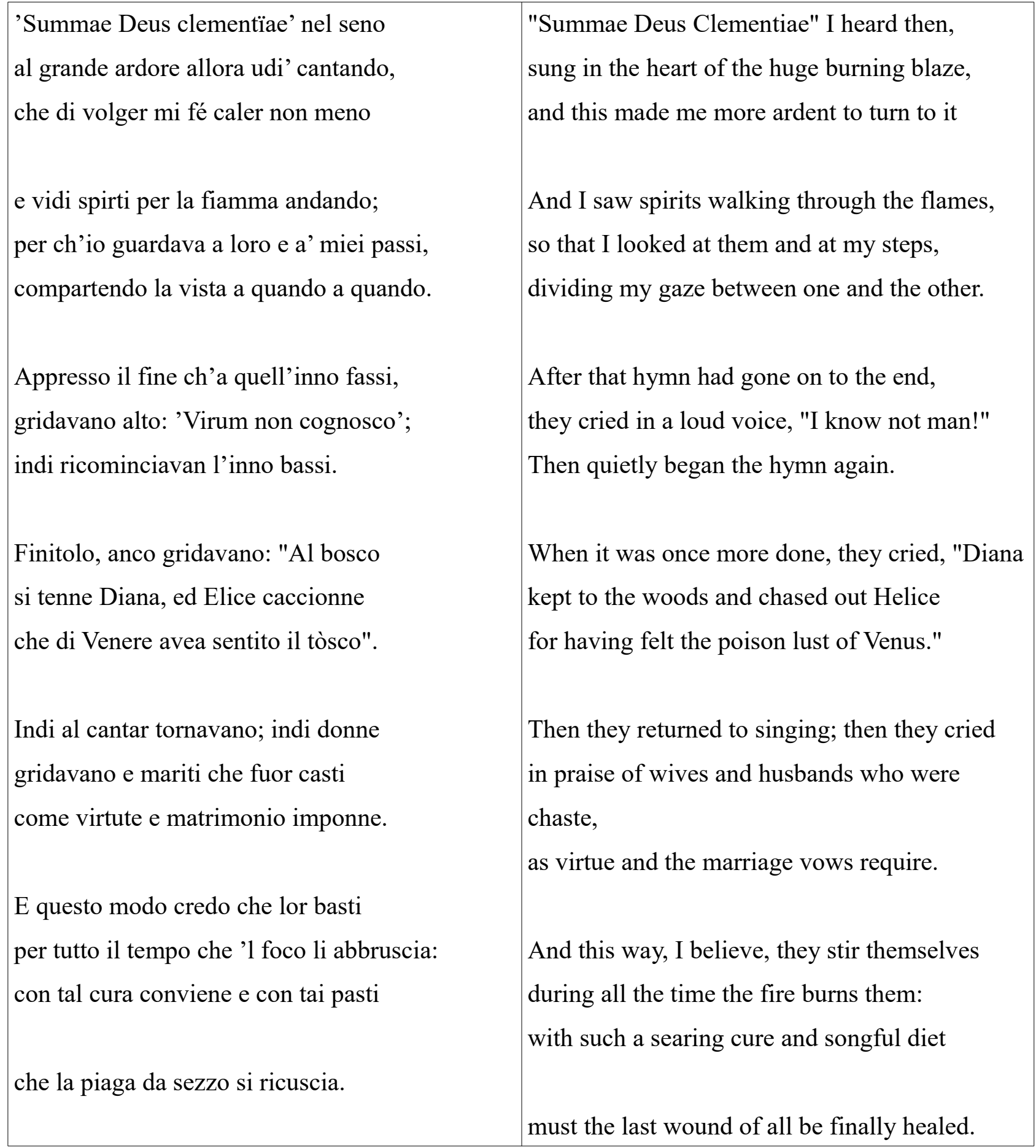


The text of Summae Deus clementiae, as Ciabattoni informs us, was modified in 1632 (Ciabattoni 2010, 135). The Solesmes standard version of 1983 uses the text from before 1632:

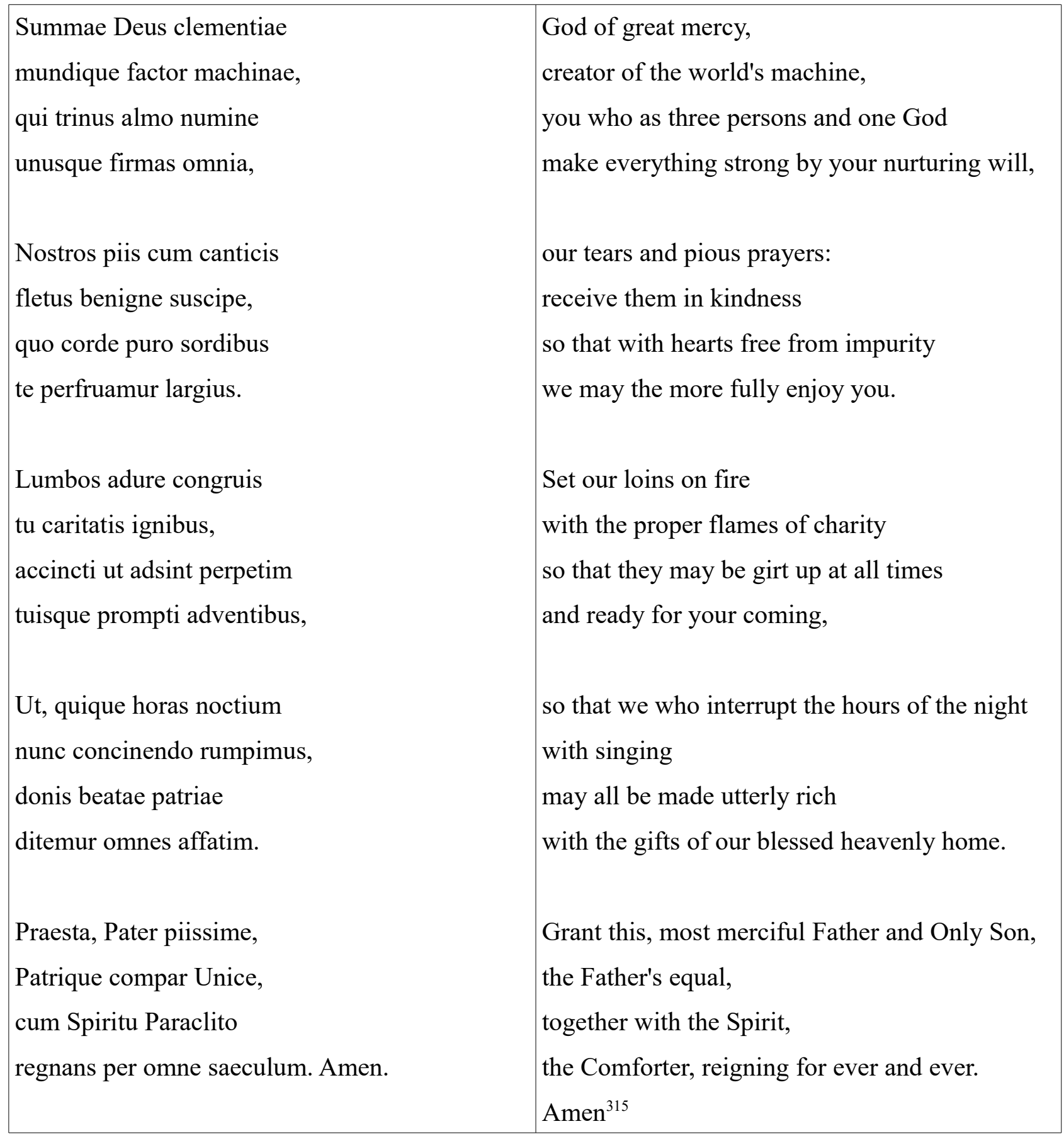

The third paragraph is perfectly suitable to these souls. The words they shout in between are representing three levels of laws according to Teodolinda Barolini, expert in Late-Medieval Italian literature: "Mary and Diana are examples of a 'divine law', Pasiphaë of a 'bestial law', while 'human 
law' is upheld by the chaste husbands and wives who preserve marriage and society." ${ }^{" 316}$ Ciabattoni claims that a monophonic performance is suggested by the text, because shouts and cried-out words are alternated with the singing and they sing all at once with the same intensity. (Ciabattoni 2010, 137). Although this does not exclude the possibility of organum, a monophonical performance indeed seems more plausable.

At the last stage, just before the curtain of fire separating Purgatory from the Terrestrial Paradise, the angel sings the last Beatitude for all the souls that must cross the fire, including Dante (Purgatory 27.7-9):

Fuor de la fiamma stava in su la riva, e cantava 'Beati mundo corde!' He stood upon the bank, outside the flames, in voce assai più che la nostra viva. and sang aloud, "Blessed are the clean of heart!" in a voice far more alive than ours.

The text of this Beatitude is:

Beati mundo corde
quoniam ipsi deum videbunt. Blessed are the pure in heart because they will see God.

Only those that have a clean heart, purified from the sin of lust, can cross the fire and enter the Terrestrial Paradise. Once in the fire, the eyes will not see anything and the voice of an angel will be the only guidance to the other side. The song that Dante hears when he is in the fire is Venite, benedicti Patris mei (Purgatory 27.55-60):

\begin{tabular}{|l|l|}
\hline $\begin{array}{l}\text { Guidavaci una voce che cantava } \\
\text { di là; e noi, attenti pur a lei, } \\
\text { venimmo fuor là ove si montava. }\end{array}$ & $\begin{array}{l}\text { A singing voice, beyond, was guiding us; } \\
\text { and we, while listening all the time to it, } \\
\text { came outside at the point which starts to climb. }\end{array}$ \\
'Venite, benedicti Patris mei', \\
$\begin{array}{l}\text { sonò dentro a un lume che lì era, } \\
\text { tal che mi vinse e guardar nol potei. }\end{array}$ & $\begin{array}{l}\text { "Come, you who are blessed of my Father," } \\
\text { resounded from within a light, so bright } \\
\text { it overcame me, and I could not look. }\end{array}$ \\
\hline
\end{tabular}

The text as it appears in Matthew 25:34 of Venite, benedicti Patris mei is as follows:

316 Barolini, Teodolinda. "Purgatorio 26 : Human Sexuality." Commento Baroliniano, Digital Dante. Center for Digital Research and Scholarship. New York, NY: Columbia University Libraries, 2014.

http://digitaldante.columbia.edu/dante/divine-comedy/purgatorio/purgatorio-26/ [accessed 3-8 2015] 


\begin{tabular}{|l|l|}
\hline Venite benedicti Patris mei & $\begin{array}{l}\text { Come, ye blessed of my Father, } \\
\text { possidete paratum vobis regnum } \\
\text { a constitutione mundi }\end{array}$ \\
\hline
\end{tabular}

Ciabattoni tells us that this text actually appears in a mosaic in the Florence Baptistry (Ciabattoni 2010, 144). However, all musical settings beginning with Venite benedicti Patri mei paraphrase the original text:

\begin{tabular}{|l|l|}
\hline Venite benedicti Patris mei & $\begin{array}{l}\text { Come, ye blessed of my Father, } \\
\text { inherit the kingdom } \\
\text { percipite regnum }\end{array}$ \\
quod vobis paratum est ab origine mundi & prepared for you since the foundation of the world \\
\hline
\end{tabular}

The only place where we have encountered such a text is in St. Augustine's sermon 77 on the New Testament, commenting on the meaning of these words. ${ }^{317}$ It seems that Augustine knew an alternate translation from the original Greek, which must have been well known if it became the text of the chant. The only historical chants with the exact words of the version of Matthew 25:34 as we know it are those that start with the words of Matthew 25:1, not with Venite itself.

When Dante has crossed the fire, he arrives to a beautiful forest which has its own musicality (Purgatory 28.7-18):

Un'aura dolce, sanza mutamento
avere in sé, mi feria per la fronte
non di più colpo che soave vento;
per cui le fronde, tremolando, pronte
tutte quante piegavano a la parte
u' la prim'ombra gitta il santo monte;
non però dal loro esser dritto sparte
tanto, che li augelletti per le cime
lasciasser d'operare ogne lor arte;

A sweetly scented breeze, which did not vary within itself, struck me across the forehead with no more force than would a gentle wind;

the branches quivering at its touch all bent spontaneously in the direction where the holy mountain casts its shadow first;

yet the trees weren't so swayed from standing straight

that little birds among the topmost boughs

317 Augustinus, Sermones, 11, 77 - SERMO LXXVII. De verbis Evangelii Matthaei, cap. XXV, 34-43, Venite, benedicti Patris, etc. . http://www.monumenta.ch/latein/text.php?tabelle=Augustinus\&rumpfid=Augustinus, \%20Sermones, $\% 2011, \% 20 \% 20 \% 2077 \& n f=1$ [accessed 3-8 2015] 
ma con piena letizia l'ore prime, cantando, ricevieno intra le foglie, che tenevan bordone a le sue rime had to leave off the practice of their art,

but with their song they welcomed, full of joy, the early morning hours among the leaves which kept up an accompaniment to their rhymes

This rustling is one of the quotations of Virgil's writings before he disappears, which is the phrase illice, sic leni crepitabat brattea vento ("The leaves there rustled to the light breeze", Aeneas VI.209). Ciabattoni describes the connection between Virgil's and Dante's writings: "at this point in Virgil's poem, Aeneas is preparing to descend into Hell and meet his long lost wife Creusa. The pilgrim of the Commedia is, therefore, in a similarly liminal position, about to cross the threshold that will reveal to him a dead lover" (Ciabattoni 2010, 146 footnote). Ciabattoni adds that "the allegorical scenes that follow celebrate a liturgy whose musical component is integrated with the textual, the visual, and the gestural" (Ciabattoni 2010, 146).

When Dante meets Matelda, a beautiful young woman who seems to be representing the innocence of mankind before the fall, she is dancing and singing on the other side of the river (Purgatory 28.79-81). When she is close enough, she tells him the following:

\begin{tabular}{|l|l|}
\hline $\begin{array}{l}\text { maravigliando tienvi alcun sospetto; } \\
\text { ma luce rende il salmo Delectasti, } \\
\text { che puote disnebbiar vostro intelletto. }\end{array}$ & $\begin{array}{l}\text { "A doubt of some kind keeps you wondering, } \\
\text { but the psalm 'You made me glad' sheds light } \\
\text { that can clear up the mist that clouds your minds. }\end{array}$ \\
\hline
\end{tabular}

The psalm she refers to is the first part of psalm 91 (92):

\begin{tabular}{|l|l|}
\hline $\begin{array}{l}\text { Bonum est confiteri Domino et psallere nomini } \\
\text { tuo Altissime }\end{array}$ & $\begin{array}{l}\text { It is good to praise the Lord and make music to } \\
\text { your name, O Most High } \\
\text { ad adnuntiandum mane misericordiam tuam et } \\
\text { veritatem tuam per noctem } \\
\text { in decacordo psalterio cum cantico in cithara } \\
\text { to proclaim your love in the morning and your } \\
\text { faithfulness at night, } \\
\text { to the music of the ten-stringed lyre (psaltery) } \\
\text { and the melody of the harp (cithara) }\end{array}$ \\
$\begin{array}{l}\text { quia delectasti me Domine in factura tua et in } \\
\text { operibus manuum tuarum exultabo }\end{array}$ & $\begin{array}{l}\text { For you make me glad by your deeds, O LORD; } \\
\text { I sing for joy at the works of your hands. }\end{array}$ \\
\hline
\end{tabular}


Then she continues her jubilant singing (Purgatory 29.1-3):

Cantando come donna innamorata, continüò col fin di sue parole:

'Beati quorum tecta sunt peccata!'.
Singing like a woman who is in love, she - after finishing her speech — continued,

"Blessed are they whose sins are covered over!"

The text she is singing is a blend of the two original phrases in Psalm 31:

Beati quorum remissae sunt iniquitates:

Blessed are they whose iniquities are forgiven:

et quorum tecta sunt peccata. and whose sins be covered.

From this point on there will be a Divine procession introducing Beatrice to Dante. The enchanting music they sing precedes their colourful sight, but only when Dante discerns the candles as the banners of the procession (literally called as such - insegne - in Purgatory 29.154), he discerns the text: "the voices sang the word Osanna' " (Purgatory 29.51). This could refer to the HosannaOsanna filio david: benedictus qui venit in nomine domine, rex israel, osanna in excelsis ("Hosanna to the son of David: Blessed is he who cometh in the name of Lord, the King of Israel, Hosanna in the Highest"). Although it could also refer to a Sanctus, which contains the expression Osanna in excelsis, a Hosanna is more plausible because Dante does not mention the word sanctus.

The next song soon afterwards (Purgatory 29.85-87) seems to be referring to the Ave Maria:

Tutti cantavan: "Benedicta tue ne le figlie d'Adamo, e benedette sieno in etterno le bellezze tue!".
They all were singing, "Blessed are you among the daughters of Adam, and blessed be your beauties throughout all eternity!"

As we can observe in the text of the Ave Maria, only the first part matches the original chant:

Ave Maria, gratia plena,

Dominus tecum.

Benedicta tu in mulieribus, et benedictus Fructus ventris tui, Iesus. Sancta Maria, Mater Dei, ora pro nobis peccatoribus, nunc et in hora mortis nostrae. Amen.
Hail Mary, full of grace,

the Lord is with thee.

Blessed art thou amongst women, and blessed is the fruit of thy womb, Jesus.

Holy Mary, Mother of God, pray for us sinners, now and at the hour of our death. Amen. 
There is a thunderclap in Purgatory 29.152, the only one in the whole Commedia besides the blast in Inferno 4.1 when Dante regained conscience in Limbo. This time the thunderclap functions as a signal for the procession to stop. If we add Dante's definition of the candles as banners and of the procession being a divine army, we could even associate it with a military order to stop. They all turn to the chariot carrying Beatrice and one of them sings Veni sponsa de Libano ("Come, my spouse, from Libanon") three times, followed by the others. All the songs by the procession are for the grand annunciation of Dante's meeting with Beatrice.

After Beatrice's harsh reprimand at Dante's tears when Virgil has disappeared, the angels sing straightway In te, Domine, speravi until the words pedes meos (Purgatory 30.83). They do not sing any further because the next words in the chant text are miserere mei, and Dante expert Robert Hollander states that mercy is not necessary here anymore because Dante is rewarded for his hope $^{318}$. These words derive from Psalm 30:

\begin{tabular}{|c|c|}
\hline $\begin{array}{l}\text { in te domine speravi; non confundar in } \\
\text { aeternum in iustitia tua liberame }\end{array}$ & $\begin{array}{l}\text { In you, O Lord, I hoped; let me not be confounded } \\
\text { into eternity, liberate me in your justice }\end{array}$ \\
\hline $\begin{array}{l}\text { inclina ad me aurem tuam adcelera ut eruas me } \\
\text { esto mihi in Deum protectorem et in domum } \\
\text { refugii ut salvum me facias }\end{array}$ & $\begin{array}{l}\text { Turn your ear to me, come quickly to my rescue; } \\
\text { be my rock of refuge, a strong fortress to save me. }\end{array}$ \\
\hline $\begin{array}{l}\text { quoniam fortitudo mea et refugium meum es } \\
\text { tu et propter nomen tuum deduces me et } \\
\text { enutries me }\end{array}$ & $\begin{array}{l}\text { Since you are my rock and my fortress, for the } \\
\text { sake of your name lead and guide me. }\end{array}$ \\
\hline $\begin{array}{l}\text { educes me de laqueo hoc quem absconderunt } \\
\text { mihi quoniam tu es protector meus }\end{array}$ & $\begin{array}{l}\text { Free me from the trap that is set for me, for you } \\
\text { are my refuge. }\end{array}$ \\
\hline $\begin{array}{l}\text { in manus tuas commendabo spiritum meum } \\
\text { redemisti me Domine Deus veritatis }\end{array}$ & $\begin{array}{l}\text { Into your hands I commit my spirit; redeem me, O } \\
\text { Lord, the God of truth. }\end{array}$ \\
\hline $\begin{array}{l}\text { odisti observantes vanitates supervacue ego } \\
\text { autem in Domino speravi }\end{array}$ & $\begin{array}{l}\text { I hate those who cling to worthless idols; I trust in } \\
\text { the Lord. }\end{array}$ \\
\hline
\end{tabular}


exultabo et laetabor in misericordia tua quoniam respexisti humilitatem meam salvasti de necessitatibus animam meam

nec conclusisti me in manibus inimici statuisti in loco spatioso pedes meos
I will be glad and rejoice in your love, for you saw my affliction and knew the anguish of my soul.

You have not handed me over to the enemy but have set my feet in a spacious place.

The angels sing it as a kind of consoling Dante after Beatrice's hard words, and their singing has the desired effect on Dante (Purgatory 30.91-99):

così fui sanza lagrime e sospiri

anzi 'l cantar di quei che notan sempre

dietro a le note de li etterni giri;

ma poi che 'ntesi ne le dolci tempre lor compartire a me, par che se detto avesser: 'Donna, perché sì lo stempre?',

lo gel che m'era intorno al cor ristretto, spirito e acqua fessi, e con angoscia de la bocca e de li occhi uscì del petto. so was I senseless without tears or sighs before I heard the song of those whose notes are ever in tune with the eternal spheres;

but when I sensed how in their sweet harmonies they took my part, almost as if to say, "Lady, why do you shame him in this way?"

The ice that was packed tight around my heart turned into breath and water, and with anguish poured from my breast out of my mouth and eyes.

The word tempre has been translated here into "harmonies", but the literal translation would be "temperaments". Its etymologic origin is the Latin temperamentum, which means "proper mixture" (temperare means "to mix"). ${ }^{319}$ Literary scholar Leo Spitzer points out in his book Classical and Christian Ideas of World Harmony that many early Christian writers used the term temperare or its Italian version tempra to refer to something similar to the English word "chord". ${ }^{320}$ Again, the difficulty of interpreting Medieval definitions of musical harmony or monophony makes it problematic to formulate a precise modern definition. Perhaps temperare just referred to harmony in the sense of being together in balance, as Margaret Bent's article indicates. This section in the Commedia does not really specify with certainty if they sing monophonically or polyphonically, in spite of Spitzer's and Ciabattoni's conclusions about the word tempra.

319 Douglas Harper, http://www.etymonline.com/index.php?term=temperament [accessed 4-8 2015] 
Singing and dancing is something inherent to this heavenly procession appearing in the Terrestrial Paradise and it will actually be a characteristic of all souls in Dante's Paradise. In Purgatory 29.128 the dancing women are symbolizing the theological and cardinal virtues ${ }^{321}$, and dal canto di questa l'altre toglien l'andare e tarde e ratte ("from their leader's song the others took the measure fast and slow"). Also they dance in Purgatory 31.131-138: danzando al loro angelico caribo ("dancing to their angelic roundelay") while singing the petition to Beatrice to take away the veil covering her mouth: la sua canzone ("their song"). Indeed, Margaret Bent points out that canzone as a general term was understood as "song", although it could also mean a poetic genre (Bent 2004, 172).

The washing of Dante in the two Divine rivers (Lethe and Eunoe) is a ritual of purging so that Dante's soul will be pure enough to meet Beatrice and, under her guidance, continue his journey to Paradise (Purgatory 31.94-102):

\begin{tabular}{|l|l|}
\hline $\begin{array}{l}\text { Tratto m'avea nel fiume infin la gola, } \\
\text { e tirandosi me dietro sen giva } \\
\text { sovresso l'acqua lieve come scola. }\end{array}$ & $\begin{array}{l}\text { She plunged me in the stream up to my neck } \\
\text { and, pulling me behind her, passed along, } \\
\text { lighter than a shuttle, on the water. }\end{array}$ \\
$\begin{array}{l}\text { Quando fui presso a la beata riva, } \\
\text { 'Asperges me' sì dolcemente udissi, } \\
\text { che nol so rimembrar, non ch'io lo scriva }\end{array}$ & $\begin{array}{l}\text { When I had nearly reached the sacred shore, } \\
\text { I heard "Asperges me" so sweetly sung } \\
\text { that I cannot recall, much less describe it. }\end{array}$ \\
$\begin{array}{l}\text { La bella donna ne le braccia aprissi; } \\
\text { abbracciommi la testa e mi sommerse } \\
\text { ove convenne ch'io l'acqua inghiottissi. }\end{array}$ & $\begin{array}{l}\text { The lovely woman opened her arms wide; } \\
\text { she clasped me by the head and dipped me under, } \\
\text { so deep that I was forced to swallow water. }\end{array}$ \\
\hline
\end{tabular}

The ritual is thus accompanied by voices singing Asperges me, Psalm 50:9 (51:9), which is normally sung at baptism:

\begin{tabular}{|l|l|}
\hline $\begin{array}{l}\text { Asperges me, Domine, hyssopo et mundabor, } \\
\text { Lavabis me, et super nivem de albabor. }\end{array}$ & $\begin{array}{l}\text { Sprinkle me with hyssop, Lord, and I shall be } \\
\text { cleaned, } \\
\text { Miserere mei, Deus, secundum magnam }\end{array}$ \\
\hline
\end{tabular}

321 The three theological virtues are Faith, Hope and Charity. They were called as such from the Middle Ages on in order to distinguish them from the four cardinal virtues: Prudence, Justice, Temperance and Fortitude. While the cardinal virtues are important in both Classical and Medieval Christian writings, the theological virtues are specifically Christian, centred around the understanding of the Divine (Mazzotta 2008, Lecture 21) 
misericordiam tuam.

Pity me, Lord, according to thy great mercy.

Purgatory 32.16-24 gives us other military references for this heavenly procession, apart from the fragments where the candles are called "banners" and where the procession comes to a halt at a thunderclap:

\begin{tabular}{|l|l|}
\hline $\begin{array}{l}\text { vidi 'n sul braccio destro esser rivolto } \\
\text { lo glorïoso essercito, e tornarsi } \\
\text { col sole e con le sette fiamme al volto. }\end{array}$ & $\begin{array}{l}\text { I saw that the magnificent army there } \\
\text { had wheeled round to the right, and was now } \\
\text { turning } \\
\text { with faces toward the sun and the seven flames. }\end{array}$ \\
$\begin{array}{l}\text { Come sotto li scudi per salvarsi } \\
\text { volgesi schiera, e sé gira col segno, } \\
\text { prima che possa tutta in sé mutarsi; }\end{array}$ & $\begin{array}{l}\text { Just as a squadron, underneath their shields, } \\
\text { turn to retreat and, with the standard, wheel } \\
\text { around before the rest can swing about, }\end{array}$ \\
$\begin{array}{l}\text { quella milizia del celeste regno } \\
\text { che procedeva, tutta trapassonne } \\
\text { pria che piegasse il carro il primo legno. }\end{array}$ & $\begin{array}{l}\text { so the militia of the celestial realm } \\
\text { in the advanced guard passed in front of us } \\
\text { before the chariot circled on its pole. }\end{array}$ \\
\hline
\end{tabular}

This heavenly army moves to "an angelic tune" (Purgatory 32.31-33). We can compare it to the way the devils moved in Inferno 22.10-12: né già con sì diversa cennamella cavalier vidi muover né pedoni, né nave (...). ("But never before have I seen horsemen, footsoldiers, or ships (...) move to a stranger bugle.") Clearly, the heavenly procession and the diabolic march are the total opposite of each other.

\begin{tabular}{|l|l}
\hline $\begin{array}{l}\text { Sì passeggiando l'alta selva vòta, } \\
\text { colpa di quella ch'al serpente crese, } \\
\text { temprava i passi un'angelica nota. }\end{array}$ & $\begin{array}{l}\text { So pacing through the soaring forest, empty } \\
\text { because of her who trusted in the serpent, } \\
\text { our steps kept time to an angelic tune. }\end{array}$ \\
\hline
\end{tabular}

The heavenly creatures sing a hymn that exceeds Dante's mortal comprehension (Purgatory 32.6163):

\begin{tabular}{|l|l|}
\hline Io non lo 'ntesi, né qui non si canta & I did not understand — it is not sung \\
l'inno che quella gente allor cantaro, & on earth — the hymn that company sang there, \\
né la nota soffersi tutta quanta. & nor could I hear the music to the end.
\end{tabular}


This Divine music that is too perfect to be understood by mortal ears will reappear constantly in Paradise. As we pointed out in chapter 3, in Paradise Dante's body will be improved gradually so he will be able to understand the perfect music better than at this point in Purgatory.

A dramatization of the chariot symbolizing the corrupted Church follows and the procession sings Deus venerunt gentes in Purgatory 33.1-3, "one of invocation of righteous vengeance and contempt against those who have defiled the temple of God" (Ciabattoni 2010, 152):

\begin{tabular}{|l|l|}
\hline 'Deus, venerunt gentes', alternando & "O God, the Heathen Come," alternating \\
or tre or quattro dolce salmodia, & now three, now four, melodic psalmody, \\
le donne incominciaro, e lagrimando & the weeping women now began to sing \\
\hline
\end{tabular}

Ciabattoni suggests that this is a clear indication for singing in alternatim by the Theological Virtues on one side and the Carnal Virtues on the other. He adds that "the way this song is introduced connects back to the last song of Hell, the perverted version of 'Vexilla regis': not only do both songs appear in the very first line of the last canto of their canticas, but they were both designated for the liturgy of Good Friday" (Ciabattoni 2010, 152). 


\subsection{Paradise}

In her article on Dante's definitions of musical and poetical terms, Margaret Bent enumerates the fragments that might refer to polyphonic music:

"possible candidates include Paradiso VI.124, XXVIII.94, 118, XXVIII.4, and probably most explicitly in Paradiso VIII.16-18. For Paradiso XXIII John Stevens rightly warns against interpreting «la circulata melodia» as a polyphonic reference. E dicemo bello lo canto, quando le voci di quello, secondo debito de l'arte, sono intra sé rispondenti (Convivio I v. 13) could be construed as a reference to polyphonic voices." 322

The last sentence in English would be: "And song is beautiful, when its voices, according to the debt of the art, within themselves are responsive". These somewhat enigmatic words explain that when a melody is circulata, "circulated", it refers to an inner coherence rather than a polyphonic form.

Before discussing all heavenly musical references, we shall list the five references which are considered by Margaret Bent as possible candidates for polyphony. The first fragment Bent refers to is expressed by Justinian in the sphere of Mercury (Paradise 6.124-126):

Diverse voci fanno dolci note; così diversi scanni in nostra vita rendon dolce armonia tra queste rote.
Assorted voices make sweet melody: and so the varied ranking of our lives renders sweet harmony among these gyres.

Bent considers Paradise 8.16-18 as the most explicit reference to possible polyphony, but it is not about an actual sound in the Commedia, only a metaphor:

\begin{tabular}{|l|l|}
\hline $\begin{array}{l}\text { E come in fiamma favilla si vede, } \\
\text { e come in voce voce si discerne, } \\
\text { quand' una è ferma e altra va e riede, ... }\end{array}$ & $\begin{array}{l}\text { And as we see a spark within a flame } \\
\text { or as a voice sounds in a voice when one } \\
\text { holds steady while the other comes and goes, ... }\end{array}$ \\
\hline
\end{tabular}

Bent lists Paradise 28.4 as the fourth option in her article, but she has confirmed that this should be Paradise $12.4:^{323}$

322 Bent, M. "Songs without music in Dante's De vulgari eloquentia: cantio and related terms", in "Et facciam dolçi canti". Studi in onore di Agostino Ziino in occasione del suo $65^{\circ}$ compleanno. ed. Bianca Maria Antolini, Teresa M. Gialdroni, Annunziato Pugliese (Lucca: LIM- Libreria Italiana Musicale, 2004), vol. I, p. 161 footnote 4 323 Personal e-mail correspondance. 
e nel suo giro tutta non si volse

prima ch'un'altra di cerchio la chiuse,

e moto a moto e canto a canto colse
And it had not yet turned completely when

a second circle closed around the first,

motion matched with motion, song with song

In fact, a little more ahead, Dante refers to the effect of an echo in the singing (Paradise 12.13-15):

nascendo di quel d'entro quel di fori, a guisa del parlar di quella vaga

ch'amor consunse come sol vapori,
The outer band formed by the inner one: the way the words were of the wandering nymph whom love consumed as sunlight consumes vapors

Dante here mentions the nymph Echo, who wasted away in a mere voice because her beloved Narcissus did not love her back since he was in love with his own reflection (Metamorphoses III, 305-411).

The following fragment is where the entire choir of angels sings (Paradise 28.94-96):

Io sentiva osannar di coro in coro al punto fisso che li tiene a li ubi, e terrà sempre, ne' quai sempre fuoro.
From choir to choir I heard Hosanna sung to the Still Point that holds them fast forever to that one spot where they have always been.

Finally, in Paradise 28.118-120 Beatrice speaks about the angelical circles mentioning the same Hosanna:

perpetüalemente 'Osanna' sberna con tre melode, che suonano in tree ordini di letizia onde s'interna. unceasingly in birdsong sings Hosanna with triple melodies that warble from the three degrees of bliss that form the triad.

These are the sections in which Margaret Bent recognizes a possible reference to polyphony. She does stress, however, that the main polyphony that Dante might have had in mind was the simple improvised organum, not the rhythmically independent lines of what we understand as polyphony. Furthermore, as we mentioned before, Dante's descriptions are not technical indications of how the music must have sounded, but rather of the impact it had on him (Bent 2004, 164-166). It is important to keep this information in mind as we will discuss the musical references chronologically. 
Music in Paradise has a different function than in the other canticles. While in Inferno the lack of music served as a punishment, in Purgatory music was a means of purgation and healing. Now, in the representation of Paradise that the protagonist Dante is witnessing, music expresses the harmony among the souls that live in it, or in the words of Ciabattoni: "musical metaphors (...) act as a symbolic allegory of the reconciliation of the multiplicity of human nature in the unity of God". He adds that,

\begin{abstract}
"as an expressive means of low semanticity, music is employed to accompany the more mystical and mysterious steps of the pilgrim's ascent. Indeed the exact meaning of the songs' words becomes incomprehensible to the pilgrim, (...) [an] extraordinary spiritual experience, (...) who is incapable of recollecting it rationally or transcribing it." (Ciabattoni 2010, 155).
\end{abstract}

Nonetheless, the final moment of Dante in Paradise is seemingly a non-musical, visual experience or at least his memory has not preserved any musical aspect.

The music of Paradise is not comprehensible for mortal ears, a fact that Dante already prefaces at the end of Purgatory. Dante's body gradually becomes more perfect throughout Paradise, as Gragnolazzi has pointed out (see chapter 3). Dante uses the neologism trasumanar ("transhumanize", in Paradise 1.70) to describe this phenomenon. One of the new abilities of his perfected body is that it will allow him to comprehend most of the heavenly music. His physical progression is gradual and does not always reach the level of understanding of the music at every stage. For example, in the sphere of Saturn, Dante only hears silence because the singing would have been too much for his senses (Paradise 22.10).

Another important issue is Dante's adaptation of the theory of musica universalis, the Harmony of the Spheres (see chapter 1). The music of Paradise is musica mundana, which is about perfect proportions among the heavenly spheres. It was Cicero in his Dream of Scipio (Somnium scipionis, ca.51 BC) who had actually argued that each planet sounded in a different tone of the scale because of their different vibrations. He based himself upon the argument of Pythagoras that the planets made a humming sound. Cicero added the idea of one tone for each planet: the faster the planet, the higher the pitch of the note. This sound depended on the speed of their orbit. The Moon would sound lowest and the Fixed Stars the highest, while Mercury and Venus would sound at the same tone because they were thought to move at the same speed. The only problem with Cicero's argument was the fact that all planets together would sound as one great dissonance. The Roman writer Macrobius in his Commentary on the Dream of Scipius (early $5^{\text {th }}$ century) added Plato's 
mathematical conception of the world soul to Cicero's argument, stating that the notes had to be consonant together. In Plato's Timeo the planets are numbered by their distance from the Earth, taking as a measurement unity the distance between Earth and Moon, which would be 1. This results in the following number series: 1 (Moon), 2 (Sun), 3 (Mercury), 4 (Venus), 8 (Mars), 9 (Jupiter), 27 (Saturn). Philosopher Luc Brisson, specialized in Plato, comments that

\begin{abstract}
"there are three types of intervals that correspond to musical ratios, already known in Plato's time: the fourth 4:3, the fifth 3:2 and the whole tone 9:8. (...) Seen from a strictly musical point of view, the mathematical structure of the world soul would thus include 4 octaves, one fifth and one whole tone: $2: 1 \times 2: 1 \times 2: 1 \times 2: 1 \times 3: 2 \times 9: 8=27$. But it must be noted that Plato did not intend to apply the theory to the type of music that the celestial bodies could emit." 324
\end{abstract}

As Guy P. Raffa tells us, $12^{\text {th }}$ century Alan of Lille distinguishes the slow, low tones of the Moon (Anticlaudianus 4.347-55), the 'sweet and finer sound' of the Sun (4.386-88), the 'treble voice' of Venus (matched by Mercury's song [4.408-13]), the 'Siren of thundering Mars' (4.434-36), Jupiter's 'sweet song' (4.458-62), and the 'matured harmony' of Saturn's voice (4.478-81)." 325

Long before the Commentary by Macrobius, Aristotle had expressed severe critics on the theory of Plato, arguing that the idea of the planets emitting sound is impossible. In the first part of the Middle Ages, however, many of Aristotle's writings had not been conveyed. In early Medieval Europe ancient Greek was no longer studied, so only his Organon was known due to the translation into Latin by the $6^{\text {th }}$ century philosopher Boethius. Boethius had planned to translate all of his works into Latin, but his death sentence ended with his life at the age of 44 . In the $12^{\text {th }}$ and $13^{\text {th }}$ centuries Aristotle's works were introduced in Christian Europe through Arabic translations and because of a renewed study of the original Greek. It was only then that Aristotle's ideas began to enter European thinking. Dante had knowledge of both Platonic and Aristotelian ideas. In his Commedia, there is one reference to a strange new sound he hears at entering Paradise, which implies that, in a poetic way, he is referring to the Platonic idea of the Harmony of the Spheres. This is the only reference to the sound of orbiting planets; in general only the souls themselves and the angels are singing. There is even silence in the sphere of the contemplatives, which clearly contradicts the Platonic idea. Guy P. Raffa states that "Dante does not treat the celestial harmony systematically in the Paradiso, but he

324 "trois types d'intervalles correspondent à des rapports musicaux, déjà connus à l'époque de Platon : la quarte 4/3, la quinte $3 / 2$ et le ton $9 / 8$. (...) Considérée d'un point de vue strictement musical, la structure mathématique de l'Âme du monde comprendrait donc 4 octaves, une quinte et un ton : $2 / 1 \times 2 / 1 \times 2 / 1 \times 2 / 1 \times 3 / 2 \times 9 / 8=27$. Mais il faut bien remarquer que Platon n'a pas du tout l'intention de faire la théorie du type de musique que pourraient émettre les corps célestes". Plato, Timée/Critias (Garnier-Flammarion, 1996), p. 287

325 Guy P. Raffa, http://danteworlds.laits.utexas.edu/paradiso/07saturn.html\#harmony [accessed 4-8 2015] 
conceives of God as both the composer and conductor of the heavenly music (Par. 1.76-85)." ${ }^{326}$

When Dante just arrives in Paradise he is surprised by la novità del suono e 'l grande lume ("the strangeness of the sound and the bright light", Paradise 1.82) of the revolving planets, which is the only explicit Platonic-inspired idea about the Harmony of the Spheres (Paradise 1.76-84):

\begin{tabular}{|l|l|}
\hline $\begin{array}{l}\text { Quando la rota che tu sempiterni } \\
\text { desiderato, a sé mi fece atteso } \\
\text { con l'armonia che temperi e discerni, }\end{array}$ & $\begin{array}{l}\text { When that revolving, which you make unending } \\
\text { by longing for you, captured my attention } \\
\text { with the harmony you tune and modulate, }\end{array}$ \\
$\begin{array}{l}\text { parvemi tanto allor del cielo acceso } \\
\text { de la fiamma del sol, che pioggia o fiume } \\
\text { lago non fece alcun tanto disteso. }\end{array}$ & $\begin{array}{l}\text { so much of heaven then seemed to me aflame } \\
\text { with fire from the sun that rain or river } \\
\text { never formed a lake that spread so wide. }\end{array}$ \\
$\begin{array}{l}\text { La novità del suono e 'l grande lume } \\
\text { di lor cagion m'accesero un disio } \\
\text { mai non sentito di cotanto acume. }\end{array}$ & $\begin{array}{l}\text { The strangeness of the sound and the bright light } \\
\text { inflamed in me an ardor to know their cause, } \\
\text { sharper than I had ever felt before. }\end{array}$ \\
\hline
\end{tabular}

He speaks of la novità del suone: the newness or strangeness. Here he refers to the kind of sound that the imperfect human hearing cannot capture. Now that he is "transhuminized", for the first time he can hear their sound.

The sphere of the Moon is the only one where the souls still appear in the form of shades, but they are more beautiful than when still alive. They seem specchiati sembianti, "mirrored semblances" to Dante. The Ave Maria that is sung by one of the souls is supposedly still a "human" version (Paradise 3.121):

Così parlommi, e poi cominciò 'Ave, Maria' cantando, e cantando vanio come per acqua cupa cosa grave.
So she addressed me, and then began to sing Ave Maria, and singing, disappeared, just like a solid weight down through deep water.

Ave Maria gratia plena dominus tecum, benedicta tu in mulieribus et benedictus fructus ventris tui, Iesus, "Hail, Mary, full of grace, the Lord is with you; blessed are you among women, and blessed is the fruit of your womb, Jesus". She does not need to sing more, because the following part of the 
Ave Maria is a petition for Mary to pray for "us sinners, now and at the hour of our death". This soul already perfectly happy in Paradise and does not need Maria to pray for her anymore. The Ave Maria is a suitable symbolization of these souls who broke their vows to God.

The next musical reference, in the sphere of Mercury, is one of Bent's candidates for polyphony. It is what the political ruler Justinian tells Dante (Paradise 6.124-126):

Diverse voci fanno dolci note; così diversi scanni in nostra vita rendon dolce armonia tra queste rote.
Assorted voices make sweet melody: and so the varied ranking of our lives renders sweet harmony among these gyres.

As Ciabattoni argues, "the different voices, the sweet harmony, and the verb rendere - in its implication of 'to respond', 'to sing against' (...) also appearing in Paradiso X.146 - are all elements that suggest polyphony" (Ciabattoni 2010, 157) but at the same time they refer to a political harmony. Paradise 10.146 is about the wise men dancing around the sun and contains the same verb: render voce a voce in tempra ("answer voice to voice with harmony"). Dante did not indicate a specific chant here.

Justinian himself sings the next song (Paradise 7.1):

«Osanna, sanctus Deus sabaòth,
superillustrans claritate tua
felices ignes horum malacòth!».
"Hosanna to the holy Lord of Hosts, relighting by your brightness from above the blissful burning fires of these kingdoms!"

He sings a mixture of Latin and Hebrew and although it seems to be a Sanctus, it starts with the word osanna instead of sanctus. The regular Sanctus is as follows:

\begin{tabular}{|l|l|}
\hline Sanctus, Sanctus, Sanctus & Holy, Holy, Holy \\
Dominus Deus Sabaoth. & Lord God of hosts. \\
Pleni sunt cæli et terra gloria tua. & Heaven and earth are full of your glory. \\
Hosanna in excelsis. & Hosanna in the highest. \\
Benedictus qui venit in nomine Domini. & Blessed is he who comes in the name of the Lord. \\
Hosanna in excelsis. & Hosanna in the highest. \\
\hline
\end{tabular}


The first part of the Sanctus comes from Isaiah 6:3, et clamabant alter ad alterum et dicebant sanctus sanctus sanctus Dominus exercituum plena est omnis terra gloria eius (“And they were calling to one another: 'Holy, holy, holy is the Lord Almighty; the whole earth is full of his glory.' ”). The part from Benedictus on comes from Matthew 21:9, turbae autem quae praecedebant et quae sequebantur clamabant dicentes hosanna Filio David benedictus qui venturus est in nomine Domini hosanna in altissimis ("The crowds that went ahead of him and those that followed shouted, 'Hosanna to the Son of David!' 'Blessed is he who comes in the name of the Lord!' 'Hosanna in the highest heaven!' ") As we can see, Dante has not taken his fragment from the Bible, but from the Sanctus and has placed Hosanna in front of it, while the second part of his song is newly invented.

In the sphere of Venus a Hosanna is sung (Paradise 8.28-31):

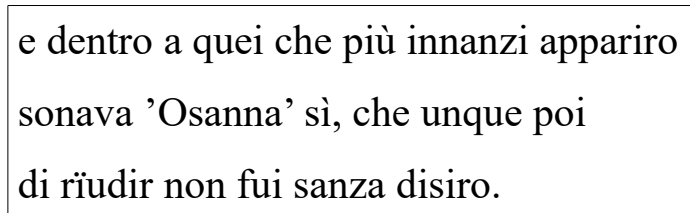

And from the midst of those appearing foremost Hosanna sounded in such strains that I have always craved to hear it once again.

This time it is probably a Hosanna and not a Sanctus. The Hosanna focusses on the above mentioned phrase from Matthew 21:9. In fact, there are many Medieval manuscripts that contain the Hosanna, which has a slightly different text but still conveys the same meaning as in Matthew 21: Hosanna filio David benedictus qui venit in nomine domini rex Israel hosanna in excelsis.

Paradise 10, the sphere of the Sun, is full of nonspecific musical references. In 10.66 più dolci in voce che in vista lucenti, "with voices sweeter than their looks were bright". In 10.70-81 Ne la corte del cielo...molte gioie...e 'l canto di quei lumi era di quelle. Poi, sì cantando, quelli ardenti soli si fuor girati intorno a noi tre volte, donne mi parver, non da ballo sciolte, ma che s'arrestin tacite, ascoltando fin che le nove note hanno ricolte. ("In the courts of heaven... are myriad jewels...it was of them these radiances sang. When, singing in this way, those flaming suns three times had circled round about us both, they looked like ladies pausing in the dance to listen to the music silently until they catch up to the tune anew"). In canto 10.106 one of the souls talks of them as il nostro coro (“our choir").

The last fragment of Paradise 10 uses the image of a clock for the dance of the wise men (Paradise 10.139-148): 
Indi, come orologio che ne chiami

ne l'ora che la sposa di Dio surge

a mattinar lo sposo perché l'ami,

che l'una parte e l'altra tira e urge, tin tin sonando con sì dolce nota, che 'l ben disposto spirto d'amor turge;

così vid' io la gloriosa rota muoversi e render voce a voce in tempra e in dolcezza ch'esser non pò nota

se non colà dove gioir s'insempra.
Then, like a clock that chimes us at the hour when the Bride of God rises to sing her matins to her Spouse to make him love her,

with one part pulling and the other pushing, sounding ding-dong with notes so dulcet that the true-devoted spirit swells with love,

just so I saw the wheel of glory rotate and answer voice to voice with harmony and sweetness that can never be conceived except where joyfulness is everlasting.

The souls are turning around Dante and Beatrice just like the hands of a clock, which was actually a relatively recent invention from the $13^{\text {th }}$ century. As mentioned before, the verb rendere of canto 6.124-126 is used here as well. The image of the clock corresponds well with the rhythmical pulse of music, as Dante expert John Freccero has implied ${ }^{327}$, but also with the rhythmic dance these Franciscans and Dominicans perform in harmony. Moreover, the relationship of the clock with the Sun is evident, which marks time every day on Earth. Ciabattoni observes an extension of this theme into the sphere of Mars, arguing that "the measurement of time is associated with the Trinity because the Father, the Son, and the Holy Spirit are brought together in the incarnation, and consequently the eternity of time enters contingency. Indeed, the thematic transition in Canto 15 [sphere of Mars], where the Cross and Christ's victory over death are protagonists, hinges, in Solomon's words, precisely on this connection: God's eternal time is shared with man through Christ's death on the cross and resurrection. The pilgrim is still mired in the coils of mortal tempo, and his confusion about time and songs is underscored by the passing references to Beatrice's superiority to and independence from time". 328

Paradise 12.4-15 is considered by Margaret Bent as the most explicit reference to polyphony. As mentioned before, in the last lines, Dante is referring to the nymph Echo: 
e nel suo giro tutta non si volse

prima ch'un'altra di cerchio la chiuse,

e moto a moto e canto a canto colse

canto che tanto vince nostre muse,

nostre serene in quelle dolci tube,

quanto primo splendor quel ch'e' refuse.

Come si volgon per tenera nube

due archi paralelli e concolori,

quando Iunone a sua ancella iube,

nascendo di quel d'entro quel di fori,

a guisa del parlar di quella vaga

ch'amor consunse come sol vapori,
And it had not yet turned completely when

a second circle closed around the first,

motion matched with motion, song with song

song that surpassed in those sweet-sounding pipes the music of our Muses or our Sirens

much as a ray surpasses its reflection.

Just as, across the thinned-out clouds two rainbows,

parallel and alike in color, bend

when Juno gives the order to her handmaid -

The outer band formed by the inner one:

the way the words were of the wandering nymph

whom love consumed as sunlight consumes vapors

Dante describes the effect of an echo, which immediately makes us think of a canon. The secular canon was called rondellus in England, chaçe in France, caça in Spain and caccia in Italy. Later on it would be known internationally as fuga, which would be the name for the canon until at least the $16^{\text {th }}$ century. It could be called rota in Latin, meaning "wheel" but translated as a round. While the rondellus was already present in $13^{\text {th }}$ century manuscripts, the French chaçe is only mentioned for the first time at around 1350. It was not yet listed in Paraisian musical theorist Johannes de Grocheio's compendium of secular genres (Ars musice, ca. 1300). In Italy, the earliest known caccia was found in the Rossi Codex, whose music dates from 1325 to 1355. This secular genre became popular between 1340 and $1360 .{ }^{329}$ No earlier written evidence has been found, but possibly it was an improvised practice before becoming a notated one. Johannes de Grocheio listed it as a secular genre but did not write about existing practices in church. However, Dante's words can be

329 Oxford Music online: Alfred Mann, et al. "Canon (i)." Grove Music Online. Oxford Music Online. Oxford University Press, accessed August 8, 2015,

http://www.oxfordmusiconline.com/subscriber/article/grove/music/04741. Ernest H. Sanders. "Rondellus." Grove Music Online. Oxford Music Online. Oxford University Press, accessed August 8, 2015 , http://www.oxfordmusiconline.com/subscriber/article/grove/music/23785. Virginia E. Newes. "Chace." Grove Music Online. Oxford Music Online. Oxford University Press, accessed August 8, 2015, http://www.oxfordmusiconline.com/subscriber/article/grove/music/05352. Kurt von Fischer and Gianluca D’Agostino. "Caccia." Grove Music Online. Oxford Music Online. Oxford University Press, accessed August 8, 2015, http://www.oxfordmusiconline.com/subscriber/article/grove/music/04517. 
interpreted in another way as well, especially if he had no technical musical knowledge. The exchange of voices, sometimes sounding similar to the structure of a canon, is a characteristic of earlier liturgical music. Ciabattoni gives the example of a Nôtre Dame organum such as Perotinus' Sederunt (ca.1200), a conductus ${ }^{330}$ such as Procurans odium, or a motet ${ }^{331}$ such as $S^{\prime}$ on me regarde / Prenez en garde / Hé mi enfant (Ciabattoni 2010, 177). Rather than being a canon, there is an exchange of melodic material to the extent that the audible effect of echo can be heard by nonmusicians. This does not take away the possibility of a canonic improvised practice. Moreover, it makes sense that the genre of rodellus, chaçe, caça or caccia co-originated in an existing practice.

Paradise $13.25-30$ is the next musical reference, also a nonspecific one:

\begin{tabular}{|l|l|}
\hline $\begin{array}{l}\text { Lì si cantò non Bacco, non Peana, } \\
\text { ma tre persone in divina natura, } \\
\text { e in una persona essa e l'umana. }\end{array}$ & $\begin{array}{l}\text { They sang no Paean there nor hymn to Bacchus, } \\
\text { but to Three Persons in the Godhead's nature, } \\
\text { and God and human nature in one Person. }\end{array}$ \\
$\begin{array}{l}\text { Compié 'l cantare e 'l volger sua misura; } \\
\text { e attesersi a noi quei santi lumi, } \\
\text { felicitando sé di cura in cura. }\end{array}$ & $\begin{array}{l}\text { The song and circling ran to their full measure, } \\
\text { and then those holy lights attended to us, } \\
\text { Happy to pass from caring to new care. }\end{array}$ \\
\hline
\end{tabular}

Ciabattoni gives the suggestion that three-part organum would suit a song for the Trinity perfectly well (Ciabattoni 2010, 159). Although it is an artistically interesting thought, it has no basis in Dante's exact words.

In the same canto (Paradise 14.23-24) li santi cerchi mostrar nova gioia nel torneare e ne la mira nota ("the saintly circles in their gay gyrations and marvellous melodies displayed new joy"). A little bit further ahead Dante picks up the theme of the Trinity again, poetically reinforcing his description of the subject of their song (Paradise 14.28-33):

Quell' uno e due e tre che sempre vive e regna sempre in tre e 'n due e 'n uno, non circunscritto, e tutto circunscrive, The One and Two and Three that lives forever and ever reigns in Three and Two and One, uncircumscribed and circumscribing all,

\footnotetext{
330 Sacred, but non-liturgical vocal composition for one or more voices, originating in Aquitaine at the end of the $12^{\text {th }}$ century and assimilated by the Notre Dame school. See Chapter 1.

331 A genre of the Notre Dame school in which one or more texted voices move rhythmically above a tenor with extended notes, taken from a melismatic segment of plainchant. See Chapter 1.
} 
tre volte era cantato da ciascuno

three times was sung by each one of the spirits

di quelli spirti con tal melodia,

ch'ad ogne merto saria giusto muno.

of those two rings, with such a melody

as would be fit reward for every merit.

The last reference to music in Paradise 14 is to an apparently existing chant (Paradise 14.118-126), for the first time mentioning the arpa (harp) and giga (viol) instead of the cithara.

\begin{tabular}{|l|l|}
\hline $\begin{array}{l}\text { E come giga e arpa, in tempra tesa } \\
\text { di molte corde, fa dolce tintinno } \\
\text { a tal da cui la nota non è intesa, }\end{array}$ & $\begin{array}{l}\text { And as a viol or harp that is strung } \\
\text { with many cords for harmony chimes sweetly } \\
\text { on ears that cannot catch the melody, }\end{array}$ \\
$\begin{array}{l}\text { così da' lumi che lì m'apparinno } \\
\text { s'accogliea per la croce una melode } \\
\text { che mi rapiva, sanza intender l'inno. }\end{array}$ & $\begin{array}{l}\text { so from the lights appearing to me there, } \\
\text { a music swelled throughout the cross and held me } \\
\text { enraptured though I could not tell the hymn. }\end{array}$ \\
$\begin{array}{l}\text { Ben m'accors' io ch'elli era d'alte lode, } \\
\text { però ch'a me venìa «Resurgi» e «Vinci» } \\
\text { come a colui che non intende e ode. }\end{array}$ & $\begin{array}{l}\text { I firmly marked it was a song of praise } \\
\text { because "Rise up," and "Conquer" came to me } \\
\text { as one who hears but does not understand. }\end{array}$ \\
\hline
\end{tabular}

Ciabattoni argues in his article "Dante and Music" that the chant belonging to the words resurgi and vinci ("rise up", "conquer") has not been identified satisfactorily, with the exception of a suggestion by Romanist and Italian scholar Charles Hall Grandgent (1862-1939), later proposed again by Robert Hollander, who writes that there is a sequentia ("sequence") in the missal for Thursday of Easter week which includes the phrase Resumpta carne resurgit victor die in tertia. Ciabattoni explains in this article the background of this sequence:

"Sequences were poetic texts originally composed by local authors for local rites and differed from town to town. Sequences held a rightful place in the liturgy until the Council of Trent banned almost all of them due to their often-unorthodox content. Manuscript evidence, however, shows that the words quoted by Dante and highlighted by Grandgent belong to a sequence that begins Concinat orbis cunctus, found in sixty-nine manuscripts of English and northern French origin. Of these, nineteen date before or during Dante's lifetime. (...) Sequences were non-biblical liturgical texts, originally composed as aids to memorize the long melodies of melismatic Alleluias. Sequences originated from melismas on Alleluias because such embellishments had become too long and elaborate to remember. New words were interpolated into the melisma, one note to one syllable, in order to make it easier to commit to memory the most flourished melodies. The golden age of the sequence as a poetic genre was from the 
ninth to the twelfth century. Sequences were perceived as a creative space within liturgy that monks and Christian poets could fill with their own original and often-innovative compositions" (Ciabattoni 2013, 25-26 and 39).

Here follows the entire text of the sequence Concinat orbis cunctus:

\begin{tabular}{|c|c|}
\hline Concinat orbis cunctus & The whole world sings \\
\hline Alleluja, votis, voce solemnia & Alleluia, with vows, with solemn voice \\
\hline Celebrando Paschalia. & Celebrating Easter. \\
\hline Insontum tenera congaudeat turma, sacro & Let the young multitude rejoice white as snow at \\
\hline fonte nivea, & the holy spring \\
\hline Spernens Phlegethontis undas. & Fleeing the waters of Phlegethon. \\
\hline Nos quoque laxas aptemus fibras arte & $\begin{array}{l}\text { And we draw taut the loosened strings with } \\
\text { musical art }\end{array}$ \\
\hline Voce sonora modificantes prosis aneumata & $\begin{array}{l}\text { We change the notes to the lyrics with aneumata } \\
\text { melodious voice }\end{array}$ \\
\hline Voce satis tinnula & With a tinkling voice \\
\hline Christus namque mitis hostia & Christ, example of meekness, became our Host \\
\hline Factus nostra ob remedia, & As a remedy he bore the infamy of the cross \\
\hline Crucis pertuli probra & And, while still alive, suffered the supplice of \\
\hline Et jugis vita manens subiit lethalia. & the yoke. \\
\hline Fellis amara passus praelibare pocula & He drank the bitter chalice of gall \\
\hline Vulnera satis toleravit dira, tranfixus clavis et & He endured cruel wounds, pierced by nails and \\
\hline lancea & lance. \\
\hline Sic tolerando, mala gerens nostra, & Thus having suffered for us, he took on himself \\
\hline descendit ad ima tartara. & our sins and descended to Hell. \\
\hline Hostis antiqui quo defringens arma, & There he defeated the army of the old enemy \\
\hline revehit potens ampla ovando tropaea & and returned rejoicing in his great victory. \\
\hline Sicque devicta morte ac resumpta carne, & And thus, having defeated death and taken back \\
\hline resurgit victor die in tertia. & his flesh, He rose victorious on the third day. \\
\hline Unde jam jocundas ipsi canamus odas, & Therefore we raise joyful praises to him \\
\hline Per quem nobis vita redit aeterna et caeli clara & Who gave us eternal life and opened the gates of \\
\hline nobis patescit aula; & the palace of Heaven; \\
\hline Cui sit laus preclara. & High praise to him. ${ }^{332}$ \\
\hline
\end{tabular}


Ciabattoni reports not only the relation of the words la carne gloriosa e santa / fia rivestita with the references to Christ's resurrection in Canto 14, but also the fact that both texts use the image of plucked instruments used as a metaphor for the various voices. "We find, as Grandgent noted, almost identical words for Christ's resurrection and victory over death ('Resurgi' e 'Vinci' / resurgit victor), along with the explicit mention of praise (alta lode / laus preclara)" (Ciabattoni 2013, 38). He also comments on the remarkable coincidence of di molte corde fan dolce tintinno with voce satis tinnula. However, the sequence Concinat orbis cunctus is not found in Italian collections. Since sequences usually remained of local diffusion and all of the surviving manuscripts that contain Concinat orbis cunctus are from England or northern France, the question arises if Dante really had in mind this particular sequence, and if so, if he would have traveled to France (Ciabattoni 2013, 39). Notwithstanding, if Dante wished to suggest a link with Concinat orbis cunctus to his Florentine readers, he must have supposed that they knew it. The case of this sequence thus remains a mystery for the moment.

At the beginning of Paradise 15, Dante resumes the image of a multi-stringed instrument, this time played by God himself (Paradise 15.4): Benigna volontade (...) silenzio puose a quella dolce lira, $e$ fece quietar le sante corde che la destra del cielo allenta e tira. ("Gracious will (...) hushed to silence the sweet-sounding lyre and stilled the sacred strings that the right hand of heaven either slackens or sets tight").

In Paradise 18 there are also various nonspecific musical references. Paradise 18.50: mostrommi l'alma che m'avea parlato qual era tra i cantor del cielo artista ("the soul who'd spoken to me let me hear his art among the singers of that heaven"). Paradise 18.79-81: Prima, cantando, a sua nota moviensi; poi (...) un poco s'arrestavano e taciensi. ("At first they moved in rhythm with their song, but then (...) they stopped for a brief interval in silence.”) Paradise 18.99: li quetarsi cantando, credo, il ben ch'a sé le move ("come to rest there, singing, I believe, the Good that draws them").

In this Divine dramatical representation, the souls of the sphere of Jupiter first spell out the words diligite iustitiam qui iudicatis terram and then form the figure of an eagle, which sings a melody

Hymnica Medii Aevi 40 (1902): 39-40. Also to be encountered directly in historical sources such as Missale ad usum insignis et praeclarae ecclesiae Sarum, available on http://www.archive.org/stream/missaleadusumin00cathgoog/missaleadusumin00cathgoog_djvu.txt and Liber Ecclesiae Beati Terrenani de Arbuthnott; missale secundum usum Ecclesiae Sancti Andreae in Scotia. [Edited by A.P. Forbes, Bishop of Brechin], available on http://archive.org/stream/liberecclesiaebe00cath/liberecclesiaebe00cath_djvu.txt [accessed 6-8 2015]. 
that Dante does not comprehend (Paradise 19.97-99):

Roteando cantava, e dicea: «Quali

son le mie note a te, che non le 'ntendi,

tal è il giudicio etterno a voi mortali».
Wheeling it sang, and said, "As are my notes

to you who do not comprehend them, such is the eternal judgment to you mortals."

Paradise 20.11 confirms that Dante's human senses, including his memory, have their limitations: cominciaron canti da mia memoria labili e caduci, "each began to sing hymns that have slipped out of my memory". The supernatural music was comprehensible to him during his journey through Paradise due to the fact that his body was granted qualities of a resurrected body, but once back on Earth he has returned to his limited human abilities.

In Paradise 21.58-63 Dante's body is not ready yet to understand the celestial music of the contemplative souls, so the souls keep silence just as Beatrice does not smile:

«e dì perché si tace in questa rota la dolce sinfonia di paradiso, che giù per l'altre suona sì divota».

«Tu hai l'udir mortal sì come il viso», rispuose a me; «onde qui non si canta per quel che Bëatrice non ha riso.
"And tell me why within this wheeling sphere the sweet symphony of paradise is silent, which through the spheres below sounds so devoutly."

"You have the sight and hearing of a mortal," he answered me; "there is no singing here for the same reason Beatrice has not smiled.

When they utter a collective shout, Dante is bewildered (Paradise 21.139-142):

Dintorno a questa vennero e fermarsi, e fero un grido di sì alto suono, che non potrebbe qui assomigliarsi;

né io lo 'ntesi, sì mi vinse il tuono.
They flocked around this spirit and stood still and lifted up a shout so deep in sound that nothing heard on earth resembles it;

the thunder dashed me so, I could not grasp it.

Beatrice explains to him the reason for the silence in this sphere, the same reason why she has not smiled (Paradise 22.10-15): 
Come t'avrebbe trasmutato il canto, e io ridendo, mo pensar lo puoi, poscia che 'l grido t'ha mosso cotanto;

nel qual, se 'nteso avessi i prieghi suoi, già ti sarebbe nota la vendetta che tu vedrai innanzi che tu muoi.
Now you can comprehend how they by song and I by smiling would have changed your soul, when just this shout has moved you so profoundly.

By this cry, had you understood their prayers, you might have known already of the vengeance which you shall see down there before you die.

Thus, not only is this music incomprehensible but it can even be harmful to Dante's human body. In fact, Beatrice explained to Dante that he would turn into ashes if she were to smile at him, and in canto 25 Dante becomes temporarily blind because he looks too intensely to Saint John's light. We could even speculate that this might be the reason why Dante's vision at the end of Paradise is without music, or at least he does not remember any musical experience afterwards.

Paradise 23.97-111 seem to be mentioning a kind of Regina coeli:

Qualunque melodia più dolce suona qua giù e più a sé l'anima tira, parrebbe nube che squarciata tona,

comparata al sonar di quella lira onde si coronava il bel zaffiro del quale il ciel più chiaro s'inzaffira.

«Io sono amore angelico, che giro l'alta letizia che spira del ventre che fu albergo del nostro disiro;

e girerommi, donna del ciel, mentre che seguirai tuo figlio, e farai dia più la spera supprema perché lì entre».

Così la circulata melodia si sigillava, e tutti li altri lumi facean sonare il nome di Maria.
The sweetest-sounding melody on earth, which draws the soul the closest to its strains, would seem to be a thunder-shattered cloud

compared to the tuned music of the lyre that crowns the most beautiful of sapphires by which the brightest heaven is bejeweled.

"I am angelic love who wheels around the exalted gaiety breathed from the womb which was the inn of all the world's desire;

"And, Lady of Heaven, I will wheel until you follow your Son to the highest sphere to make it more divine by entering it!"

In this way the encircling melody came to a close, and all the other lights rang out with echoes of the name of Mary. 
We saw already in Margaret Bent's article that musicologist John Stevens warns against la circulata melodia as a reference to polyphony, stating that it rather refers to inner melodic coherence. In this case it is even logical, because he is singing alone. The text of Regina Coeli is as follows:

Regina cæli, lætare, alleluia:

R. Quia quem meruisti portare, alleluia, Resurrexit, sicut dixit, alleluia,

R. Ora pro nobis Deum, alleluia.

Gaude et lætare, Virgo Maria, alleluia.

R. Quia surrexit Dominus vere, alleluia.

Oremus.

Deus, qui per resurrectionem Filii tui, Domini nostri Iesu Christi, mundum lætificare dignatus es: præsta, quæsumus, ut per eius Genitricem Virginem Mariam, perpetuæ capiamus gaudia vitæ.

Per eundem Christum Dominum nostrum. R. Amen.
Queen of Heaven, rejoice, alleluia.

R. The Son whom you merited to bear, alleluia. Has risen, as He said, alleluia.

R. Pray for us to God, alleluia.

Rejoice and be glad, O Virgin Mary, alleluia.

R. For the Lord has truly risen, alleluia.

Let us pray.

O God, who through the resurrection of your Son Jesus Christ gave rejoicing to the world, grant, we pray, that through his Mother, the Virgin Mary, we may obtain the joy of everlasting life.

Through Christ our Lord. Amen.

A Regina Coeli would be the most natural choice, at least if we assume that at this point the music that Dante hears is still connected with the liturgical music he knows.

Paradise 24.13-24 uses again the image of the clock to indicate the movement of the dancing souls. While he remembers perfectly well the visual aspect of their dancing in different velocities, it has been impossible for him to remember the music they sing:
E come cerchi in tempra d'orïuoli si giran sì, che 'l primo a chi pon mente quïeto pare, e l'ultimo che voli;

And as wheels turn within the works of clocks, so that the largest seems, to the observer, to stand still while the smallest seems to fly, 
così quelle carole, differente-

mente danzando, de la sua ricchezza

mi facieno stimar, veloci e lente.

Di quella ch'io notai di più carezza

vid' io uscire un foco sì felice,

che nullo vi lasciò di più chiarezza;

e tre fiate intorno di Beatrice

si volse con un canto tanto divo,

che la mia fantasia nol mi ridice. just so those singing rings, to different measures

dancing in swift circles and in slow,

enabled me to judge their wealth of joy.

From the one I observed to be the richest

I saw burst out a flame so joyful that

none ever shone with sharper brilliancy.

And three times it revolved around Beatrice

with so divine a song, there is no way

for my imagination to record it.

Although Ciabattoni is convinced that the souls are singing in different rhythms (Ciabattoni 2010, 186), the text actually only specifies that they are dancing faster or slower, but not if they are also singing different rhythms simultaneously.

A Te Deum is sung in Paradise 24.113:

Finito questo, l'alta corte santa risonò per le spere un 'Dio laudamo'

ne la melode che là sù si canta.
This ended, through the spheres the saintly court On high resounded "Te Deum," praising God

With melodies such as they sing up there.

We already encountered a Te Deum in Purgatory 9.140-141 (e 'Te Deum laudamus' mi parea udire in voce mista al dolce suono, "And thought I heard "Te Deum: Praise to God" chanted by voices mixed with that sweet strain"), where these voices blended with the clangor of the gate to the next terrace. Perhaps this Te Deum sounds different since Dante points out that its melody is "as they sing up there", but Dante seemingly did not comprehend very well the first Te Deum when he had still a more imperfect body. ${ }^{333}$

Sperent in te sounds in Paradise 25.97-99:

333 “Io mi rivolsi attento al primo tuono, / e 'Te Deum laudamus' mi parea / udire in voce mista al dolce suono. / Tale imagine a punto mi rendea / ciò ch'io udiva, qual prender si suole / quando a cantar con organi si stea; / ch'or sì or no s'intendon le parole." ("I turned around at the first thundering sound / and thought I heard "Te Deum: Praise to God" / chanted by voice(s) mixed with that sweet strain. / The notes I heard conveyed to me the same / exact impression which we have at times / when people sing con organi / and now and then we just make out the words.") Purgatory 9.139-145, see above in Chapter 3. 
E prima, appresso al fin d'este parole,

'Sperent in te' di sopr' a noi s'udì;

a che rispuoser tutte le carole.
First, as these words were coming to an end,

"Let them find hope in Thee," rang out above us,

And to it all the choirs around re-echoed.

Dante continues his description of the singing in Paradise 25.130-132:

\begin{tabular}{|l|l|}
\hline $\begin{array}{l}\text { A questa voce l'infiammato giro } \\
\text { si quïetò con esso il dolce mischio } \\
\text { che si facea nel suon del trino spiro }\end{array}$ & $\begin{array}{l}\text { While this voice spoke, the flaming gyre grew still } \\
\text { together with the sweet mixed harmony } \\
\text { made by the singing of the three-part breathing }\end{array}$ \\
\hline
\end{tabular}

Dante tells us it is trino spiro ("three-part breathing") referring to the three saints singing together (Peter, James, and John), and calls it dolce mischio ("sweet mixture"). This does appear to refer to organum. Sperent in te comes from Psalm 9:11, et sperent in te qui noverunt nomen tuum quoniam non dereliquisti quaerentes te Domine ("And let them trust in thee who know thy name: for thou hast not forsaken them that seek thee, O Lord"). It is the happy response of the heavenly souls to Dante's success in his "exam" on faith, hope and charity. This chant appears in neume manuscripts, but does not seem to have been present in many note manuscripts. On the internet site www.cantusdatabase.org only one example is listed, as early as the $11^{\text {th }}$ century ${ }^{334}$, but no later version appear.

In Paradise 26.67-69 Dante regains his eyesight after having been blinded by the light of Saint John, accompanied by Sanctus, sanctus, sanctus:

Sì com' io tacqui, un dolcissimo canto
risonò per lo cielo, e la mia donna
dicea con li altri: «Santo, santo, santo!».

As soon as I grew still a most sweet song Resounded through the heavens, and my lady Sang with the others, "Holy, Holy, Holy!"

Now his eyesight is able to withstand all heavenly visions. The only information on the chant is that it is the beginning of a Sanctus and does not seem to be continued beyond those words. After Adam's intervention, the next song that Dante hears is a Gloria Patri et Filio, et Spiritui Sancto (Paradise 27.1-3):

'Al Padre, al Figlio, a lo Spirito Santo', "Glory to the Father, Son, and Holy Spirit!" 
cominciò, 'gloria!', tutto 'l paradiso,

sì che m'inebrïava il dolce canto. the whole of paradise at once poured forth, so sweet a song I felt inebriated.

The last two references mentioned by Bent to be possible candidates for polyphony are 28.94-96 and 28.118-120:

\begin{tabular}{|l|l|}
\hline $\begin{array}{l}\text { Io sentiva osannar di coro in coro } \\
\text { al punto fisso che li tiene a li ubi, } \\
\text { e terrà sempre, ne' quai sempre fuoro. }\end{array}$ & $\begin{array}{l}\text { From choir to choir I heard Hosannah sung } \\
\text { to the Still Point that holds them fast forever } \\
\text { to that one spot where they have always been. }\end{array}$ \\
$(\ldots)$ & $(\ldots)$ \\
perpetüalemente 'Osanna' sberna \\
$\begin{array}{l}\text { con tre melode, che suonano in tree } \\
\text { ordini di letizia onde s'interna. }\end{array}$ & $\begin{array}{l}\text { unceasingly in birdsong sings Hosannah } \\
\text { with triple melodies that warble from } \\
\text { the three degrees of bliss that form the triad. }\end{array}$ \\
\hline
\end{tabular}

Ciabattoni reasons that

\begin{abstract}
"if there are three different melodic lines and they are sung perpetually, there will necessarily result a polyphonic performance. In fact, some early commentators understood these three melodies as a tripartite song that recalls a three-voice organum. Benvenuto of Imola [ca.1320 - 1388] expresses it in the clearest way: the angels sing 'a threefold song, because every triad makes its own distinct song according to their different offices, and still they all resound and harmonize in magnificent intervals."' (Ciabattoni 2010, 167).
\end{abstract}

The word Hosanna is derived from the Aramean "save" or "saviour". It is a word of praise to Divinity's rescuing facet. In fact, in the Bible it appears in the story of Jesus' entering in Jerusalem and the people are praising him exclaiming Hosanna (Mark 11). Ciabattoni suggests that it could be seen as the final glorious moment of a journey from the musicless Miserere uttered by Dante in the beginning, through the Miserere sung by the souls in Ante-Purgatory, resulting in this chant which is a song of praise but etymologically means "saviour" or "save (us)" (Ciabattoni 2010, 168).

Paradise 31.4-5 speaks of the angels volando vede e canta la gloria di colui che la 'nnamora "singing the glory of him who fills them with his love". Their song must be without words, since according to Dante they do not use verbal language (see chapter 3). Paradise 31.133 speaks of lor giochi quivi e (...) lor canti, "their sports and songs there". This is the culmination of the aesthetic and joyous Divine representation. 
There is a reference to an Ave Maria in Paradise 32.94-99:

\begin{tabular}{|l|l|}
\hline $\begin{array}{l}\text { e quello amor che primo lì discese, } \\
\text { cantando 'Ave, Maria, gratïa plena', } \\
\text { dinanzi a lei le sue ali distese. }\end{array}$ & $\begin{array}{l}\text { And that same Love who first flew down to her, } \\
\text { singing there, "Hail Mary, full of grace," } \\
\text { now spread his wings out wide in front of her. }\end{array}$ \\
$\begin{array}{l}\text { Rispuose a la divina cantilena } \\
\text { da tutte parti la beata corte, } \\
\text { sì ch'ogne vista sen fé più serena. }\end{array}$ & $\begin{array}{l}\text { From every side the blessed court responded } \\
\text { so warmly to the canticle of heaven } \\
\text { that with the song each face grew more serene. }\end{array}$ \\
\hline
\end{tabular}

Here is a re-enactment of the Annunciation, so it would be plausible that the Archangel Gabriel actually sings the Ave Maria. We can imagine that the response of the "blessed choir" might be the final Amen of the Ave Maria. It is also the last reference to any chant in Paradise.

\subsection{The ineffable and its interpretation: beyond polyphony}

We have seen that the Anti-Music of Inferno is both an expression of the souls' mental state and their punishment: they are not able nor allowed to produce music and must listen eternally to chaotic and unpleasant sounds. The general soundscape of Inferno is one of cacophony and lack of harmonious music.

The music of Purgatory consists of three types. First of all, there are a few examples of seductive music (Casella, the Siren in Dante's dream). Second, at each gate to the next terrace there is a Beatitude sung by an angel or by immaterial voices. Third, the souls themselves sing liturgical chants as an means of purgation and healing. The Beatitudes and the healing chants reflect perfectly the sins of each terrace. In the Terrestrial Paradise, Matelda and the heavenly procession give a foretaste of the abundant singing and dancing in Paradise. Most chants in Purgatory can be performed from late-Medieval sources, so historically and musically this canticle is a very interesting one.

The music of Paradise has a supernatural nature. It is the canticle where less can be said about the 
sounding music itself, leading to most speculation in writings on the subject. There are only a few definable chants in Paradise, while most are lyrical descriptions of how the protagonist Dante perceives the music of Paradise. If we assume that Paradisal music is unlike human chant, then this makes perfect sense. Sometimes a chant appears to be a known liturgical version, but then suddenly the soul or angel changes its text, a phenomenon that we could observe already slightly in some songs of Purgatory's angels. Ciabattoni's conclusion is that Paradisal music must be polyphonic because of some of its descriptions. However, he bases himself on the premise that it functions like musica instrumentalis even if it is musica mundana. Indeed, musica instrumentalis is an inferior reflection of musica mundana, and perfect proportions are essential to both, but still such supernatural music might function in a way we cannot imagine. If Dante tells us that he does not comprehend what he hears - because his human body has not yet reached the perfection in order to grasp it - the question arises if polyphony is enough to cover the Paradisal sound Dante had in mind. In this perspective, the conclusion that Purgatory is about monophony while Paradise is about polyphony drawn by Ciabattoni and others is a somewhat simplistic view which does not take into account that the Paradisal music is of a complete different order than any kind of human music. We should rather say that Purgatory is about human music while Paradise is about angelic music, and the rest can only be vaguely imagined, just as Dante must have done. However, as a basis of inspiration for a performance, this hypothesis is of interest, because in performance we can only express Dante's references with our imperfect musica instrumentalis. 


\section{CHAPTER 5 - HISTORICAL SOURCES OF THE COMMEDIA'S CHANTS, THEIR TRANSCRIPTION AND COMPOSITION OF ADDITIONAL VOICES}

The sonorous references in the Commedia, both musical and non-musical, constitute the basis for the sounds in the music theatre work Incipit. While in chapter 4 all musical references in the text were analysed, chapter 5 focuses on historical versions of the identifiable chants and their transcription. For this research only digitalized historical manuscripts have been used. Italian archives that contain chant manuscripts have not systematically digitalized and indexed them, and it is beyond the scope of our research to study, index, and scan the musical manuscripts of the Florence cathedral. However, this study encourages such musicological research in order to reach an even more precise idea of what melodies Dante might have had in mind. The digitalized, online available manuscripts are mostly of Parisian, Swiss or Austrian origin. Since Switzerland and Austria were peripheral areas in relation to Paris - just like Italy - they have been thought to represent a somewhat different way of interpretation. While in Paris there were musical experiments with faster voices against an extremely slow tenor voice, in the peripheral areas the practices were rather based on improvised note-against-note organum. Florence might have experienced a continuing influence of Rome and its musical practices, but we do not know in what extent Roman chant was still very different from the chant of the rest of Europe, taking into account the fact that the Church always sought for unity in its repertoire. Furthermore, Dante's lifetime saw the liturgical work of the Franciscans and the Dominicans, who travelled throughout Europe. It is not clear to what extent the Florentine practices were similar to other European practices, but there must have been a certain European union and intercommunication, especially among the relatively close-by peripheral areas, which preferred the improvised note-to-note practice above the Parisian one. Therefore, mainly $14^{\text {th }}$ century Swiss and Austrian manuscripts have been used for this study, which are digitalized and indexed at cantusdatabase.org.

The original notation has been transcribed with Finale into modern standard five-line notation with g-clef a la $8 v a^{335}$. The original melodies are indicated mostly with a c-clef. Notated pitch was not an absolute indication, but a relative one: the singers could sing within a range that suited them best. The notes were entered in Finale as quarter notes. The notes were grouped according to their unity within the chant (i.e. a phrase or a long word) and divided into bars with time signatures that suited the number of notes of each group. For example, for a phrase of 19 notes, a bar was created with a time signature of 19/4. For the next phrase, consisting of 15 notes, a bar of 15/4 would be created.

335 With an 8 below the clef, which transposes all notes with an octave, so that they are at the same pitch as the original melody, written around the central c. 
Then, the bar lines, key signatures, note stems and rests were hidden. In this way, they appear as notes without any rhythmic meaning, just like the square notation of Dante's time. We have added slurs to melismas despite the fact that these are not present in the original notation. The reason for this was a compromise for the fact that the melismas in the original notation are usually written with a ligature:

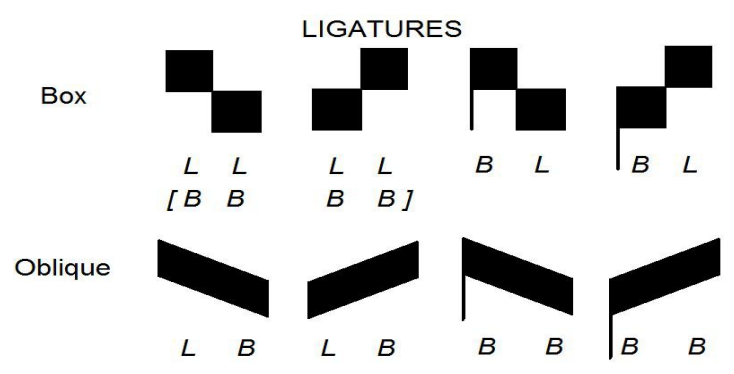

Fig. 43 Ligatures

Visually they function in the same way as our slurs: they help the reader to distinguish a group of slurred notes from other syllabic notes.

Since there is no music in Inferno, this chapter begins directly with the chants of Purgatory. The first chant, In exitu israel, is a psalm (Purgatory 2.46). Psalms could be sung on psalm tones, as we saw before. There are eight psalm tones, each in a different mode ${ }^{336}$. The ninth psalm tone is the tonus peregrinus $^{337}$, because it travels from one recitation tone to the other (from a to $\mathrm{g}$ ). In exitu israel was sung to this psalm tone. Standard psalm tones have not been transcribed into 5-line notation because they are a short comprehensible melody line which is repeated for each phrase and adapted to its rhythm. Below are both the present-day standard tonus peregrinus and its appearance in the writings by Jacob of Liège (also called Jacques de Liège or Jacobus Leodienses, ca.1260-after 1330). ${ }^{338}$ The first two fragments are from the sixth book of his Speculum Musicae and the third one from his Tractatus de intonatione tonorum. Jacob of Liège only gives the incipit of the melodies, because they are just musical examples in his treatise. Thus most melodies in his treatise are too incomplete to analyse them them, but In exitu israel appears with its whole first phrase.

336 As explained in chapter 1, the eight modes consist of four authentic modes, which are called doric, phrygic, lydic, mixolydic, and four plagal versions, which are hypodoric, hypophrygic, hypolydic, hypomixolydic.

337 Literally meaning "stranger's tone" or "crusader's tone".

338 Respectively JACSP6B_20GF from http://www.chmtl.indiana.edu/tml/14th/JACSP6B TEXT.html;

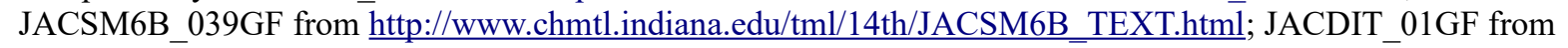
http://www.chmtl.indiana.edu/tml/14th/JACDIT_TEXT.html 
113-PER

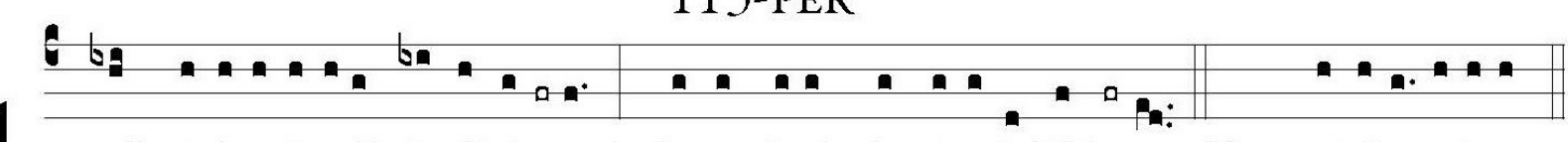

. In éx-i-tu Isra-ël de Æggýp-to, * domus Jacob de pópu-lo bárba-ro: Flex: palpábunt: †

Fig. 44 The current version of In exitu israel CSII: 335,3
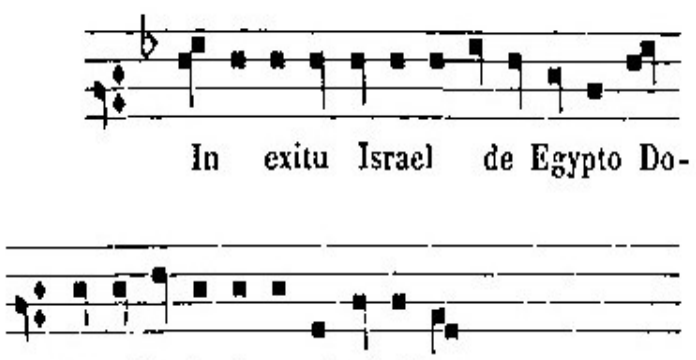

mus Jacob de populo barharo.

Fig. 45. In exitu israel in the sixth book of Jacques de Liège's Speculum Musicae

CSMIII $6: 251,2$

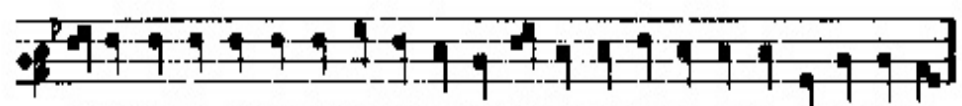

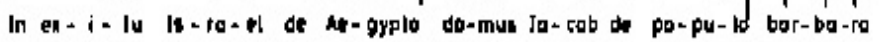

CSMIII6:251,3

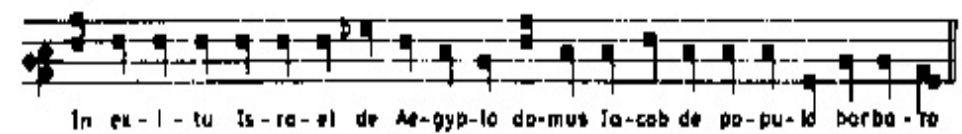

Fig. 46. Two versions of In exitu israel in the same book

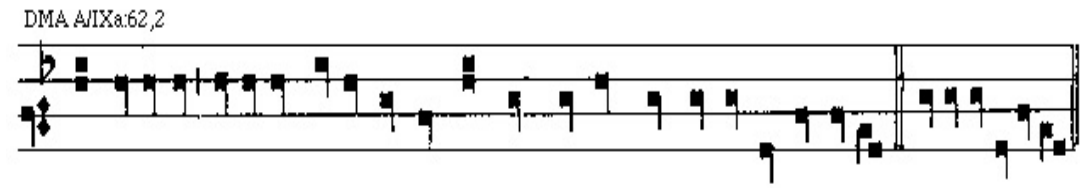

In e-xi-tu is-rahel de egypto domus Jacob de populo barbaro. E u o u a e.

Fig. 47. In exitu israel as it appears in the Tractatus de intonatione tonorum

We can observe that in all versions of Jacob of Liège the word domus has other notes than the current one $(a-b$ flat $-g$ instead of $g-g-g)$. Even though it is not notated in the modern version, 
in practice only the word domus is sung like this. Subsequent phrases go directly to the repeated g. The second version of Speculum's sixth book is the only one that replaces $\mathrm{a}-\mathrm{b}$ flat with $\mathrm{a}-\mathrm{c}$, both on the word in and on domus. Another difference is that in the modern version the word Jacob has a repeated $\mathrm{g}$, while in all version of Jacob of Liège it uses $\mathrm{g}-\mathrm{a}$. In the rehearsal process for the soundtrack of the music theatre work Incipit ${ }^{339}$, the version of $\mathrm{g}-\mathrm{a}$ first was applied to all phrases, but mostly it resulted unclear where to place the a. Since this was a melody sung by a group, the most plausible is a simple melody, without the uncertainty about where the a should be sung. Therefore, we have chosen to follow the modern version with the repeated g.

For the Miserere in Purgatory 5.24 a $14^{\text {th }}$ century version has been chosen, which has the same melody as two $12^{\text {th }}$ century diastematic neume versions ${ }^{340}$ from Klosterneuburg, Austria (AT50001010_86r and AT5000-1013_100r). It is the manuscript Stiftsbibliothek codex 61189 sbe0611_049r, a $14^{\text {th }}$ century antiphoner from the monastery of Einsiedeln, Switzerland. ${ }^{341}$

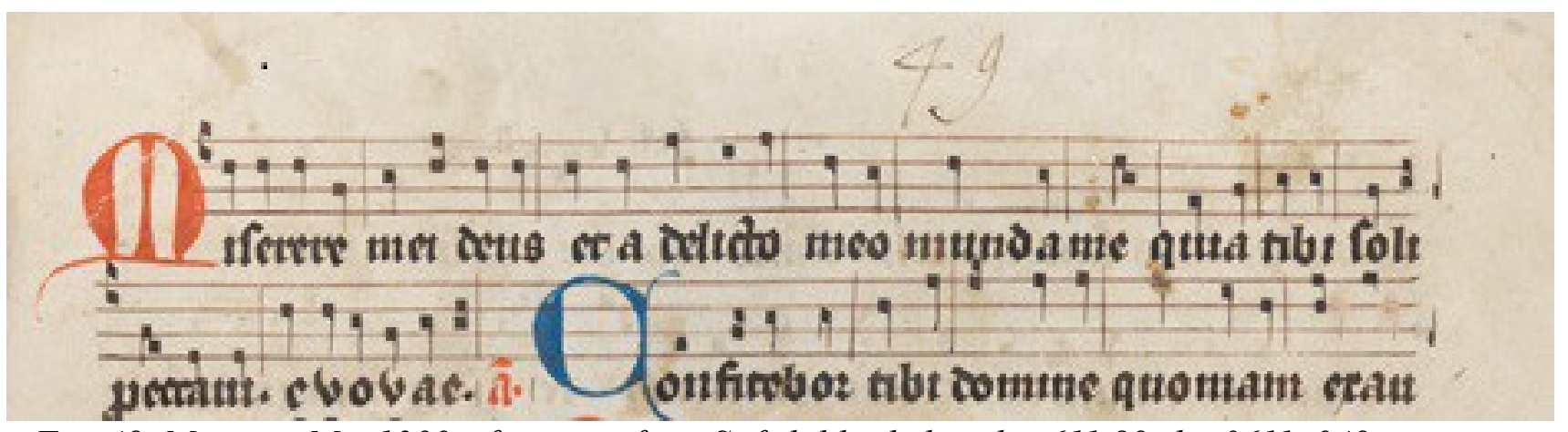

Fig. 48. Miserere Mei 1300s, fragment from Stiftsbibliothek codex 61189 sbe-0611_049r

The separating lines are not bar lines as we understand them ${ }^{342}$, a concept that only appeared in the mid- $17^{\text {th }}$ century. Until then, lines were sometimes written as a visual aid to divide sections, but without any intention of marking measured unities. The letter evovae at the end of this Miserere stand for saeculorum amen ${ }^{343}$, which is a formula for finishing a psalm tone.

Below are the two $12^{\text {th }}$ century neumatic versions which clearly show the same melody ${ }^{344}$ :

339 All chants were recorded. The chants of Purgatory were recorded various times in order to create a choir of various monophonic voices. Those of Paradise were recorded as 3-voice organum with one voice per part. The added second and third voices were composed according to the rules of improvised organum.

340 See chapter 1. Diastematic neumes are neumes that indicate relative difference of pitch.

341 Einsiedeln, Stiftsbibliothek, Codex 611(89), f. 49r - Antiphonarium pro Ecclesia Einsidlensi (http://www.ecodices.unifr.ch/en/list/one/sbe/0611)

342 Nowadays, bars are unities of time corresponding to a specific number of beats, marked by bar lines.

343 They are the vowels of this expression. Saeculorum Amen derives from the lesser doxology or Gloria Patri, which ends with the phrase In saecula saeculorum, Amen.

344 Klosterneuburg, Austria, AT5000-1010_86r, http://www.ksbm.oeaw.ac.at/images/AT/5000/AT5000-1010/AT50001010 86r.jpg and Klosterneuburg, Austria, AT5000-1013_100r, http://www.ksbm.oeaw.ac.at/images/AT/5000/AT5000-1013/AT5000-1013 100r.jpg 


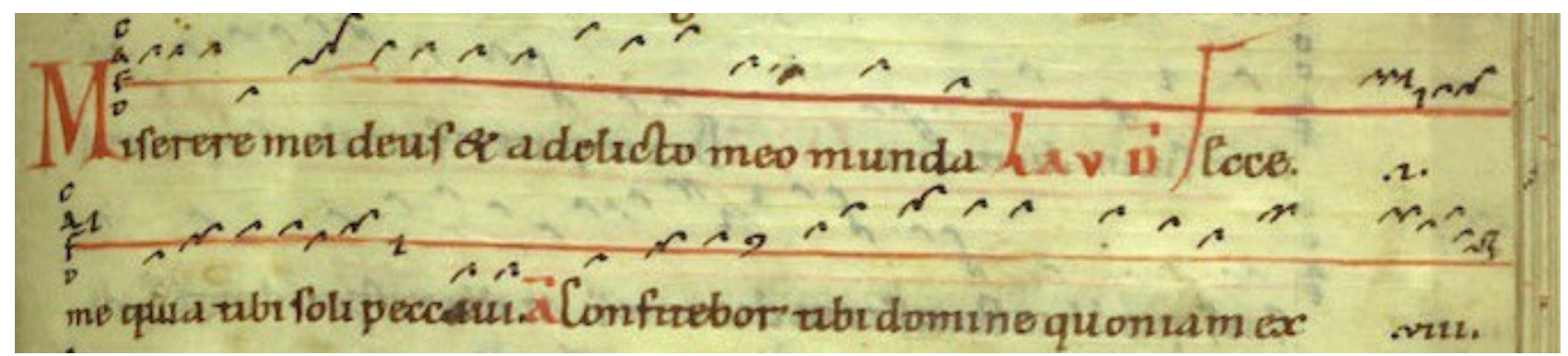

Fig. 49. Twelfth-century antiphoner from Klosterneuburg, Austria, AT5000-1010_86r

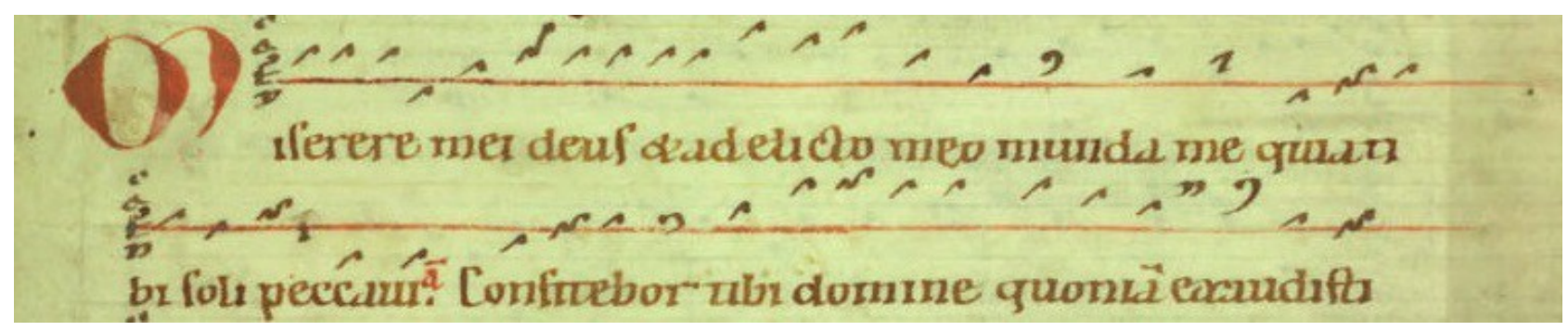

Fig. 50. Twelfth-century antiphoner from Klosterneuburg, Austria, AT5000-1013_100r

These manuscripts are more difficult to interpret if there is no version of square notation to compare them with. The f-line is the red line, and on the left the vertical positions of $\mathrm{d} f \mathrm{a}$ and $\mathrm{c}$ are indicated. The similarity between these versions indicates that there was probably not very much variety in the melody throughout Europe, and it is possible that Dante may have had this melody in mind.
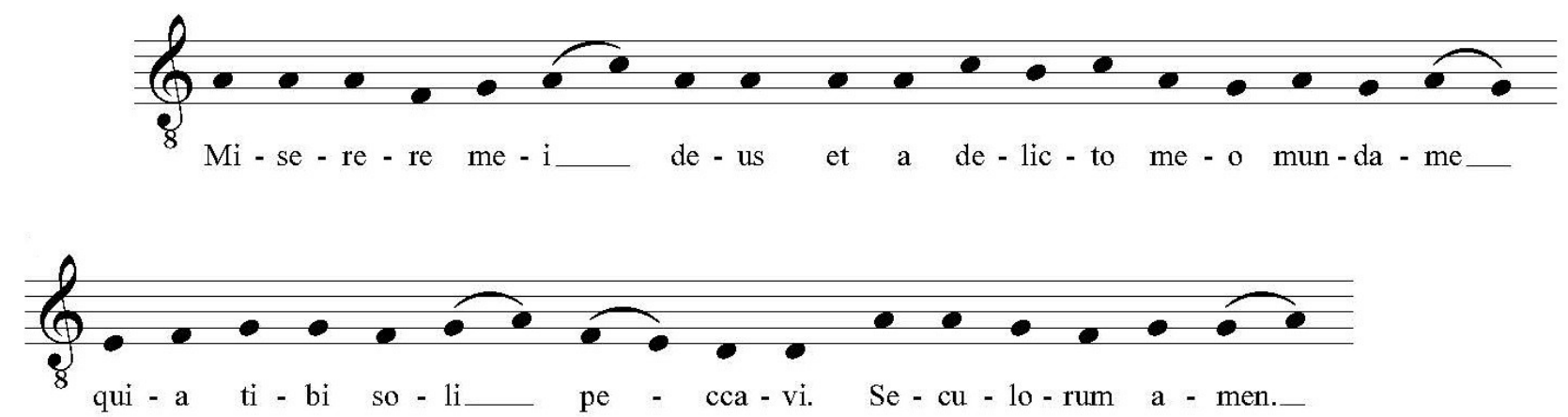

Fig. 51. Transcription of the Miserere from the 14th-century Einsiedeln antiphoner

Of the Salve Regina (Purgatory 7.82) there are not many digitalized manuscripts, actually none from the $14^{\text {th }}$ century. For our transcription, the incipit of Jacques de Liège has been used. He was a contemporary of Dante, although we must keep in mind that he was a Franco-Flemish music theorist who had studied in Paris and that his writings are rather of the second quarter of the $14^{\text {th }}$ century. This means that he studied modal rhythms and is thus most likely of a different school than 
the Florentine one, where the ternary modal rhythms do not seem to have pervaded liturgical music $^{345}$. The difference between this incipit and the $16^{\text {th }}$ century Salzinner version on which we have based the rest of the transcription is very small: the 16th-century version has a few notes extra in between, it is somewhat more ornamented. Where our transcription does differ from the Liège version is the first note. In the $11^{\text {th }}$ century non-diastematic neumatic version ${ }^{346}$ the first two notes are written in a way that might suggest a small lowering of tone and ascending again to the principal tone. In the $16^{\text {th }}$ century version this note is written twice. Therefore, we have transcribed it as two notes, with the additional idea of performing a type of small lowered added note in between them. In fact, there are many chants with repeated notes within a melisma, which raises the question how to perform these tones. In the section about the Medieval voice in chapter 1 we cited McGee on the possible sound of the older Roman style:

\footnotetext{
"The technique involves the ability to sing with a clear (without vibrato) voice, rapid throat articulation and pulsation, slow, fast, and accelerating vibrato at variable intervals, and voice placement that alternates between a bright sound made in the front of the mouth and a dark tone from the throat. The sounds include fixed and sliding tones, diatonic and non-diatonic pitches, aspirated, gargled, and sibilant sounds, and both clear and covered tone qualities". ${ }^{347}$
}

We are not sure if this technique was still used by the $14^{\text {th }}$ century or in Florence. For the repeated notes in a melisma, we decided to apply a technique of inserting an accentuated, slightly lower note in between the others, connected to them by a glissando. In the manuscript containing the Miserere a few flats were written in the score. We can observe that they are of a lighter colour than the notes, and it is not sure if they are original or written later in the score. In our transcription they have been written on top of the notes. Another observation is the sudden clef change in the $16^{\text {th }}$ century version from $\mathrm{f}$ in the third system to $\mathrm{c}$ in the fourth. This is a common phenomenon in the sources used for this thesis.

345 The later Italian modal music from the $14^{\text {th }}$ century had a tendency toward binary rhythm rather than a ternary one. The Italian liturgical sources do not show a tendency toward the Parisian polyphonic genres at the beginning of the $14^{\text {th }}$ century.

346 Neumes without indication of relative pitch.

$347 \mathrm{McGee}, \mathrm{T}$. J. The Sound of Medieval Song. Ornamentation and vocal style according to the treatises (Oxford, 1998), p. 120 
The two incipits of Jacob of Liège ${ }^{348}$ :

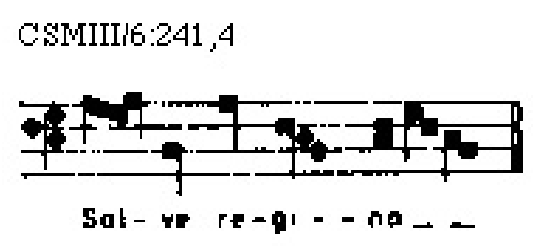

Fig. 52. The incipit Salve Regina from the sixth book of Speculum Musicae Liber

CSII 328,6

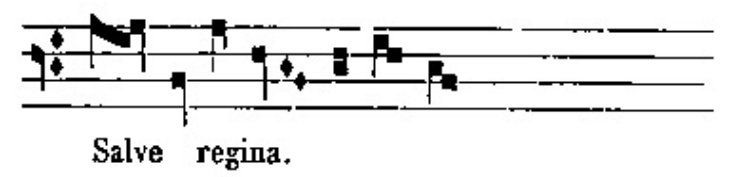

Fig. 53. The incipit Salve Regina in the same book

Here is the first part of the Salve Regina as it appears in the Salzinnes Antiphonal CDN-Hsmu M2149.L4 of $1555^{349}$, the only complete digitalized version: 


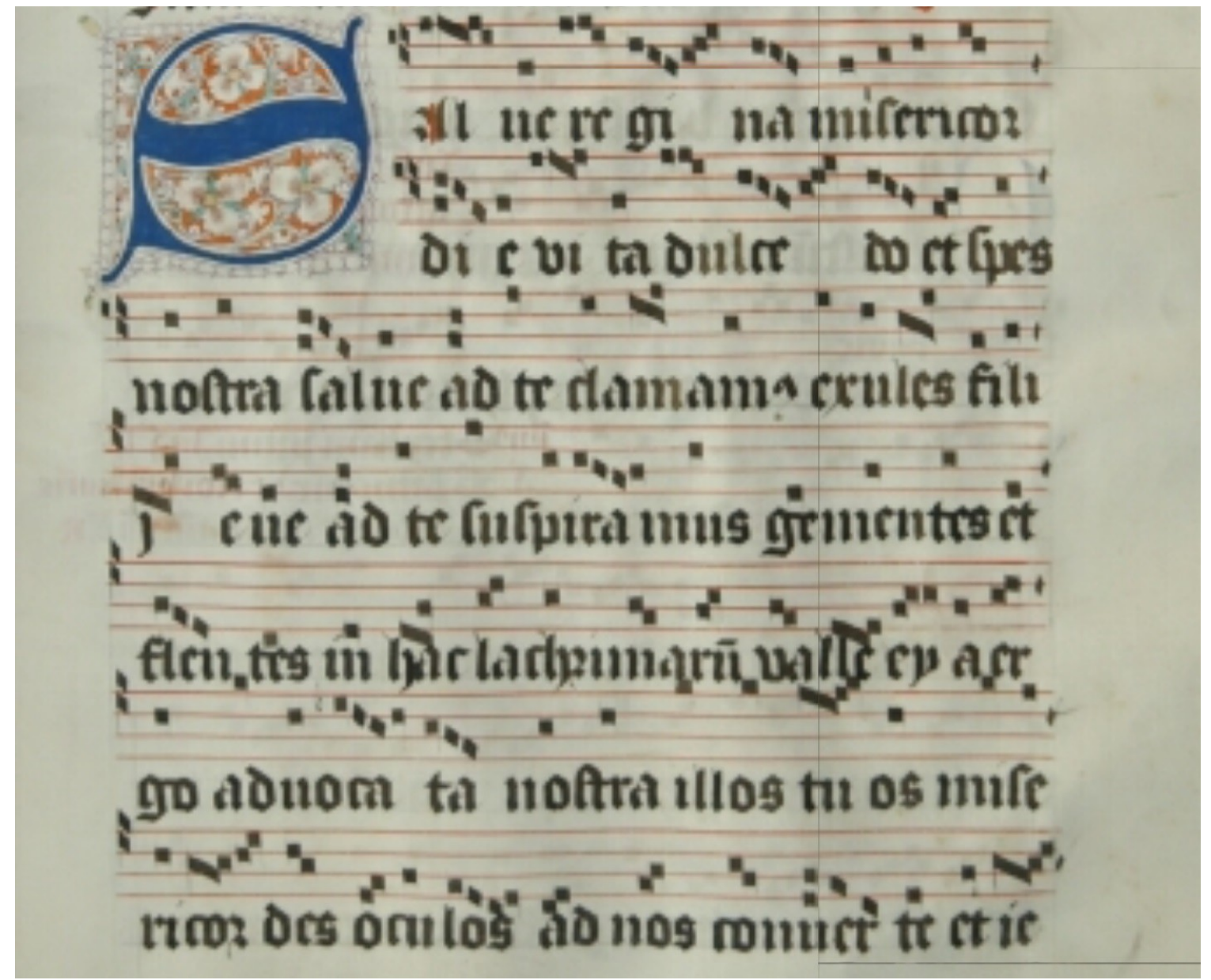

Fig.54. Fragment of Salve Regina in the Salzinnes Antiphonal of 1555

To compare this melody with a very early version, we include this diastematic neume fragment of the $12^{\text {th }}$ century Austrian Klosterneuburg ${ }^{350}$ :

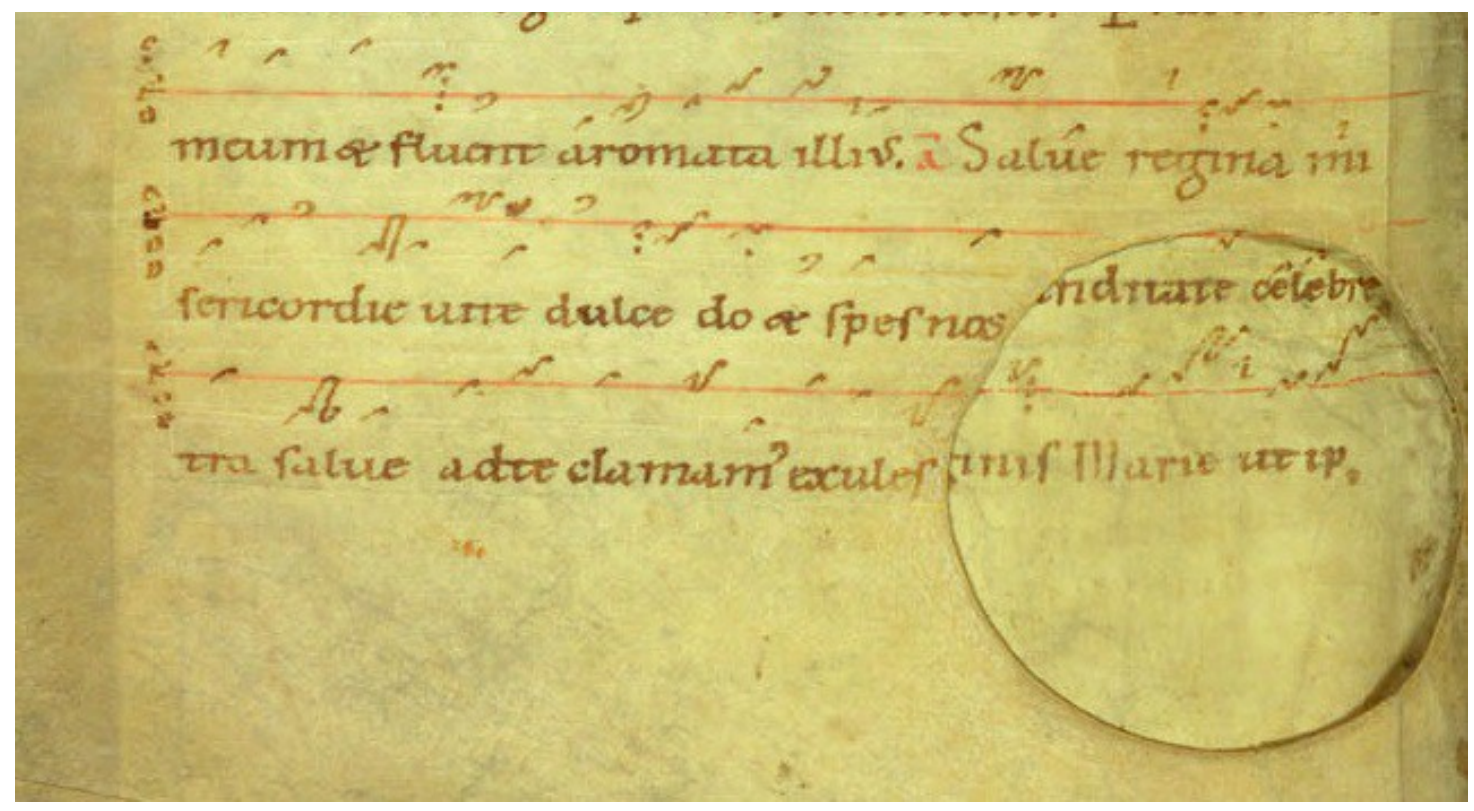

Fig. 55. Salve Regina in the 12th century manuscript from the Klosterneuburg monastery in Austria

350 Klosterneuburg Austria (AT5000-1012_48v), 12 ${ }^{\text {th }}$ century, http://www.ksbm.oeaw.ac.at/images/AT/5000/AT50001012/AT5000-1012 48v.jpg 
At the beginning of this Salve Regina we see the neume connecting the repeated notes. Its form does not indicate necessarily any ornament, since the single neumes all end in a downward note-like dot.

We have based our transcription on the incipits of Jacob of Liège and its continuing phrase on the Salzinnes Antiphonal of 1555. For Incipit we only used the chant until the words in hac lacrimosa valle ("in this valley of tears"). It was important to include this last phrase, because the souls are literally in a valley, waiting until they can finally ascend to Purgatory Proper. Below is our transcription of this part of Salve Regina.
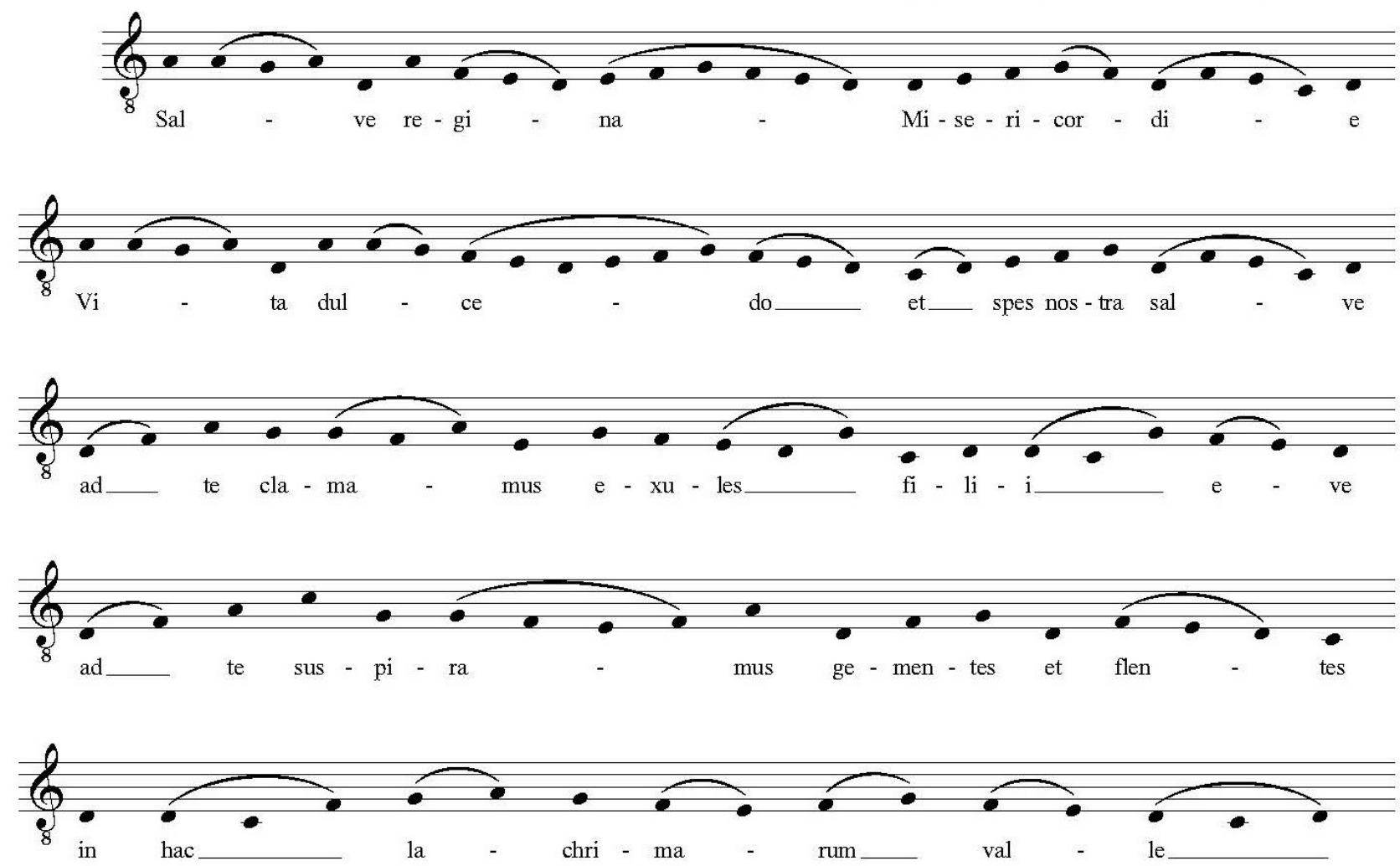

Fig. 56. Transcription of the Salve Regina based on the different sources

The chant Te lucis ante (Purgatory 8.13) is an old Latin hymn. It is the hymn at Compline ${ }^{351}$ in the Roman Breviary ${ }^{352}$. It was already found in a hymnary of the eighth or early ninth century, and might be even older. Musicologist Susan Boynton defines the Latin hymn as " a strophic composition, sung in the Divine Office, with a metrical poetic text and a predominantly syllabic melody. 'Hymn' here designates compositions for the Office, as distinguished from other liturgical poetry. In the Middle Ages some hymns were also sung outside the Divine Office, such as Pange

351 Compline is the final church service of the day in the Divine Offices of the Canonical Hours (see chapter 1).

352 The Roman Breviary is the liturgical book of the Latin liturgical rites of the Catholic Church containing the prayers, hymns, Psalms, readings, and notations for everyday use, especially in the Divine Office of the Canonical Hours. 
lingua for the Veneration of the Cross on Good Friday, and stichic ${ }^{353}$ hymns for processions. (...) Many hymn melodies were transmitted internationally, while others were of limited local usage. The wide variation between sources sometimes makes it difficult to identify concordances." 354

Indeed, in the digitally available sources there are many differences between the different version of the hymn Te lucis ante. For the music theatre work Incipit we have chosen a version with a written down additive voice. The author of this thesis has not encountered any cases of notated cantus planus binatim $^{355}$ other than this example and another 2-voice version of Te lucis ante in the same manuscript. The other version contains much more parallel movement in fifths, therefore we have not chosen that version for Incipit. Both are from a late $14^{\text {th }}$ century antiphoner from the Abbey of Sankt Lambrecht (Steiermark, Austria). ${ }^{356}$ In the scene of Purgatory where this hymn is sung, a soloist is singing the melody once alone and is then joined by the choir. The soloist would sing the same as the choir; there is no record of a soloist singing another voice simultaneously with the choir. It could be, though, that the choir would sing the two voices. Although this two-voice version is probably a regional setting, we have chosen it because of its exemplary value of $14^{\text {th }}$ century organum from a peripheric area. Musicological research of the archive of the Florence cathedral could perhaps give more clarity if this hymn is found. Below are both originals and transcriptions so that their different types of organum can be observed.

353 Poetry made up of lines of the same approximate meter and length, not broken up into stanzas.

354 Warren Anderson, et al. "Hymn." Grove Music Online. Oxford Music Online. Oxford University Press, http://www.oxfordmusiconline.com/subscriber/article/grove/music/13648 [accessed November 7, 2014]

355 The normally improvised practice of two-voice organum.

356 Antiphonarium Benedictinum, Benediktinerstift St. Lambrecht, UBG.Ms.29, http://www.literature.at/viewer.alo? $\underline{\text { objid }=1138 \& \text { viewmode }=\text { fullscreen } \& \text { scale }=2 \& \text { rotate }=\& \text { page }=760}$ 


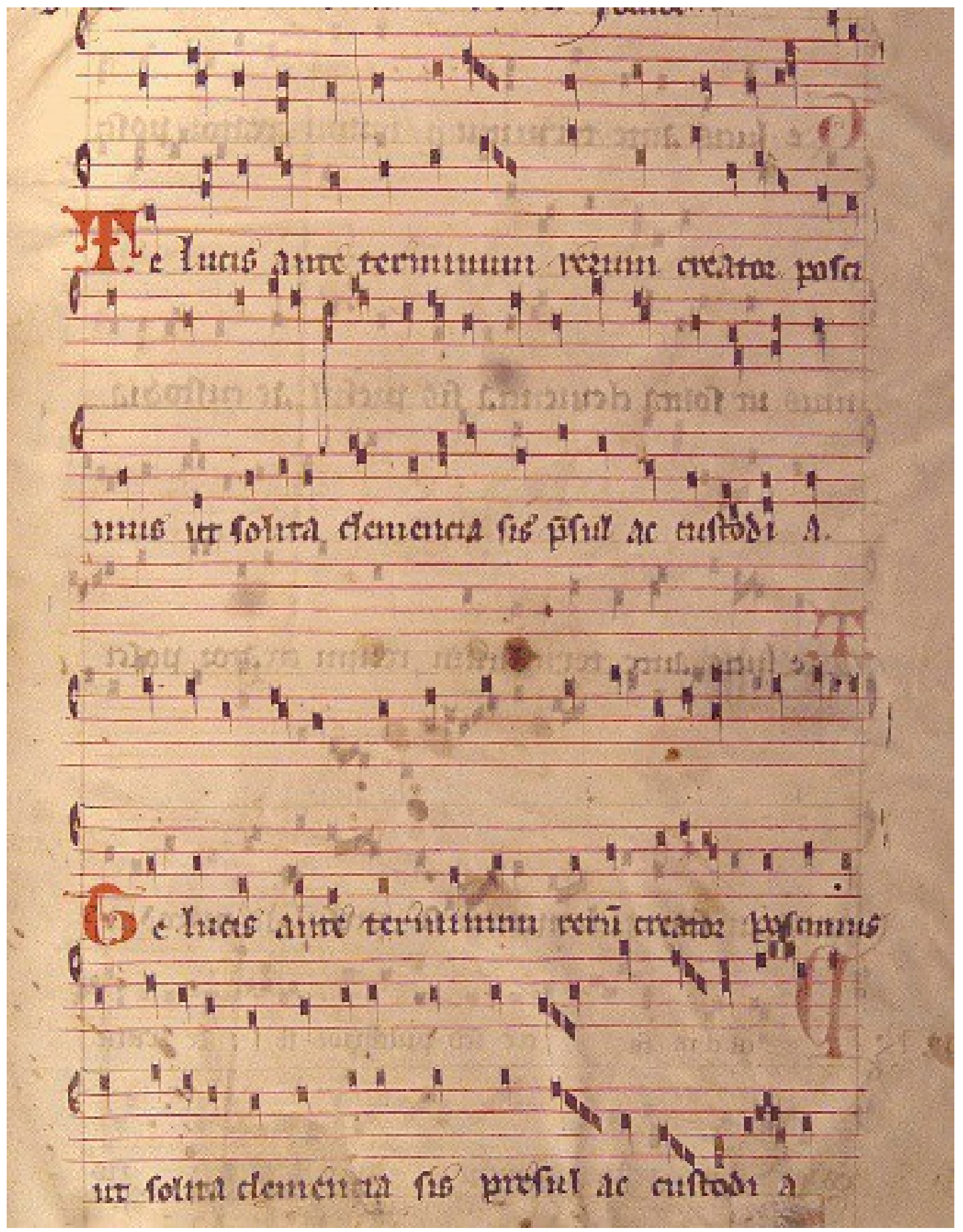

Fig. 57. Two two-voice versions of Te lucis ante in the 14th century Antiphonarium Benedictinum of St. Lambrecht

Below are the two transcriptions. The first has been chosen for the performance of Incipit. 

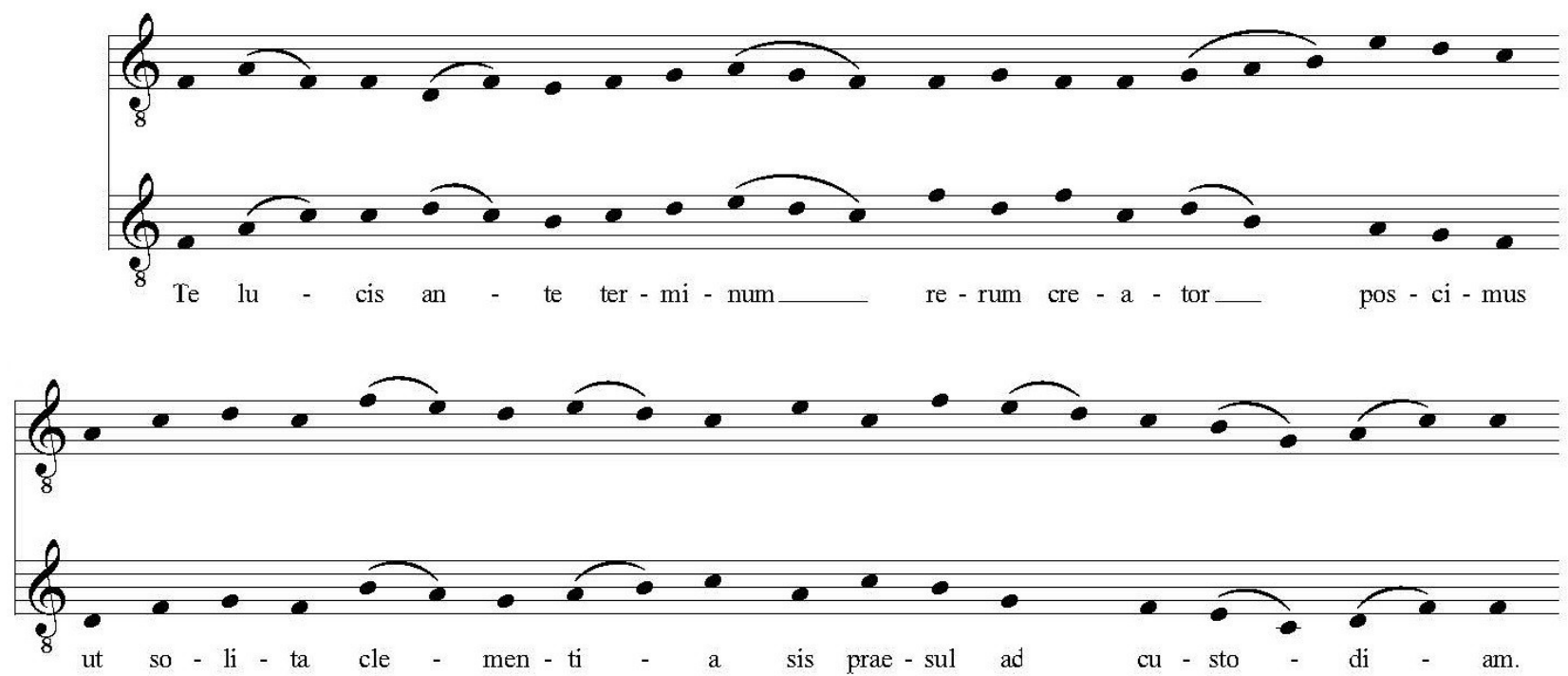

Fig. 58. Transcription of the first Te lucis ante from the Antiphonarium Benedictinum of St. Lambrecht
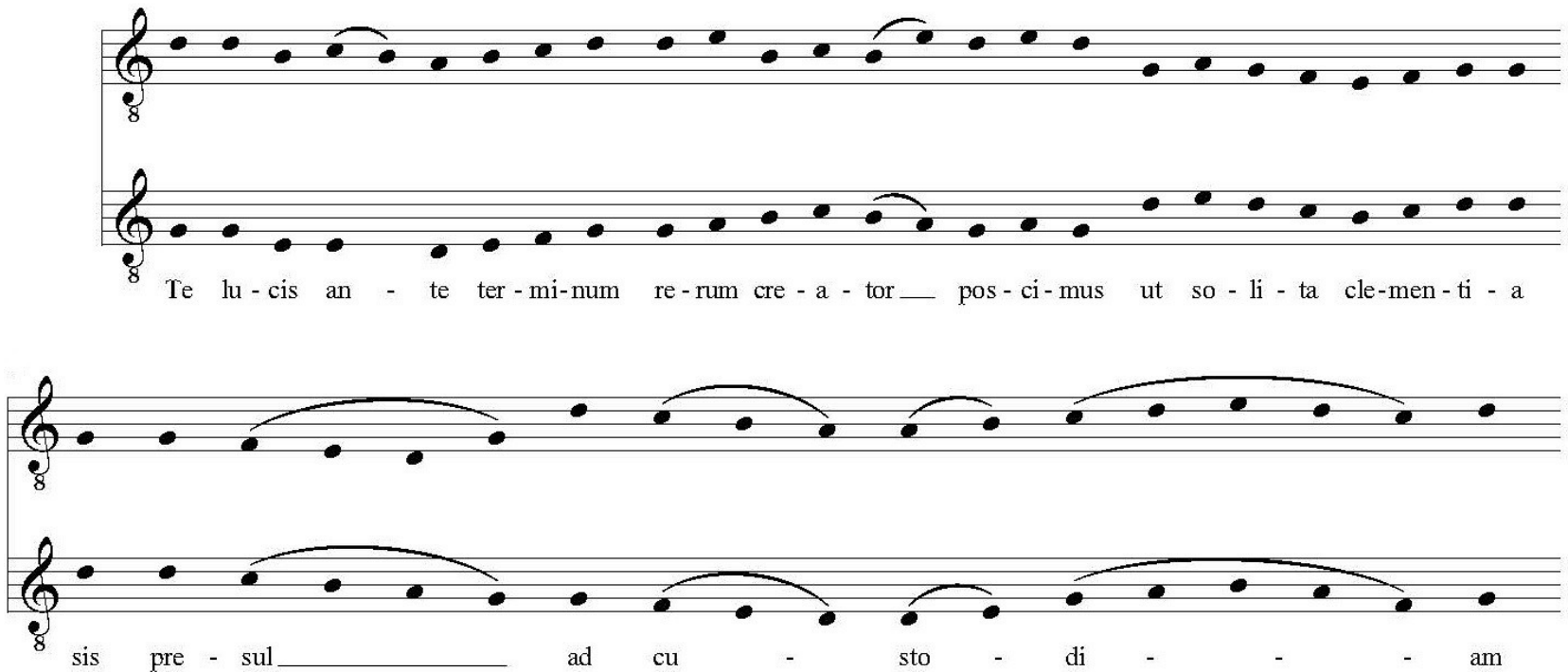

Fig. 59. Transcription of the second Te lucis ante

In both versions parallel fifths are common, but especially the second Te lucis ante contains parallel movement. They also show that voice-crossing is common. In the first version, on the word creator the original voice has 4 notes while the second voice has 5 notes. In the original the last three notes are grouped. In order to avoid the interval of a second, the first two notes of the additive voice ( $\mathrm{g}-$ a) should be sung double as fast. In our rehearsal and recording process, we experimented with the option of treating the additive voice as if it were independent. Rhythms were not written and it is unclear if the rules that Jerome of Moravia ${ }^{357}$ set out were also followed in Italy. Some of his rules 
are even ambivalent ${ }^{358}$, but at present they are the only surviving set of rules for plainchant from Dante's time. ${ }^{359}$ In general, we have followed his rules in lengthening the first note, the last note and - if necessary for the natural binary rhythm - the penultimate note of each phrase. Sometimes we have lengthened the second note of a melisma ${ }^{360}$, where it did not interrupt the natural flow. We have tried to follow a natural rhythm, following the accents of the text. In the case of the word creator, in the original melody it is logical to lengthen the syllable of a (re-rum cre- $\underline{a}$-tor). In this way, there are long notes and short notes. To insert even shorter notes in the additive voice would not have been the most evident choice for its melodic flow. Our experiment was to make all syllables of the word creator of the same duration. The result was that the syllable tor did not coincide in the same moment for both voices. Both options are unusual, but after the rehearsal and recording process our conclusion is that the option to sing all syllables at the same time and fit the faster notes on the syllable tor, would probably be more plausible. The notation seems to suggest such a solution and it seems more natural to have the syllables coincide in both voices.

The Te Deum (Purgatory 9.140), sung by “voice(s)" mixed with the clangour of the entrance gate to Purgatory Proper ${ }^{361}$, is listed in many manuscripts from the $14^{\text {th }}$ century but apparently it was so well known that the melody was not notated in all manuscripts that are indexed on cantusdatabase.com (http://cantusdatabase.org/id/909010). Its melodic incipit appears in only two $14^{\text {th }}$ century sources, while an entire Te Deum appears in a Post-Tridentine ${ }^{362}$ manuscript. Below are the incipit from the $14^{\text {th }}$ century antiphoner sbe-0611_122v from the monastery of Einsiedeln (Switzerland) ${ }^{363}$, the incipit from the $13^{\text {th }}$ century Bréviaire de Paris ${ }^{364}$ and the full version from the $16^{\text {th }}$ century Cistercian antiphonal CDN-Hsmu M2149.L4 from the Abbey of Salzinnes (Belgium) ${ }^{365}$

to have worked in Paris at a Dominican convent. His treatise Tractatus de Musica is an encyclopedic discussion of the most important aspects of music in his time, especially those of plainchant.

358 In practice, his rule of lengthening the second note in a melisma often leads to odd results and has to be ignored regularly.

359 See chapter 1 .

360 This created a flowing movement which we would call a syncope (short - long - short). Indeed, the secular music of some decades later shows a considerable number of such "syncopic" rhythms, which could indicate that in musical practice they were already common.

361 "in voce mista al dolce suono". See chapter 4.

362 After the reforms of the Council of Trent (1545-1563). See chapter 1.

$363 \mathrm{http}: / / \mathrm{www} . \mathrm{e}-$ codices.unifr.ch/en/sbe/0611/122v

$364 \mathrm{http}: / /$ gallica.bnf.fr/ark:/12148/btv1b8447768b/f374.item

$365 \mathrm{http}: / /$ salzinnes.simssa.ca/\#z=2\&n=5\&i=1-122v.tif\&y=1 


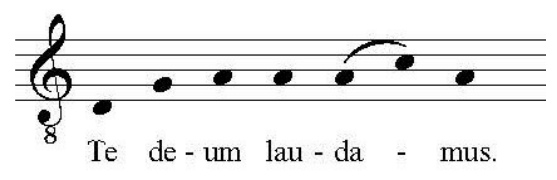

Fig. 60. Transcription of Incipit of Te Deum

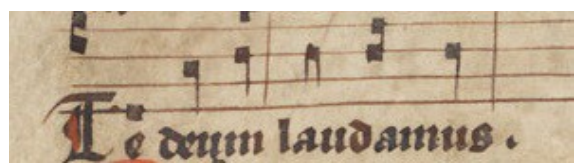

Fig. 61. Incipit of Te Deum

(Einsiedeln, Switzerland)

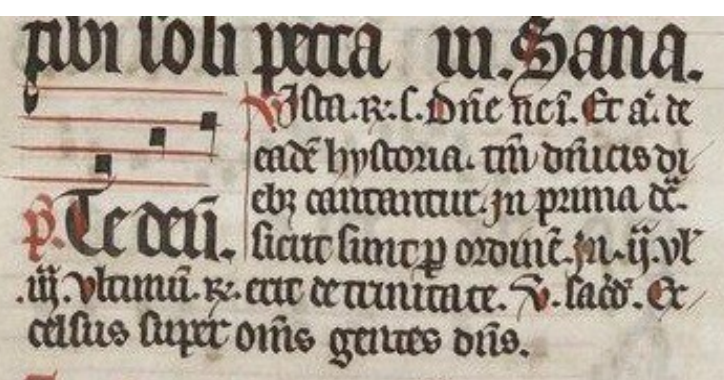

Fig. 62. Incipit of Te Deum (Bréviaire de Paris)

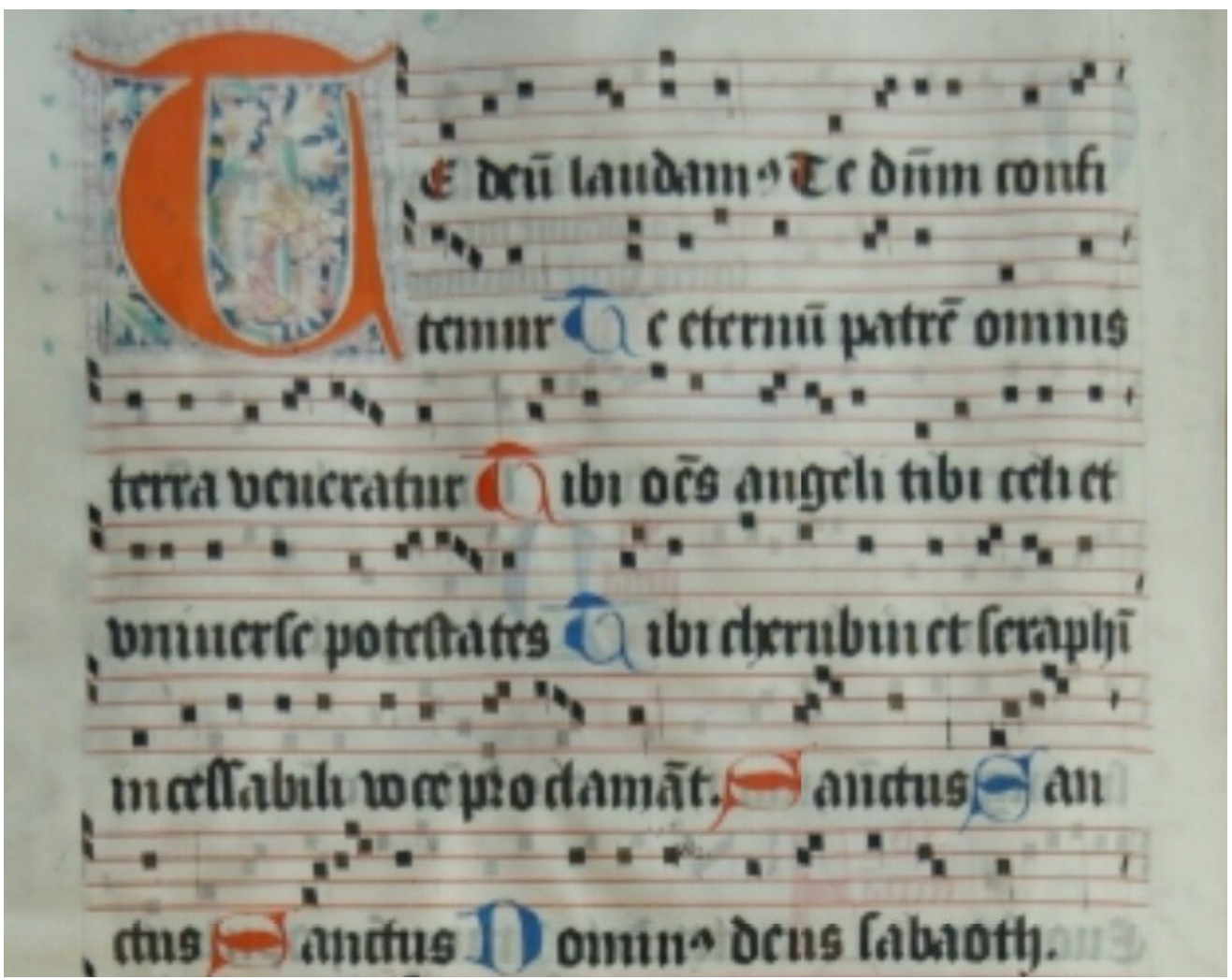

Fig. 63. First part of Te Deum in the Salzinner Antiphonal 
The transcription of the Te Deum until Domine deus sabaoth is as follows:
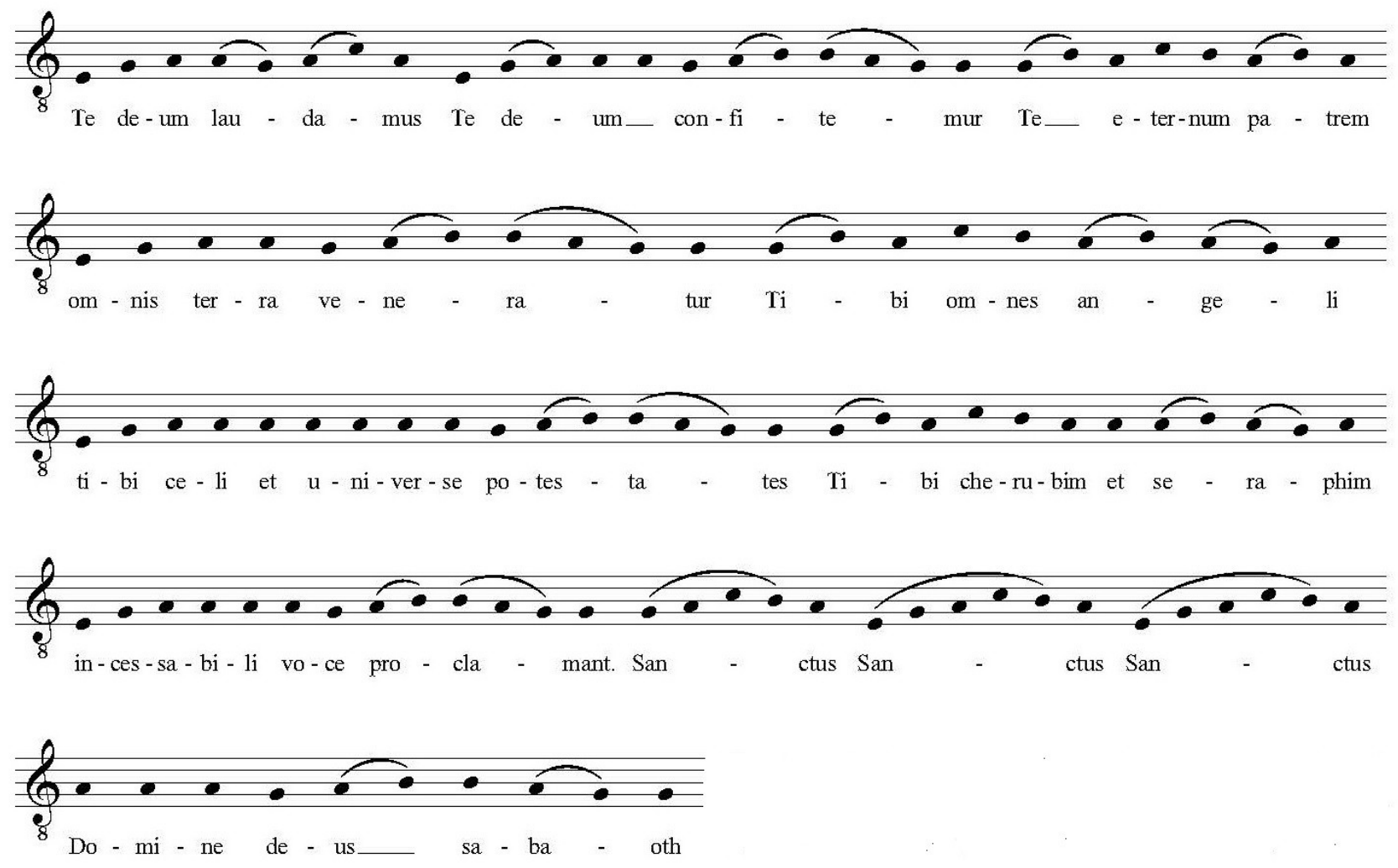

Fig. 64a. Partial transcription of Te Deum

For the Te Deum a second voice was composed. In chapter 4 the notes of Francesco Ciabattoni were cited on this passage in the Commedia. Since the text says in voce mista al dolce suono (literally "voice mixed with that sweet strain"), it is not clear if it is about one voice or about vocal sound in general. Dante also wrote in this passage that the impression of the sound was as if con organi is sung (a cantar con organi si stea). We have seen the various possible interpretations of these words in chapter $4 .{ }^{366}$ We have opted for two-voice organum, above the highly stretched sound of the clangour of a gate. ${ }^{367}$ In this way, we included the two possibilities mentioned by Ciabattoni. In Dante's Paradise a Te Deum is sung; the Te Deum of Purgatory's entrance gate has been resumed there, but in a three-voice setting. We will come back to it in our discussion of the music in Paradise. Below is the Te Deum with the second voice we composed according to the rules of improvised organum around 1300:

366 Either to sing organum, or to sing with an organ. The latter option is unusual, because even if a church had an organ, it was not meant to be played simultaneously with the singing. On the other hand, it could well reflect a poetical idea.

367 This was done with paulstretch in Audacity. The result was a drone accompanying the first phrase of the Te Deum, until the closing of the gate. 

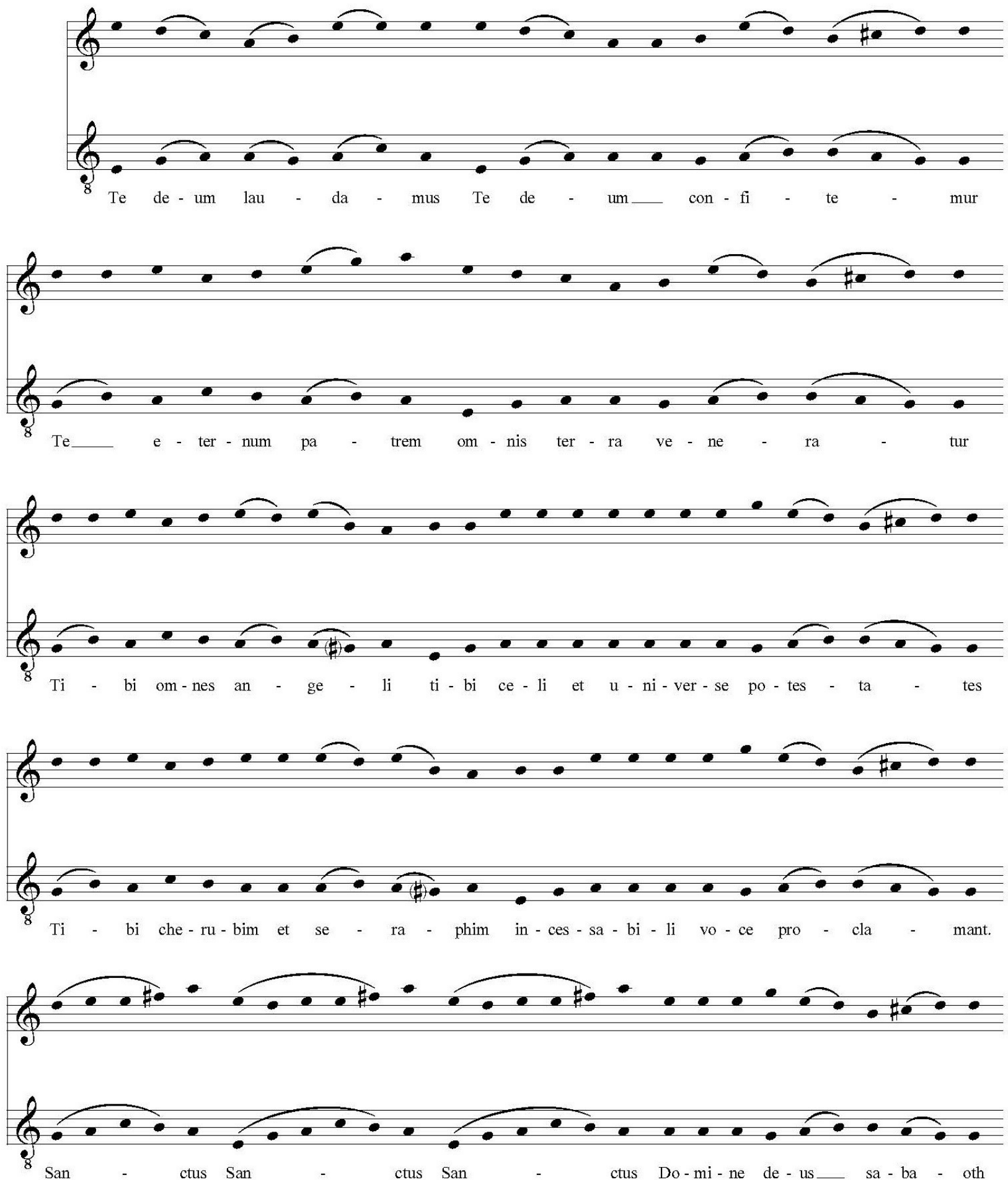

Fig. 64b. Te Deum a 2. 
One of the names given to improvised organum in the Middle Ages is cantus planus binatim, a term which was assimilated by music historian Franco Alberto Gallo from a treatise of Prodoscimus de Beldemandis (ca. 1400). In 1980, an international congress on this kind of organum ${ }^{368}$ was held at Cividale del Friuli. The book Le Polifonie primitive in Friuli e in Europa: Atti del congresso internazionale Cividale del Friuli, 22-24 agosto $1980^{369}$ was the report of the contributions in the congress. In 1993, Shai Burstyn wrote an article on the contrapuntal movements given in LateMedieval and early Renaissance treatises and examples found in musical works. ${ }^{370}$ In this article, the basis rules are already summarized. Also the singer and doctorandus at Leiden University Niels Berentsen $^{371}$ bases his writing on various treatises on improvised organum. His article "From Treatise to Classroom: Teaching Fifteenth-Century Improvised Counterpoint" includes the basic rules for this improvised practice ${ }^{372}$ :

- from a unison to a third;

- if it is a minor third ${ }^{373}$, it has a tendency to go to a unison;

- if it is a major third ${ }^{374}$, it has a tendency to go to a fifth;

- from a fifth either back to third or opening to an octave. It can take the detour of a major sixth.

- From an octave to a fifth.

As chapter 1 has shown, only the $\mathrm{b}$ flat fitted in the hexachord system. All notes that fitted in the hexachord system were called musica recta, while the other notes were collected under the term musica ficta ("false music"). Following the rules for improvised organum, there are moments in which musica ficta is the best solution. In the case of our transcription, c sharp was added to the composition of the second voice in order to be able to open up to a fifth. If we would have left the $\mathrm{c}$ natural, it would have had the tendency to return to a unison, which would have been less aesthetic and it would force the music to stay in unison and third. However, sharpening the c would pull it toward a fifth; from there on the music could develop with much more ease. The c sharp would not have been notated, it would just have been performed. The practice of organum according to these

368 In the congress it was mainly called "primitive polyphony".

369 Ed. C. Corsi and P. Petrobelli, Le polifonie primitive in Friuli e in Europa [Cividale del Friuli 1980] (Rome, 1989)

370 Burstyn, S., "Contrapuntal texture in non-learned medieval polyphony", ed. Meyer, C., Polyphonies de tradition orale: histoire et traditions vivantes (Paris: Éditions Creaphis, 1994)

371 His doctoral thesis, Discantus and Cantare super librum : towards a practical understanding of 14th and early 15 th century counterpoint will go deeper into improvised and non-improvised polyphony of these two centuries.

372 Berentsen, N., "From Treatise to Classroom: Teaching Fifteenth-Century Improvised Counterpoint", Journal of the Alamire Foundation 6/2 - 2014, especially p.228 where he explains that these rules were reflected in various $14^{\text {th }}$ century treatises.

373 Smaller than the minor third in equal temperament and much smaller than the minor third in mesotonic temperament, so it "pulls" toward the unison. See chapter 1.

374 Larger than the major third in equal temperament and much larger than the peaceful major third in mesotonic temperament, therefore it tends to "pull" outwards to the fifth. See chapter 1. 
rules makes much clearer why musica ficta emerged. For musicians performing Medieval music, this practice would be very helpful to let them understand at what moments in music they can apply musica ficta or explain to them the mechanism behind their intuitive musical decisions. The f sharp was used in order to obtain a perfect fifth against the b. Finally, g sharp was notated between brackets, indicating that it is not original, but probably it was done at cadences, in order to get a minor third with the second voice which would resolve into a unison.

Two identical versions were found of the first Beatitude, Beati pauperes spiritu (Purg. 12.110), in Switzerland and Austria. ${ }^{375}$ We therefore have assumed this was a standard melody throughout Europe.

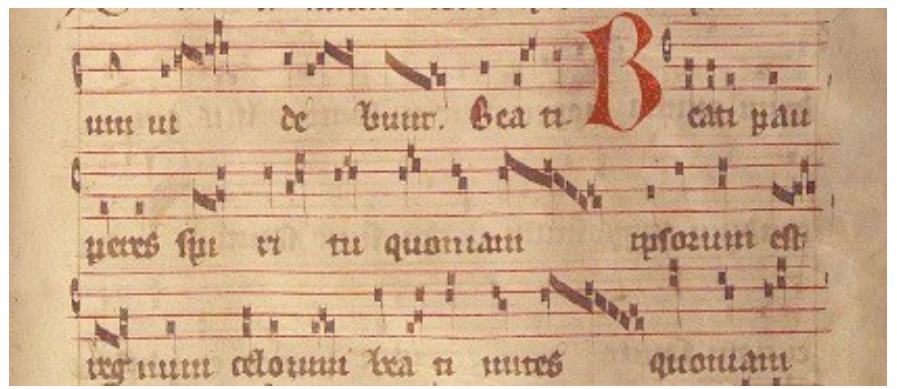

Fig. 65. Beati pauperes spiritu, Benediktinerstift St.

Lambrecht, Antiphonarium Benedictinum Pars aestiva (1400)

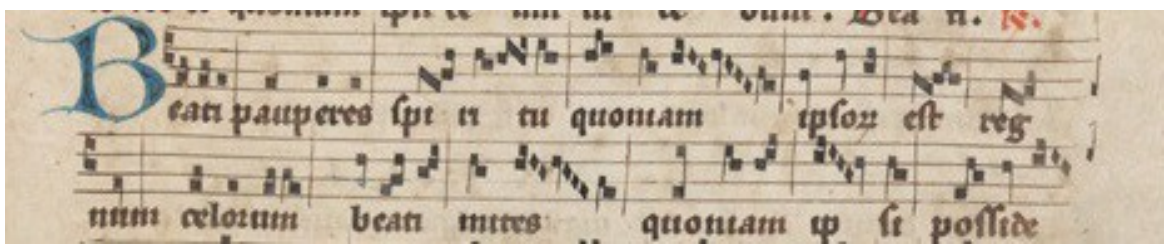

Fig. 66. Beati pauperes spiritu, Antiphonarium pro Ecclesia Einsidlensi (prior to 1314)

We have assumed that all the angelic Beatitudes are monophonic (see chapter 4). Our transcription is as follows:

375 Antiphonarium Benedictinum Pars aestiva, Benediktinerstift St. Lambrecht (Austria): http://www.literature.at $/$ viewer.alo? objid $=1141 \&$ viewmode $=$ fullscreen\&scale $=2 \&$ rotate $=\&$ page $=583$ and Einsiedeln, Stiftsbibliothek, Codex 611(89), f. 239r - Antiphonarium pro Ecclesia Einsidlensi, http://www.ecodices.unifr.ch/en/list/one/sbe/0611 

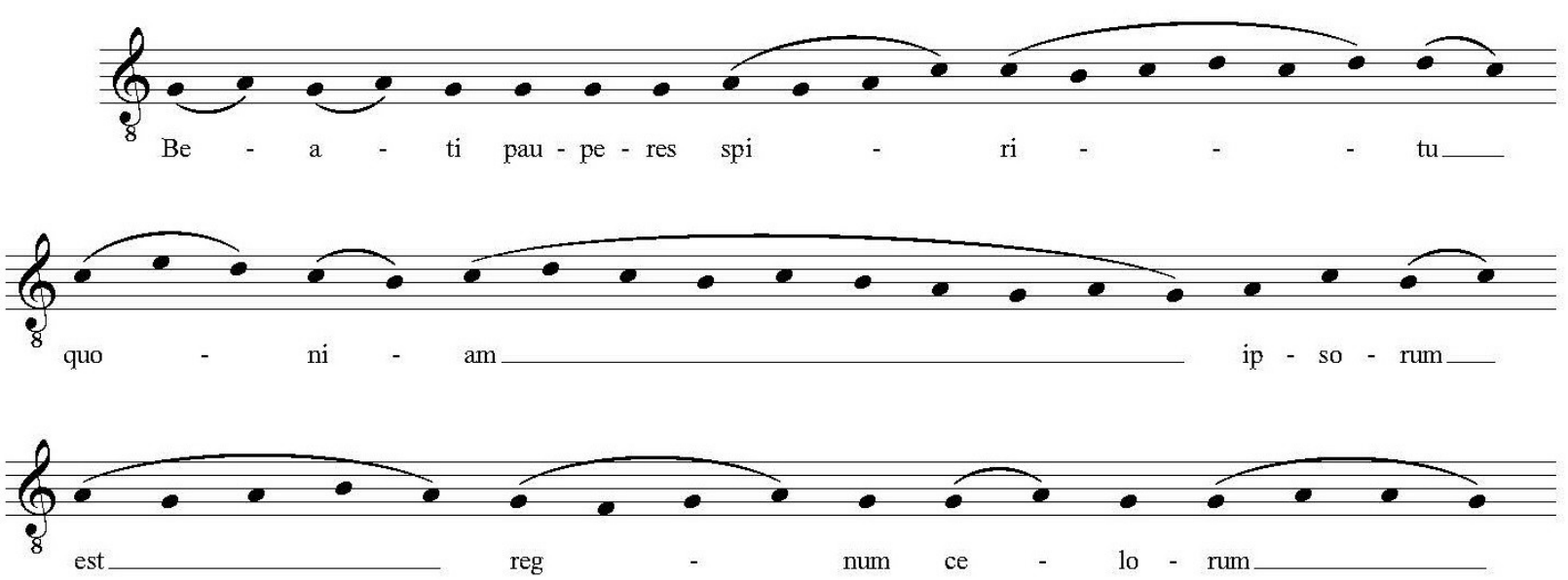

Fig. 67. Transcription of Beati pauperes spiritu

For the Litany of All Saints we have used the standard modern recitation melody because there are no historical sources containing its musical score. We only encountered its incipit of Kyrie Eleison, which nowadays is sung on a different tone than the rest of the chant. We based our melodic line (f $-\mathrm{g}-\mathrm{e} ; \mathrm{e}-\mathrm{d}-\mathrm{e}-\mathrm{f}-\mathrm{f}$ ) on practices as recorded in an audio format. ${ }^{376}$

Beati misericordes and Gaudete et exultate "ring out" in song at the gate at the end of the terrace of the envious (Purgatory 15.39-40). We encountered a very similar melody for both of them in $14^{\text {th }}$ century manuscripts, which reinforces the idea that Dante, in coupling these two, might have thought of these melodies. ${ }^{377}$

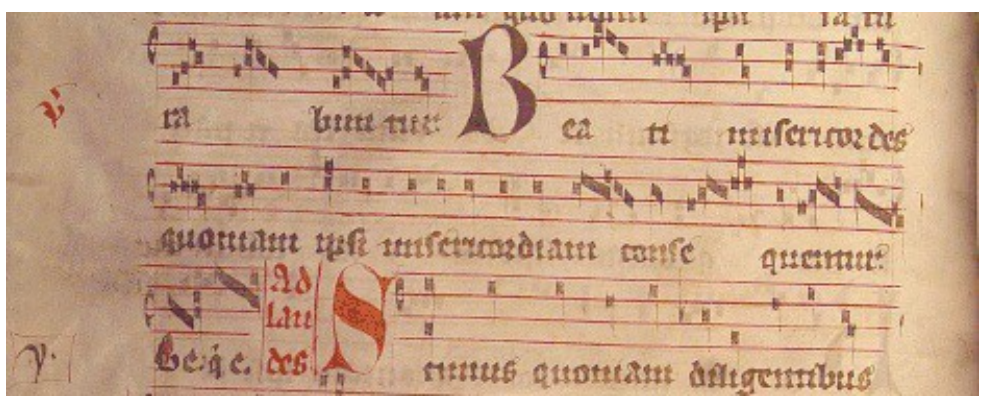

Fig. 68. Beati misericordes, Benediktinerstift St.

Lambrecht, Antiphonarium Benedictinum Pars aestiva (1400)

376 These two links lead to the same audio of a recording of the Litaniae Sanctorum: https://www.youtube.com/watch? $\mathrm{v}=\mathrm{jb} 23 \mathrm{Z} 5 \mathrm{X} 3 \mathrm{uhA}$ and https://www.youtube.com/watch? $\mathrm{v}=6$ ExmMllyuLE. The accompaniment of the organ has not been included in our performance due to the fact that this is a much newer practice.

377 The two versions of Beati misericordes can be found on http://www.literature.at/viewer.alo?

objid $=1141 \&$ viewmode $=$ fullscreen $\&$ scale $=2 \&$ rotate $=\& p a g e=582$ and http: $/ /$ www.e-

codices.unifr.ch/en/sbe/0611/239r and the version of Beati misericordes on

http://gallica.bnf.fr/ark:/12148/btv1b6000531z/f404.image 


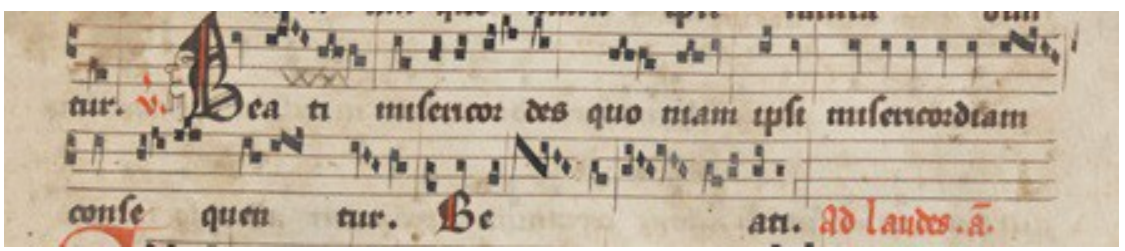

Fig. 69. Beati misericordes, 14th-century antiphoner from the monastery of Einsiedeln (Switzerland)

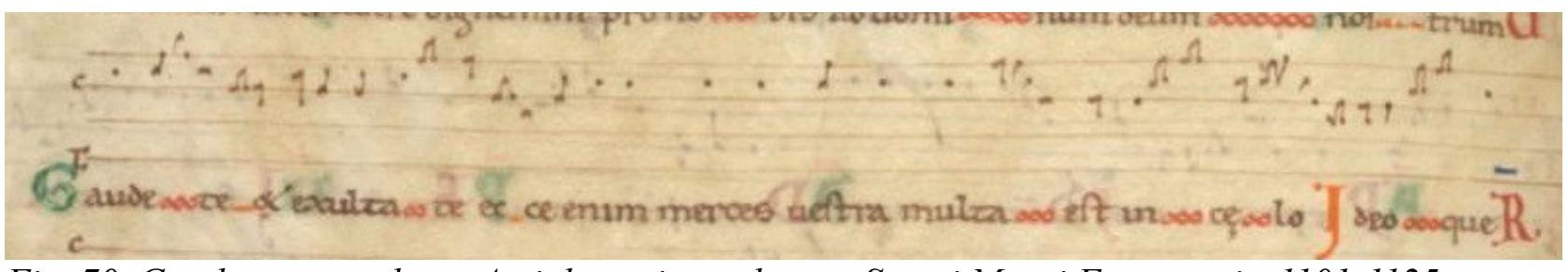

Fig. 70. Gaudeate et exultate, Antiphonarium ad usum Sancti Mauri Fossatensis, 1101-1125 (France)

The $12^{\text {th }}$ century version of Gaudeate is a bit more difficult to understand. What seems to be two connected eighth note stems are in fact notes themselves. There are no note staffs, the lines are connecting two notes. This versions shows a very similar melody to the melody of the Beati misericordes, as the transcriptions show more clearly.
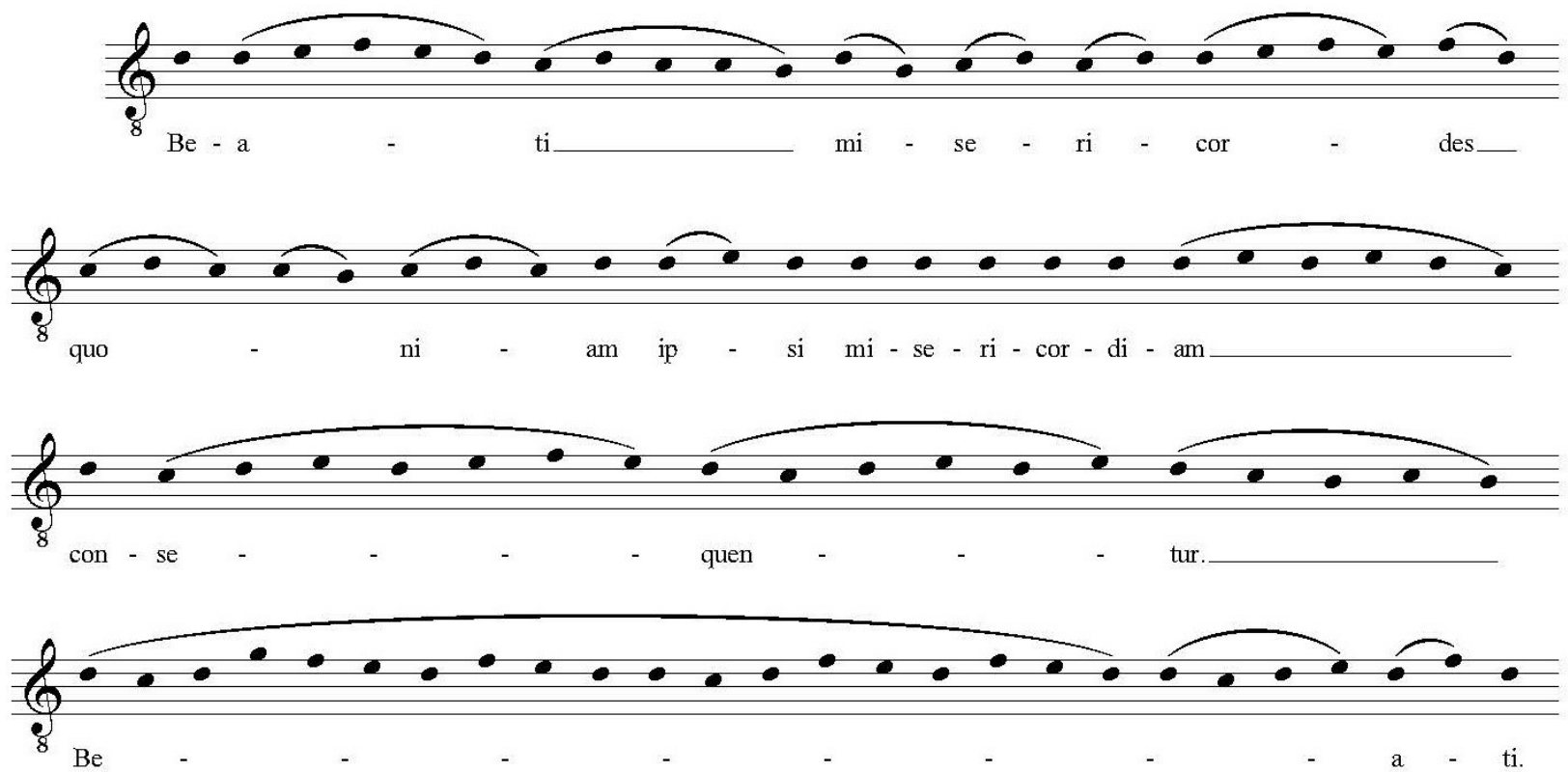

Fig. 71. Transcription of Beati misericordes 

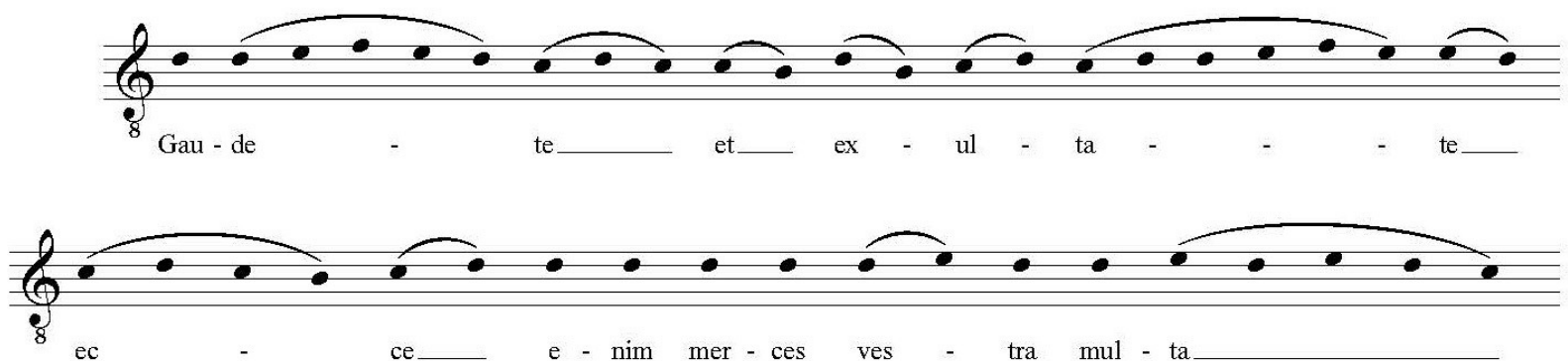

- ce_e e - nim mer - ces ves - tra mul - ta

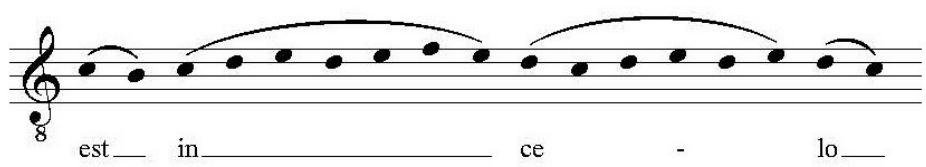

Fig. 72. Transcription of Gaudete

There are very few indexed versions of Agnus Dei (Purgatory 16.19) and none are digitalized on cantusdatabase.org. In the book Il canto fratto nei manoscritti della Fondazione Biblioteca S. Bernardino di Trento ${ }^{378}$ there is a transcription of an Agnus Dei from Parma, Archivio della Fabbriceria del Duomo, ms F-4 cod. 301v. (14 ${ }^{\text {th }}$ century). This would be the closest to Dante's time and area of all the versions of Agnus Dei that have been encountered. Our version is without his rhythmic interpretation. ${ }^{379}$
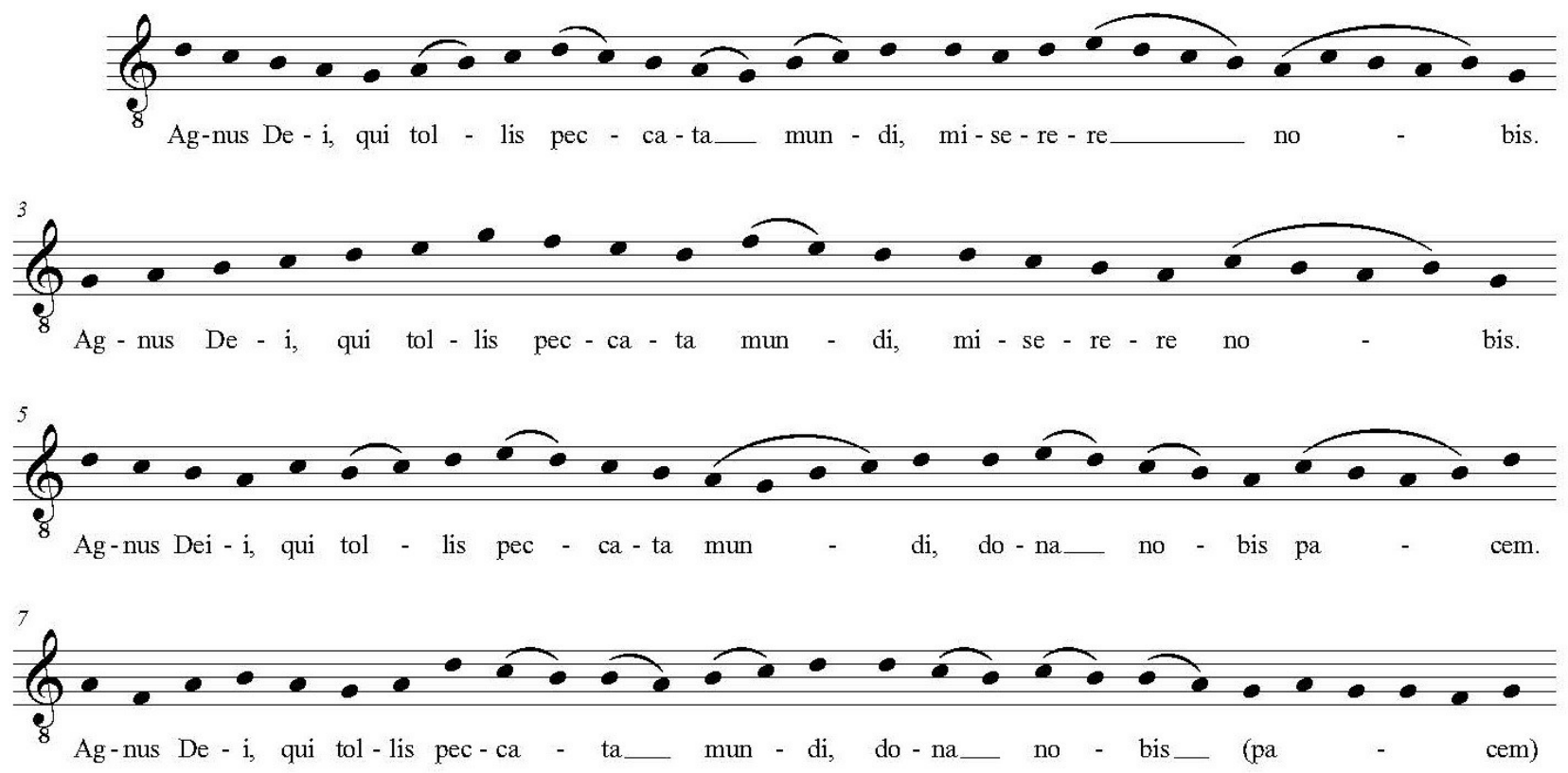

Fig. 73. Transcription of Agnus Dei

378 M. Gozzi , "La Missa di Parma", M. Gozzi (a cura di), Cantus fractus italiano: un'antologia (Hildesheim: Olms, 2012), p. 173-182.

379 The original does not appear in his book and there were several intents of communicating with Marco Gozzi without result. Therefore, we can only mention his transcription but not show it, nor can we show the original. 
Of the next Beatitude, Beati pacifici (Purgatory 17.68), there are only 2 digitalized versions, but more than 10 non-digitalized Italian versions. One of the two digitalized versions is in mode 1, just like the non-digitalized indexed versions. It is a $12^{\text {th }}$ century version ${ }^{380}$ :

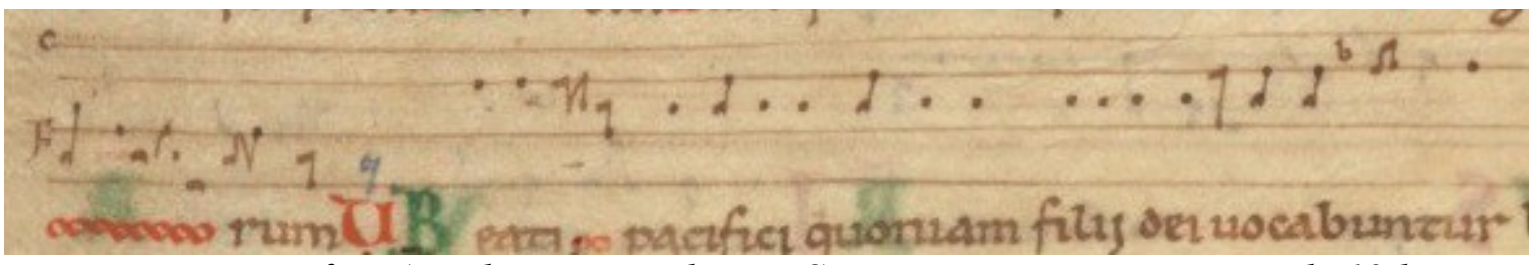

Fig. 74. Beati pacifici, Antiphonarium ad usum Sancti Mauri Fossatensis, early 12th century, St-Maur-F (France)

Its transcription is as follows:
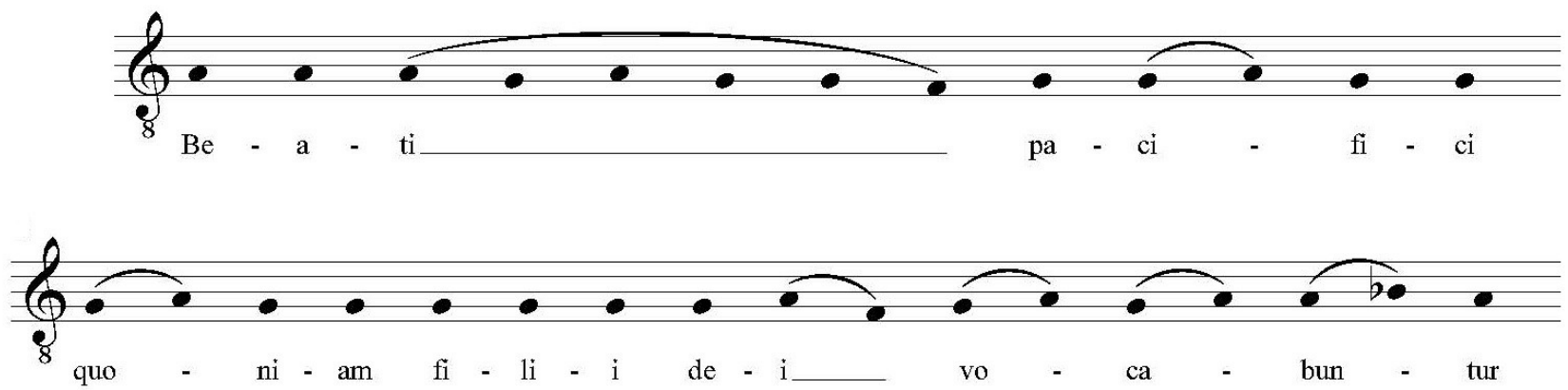

Fig. 75. Transcription of Beati pacifici

The sources of Beati qui lugent (Purgatory 19.50) are the same as the ones of Beati pauperes spiritu; this phrase seems to be the continuation of the same chant, including various beatitudes. 


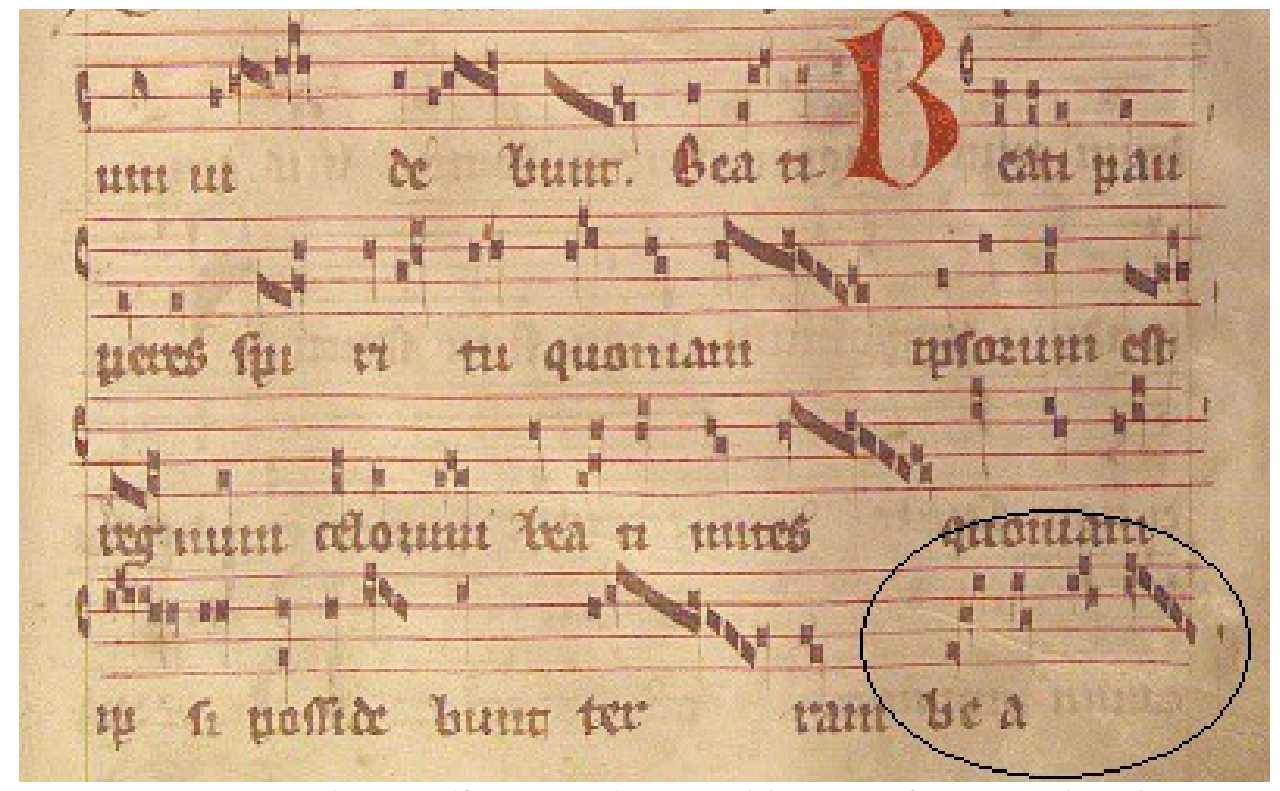

Fig. 76. Beati qui lugent (first page), Benediktinerstift St. Lambrecht, Antiphonarium Benedictinum Pars aestiva (1400)

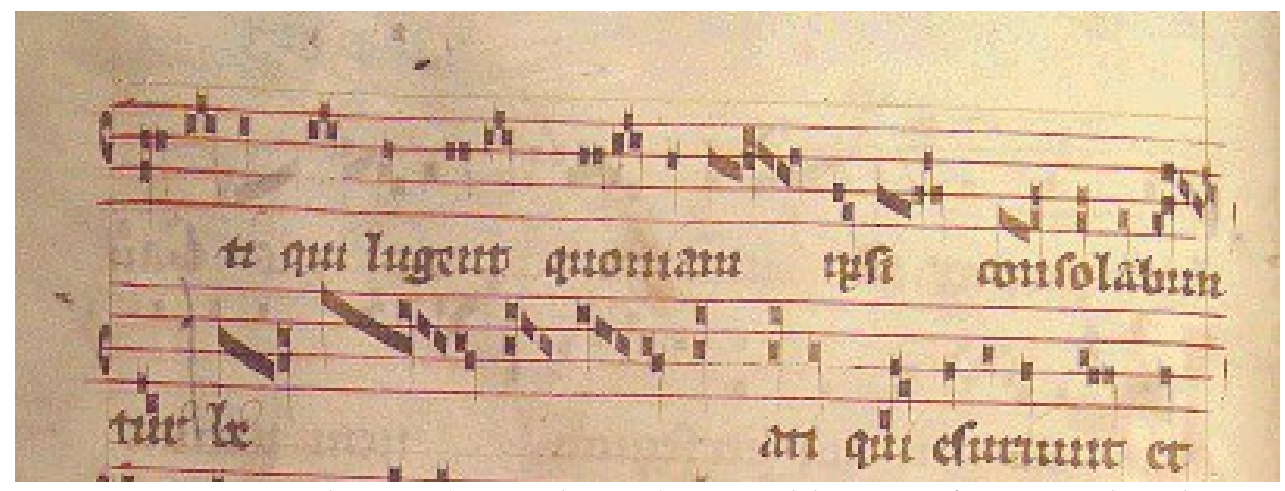

Fig. 77. Beati qui lugent (second page), Benediktinerstift St. Lambrecht, Antiphonarium Benedictinum Pars aestiva (1400)

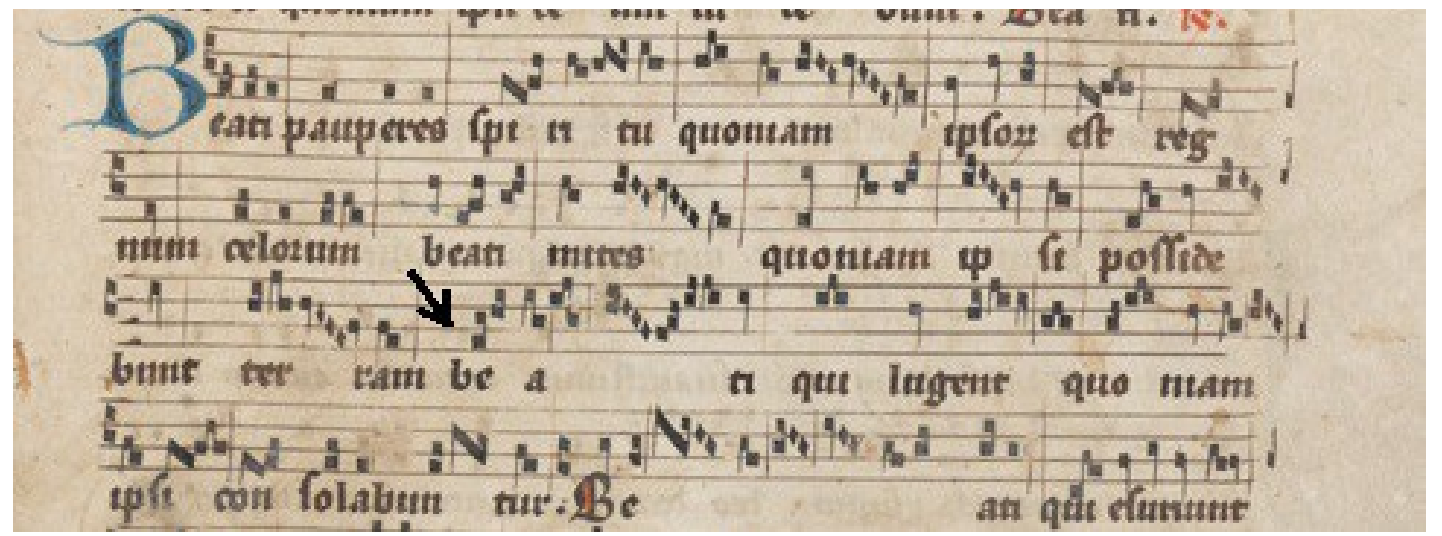

Fig. 78. Beati qui lugent, Antiphonarium pro Ecclesia Einsidlensi (prior to 1314) 

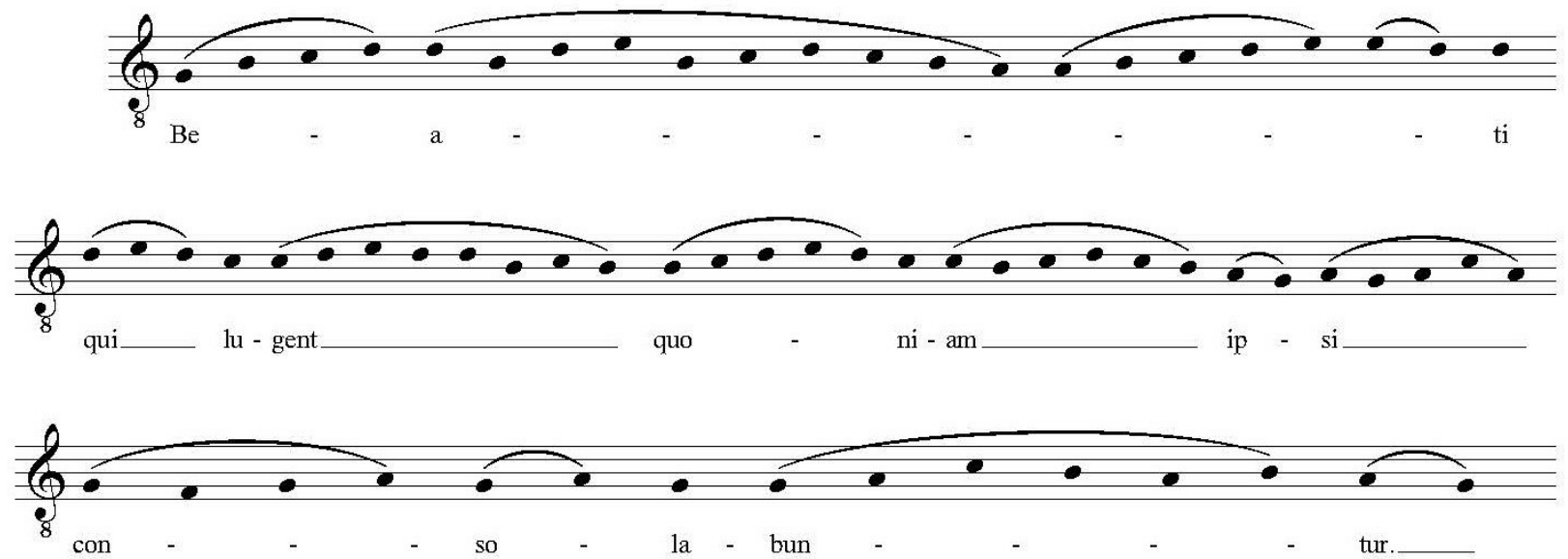

Fig. 79. Transcription of Beati qui lugent

Of the psalm Adhaesit pavimento anima mea (Purgatory 19.73) no historical notated version was found, so a psalm tone has been chosen for it. Through history, the eight modes have been associated to different moods, although their relation with specific moods changed over time and for different authors. We have followed the interpretation ascribed to Guido of Arezzo (995-1050) in which the first mode is serious, the second is sad, the third is mystic, the fourth is harmonious, the fifth makes happy, the sixth is devout, the seventh angelical, and the eighth is perfect. We have chosen the "serious" mode 1, Dorian.

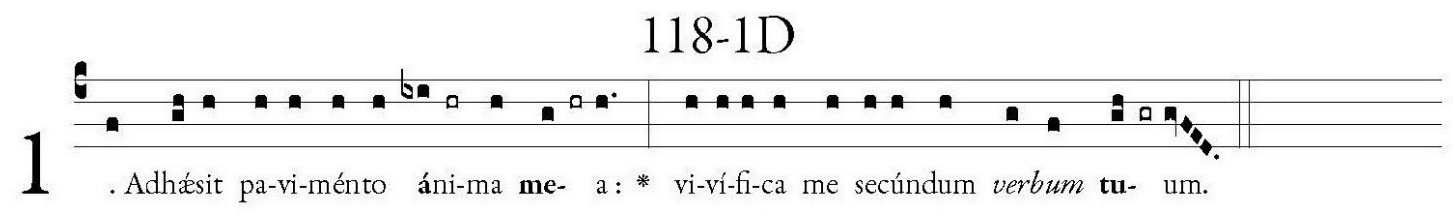

2. Vias meas enuntiávi et exaudísti me : * doce me justificatiónes tuas.

3. Viam justificatiónum tuárum ínstrue me : * et exercébor in mirabílibus tuis.

4. Dormitávit ánima mea præ tádio : * confírma me in verbis tuis.

Fig. 80. Adhaesit pavimento anima mea and its first four verses

There are more subsequent verses, but for the performance it was decided to sing verses 1 and 4 (" 1 . My soul has cleaved to the pavement: revive me according to thy word. 4. My soul has slept through heaviness: strengthen me in thy words). Both of these version have associations with lying 
down, with a heavy body that does not have the strength to separate itself from the ground, exactly what these avaricious souls in Purgatory are experimenting.

Gloria in excelsis Deo (Purgatory 20.136), sung by the souls when one of them is liberated from his purgation, was also used in Paradise for a three-voice organum. This composition will be discussed below with the other musical works in Paradise. The Swiss and Austrian sources coincide in their melody for the Gloria: ${ }^{381}$

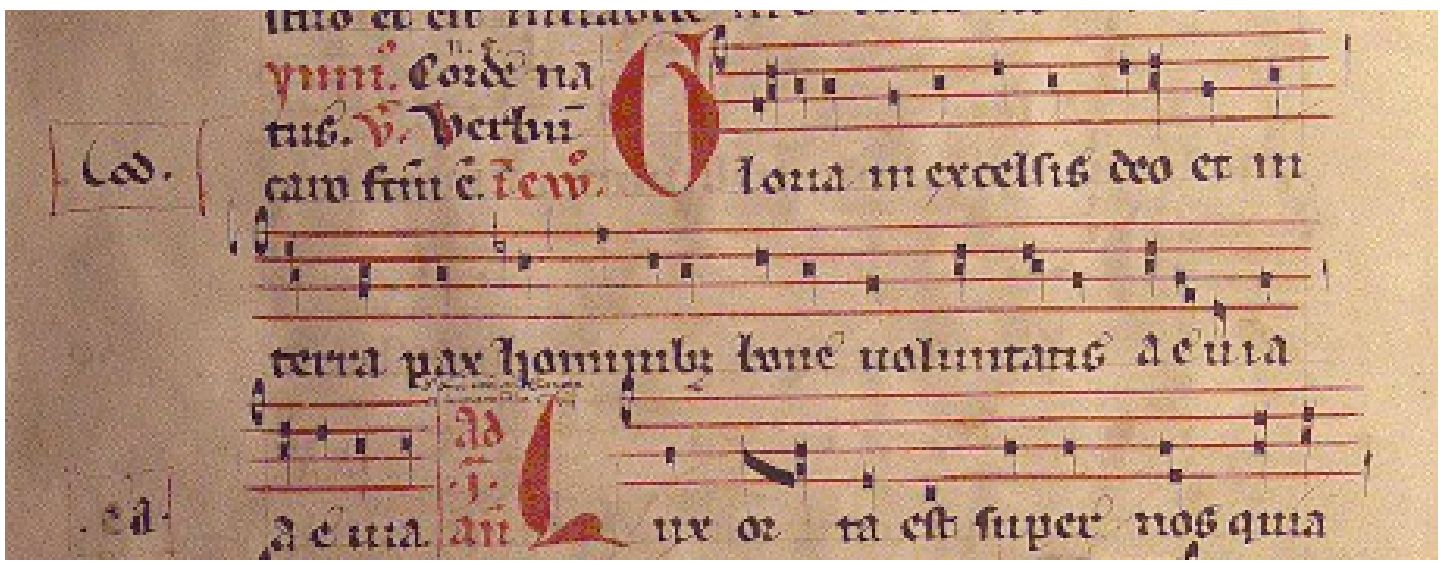

Fig. 81. Gloria, Antiphonarium Benedictinum, Sankt Lambrecht, Steiermark, Austria (1400)

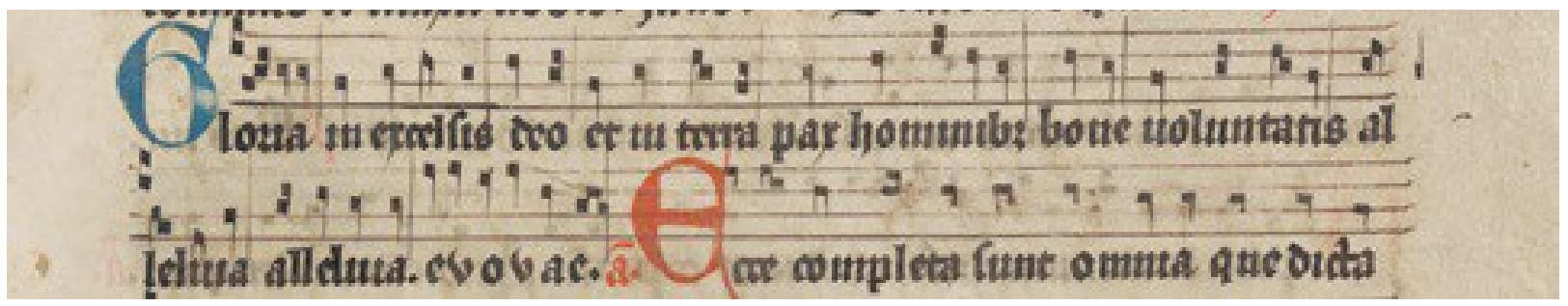

Fig. 82. Gloria, Antiphonarium pro Ecclesia Einsidlensi, Switzerland (14th century)

In the Antiphonarium Benedictinum a sign can be observed which appears to be a not exist in the Middle Ages. At the beginning of the line, a b flat seems to be written. This sign could either be another flat or a later addition. It is not present in the Swiss version. Therefore, this $\mathrm{b}$ has been transcribed as a natural $\mathrm{b}$.

381 Antiphonarium Benedictinum, Abbey of Sankt Lambrecht (Steiermark, Austria), UBG.Ms.29, http://www.literature.at $/$ viewer.alo? objid $=1138 \& v i e w m o d e=$ fullscreen\&scale $=2 \&$ rotate $=\& p a g e=91 . ~ E i n s i e d e l n$, Stiftsbibliothek, Codex 611(89), f. 21r - Antiphonarium pro Ecclesia Einsidlensi, http://www.ecodices.unifr.ch/en/list/one/sbe/0611 

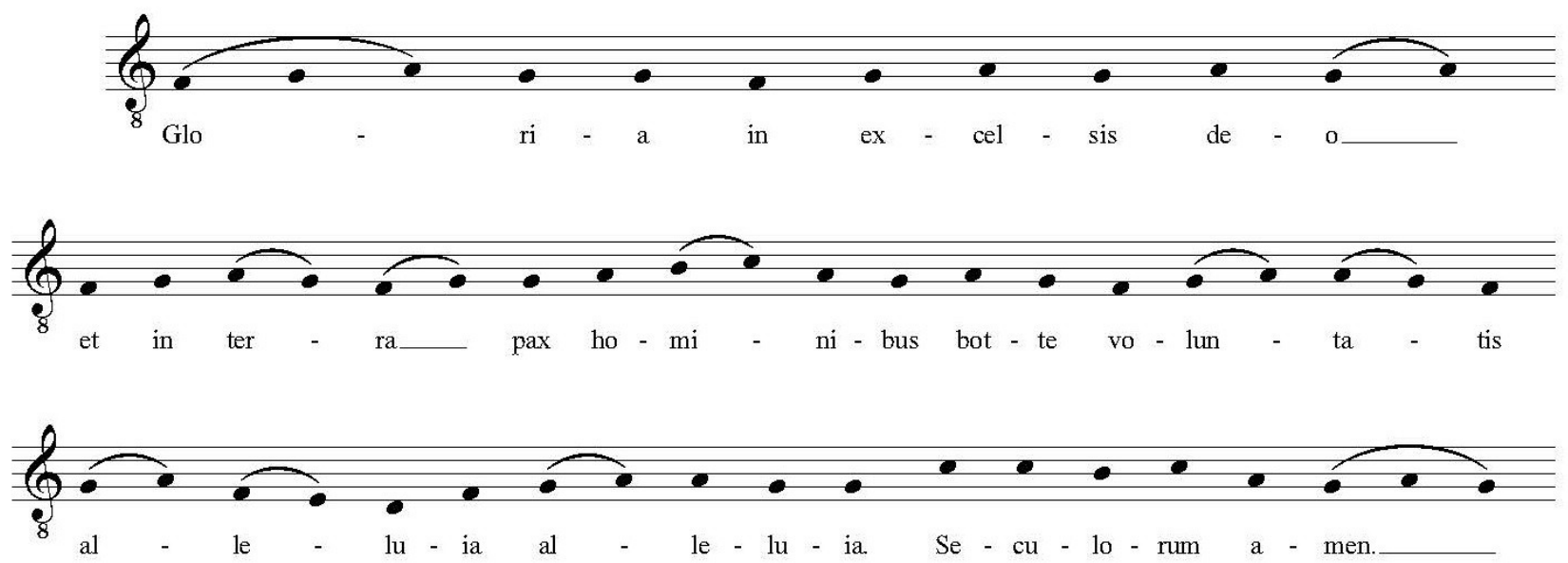

Fig. 83. Transcription of Gloria in excelsis

The chant Beati qui sitiunt (Purgatory 22.6) is part of the Beatitude Beati qui esuriunt et sitiunt. The part of Beati qui esuriunt is sung at the next gate (Purgatory 23.64), after Domine labia mea (Purgatory 23.10). We have skipped the fragment of the words esuriunt et for Purgatory 22.6 in order to sing only the section of Beati qui ... sitiunt. For Purgatory 23.64 we skipped the words et esuriunt and finished the entire phrase of the Beatitude. The source is the same as the one for Beati pauperes spiritu.

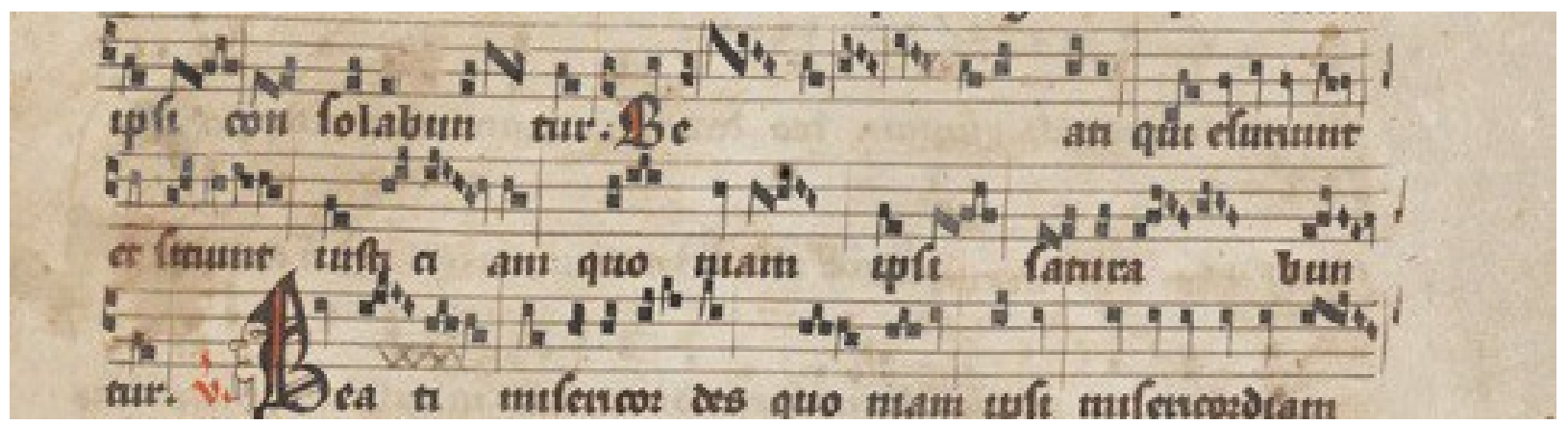

Fig. 84. Beati qui esuriunt et sitiunt, Antiphonarium pro Ecclesia Einsidlensi (prior to 1314) 

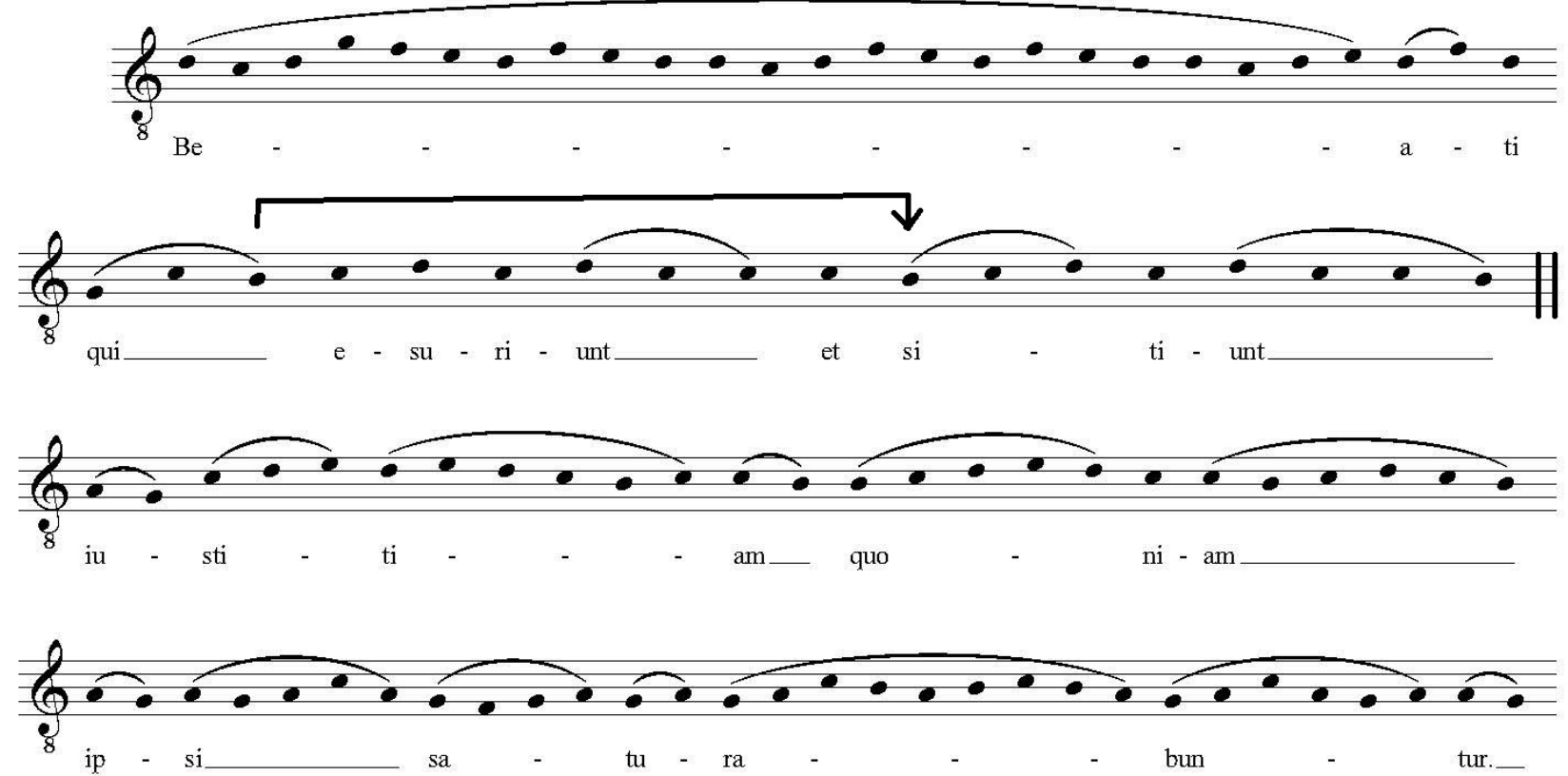

Fig. 85. Beati qui sitiunt

Of Domine labia mea (Purgatory 23.10), the chant in between the two parts of Beati qui esuriunt et sitiunt, exist various sources with a small number of differences in their versions. ${ }^{382}$

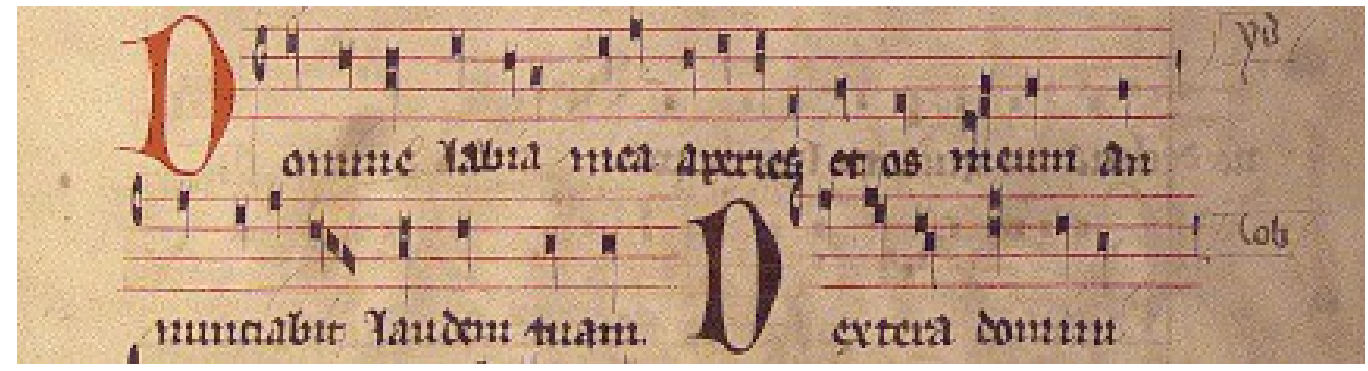

Fig. 86. Domine labia mea, Antiphonarium Benedictinum, Austria (1400)

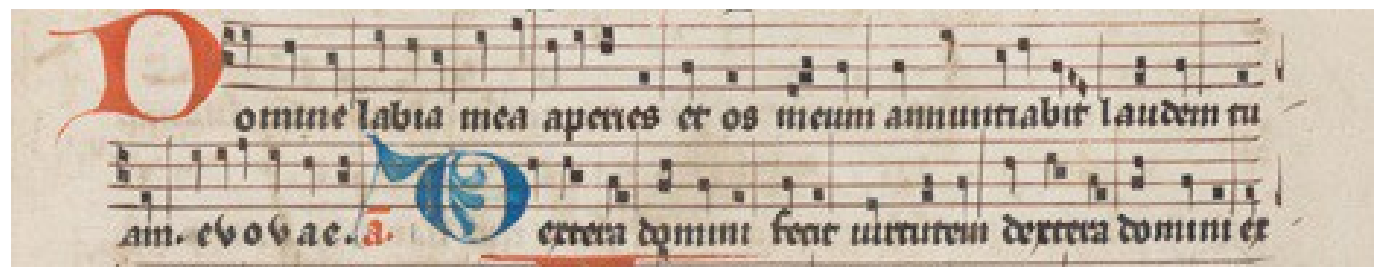

Fig. 87. Domine labia mea, Antiphonarium pro Ecclesia Einsidlensi, Switzerland (14th century)

382 The two versions shown here are Antiphonarium Benedictinum, UBG.Ms.29, Benediktinerstift St. Lambrecht, http://www.literature.at/viewer.alo?objid $=1138 \&$ viewmode $=$ fullscreen \&scale $=2 \&$ rotate $=\& p a g e=224$ and Einsiedeln, Stiftsbibliothek, Codex 611(89), f. 60r - Antiphonarium pro Ecclesia Einsidlensi, http://www.ecodices.unifr.ch/en/list/one/sbe/0611 
We based our transcription on the Swiss version because of its slightly earlier date.
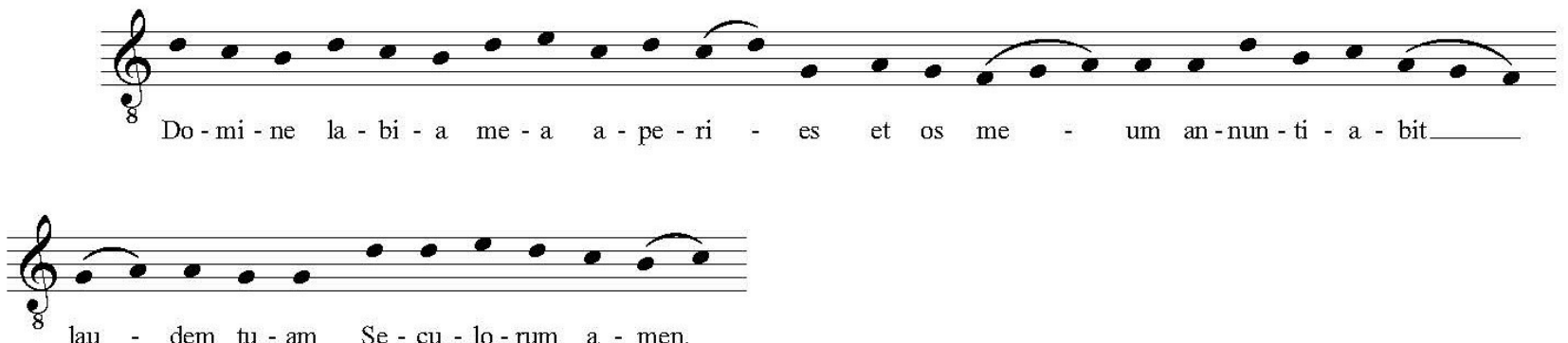

Fig. 88. Transcription of Domine labia mea

The Beati qui esuriunt sounds afterwards:
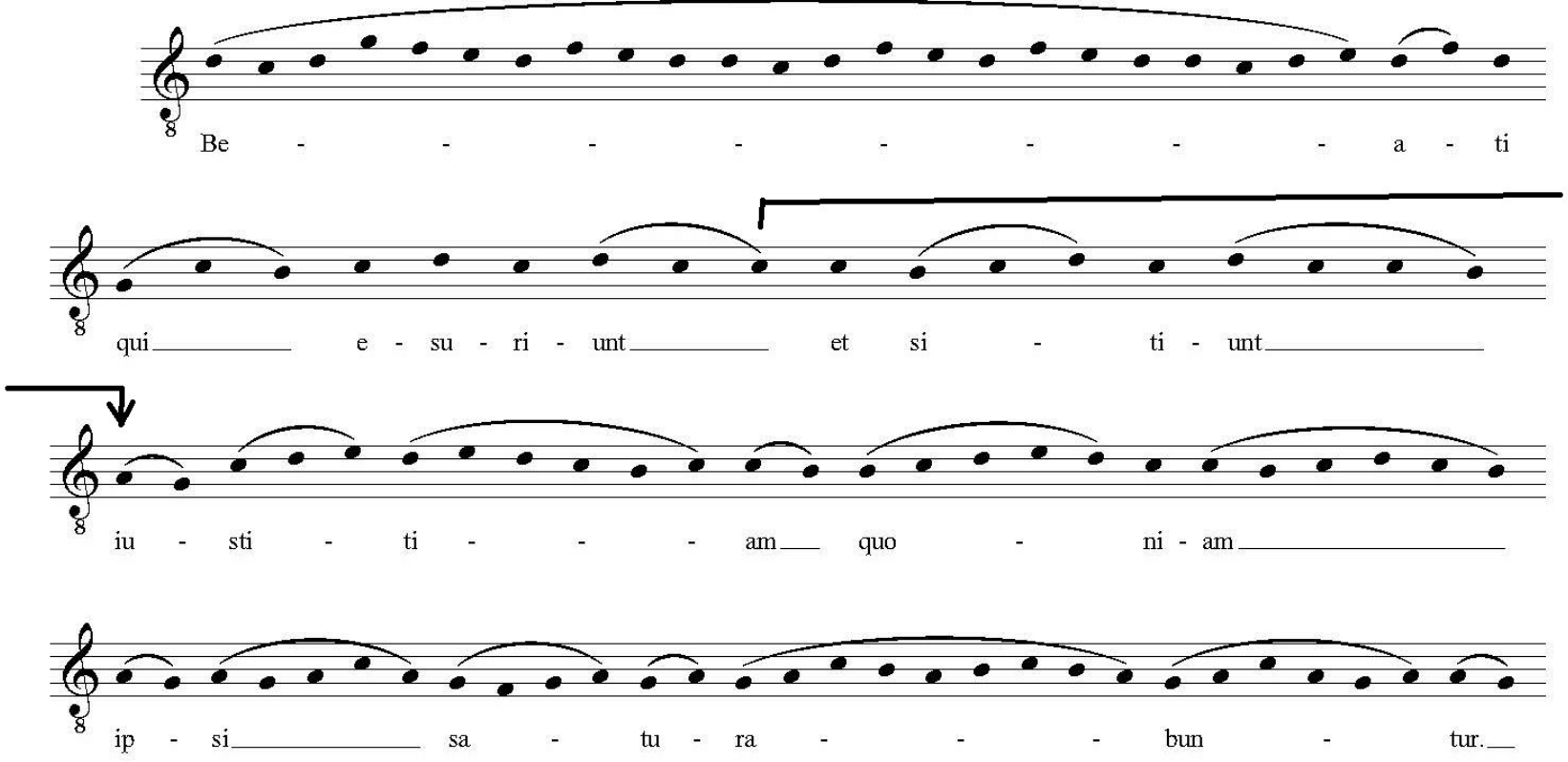

Fig. 89. Beati qui esuriunt

The entire hymn Summae Deus clementiae (Purgatory 25.121) is not digitalized. However, its incipit is found in the antiphoner from the Monastery of St. Maur-des-Fosses from the early 12th century. ${ }^{383}$ 


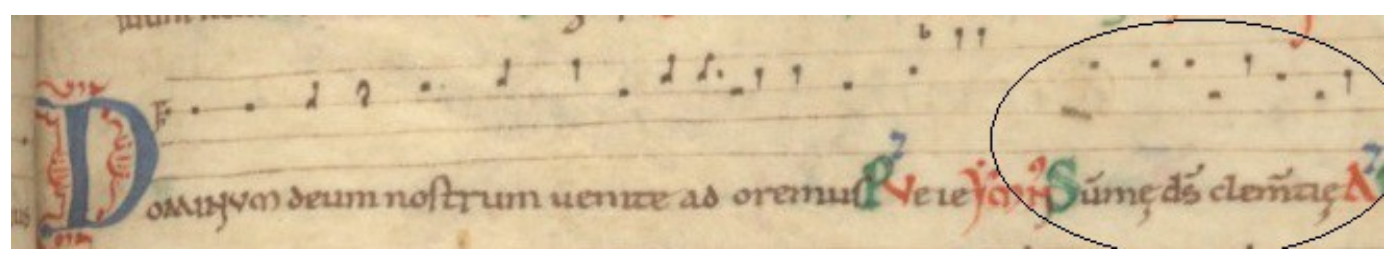

Fig. 90. Incipit of Summae Deus, St. Maur-des-Fosses (12th century, France)

This incipit is not the same as the standard melody used nowadays. It contains the notes $\mathrm{d}-\mathrm{c}-\mathrm{g}-$ $\mathrm{g}-\mathrm{g}-\mathrm{e}-\mathrm{g}-\mathrm{f}-\mathrm{e}-\mathrm{f}$, while the Solesmes version starts with $\mathrm{d}-\mathrm{e}-\mathrm{f}-\mathrm{g}-\mathrm{e}-\mathrm{g}-\mathrm{f}-\mathrm{e}-\mathrm{f}$. The beginning of the phrase is not the same, but they do share the same ending.

For the performance of Incipit, verses 1 and 3 were selected. It is verse 3 that contains the relevant words about these lustful souls themselves: "Set our loins on fire with the proper flames of your charity (love), so that they may be girt up all the time and ready for your coming", a very interesting text about the love relationship with God.

Of Beati mundo corde (Purgatory 27.8) exists a very similar melody in the Swiss and Austrian sources, with some differences in individual note pitches. ${ }^{384}$

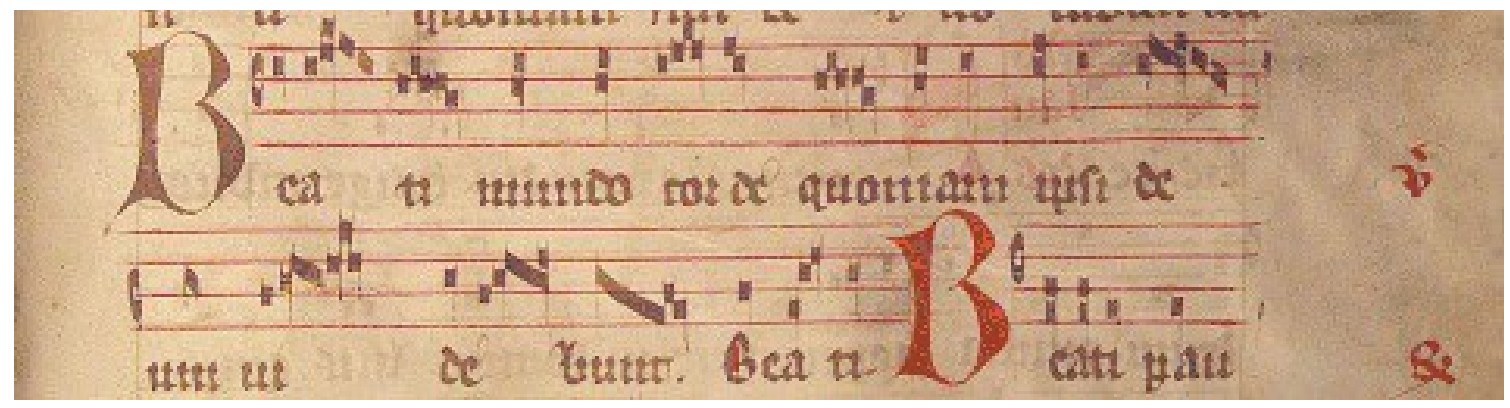

Fig. 91. Beati mundo corde, Antiphonarium Benedictinum Pars aestiva (1400), Benediktinerstift St. Lambrecht (Austria)

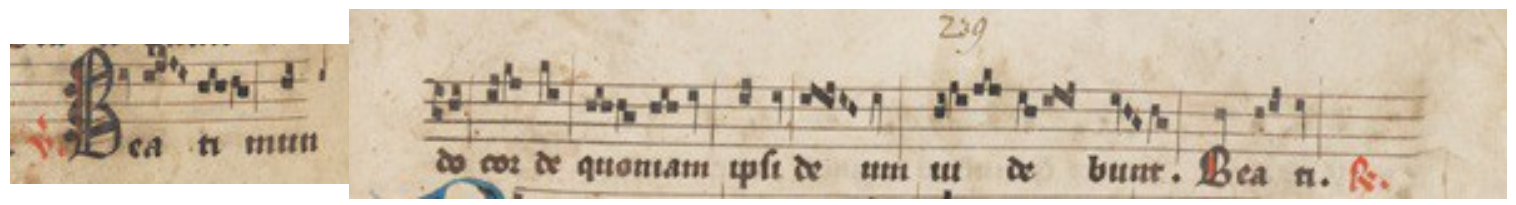

Fig. 92. Beati mundo corde, Antiphonarium pro Ecclesia Einsidlensi, Switzerland (prior to 1314)

384 Antiphonarium Benedictinum Pars aestiva (1400) Benediktinerstift St. Lambrecht (Austria), UBG.Ms.30, http://www.literature.at $/$ viewer.alo?objid $=1141 \&$ viewmode $=$ fullscreen\&scale $=2 \&$ rotate $=\& p a g e=583$ and Einsiedeln, Stiftsbibliothek, Codex 611(89), f. 238v - Antiphonarium pro Ecclesia Einsidlensi (http://www.ecodices.unifr.ch/en/list/one/sbe/0611) 
We have chosen the Austrian version for our transcription. The Swiss version seemingly has a g on the syllable $d e$ of the word corde, although it might be an $\mathrm{f}$. Our decision was to follow the most precise version.

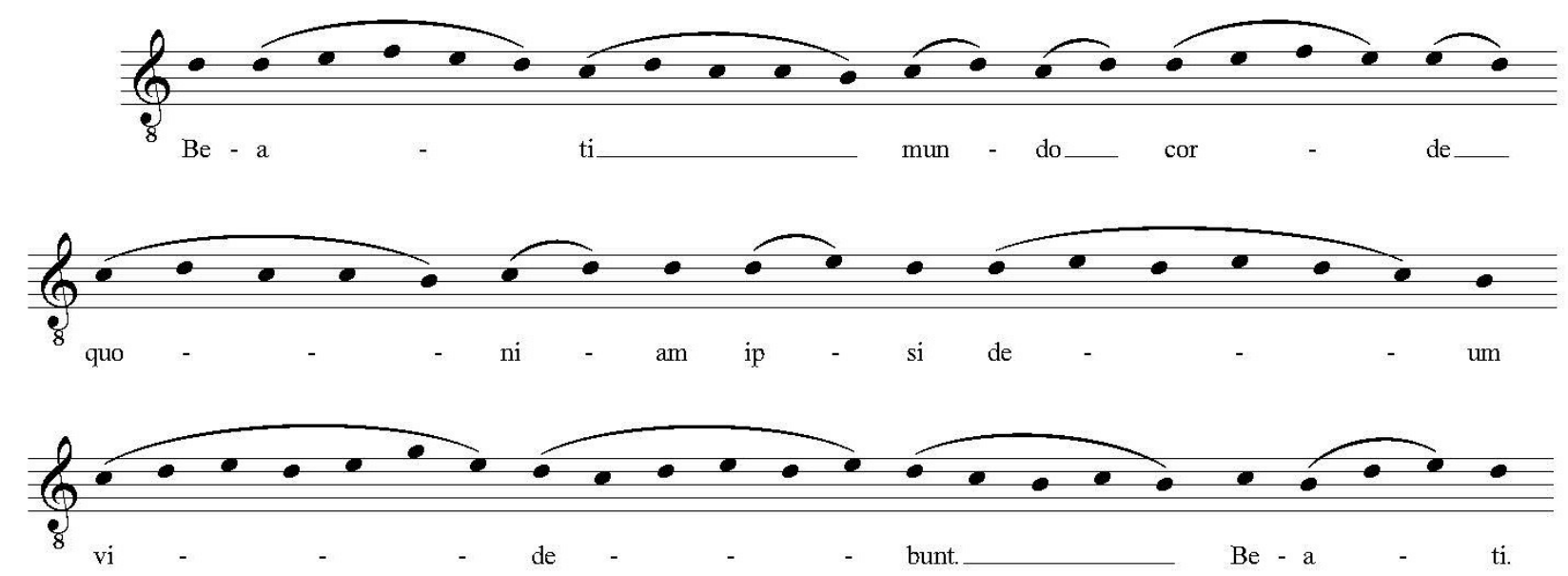

Fig. 93. Transcription of Beati mundo corde

Of Venite, benedicti Patris mei (Purgatory 27.58) exist both an antiphon and a responsory verse. The responsory verse is very similar but not equal in the different sources. In the following three sources $^{385}$ the differences show a historical reality in which the liturgical chants were not a completely fixed, everlasting repertoire but rather a melodic skeleton which often slightly varied in different locations.

385 Antiphonarium Fratrum Minorum Secundum Consuetudinem Romanae Curiae, Fribourg/Freiburg, Couvent des Cordeliers/Franziskanerkloster, Ms. 2, f. 235v - Antiphonarium (http://www.e-codices.unifr.ch/en/list/one/fcc/0002). Einsiedeln, Stiftsbibliothek, Codex 611(89), f. 256v - Antiphonarium pro Ecclesia Einsidlensi (http://www.ecodices.unifr.ch/en/list/one/sbe/0611). Antiphonarium Benedictinum (1400), Benediktinerstift St. Lambrecht, Austria, UBG.Ms.29 ( http://www.literature.at/viewer.alo? objid $=1138 \&$ viewmode $=$ fullscreen $\&$ scale $=2$ \&rotate $=$ \&page $=646$ ). 


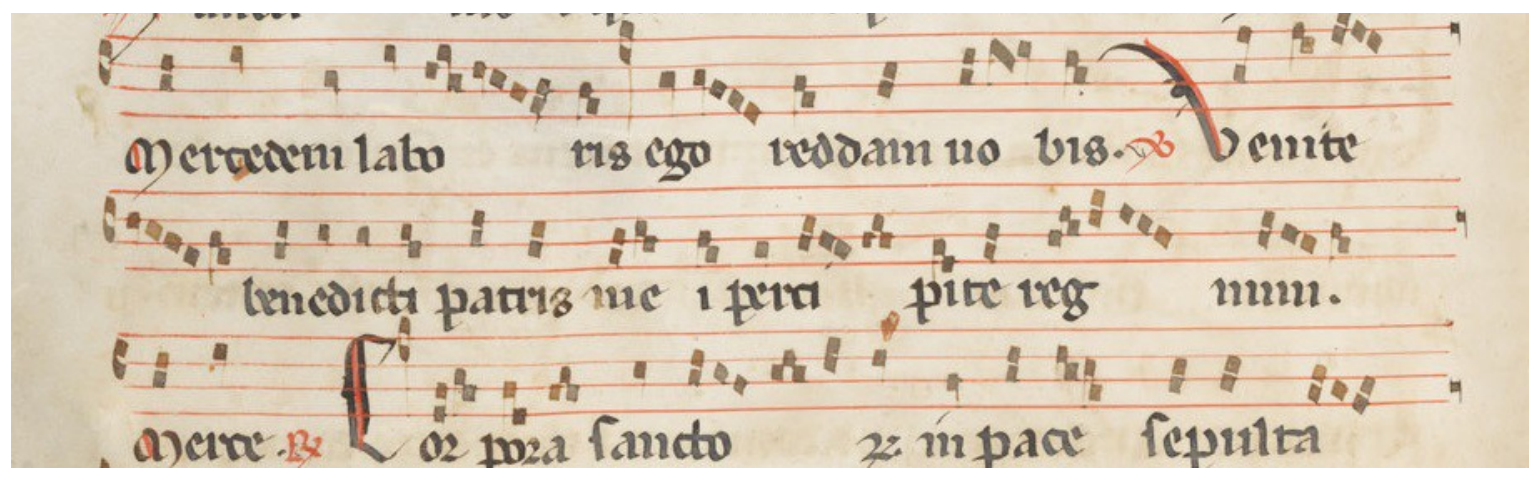

Fig. 94. Venite benedicti Patris mei, Antiphonarium Fratrum Minorum Secundum Consuetudinem Romanae Curiae (ca.1300), Freiburg

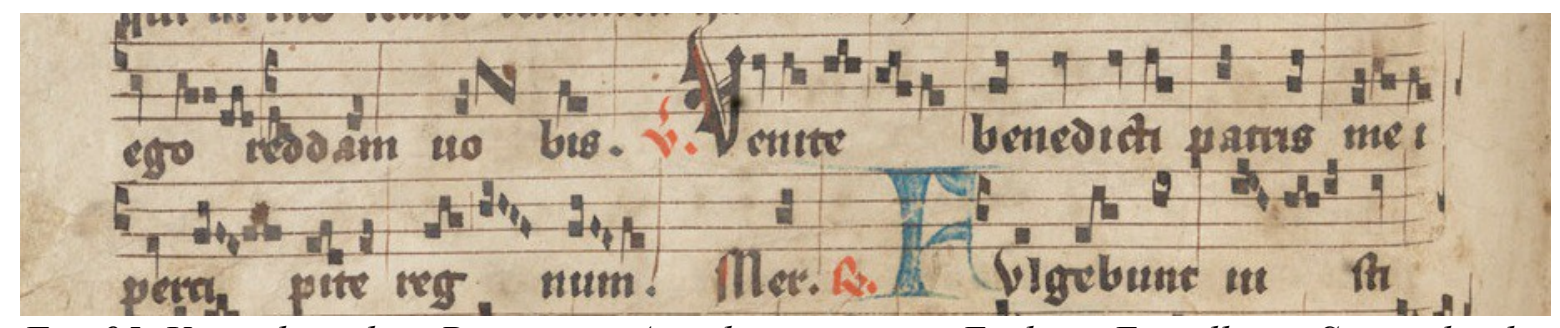

Fig. 95. Venite benedicti Patris mei, Antiphonarium pro Ecclesia Einsidlensi, Switzerland (14th century)

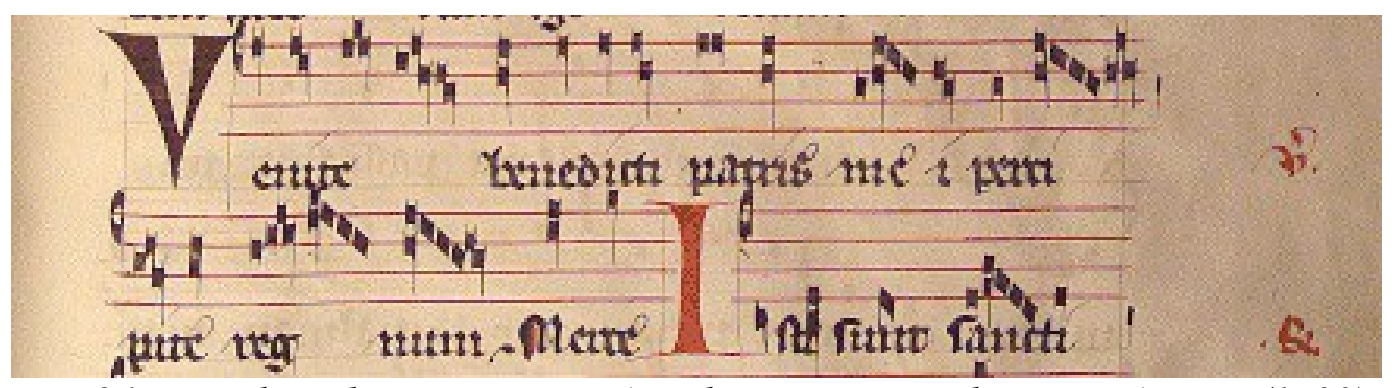

Fig. 96. Venite benedicti Patris mei, Antiphonarium Benedictinum, Austria (1400)

For our transcription we have followed the version of Einsiedl:
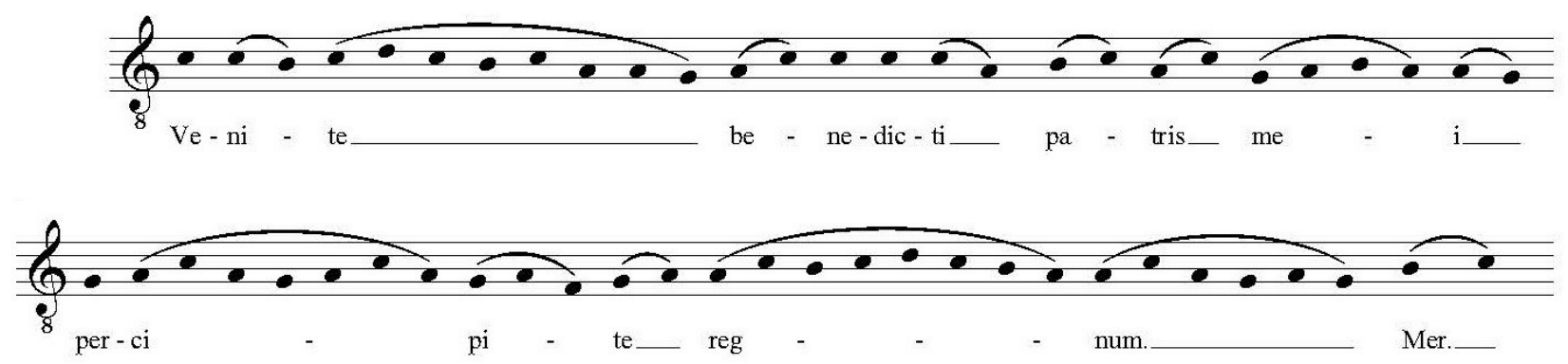

Fig. 97 Transcription of Venite benedicti Patris mei 
In the Terrestrial Paradise, Matelda mentions "Delectasti" ("you made me glad"), according to Dante a psalm (Purgatory 28.80). As reflected in chapter 4, these words belong to the psalm Bonum est confiteri. Bonum est confiteri is the second verse of Psalm 91 (92). Delectasti is its fifth verse. We have applied the melody of Bonum to Delectasti. Below are two versions of Bonum. ${ }^{386}$

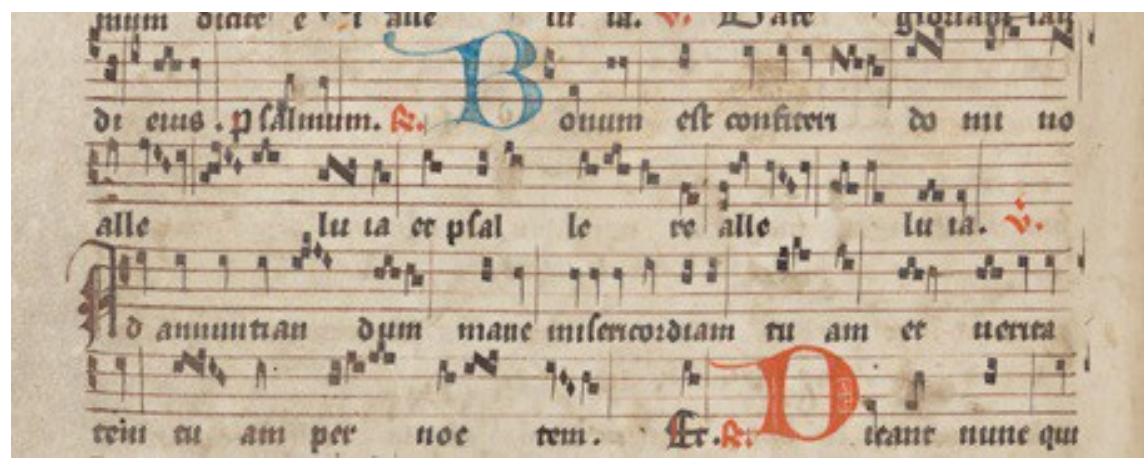

Fig. 98. Bonum est confiteri, Antiphonarium pro Ecclesia Einsidlensi, Switzerland (14th century)

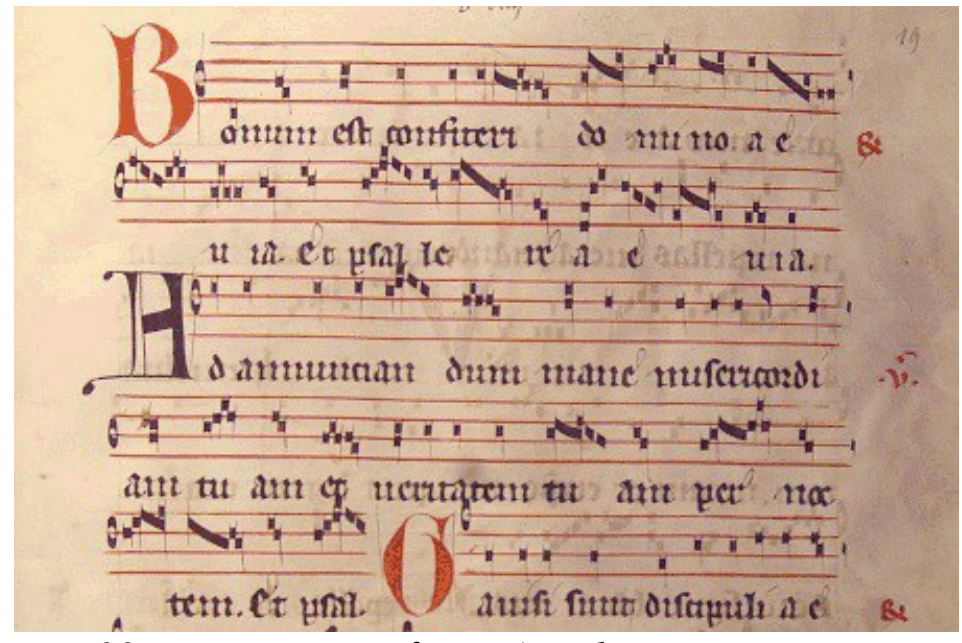

Fig. 99. Bonum est confiteri, Antiphonarium

Benedictinum Pars aestiva, Austria (1400)

Our transcription follows the Austrian version due to aesthetic motivations: the last alleluia is more "ludic" in the Austrian version. However, we have made a small compromise between both versions in our performance of this chant. In the last alleluia there is an extra note: $\mathrm{fac} \mathrm{d} \mathrm{c} \mathrm{b} \mathrm{a} \mathrm{c} \mathrm{g} \mathrm{c} \mathrm{b} \mathrm{a} \mathrm{c} \mathrm{g}$ which would make $\mathrm{c}-\mathrm{b}-\mathrm{a}$ of an even faster value. We chose to leave out the $\mathrm{b}$, just as the Swiss version had done. In this transcription, it is added in order to show the correct transcription of the Austrian version. Since Matelda is referring specifically to delectasti, in Incipit we have performed only the verse beginning with quia delectasti me.

386 Einsiedeln, Stiftsbibliothek, Codex 611(89), f. 102v - Antiphonarium pro Ecclesia Einsidlensi (http://www.ecodices.unifr.ch/en/list/one/sbe/0611) and Antiphonarium Benedictinum Pars aestiva. (1400), UBG.Ms.30, Benediktinerstift St. Lambrecht (http://www.literature.at/viewer.alo? objid $=1141 \&$ viewmode $=$ fullscreen $\&$ scale $=2$ \&rotate $=$ \&page $=39$ ) 

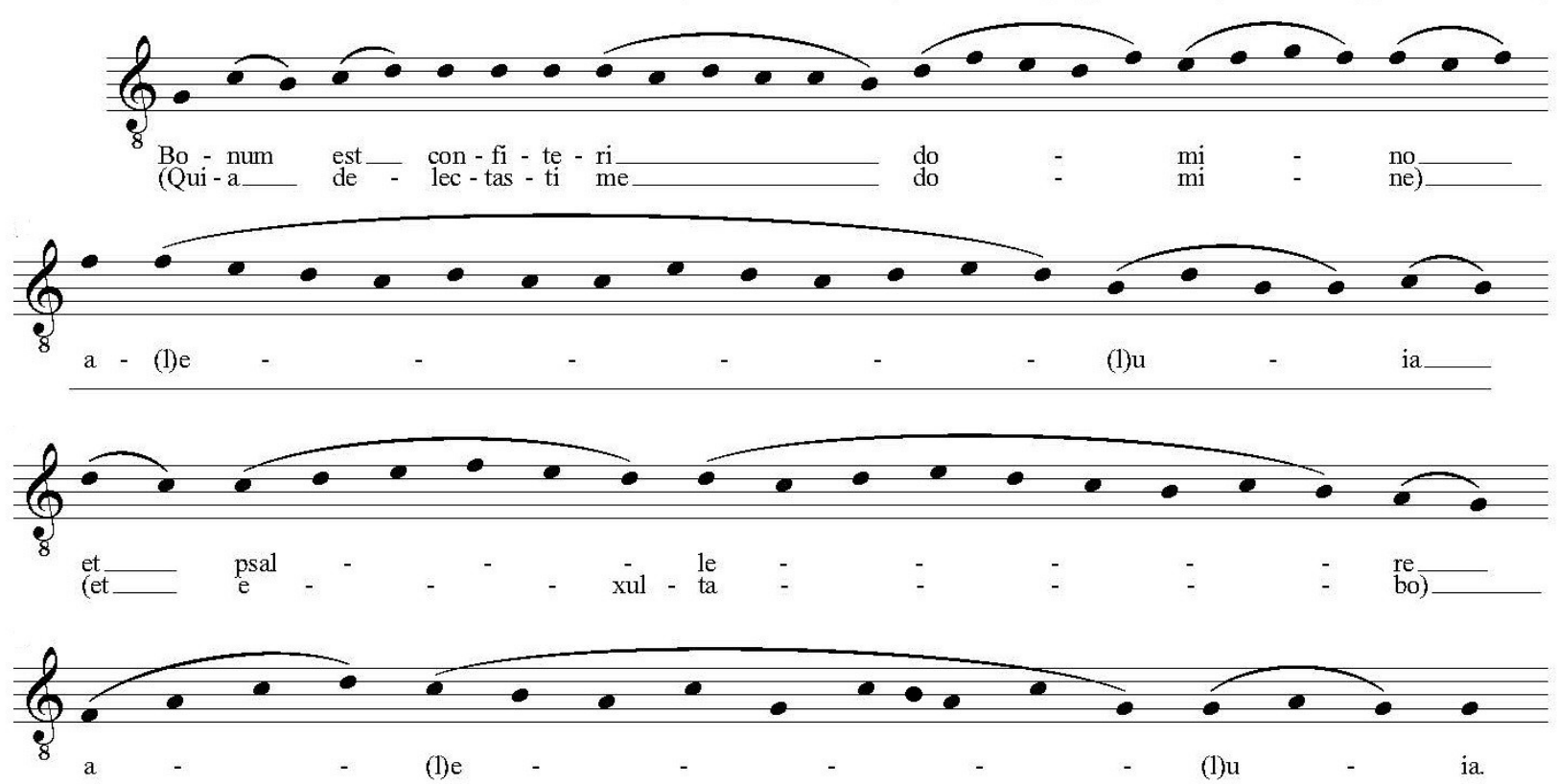

Fig. 100. Transcription of Bonum confiteri est

Matelda also sings "Blessed are they whose sins are covered over!" (Purgatory 29.3). This is a reference to Psalm 31: beati quorum remissae sunt iniquitates et quorum tecta sunt peccata ("Blessed are they whose transgressions are forgiven, whose sins are covered."). If we take Matelda's words literally, she is singing beati quorum tecta sunt peccata, a more compressed variation. We therefore skipped the part of the musical phrase of remissae sunt iniquitates et quorum. There are no indexed antiphonal or responsorial versions of it. Mode 5 for Guido d'Arrezo has a happy character, therefore our decision was to apply this mode to the joyful song of Matelda.

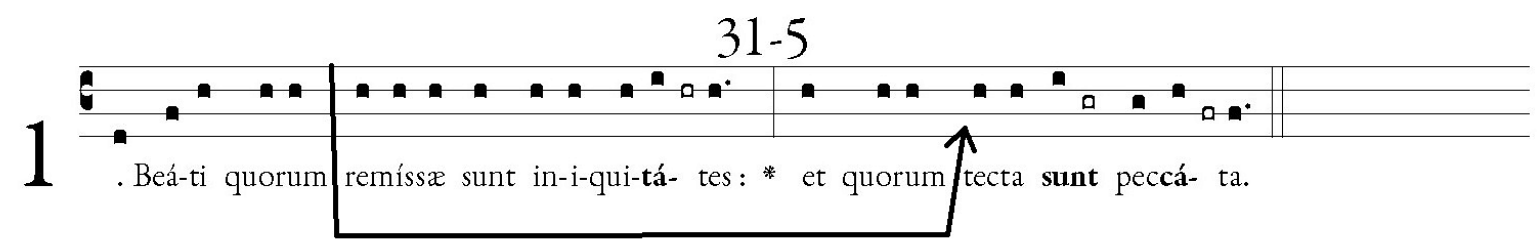

Fig. 101. Beati quorum...tecta sunt peccata

The Hosanna sung by the heavenly procession (Purgatory 29.51) is the first musical reference for which we have written two additional voices. In chapter 4 we challenged Ciabattoni's assumption that Dante had a journey toward polyphony in mind, arguing that it would be more plausible for the music of Dante's Paradise to be a supernatural type of music, not necessarily connected to the idea of polyphony. However, we also indicated that it is an interesting artistic concept for a human performance whose aim is to stay as close to the Late-Medieval sonorous world as possible. Therefore, it has formed the musical concept behind Incipit's soundscape. The Hosanna in Incipit 
has been based on a Swiss version. There is an Austrian version similar but not equal. The Swiss version is clearly comprehensible and also aesthetically a motivation to select this source. ${ }^{387}$

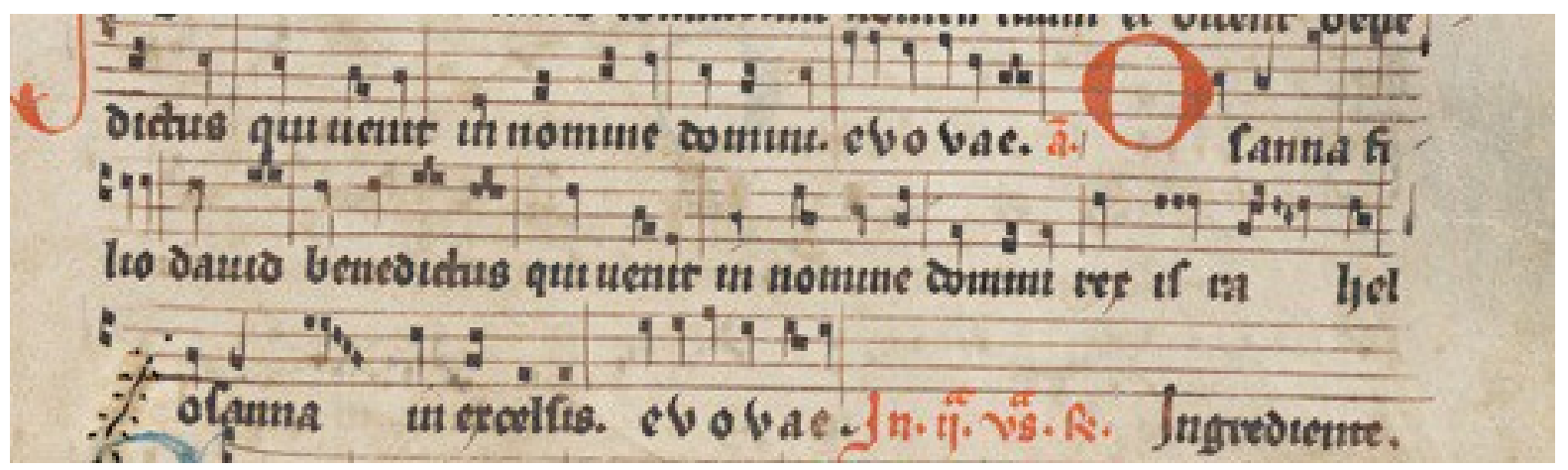

Fig. 102. Hosanna, Antiphonarium pro Ecclesia Einsidlensi, Switzerland (14th century)

Our transcription contains the original melody on the third stave. The second voice that was composed is on the first stave, because it is higher than the original melody. The third composed melody has regular voice-crossing with the second voice. It almost never goes below the first voice, although with experience it could be composed that low. The lowest voice would then count as the principal pitch on which to construct the other intervals according to the basic rules of improvised organum. A sharp has been added to the $\mathrm{c}$ in the original chant, an alteration that was probably done in practice, as the cadences of $14^{\text {th }}$ century secular music show. This Hosanna was recorded for the Terrestrial Paradise and performed at the end of the immaterial Paradise in Incipit. Thus, not only the Gloria of Purgatory 20.136 is performed polyphonically in Incipit's Paradise, but also the Hosanna. The reason for this decision is that Dante's references in Paradise are mainly non-specific, at times indicating that the souls are singing to God, the Trinity or Christ. These two chants are both songs of praise for Divinity, therefore they could very well have been sung in Dante's Paradise. Furthermore, the repeated use of these plainchants augmented the musical coherence throughout Incipit. On the other hand, the suggestion of a varied version of Regina caeli in Paradise 23.103 has not been brought into practice, nor has this been the case for the last Ave Maria in Paradise 32.95, where the Archangel Gabriel re-enacts the Annunciation. The reason for leaving out the first is the fact that it deals with an imaginary heavenly version reminiscent of the Regina caeli, and we have preferred not to use a version which Dante probably did not have in mind. As to the second, in Incipit the moment and manner of visiting Dante's Paradise is different and the characters that were important to Dante might not have the same importance to the modern audience. Therefore, it was decided to focus as much as possible on general aspects of spirituality in Dante's metaphysics, especially in Paradise. Only the first Ave Maria, sung by the soul in the sphere of the Moon, has 
been performed in Incipit.

As to the last chants in Purgatory, there are a number that has not been performed in Incipit either. Ave Maria gratia plena dominus (Purgatory 29.85) seems to be suggested by the words " "Blessed are you among the daughters of Adam, and blessed be your beauties throughout all eternity!", but at the same time these words are implicitly referring to Beatrice. All further chants of the procession with a specifically catholic character or connected to Beatrice - a character who is not present in our own visit to Dante's Afterworld (see chapter 3) - have not been performed in Incipit. These are

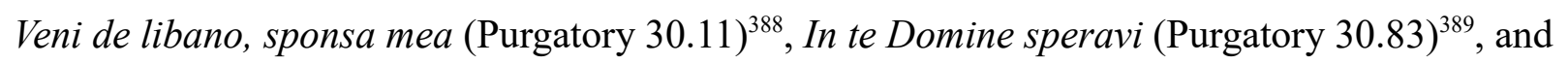
Deus venerunt gentes (Purgatory 33.1). ${ }^{390}$

Asperges me (Purgatory 31.98) accompanies the ritual of washing in order to be pure enough to proceed to the immaterial Paradise ("Thou wilt sprinkle me, O Lord, with hyssop and I shall be cleansed. Thou wilt wash me, and I shall be washed whiter than snow." $)^{391}$ There are no historical digitalized notated versions of it listed in cantusdatabase.org, but the digitalized Graduale Fratrum Minorum from either Padua or Bologna (beginning 14th century) does contain a notated version of it. The manuscript was used in the Franciscan cloister of St. Francis of Locarno. Although it is published online, it is not indexed..$^{392}$

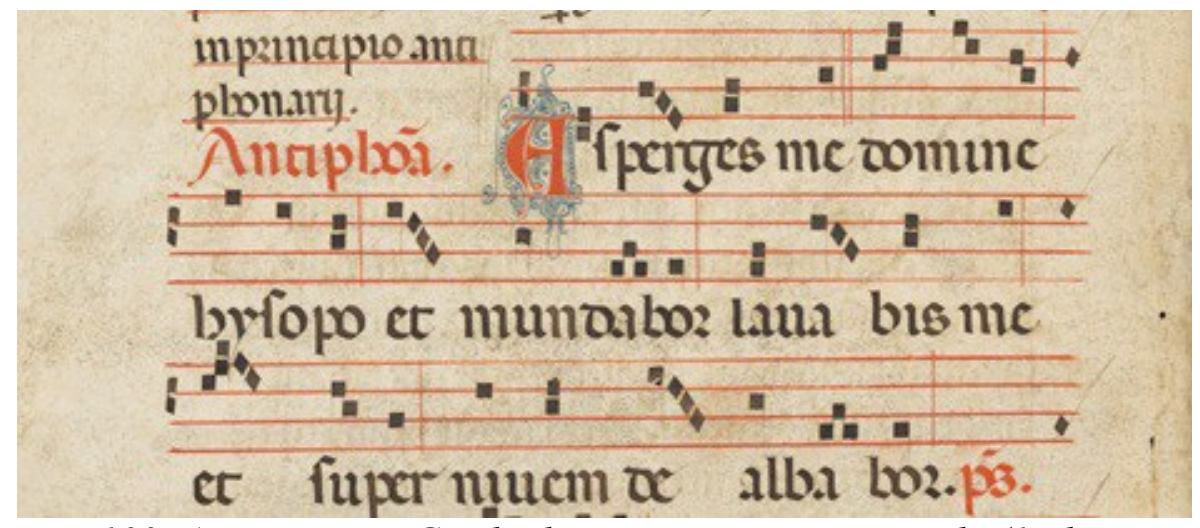

Fig. 103. Asperges me, Graduale Fratrum Minorum, Italy (14th century)

Apart from the Hosanna (Paradise 28.118), of Dante's specific references to chants in Paradise remain the Ave Maria, Sanctus (Paradise 7.1 - 8.29 - 26.69), Te Deum (Paradise 24.113), Sperent in

388 This is sung by one of the biblical figures within the procession. The procession is a highly elaborated metaphor of the Bible and of Christianity.

389 The angels sing it after Beatrice's harsh rebuke, in order to confort him.

390 This scene deals with the Church being attacked and perverted.

391 This is normally sung at baptism.

392 Orselina, Convento della Madonna del Sasso, Codice I, f. 181v - Graduale Fratrum Minorum (http://www.ecodices.unifr.ch/fr/list/one/oms/0001). 
te (Paradise 25.98), and Gloria Patri (Paradise 27.1). We have added to these the already mentioned Gloria, an Alleluia x, and the sequence Victimae paschali laudes. ${ }^{393}$ Although Incipit's Paradise does not represent the concept of the Ptolemaic universe, each chant stands for each sphere in Dante's universe.

A joyful soul sings Ave Maria on Dante's Moon, as an illustration that ogne dove in cielo è paradiso ("everywhere in heaven is paradise", Paradise 3.88-89) and that she is grateful for it. The Ave Maria exists as a digitalized format in several modes. We selected the version in mode 5, the "happy" mode. $^{394}$

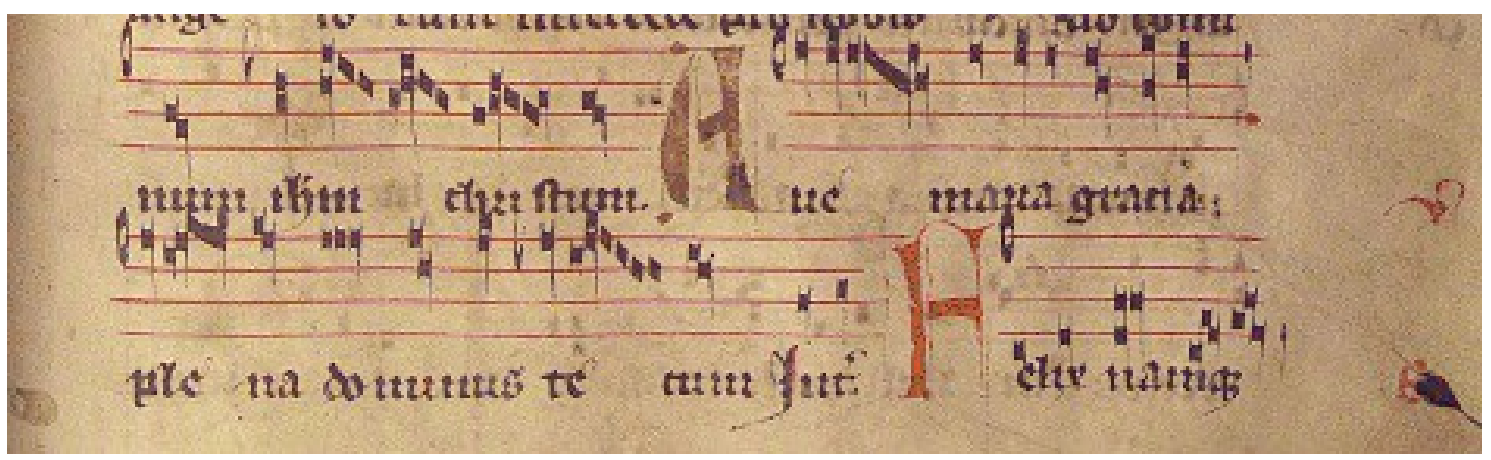

Fig. 104. Ave Maria, Antiphonarium Benedictinum Pars aestiva, Austria (1400)
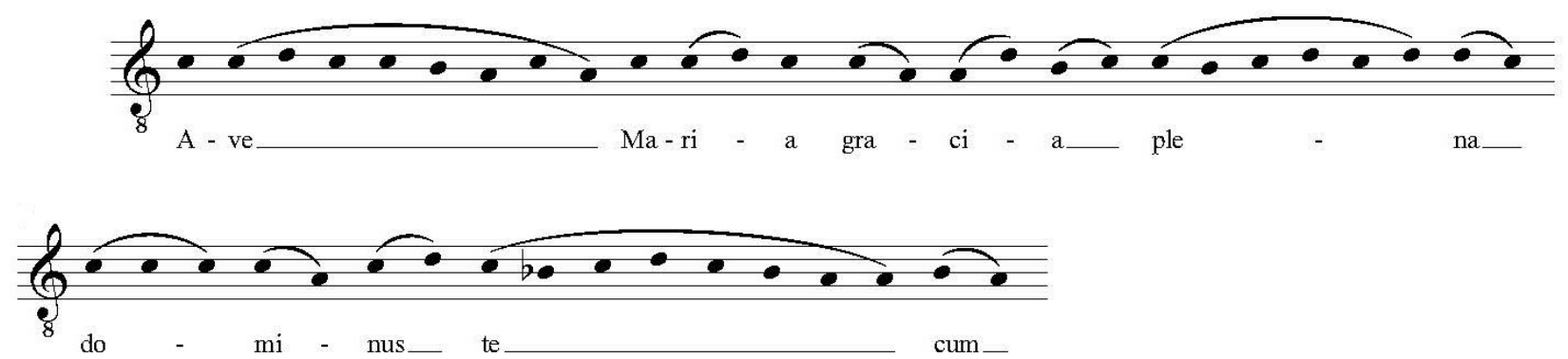

Fig. 105. Transcription of Ave Maria

The Sanctus appears in different places and manners. In Paradise 7 (Mercury) an alternative version is sung by Justinian. In Paradise 8 (Venus) all the souls sing the word Hosanna which could be a Hosanna but also the last part of the Sanctus. The Sanctus returns in Paradise 26.69, where all sing Santo, santo, santo! at Dante's regained eyesight. It has thus been included in Incipit's Paradise,

393 In Paradise 14.118 Dante seems to refer to the sequence Concinat orbis cunctus but there are arguments against it. For the moment, we decided to perform the sequence Victimae paschali laudes, which is one of the few sequences of which a melody survived and which is similar in its textual meaning. See chapter 4 about the sequence Concinat orbis cunctus.

394 Antiphonarium Benedictinum Pars aestiva, UBG.Ms.30, Benediktinerstift St. Lambrecht (Austria) (http://www.literature.at/viewer.alo?objid=1141\&viewmode=fullscreen\&scale=2\&rotate=\&page=473) 
representing both Mercury and Venus. Of Sanctus sanctus sanctus domine deus sabaoth pleni sunt caeli et terra gloria tua hosanna in excelsis there are no digitalized scores in cantusdatabase.org. However, there is a digitalized Italian score of it, which unfortunately lacks the second part of the chant. ${ }^{395}$ Therefore, we have only transcribed and performed its first part.

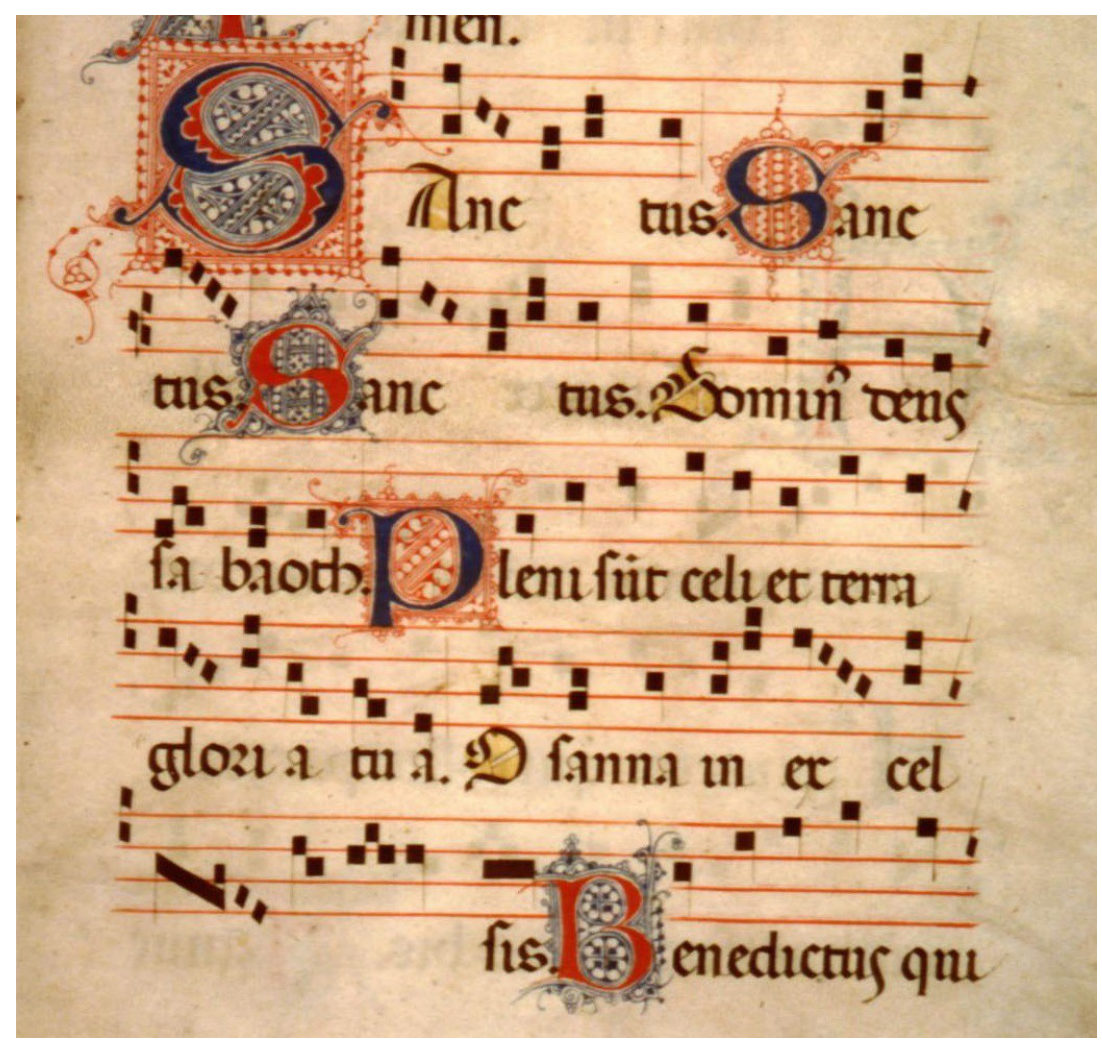

Fig. 106. Sanctus, 15th century, Italy

We have experimented with the 5-6-8 sequence in the word Sanctus (third and first staff), and also with one of the added voices going below the original melody (pleni sunt celi et terra gloria tua, osanna in excelsis). However, Niels Berentsen notes that the lowest pitch determines the intervals above it. If one of the additive voices goes lower than the principal voice, it functions as the basis. In that case, our organum is not according to the intervallic rules for improvised organum. On the other hand, if two additional voices were improvised, they would know the principal melody and would sing their intervals in relation to it rather than to an unknown improvised voice. If that is true, then going below the principal voice would result into more frequent sixths $(\mathrm{D}-\mathbf{d}-\mathrm{b})$ or sevenths (i.e. $B-\mathbf{d}-$ a) being $d$ the note of the principal melody. A fourth below the principal voice would solve the risk of the seventh, but Italian sources of notated 3 -voice pieces of the $14^{\text {th }}$ century should be studied in order to see if they based on fourths at any moment, if possible from before the writings of Marchetto da Padova (see chapter 1). 

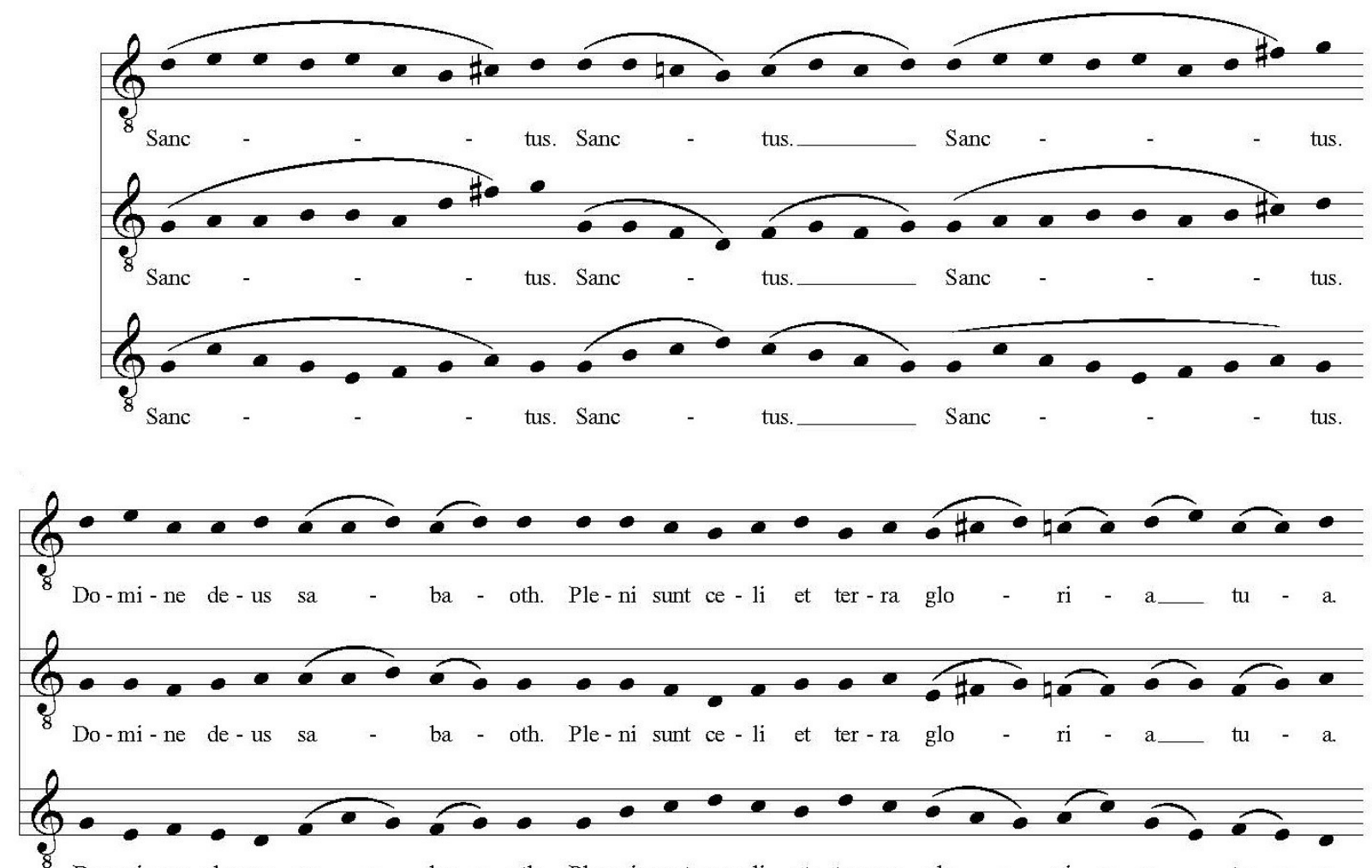

8 Do-mi-ne de-us sa - ba - oth. Ple-ni sunt ce - li et ter-ra glo - ri - a__ tu - a.

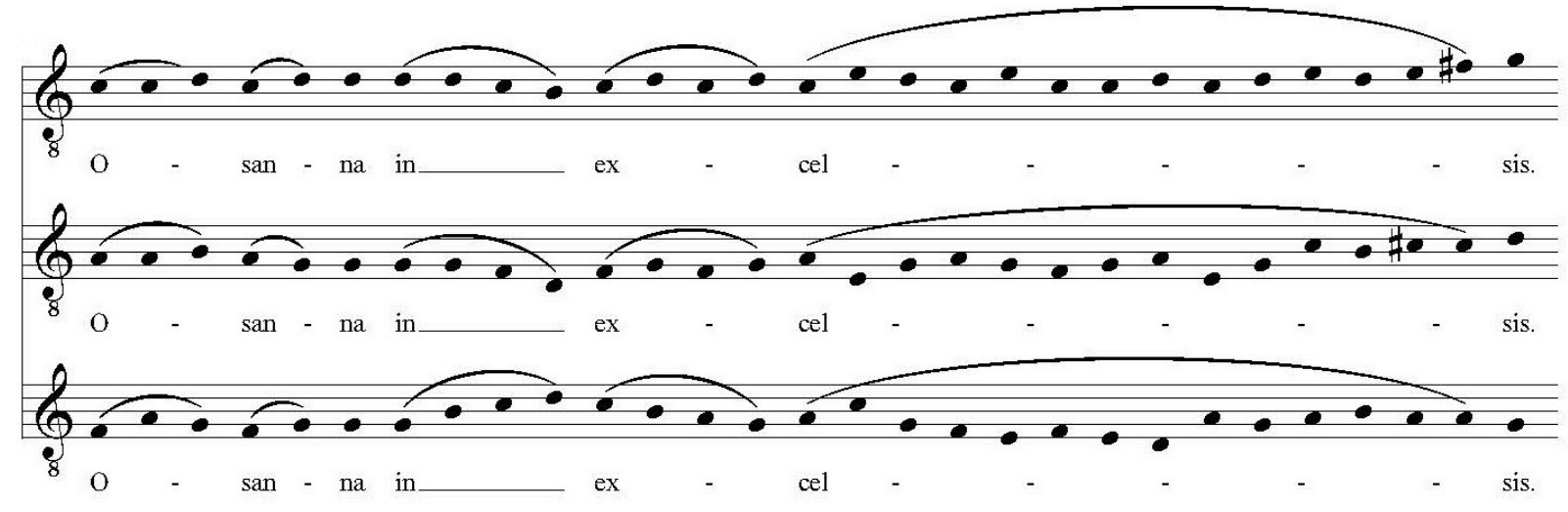

Fig. 107. Transcription and organum for Sanctus

The Gloria is based on the same melody of Purgatory; its source and principal melody have been discussed earlier in this chapter. In Purgatory, seculorum amen was not sung. 

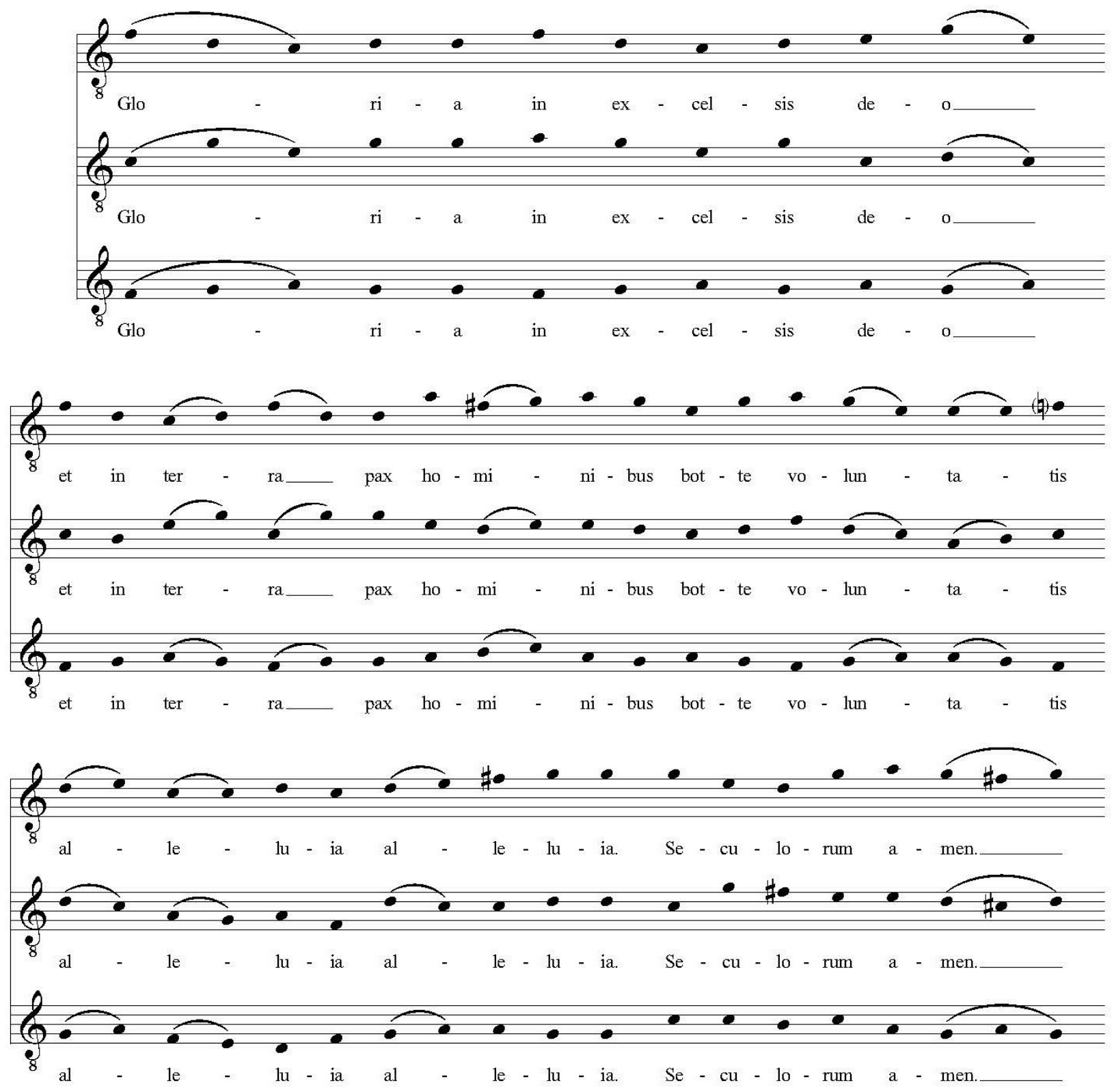

Fig. 108. Transcription and organum for Gloria

Alleluia $x$ means ten times Alleluia. In Inferno 12.88-89 Virgil says " A spirit came from singing 
alleluia to commission me with this new office" ${ }^{״ 96}$, referring to Beatrice. Beatrice resides in the highest heavenly sphere, but it seems to be a general statement about all souls in Paradise. The souls in the Sun are described by Dante to sing echo-like chants (see chapter 4). Canons were perhaps improvised but not notated, nor do the elaborate melodies of existing chant lend themselves to such a treatment. Moreover, they are singing of the "myriad jewels" in the court of heaven (ne la corte del cielo...molte gioie) and to "Three Persons in the Godhead's nature, and God and human nature in one Person" (tre persone in divina natura, e in una persona essa e l'umana). Ciabattoni refers to Parisian forms where indeed there is an echo-effect because of exchange of melodies between the higher, faster voices. However, in Italy, where these forms do not seem to have been practised, it appears that Dante is either referring to a real canon or is reflecting impressions that other musical forms might give to non-musicians. For Incipit, it was decided to perform an Alleluia, because Dante indicates that it is sung in the heavens, and because this Alleluia $\mathrm{x}$ has a slightly cyclical character due to its short musical phrases.

In cantusdatabase.org there is a Florentine source of Alleluia $\mathrm{x}$ indexed but not digitalized. One of the few other versions of Alleluia in the same mode - mode 8 - is the following Franciscan Fribourg source from the late 13 th or early 14 th century. ${ }^{397}$

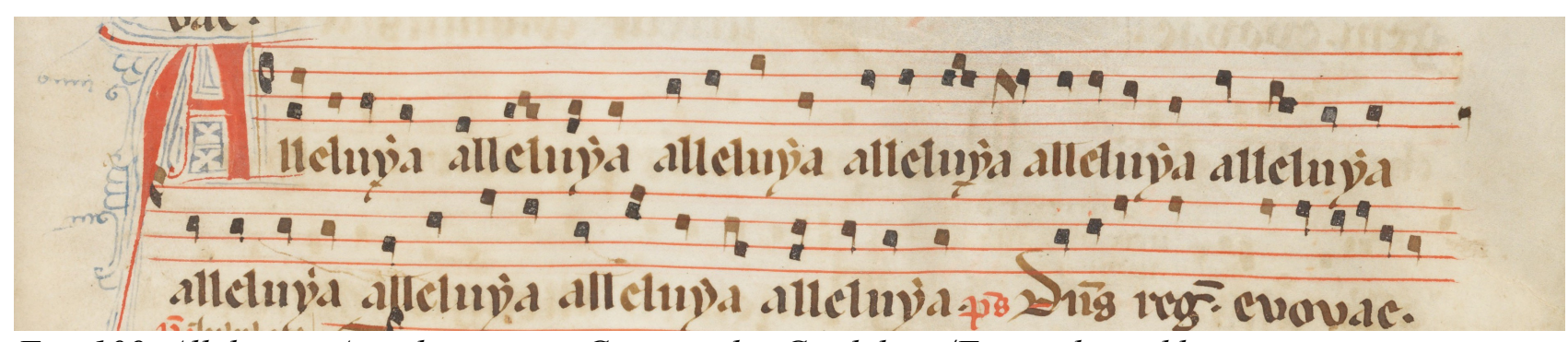

Fig. 109. Alleluia x, Antiphonarium, Couvent des Cordeliers/Franziskanerkloster, Freiburg/Fribourg

396 "Tal si partì da cantare alleluia / che mi commise quest'officio novo"

397 Fribourg/Freiburg, Couvent des Cordeliers/Franziskanerkloster, Ms. 2, f. 113r - Antiphonarium (http://www.ecodices.unifr.ch/en/list/one/fcc/0002) 

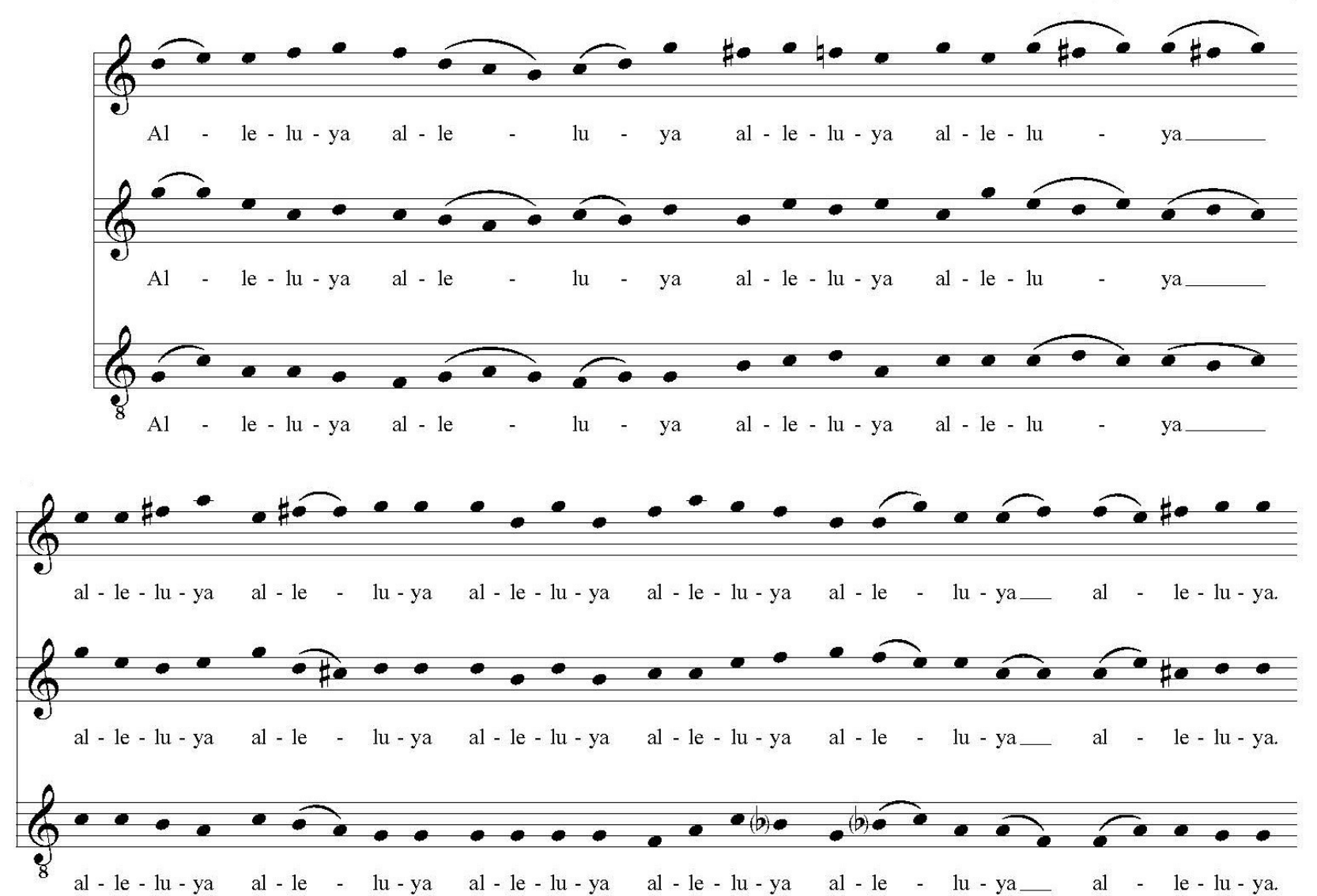

Fig. 110. Transcription and organum for Alleluia $x$

Although originally it is not indicated, we have performed $a b$ flat instead of $a b$ natural in two of the three final alleluias. It is the most plausible for them to be in a hexacordium mollum, ${ }^{398}$ especially the $\mathrm{f}-\mathrm{a}-\mathrm{c}-\mathrm{b}$ series, where the $\mathrm{b}$ has to be flat in order to serve as a $f a$ for the $\mathrm{f}$. In our organum of this chant, we have also experimented with the 5-6-8 rule, as can be observed in alleluias number 1,6 , and 10 .

The sequence Victimae paschali laudes (11 ${ }^{\text {th }}$ century) represents Mars in Incipit. In chapter 4 the musical reference Dante gives for this sphere was discussed amply. It is not sure which chant Dante is referring to. Although some scholars point to the sequence Concinat orbis cunctus (see chapter 4), there are doubts about this possibility. Since sequences were set to the notes of Alleluia melismas, their melodies were not notated. No melody of Concinat orbis cunctus is digitalized, if any even exists together with the text. At the moment, there are only three old sequences of which the melody has survived, of which Victimae paschali laudes is one. It does not contain the Latin translations of Resurgi and Vinci, while Concinat does contain the words resurgit and victor. 
However, the contents are quite similar (Christ who conquered Death). Therefore, this sequence was a valid choice for Dante's musical references in the sphere of Mars.

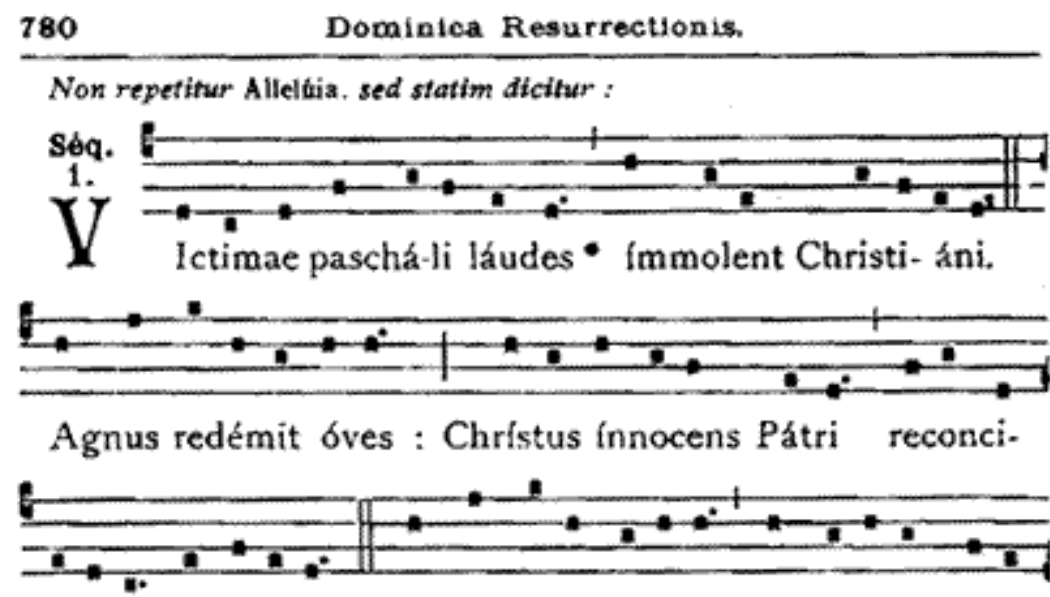

li-ávit peccatóres. Mors et ví-ta du-éllo conflixére mirán-

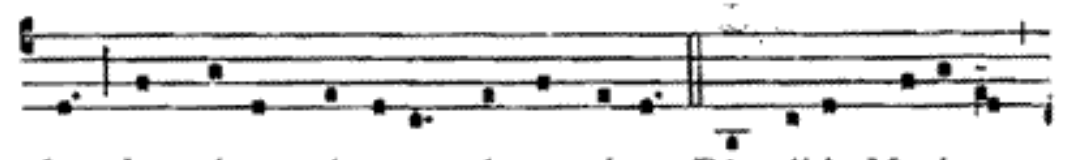

do : dux vitae mórtu-us, régnat vívus. Dic nóbis Mari- a,
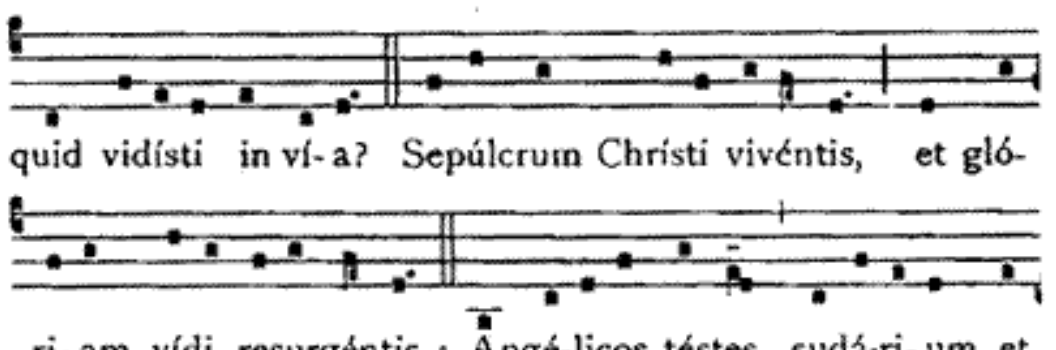

ri-am vídi resurgéntis : Ângé-licos téstes, sudá-ri-um, et
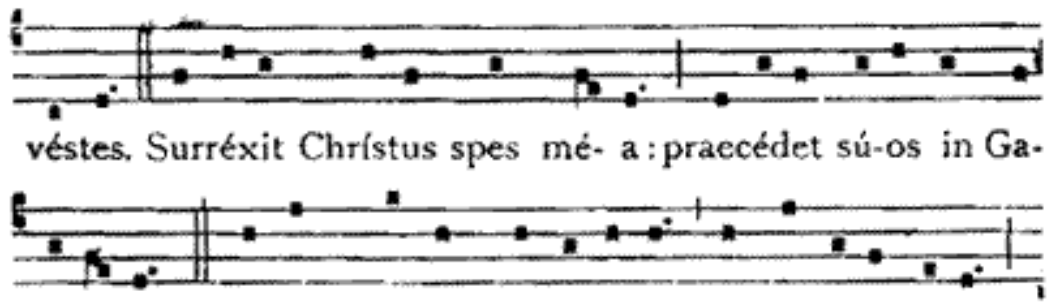

lilaé-am. Scímus Chrístum surrexísse a mórtu- is vere :

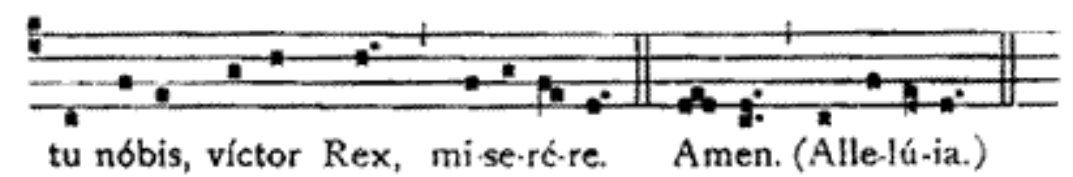

Fig. 111. Victimae Paschali Laudes

For our organum setting, we have left out the narrative part where Maria tells how she found Christ. After all, in heavenly spheres such exempla are not necessary anymore. For the same reason, $t u$ nobis, victor Rex, miserere has been left out. These souls are perfectly happy and they do not ask for God's forgiveness. 

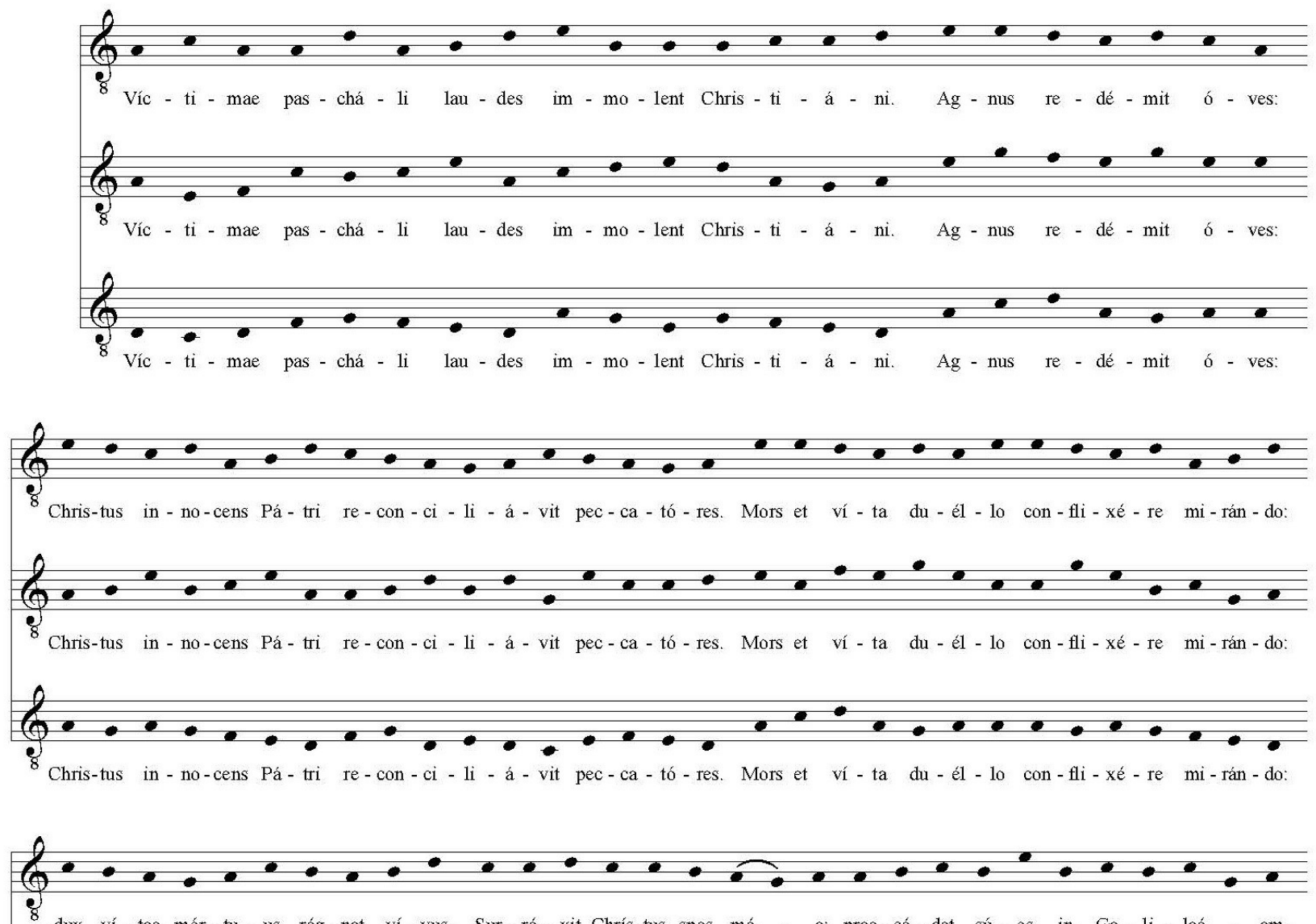

dux ví - tae mór - tu - us, rég - nat ví - vus. Sur - ré - xit Chrís-tus spes mé - a: prae - cé - det sú - os in Ga - li - laé - am.

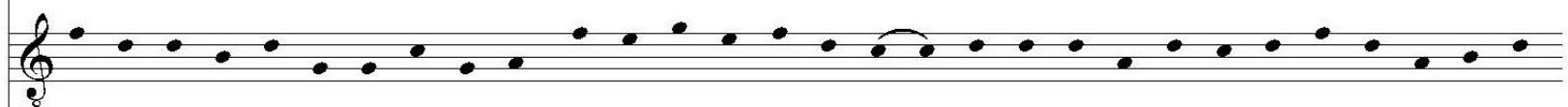

dux ví - tae mór - tu - us, rég-nat ví - vus. Sur - ré - xit Chrís-tus spes mé - a: prae-cé - det sú - os in Ga-li - laé - am.

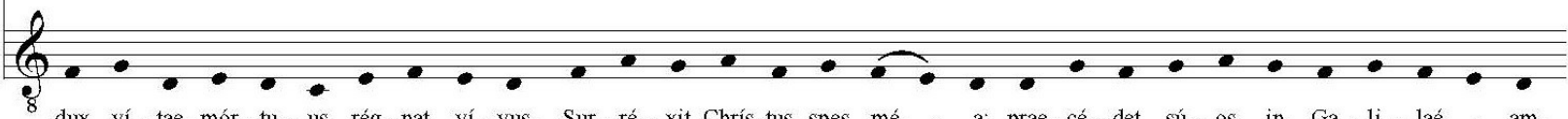

dux ví - tae mór - tu - us, rég-nat ví - vus. Sur - ré - xit Chrís-tus spes mé - a: prae - cé - det sú - os in Ga-li - laé - am.

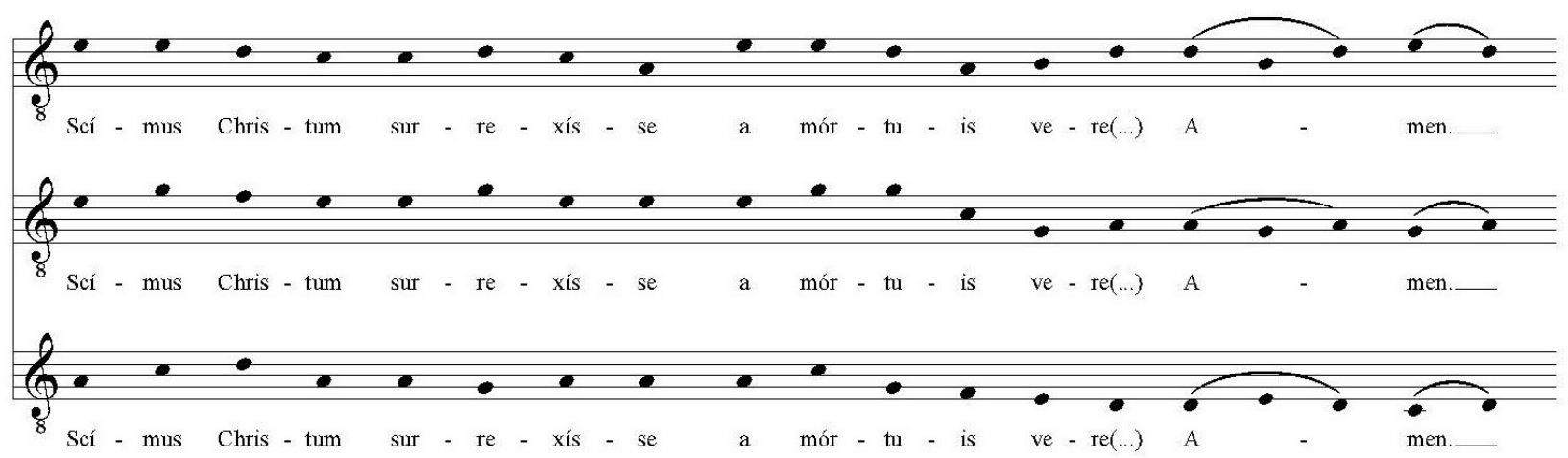

Fig. 112. Transcription and organum for Victimae paschali laudes

The Te Deum was already sung in a 2-voice organum at the entrance gate to Purgatory Proper. In

Paradise 24.113 it sounds again, but this time as a 3-voice organum. 

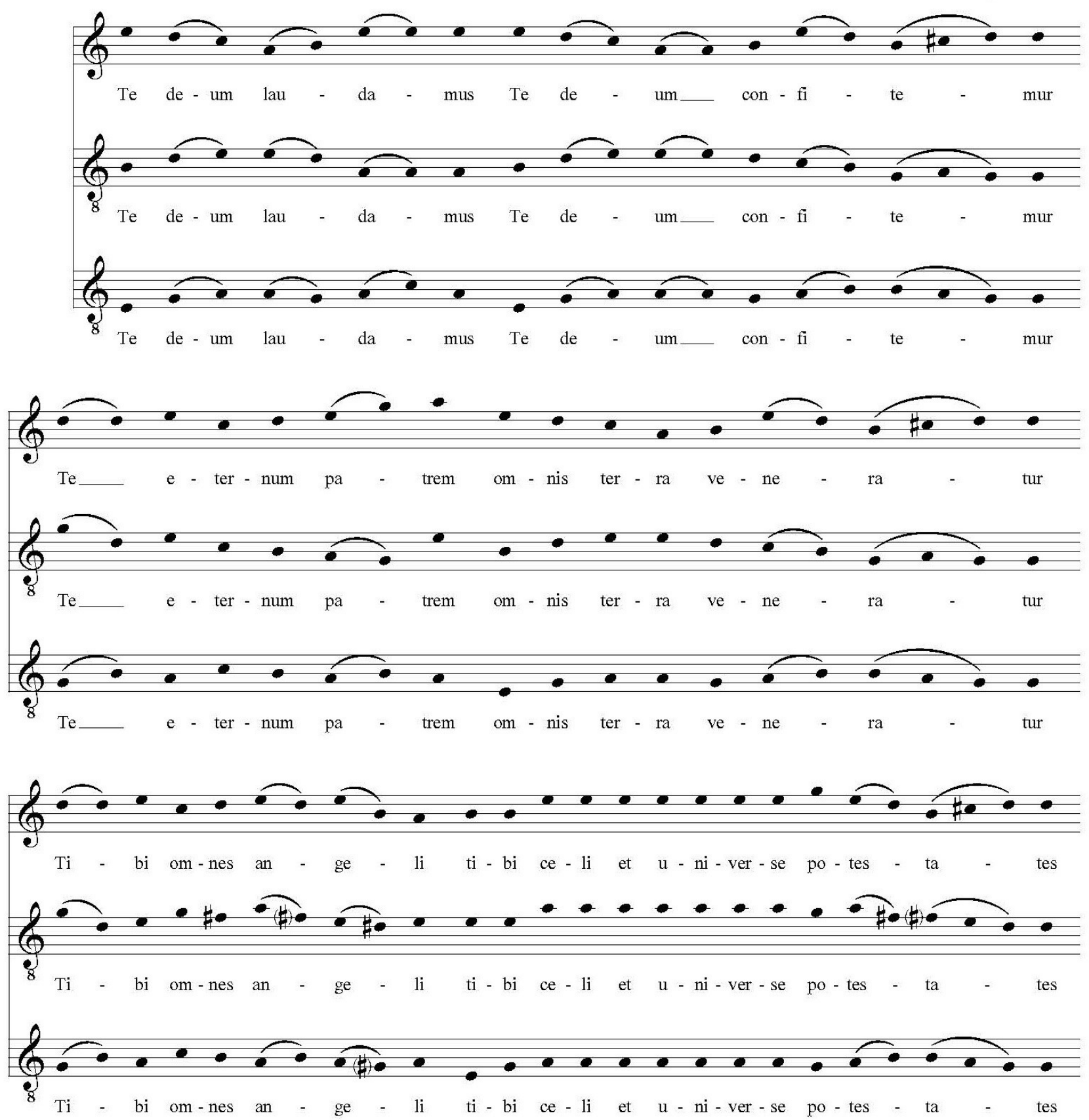

Fig. 113. First part of transcription and organum for Te Deum 

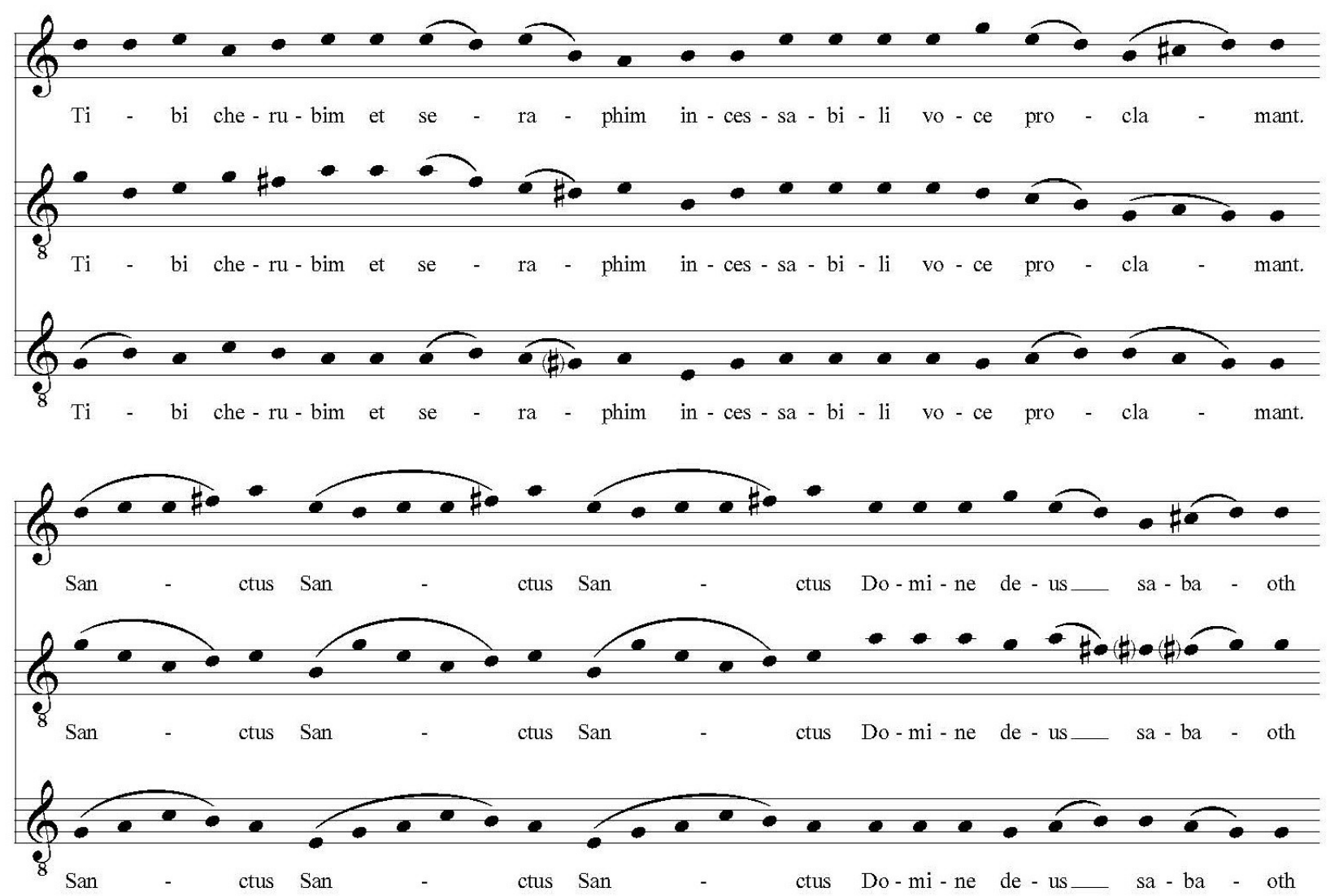

Fig. 114. Continuation of transcription and organum for Te Deum

Of Sperent in te there is only a German indexed, but not digitalized, version from the $11^{\text {th }}$ century on cantusdatabase.org. Therefore, the modern standard version was taken as a basis for the 3-voice organum. Its transcription includes the entire piece, but it was only performed in Incipit until in Sion. The part after this is much lower in pitch and bears the text quoniam non est oblitus orationem pauperum ("because He has not forgotten the prayers of the poor"). Dante's Paradise is one of heavenly celebration and Incipit aimed to accentuate this aspect. Thus, this last part was not included. 

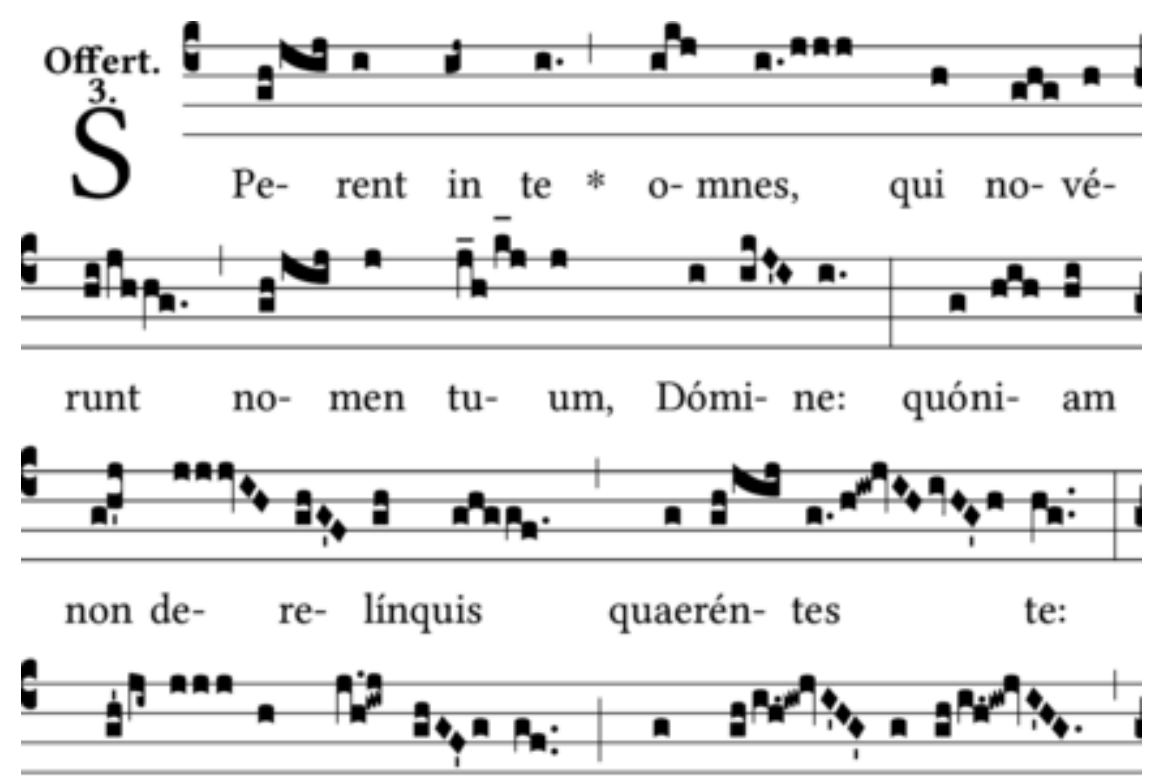

psál- li- te Dó-mi- no, qui há- bi-tat

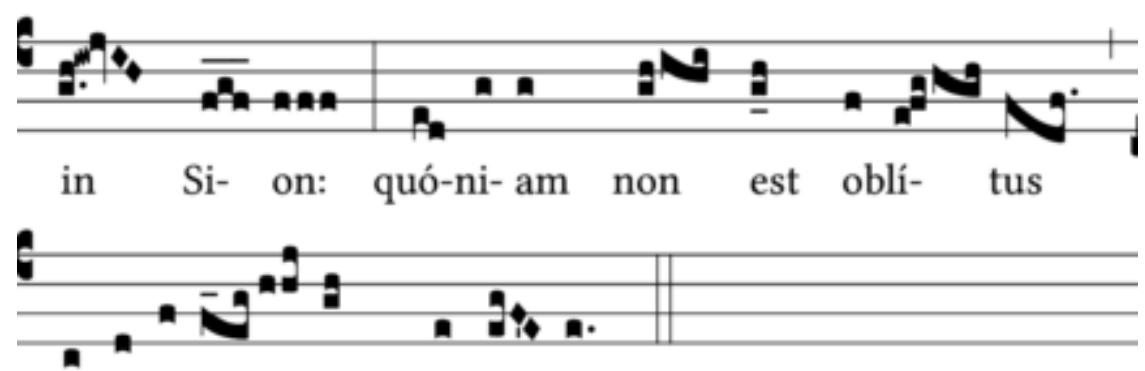

o-ra-ti- ó- nem páupe- rum.

Fig. 115. Sperent in te

Again, in this organum setting the 5-6-8 series was applied. Normally, the major sixth is combined with a major third above the principal voice. However, in querentes te a c sharp was awkward after a hexacordium naturalis accentuating the c natural on the syllable tes. Therefore, the syllable te includes a minor third combined with the major sixth, creating an augmented fourth between them, which was not the most aesthetic solution. ${ }^{399}$ Furthermore, this minor third on $\mathrm{c}$ has been resolved into a fifth on $\mathrm{d}$ instead of a unison on $\mathrm{g}$. It may be that such exceptions existed in practice, especially in improvised organum.

399 According to William Drabkin, the tritone was classified as a discordantia perfecta in the $13^{\text {th }}$ century, a perfect dissonance, together with the minor second and the major seventh. William Drabkin. "Tritone." Grove Music Online. Oxford Music Online. Oxford University Press, accessed September 25, 2015, http://www.oxfordmusiconline.com/subscriber/article/grove/music/28403. 

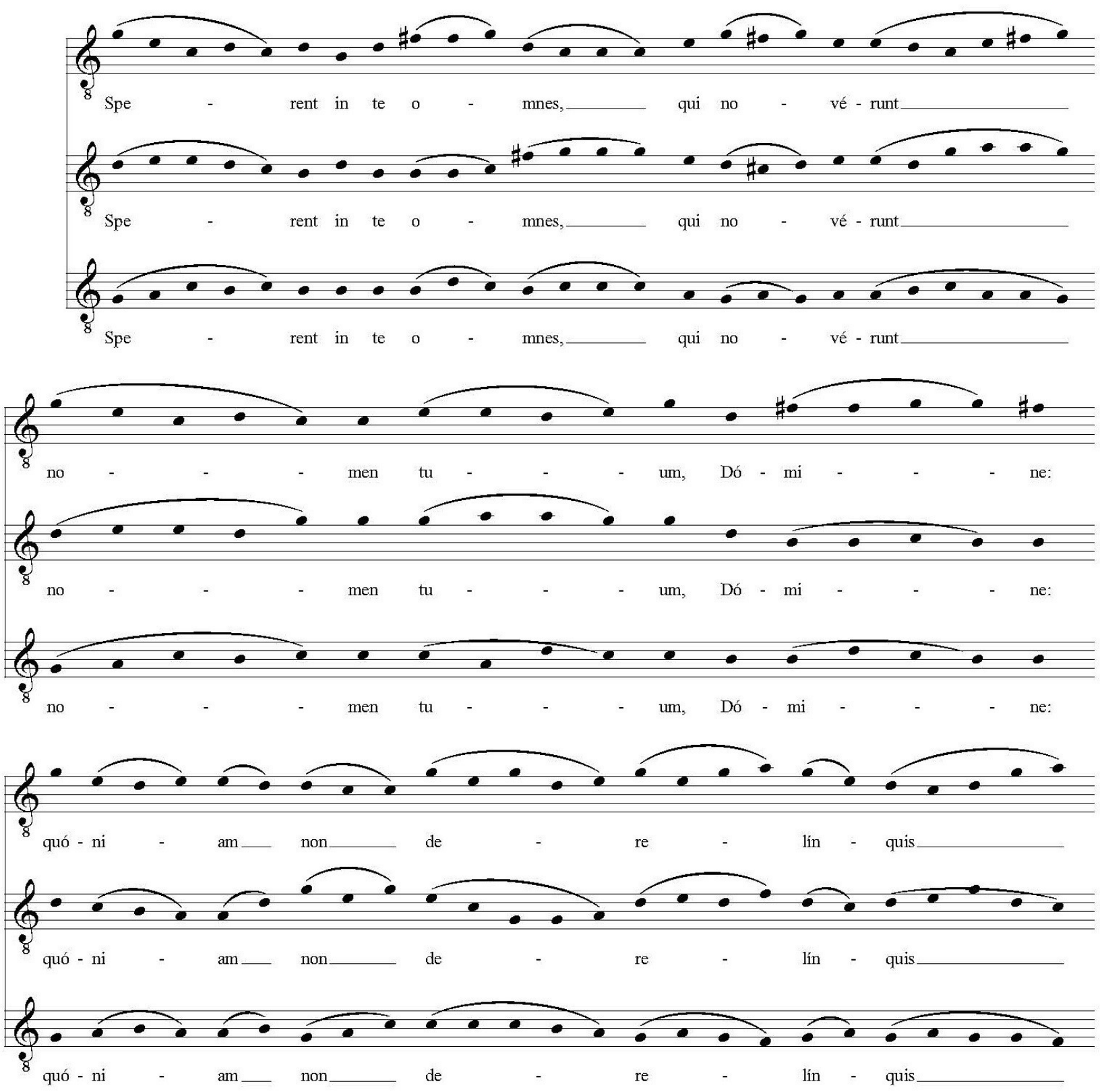

Fig. 116. First part of transcription and organum for Sperent in te 

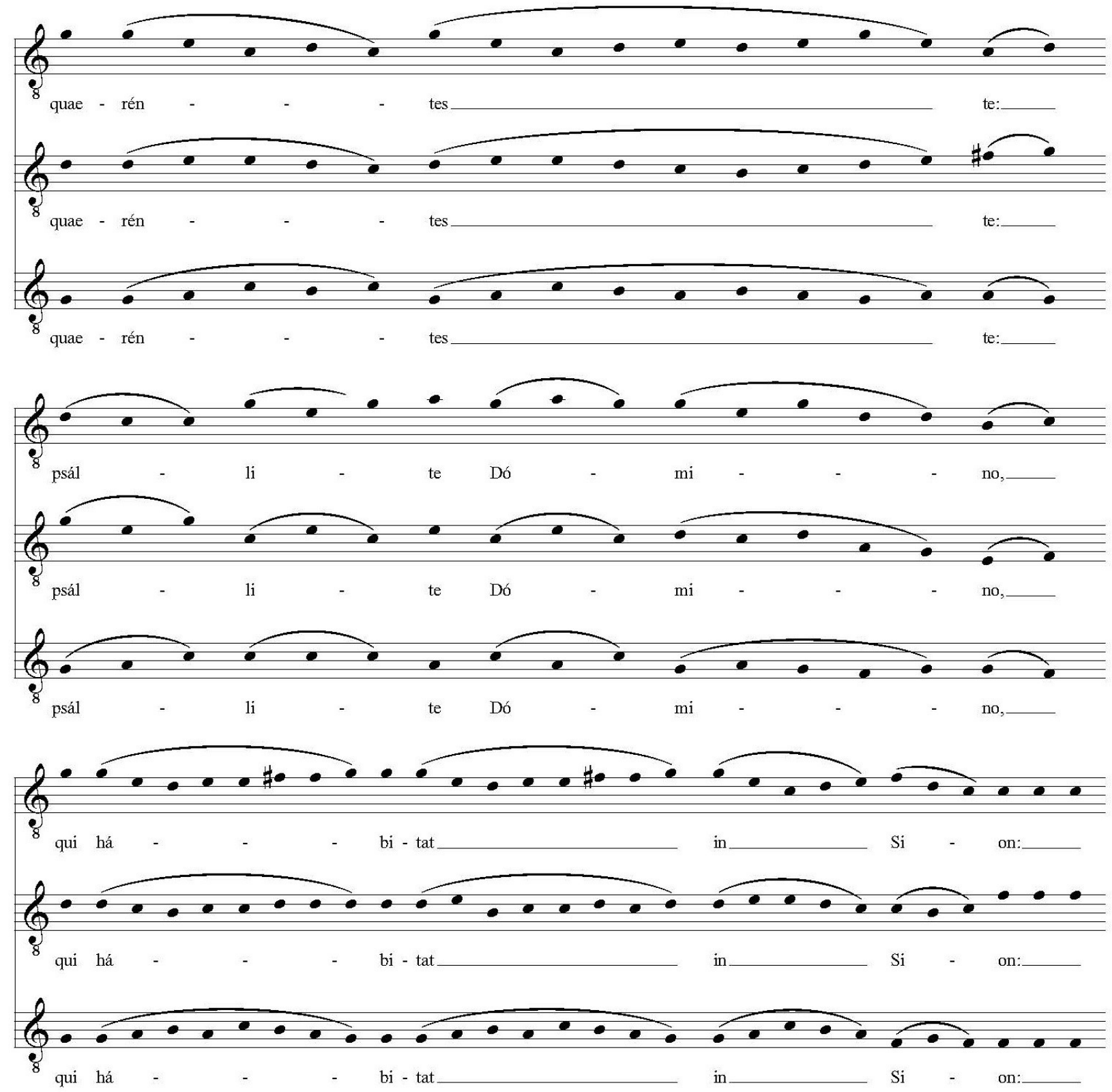

Fig. 117. Continuation of transcription and organum for Sperent in te 

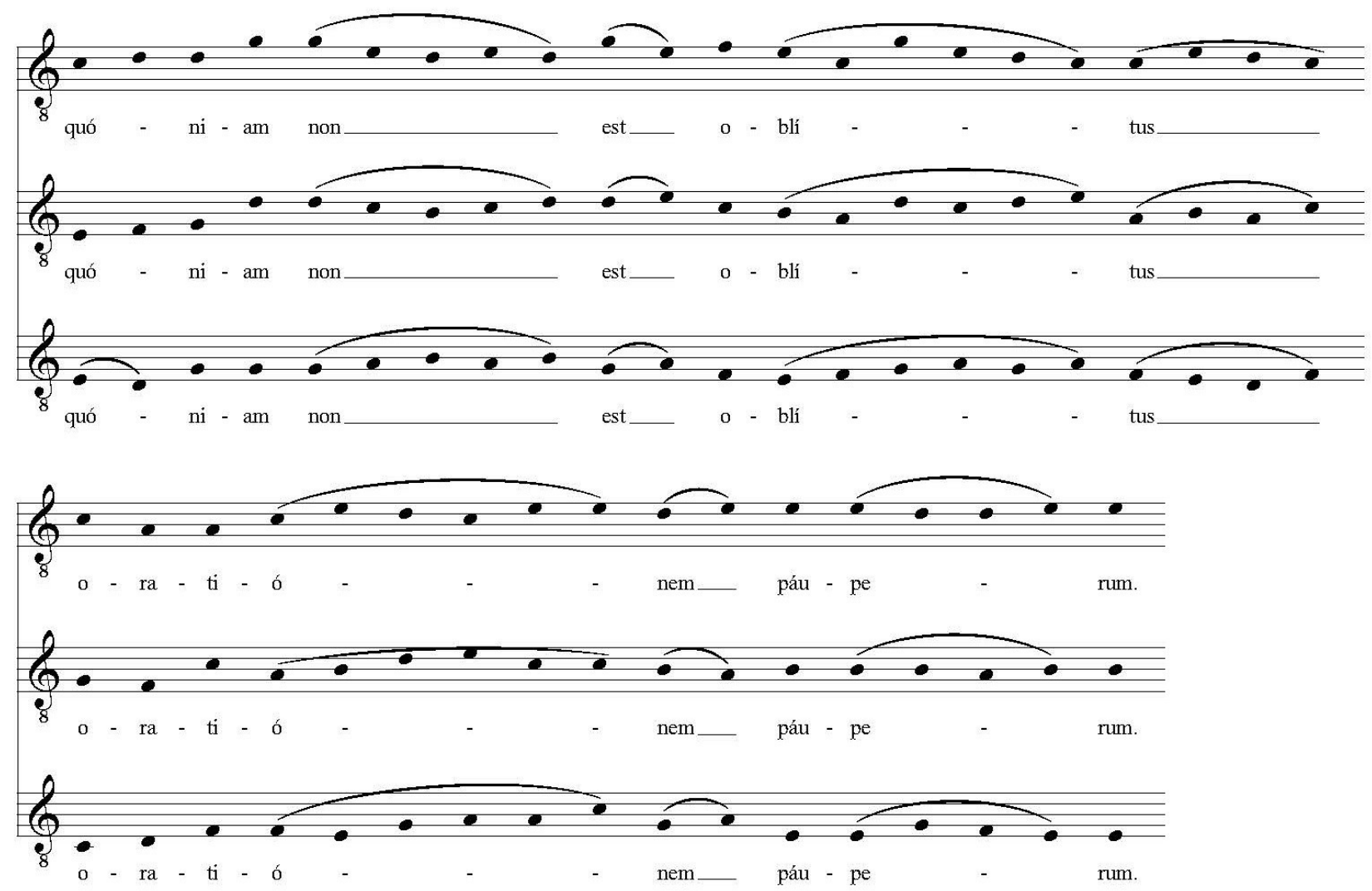

Fig. 118. Last part of Sperent in te, which was not performed

For Gloria Patri (Paradise 27.1), representing the sphere of the Primum Mobile in Incipit, several melodies exist since it was frequently used at diverse points in service. For Incipit, the following Swiss version was selected: ${ }^{400}$

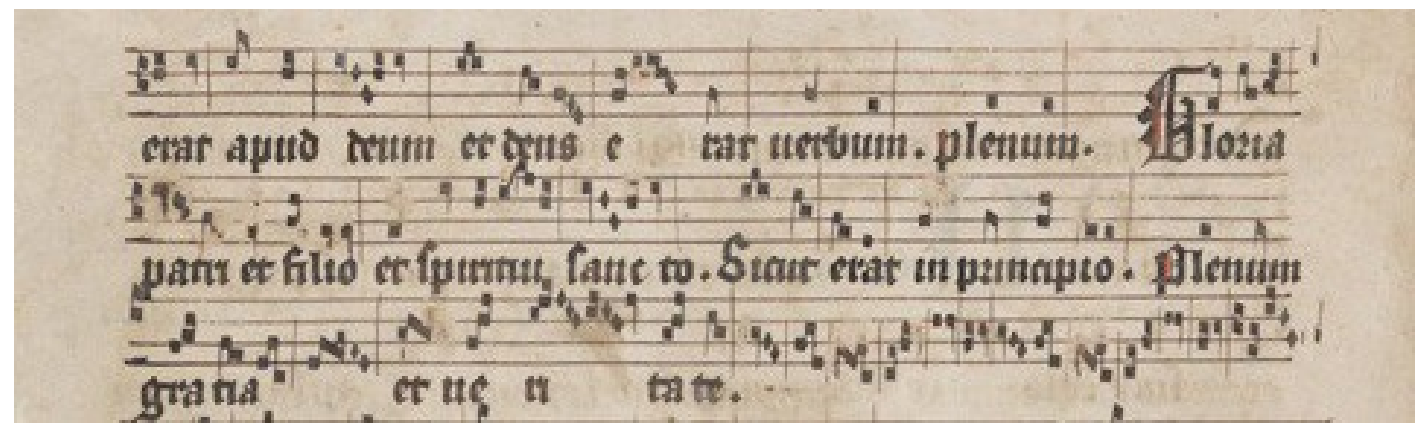

Fig. 119. Gloria Patri et Filio, Antiphonarium pro Ecclesia Einsidlensi,

Switzerland (14th century)

400 CH-E 611, Einsiedeln, Kloster Einsiedeln - Musikbibliothek, 611, Provenance: Einsiedeln, Date: 1300s. Einsiedeln, Stiftsbibliothek, Codex 611(89), f. 20v - Antiphonarium pro Ecclesia Einsidlensi (http://www.ecodices.unifr.ch/en/list/one/sbe/0611) 

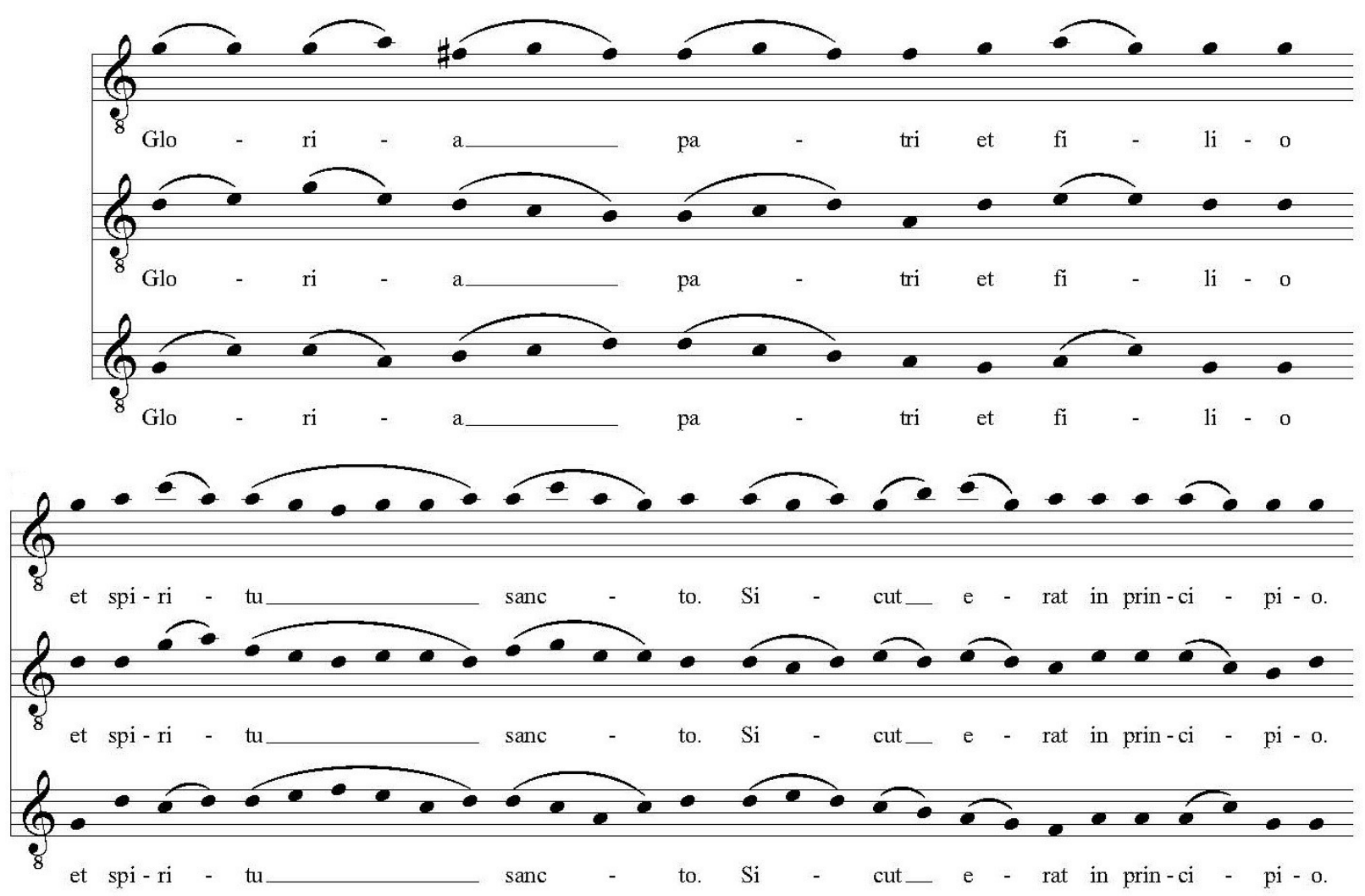

Fig. 120. Transcription and organum for Gloria Patri

Incipit's Paradise ends with the three-part Hosanna already heard in the end of Purgatory, but this time one of the voices is performed live. In the Commedia, the souls sing Hosanna in Paradise 28.118. Musically, it connects the Terrestrial Paradise, where Hosanna was heard by heavenly metaphoric figures, to the end of Paradise, where the souls themselves sing this chant. In chapter 4 we saw that the word hosanna is derived from the Aramean "save" or "saviour", thus converting it into a word of praise to Divinity's salvation of man. This Hosanna at the end of Incipit's Paradise accentuates the fact that the soul is rescued. 


\section{CHAPTER 6 - PROJECT}

\subsection{Concepts underlying Incipit}

Incipit is not only a work that merges music with other theatrical elements, but it is also based upon a musical way of "composing" the theatrical score. The original concept of Incipit was to select all references to sound, movement or gesture, colour or light and arrange them chronologically in order to compose a theatrical score consisting merely of these isolated fragments. Thus, the Commedia would not be represented literally but rather through the abstract "polyphony" of these fragments. This concept is reminiscent of the rhythmic spaces of Adolphe Appia (1862-1928) $)^{401}$, and in line with the work of musical-theatrical composers and makers. According to David Roesner and Matthias Rebstock, they "approach the theatrical stage and its means of expression as musical material. They treat voice, gesture, movement, light, sound, image, design and other features of theatrical production according to musical principles and compositional techniques and apply musical thinking to performance as a whole." ${ }^{402}$

At the moment of the first rehearsals it was realized that many sounds and movements or gestures illustrated each other rather than combining into a new aesthetics. Of all these fragments, the Commedia's sonorous references were the main point of interest for Incipit and were aimed to be maintained as complete as possible. Therefore, the soundscape of the Commedia became the leading element in the work process, while other scenic elements would be combined with it at a later stage, when the musical recordings were finished and the physical rehearsal process began.

Another important facet of Incipit is that it is a solo-performance of one creator-composer-directorperformer. The principal motivation for this choice was to experiment all creative phases personally in order to have maximum control over the creative process. Despite the difficulties it would provoke ${ }^{403}$, it was a very interesting choice for the Commedia. It forced the creator to reflect about

401 The stage designer and musician Adolphe Appia designed several innovative mises-en-scene for Wagner's works and had a great influence due to his concepts of space and lighting. For Appia, the base of the representation was not the text but the rhythm of the music. The rhythm could be the base of the actor's movements and gestures and it could also determine the design and the lighting. This was how, according to Appia, all disciplines would be merged in a natural way. Roesner, D., Musicality in Theatre: Music as Model, Method and Metaphor in Theatre-Making (Ashgate: Surrey, 2014), p.23-56.

402 Rebstock, M. and Roesner, D., Composed Theatre: Aesthetics, Practices, Processes (Bristol: Intellect Ldt, 2012), introduction

403 There are many facets to a performance and they are all very demanding. Moreover, when one is performing, being a stage director at the same time is very challenging because the performer cannot see herself from the outside. Rehearsals were videotaped and watched every night, so part of the stage direction was with one day's delay. The lighting and audio could not be objectively appreciated from the performer's location and a video camara cannot capture these elements just as they are for the audience, so these elements could not be controlled as much as by a director seated facing the stage. 
the role of one single person on stage performing somehow the three canticles of the Commedia and led to the concept of the performer representing humanity in all its facets. Instead of being an apparent external world in Dante's narrative ${ }^{404}$, in Incipit it becomes an internal world, expressed by one human body and voice. Moreover, the performer is singing polyphony with herself (recorded audio), which reinforces the idea of humanity within one person. She carries Inferno, Purgatory and Paradise within herself. Her sonorous and physical expression is the medium through which the spectator visits the Afterworld inwardly. The performer represents the human soul in all its possible forms. Incipit is not Dante's journey, but the audience's journey through Dante's Afterworld on a more abstract or timeless level, where Dante and all Commedia's characters that were significant to him do not present themselves anymore to the audience. Moevs argues that if the Commedia has a purpose, it is one of being a mirror to the reader, so that the act of reading is undertaking one's own personal journey (Moevs 2005, 182). This idea has been one of Incipit's inspirations.

The basic motivation behind Incipit was to combine early music and experimental music theatre, based on the Commedia of Dante. Therefore, the chants mentioned by Dante were explored in a historically informed manner, something which has not been done so far. This soon developed into the intention of including the general soundscape of the Commedia and thus making a sonorous journey through it. Indeed, the group Zephyrus under the direction of Paul Walker recorded these chants, but within the post-Solesmes performance tradition (see chapter 1) and only from the standard repertoire. Moreover, as far known to the author, there is no musical-theatrical performance of the Commedia including the chants, not to mention a historically informed performance of them.

In Incipit, the recorded soundtrack determines the measure of the actions and the duration of the performance. The protagonist is lead by the sound in her chant and actions. Many of her actions, especially in Inferno and Paradise, are musicalized: they are created from a musical way of thinking, focussing on its rhythm and timing and its "polyphony" with the sounds; which is exactly what makes this a creation within the area of experimental music theatre according to Hübner's definition. ${ }^{405}$ The musical use of the body is also present in dance theatre, and indeed Incipit's

404 Apparent because Dante uses the world he creates (the Afterworld of the Commedia) to show that it is yet another creation, just as real or unreal as the world we know, and never as real as the Divine infinite. See Moevs, C., The Metaphysics of Dante's Comedy (New York, 2005), p.6: "Space and time, (...) they are not self-subsistent realities; they do not consist in anything, in any smallest units or building blocks. In this profound sense, they are appearance, or sembianza, nothing but a self-experience of Intellect-Being." and "Beatrice tells Dante that when he realizes that all spatial extension is parvenza (appearance, not a self-subsistent reality), he will see that the two opposing pictures of creation are perfectly equivalent."

405 As mentioned above. "music theatre is a) multimedial by definition, always staging more than one medium, and b) primarily music-driven, working with specifically musical structuring and musical thinking while creating a performance." (Hübner 2013, 53) 
movements have a contemporary dance-like quality. Goebbels expresses very precise this musical way of thinking.

"I direct like a composer: I work very formally and consider theatre as a very musical process. I firmly believe in the musical space of an aesthetic experience and rather think about the rhythm of scenes, the harmonic or contrapuntal relationship of the theatrical elements and the different levels between a 'visual' and an 'acoustic' stage. Once I have chosen the text I reflect the sound of a language- the sound in different languages, the rhythm, the melody of a spoken text. (...) I also work on the polyphony of the media, their contrapuntal function and look for the rhythm of a performance, the chords of the colours since colours also have a very strong acoustic resonance when they come to life. (...) The best way to define a musical approach on theatre is to be conscious about form, to undertake research on forms. It doesn't mean it is formal - forms always mean something, forms always have a very strong impact on our perception, more perhaps than the perspective reduced to semantics and topics. The idea of a 'form' can be very rich and open and does not have to not be reduced to 'symmetry', 'repetition' or 'rhythm'.",406

This formal thinking has formed the basis of Incipit as well, both in its sounds and its actions.

The Commedia's Inferno, Purgatory and Paradise have been translated into three formal types. Inferno focusses on action and on the relationship between body and sound. The body reacts to the recorded sounds, as if it were controlled by them, and there is an interaction between the bodily movement and the sounds it produces. While for the other canticles the sonorous landscape is less important than the chants, in Inferno it is what constitutes the "music". It is not about chants that are to be connected through non-musical sounds, but about non-musical sounds that are to be connected directly with each other in a "musical" way, thus giving rise to a more profound compositional process. Inferno is a musical composition consisting of a collage of existing unmusical sounds, which is somewhat reminiscent of the work of Fluxus ${ }^{407}$. The facial expressions are annulated because the performer's face is covered by her hair throughout Inferno. ${ }^{408}$ This focusses the attention on the muscle movement and bone structure in the different scenes. Moreover, at times it creates an ambivalence of the bodily form. ${ }^{409}$ Her lower legs and knees are dressed in black and are mostly stuck to the floor, creating the sensation that the performer is either buried until her knees in the

406 Goebbels, H., “'It's all part of one concern': A 'Keynote' to Composition as Staging”, in Rebstock, M. and Roesner, D., Composed Theatre: Aesthetics, Practices, Processes (Bristol: Intellect Ldt, 2012), p.114

407 A movement in the 1960s, origination in the work of George Maciunas among others, that used interdisciplinarity for their "anti-art". Most Fluxus artists tended to work with materials at hand, thus fomenting the technique of collage. Life and actions of the individual artists themselves were already considered artworks, thus elevating nonartistic facets to art.

408 See for example fig. 208 (p.367).

409 Especially at the beginning, but also in the scene of the suicidals (the "tree scene"), the scene of the sorcerers walking backwards, or the final scene of Inferno (see fig.210, p.370). 
ground or that her lower legs are forming part of the black floor. What is left is little more than the torso and the arms. The performer is due to stay throughout Inferno on the same spot without getting up, which augments the sensation of inescapability and agony. Inferno only focusses on flesh and bones expressing the suffering and extreme emotions in Inferno. It is the most performative part of Incipit due to its focus on the body and on its actions.

Both Inferno and Purgatory are situated on one spot in the centre, without any further instruments than the performer herself and Purgatory's chair, which makes their mise-en-scene minimalistic. While thoughout Inferno the performer is on her knees, in Purgatory she is mostly seated on a chair but free to stand up. ${ }^{410}$ In Purgatory, the face becomes the main instrument of expression because the hair is no longer covering it. Although the infernal aspect of the soul is still present at every transition $^{411}$, the protagonist mainly interprets the scenes with facial expressions and bodily posture. The interaction is mainly between the performer's singing and her facial-bodily expressions. Instead of being performance-like, this part is rather a theatrical representation.

Paradise includes choreographed movement of the performer, from one light projection to the other. It is a carefully composed choreography for light and performer, ${ }^{412}$ whose singing merges with her recorded voices. Sonorously and metaphorically, she is simultaneously one and multiple. Visually, she appears and disappears. It is an interaction between presence and non-presence, between touchable and virtual reality. She is entirely dressed in black, except for her hands and face; thus her body disappears against the black background of the theatre when she is out of the light.

Therefore, there is a progression from Inferno's emphasis on the nude suffering flesh and the annulation of the facial expression to the Paradisical disappearance of the physical body and the presence of only face and hands. While in Inferno there is sonorous and mental chaos, in Paradise there is order. The Commedia's Paradise is a Divine representation of the immaterial Paradise adapted to Dante's mortal senses, and so is Incipit's Paradise. Paradise is not tangible but at the same time it exists, only not in time or place. If Inferno is a performance and Purgatory a theatrical representation, Paradise is a choreographed concert, an aesthetic gift to its visitor. While Paradise to Dante was represented as an abundance of light, for Incipit's audience it shows as an internalized state of bliss in a dream-like appearance.

410 Examples are fig. 212 (p.372), where she is seated, and fig. 233 (p.382), where she is runnning behind the chair. 411 The most clear example is the Te Deum, where the protagonist comes up very slowly from her folded position, her face covered by her hair. In general, at the beginning and at all the "gates" (the sound that marks the transitions from one sin to another), the folded posture with the hair covering the face and knees is reminiscent of the character of Inferno.

412 For example, see fig. 268 (p.398), fig. 272 (p.400) or fig. 274 (p.401). 
All texts in Dante's $14^{\text {th }}$ century Italian have not been translated. Again, the motivation for this is a musical one: there is a musicality in his text that is lost when translated. The texts that have been used are short and not too complex, and are relatively comprehensible to speakers of Romance languages (Spanish, Catalan, Portuguese, French, Romanian). They contain contributive but not significant information; in our choice of keeping them in their original language musicality was more important than meaning. Both for the spoken Florentine texts and for the sung Latin of the chant have not been subtitled or translated in a booklet either. Subtitles take away the attention from the dramatical action; information in a booklet gives away details of the plot. 


\subsection{References}

\section{Composer-director-performer}

Incipit is a work for soloist created and performed by the same composer-director-performer. In this aspect, Meredith Monk and Laurie Anderson have been essential references for the author. Meredith Monk (born 1942) is an American composer, performer, director, vocalist, film maker, and choreographer. Her work includes musicalized movement, which tends to be highly abstract and sculpture-like. Her music and movements are characterized by repetition, a technique also used in minimal music. There is a quality of spirituality and timelessness in her music, reinforced by her visual aesthetics. As Virginie Bobin notes, "Monk is primarily known for her innovative vocal compositions and performances, including an extended range of [vocal] techniques that she developed with the Meredith Monk and Vocal Ensemble she formed in 1978 to explore new textures and forms, resulting in such pieces as Dolmen Music (1979), considered by many a groundbreaking masterpiece in the history of vocal composition. ${ }^{{ }^{413}}$ Her solo from Education of the Girlchild (1972) focusses on a sculpture-like quality of movement and image where the singing and the movement both show a stillness. Her movements are musical, her singing is fragmentary above a basso ostinato of a piano.

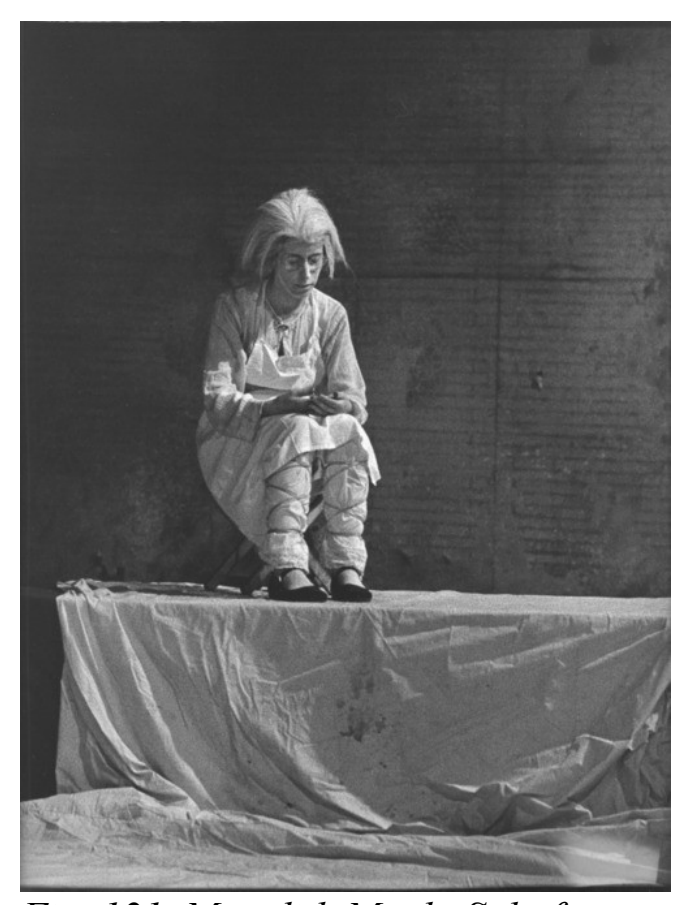

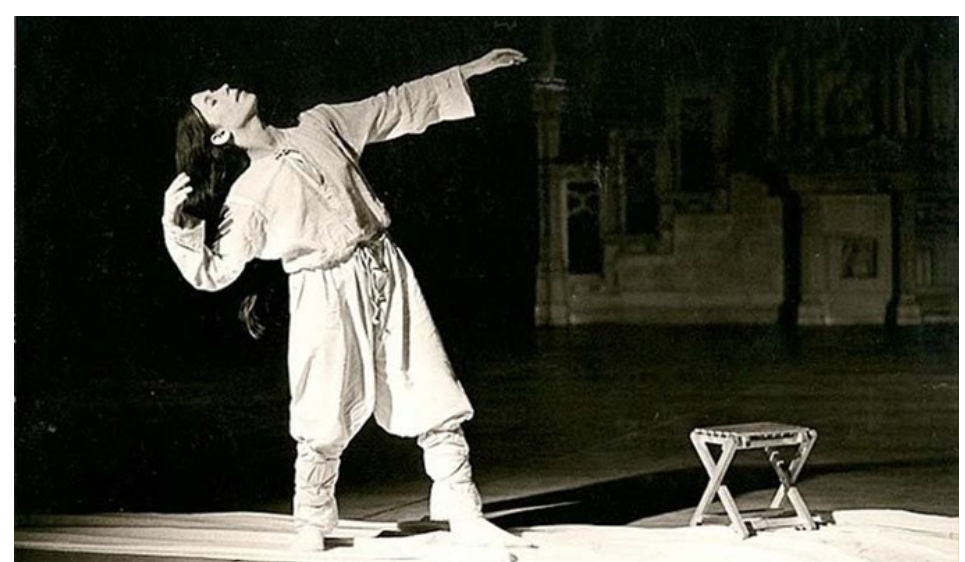

Fig. 122. Meredith Monk: Solo from Education of the Girlchild (1972). The girlchild.

Fig. 121. Meredith Monk: Solo from

Education of the Girlchild (1972). The old woman.

413 Virginie Bobin. "Monk, Meredith." Grove Art Online. Oxford Art Online. Oxford University Press, accessed October 3, 2015, http://www.oxfordartonline.com/subscriber/article/grove/art/T2090519. 
Her work Turtle Dreams (Waltz) for 4 voices and 2 electric organs (1980) illustrates her minimalistic composition and choreography. It shows four singers who make simple, repeated steps and as a group form a symmetrical, highly stylized image which interacts with the passacaglia-like music. $^{414}$

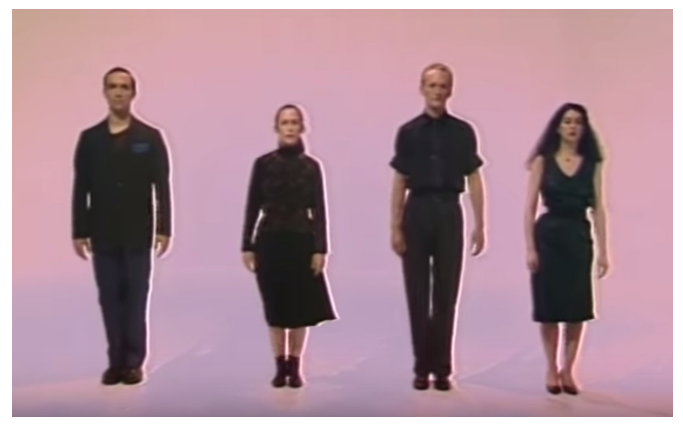

Fig. 123. Meredith Monk: Turtle Dreams (1980)

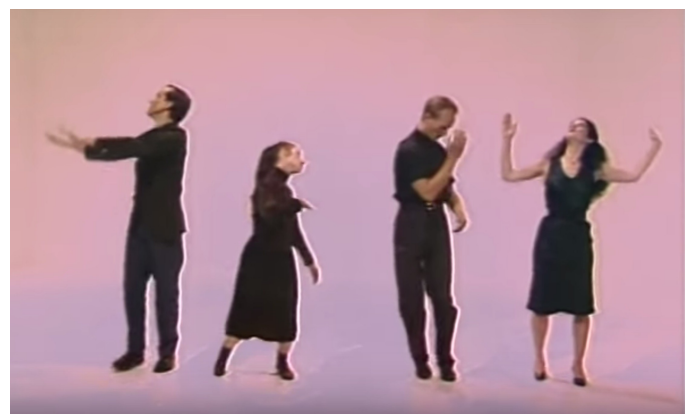

Fig. 124. Meredith Monk: Turtle Dreams (1980)

Monk's Songs of Ascension (2008) for vocal ensemble, woodwinds, percussion, and string quartet was commissioned by the Kronos Quartet and in collaboration with visual artist Ann Hamilton. Ann Hamilton's tower was designed for the Steve Oliver Ranch in Geyserville (California) and is an 80 foot concrete tower containing a double spiral staircase that ascends and descends from opposite sides of the tower "to spatially suspend the audience and performer in an alternative to a traditional face to face performance" ${ }^{\$ 15}$. Her tower resembles, in a more contemporary version, the inverted tower in the estate Quinta da Regaleira (Sintra, Portugal) ${ }^{416}$. The tower's architecture reminds of Dante's Inferno, but Monk converts the space in an instrument for the expression of spiritual ascension.

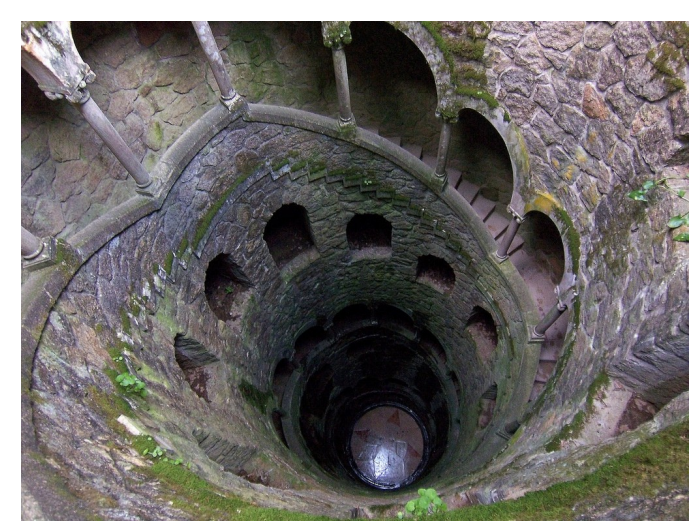

Fig. 125. The well in the form of an inverted tower in the Quinta da Regaleira

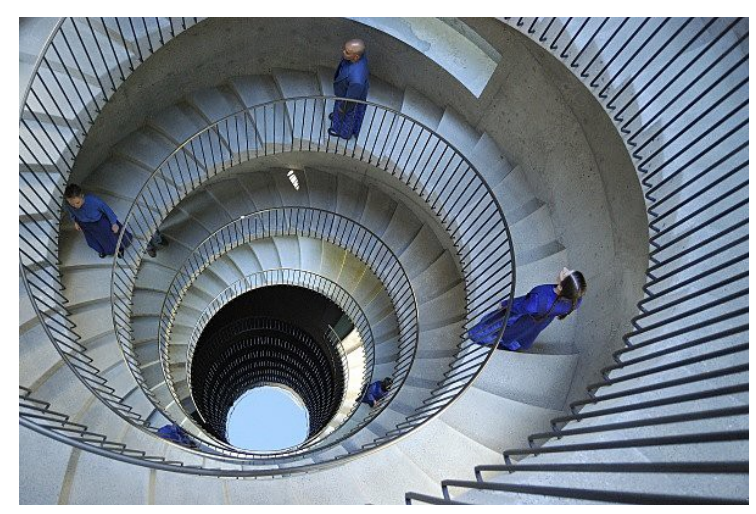

Fig. 126. Meredith Monk: Songs of Ascension (2008) in Ann Hamilton's tower

414 There is a basso ostinato, playing constantly the same accompaniment for their vocal sounds. 415 Ann Hamilton, http://www.annhamiltonstudio.com/projects/tower.html [accessed 3-10 2015] 416 This well, in the form of a spiralled inverted tower, has nine hallways, just like the nine circles of Dante's Inferno. 
The association between the architecture of a well and Dante's Inferno is implicitly present in Samuel Beckett's story “The lost ones”, on which Tomaž Pandur based his Inferno of 2001 (see below).

Another main composer-director-performer is Laurie Anderson (1947), also visual artist, instrumentalist (violin and keyboard), vocalist, poet, photographer, and filmmaker. She began making performance art in the 1960s, of which her Skates on Ice were discussed earlier in this chapter. She crossed over to the pop music world when in 1980 her single "O Superman" rose to number two on the British pop charts. She uses electronic instruments, some of her own design. ${ }^{417}$ Her works are often characterized by political and social commitment. Her performances mix the setting of a (pop) concert with experimental contents and forms.
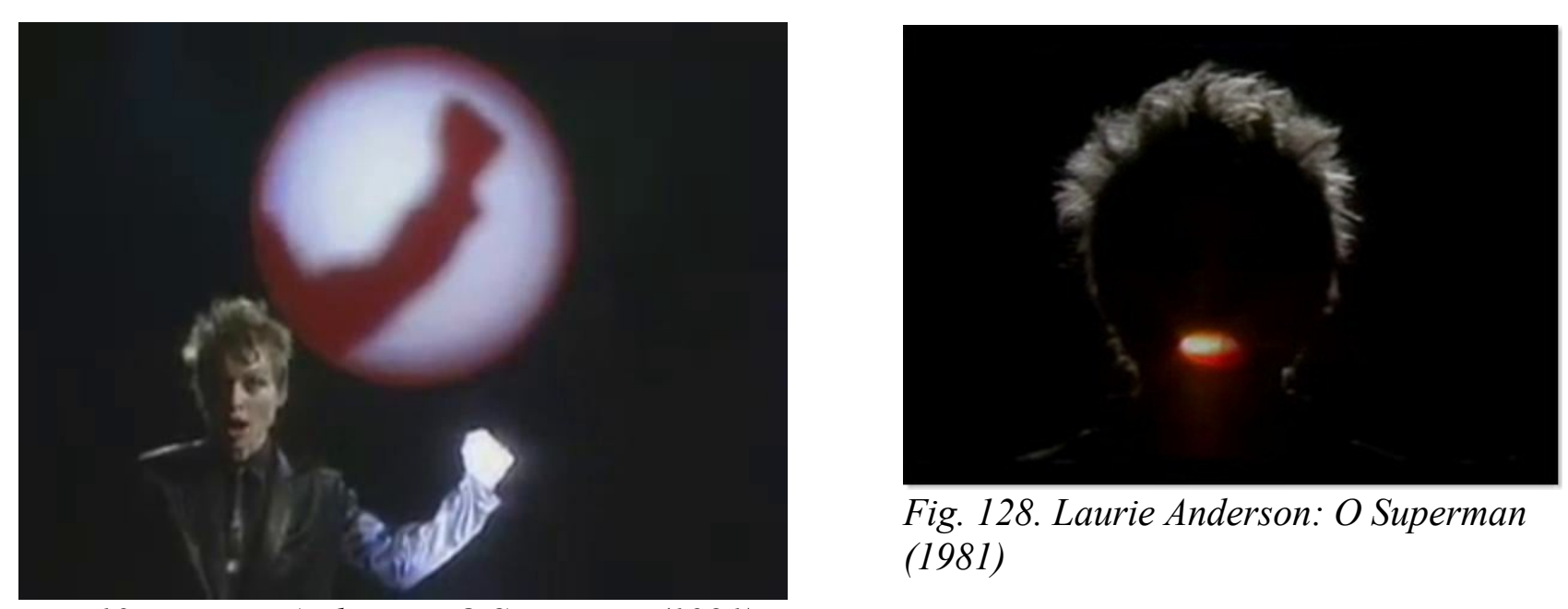

Fig. 128. Laurie Anderson: O Superman (1981)

Fig. 127. Laurie Anderson: O Superman (1981)

Also a "total" artist is Pamela Z (1956), an American composer, performer, singer and media artist whose solo works usually include electronic processing of her voice in real time by means of layering, looping and altering her live vocal sound. Her vocal style consists of both a classical singing technique and extended techniques and spoken word. ${ }^{418}$ Her work Voci (2003) is a comical performance in which the sung and spoken voice and its electronic processed sound interact with theatrical elements and video. Baggage allowance (2010) consists of three interconnected components: a solo multi-media performance, a gallery installation, and an interactive web portal.

417 http://www.laurieanderson.com/downloads/LaurieAndersonBio.pdf [accessed 3-10 2015] and "Anderson, Laurie." Grove Art Online. Oxford Art Online. Oxford University Press, accessed October 3, 2015, http://www.oxfordartonline.com/subscriber/article/grove/art/T002694.

418 Garrett, Charles Hiroshi. 'The Grove Dictionary of American Music”, "Pamela Z”, Oxford University Press 2013 
"The work explores the concept of baggage in its many senses - physical, intellectual, and emotional - baggage as impediment and baggage as treasure." ${ }^{419}$ She sings polyphonically with her own recorded voices.

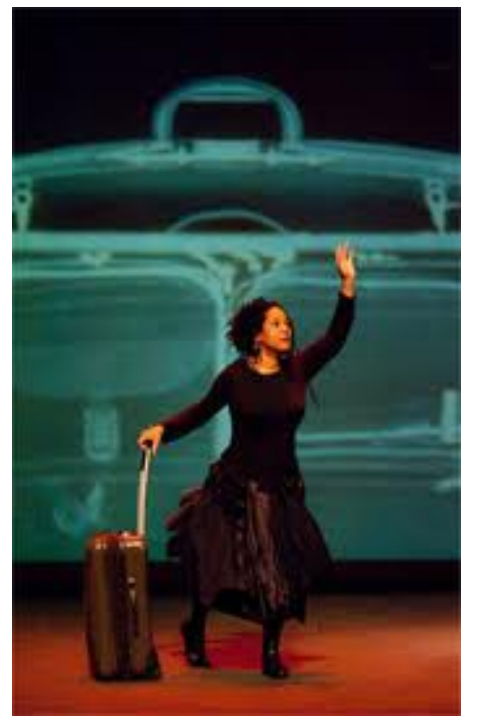

Fig. 129. Pamela Z: Baggage Allowance (2010)

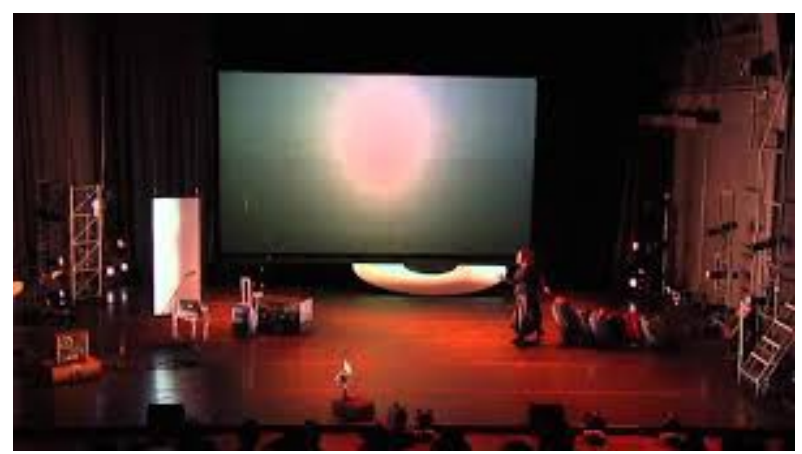

Fig. 130. Pamela Z: Baggage Allowance (2010)

Both Meredith Monk and Pamela $\mathrm{Z}$ explore the possibilities of the voice, but it was Cathy Berberian (1925-1983) who was one of its pioneers. She had a great vocal range, flexibility and expressivity and interpreted avant-garde music. She also composed and performed her well-known Stripsody (1966), an exploration of the vocal expression of cartoon sounds.

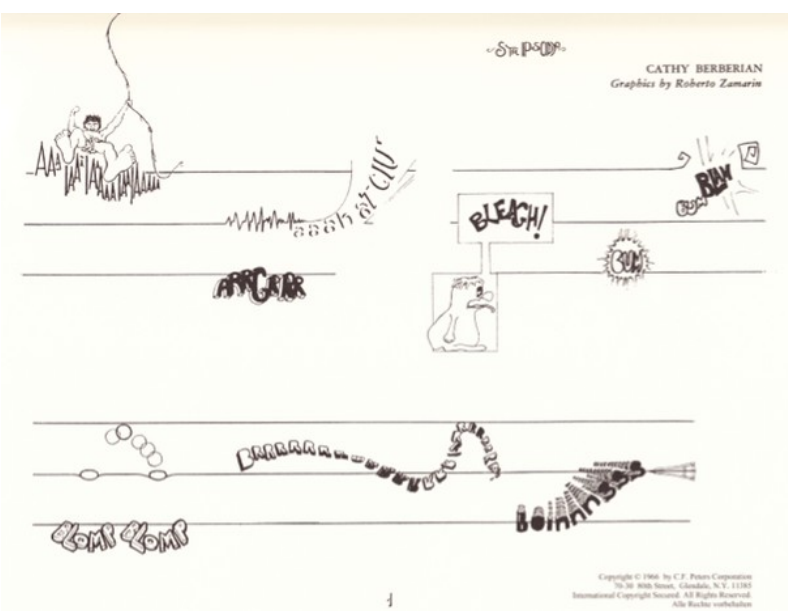

Fig. 131. Cathy Berberian: Stripsody (1966)

419 From the personal webpage of Pamela Z. http://www.pamelaz.com/baggageallowance.html\#performance [accessed 3-10 2015] 
In this aspect, it is worth mentioning the Récitations (1977-78) for solo voice by composer Georges Aphergis. These are graphical scores with repetitive phrase where each time a new sound is added.

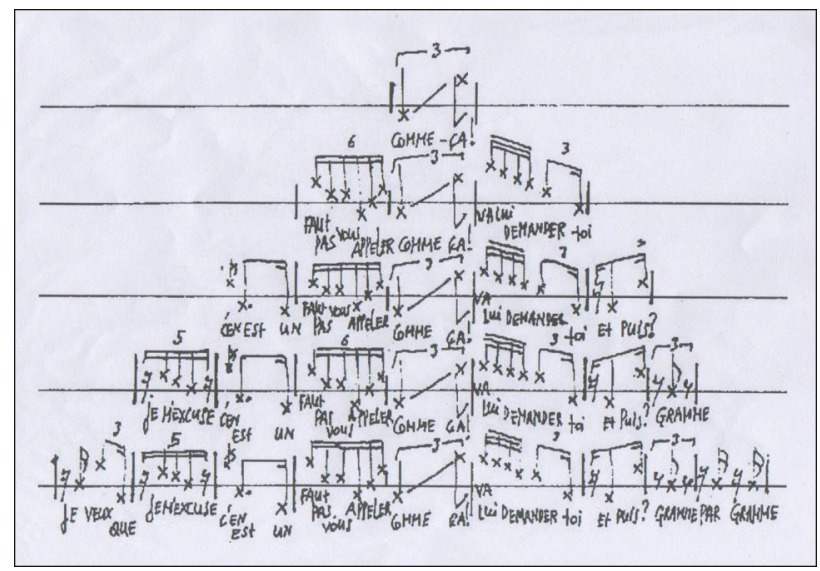

Fig. 132. Georges Aperghis: Récitations (197778), $n^{\circ} 11$ (detail)

\section{Visual-sonorous aesthetics and the Commedia}

In the field of music theatre there are many references for Incipit. As to the work process of Incipit, the most important reference is the concept behind Heiner Goebbels' work. Cited earlier in this chapter on page 296, he indicates that his work method is a musical one: he directs as a composer, just as he intents to compose as a director, taking into account the performers and their personalities. His idea of "polyphony" in the combination of different disciplines is a highly musical one and indeed defines very well many types of music theatre. All sounds are musical to him:

"I listen to language, especially to languages I do not understand, while working with French actors, with Greek, African, Japanese or English musicians. It enables me to discover the musical quality of a spoken text." ${ }^{420}$

It is exactly this musical character of Dante's text that makes it necessary to be recited in the original Florentine. Goebbels' works are large-scale, with many musicians and other performers as well as video-projections and electronic devises. 
Other large scale creators that inspired Incipit, not composers but stage directors, were Tomaž Pandur and Robert Wilson. Both are rather visual thinkers than compositional ones. Robert Wilson has also worked as a choreographer, performer, painter, sculptor, video artist, and sound and lighting designer. His aesthetics is one of dream-like, alienating scenes. He works with text in a musical way, but also noise and silence. Movement and visual art, however, are the most essential elements in his work. ${ }^{421}$ Incipit's Paradise has been inspired by his dream-like aesthetics. Goebbels comments that Wilson told him that all different art disciplines are part of one concern.

"He did not explain what that means, but you may find clarity in his aesthetic approach of reduction, of clarity, of minimalism, of creating a space for the imagination in all those disciplines. At the same time it is evident that he never mixes these different elements. He insists on a total separation of elements and separates each element from all the others. He separates the movements from the language - because his performers do not do what they speak about, or if they do they do not do it in a naturalistic but in a very formal or aesthetic way. He separates the language from the bodies - because the performer's voices are never heard in a direct way, they're picked up with little microphones and amplified by speakers, and consequently the sound never reaches the spectators in a direct communication. He separates the bodies from each other - by creating different light zones on stage, with which he can create a distance even between people who are standing next to each other. He even fragments the different parts of the performer's body - by focussing the light so precisely that an isolated hand or head or shoe of a performer can start to tell the story. It is indeed surprising for somebody who says 'it's all part of one concern' to separate all those individual disciplines and create such a space in between - which is so fundamental and so essential for our imagination." ${ }^{422}$

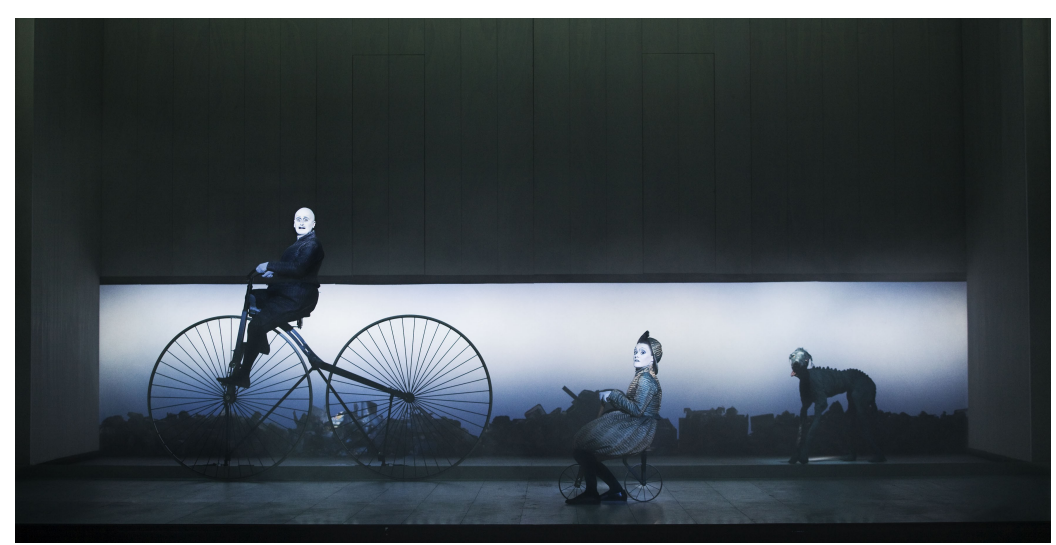

Fig. 133. Robert Wilson: Sonnets (2009)

421 Morey, M. and Pardo, C., Robert Wilson (Poligrafa: Barcelona, 2003)

422 Goebbels, H., “'It's all part of one concern': A 'Keynote' to Composition as Staging”, in Rebstock, M. and Roesner, D., Composed Theatre: Aesthetics, Practices, Processes (Bristol: Intellect Ldt, 2012), p.114 


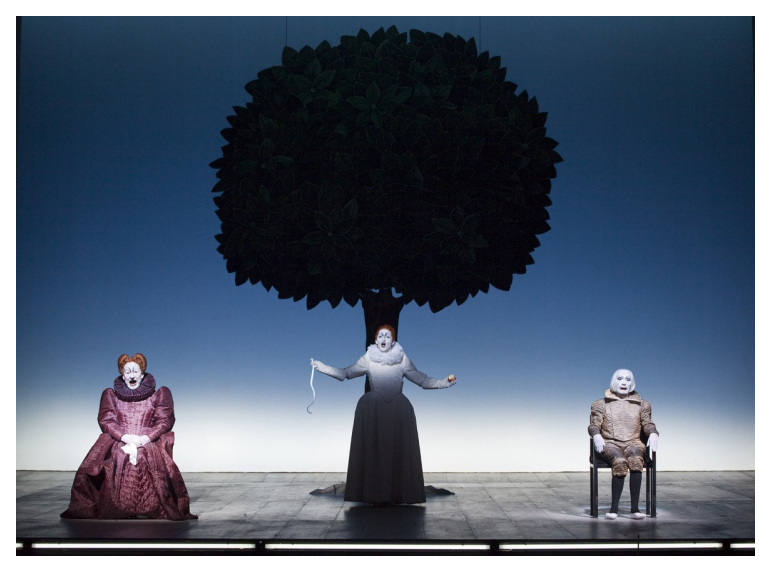

Fig. 134. Robert Wilson: Sonnets (2009)

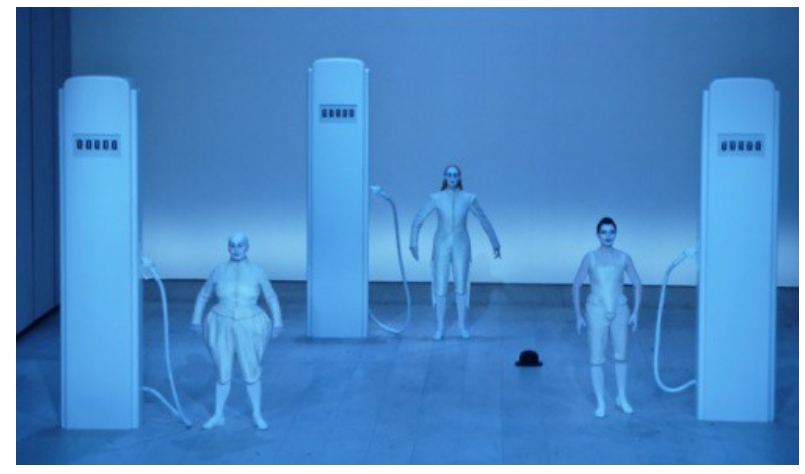

Fig. 135. Robert Wilson: Sonnets (2009)

Wilson has also created the mise-en-scene for various operas, such as Richard Strauss's Die Frau ohne Schatten (Paris, 2002), Verdi's Aida (London, 2003), Monteverdi's L'Orfeo (Milan, 2009) and Claude Debussy's Pelléas et Mélisande (Madrid, 2011). The latter has a highly dream-like staging, almost like a painting, very minimalistic and focussed on colour and lighting.

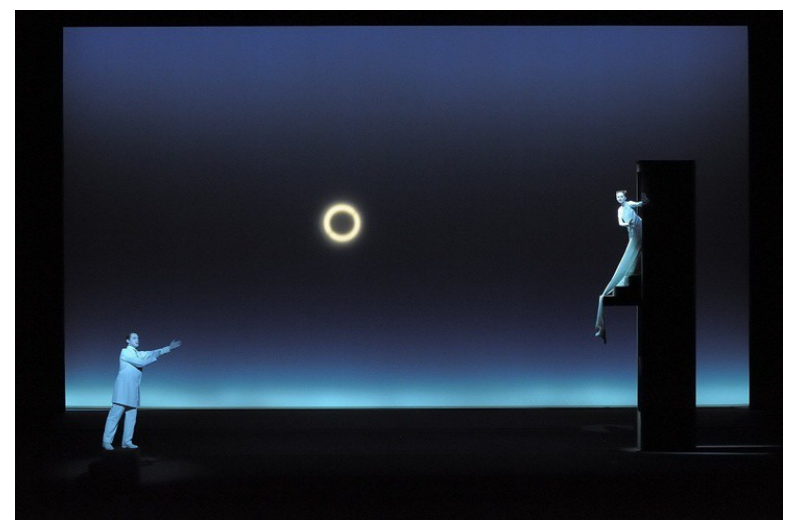

Fig. 136. Robert Wilson: Claude Debussy's Pelléas et Mélisande (2011)

In Tomaž Pandur's 2001 interpretation of Dante's Commedia (La Divina Commedia - Inferno, Thalia Theater, Hamburg), his Inferno is a cylindrical space with two long ladders against the sides, where there are a few ledges at different heights. At the bottom there is water, just like in a well. The colour of the space is a blue-grey with little light. Pandur's space is inspired in Beckett's cylinder, but the latter is bright yellow without any water. In Beckett's "The Lost Ones", ${ }^{423}$ there are four types of bodies: the Searchers, Sedentary-Searchers, Sedentary and Vanquished. The Searchers 
are the most hopeful, who are actively searching for an exit, while the Vanquished gave up all search and in a way are the only ones who escape, because all their senses do not function anymore. The souls lying in Pandur's water are reminiscent of Beckett's Vanquished. The idea of a cylinder from where there is no escape, have been inspirational for Incipit's Inferno.

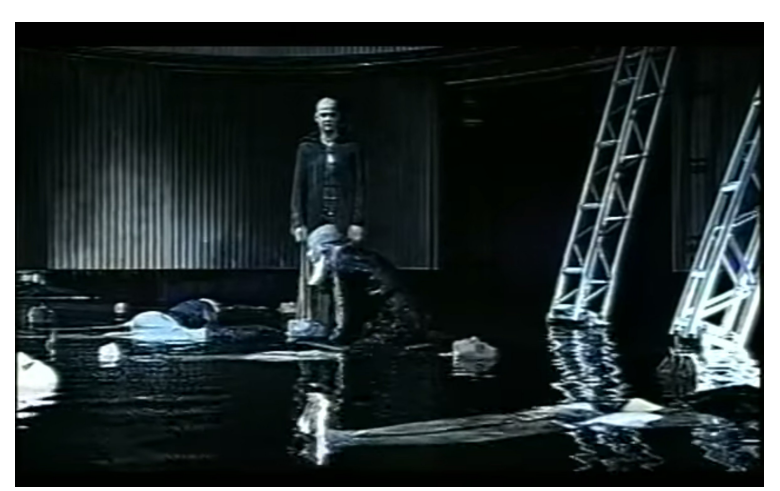

Fig. 137. Tomaž Pandur: La Divina Commedia - Inferno (2001). The bodies in the water.

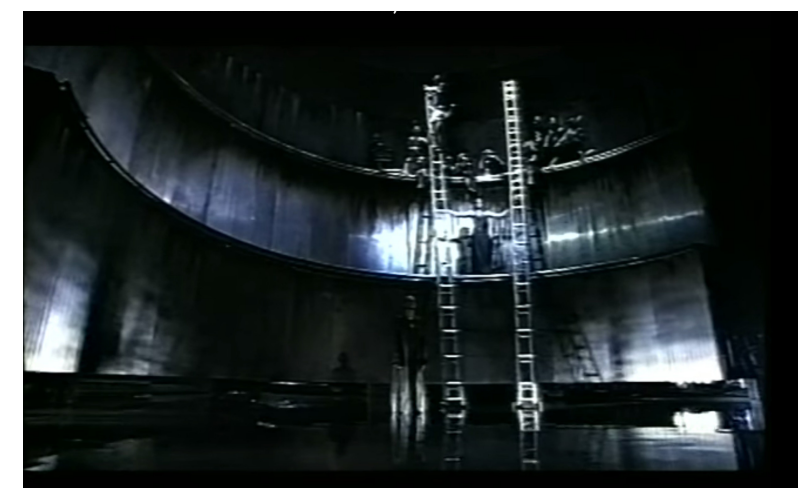

Fig. 138. Tomaž Pandur: La Divina Commedia - Inferno (2001). The ladders.

In this aspect, a more direct visual source of inspiration for Incipit's faceless body derives from the cinematographic field. In the film The Ring (2001), an American remake of the Japanese horror film Ring, the body of a dead girl lies in the water on the bottom of a narrow deep well, while her evil spirit haunts those who have seen a videotape with her curse. The image of this well, much narrower than the cylinder in Beckett's and Pandur's concepts, has been the inspiration for Incipit's Inferno. It gives a suffocating intensity to the sensation of being trapped and being completely alone in her suffering. Moreover, The Ring's evil spirit wears her face covered by her hair, another facet that Incipit and The Ring have in common. However, while the Ring's spirit is evil and her hair conceals her monstrous face, Incipit's protagonist in Inferno is lowered to her beastly state and has lost the possibility of facial expression.

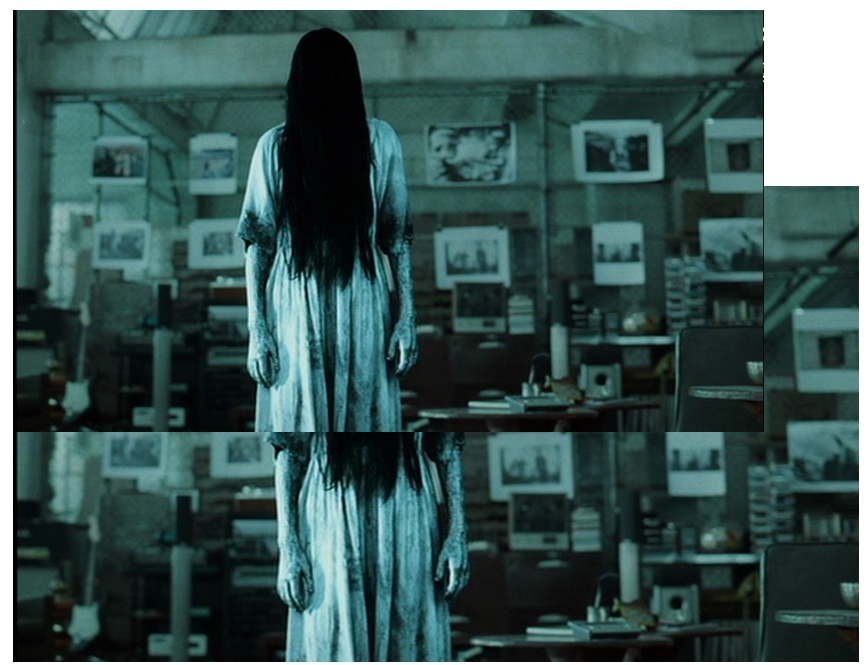

Fig. 141. The Ring 2 (2005)

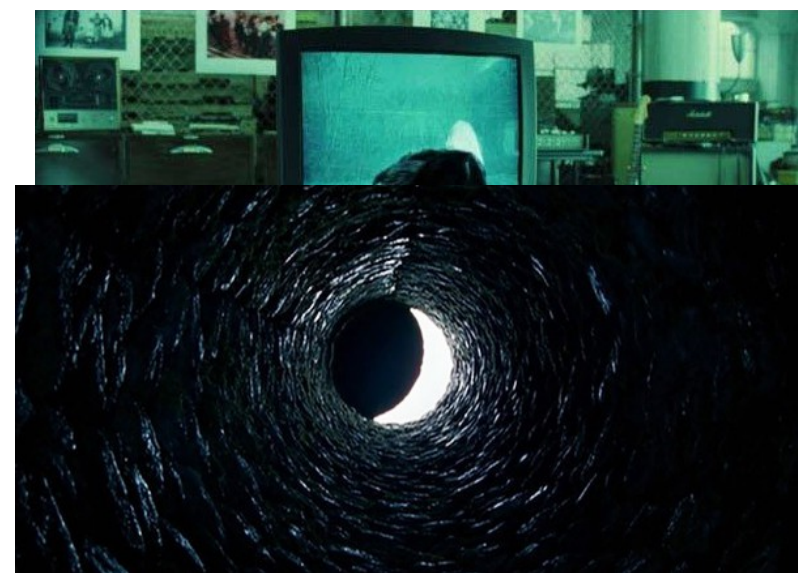

Fig. 142. The Ring 2 (2005): the view of the interior of the well from the bottom 
Romeo Castelluci (1960) is an Italian theatre director, playwright, artist, designer, and artistic leader of his own company Socìetas Raffaello Sanzio. ${ }^{424}$ He directed the Dante trilogy at the Avignon Festival 2008 (Divina Commedia: Inferno, Purgatorio, Paradiso), which is a large-scale multidisciplinary show, where Inferno is connected to love and life, to the humane. ${ }^{425}$ It is a trilogy where Dante's own text has made place for multidisciplinary scenes where sound, video, light, images and the unusual presence of dogs and children are merged into powerful impressions. Castelluci said about the role of the music.

"Sounds are truly carrying a form already; they don't accompany a form; they are a form themselves and in this way and this mode they are directly dramatic. When you do not exclude the visual imagination of sounds, they create spaces, they create colours, but you have to be careful not to put everything on top of each other. In conventional ways of directing opera very often the directors do not create any space for the form which lays within the music itself; instead, they superimpose ideas and ideas and images up to a degree where the imagination of the listener and the viewer is collapsing, because there is no space left." ${ }^{426}$

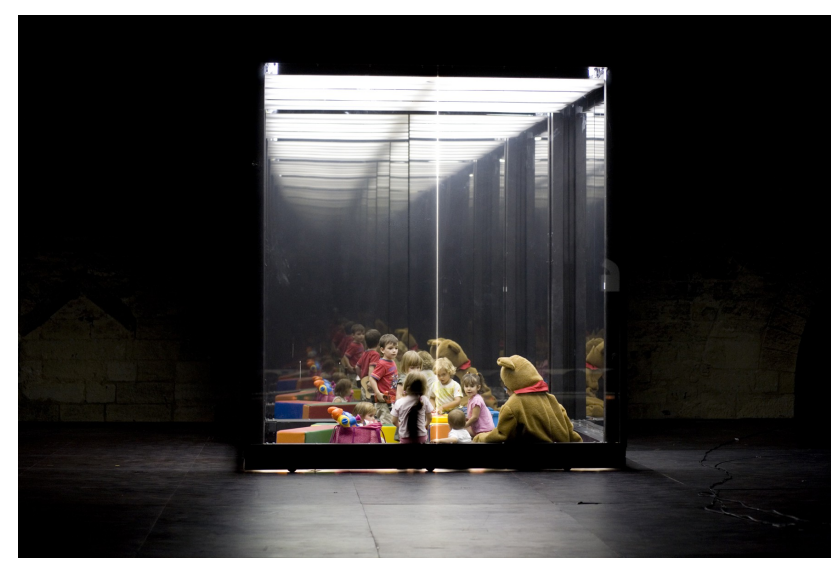

Fig. 143. Romeo Castellucci: Inferno (2008)

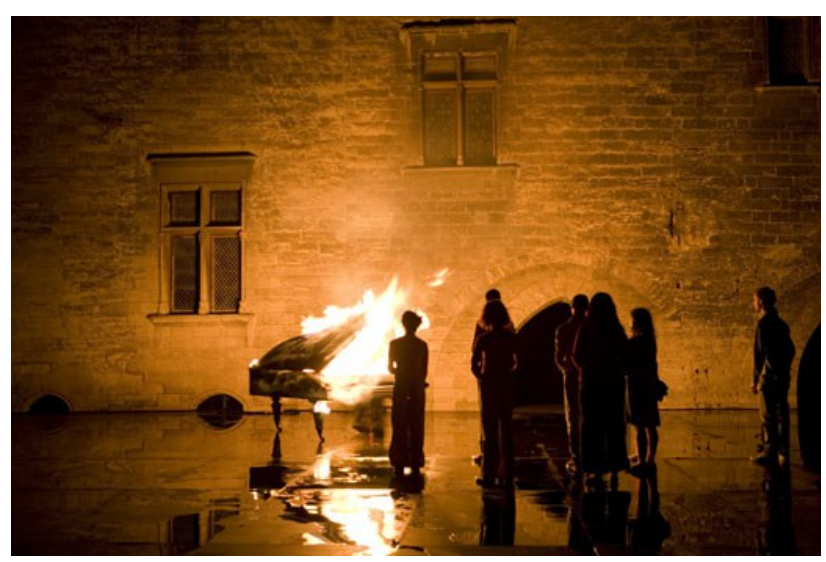

Fig. 144. Romeo Castellucci: Inferno (2008)

424 Castellucci, R. and Castellucci, C., trad. Matteini, C., Los peregrinos de la materia (Madrid, 2013)

425 According to Castellucci's words: "Il s'agit d'affections. L'enfer c'est plutôt dans les affections, dans l'amour. .. mais surtout dans l'amour et la vie... Dante dans l'enfer est le voyager, doncs dans le royaume de l'obscurité, mais il a rencontré tout le temps des hommes et des femmes, seulement dans l'enfer il y a des histoires d'amour ...et doncs on peut dir que c'est le poème le plus connecté a la vie ... a la faim de vie. Il y a un accrouchement a la vie absolument extraordinaire." Belgian TV channel Klara: an interview with Italian theatre director Romeo Castellucci about his vision of Hell, Purgatory and Paradise (2009). https://www.youtube.com/watch?v=alxo8ynoIrg

426 Castelluci, R., "Das Haus muss brennen. Romeo Castelluci im Gespräch mit Lena Schneider und Frank Raddatz", Theater der Zeit, 09/2008, p.16-20, as cited and traslated in Goebbels, H., "It's all part of one concern", chapter 4 of Rebstock, M. and Roesner, D., Composed Theatre: Aesthetics, Practices, Processes (Bristol: Intellect Ldt, 2012), p. 115 


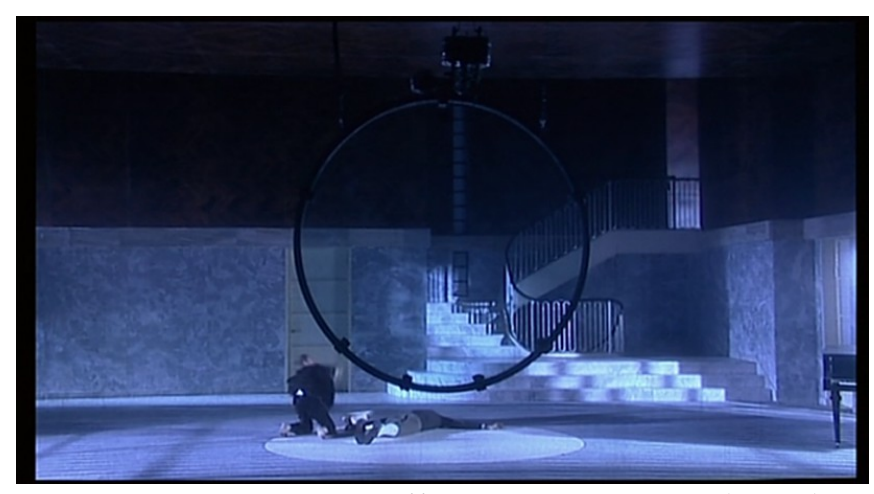

Fig. 145. Romeo Castellucci: Purgatorio (2008)

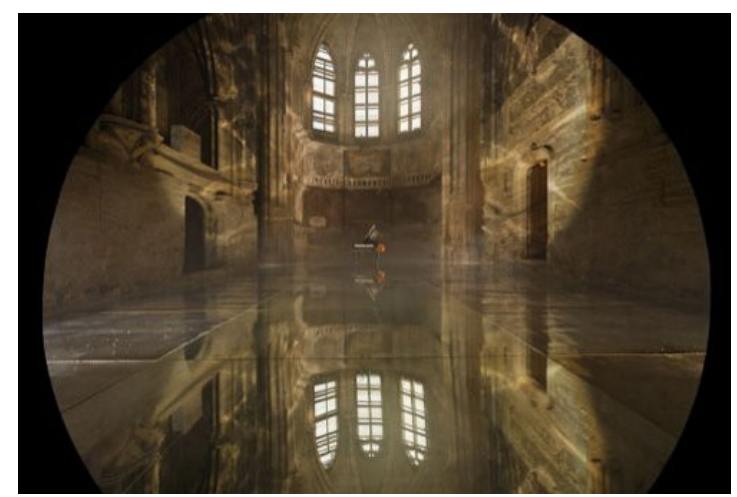

Fig. 146. Romeo Castellucci: Paradise (2008)

Romeo Castellucci's Tragedia Endogonidia (L.\#09 London) (2002-2004) begins with a performer wearing a long blond wig and a neutral black face mask. Her naked and faceless body in highly slow and sometimes provocative movement give a sensation of alienation and unease. She is completely silent and is accompanied by a recording of soft noise, until she knocks on the floor by lifting and dropping her lower arms. A whispered voice sounds: "Who is it" and "It's me", after which the noise augments. Incipit's Inferno is reminiscent of Castelluci's aesthetics in this specific scene, but the entire series of Tragedia Endogonidia has an eery, suffocating and violent quality to it that has inspired Incipit.

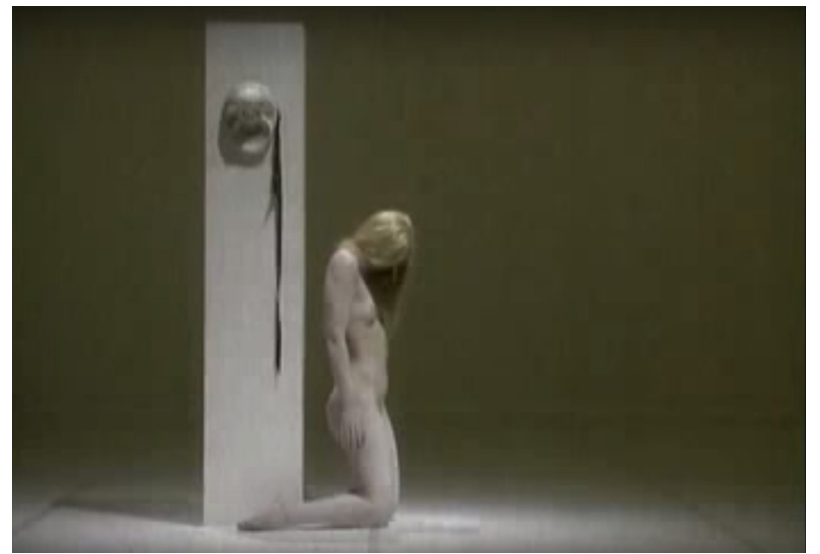

Fig. 147. Romeo Castellucci's Tragedia Endogonidia (L.\#09 London)

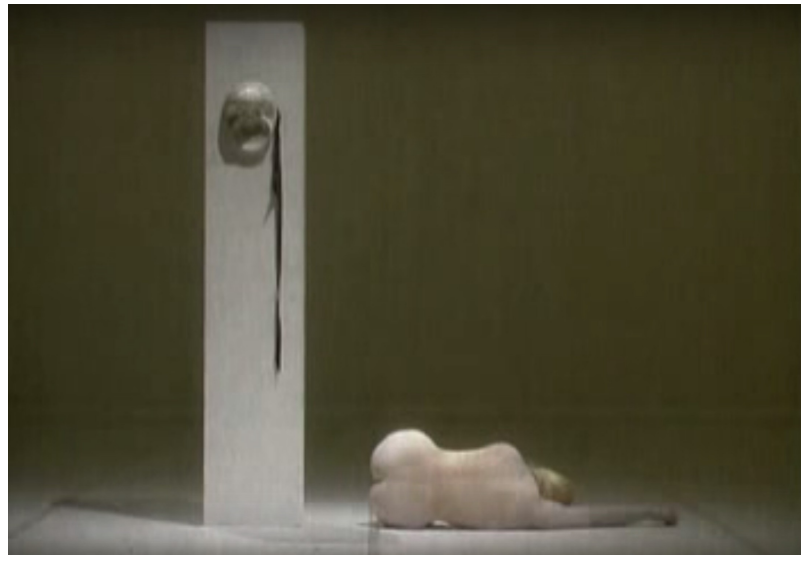

Fig. 148. Romeo Castellucci's Tragedia Endogonidia (L.\#09 London) 


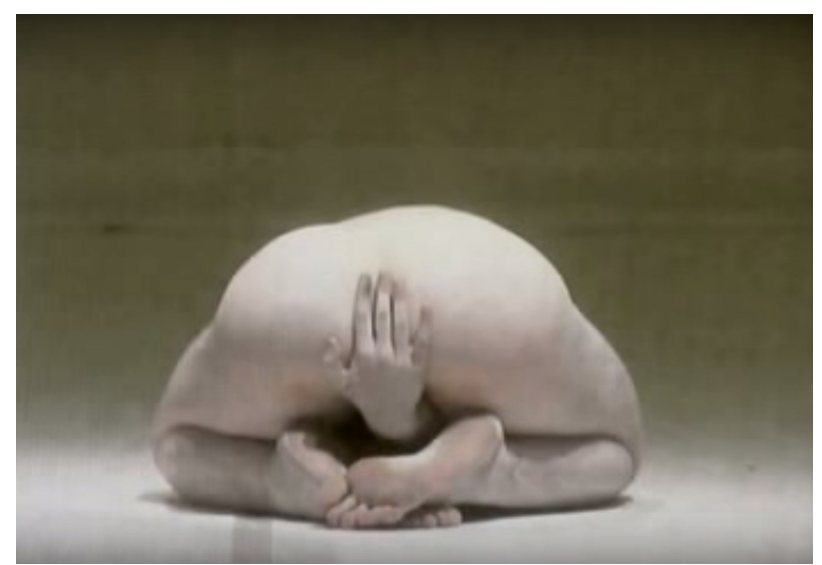

Fig. 149. Romeo Castellucci's Tragedia Endogonidia (L.\#09 London)

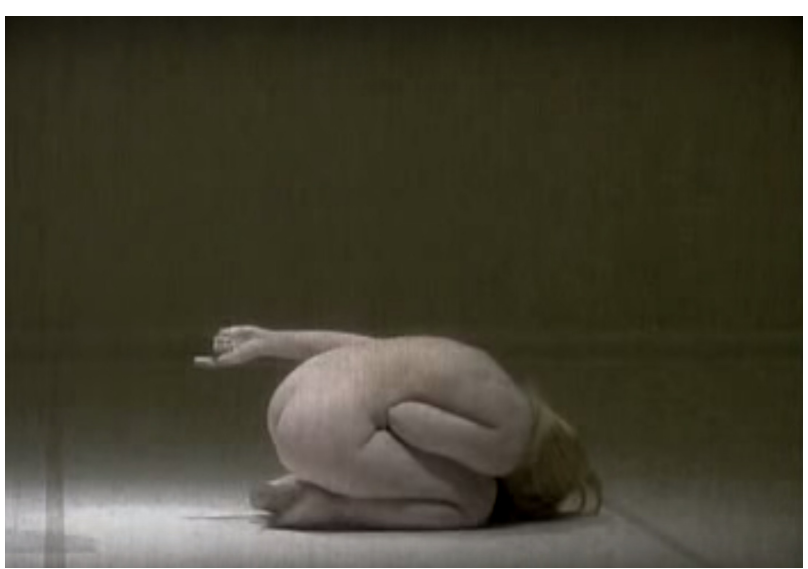

Fig. 150. Romeo Castellucci's Tragedia Endogonidia (L.\#09 London)

The work of Theatre Cryptic ${ }^{427}$ should also be mentioned. Their productions are varied, but in general there is a strong visual accent in them and many of their works have a dream-like aesthetics. Their collaboration with T'Ang Quartet in the work "Optical Identity" directed by Cathie Boyd was formalized in two ways: there was a staging in collaboration with architectural and costume designers and a different video was made. In the video, the musicians are playing without cloths and the camera focusses in close-up on their muscles while playing. This focus on the interaction between body and making music is also present in Incipit's Inferno, where the voice and the body influence each other.

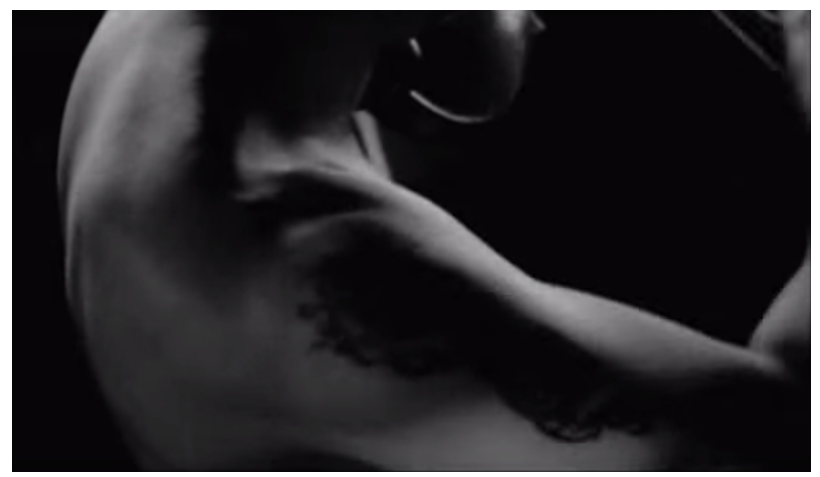

Fig. 151. Dir. Cathie Boyd: Optical Identity by Theatre Cryptic and T'ang Quartet (2007)

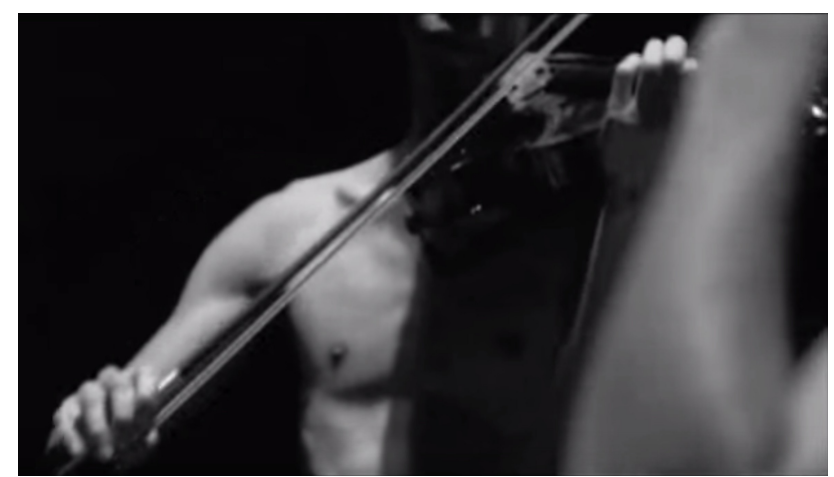

Fig. 152. Optical Identity (2007)

Samuel Beckett's performance works often bear Dante's influence. Not only appears the figure of Belacqua in many of Beckett's works, also other examples of inspiration are present, such as the characters entombed until their neck in huge jars which suggest Dante's Cavalcani whose head is the only thing that reaches out of his tomb. Michael Robinson warns us against the impulse of searching for direct parallels between figures and situations from Dante's Inferno or Purgatory and Beckett's work: his inspiration is rather associative. While Dante's Afterworld offers a very clear 
idea of the temporalization and form of the situations, Beckett's characters never know where they stand:

"One torment Beckett's characters have to suffer is precisely this ignorance of where they are and for how long they will remain there. Such uncertainties are unknown in the Commedia, where the souls of the dead have become their essential selves, beyond the contingency of life. (...) Beckett's characters are eternally prevented from discovering their true selves by their continuous immersion in time and language. Through his enormous presumption to know God's judgement, Dante's vision of the afterlife is concrete: purpose and meaning are manifest in every detail of the poem, as, for example, in the appropriate punishments of the damned or the measured ascent of those in Purgatory to the timeless perfection of Paradise. But in Beckett's world, meaning is withheld and the characters can only speculate on infernal punishment or purgatorial progress." 428

Beckett's characters, who do not know where they are and for how long, was influential for Incipit's Inferno, where the performer is also constantly surprised by the Hellish manipulation on her body and mind, made explicit mostly through the soundtrack, as if she were directly manipulated by the sounds.

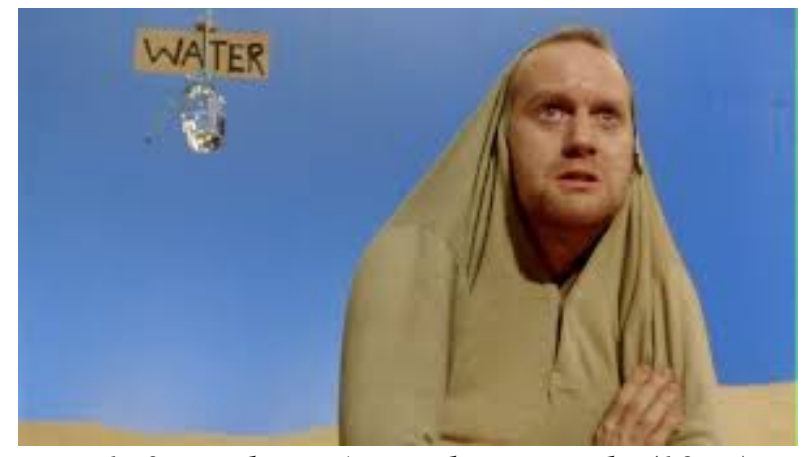

Fig. 153. Beckett: Act without words (1957)

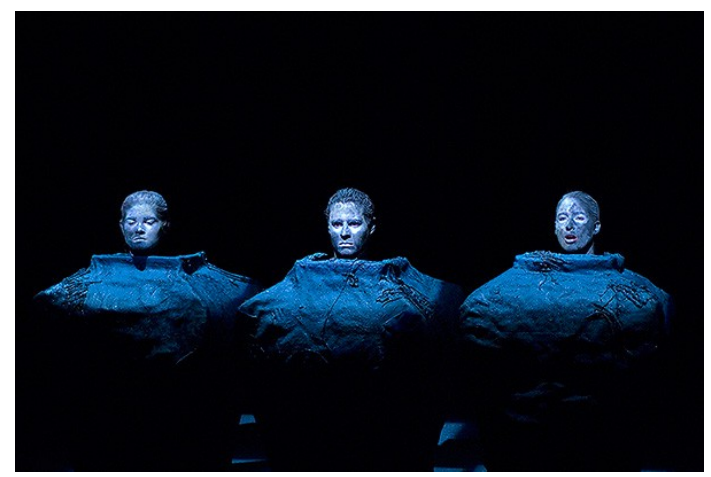

Fig. 155. Beckett: Play (1964)

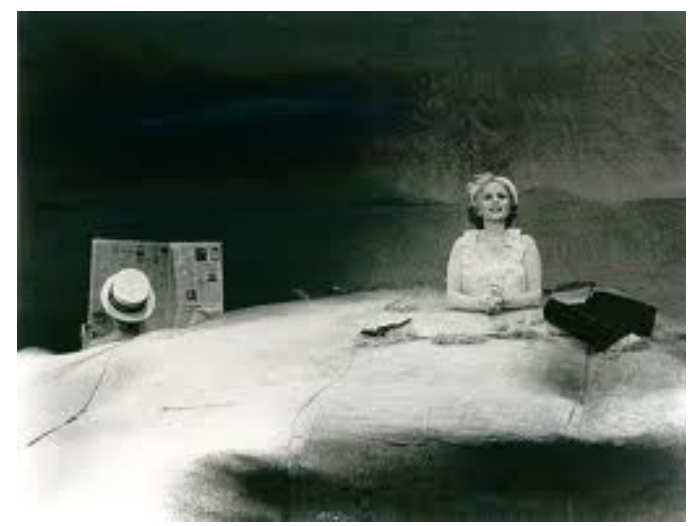

Fig. 154. Beckett: Happy Days (1961)

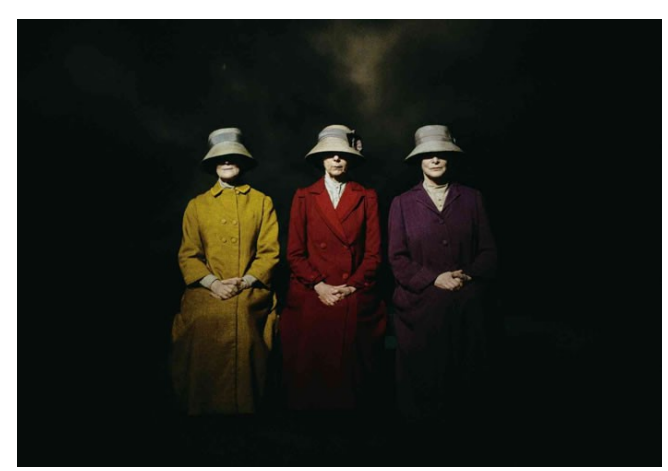

Fig 156 Beckett: Come and Go(1966)

428 Robinson, M., "From purgatory to inferno: Beckett and Dante revisited", Journal of Beckett Studies (5, Autumn 1979), 69-82 
In Act without Words (1957) ${ }^{429}$, a man is trapped in a desert and different objects that would help him to feel better are handed to him, but in a way that he never gets what he really needs. He becomes so desperate that, even when the water - which was out of his reach - hangs in front of him, he does not take it anymore, he only looks at his hands. In Happy Days $(1961)^{430}$, a woman buried to her waist follows her daily routine and rattles to her husband, who is largely hidden and taciturn. Later, she is buried up to her neck, but continues to talk and remember happier days. Play $(1964)^{431}$ shows three people each in an urn, the man in the centre, his wife and his mistress in the other. Only one speaks at a time, when the spotlight is focussed on that person and the others are in the dark, and they do not seem to be aware of any existence outside of themselves. Come and go $(1966)^{432}$ is a choreographically and textually symmetric and minimalistic work, where each time tone of the three friends, seated in the middle, stands up and goes, after which the second slides to the middle and whispers about her to the third. The first comes back and takes the old place of the second. This repeats itself twice more. Beckett has a very musical way of using text and sometimes even movement, for example in Come and Go.

\section{The role of the body: physical theatre}

From the area of dance theatre, Incipit also has its references. The choreographer and dancer Xavier Le Roy created and performed his Self-unfinished (1998), where the ambivalence of the body is being explored. ${ }^{433}$ The cloths he wears, hiding his head in a skirt-like cloth, and the way he walks on his hands and feet makes the spectator view his hands as feet and vice versa. At times it even seems like two people in one fighting each other. In a later scene, he is naked and lies on his neck, also creating unexpected images of his body. It is this ambivalence of the form of the body that is explored. In Le Roy's Low Pieces (2010), the bodies of various naked dancers mainly lie on the ground and seem to function as interdependent parts of an organic unity: their movements are not equal but similar and they resemble mechanical or vegetative bodies rather than human ones.

429 Beckett, S., Endgame and Act Without Words (New York: Grove Press, 2009)

430 Beckett, S., Happy Days: A Play In Two Acts (New York: Grove Press, 1970)

431 Beckett, S., The Collected Shorter Plays (New York: Grove Press, 2010)

432 Ibid.

433 Cvejic, B. "Investigar la investigación de Xavier Le Roy - Dos estudios de caso, 'Self Unfinished' y 'Untitled' “, Cairon: revista de ciencias de la danza, $\mathrm{N}^{\mathrm{o}} 13,2010, \mathrm{p} .239-252$ 

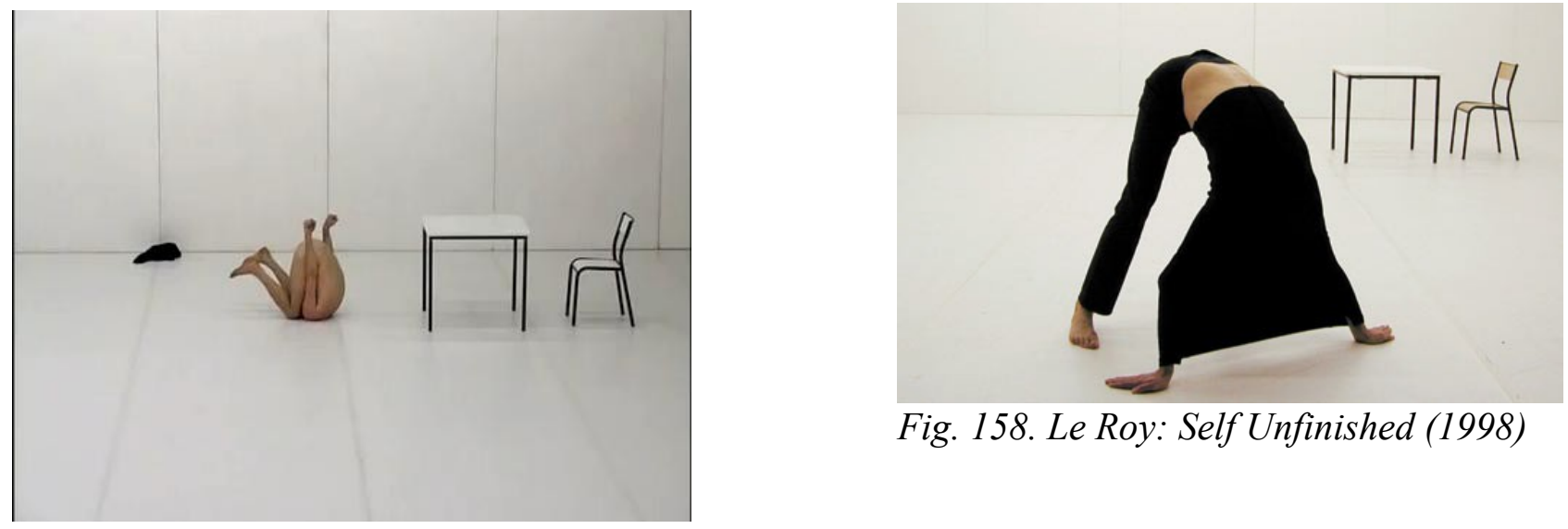

Fig. 158. Le Roy: Self Unfinished (1998)

Fig. 157. Le Roy: Self Unfinished (1998)

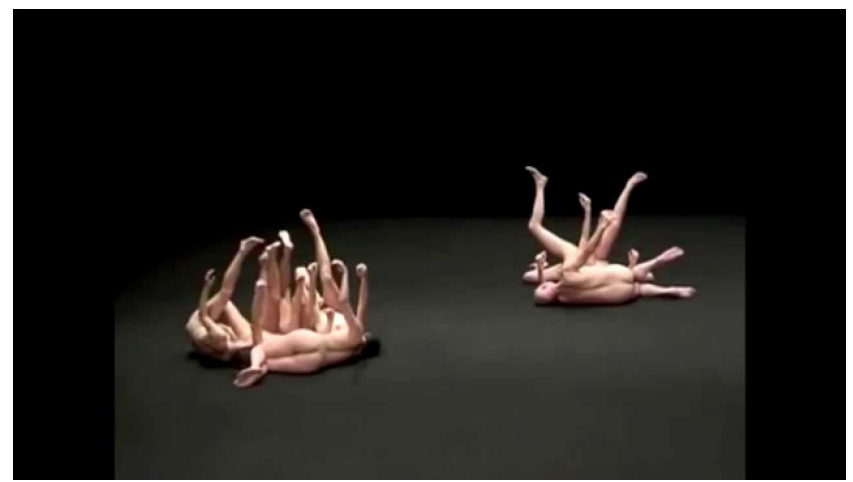

Fig. 159. Le Roy: Low Pieces (2010)

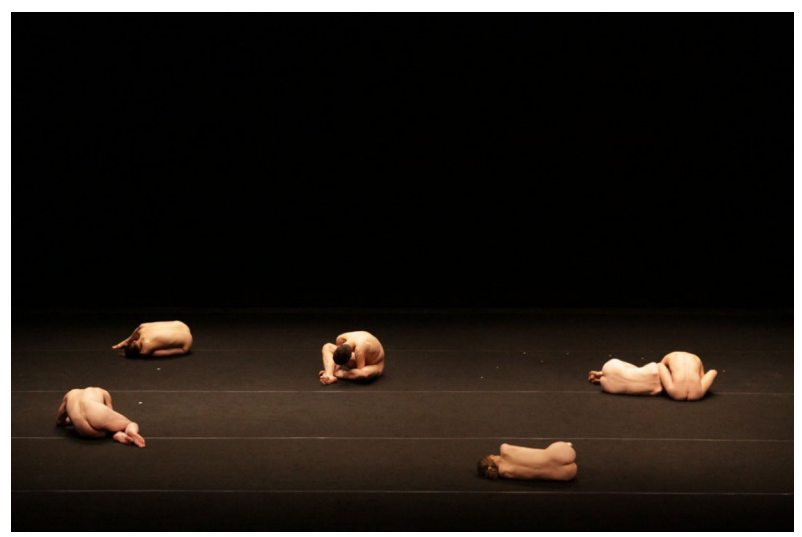

Fig. 160. Le Roy: Low Pieces (2010)

Another choreographer who has done an exploration on the concept of the human body, is Sasha Waltz in her impressive work Körper (2000). She mixes recited texts about the body with contrasting bodily movement or gestures, and explores corporal basic material: its skin, muscles and bone structure.

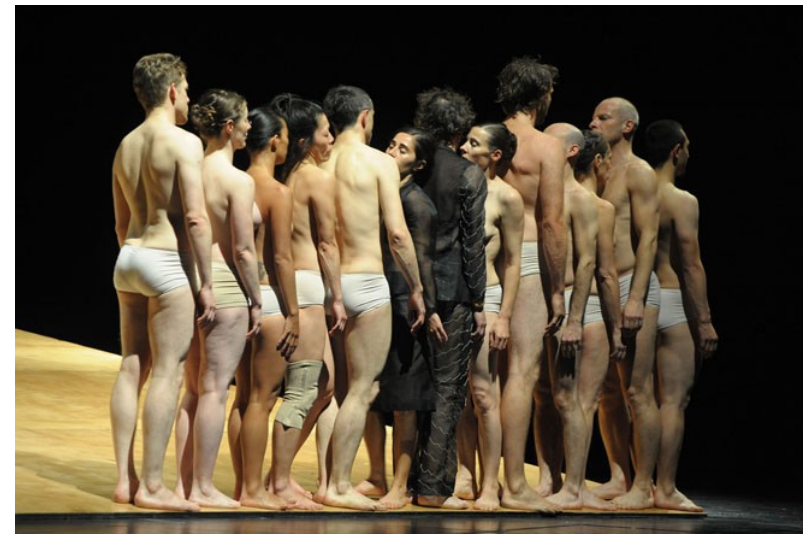

Fig. 161. Sasha Waltz: Körper (2000)

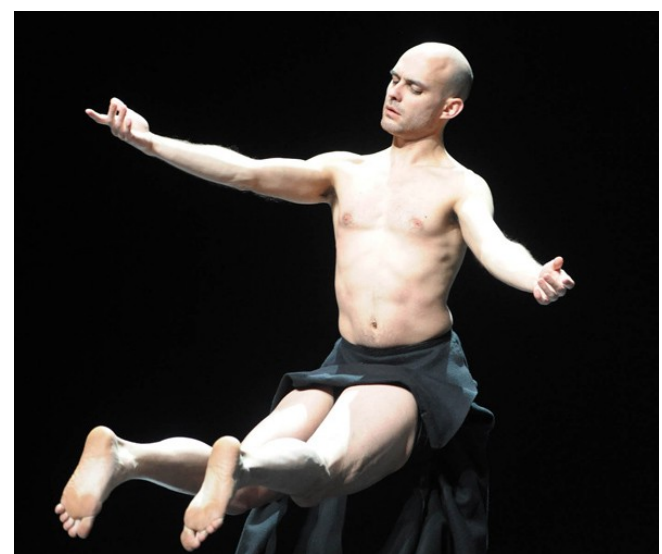

Fig. 162. Sasha Waltz: Körper (2000) 
The collaboration between musician and filmmaker Thierry de Mey and choreographer and dancer Anne Teresa de Keersmaeker led to the filming of her highly musical choreographies of Fase, Four Movements to the Music of Steve Reich (1982) - Piano Music, Violin Music, Come Out and Clapping Hands. The dances are composed of repeated movements, which are treated like musical elements. Piano Music, Come Out and Clapping Hands are for two dancers, where they begin together but each starts to vary the order of their movements so that they get out of phase in relation to each other, just like the music that is sounding. Violin Music is a solo where the dancer's feet movements on a sandy surface create a large symmetrical figure. Come out is performed entirely seated on a chair. The tight relation between music and body is focussed on gesture, just as in the music.

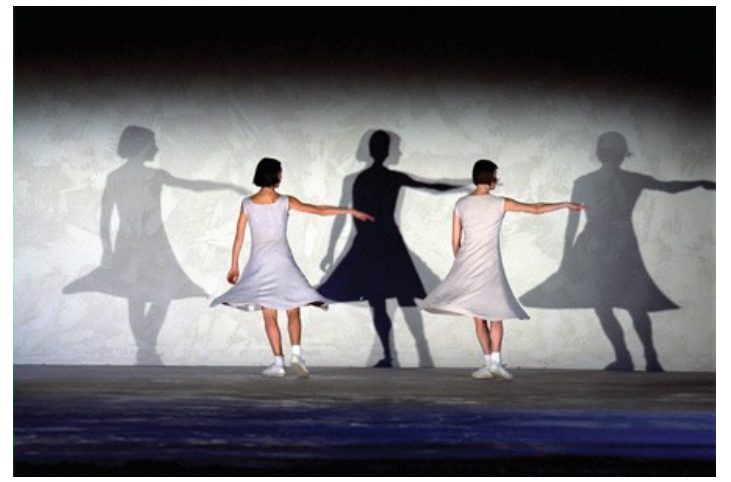

Fig. 163. Anne Teresa de Keersmaeker: Piano Music (Fase, 1982)

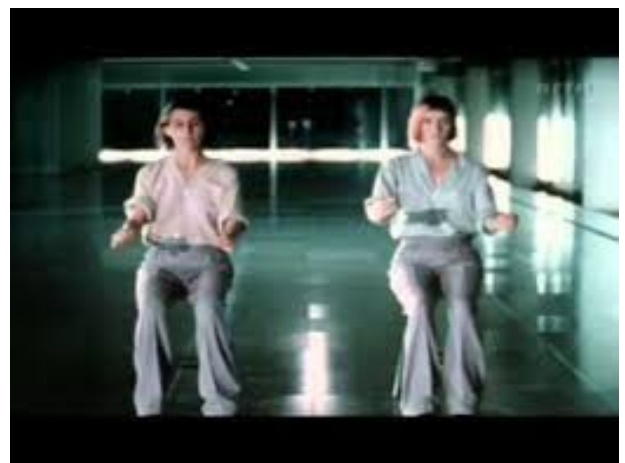

Fig. 164. Anne Teresa de Keersmaeker: Come Out (Fase, 1982)

\section{Early Music and Contemporary mise-en-scene}

The combination of Medieval music historically informed with experimental music theatre is one of Incipit's main characteristics, which has no existing references, as far as known to the author. The musical ensemble Hibernia under the direction of musician and composer Óscar Mascareñas has combined their post-Solesmes Gregorian singing with video dance (Erika Charters) in Multitudo languentium, Vir erat, Vox in Rama, and O cruor sanguinis (2010). These are the names of the Gregorian chants this ensemble had taken as a departure point for their harmonic experiments of this repertoire and its combination with video dance. The videos focus on a specific colour, slowmotion and details of the dancer's face and body. Their combination with the spiritual chants gives the works an alienating result. 


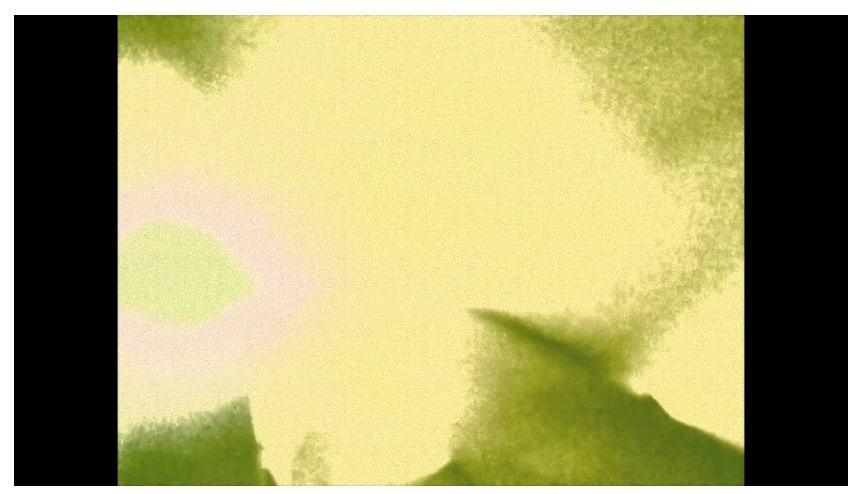

Fig. 165. Hibernia: Multitudo languentium (2010)

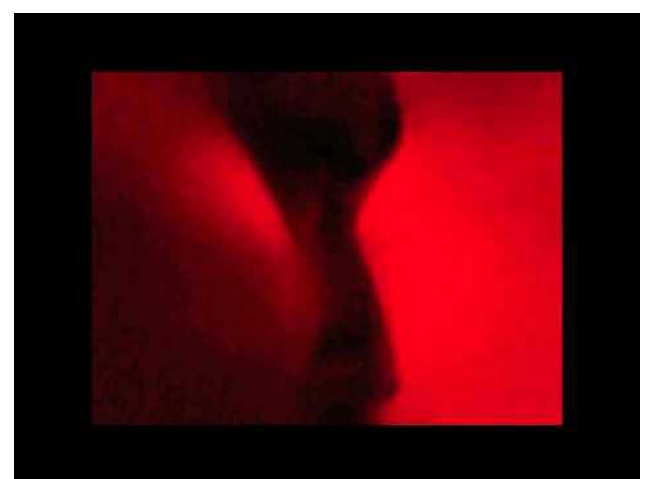

Fig. 166. Hibernia: Vir erat (2010)

Ensemble Hibernia's approach of Gregorian chant opens it up to new ways of performing this repertoire, and taking it out of its liturgical context. Hibernia "specialises in the performance of early music from a contemporary perspective" ${ }^{\$ 434}$, although the standard Gregorian chant is not Early Music, as we have discussed in chapter 1 . There has not been any initiative at present known to the author of combining Historically Informed Performance of Medieval plainchant with a contemporary mise-en-scene. Within the field of Early Music, the practice of adding additional voices to the plainchant melody according to historical rules has only been revived recently. Singer and Medieval expert Niels Berentsen is one of the first musicians working with such improvisation, both as a singer and a teacher.

Medieval and Renaissance music have been combined scarcely with any contemporary visual elements. Baroque operas, however, are regularly combined with a contemporary mise-en-scene. Musically-historically informed examples are Monteverdi's L'Orfeo (1998) directed and choreographed by Trisha Brown (conductor René Jacobs) or Händel's Theodora, an oratorio in three acts, directed by Peter Sellars (Baroque orchestra Les Arts Florissents conducted by William Christy). As in most operas, the orchestra is separated from the stage. In this aspect, the Belgian Baroque Orchestra B'Rock represents perhaps one of the most innovating initiatives. In their 2012 version of "The Indian Queen" by Henry Purcell (1659-1695), the stage director Jan Decorte has placed them on the stage, along with the singer-actors. The work "Arthur" (2014) is a semi-opera based on Purcell's "King Arthur" and is a co-production of B'Rock with Muziektheater Transparant, Capella Amsterdam and the experimental music theatre company De Veenfabriek, whose director Paul Koek has staged the work. The orchestra is situated in the centre of the stage and the whole mise-en-scene is literally around it. Still, the orchestra continues being a static element. 


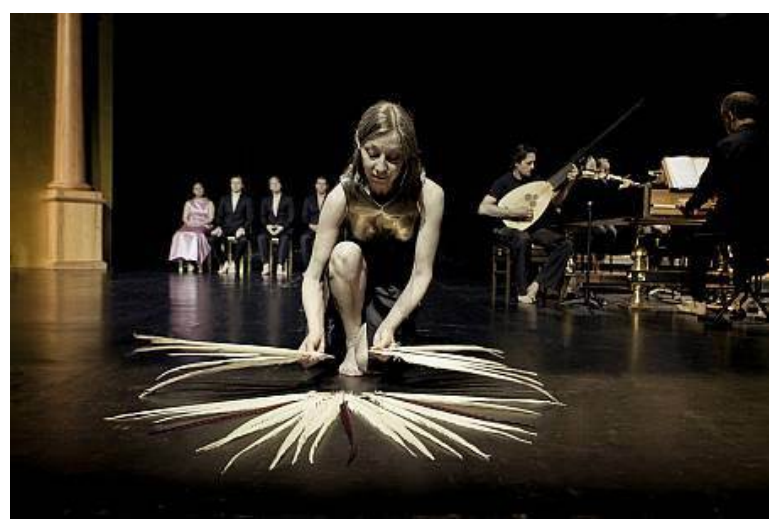

Fig. 167. The Indian Queen (2012), B'Rock, dir. Jan Decorte

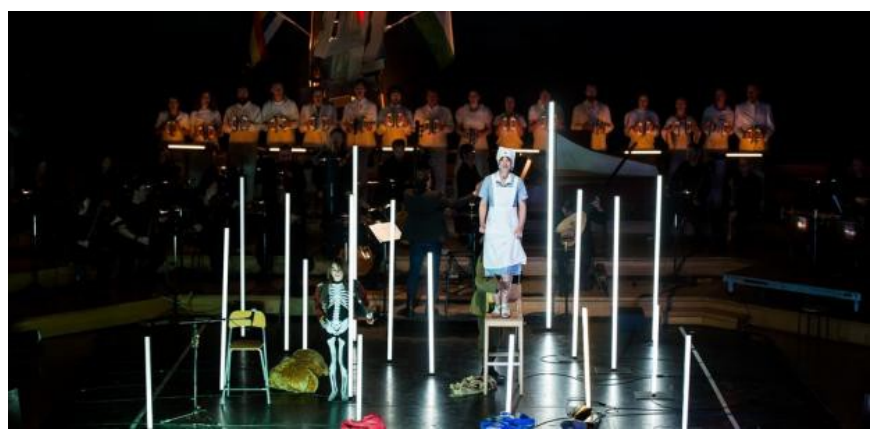

Fig. 168. Arthur (2014). B'Rock, Capella Amsterdam, De Veenfabriek et. al. Dir. Paul Koek

Outside of the field of opera, merged forms of Historically Informed Performance of Early Music with contemporary mise-en-scene are difficult to encounter. This combination within experimental music theatre, where the performer is also the actor, has not been undertaken until the present research, as far known to the author. 


\subsection{Creative process of composition and recording}

Once all sonorous references within the Commedia were listed, it was decided that other theatrical elements - movement, gesture and light or colour - were listed as well. This resulted into a scheme of all these references, isolated from their context. The sonorous references were taken as the departure point and axis of Incipit.

Annex 1 contains the scheme of all references to sound, movement, gesture, colour and light as they appear in the Commedia. This scheme can serve as an informative source for any further investigation on its references to these elements. The fragments in bold were considered the most relevant for Incipit.

The great amount of literal references were reduced to a scheme in which a selected number of contents, sounds, movements and colours were expressed in a more summarized way. Annex 2 shows this scheme, which was the work basis for Incipit. An essential choice had been made for its filtering criterion. The original scheme contained too much information, too many actions, scenes, characters, text. Furthermore, it would still have resulted in a too literal representation of the Commedia's narrative, while our aim was to go beyond its surface and represent Dante's philosophical ideas behind it as far as possible.

The essential questions at that point were: who or what am I going to represent? Would I be representing a person or a concept? It was soon realized that the aim of Incipit was not to represent the journey Dante himself had made, thus the performer was not going to be Dante, Virgil or Beatrice. The audience was to be the visitor of Dante's Afterworld, and why would they meet historical, mythical or biblical characters that they are not familiar with? Therefore, it was decided that the audience's visit to Dante's world would take place on another moment and in another form. However, Dante aimed for his work to be his readers' own journey toward Divinity within themselves. ${ }^{435}$ Incipit has been inspired by this idea. The performer would take on the role of an intermedium between Dante's world and the audience, representing the human soul in all its possible forms in the Commedia. Moreover, all the characters that had a significance for Dante which is now lost for us have been left out of the mise-en-scene. The consequence was that all the scenes that specifically focus on them were eliminated from the script. The remaining fragments were set up in the simplified table of Annex 2: ideas, sounds, movements/gestures, and colour/light. This was the basis for the rehearsals and the final selection and composition. An important 
consequence of this decision was that the performer does not represent any demonic or angelical being and therefore does not verbalize any of their expressions. It does not represent Divinity but humanity.

The sounds were taken as the leading factor in the creation process of Incipit. First, all non-musical sounds were either searched on www.freesound.org ${ }^{436}$ or recorded and a database of these sounds was created, ordered by their chronological appearance in the Commedia. Then, the soundtrack of Inferno was composed with these sounds in Audacity, an open source digital audio editor and recording software. Only natural, non-synthetic sounds were used. Some of them were altered, such as the suicides' forest, which is a complex of various recorded sounds. ${ }^{437}$ Most sounds were overlapped and given a fade-in and fade-out, in order to connect the sounds in a natural way, as if the visitor were really moving forward from one place to the other. For most scenes, various sounds from www.freesound.org were mixed in order to incorporate all the simultaneous sounds of that scene. Other effects were panning (ramp) $)^{438}$, time change ${ }^{439}$, tempo change ${ }^{440}$, pitch change ${ }^{441}$, reversal $^{442}$, noise reduction ${ }^{443}$, phaser $^{444}$, hard limit and amplification ${ }^{445}$, reverb ${ }^{446}$. We will now discuss the main compositional aspects of the three canticles.

436 Sounds free from copyright.

437 https://freesound.org/people/thatjeffcarter/sounds/220110/ and https://freesound.org/people/thatjeffcarter/sounds/220109/. I mixed them with non-manipulated sounds: https://freesound.org/people/jorickhoofd/sounds/180302/ and https://freesound.org/search/? $\mathrm{q}=180299$ jorickhoofd male-inhale-scream-6

438 Pan stands for panorama. There is an absolute panning, which only allows the sound to be either on the left, in the middle, or on the right. The pan (ramp) option, though, gives the possibility to move the sound gradually from one side to the other, with values varying from -10 to 10 , where 0 is the centre.

439 The option "change time" can slow down or accelerate sound without changing its pitch. It does not alter the sound notably until a certain limit.

440 The option "change tempo" alters speed and pitch simultaneously. It was used in the scene of the devils.

441 The option "change pitch" heightens or lowers the pitch of the sound without changing its tempo. Up to a fourth the result can still sound natural; from a fifth on the sound begins to be considerably different from its original.

Sometimes such an effect is desirable, such as in the first babbling sound in the neutrals' choir, which was originally a baby's muttering: https://freesound.org/people/Robinhood76/sounds/61701/ but now sounds like an adolescent babbling nonsense.

442 This reverses the selected sound. It was used for the babbling in the neutrals' choir, which was originally chatter in English: https://freesound.org/people/Walter Odington/sounds/32368/

443 In audacity the criteria for the noise removal can be selected. The noise can be lowered in volume more or less, and a broader range of frequencies can be selected. If both values are high, the result is a metallic sound, which sometimes has been used deliberately, such as in all the Beatitudes in Purgatory, in order to alienate the sound of the angelic chants.

444 The phaser combines phase-shifted signals with the original one. This effect was used in the neutrals' choir after the panning (ramp), so that the moving sound from left to one sight to the other and back was not too "clean". After all, the choir is large and they are not neatly moving all together on the left or the right, but their situation is rather chaotic.

445 Hard limiting eliminates the high ends of the waves that are too loud. Some waves stood out considerably and only in this way, the volume of the entire sound could be amplified. Amplification has been used both for augmenting and diminishing of volume, in order to equalize the sound level throughout the performance.

446 Reverb has been applied especially to the chants of Paradise, and to the angelic song in Purgatory. 


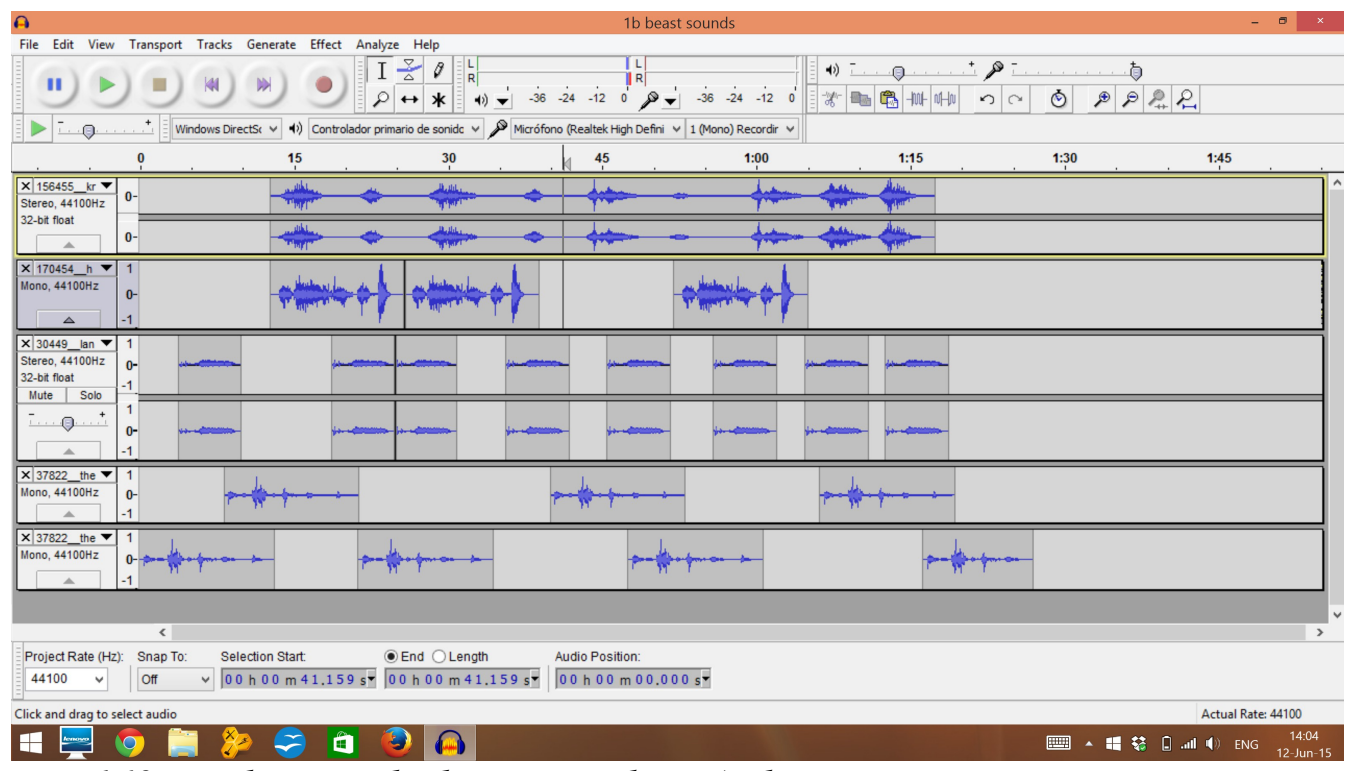

Fig. 169. Working on the beast sounds in Audacity

Inferno has no music at all. As we discussed in chapter 4, it is the realm of Anti-Music. However, the concept of Historically Informed Practice can be transcended to extra-musical sounds, in the sense that the departure point is the question of what possible sound it could be Dante was thinking of. We are using the word "possible" because we will never know what exact sound Dante was thinking of, as chapter 1 in its authenticity discussion about the "intentions of the composer" showed. The word "possible" indicates that we are looking for sounds that might be similar to the sounds in Dante's area and time. As the section of chapter 1 on the Medieval voice demonstrated, we do not know if the human vocal sound in Dante's time was similar to ours, and even less how the voice was used to express human feelings, nor are we ever going to have certainty about the matter. However, working with natural sounds comes as close as possible to the sounds Dante could have imagined. The composition process began with an approximate timeline of sonorous scenes. The intention was to reach maximum 30 minutes of sound per canticle. The soundtrack would determine the duration of the work. During the composition process, it was discovered that for all three canticles about 20 minutes of actual sound (not counting the silences) were optimal. The composing method for Inferno was different than for the other canticles, because of the nature of its sonorous material. There were no chants but unmusical sounds which had a less fixed pre-existing form. While in Purgatory and Paradise it was tried to connect existing music, in Inferno there was an entire composition process with the sounds as if they were notes. Timing, dynamics, crescendi and decrescendi, polyphony, all these were essential compositional elements in Incipit's Inferno. 


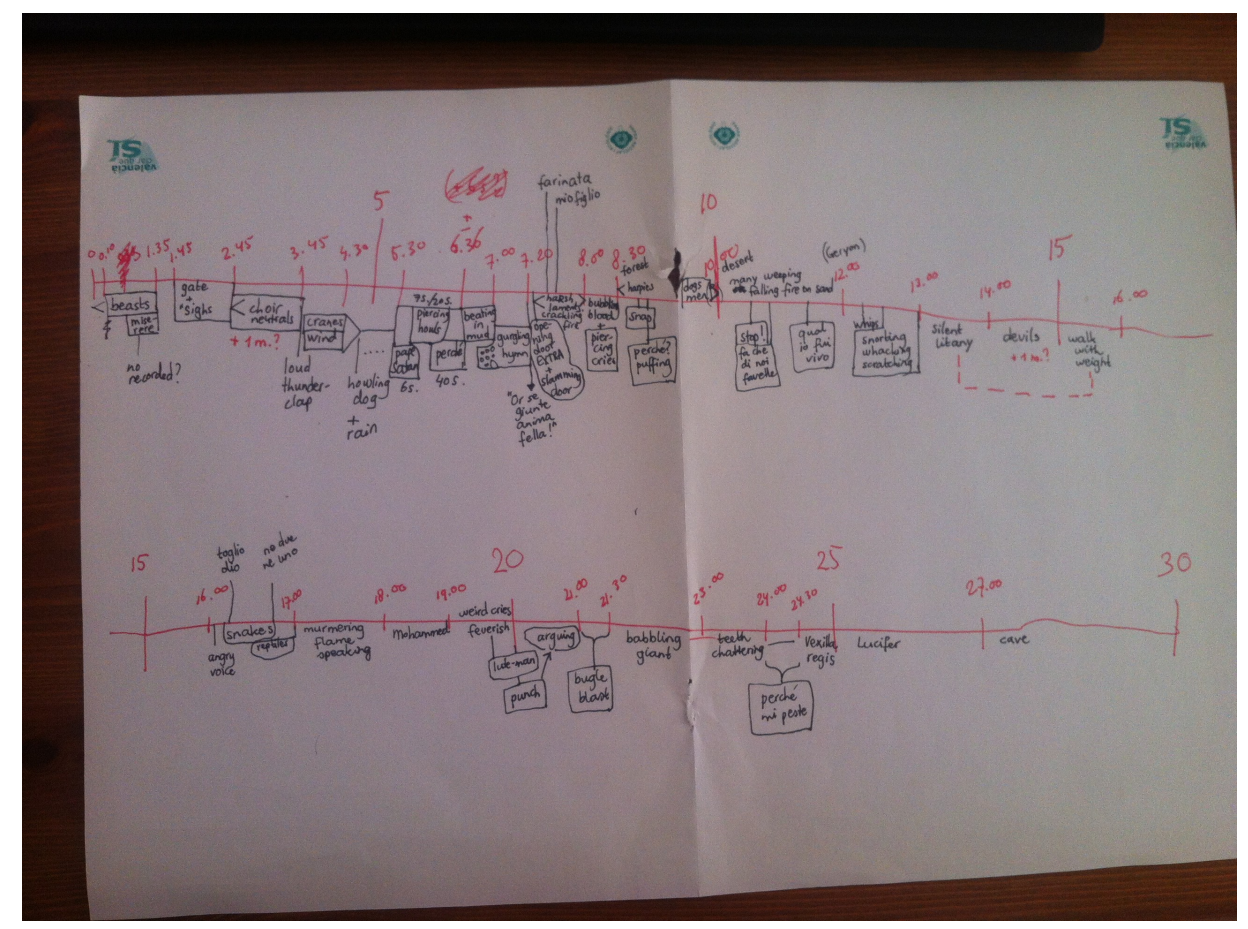

Fig. 170. A first sketch for Inferno's composition and timing of the soundtrack

In Inferno, the beginning scene of the beasts consists of five different beast sounds, of which three are growling, one is breathing, and one is smacking, thus sonorously resulting into three distinguishable beasts. A natural fade-in was sought for, beginning with only one beast sound and gradually building up toward all beast sounds present simultaneously, after which the reverse effect is sought for, ending with one beast. It was thought that the words miserere di me were spoken by the performer.

Originally the text written on the entrance gate was recorded as a whispered voice and later completed with a delay effect. ${ }^{447}$ Although its sonorous result was highly satisfactory to the author, during rehearsals it was decided that these words had better be produced by the performer and it was removed from the sound track. The sonorous scene of the neutral souls was one of the most complex. It consists of sighs, moans, cries, babbling tongues, inflections of deep anger, clapping hands and swarming wasps. Most of these sounds are a compound of various sound files, combined and then combined again as clusters. A similar procedure was followed for other groups, such as the wrathful beating and tearing each other in the mud, the souls in the desert, and the flatterers snorting while scratching and whacking themselves.

447 The delay effect is meant for creating "a multiple echo effect with options for variable delay times between successive echoes and the number, amplitude and pitch of successive repeats.", Audacity Manual, http://manual.audacityteam.org/o/man/delay.html 
The choir of neutral angels is cut off by the sound of a thunderclap, which marks the beginning of the sighing souls in Limbo. During the compositional process, it was decided that the sighs gradually turn into the wind of the lustful souls. Therefore, the growling sound of King Minos was excluded from the sound track, as it would interrupt this transition. For the scene of the lustful real sounds of cranes were included, based upon Dante's text E come i gru van cantando lor lai, faccendo in aere di sé lunga riga, così vid'io venir, traendo guai, ombre portate da la detta briga ${ }^{448}$. Dante compares implicitly their cries to the "chanting" of the cranes. Their sound is unlike the singing of some birds, just as the souls here can only produce a sound unlike singing. We interpreted this phrase literally, and included not the human cries but the cranes' call. This metaphoric concept was meant as an expression of the tragic quality of this scene.

The howling Cerberus cuts the scene abruptly. Its sound is the same howl at three pitches at an dissonant interval from each other (two minor seconds), with the effect of hard limiter and amplified, in order to get the most unpleasant sound as possible ${ }^{449}$ but still recognizable as a threeheaded dog's howl. His howl introduces the rain. Also the guardian of the next circle was maintained: Plutus who - with clacking voice - utters Pape Satan, pape satan, aleppe! (Inferno 7.1). First, the words were recorded with a quite guttural voice. Then, a clacking sound with the tongue was recorded in the same rhythm of the words. They were combined in one sound file. Originally, the phrases shouted to each other by the avaricious and prodigals - Perché tieni? Perché burli? - were recorded with a pan effect (left - right).

As mentioned before, the sonorous scene of the wrathful was a complex one. Moreover, the sullen are gurgling their hymn simultaneously. Therefore, the envelope tool was employed in order to lower the volume of the fighting sounds when the gurgling starts, thus only present as a background noise as if we had descended to the bottom of the river. The gurgling was recorded with some water in mouth and throat. This recording was copied twice and to each was applied the effect of Tempo Change in Audacity, which changes both tempo and pitch. When the gurgling ends, the fighting sounds are brought back to their initial volume. The shouted phrase by Phlegyas - Or che giunta, anima fella! - was chosen because of its additive value of expressing the general anger in this scene. His voice was also considered musically as a crescendo leading to the banging sound of the slammed door, followed by a subito piano.

448 "And as the cranes fly over, chanting lays, forming one long line across the sky, so I saw come, uttering their cries, shades wafted onward by these winds of strife", Inferno 5.46-49

449 Dante indicates that Cerberus' howl makes the souls wish that they were deaf. "lo demonio Cerbero, che 'ntrona l'anime sì, ch'esser vorrebber sorde", Inferno 6.32-33. 
In the scene after the door, in the background we hear the flames of the heretics' cemetery. The original idea was to have a counterpoint of the phrases of the two souls that Dante encounters here. Although it was decided not to focus on the historical characters Dante meets, here an exception was made because their expressions illustrate perfectly the fact that they are not listening to each other or feeling any empathy. The phrases Chi fuor li maggior tui and Mio figlio, ov'è?? were to sound repeatedly but each in their own rhythm. While in the beginning they are to sound in alternation, later they begin to overlap each other, because they are not listening to each other at all. This would be a musicalization of human expression. The scene is interrupted by the piercing cries in boiling blood. The sound of the bubbling blood derives from someone blowing bubbles in a thick liquid, removing her inhaling sound.

After a small fade-out, the aggressive sounds arrive at the dreamlike ambience of the dead forest. Musically, it has the same function as Limbo: it is a moment of relative calmness in the midst of the chaos. The words Perché mi schiante? Perché mi scerpi? are not subsequent in Dante's text, but both musically and substantively the phrases with perché (why) are relevant in Incipit's Inferno (see chapter 4). They are spoken by the performer, therefore they have not been added to the soundtrack, but the puffing sound of the trees was recorded and included.

For the sound of the walking in the desert and the falling flames, the unexpected sound of footsteps in snow and in sand were used. ${ }^{450}$ The sound of the branches in the snow recording is the closest to our imagination of "raining" flames. The heavy weeping of the souls is also included as well as the running feet of the three souls that are to form a circle. A fade-out of the desert noises is leading to the sound of the faded-in waterfall. It is interrupted in its fade out by the sound of whips, followed by the scratching, whacking and snorting of the flatterers. The noises of the simonists are not really described, so their scene is left out.

After the silent litany, only audible by soft footsteps, the scene of the devils follows. The comic and bizarre military quality to it have been accentuated in the soundtrack. Although in Dante's Commedia they are perfectly able to speak, in Incipit their words are not important but their tone is. Therefore, an already existing recording in gibberish was used to mark their energetic, aggressive but comical conversation. ${ }^{451}$ It was multiplied by three and two of them had a tempo change, altering both their pitch and speed, resulting into what seems a conversation between three different

\footnotetext{
450 "The sound of a small group of people walking through the snow, branches creaking and ice crunching.", http://freesound.org/people/Incarnadine/sounds/34565/ and footsteps in sand:

http://freesound.org/people/DasDeer/sounds/161815/ and http://freesound.org/people/hintringer/sounds/249933/ 451 https://freesound.org/people/Bananaboatman33/sounds/315655/
} 
devils but is actually a musical treatment of the same sound. After one of the devils makes "a bugle of his ass" (Inferno 21.139) and another reacts with a raspberry, a somewhat chaotic procession or military sound was searched for Incipit. This is not an original sound, but it reflects the chaotic military aspect to their march as Dante described. Furthermore, it is used to oppose the angelic military aspect to the procession in the Terrestrial Paradise, which does not need any percussion instruments but proceeds softly through nature. For the devils' march, a recording of a not too rhythmical protest procession was used. ${ }^{452}$ It is followed by yet another silent scene, this time of the hypocrites trampling the crucified Caiaphas. The accent in this scene lies on the sounds of Caiaphas "breathing hard in his beard with sighs".

The ditch of the thieves full of snakes and reptiles is introduced by "an angry voice incapable of forming words", which is the first thing what Dante hears of this ditch. A recording of gibberish was found that suited such a description ${ }^{453}$. Both existing recordings of snakes and the author's own recordings were mixed into a fading-in ambience sound. The words Togli, Dio, ch'a te le squadro! were recorded and transposed down in order to convert the voice into a male one, after which the snakes sound louder as to attack this soul. The expression Vedi che già non se 'nè due nè uno was also recorded, in order to reflect the parody on the Incarnation (see chapter 3).

In Incipit, the scene of the fraudulent rhetoricians - where we are not meeting Odysseus, who was so important for Dante - focusses on the onomatopoeic speech by one of the souls: S'io credesse che mia risposta fosse a persona che mai tornasse al mondo, questa fiamma staria senza piu scosse. ${ }^{454}$ This has been clearly a musical decision: the speech both reflects the calculating aspect of these souls' character and the sound of the flame. The sound of the horror scene where the dividing souls are constantly cut into pieces is placed just before the scene of the feverish counterfeiters. The latter scene contains coughing and moans. Also it was decided to respect the argument between Master Adam and Sinon after a punch in his lute-like body sounding as a drum, even though it lost its metaphoric meaning. However, their argument forms part of the chaotic and disagreeable soundscape of Inferno.

The bugle sound of the giants introduces Nimrod's "psalm" Raphel mai amecche zabi almi, both essential due to their musical meanings. Nimrod's words, which also express his inability of communication, were recorded and lowered in pitch. The next circle is marked by "teeth chattering

$452 \mathrm{https} / / /$ freesound.org/people/superliminal/sounds/121764/ Of course, only the fragment until the sirens, which are not exactly a Medieval sound. 
with the clatter of a stork". The phrases Perché mi peste? and Perché mi moleste? were selected and joined together because of their use of perché (see chapter 3). They were recorded according to the character who pronounced them, with hysterical anger and pain, which gave them a somewhat comical touch.

Lucifer is represented in sound as a creature smacking and eating like a beast but at the same time almost choking on his own food, which gives him a pathetic character. Dante illustrates Lucifer as defeated Evil, not being able to talk, dirty, crying, and seemingly mindlessly chewing on three souls, as if he were a huge baby. Virgil had announced their arrival at Lucifer with the words Vexilla regis prodeunt Inferni ("The Banners of the King of Hell Advance") referring to the liturgical chant without the word Inferni, as a anti-musical and anti-liturgical parody. For Incipit, the first stanza of this chant was recorded in spoken language and not sung, because in Inferno music cannot exist. It is an ironic final commentary on Inferno and the pathetic figure representing Evil. It was first lowered to a male voice, but in the rehearsals the original voice was re-inserted, as an alter ego of the performer.

Vexilla regis prodeunt,

fulget crucis mysterium, quo carne carnis conditor suspensus est patibulo.
The banners of the king issue forth, the mystery of the cross does gleam, where the creator of flesh, in the flesh, by the cross-bar is hung.

The sound of a cave with water drops forms the bridge between Inferno and Purgatory.

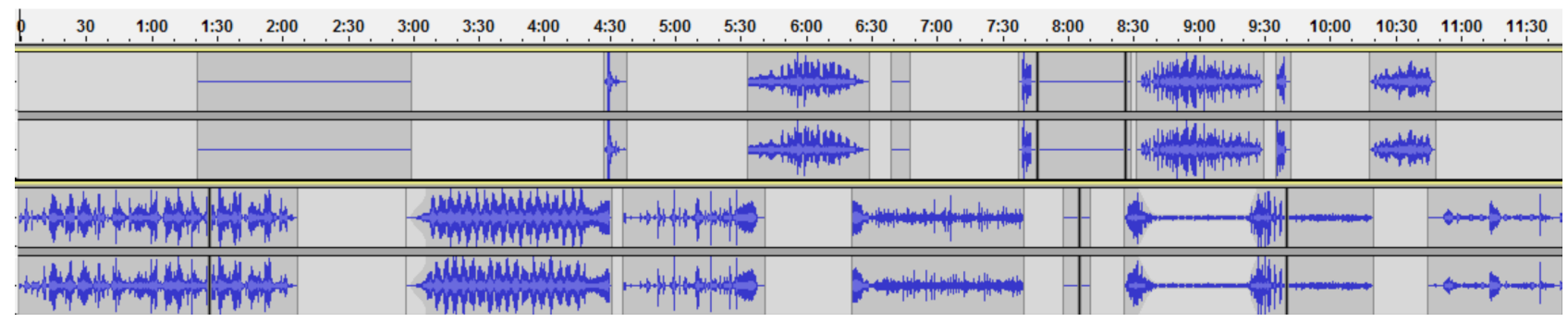

Fig. 171. First half of the final soundtrack of Inferno

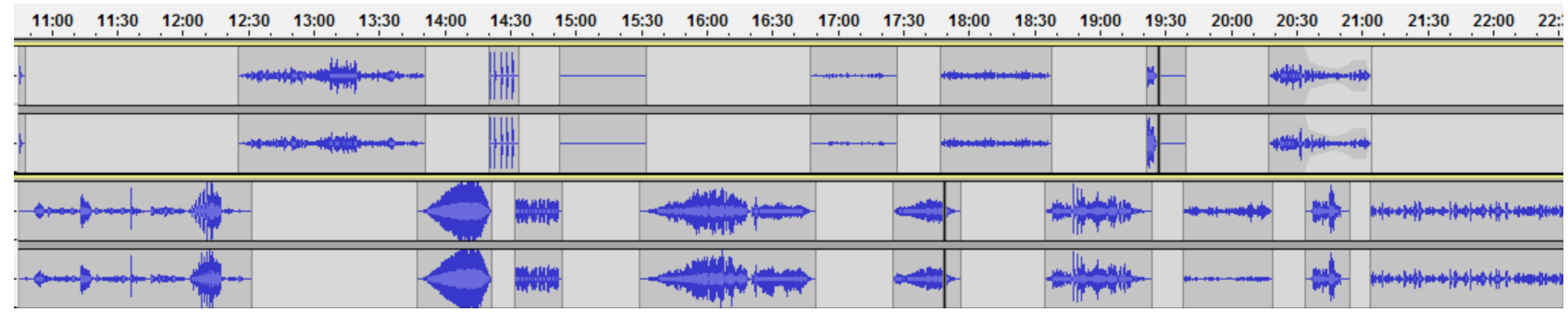

Fig. 172. Second half of the final soundtrack of Inferno 
Purgatory starts with the sound of the sea. In Inferno, there were a number of natural sounds but none of them had a peaceful character. In Purgatory, this is different: nature is calming and gentile. The first chant, In exitu israel, was recorded to be mixed with the soft sound of the waves. Of this psalm, 9 lines were recorded various times in order to form a choir. Since the text is somewhat difficult to recite faultlessly throughout the end of line 9, it was recorded monophonically ${ }^{455}$. This meant that some voices had to be transposed an octave down in order to obtain male voices, and the transposition with such a great interval results into giant-like voices. Therefore, the relative volume of these voices was kept low, but sufficient to make them audible. Furthermore, for a more massive effect - Dante speaks of a hundred voices singing monophonically - a "Multivoice Chorus" effect was applied to it. ${ }^{456}$

The sound of a gentle breeze through grass overlaps a bit the sea sound and then takes over, until Te lucis ante. The souls are now in Ante-Purgatory and sing Miserere. We experimented with parallel fifths and octaves, which would be a musical possibility for this scene. However, it was decided to leave the parallel organum for the Gloria in excelsis that the souls sing to celebrate the liberation of a prodigal soul. Thus, the musical concept follows partly Ciabattoni's suggestion: the souls mainly sing in monophony, except in celebratory cases, which are the Te lucis ante and Gloria in excelsis. We imagine that the souls in general sing monophonically when they are suffering, because physical or mental suffering tends to demand much of one's energy and concentration, so the organism focusses on the minimum.

A few simple ornaments were experimented with, based on the observations of McGee (see chapter 1) about the Medieval voice. It was decided to make only few ornaments because the actual knowledge of Medieval ornaments is based on speculations. Therefore, we preferred to make the ornamentation that subjectively felt natural to our voice and with our experience with Medieval music, and at the same time was not present enough to place itself in the foreground, thus leaving space for any other type of interpretation of these chants. The first of them is a guttural "grace-note" when notes are repeated on a melisma. This ornament was slightly lower, connected to the main notes by a glissando-like movement. Sometimes it was also done more subtly on repeated syllabic notes. Another ornament that has been used was an upward mordent on the second note of descending seconds (for example, e - ded) mostly followed by the third ( $\mathrm{c}$ in this case) and on a melisma. There were some glissando-like movements. The mordents were performed in Miserere,

455 And not with some parallel voices a fourth or fifth lower, as was the case for most other chants.

456 Maximum 8 voices of each recorded voice. A technique that is not as natural as recording several voices, so it has been done only in the case of In exitu israel, where Dante speaks of such a great number of many souls. A downloadable plug-in created by Steve Harris, http://plugin.org.uk/ladspa-swh/docs/ladspa-swh.html 
Salve Regina, and Gloria in excelsis Deo and in Matelda's Quia delectasti. ${ }^{457}$ The technique for repeated notes was applied in all chants with such characteristics, also in Paradise. Experimentation with ornaments and vocal style around 1300 should not be limited to existing conventions but should be based on theoretical-practical knowledge of both Medieval plainchant throughout the Middle Ages and the secular music from the $14^{\text {th }}$ century. For inspiration and study of vocal techniques one can learn from other cultures, always keeping in mind that their performance practice is not the same as it was in the Middle Ages and their tonal systems and history are different from the European one.

For the rhythmical interpretation of the chants, the rules of Jerome of Moravia were followed (see chapter 1). In general, the first note and last note of a phrase were lengthened, except if the natural rhythm demanded otherwise. The penultimate note was lengthened where possible. His other rule, to lengthen the second note of a melisma, was experimented with. Frequently, it was not a good solution, but at other times it offers a fluent, organic movement.

The Miserere was sung quite low, in the chest voice. The musical concept behind this is the idea of beginning with a more terrestrial chest voice and ending up with a more celestial head voice in Paradise, although throughout Purgatory the ascension is not stepwise: the worldly matters keep forming a part of the souls. Only the angelical voices sounding in Purgatory are mostly sung in the mixed or head register. The Miserere, that asks for pity, was thought to be sung lower than most chants. It is ended in an extended $o$ when the souls discover the alive visitor, which in the case of Incipit is the audience. It was finally recorded with some voices at a parallel fifth below, which were transposed to an octave below, resulting in natural male voices. After the Miserere, a line on the ground is drawn by one of the souls, who begins his speech with Vedi? Sola questa riga non varcheresti doppo 'l sol partito. This phrase was selected for Incipit with the aim of explaining in a few simple words, more or less comprehensible to the audience with the help of body expression, that no one can pass that line after sunset: there are limitations to Ante-Purgatory. It would be said by the performer not a recorded sound.

The Salve Regina was the next chant to be recorded as a choir. The same recording strategy as for the Miserere was used: parallel fifths below in order to obtain natural male voices. Only until in hac lacrimarum valle was recorded, because all the chants had to be limited in time and in the case of this chant it was appropriate to end with the words that literally comment on the souls' location: a valley where they have to wait gloomily until they can finally begin their purification.

457 The latter, which is the second phrase of Bonum est confiteri, was only ornamented live, not in the first recorded sessions. 
The next chant is Te lucis ante. The idea was that the performer would sing the solo-part, and then the recorded choir would join in. Thus, a solution had to be found to ensure the performer would sing in tune and in time. Since Te lucis ante is sung every night in a small religious ritual, bells were the best option: they form part of the liturgical services on Earth, which are also Christian rituals. First, the choir was recorded. No transposition was made, since the two parts were written for equal voices. Both voices were recorded, so that the choir would sing equally in two parts and the soloist would simply sing with one of the two groups. Then, a recording of a bell tone was transposed to the basic pitch of the recording and after its copying and pasting it was adapted to the tempo of the choir. Then it was copied and pasted the sufficient number of times as to be able to begin the song with one introductory bell tone, accompany the entire solo, the choir and ring a few times more while fading out. The bell tones had their volume reduced once the choir began to sing.

After the chant, a snake appears after which one of the souls says Vedi là 'l nostro avversaro! ("See, there is our adversary!"') and there is the sound of the wings of the two angels that fly down to chase it away. Then, we reach the entrance gate to Purgatory Proper, where the two keys turning in the keyhole are included in the soundtrack. Dante indicates that a voice or voices sound above the clangour of the gate. We recorded the Te Deum in 2-voice organum above the natural sound of the clangour of a gate, transposed to the basic tone of the Te Deum, doubled at a fifth, and stretched with Paulstretch in Audacity ${ }^{458}$. It resulted in a metallic bordone (drone) below the first phrase of the Te Deum, which is abruptly ended with the clashing sound of the closed gate. Moreover, the recorded voices of the Te Deum, just like any other angelical voices in Purgatory, were treated with Noise Reduction amplifying the $\mathrm{dB}$ of noise reduction and its sensitivity, reaching a more metallic voice quality.

On the terrace of Pride, the souls are carrying very heavy boulders. The sounds of their effort in the form of grunting was both included in the form of pre-existing recordings (male voices) and our own recordings (female voices). The three stanzas of Dante's Padre Nostro that are uttered by these souls was recorded as well, in a somewhat murmured, monotonous and troubled tone. Its murmuring in a monotonous way was inspired by the way the Pater Noster is often uttered by churchgoers with a rosary, while its troubled character is due to the souls' situation. The murmuring sound is reinforced by the multiple recording of it, resulting into a group of various, slightly different mumbling voices, making it harder to understand the precise text. Within our speaking range, some were intoned higher and others lower. The lowest intoned versions were copied and transposed down to male voices.

458 This stretches sound fragments by extreme amounts without damaging the sound (which would be the case with Change Time). 
The angel at the gate says Venite. It was recorded as a spoken word, but also as the first part of the Venite benedicti Patris mei, with the underlying idea that this would add to a certain musical coherence throughout Purgatory and Paradise. Also, the Beati pauperes spiritu was recorded. Although Dante writes that voci cantaron ("voices sang") this Beatitude, it was decided to record it for one voice only. All other Beatitudes are sung by one voice and we preferred to maintain that musical symmetry throughout Purgatory.

The sound of a gate was repeated at all entrances to a new terrace, even if Dante does not specifically mention the sound. Musically, it gives a very defined structure and it represents the different gates and terraces. It is exactly the same sound, which also creates a sonorous coherence. At the next terrace, hurtling voices sound before and after the Litany of all Saints. These voices were recorded and then transposed to other pitches, so that some of the voices were male and others were female. The hurtling voices after the Litany of All Saints, examples of envy, were copied to a simultaneous exemplar a semitone higher, thus creating dissonant voices. Of the Litany of All Saints, the leading voice and the answer by the choir were recorded. The voices were recorded with the expression of zealous suffering. For the male voices it was complicated to record at a parallel fifth, so some of the voices were transposed directly one octave lower, just like for In exitu israel.

The sound of the gate precedes the recording of Beati misericordes and Gaudete ex exultate, which have very similar melodies. At this terrace, the wrathful have to sing Agnus Dei. Instead of a choir, it was only recorded for two monophonic voices, to which the performer would add a third voice; a small, intimate interpretation of this beautiful chant which asks the Lamb of God for inner peace. In the last phrase, the $\mathrm{b}$ is sung $\mathrm{as} \mathrm{a} \mathrm{b}$ flat, because it moves within the hexacordium mollum: it is the $f a$ of the $\mathrm{f}(\mathrm{f} g \mathrm{~g} b$ flat $=$ do re $\mathrm{mi}$ fa, see chapter 1$)$.

Another gate sound accompanies the Beati pacifici. As chapter 4 showed, the angel possibly sings a troped version of this chant. In the rehearsals for the recordings, the melodic phrase of the words beati pacifici was repeated for the words che son sanz' ira mala, before continuing with quoniam filii dei vocabuntur. The second step was to vary the melody for the trope. Instead of the melisma a $-\mathrm{g}-\mathrm{a}-\mathrm{g}-\mathrm{g}-\mathrm{f}$, the melisma for $\mathrm{sanz}^{\prime}$ became $\mathrm{a}-\mathrm{b}-\mathrm{c}-\mathrm{d}-\mathrm{b}-\mathrm{a}$ in order to follow on $\mathrm{g}$. Thus, the trope has the same melodic beginning and end, but the middle section is different. We notated the trope above the original notes in the original transcription. 

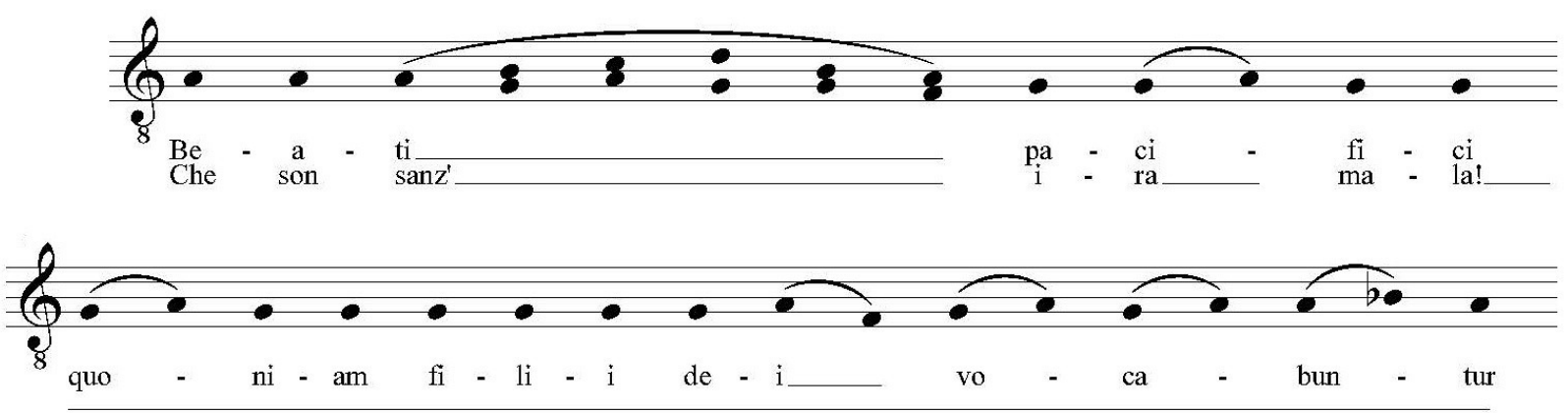

Fig. 173. The trope in Beati pacifici

The slothful are running around the terrace. Various recordings of running footsteps were combined. Then the phrases they eagerly cry out were recorded: Maria corse con fretta a la montagna! (“Maria runs quickly to the mountain!"), Ratto, ratto, che 'l tempo non si perda per poco amor! (Quick, quick, so that time is not lost because of lack of love!"), and Noi siam di voglia a muoverci sì pieni che restar non potem, però perdona se villania nostra giustizia tieni! ("We are so full of the desire to move that we cannot pause, but excuse us if our justice includes rudeness!").

The gate and Beati qui lugent precede the psalm Adhaesit pavimento anima mea. This was recorded with the mouth pressed partly against the hand, in order to recreate a sound someone lying on the floor facing it would be able to produce. In the same way a drone at the basic tone (finalis) was sung, and then copied to a fifth higher. This is not mentioned by Dante and it is not sure until what point it was still done in his time - although in nowadays performance practice of Medieval music the drone is applied regularly - but it only sounds as a background tone and musically counterbalances the dragging way of singing the chant (the souls sing with many sighs, which has been expressed in the singing). At this terrace the mount trembles because one of the souls is liberated from his penance. All souls interrupt their purging process and sing Gloria in excelsis Deo. For the scene it was decided to cut just after the inhalation for the next verse. The verses 1 and 4 are repeated after Gloria in excelsis Deo, because the text is hard to understand due to the way it is sung. ${ }^{459}$ It was not sung at the fifth below in order to obtain male voices; it was decided that there are no male voices in this choir. Also the chants after Adhaesit are only left at the pitch of female voices. Even though the last chant, Summae Deus, is sung lower than the penultimate chant, Domine labia mea, these three chants form a group of higher chants where the lower octave is not present anymore. Musically, it is a step toward the head voice used in Paradise. The interrupting Gloria does contain the lower octave because it is supposed that all souls of Purgatory are singing.

459 Which is with the mouth pressed against something. For the recording this was our hand, for the performance it was thought to sing it just like these souls, pressed against the floor. 
Parallel organum has been applied to it: lower octave with its fifth and the unison with its fifth, thus reaching 4 different pitches. It was sung a fourth lower which was copied to the octave below. The closing formula, seculorum amen, was not sung. For the trembling mountain, a recording with a very low pitch was selected, the Hard Limiter was performed on it, and the sound was amplified. In Dante's Commedia, the phrase Dolce Maria! exclaimed “as a woman in labour" (Purgatory 20.20) is followed by other exclamations before he is liberated, but for Incipit it is the phrase indicating his liberation. This voice was recorded in a low intonation and then transposed down to a male voice.

The partial Beatitude Beati qui sitiunt precedes the sound of the water drops on trees. The envelope tool was applied to this sound for the time interval of the chants, so that its lowered volume makes the singing comprehensible. Domine labia mea is sung with a higher voice. It is then followed by the other part of the same Beatitude, this time Beati qui esuriunt, finishing the entire phrase. The lustful sing Summae Deus alternated with shouted words. After one of the recording sessions, it was decided to suppress the cried out Al bosco si tenne Diana, ed Elice caccionne che di Venere avea sentito il tosco. This phrase was long, much more difficult to understand for non-Italian speakers and the recording showed that it became a chaotic sound when recorded as a choir. The phrase Ne la vacca entra Pasife, perché 'l torello a sua lussuria corra has the same situation, but of the whole phrase only the Latin word Pasiphae (instead of Pasife) was recorded. The contemporary audience might know the myth of Pasiphae, therefore it was pronounced in Roman Latin. ${ }^{460}$ The final recording had the following order: Virum non cognosco! - first verse of Summae Deus - Pasiphae! - third verse of Summae Deus - Sodom e Gomorra! - kissing and greeting of two groups of souls. These souls have a very loving and even joyful character to them, which was aimed to express in the recording.

The sound of fire had been accompanying the entire scene of the lustful. Since the last "gate, the entrance to the Terrestrial Paradise, consists of a wall of fire, the sound of the fire was maintained and only lowered in volume with the envelope tool during the scene of the lustful. After that, its volume rises. After a short while, the angelical chant sounds which has to lead the righteous ones out of the fire, Venite benedicti Patris mei. The end of the chant overlaps a few seconds with the sound of a forest and birds, just as Dante describes them in Purgatory 28.14-18. ${ }^{461}$ The song of Matelda was recorded and the envelope tool manipulated it into a fade-in starting from a very soft

460 The main differences in pronunciation between Classical Latin and ecclesiastic Medieval Latin are the following. In Classical Latin Ae sounds as [a'e:], oe sounds as [o'e:], c sounds as [k]. In ecclesiastic Latin, ae and oe sound as [e:], c sounds as [t $\mathrm{t}]$.

461 "li augelletti per le cime (...) con piena letizia l'ore prime, cantando, ricevieno intra le foglie, che tenevan bordone a le sue rime" ("little birds among the topmost boughs (...) with their song they welcomed, full of joy, the early morning hours among the leaves which kept up an accompaniment to their rhymes") 
but audible beginning, creating the sensation that she is slowly coming closer. Then, the phrase Beati quorum tecta sunt peccata is sung, very close and left quite dry (non-reverberant) so that it seems that she suddenly sings directly next to us. Her voice was heightened by a small interval so that it obtained an infantile aspect, which represents innocence. The melody ends with a descending minor third (the "cuckoo"-sound), which is present in many children's songs. Both her melodies have a high ludic quality.

The sound of streaming water has been introduced and slowly becomes stronger (envelope tool). Before its crescendo, the Hosanna begins. For the other chants the natural range of our voice had been sunstantial, but for the 3-part organa it was the decisive factor. The intention was to maintain the homogeneity of the voices as much as possible. If the lowest voice would allow still a full mixed voice sound ${ }^{462}$, it was sung using the head voice as much as possible. Regularly the range was too low for a strong mixed voice, so the chest voice was then used. The original melody was recorded first (third stave in our transcriptions) and then the second voice (first stave). Sometimes the first voice was re-recorded against this second voice in order to obtain a perfectly connected sound in which the voice depend of each other. On these voices, the third part was recorded (second stave), because it is the voice that was composed as the last one and is often moving in the middle, now crossing with the first voice, then with the second. The recordings were done with one set of ear plugs with the recorded voices and a big set of headphone over them connected directly to the microphone, thus assuring maximum coherence in intonation and rhythm. All voices were recorded, also for the chants where the protagonist would sing one of the voices together with the other two recorded ones. Sometimes, the third voice had to be recorded directly on the first, because of repeated unisons between the two, and then the second voice would be recorded. At the beginning of the rehearsals for the recordings, it was aimed to sing according to Pythagorean tuning. At the moment of recording, however, the tendency was to find a pure intonation. Where $\mathrm{c}-\mathrm{e}-\mathrm{g}$ in Pythagorean tuning is not supposed to sound agreeable due to the major third which is too big, in the recordings the tendency was to tune according to the harmonies of the other voices and the major thirds have been lowered often. It makes us wonder about the relationship between theory and practice. Was the third always intoned this high or was it adapted to the circumstances? We know that in England the third was actually an essential element in music; would this be because they had lowered permanently the third? Also, the theoretical change from Pythagorean to mean tone temperament is so drastic that it is probable that in $15^{\text {th }}$ century practice the third was already lower and theory found a solution to define an existing practice. Even in nowadays equal temperament, singers are still altering slightly to obtain a perfect fifth, for example. It is sure that 
the Medieval ear was used to a higher major third, but it may be disputed if the major third was in all cases too high, especially if we think of singers among themselves.

All the other aspects of the heavenly procession have been eliminated (see chapter 5). The Hosanna still represents the same as in Dante's narrative: it is the Divine welcome into Paradise. Now, the protagonist is ready to cleanse himself for the immaterial Paradise. For this ritual the three-part organum of Asperges me was recorded. The water sound keeps sounding a short while and then changes in the revolving sound of the planets that Dante describes in Paradise 1.82.

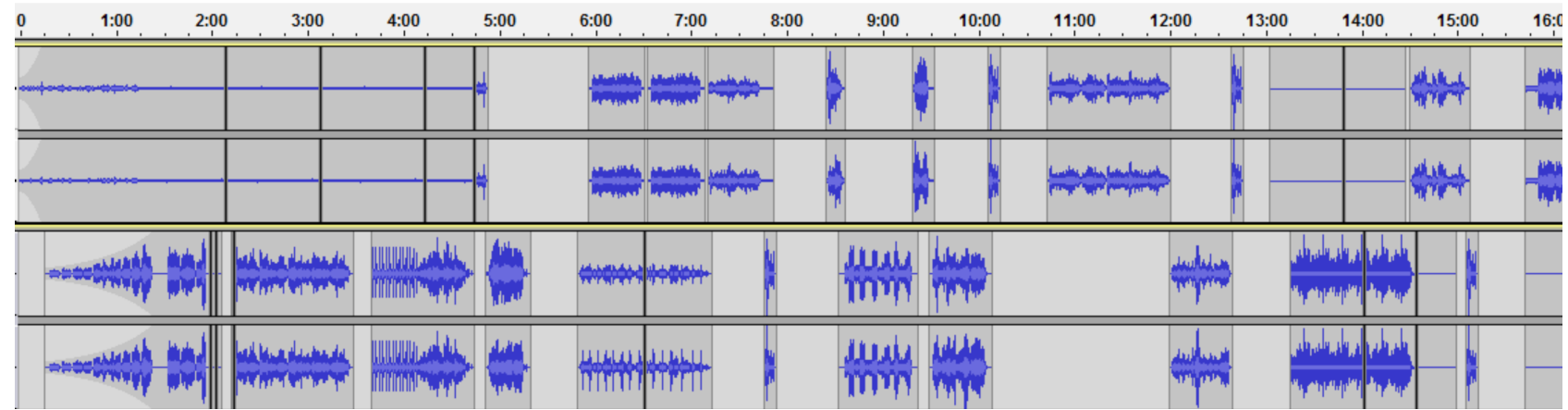

Fig. 174. First half of the final soundtrack of Purgatory

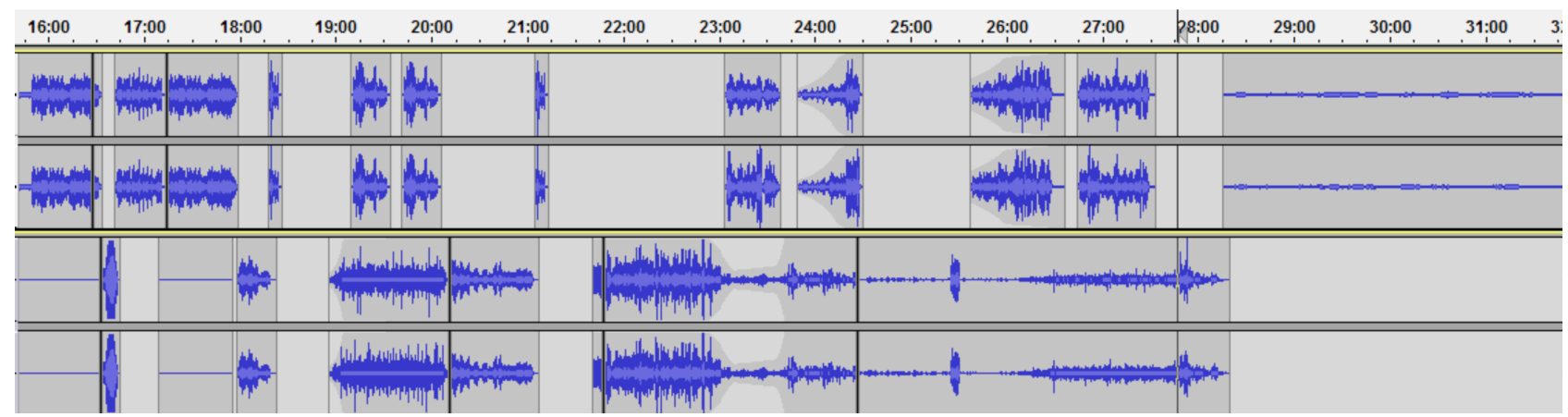

Fig. 175. Second half of the final soundtrack of Purgatory

Paradise was the most challenging part to translate into sounds, especially if one does not wish to abuse of synthetic sounds. Paradise is the part with the least action and the most reflection, but at the same time all souls are dancing and singing, pausing after every chant. Paradise is a festive Divine representation, where mind and will are one. It was decided to record the chants and a few relevant spoken phrases, leaving space for eventual later additions. It was also considered that each chant could represent a sphere (see chapter 5), even if this did not have to be obvious in the performance. After all, the audience would not make the same journey as Dante and it is not likely that to a $21^{\text {st }}$ century human being Paradise is presented as a Ptolemaic universe. To all chants for Paradise a reverb was added, contrary to the souls' chants in Purgatory, which were maintained dry and "earthly". 
The strangeness of the sound that Dante mentions is one of Incipit's few synthetic sounds. It only sounds until the first chant and with a very low volume between the first and the second. Also, the happy laughter of the souls in the sphere of the Moon were the result of two pre-existing recordings of a gently laughing woman and girl. The Ave Maria sung by one of the happy souls was recorded in the mixed voice register. The phrase ogne dove in cielo è paradiso ("anywhere in heaven in Paradise", Par. 3.88-89) is a conclusion made by Dante himself after talking with the souls on the Moon. Also the phrase Del lume che per tutto il ciel si spazia, noi semo accesi ("We are inflamed by the illumination reaching through all heaven", Par. 5.118-119) was considered relevant and was recorded. Another spoken phrase that was recorded was for a much later moment: the silence in the sphere of Saturn. Tu hai l'udir mortal sì come 'l viso (...) qui non si canta ("You have the sight and hearing of a mortal (...) there is no singing here", Par. 21.61-62)

Before each of the 3-part organum settings of the chants, a tone indication was needed in the soundtrack, so that the performer would know exactly on which intonation and moment to start. For the Sanctus, a recording of a tapped glass was transposed to different tones within the tonality of the Sanctus. Then, different samples were combined into the first sanctus of the melody and then repeated with the added melody of the second voice. Transposing the samples by a fifth and then other intervals according to the pre-settings in Audicity did not result in a well-tuned melody, so adaptions in individual samples had been made. The motivation for selecting the sound of glass was twofold: it is a natural sound, but it is also a sound that is reminiscent of a music box. For the author it represents a certain dream-like, surreal quality. Moreover, it is not a voice but it is not associated with any musical instrument in Dante's time; therefore it does not have the connotation of a worldly instrument of seduction.

For the introduction of the Gloria, the recorded second voice singing the word gloria was inserted before the actual chant. This voice would be sung by the performer, creating thus a connection of echo between what is recorded and what sounds live. In order to connect the tone of Gloria with that of the sequence Victimae, which was recorded a tone lower, different pitches ( $\mathrm{f}^{\prime \prime}-\mathrm{a}$ " flat and A flat - e' flat) were introduced in the middle, derived from rubbing the edge of a glass with water on it. They all overlap, making a gentle transition. The glass again represents a natural tone, this time with a more alienating effect. A recording of an old clock was then placed under the second tone and extended to after the last tone. Of the last 8 beats, the even beats were amplified so that they clearly marked the beginning of the sequence, whose interpretation has been the most up-tempo of all chants. The tic-tac sound represents the clock-like movement of the souls around the Sun, as described by Dante. 
For the introduction of the Alleluia x, four isolated 3-voice alleluias were manipulated with various effects in Audacity, such as extreme envelope effect of crescendo-decrescendo, noise reduction, and vocoder. After the Alleluia, a silence was introduced, representing the planet of Saturn. For this moment the mentioned expression about the silence was recorded and placed at its beginning. After a moment of silence we placed the low-frequency tremble of the souls' ungraspable shouts, overlapping with the paulstretched sound of the gate that accompanied the Te Deum in Purgatory, this time functioning as its introduction.

After the Te Deum, the recorded first voice of Sperent in te sounds, with sperent in te omnes qui noverunt as an introduction to the chant. The same procedure has been followed here as in the Gloria: the performer would sing the melody live that just sounded before as a recorded introduction. The lowest voice was selected for the performer so that this chant could serve musically as a more intimate moment. This would give variation to musical colour in the performance and it would be an appropriate choice for the theme of this chant, which is about the souls that have hope in Divinity, thus lowering down closer to the terrestrial.

Again, the sound of rubbing the rim of a glass was used to introduce the next chant, Gloria Patri et filio, while 4 glass-tapping sounds were used for the last chant, Hosanna, on its finalis and fifth. Dante writes about children's voices in the Empyrean, which accompany the introduction of Hosanna.

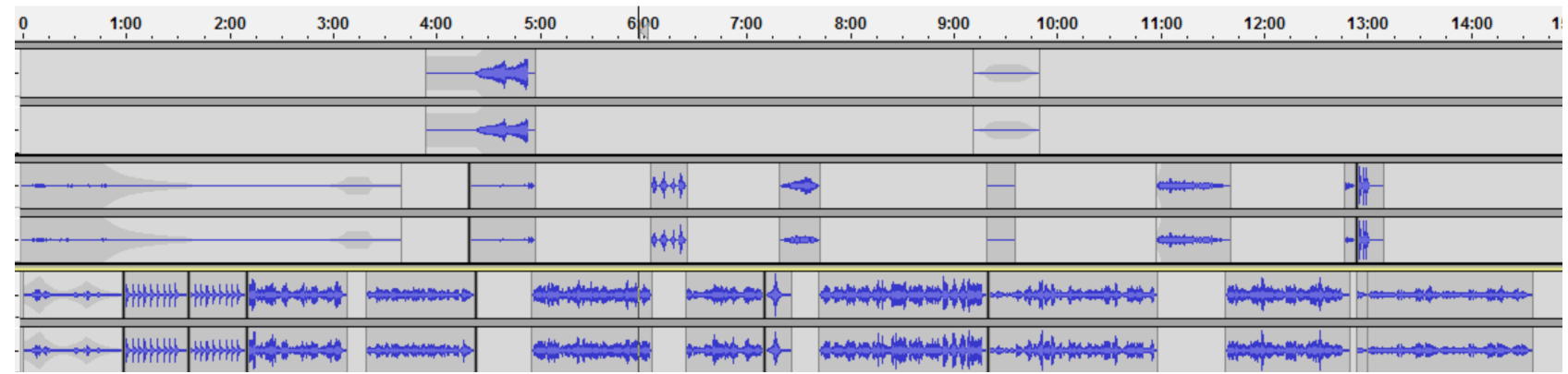

Fig. 176. Final soundtrack of Paradise 


\subsection{Rehearsal process and dramaturgy}

Once the soundtrack was finished, the physical rehearsals began. The dramatical structure follows the Commedia's separation into three canticles, which in the case of Incipit we may call "acts" or, to think in a more musical way, "movements". These three parts are again divided into "scenes" or "sections", based on the sonorous references in the Commedia where they mostly indicate a different space or situation that Dante encounters on his journey. The philosophical idea behind Dante's work that has been essential to Incipit's dramaturgy is that the journey proposed by Dante in his Commedia is in fact an interior one. In Incipit this is translated into the specific mise-en-scene in which all situations and characters are now interiorized in the performer herself: she represents humanity in all its aspects. The audience is invited to experience their inner reactions to this human being, both in its dammned version and in its blessed one. In this way, Incipit is an approach to the Medieval world through Dante and at the same time offers the audience the possibility of reflexion about humanity, the nature of good and evil, and more metaphysical issues.

At first, the scenic approach was set out departing from the idea of performing a theatrical score as shown in Annex 2: creating a "musical-theatrical" score of movements, gestures and sounds that Dante describes throughout the Commedia. However, it soon became clear that in this way most movements became representative of Dante's literal narrative, reinforcing the sounds without adding something substantial. Since Incipit is centred around Dante's soundscape, the soundtrack was left as intact as possible, and the rehearsals focussed on the reaction of the body to those sounds. Dante's references to movement and gestures were not put aside completely, they were kept in mind and performed if the movement added something substantial to the sound.

Since our proposal for the scenic space was determined by the idea of a personal, inner voyage, the mise-en-scene was a minimalistic one in which the performer is alone in an empty space. We are in the Afterlife, but not in the virtual world that Dante created to show that all finity is just a shadow of infinity.

The rehearsals and final performance took place in a small black box theatre for 80 spectators, with a wooden floor of 10.50 metres broad and 9.50 metres deep, covered by black linoleum, with black side walls and a black background. The stage floor is at ground level, while the audience sits higher. The reverb was less dry than most theatre halls due to the construction of its roof and the limited presence of cloth, which has an absorbing quality. Reverb is more suitable for liturgical chant and makes the mixing of live sound with recorded sound easier. The theatre has 24 lighting channels, 4 
speaker boxes (2 larger ones), a video projector, all controllable from two mixer tables behind the audience. There was experimentation with a wireless headset microphone. In Inferno it was impossible to be kept in place due to the violent movements of the performer. After several rehearsals, despite its sonorous advantages, ${ }^{463}$ it was too inconvenient in other ways: the microphone did not always stay in place in Purgatory, the radio transmitter that was worn on the back was visible in various scenes, there was a risk of interference and it lengthened the performer's backstage time when she had to change. After a rehearsal without microphone it was decided to suppress its use.

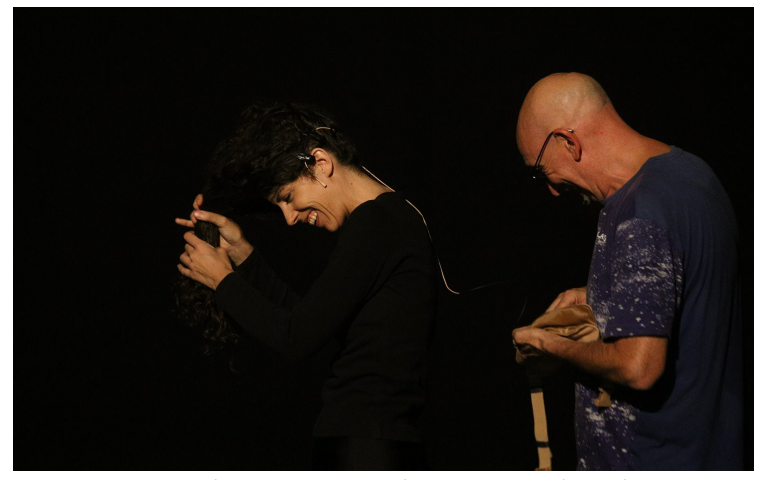

Fig. 177. Changing in between the three parts was difficult due to the headset microphone

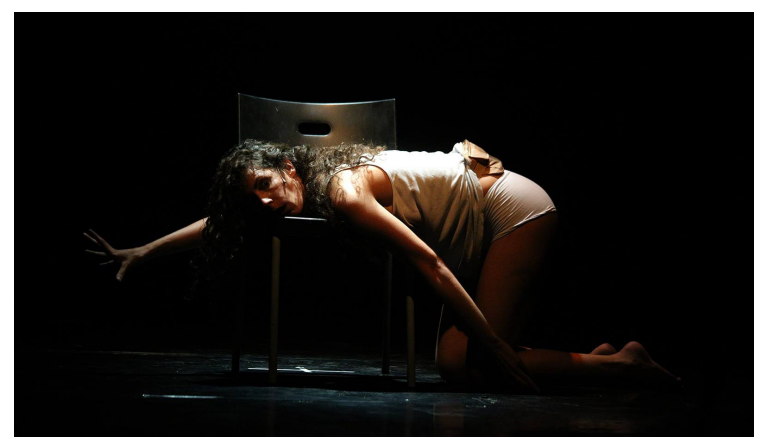

Fig. 178. Visibility of the radio transmitter

In order to show the creative proces of the mise-en-scene we will now treat each "act" or "movement" subsequently. Annex 7 consists of a detailed description of the final mise-en-scene, illustrated by snapshots from the performance.

\section{Inferno}

In the rehearsals of Inferno, the connection between body and voice was one of the aspects to be explored. Producing sound is carried by a complex bodily mechanism of muscles in the abdomen, back and lower rib cage, the precise air pressure that is effected on the vocal chords, the position and opening of mouth and throat and the projection of the voice in the nasal cavity and sinuses. When one of these parts is manipulated, it changes the sound, for example the phrase mio figlio, ov' $\grave{e}$ ?, which is continued to be uttered holding the breath and compressing the abdominals under the recorded sounds of boiling blood and screaming people. On the other hand, the production of sound influences the bodily movement, such as the sighs in Limbo or the coughing in the ditch of the 
counterfeiter (the feverish). The suffering body and the voice are the visual and the sonorous expression of the infernal soul's ill fate as represented by the performer. The expression and limits of the voice have also been explored, from the whispered register at the entrance gate to the desperate fortissimo in the choir of the neutral angel or the screeching perché mi peste? at the end of Inferno. As we will see later on, in Purgatory the intention of singing as beautifully as possible is hindered by the inner fight of the protagonist between her sins and her wish to purify herself, while in Paradise there is no obstacle of the body anymore in order to make perfect music.

In Inferno, the interpretation of mental and physical suffering was expressed best by the aesthetics of performance, in which the action is more important than the representation. Once the basic actions were marked, their transitions were worked on. Some movements for one particular sound could be continued into the next sound, thus physically connecting the differentiated sound unities. In this way, the movements - being treated in a musical way - became polyphonic with the recorded sound. Even though the recorded sound is a fixed form, it was adapted to the physical mise-en-scene when necessary. The suffering body was marked by a faceless head covered by hair, which gave the performer a more beastly aspect and took away its human facial expression. The performer's nudity shows her muscles and bone structure, which show her suffering and accentuate her physicality. Any clothing would have lessened their visual impact by covering them partially, and would have broken the sculptural corporal lines.

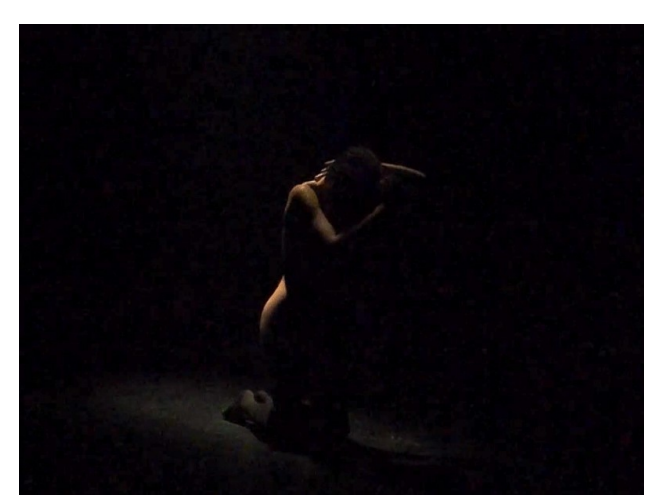

Fig. 179. The faceless body carressing her hair.

Not only physical but also mental torment was accentuated: Incipit's Inferno expresses a mental disorder and a profound suffering because of it. The overhead lighting was combined with scarce frontal lighting, which reinforced the sensation of a narrow place, like the well of the film The Ring.

At the beginning and end of Incipit and in the moments of change between the three canticles, few but significant lines from the Commedia are projected. Dante's literary rhetoric is thus included in 
its original written medium. Each canticle finishes with the significant word stelle ("stars"), and in this way so does each "act" or "movement".

At the beginning, three texts are projected on the curtain at the back end (first lines of Inferno):

\begin{tabular}{|l|l|}
\hline INCIPIT & INCIPIT \\
INFERNO & INFERNO \\
$\begin{array}{l}\text { Nel mezzo del cammin di nostra vita } \\
\text { mi ritrovai per una selva oscura } \\
\text { ché la diritta via era smarrita. }\end{array}$ & $\begin{array}{l}\text { Halfway through the journey we are living } \\
\text { I found myself deep in a darkened forest, } \\
\text { for I had lost all trace of the straight path. }\end{array}$ \\
\hline
\end{tabular}

For the beginning of the Inferno, the performer sought for an ambivalence of a body without a clear front or back, crossing her arms under her and connecting her hands in her neck, with her hair flipped over forward. The hands are representing the beasts, while the body is their victim, which is yet another corporal ambivalence, one of non-unity that attacks itself.

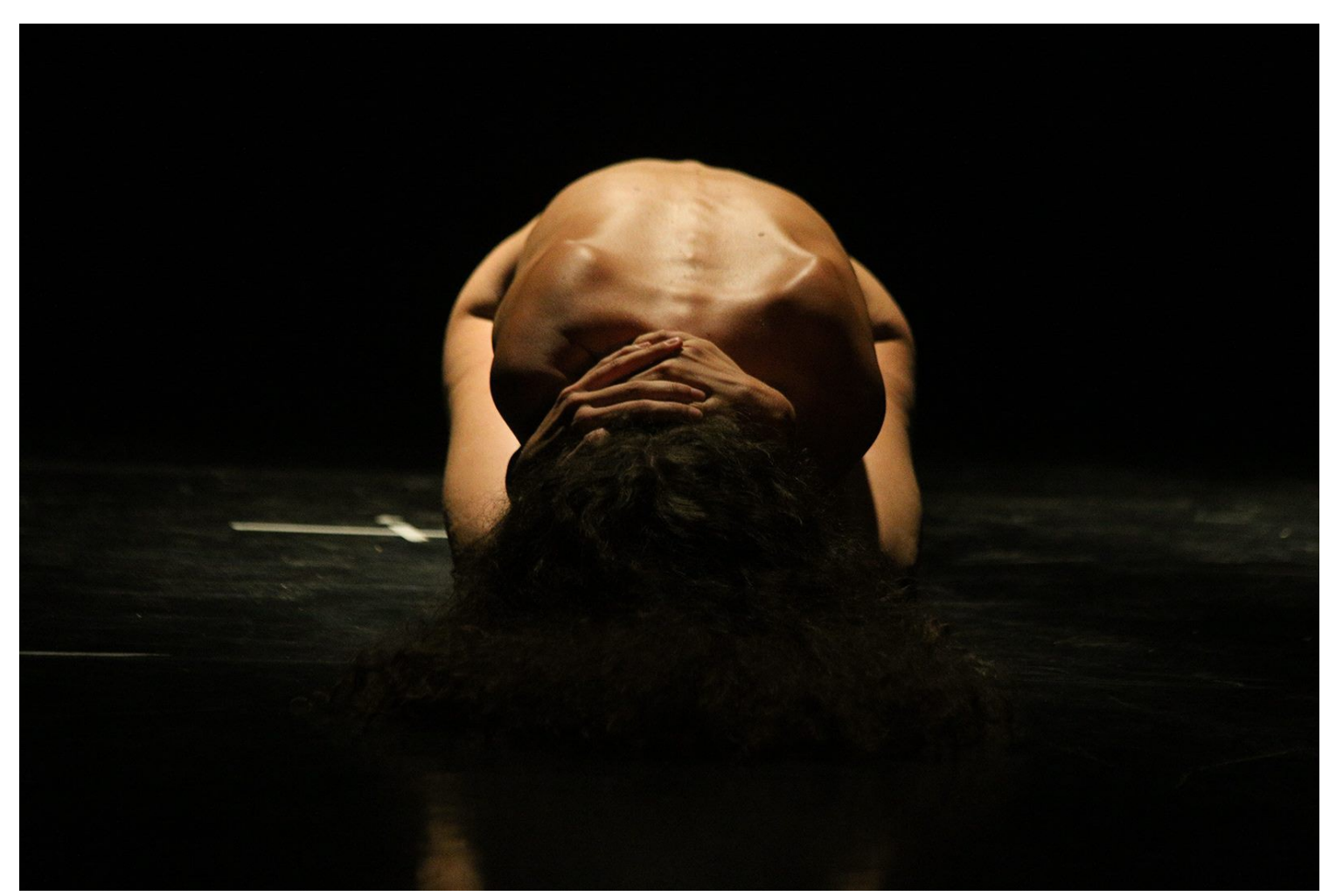

Fig. 180. Rehearsing the beginning of Inferno 


\section{The Entrance of Inferno and The Choir of the Neutrals}

Although the words miserere di me were planned to be expressed at the beginning of Inferno, they were suppressed in the rehearsal. Inserting a sudden sonorous crescendo out of place did not fit in the musical-dramatical line. In the Commedia, it is Dante who utters these words, but his spoken Miserere is a sign of his own inability of producing music and is thus representable for all infernal souls (see chapter 4).

The recorded voice with a delay-effect expressing the words of Inferno's entrance gate were supplanted by the live whispering of these words. During the choir of the neutral souls, there is a vocal exploration of limits and its interaction with the body's tiredness. The repeated movement of brushing her hair was explored and extended to the thunderclap in a gradual acceleration. The thunderclap is thus the subito piano for both sound and movement.

\section{The Sighs of Limbo and Rapture by the Wind}

The effect of sighs on the bodily movement was explored and the physical gesture was enlarged, so that movement emerged from the use of the voice. This movement then transitioned into the movement of a body that is carried by the wind. The sound of the cranes inspired a corporal reaction of throwing up the arms, reminiscent of birds that cannot fly.

\section{The Sour Rain and The Fight}

Cerberus' howl and the rain also provoked a direct corporal reaction. The rain choreography consists of a repeated action of a spastic movement of the back. For this scene, the duration of the rain had to be adapted twice until finding the right time length for the action. The movement is extended into the next scene, and from its silence arises the next action: "Perché tieni?" "Perché burli?" Originally, these sounds were recorded on the left and right of the performer, but it was considered that she could express the schizophrenic quality of this scene by saying these phrases herself, one looking to the left and one to the right. Thus, it naturally flowed into the scene of the wrathful, where she began fighting with herself. For these movements, a simple repetitive choreography was made (see Annex 3). For the gurgling wrathful submerged in the mud, a slowmotion version of the fight was performed, in order to return to the fast fighting when the sound of the fighting souls comes to the foreground again. 
The sound of the slamming door was suppressed, because it appeared to be a hint unclear for people who are not familiar with the Commedia. Now the voice itself became the musical climax before the subito piano.

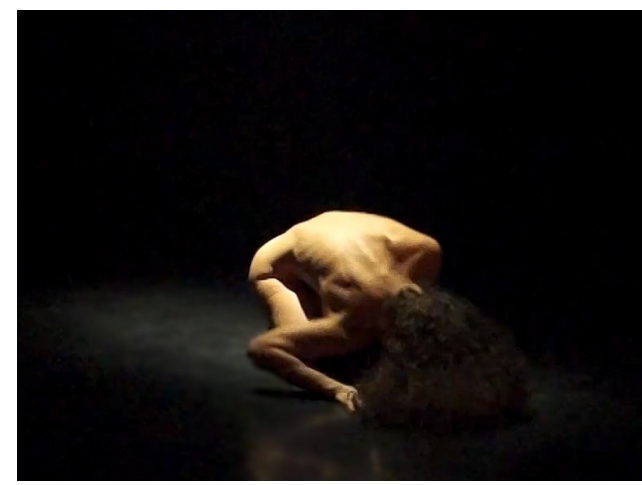

Fig. 181. The Sour Rain

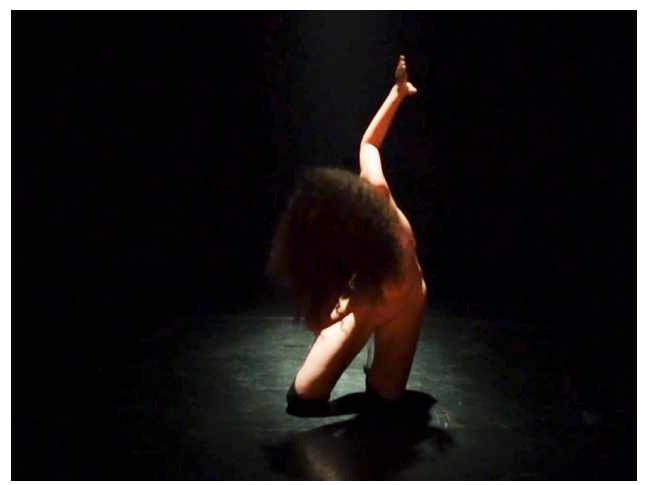

Fig. 182. The Fight

\section{Mio Figlio, Ov'e?}

The recording of the phrases Chi fuor li maggior tui and Mio figlio, ov'è? in a shifting polyphony against each other did not stimulate any specific action on the stage. Therefore, they were taken away and only the latter phrase was used, expressed by the performer herself. Its meaning changed completely: instead of expressing the ego-centrism of human beings, it shows a mother suddenly realizing she had a son and now she has lost him, as she has lost all loved ones. She is alone. The choreographed fight offered the way to enter this emotion: at the end of Plegyas' shouted words, there is enough time margin to end with the punch in her stomach. This is the signal for her to react and stop, covering her tummy with her hands, looking at it and making the transition to the realization that she has lost her son. In this way, it has become a highly tragic scene, since it shows an Inferno in which one is totally alone.

The scene after the flames is the one of the screams and the boiling blood. It was explored to keep on repeating the phrase, keep on searching for the lost son in despair, even when she is being boiled in blood. The performer's body simulated being in that situation and her voice was thus altered while she still tried to say the words.

\section{The Dead Forest and The Desert}

In the scene of the tree, the body reinforces the surrealistic ambiance by taking on a tree-like posture and moving slowly to and fro. From the dog sounds on, which result in a nervous intent to 
protect her body, there is an intense emotionality in the performer's body. Of the running souls in the desert scene, the phrase "sóstati tu!" was maintained, while "fa che di noi a la gente favelle" is not. Furthermore, the function of the sound changed in the rehearsals: the performer repeatedly calls "sóstati tu" (stop!) when she hears the running footsteps, thus converting them into a signal of temporary hope of others who could take her out of her isolated situation. When the footsteps leave, her hope is shattered and she says disdainfully "qual io fui vivo, tal son morto". Her physical movement changed from her self-protecting arm movements into repeatedly brushing off flames from her arms. In Incipit, it reinforces the expression of mental disorder, actually reflecting one of the arm movements of Dante's souls in the desert. The arm movement becomes the rhythmical accompaniment of "qual io fui vivo, tal son morto" and a dance-like movement under the sound of the waterfall.

\section{Whips and Grunts}

This is suddenly broken by the whip scene. The original male grunts were eliminated from the recording, but the grunts by the performer are based on these exact sounds. In order to connect this scene to the next one, the performer hits herself and scratches herself, grunting with each hit. In this way, the two scenes were connected by her continuing unvaried reaction of showing pain and grunting, even if she hits and scratches herself.

\section{Heading Back, The Devils, The Crucifixion and The Blasphemy}

For the scene of the souls walking backwards with their heads turned, the performer sought for a way to express the ambivalence of a body without a clear front or back, just as in the beginning of Inferno. The performer straightens up her body and lift up her face so that her frontal body has the posture of a human back. The devils are an interruption of the silence before and after, and it seems as if she is possessed by them. This is one of Inferno's moments, just like the hands of the scene of the beasts at the beginning - in which the performer's body represents the demonic residing within humanity. The comic aspect of the scene was also represented, as well as the arrhythmicality in the military scene. The opening of her arms is a transition to the crucifixion. In Dante's Commedia it is a horizontal crucifixion, but in Incipit a vertical one was chosen. This has a far more provocative significance, especially sticking up her middle finger to God when she scorns "Togli, Dio, ch'a te le squadro!". 


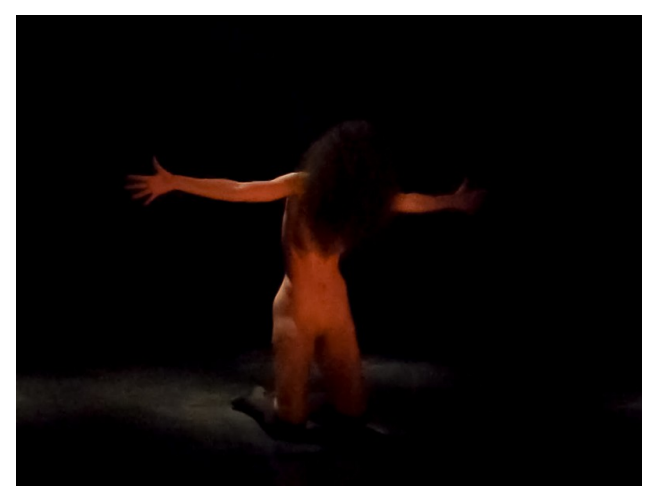

Fig. 183. The Crucifixion

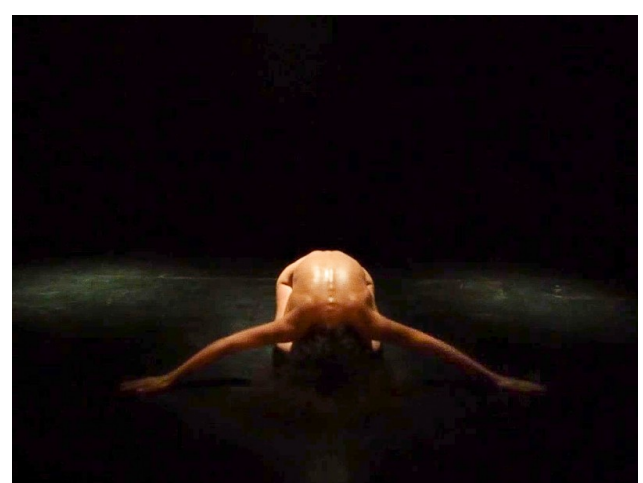

Fig. 184. The Fall

In Dante's text it is fare le fige, sticking the thumb between index finger and middle finger, but in the rehearsals it turned out to be an unclear sign. These words were originally recorded, but supplanted by the performer's own voice. The expression "Vedi che già non se ' nè due nè uno" was definitely suppressed, since it implies at least two simultaneous characters: the one saying it and the one to whom it is actually happening. The crucifixion posture was also used to fall down very quickly: the arms stopped the impact of the fall and at the same time created a sonorous impact of a hard clap, just after having defied God.

\section{The Flame}

In order to transition to the sneaky flame character of the fraudulent rhetorician, the arms are slowly withdrawn with only the fingertips touching the floor. Although the words "S'io credesse che mia risposta fosse a persona che mai tornasse al mondo, questa fiamma staria senza piu scosse" had been recorded, it was decided to supplant them for a live performed speech. In this scene, not only the way the colour of the voice and the accentuation of the consonants was important, but also the posture of a rounded back so that the neck could be seen, whose muscles and ligaments moved when the performer spoke. This is an unusual part of the body being explored in dance or theatre, but its direct relation with speech has proved it to be an essential part in this flame-like speech, where the soul is hidden within a flame. 


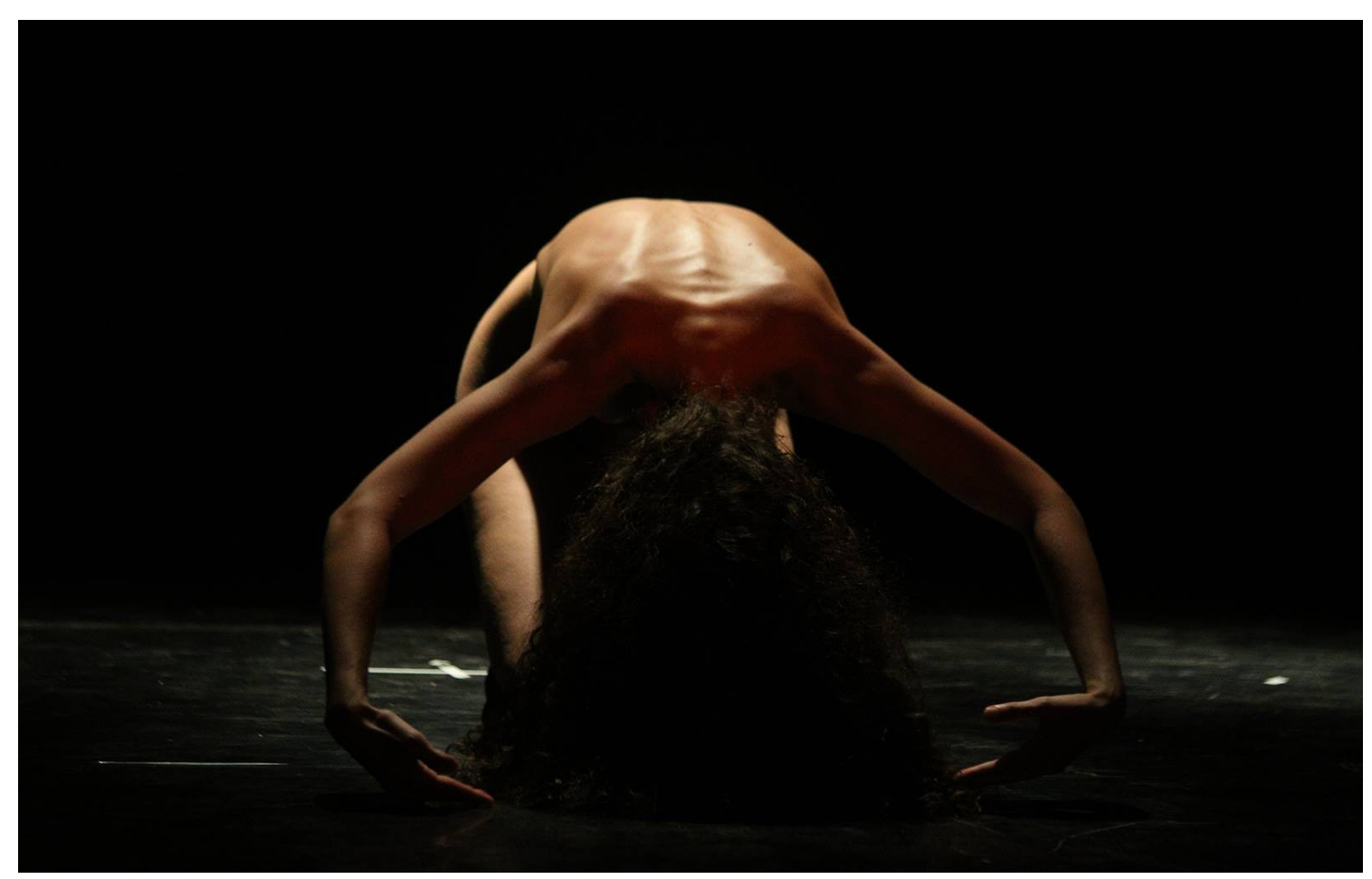

Fig. 185. Rehearsing the scene of the flame

Decay

The rounded back led to an exploration of the expressiveness of the back in its bone structure. The counterfeiters are feverish, thus it was explored with the body's mechanism for coughing. The back expands abruptly with each cough. From this point on, there is an exploration for the body's decay, as if not only the mind, but also the body gives up. The argument between Master Adam and Sinon was considered to be suppressed, because the physical expression of their violence was not natural. However, it was decided not to, since it shows the violent self-expression of the infernal souls. Instead, the performer impersonates someone else who hears them but cannot get up anymore to see where they come from. Nimrod's words were recorded but are uttered by the performer, beginning to fall down on her lower arms because she cannot support her body weight anymore. This movement increases in speed and intensity until the end, where she returns to her opening posture. The transition consists of her arms crossing under her body as if it is breaking, but then they become monstrous again.

The phrases "Perché mi peste?" and "Perché mi moleste?" had been recorded but they were uttered by the performer. The recording helped her to find the right tone, a slightly comical one, but which in the performance became intense and tragic. 


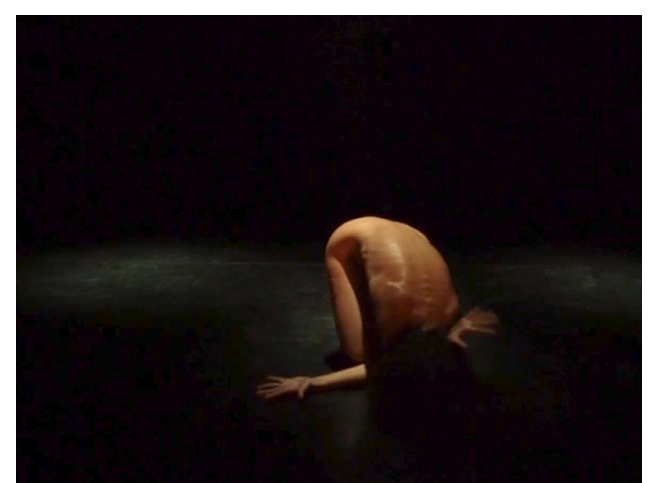

Fig. 186. Decay

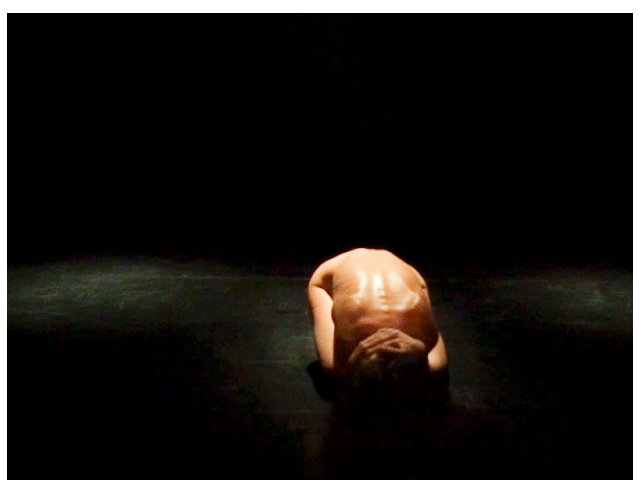

Fig. 187. Final posture of Inferno

\section{Purgatory}

For Purgatory, the interpretation of the sins and their corresponding specific liturgical chants or recitations was best expressed through dramatized theatrical representation. While in Inferno the focus is on the mental and corporal suffering, in Purgatory the focus is on the human mental fight between reason and will. It was discovered that the chants in such a performance obtained their original function, namely to help the protagonist in the specific sin she is trying to overcome. Even though in the liturgical context they have the same mental function, it is only when it is set in a dramatical context that they are really functional. Dante and his contemporaries had a daily contact with liturgical chants and knew them well, but for most of us reading alone about them does not make them as obvious as when they are really sung in the dramatical situation described by Dante.

Three texts between Inferno and Purgatory were projected on the black curtain at the back end (last lines of Inferno and lines 4-6 of Purgatory):

\begin{tabular}{|l|l|}
\hline E quindi uscimmo a riveder le stelle. & $\begin{array}{l}\text { From there we came out to see once more the } \\
\text { stars. }\end{array}$ \\
PURGATORIO & PURGATORY \\
canterò di quel secondo regno & $\begin{array}{l}\text { I shall sing this second kingdom where } \\
\text { the human spirit purifies itself, } \\
\text { dove l'umano spirito si purga } \\
\text { e di salire al ciel diventa degno. }\end{array}$
\end{tabular}




\section{The Arrival}

With In exitu israel was experimented for its length: the rehearsals began with 10 verses and ended up with 5. The reason was not only the duration of the scene itself but also of the entire Purgatory, which is the longest canticle of the three. For the scene of the boat and the scenes in Ante-Purgatory, the character of boredom was explored. The protagonist is waiting for a long time. She has the hope of being allowed into Purgatory Proper, and must behave well, but bears the boredom of a long time of repeated rituals and endless waiting. In the boat scene, it is sleepiness that is explored, extended to the scene of Miserere. The large "o" of surprise at seeing a living human being was translated into a surprise at seeing the audience. In Purgatory, the audience has been considered the witnesses that watch the soul sinning and doing penance, thus while the soul in Inferno is isolated, in Purgatory the soul can see and communicate to the audience.

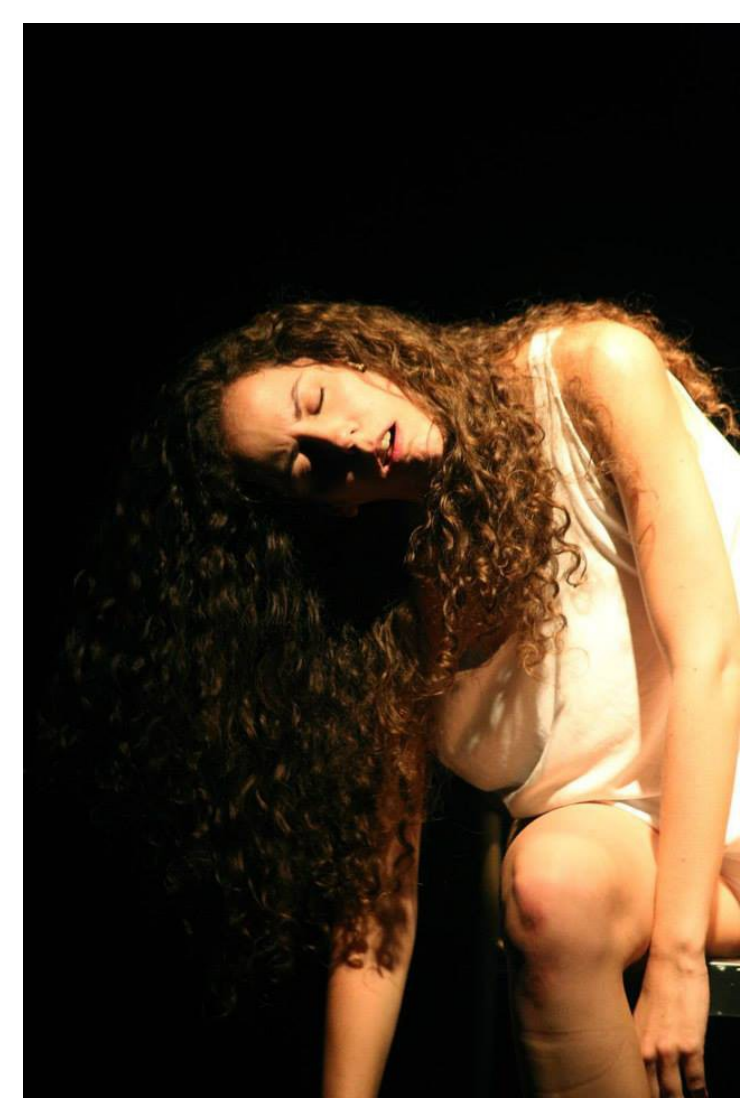

Fig. 188. The boat scene at the beginning of Purgatory

The Waiting in Ante-Purgatory

The performer draws a line and says in a somewhat pouting way the phrase "Vedi? Sola questa riga varcheresti doppo 'l sol partito". Originally, this phrase was an indication by one of the souls for 
Dante and Virgil that they cannot go any further during the night. In Incipit, it took on the meaning of the line she herself cannot pass. Salve Regina shows the boredom of Ante-Purgatory, while Te lucis ante illustrates in a comic way how the protagonist with a fake smile and quasi-innocent singing tries to convince God to let her in Purgatory Proper. When she does not get it her way, she sighs and her body drops into disappointment, while literally dropping herself on the chair. The phrase "Vedi là '1 nostro avversaro!" was originally planned to be said, accompanied by the sound of the wings of the two angels that fly down to chase it away. It did not add any substantial information to the scene and was not clear in its meaning, therefore it was suppressed.

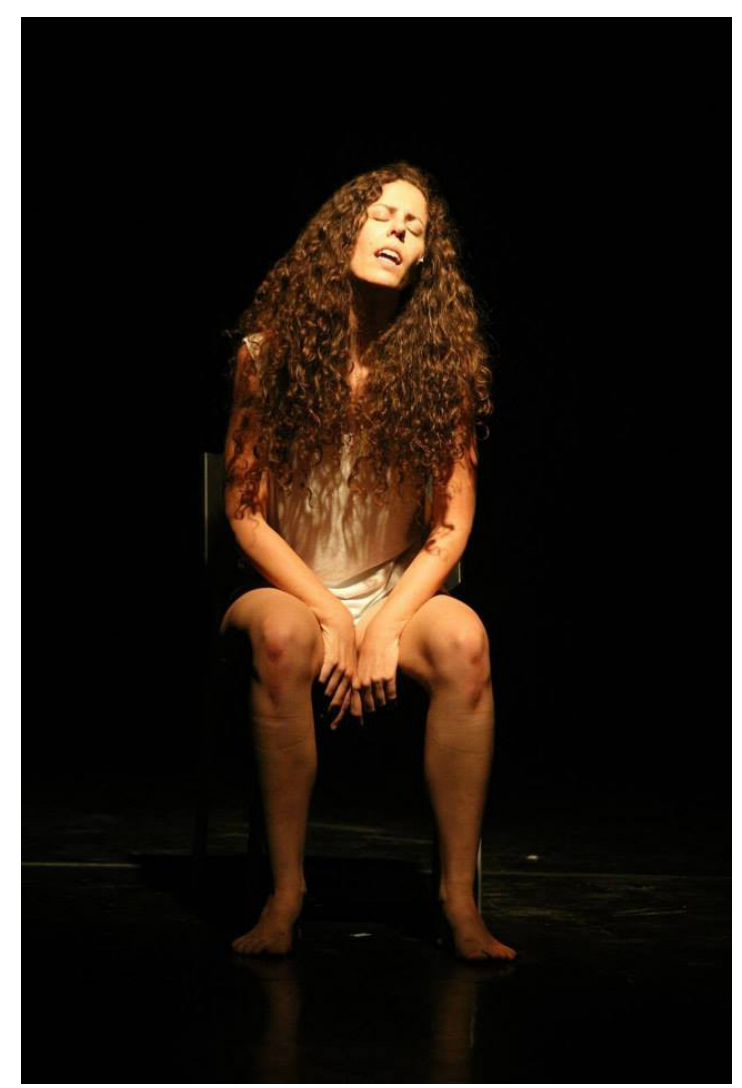

Fig. 189. Waiting and singing in Ante-

Purgatory

The folded-over position she takes was decided to use for all gates. Thus both movement and sound were clearly a repeated element, marking the different sections. At all the gates, except the first one, a dance-like closing arm movement was sought for, an opening up in order to close. In this movement, the figure of the crucifixion was included, thus referring to how Manuele Gragnolati reflected Dante's view of Purgatory: "To learn the radical love that is fundamental to the virtues of purgatory, the soul must experience the pain of the Crucifixion: by accepting it with patience and joy, and living it as a manifestation of love in the way Christ and Mary did, the soul becomes like Christ" (Gragnolati 2005, 134). The Crucifixion figure was already present in Inferno, but again citing Gragnolati: "While Infernal suffering is sterile because hell is the crystallisation of the evil 


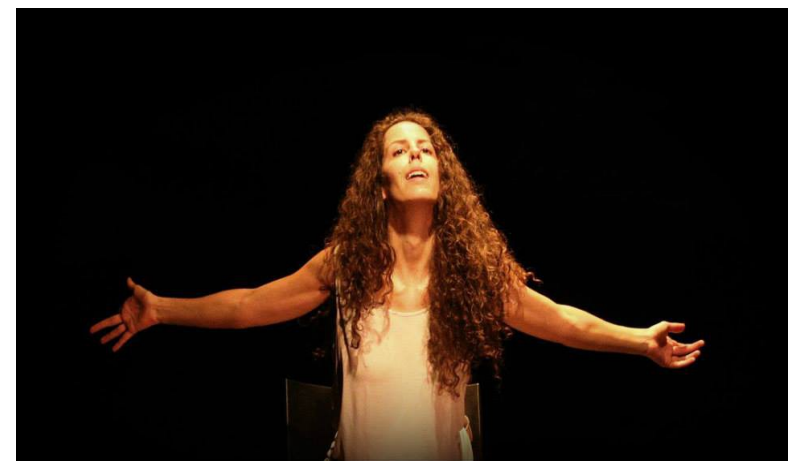

Fig. 190. The Crucifixion movement

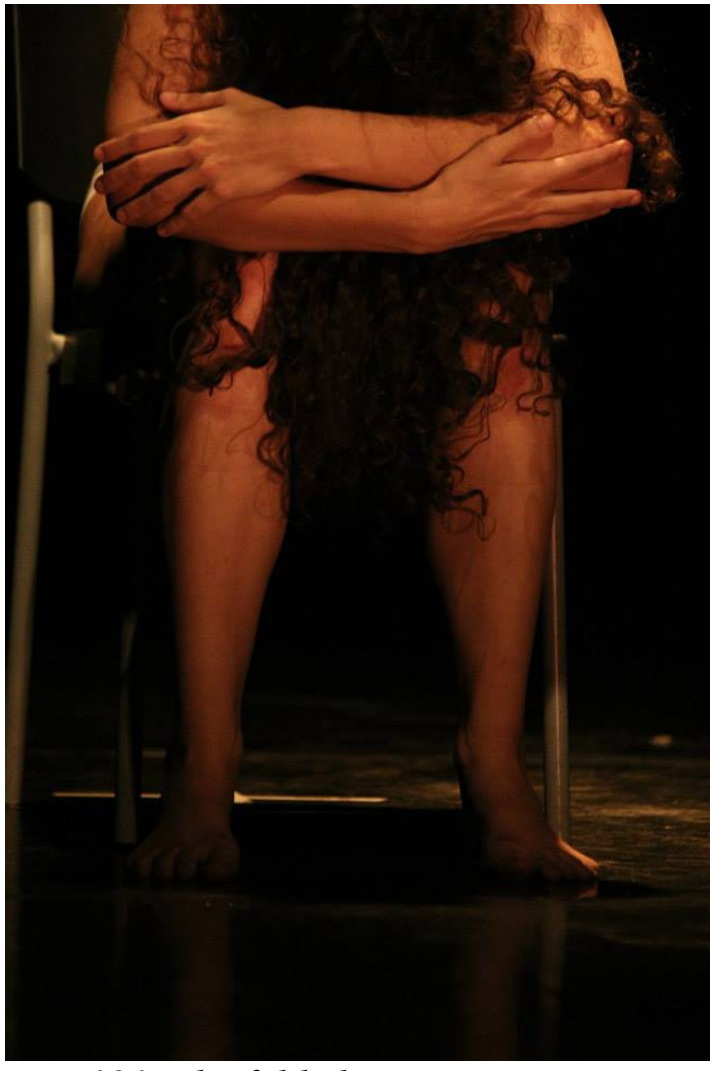

Fig. 191. The folded posture

love of sin and the place where good will is impossible, purgatorial pain is productive precisely because it is experienced through the right love" (Gragnolati 2005, 134). The Infernal Crucifixion is only a parody on the Crucifixion, just as the last Infernal words are ("Vexilla regis prodeunt Inferni", etc).

\section{Entrance Gate to Purgatory Proper}

When the body is folded over under the sound of the gate, for a moment there is a reminiscence of the beastly soul of Inferno. It is only when the performer removes her hair that it is certain that she is not infernal anymore. At the entrance gate this tension was explored most, due to the duration of the extremely slowly opened gate with the first phrase of the Te Deum sung above it. Not only was there a straightening up in slow-motion, also the hands were moved in a slow, controlled, eery way that for the performer was reminiscent of Inferno. The tension between the beastly and the humane expresses the view that the beastly side still remains, even though it is controlled. This is inspired by Dante's own view. Beatrice's words altra volta, udendo le serene, sie più forte ("the next time, that you hear the Siren's call, be stronger", Purgatory 31.44-45) show that even a purified person will always have to deal with his own darker side and be strong enough to overcome its temptation. 


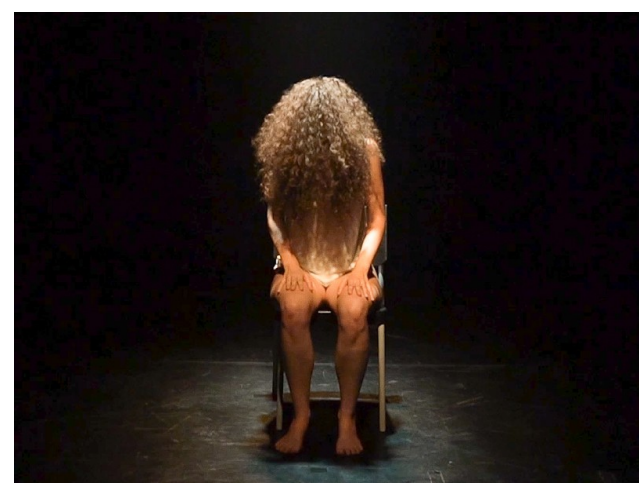

Fig. 192. The Beast Within

\section{The Beatitudes}

Although in Dante's text the Beatitudes are sung at the gate, mostly when Dante has already passed through, in the rehearsals of Incipit it was dramatically more logical to place the Beatitudes before the gate sounds. The Beatitude closes up a fulfilled penance, and the gate is the opening to a new level. Therefore, in the soundtrack the Beatitudes had to be placed before the gate sounds. The Crucifixion-like closing movement of the body had to be adapted to the length of each Beatitude, which were quite different in duration. This was also the reason why Gaudete et exultate was removed from the recording, originally paired with Beati misericordes at the gate between the envious and the wrathful: it turned out to be too long and repetitive for that scene because both chants have almost the same melody. If we take into account that Gaudete was sung specifically for Dante, it means no substantial loss to suppress this chant.

\section{The Sinners}

For each type of sinner, its characteristics and expression were explored. The proud character, interpreted as someone who finds herself fantastic while laughing about "those poor" in the audience, bored to be with such people. When she has to load the chair on her back, symbolizing the rock of Dante's Purgatory, she first arranges her hair. The envious, a nervous childish creature inspired in the comic figure Mr. Bean. 


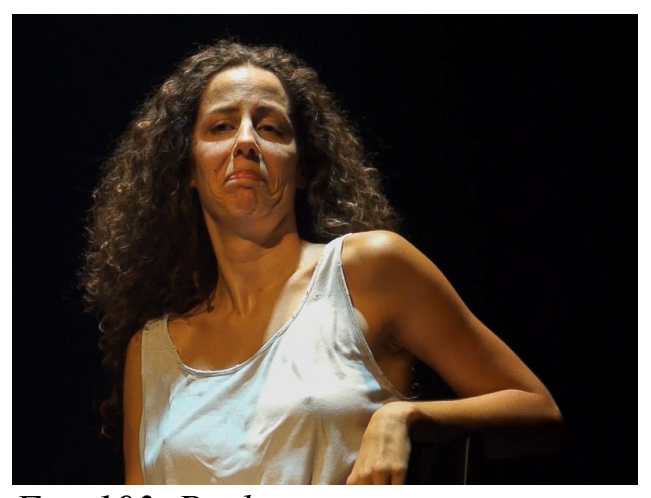

Fig. 193. Pride

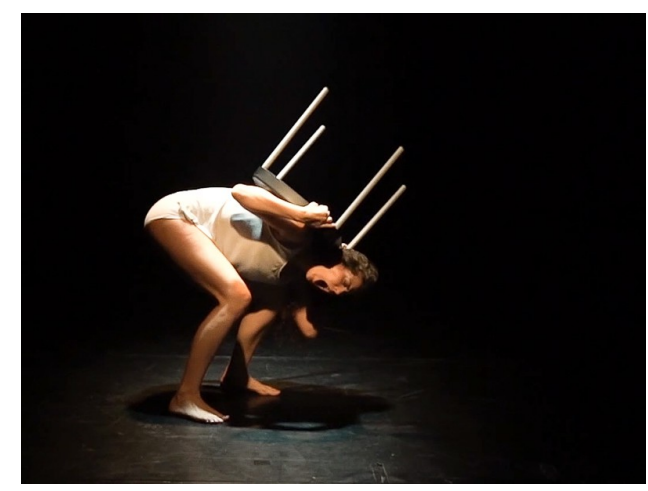

Fig. 194. Doing her penance

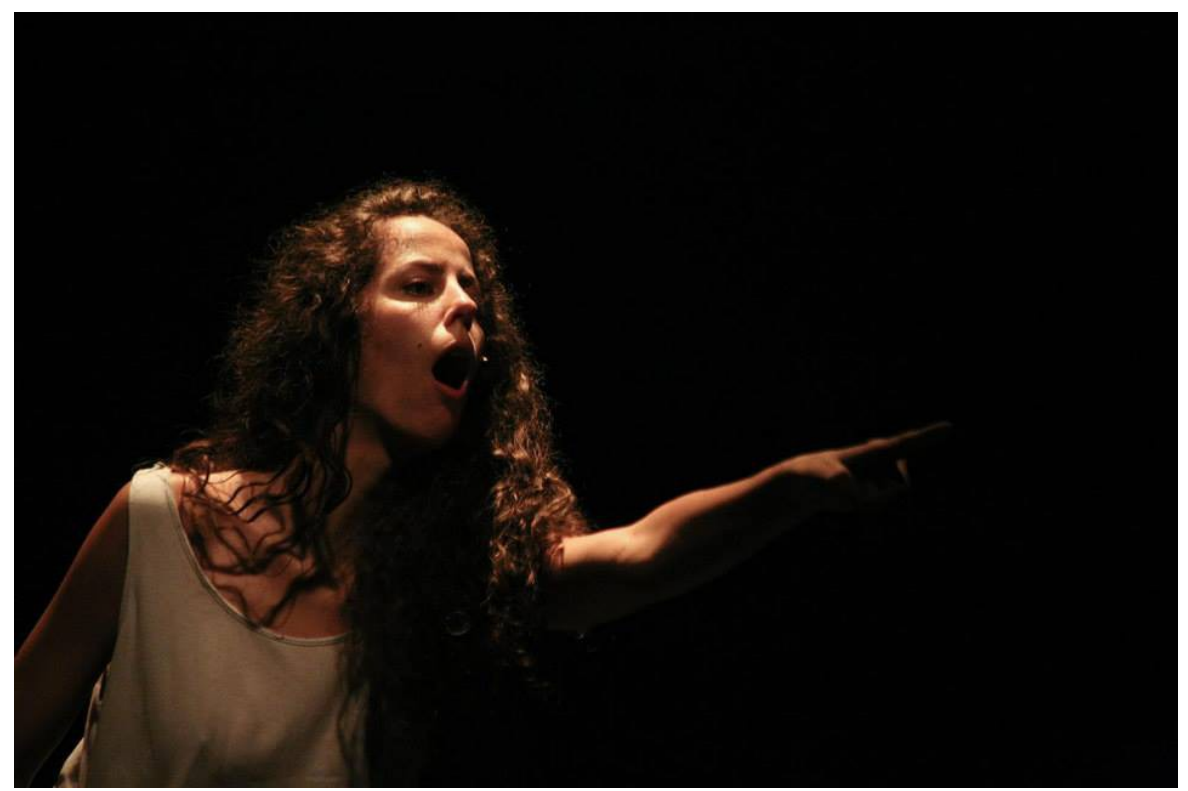

Fig. 195. Envy

The wrathful character, with a forwarded jaw and an attitude of being ready to fight, was inspired by professional boxers, the protagonist of the film Taxi Driver (1976) $)^{464}$, and a bulldog. This character was physically expressed with clenched fists, open legs and arms, heightened shoulders, frowning with wide open eyes and some menacing wiggling. When this figure sings Agnus Dei, the jaw is kept forward but the eyes show complete submission to God. 


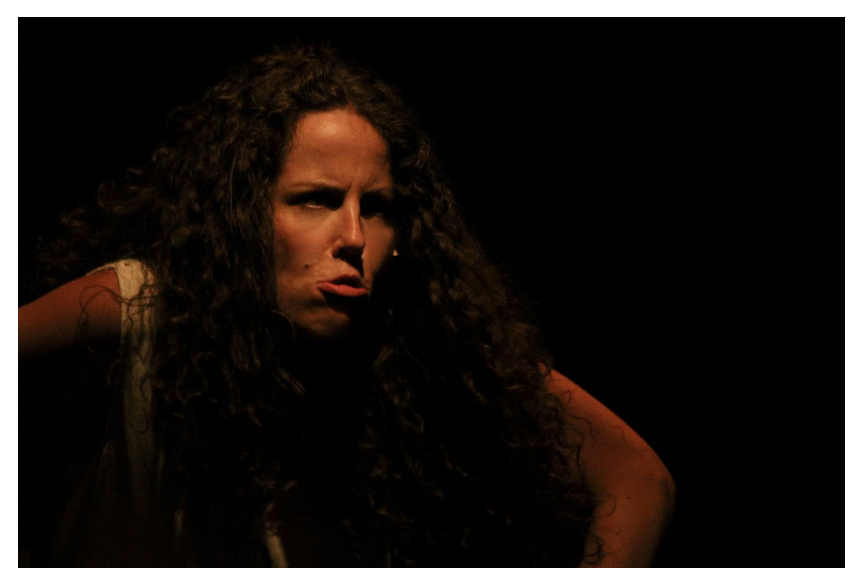

Fig. 196. Wrath

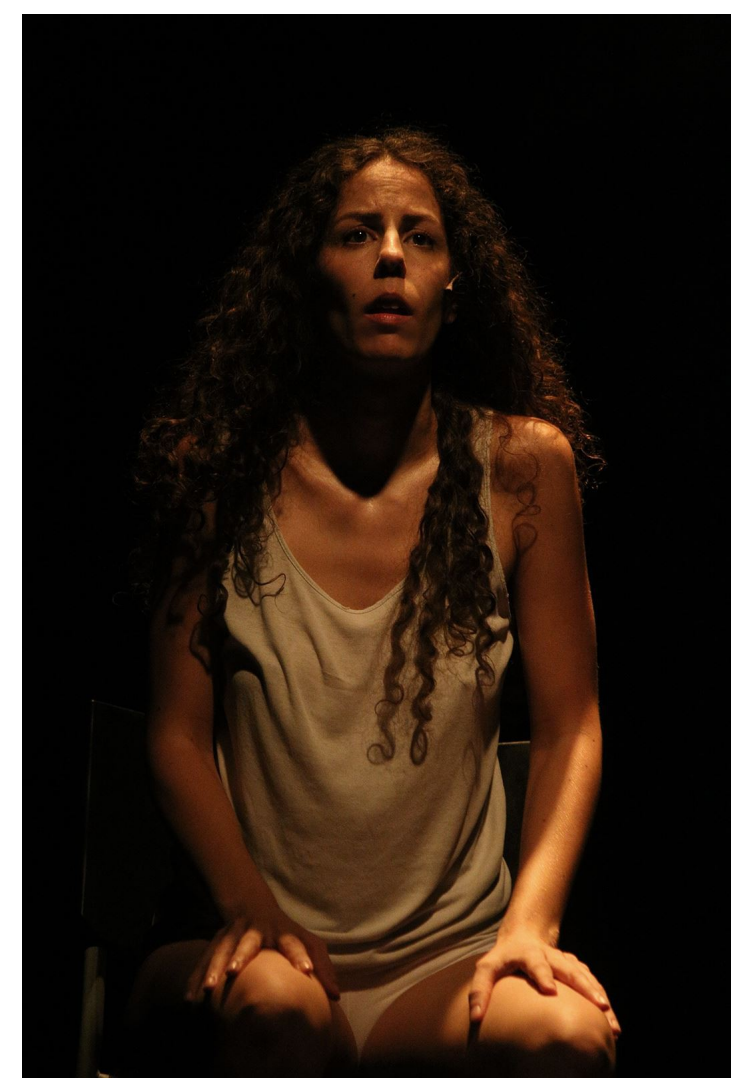

Fig. 197. Submission to God

The slothful soul is laziness and sleepiness itself. The running with the bow legs accentuates the lack of physical exercise this character has. The avaricious character was based on a mixture of Scrooge (Dickens: A Christmas Carol) and Gollum (Tolkien: The Hobbit and The Lord of the Rings $)^{465}$. Physically, there was an accentuation of crooked legs and a withdrawn neck between high shoulders.

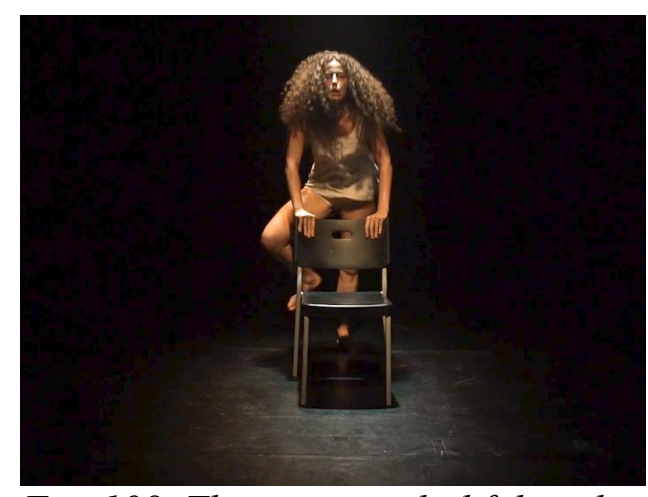

Fig. 198. The running slothful soul

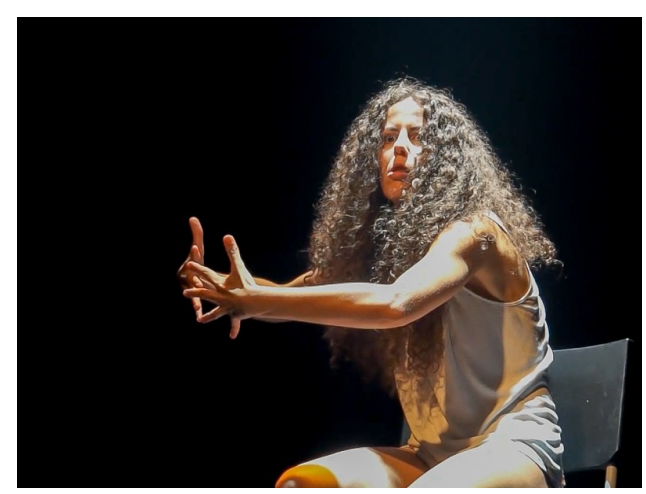

Fig. 199. The avaricious soul 
The glutton was interpreted as a jolly epicurean who converts into a pig-like glutton. Her whining childlike reaction to the water falling on the trees is based on Dante's words: "Beneath the tree I saw people lift their hands and cry I know not what up toward the leaves, like foolish and obstreperous small children" $"$.

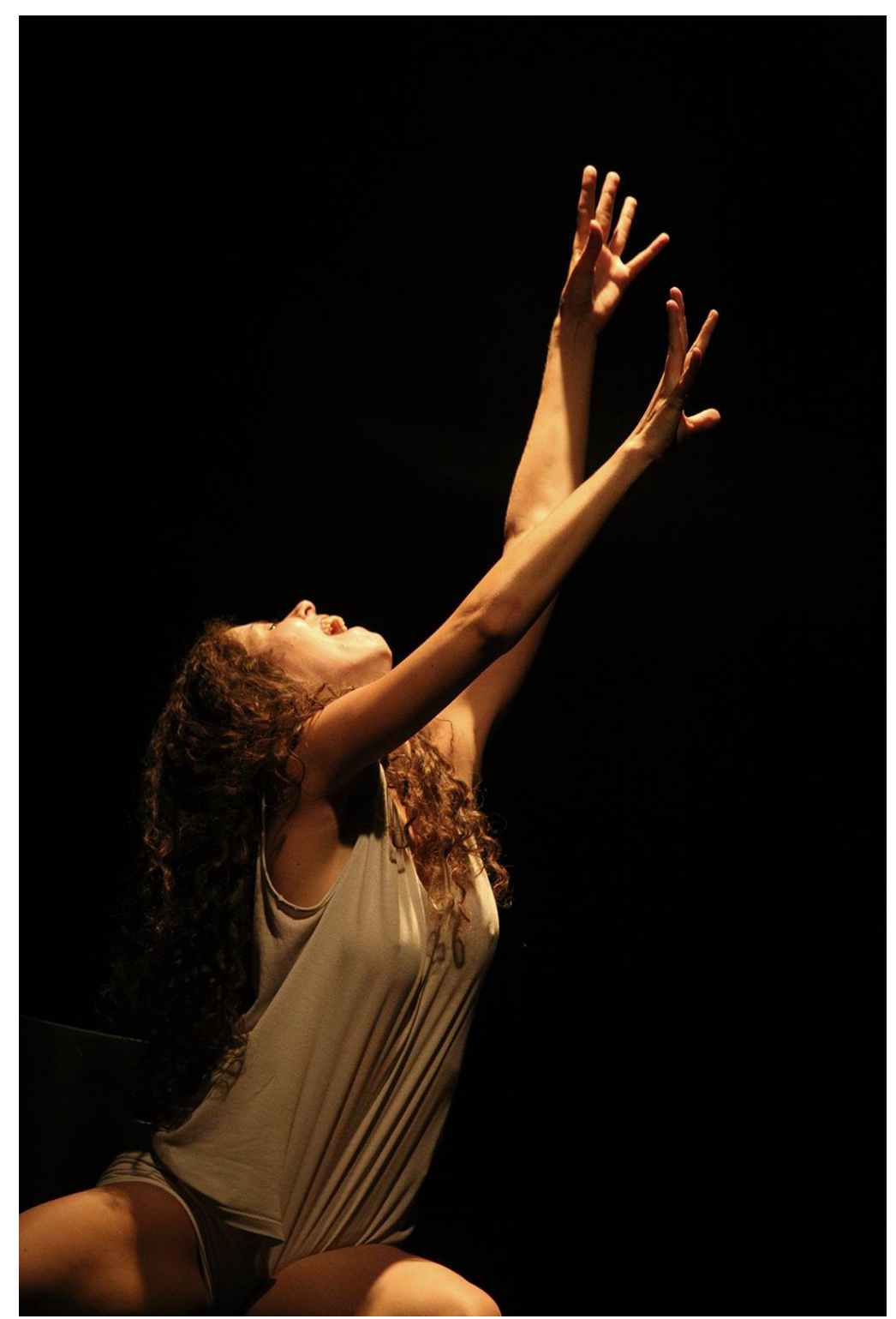

Fig. 200. Gluttony

Finally, the lustful character is, according to the performer's reading of the Commedia, a (too) loving character with a joyful aspect to it. The third verse of Summae Deus clementiae suggests a re-direction of the excessive love to God: 


\begin{tabular}{|c|c|}
\hline Lumbos adure congruis & Set our loins on fire \\
\hline tu caritatis ignibus, & with the proper flames of your love \\
\hline accincti ut adsint perpetim & so that they may girt up at all time \\
\hline tuisque prompti adventibus & and ready for your coming \\
\hline
\end{tabular}

This has been interpreted by the performer as "falling in love with God". She interprets this verse as sexuality directed towards God. Therefore, although in all the other characters there is expression of an inner fight between the sin and the wish to become better, which gives a tension in the sung parts, for the lustful character it is in reality a transformation of her bodily lust into the pleasure of saving her body for God.

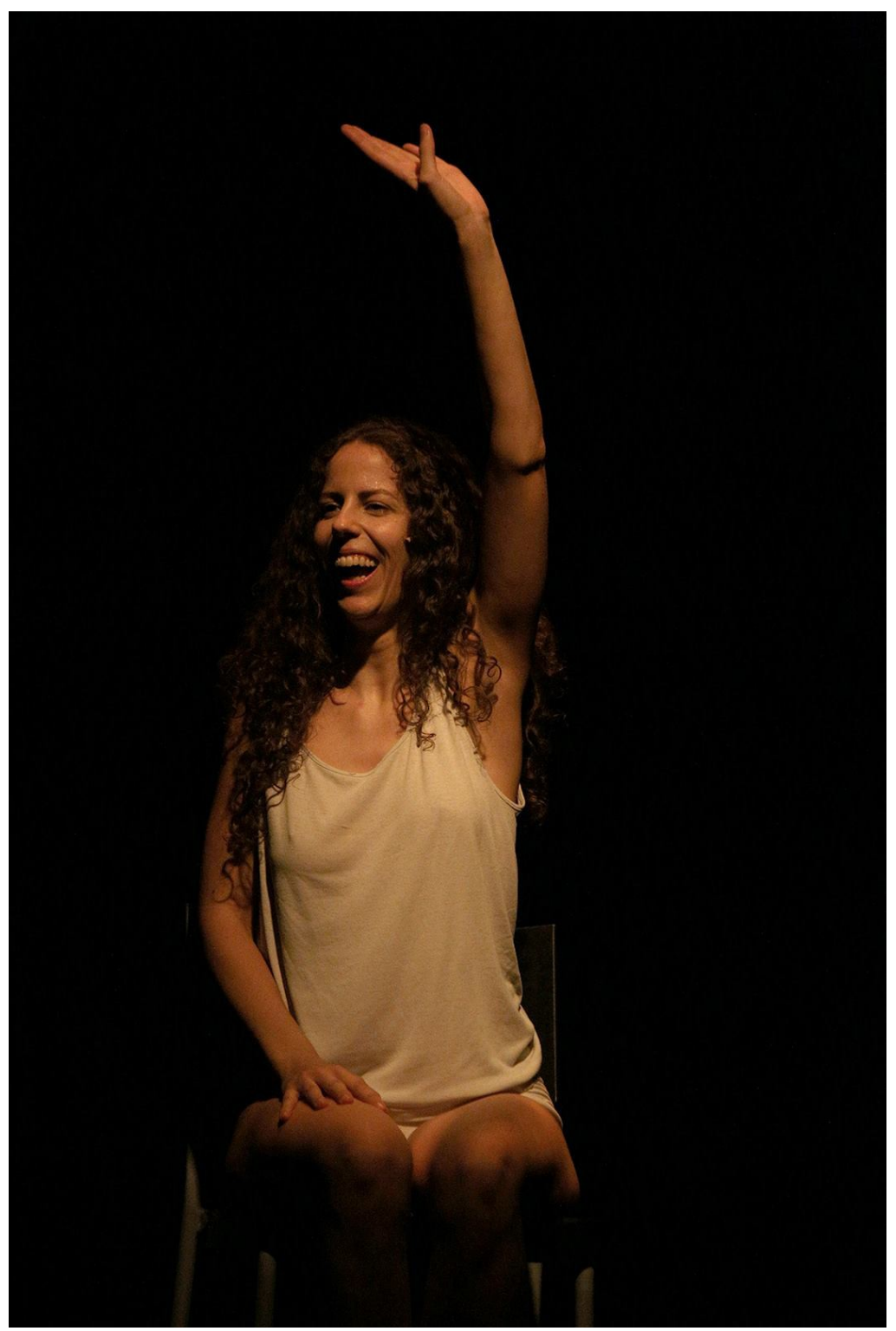

Fig. 201. The end of lust 
In the scene of the slothful, despite having been recorded, all three texts selected for Incipit were said live by the performer herself. The scene of the avaricious, in Dante's Commedia with souls lying on the ground pressing their mouths against it, was translated into pressing the face against the chair. The Gloria that interrupts this scene was given a military character, like singing the national hymn, being God the king of Purgatory.

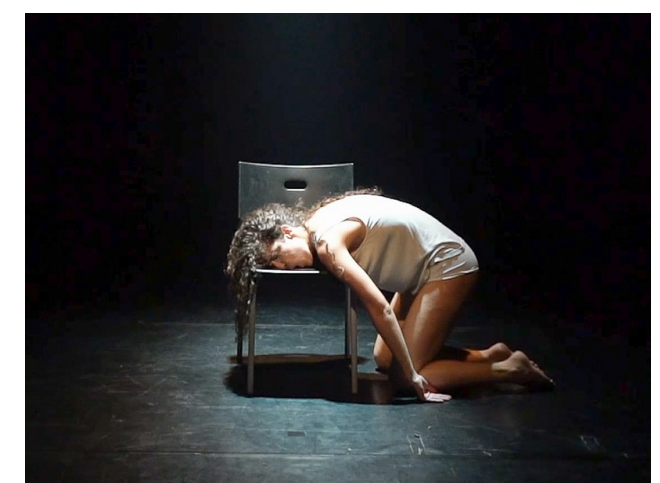

Fig. 202. Penance of the avaricious

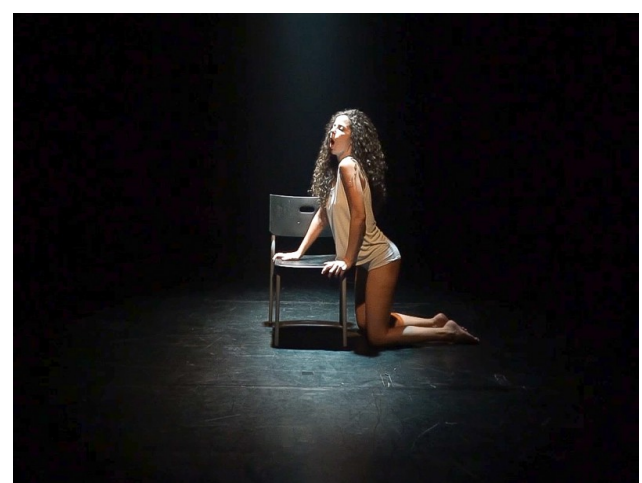

Fig. 203. Gloria in Excelsis Deo

\section{Earthly Paradise}

The scene of the wall of fire takes the performer definitively off her chair. She "walks" on the same spot, just as all other "walking" scenes (carrying the chair, running behind the chair) were on the same spot, in order to reduce the scene surface in this minimal concept.

Of Matelda's two songs, Bonum est confiteri was eliminated from the recording in order to be sung live by the performer, but only from the words on that Dante mentions: "quia delectasti". Since this is the second half of the song, the performer sings it in a way as it was a continuation of something she was already singing in her head. Matelda is the representation of human innocence, thus it was decided to sing it in a very playful and young manner. Beati quorum tecta sunt peccata was left in the recording, non-reverberant and loud as if she were directly next to the performer. The performer reacts to this and shrugs and smiles innocently to the audience once the shock is over. It is all an expression of innocence. The decision to leave only the last phrase on the recording, took away some of the performer's control over the timing and forced her to sing a quite rapidly sung quia delectasti, in order to be able to leave a short silence in the middle with her voice breaking this silence. 


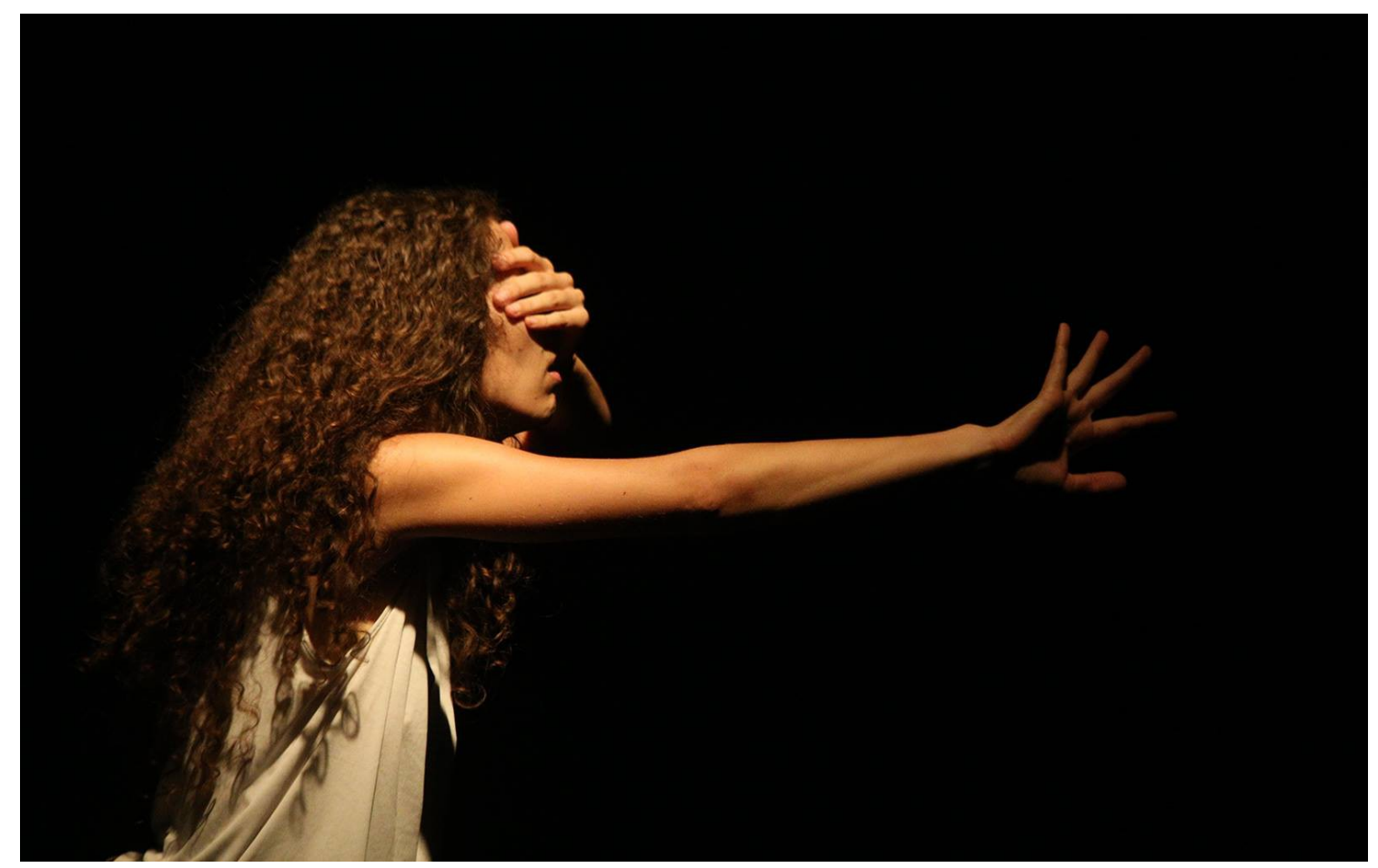

Fig. 204. The crossing of the fire

\section{The Washing}

The scene in the Terrestrial Paradise for Hosanna and Asperges me was to be of a ritualistic aesthetics, leading to the washing scene in order to be purified for the immaterial Paradise. The opening movement of the gates was repeated, but this time in a more conscious and glorified manner. The hands, that once were evil beasts in Inferno, are now illuminated hands by Divinity. The overhead lighting helped in reinforcing this concept, being able to "bath" the hands in the light. The "Crufixion" movement is now upright and does not return to a curled up posture, but to an upward posture. The movement was musically constructed: at the word "Rex" the hands were lowered again. During the last words of Hosanna, the hands and arms were washed, but only accompanied by Asperges me, the face and head was washed, directing the face up to the light as if it were washed with light. The last movement downward, when Asperges me is finished, is a meditative state of peace. 


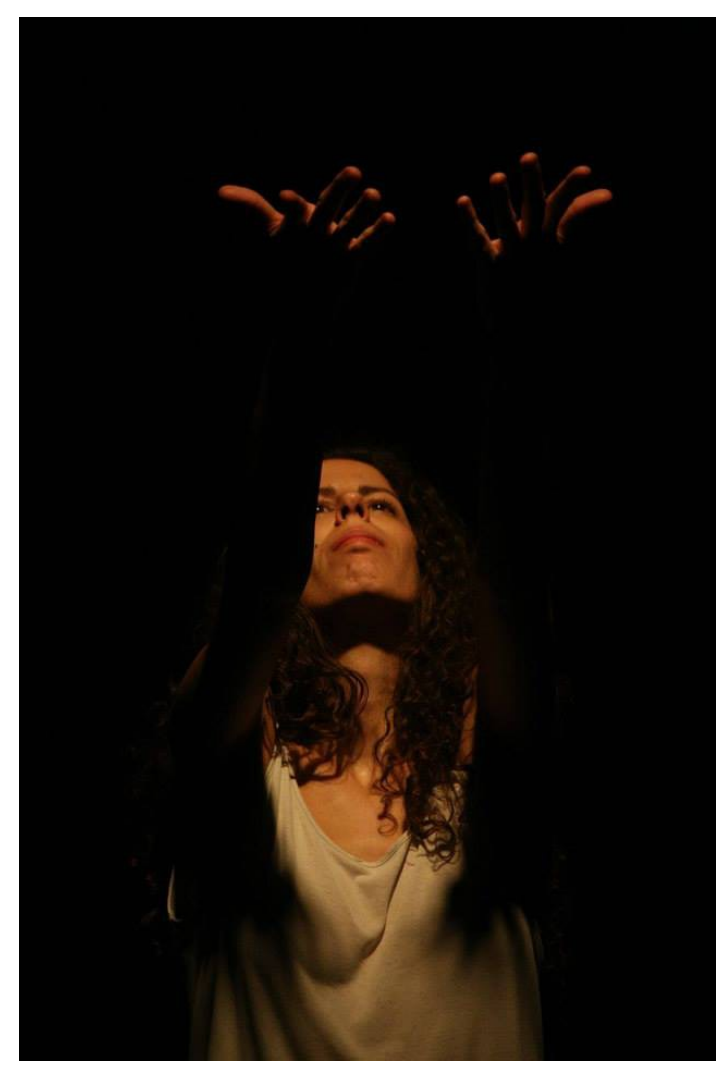

Fig. 205. Hosanna

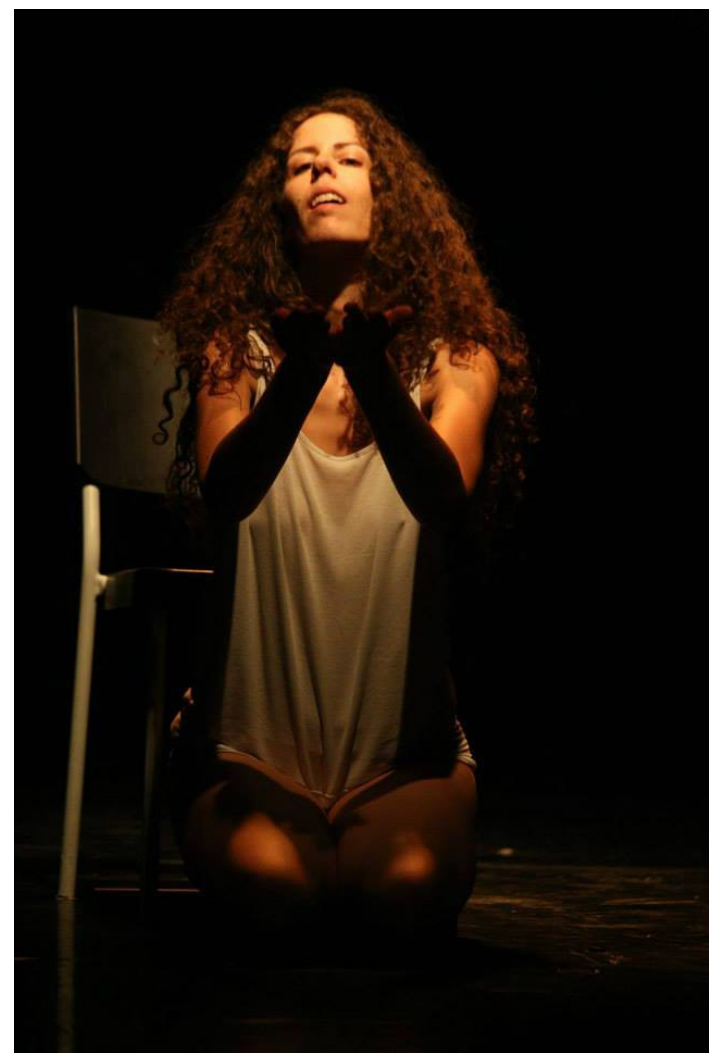

Fig. 206. Asperges me

\section{Paradise}

Paradise in Incipit is focussed around the chants. It is the realm of a dream-like tension between physicality and immateriality, which was to be expressed through the body's interaction with the lighting. Black cloths had to conceal the body except for the hands and head, and the black long dance-skirt made of spandex would expand in turns, which made it an interesting choice for the faster turns along the edge of the light in between Gloria and Victimae. The clothing reinforced the tension between presence and absence, reality and fiction. For Paradise, a narrow collaboration between the light designer and the author was necessary in order to obtain a common design of light and movement. A basic storyboard was drawn before the brainstorming session with the light designer (see Annex 4). He adapted some of these ideas, such as the scene for Victimae, where the light would not be in front of the performer but behind her, so that she would begin the chant covering the light. He also added a light pattern for Te Deum, using a gobo, a template slotted inside the overhead spotlight. In the rehearsals with all the lights, the choreography was tested and the design was refined in its last details. 
Three texts were projected between Purgatory and Paradise (last line of Purgatory, first lines of Paradise):

\begin{tabular}{|l|l|}
\hline puro e disposto a salire a le stelle. & pure and prepared to leap up to the stars. \\
PARADISO & PARADISE \\
$\begin{array}{l}\text { La gloria di colui che tutto move } \\
\text { per l'universo penetra, e risplende } \\
\text { in una parte più e meno altrove. }\end{array}$ & $\begin{array}{l}\text { The glory of Him who sets all things in motion } \\
\text { cleaves through the universe, and it flames again } \\
\text { in different places with a different force. }\end{array}$ \\
\hline
\end{tabular}

At the end the last phrase of the Commedia was projected:

l'amor che move il sole e l'altre stelle. the Love that moves the sun and the other stars.

In the rehearsals it was noted that spoken phrases broke the surrealistic aesthetics and they were thus suppressed, so that Paradise only consists of music. The obstacle for designing this part of Incipit was the fact that the lighting could only be imagined until the spotlights were set up. The rehearsals until that moment did not show the part of the lighting, making it difficult to work with material that was not actually seen. The choreographic movements were a challenge for the singing of the chants, both in coordination and in precision of placement. Some of the chants were repeated because they were just a bit short to be fully enjoyed. These chants are the Gloria, Gloria Patri and Hosanna.

Ave Maria

The Ave Maria is sung in the dark, accompanied by the sounds of laughter and a strange sound of revolving planets. The fact that the performer is not there physically and the audience is in the dark, sets the tone for the rest of Paradise. The "bell" sounds were accompanied by the performer entering the stage from behind, still in the dark, scarcely visible because there is only a small screen of light in the front. 


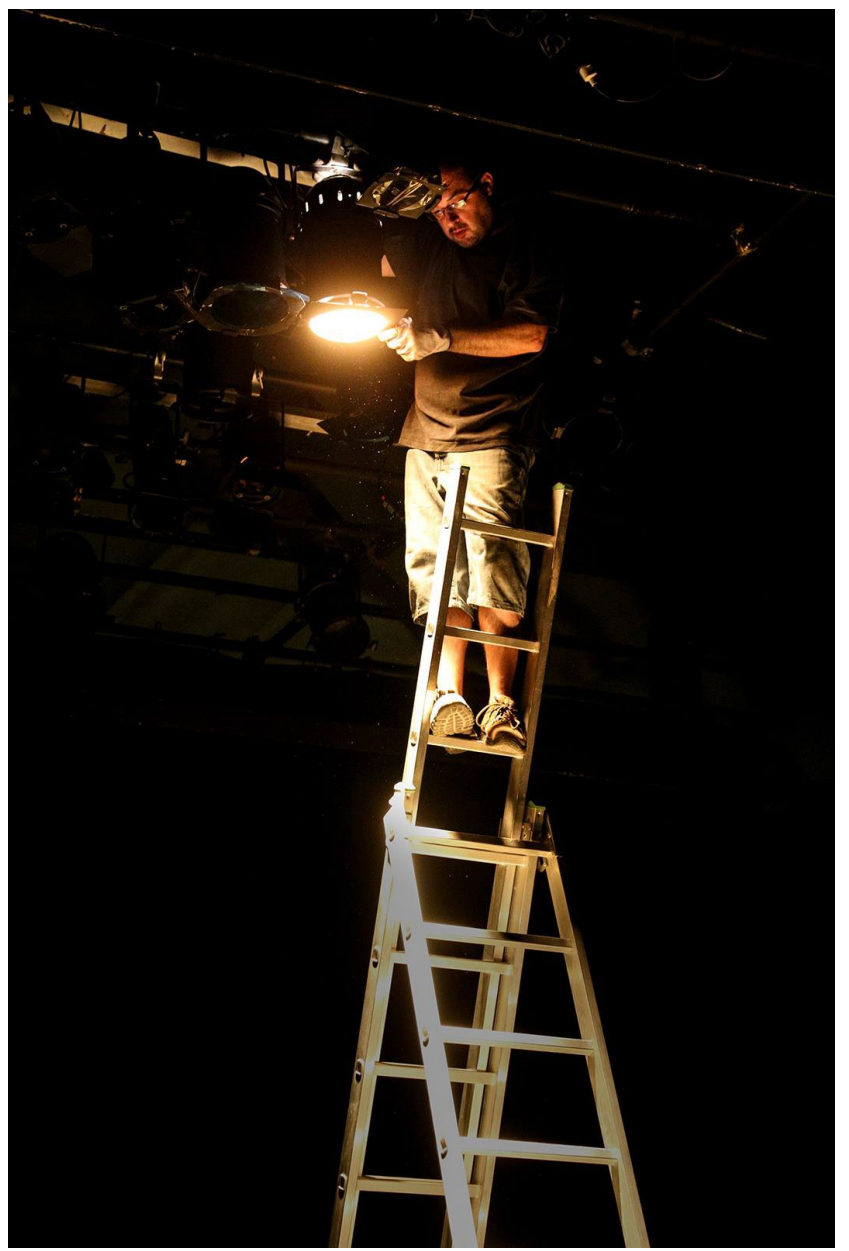

Fig. 207. Setting up the lights

\section{Sanctus}

The concept was to work with parts of the body: hands in the Sanctus, face in the Alleluia, lower body in the Sperent in te (the latter was finally not sung upright but squatted). In the Gloria, Victimae and Gloria Patri there was a relation between the shadow and the bodily form, the first two by means of obscuring the face and only showing the corporal shape. The Te Deum and the final Hosanna show the entire body. While Te Deum does this with a light-shadow labyrinth-like pattern inserted in the spotlight (the gobo), the Hosanna shines a brightly light on and around the body.

One of the inspiration sources for Paradise has been a music box without adornments, used to let children fall asleep. For the author it has associations with innocence, comfort, safety, but also silence, darkness, the stars in the sky and the imaginary space the nights provide, when the world is 
asleep. This is reflected most clearly in the "bell" sounds of the beginning ${ }^{467}$, the spinning figure at the border of the light between Gloria and Victimae, and the slowly turning figure in the light of the Te Deum. Circles are essential in Dante's Paradise and have been translated into circular movement and circular spots. The aesthetic movements of the hands in the light of Sanctus connects the end of Purgatory with Paradise. This time the hands represent innocence, illuminated by the light of God. The movement itself, following the timing of the chant, was inspired by hand movements of Tai Chi Chen. ${ }^{468}$ The rest of the body and the face stay out of the light.

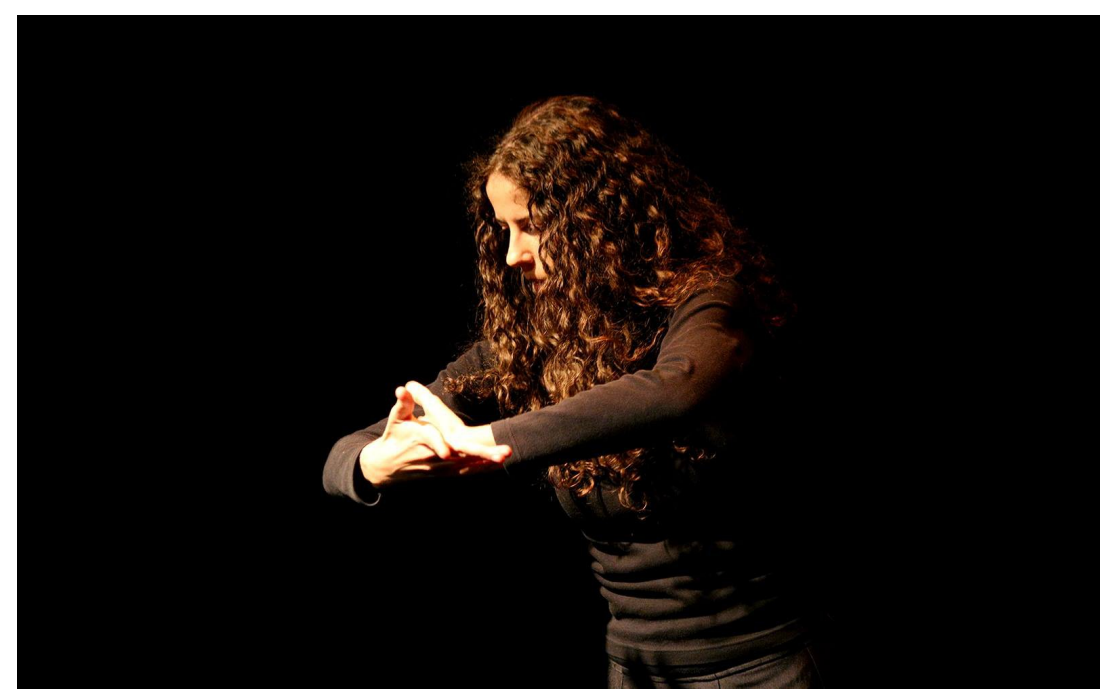

Fig. 208. Rehearsal of the hand movements for Sanctus

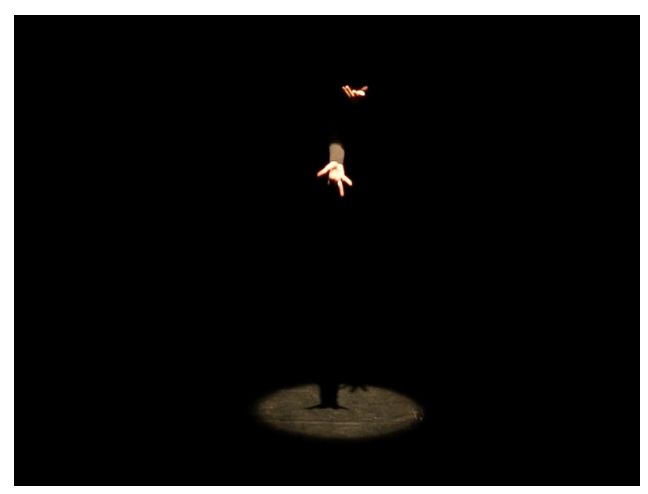

Fig. 209. Sanctus

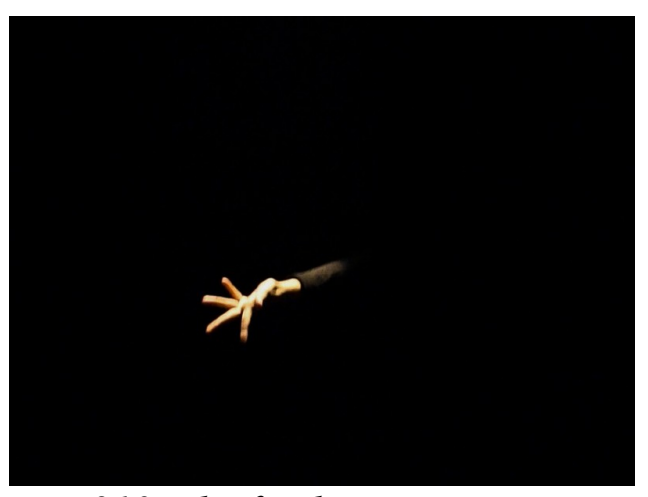

Fig. 210. The final gesture 


\section{Gloria}

The Gloria only illuminates the contour of the performer's body, leaving her frontal side in the dark, thus still not showing her face. The sound of the clock connecting the Gloria with Victimae is accompanied by spinning around the border of the spotlight. In this way, the dancing skirt is seen but the body is in the shadow, causing a sensation of someone being both present and not completely at the same time.

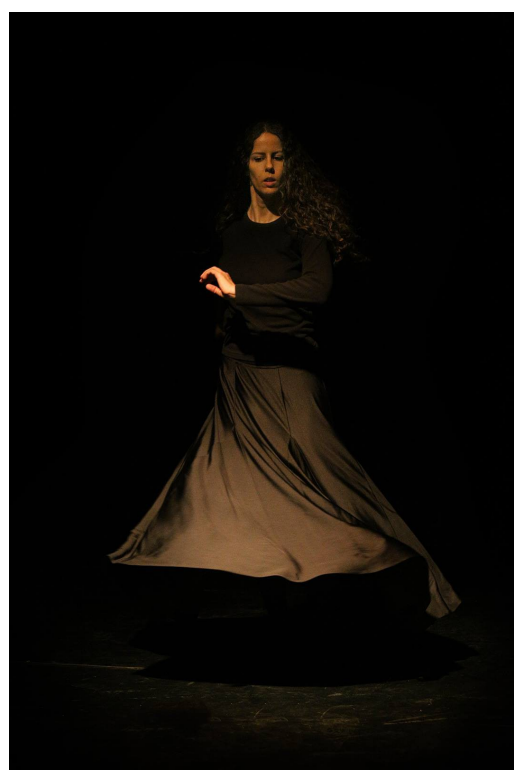

Fig. 211. Rehearsal of the circular spinning movement

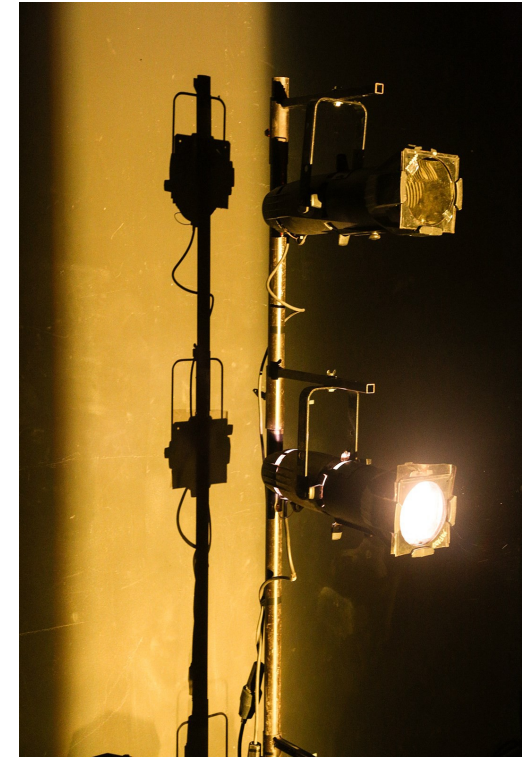

Fig. 212. The type of lights used for the diagonal light of Victimae and side light for Gloria and Gloria Patri

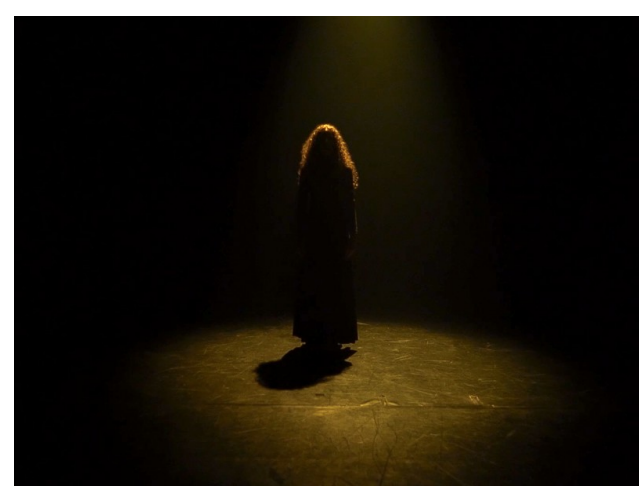

Fig. 213. Gloria 


\section{Victimae Paschali Laudes}

The scene of Victimae was first imagined as being lighted diagonally from in front, converting the performer's body into a line. Victimae is the chant of Mars, where the warriors move in the form of two crossed lines. In the performer's conversations with the light designer José Martín Márquez, it was soon clear that it would be impossible, with the equipment of the specific theatre, to make a perfect contrast between light and dark so that the imagined effect would not be possible to obtain. Therefore, the light designer proposed to situate the light on the other side of this imaginary diagonal line. In this way, her shadow would be in front of her. The performer thus ended her double circle in front of the light, so that when it turned on, her body blocked almost all its light. As she advanced, the shadow in front of her shrank from a monstrous size to her own size on the wall. This symbolized the contents of the music about the fight between Christ and death with the deceased Christ being alive.

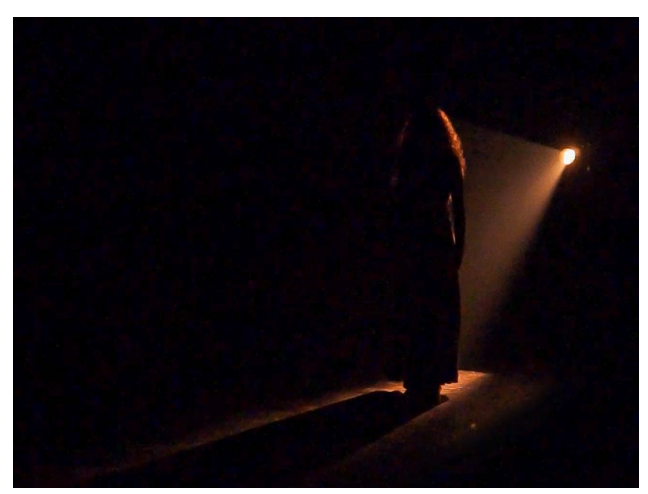

Fig. 214. Victimae Paschali Laudes

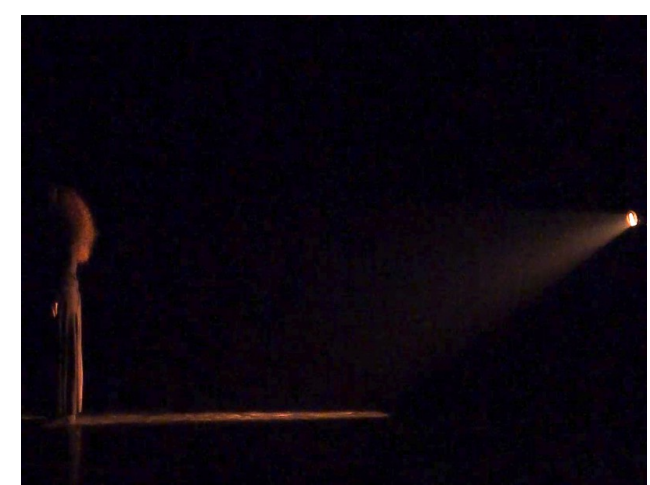

Fig. 215. The backlighting

\section{Alleluia $x$}

For the introduction to Alleluia x, consisting of 4 loose fragments, she turned out of the light and stopped at each break. Each fragment gave way to a turning dance movement in the dark; each silence gave way to immovability. Although it was not not in the light, for the audience it was still discernible. In this way she found a way to cross the stage according to the concept of circles and be in the centre, ready for the Alleluia. This chant is the first chant that focusses on the performer's face, the human expression of Divinity. The light derived from two sides in order to form a narrow light zone toward the front of the stage. The performer played with entering the light and moving out of it, not only by going backwards but also by stepping in front of it. It is this gentle movement behind, in and in front of the light which again plays with presence and absence. 


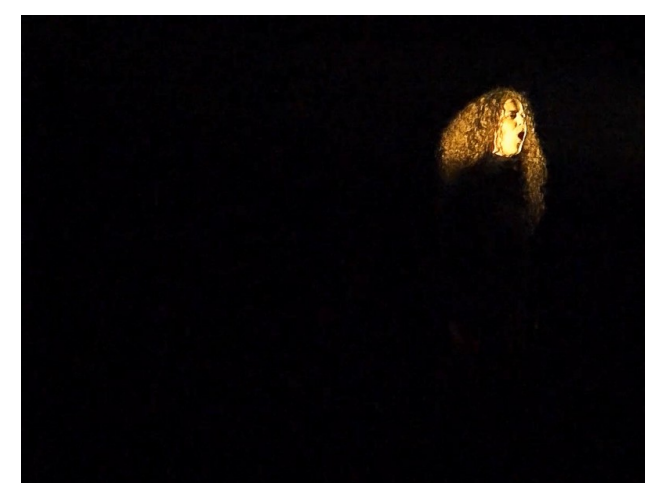

Fig. 216. Alleluia $x$

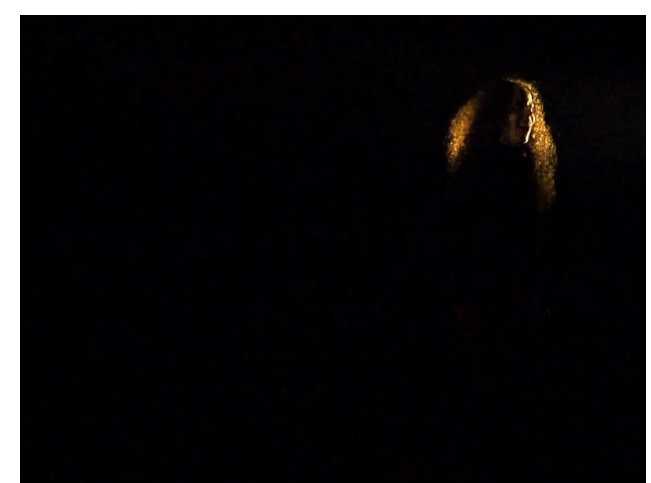

Fig. 217. Moving out of the light

\section{Te Deum}

After this scene originally there was silence included in the recording, which symbolizes the silence in Saturn, but a moment of silence would not have been comprehensible to an audience that does not know the Commedia well. Only the low-frequency trembling and the paulstretched sound of the gate were maintained, during which the performer stepped back to the centre and began to spin slowly. She experimented with the movement of the arms: at first it was a simpler, repetitive movement but then she inserted more movements. These are almost all classical ballet positions. In the rehearsals with the shadow pattern on the ground she began to experiment with a spiralled movement on the surface of the spot, still spinning round slowly, until reaching the diagonal front edge of the pattern, where her next position was.

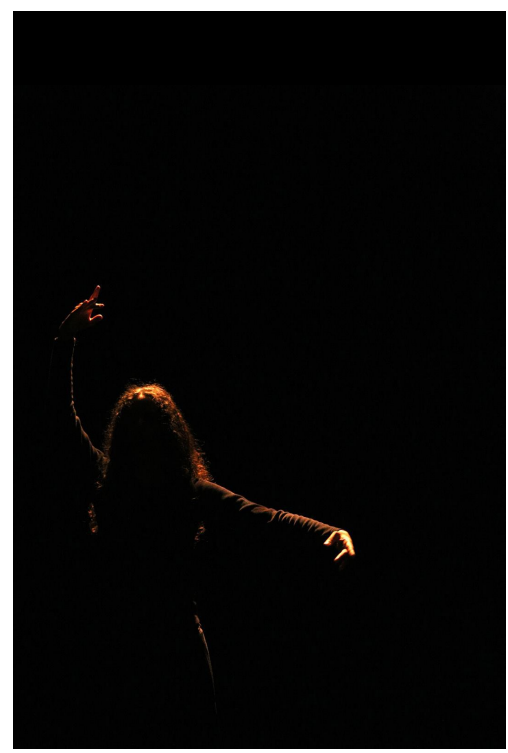

Fig. 218. Rehearsing arm movements for Te Deum

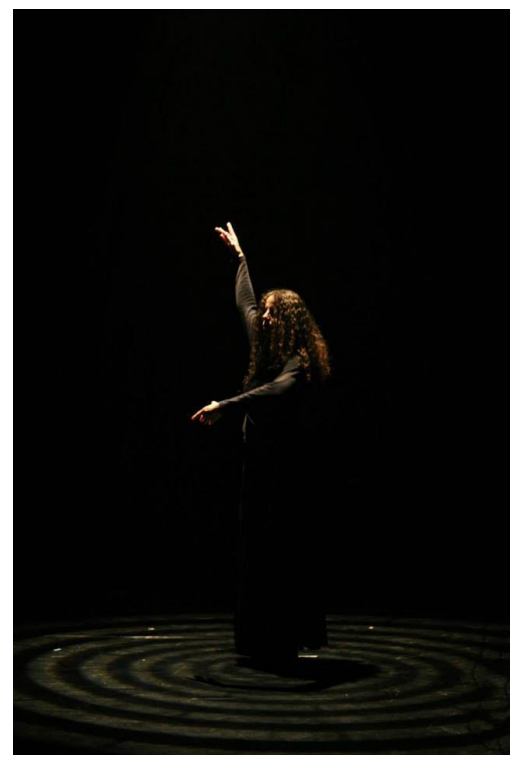

Fig. 219. Rehearsing arm movements

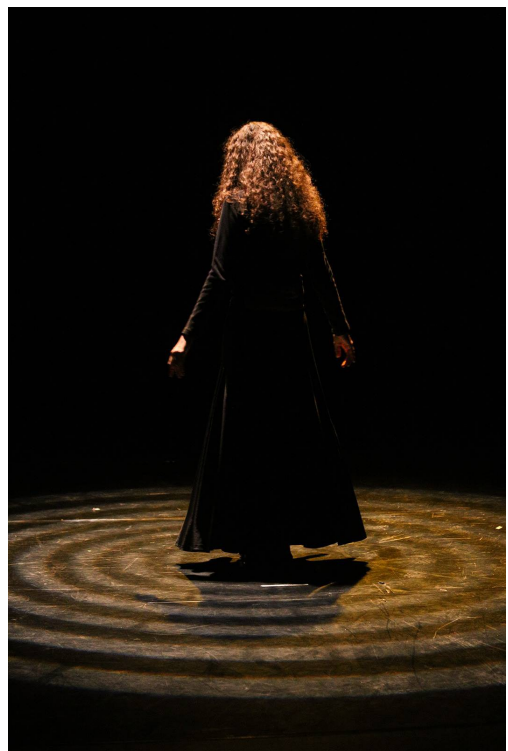

Fig. 220. Rehearsal with the shadow pattern on the floor 
A low light from the side was chosen for the next position, where she would sing Sperent in te, meaning "Let them have hope in Thee". The lowest voice was sung by the performer, and instead of staying up, she decided to come down, sitting on one knee so that getting up could be done in one fluent movement. It is about the terrestrial being so it is not only sung low, the physical position is also low. When she finishes singing, in one line she gets up.

\section{Gloria Patri}

Gloria Patri was sung in the middle. When the rehearsals started, it was considered to end the Paradise in darkness, letting the body disappear from the spotlight. In this case, Gloria Patri would have been sung in bright light and Hosanna would have been sung with a narrow curtain of light from which the performer would finally disappear singing. However, Dante's Paradise is pure light at the end and is the climax of his experience, therefore it was decided to end up in a climax of light. In order to come back to the centre of the stage, the performer walked softly backwards and sidewards in the dark continuing facing the audience, discernible to the audience as a geometricaesthetic movement in the dark. The Gloria Patri was the same type of movement as the Alleluia, but this time the whole body was lightened and the performer did not step in front of the light anymore. She slowly came forward to the light singing the entire Gloria Patri and then slowly stepped backwards into the dark while repeating the chant.

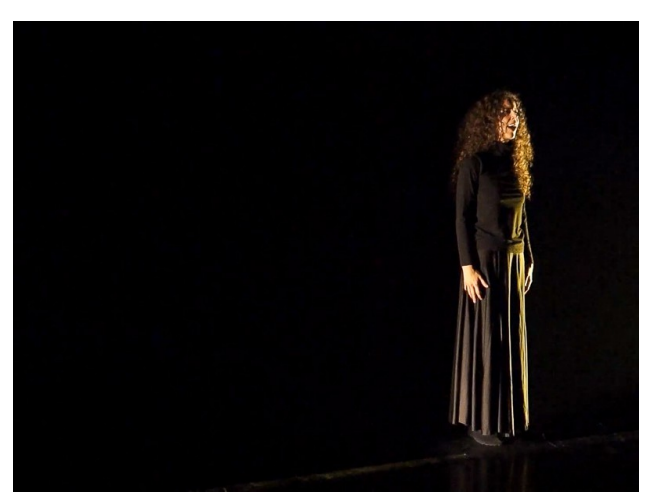

Fig. 221 Gloria Patri et Filio

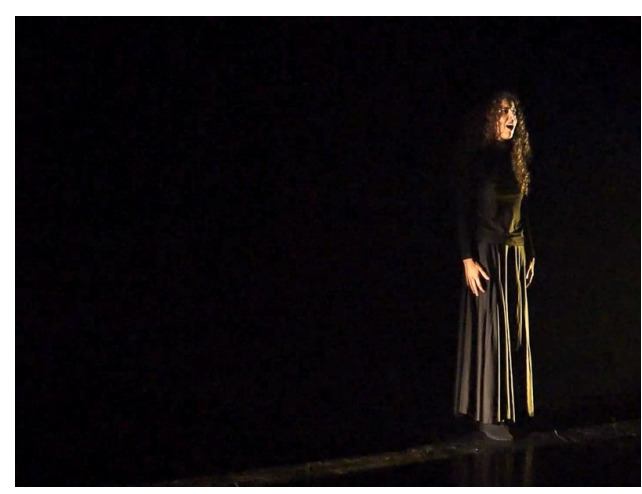

Fig. 222. Leaving slowly the beam 


\section{Hosanna}

The next location was close behind the curtain of light. This was originally marked but when all the white-coloured markers were covered by black tape, this marker was not discernible in the dark anymore, which included an extra risk of not being exactly in the white centric spot. The last Hosanna was sung in bright light and with the most energy of all the chants.

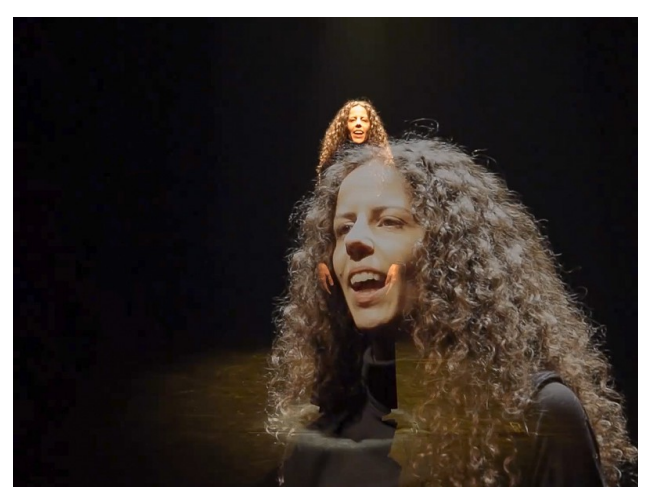

Fig. 223. Hosanna 


\section{CONCLUSION}

The subject of this thesis has been centred around practice-based research stemming from theoretical knowledge. Conclusions about investigation through artistic research will not only consider measurable parameters but also the contextualization of those parameters in an organic process, partly based on personal findings. The artistic process has an inherent subjectivity which leads to a unique outcome, but it also contains elements with a more general value. Before we discuss the creative process of this thesis, we will first refer back to the research question. It was based upon the combination of two different artistic disciplines in which the author of this thesis has been professionally trained, and led to the following question:

How do the work methods taken from Historically Informed Performance practice contribute to the creation of a contemporary music theatre performance in a mise-en-scene of the Divina Commedia?

This question not only implies the fields of Early Music and Experimental Music Theatre, but also of Literature Studies. The Commedia of Dante Alighieri (1265-1321) is a highly complex historical literary work, only fully comprehensible through ample study of specialized bibliography on Dante and his Commedia. Even though its mise-en-scene was primarily based on the Commedia's sonorous references, knowledge of its contents and underlying philosophical ideas was necessary in order to make the artistic decisions for our music theatre work Incipit, which formed the artistic framework for our research on the combination of Historically Informed Performance practice and contemporary Music Theatre. Historically Informed Performance practice has a specific methodology consisting of examining the historical musical sources and other documents or objects informing about the context and historical performance of the music. Instead of implying a more intuitive or traditionalist musical approach to the performance of the music, it is about knowing as much as possible about the historical perspective of the music and basing our musical decisions upon this knowledge. We will never know how it sounded or how Dante imagined the musical pieces he wrote about, but we can try to come as close as possible to the historical soundscape of his work. At the same time this brings us to different perspectives on our contemporary ways of expression, not only musical but also theatrical. Both come together in contemporary music theatre. This is a genre in which a musical way of thinking is essential to the creative theatrical process. What happens when this musical way of thinking has an underlying historicist methodology? How does it influence the musical-theatrical language? We have explored these questions through the elaboration of Incipit, the music theatre work essentially based on the sonorous references in Dante's Commedia, and also on his philosophical ideas. 


\section{Historically Informed Performance practice}

Chapter 1 focusses on Historically Informed Performance, also abbreviated as HIP. This is the approach used in the Early Music movement, indicating a musicological research of the musical sources and other historical documents and objects in order to come to a major understanding of a performance practice with which we do not have a direct relation anymore. It does not imply that the aim is to perform the music exactly as it sounded or according to the composer's intentions, simply because this is impossible or in some cases undesirable. Instead, the aim is to be as informed as possible about the musical piece and to decide its performance on basis of this knowledge, inspired by a wish of conveying its historical language and aesthetics to a contemporary audience. The case of Late-Medieval ecclesiastical chant is unique, due to the fact that at the end of the $19^{\text {th }}$ century the monks of Solesmes laid the foundation for a standard repertoire and performance which broke with oral traditions until then and which was not as historical as they presented it. In order to perform Late-Medieval chants in a historically informed manner, not only historical musical sources have to be studied but also the entire performance tradition of the $20^{\text {th }}$ century must be abandoned, because in matters of rhythm and voice colour it has no relation anymore to the older traditions. Furthermore, in the Late Middle Ages there were specific rules for improvising additional voices to the plainchant melody, a practice that was common in liturgical services. Chapter 1 continues with a discussion of the basic principles of Medieval music theory and performance, which are necessary for a historically informed performance practice of this music.

For Incipit the historical-musicological knowledge of the chants has determined their performance practice. Chapter 4 shows the first step in this process, the analysis of the musical references in the Commedia. Sonorously, it was an approach to the sounds that Dante might have had in mind, with the premise that an archival research of the cathedral of Florence did not enter the scope of this thesis and is believed to provide more information on the exact melodic versions of the chants. In this sense, it leaves a door open for future musicological research. As chapter 5 demonstrates, most of the musical sources were from peripheral areas outside France and relatively close to Italy, which are thought to be at least similar to the music that Dante knew. Our historical-musicological research has certainly provided a considerable difference in the chants' performance practice compared to $20^{\text {th }}$ century ecclesiastical tradition, not only in rhythm, ornaments or sound colour, but also in the addition of voices according to the rules of improvised organum. This polyphony, applied to the chants in Paradise, changed the entire sound of the performance of the plainchant melodies. They were rhythmically sung with a regular pulse and enriched with different harmonies, instead of a monophonic melody sung in a free organic rhythm. It led to a first comprehension of 
how polyphony and rhythmic treatment developed in the Middle Ages, but also of the cause and functioning of musica ficta (the use of sharps and flats outside of the hexachordic system of Guido d'Arezzo). This has been a clear case of how practice can reinforce theoretical knowledge, and independently from the mise-en-scene it provides interesting theoretical-practical knowledge which gives us a greater understanding of Medieval performance practice and the functioning of polyphony.

Inferno does not contain any music, just noises. For its soundtrack, sounds were used that were as close as possible to the ones that Dante could have had in mind. In this aspect, even the Infernal noises were chosen according to the mentality of Historically Informed Performance practice: mostly natural sounds or at least manipulated natural sounds. This has been discussed in chapter 6 (section 6.3).

In relation to performance of the standard $20^{\text {th }}$ century chants within their performance tradition, Historically Informed Performance of Late-Medieval chants requires a considerable amount of extra historical-musicological knowledge. There has been research of the Medieval sources of the chants, which has given us a glimpse of this beautiful repertoire which is worth being revived. The practice on a regular basis of improvising simple polyphony would be an excellent pedagogical tool for Early Music performers in order to better understand Medieval music and to approach the common Medieval performance practice. It would give the opportunity to get used to the system and to be more adventurous in voice-crossing and melodic movement, just as the singers in the Middle Ages did. Only practice and comparison with notated Italian music from the $14^{\text {th }}$ century can lead us to a real understanding of both this improvised practice and the written music.

\section{The Commedia as a basis for the mise-en-scene}

Chapter 3 has been dedicated to Dante's Commedia, its significance in its own time as well as its interpretations. This chapter discusses the readings that were an inspiration for Incipit. This does not imply that they were all applied to our mise-en-scene, but they formed the line of thought behind the creative work process. We have seen that for Incipit his philosophical ideas are more important than his literal narrative, except for the sonorous part of Incipit. One of the aims of this thesis has been to communicate Dante's aesthetics and thoughts to a contemporary audience. Despite being a product of its time, the Commedia transcends the mentality of its era in a highly remarkable way of debunking doctrine. Dante creates a fictional universe where historical and mythical figures coexist, which he presents as a reality like our own, demonstrating that all finite reality is nothing more than 
a creation of the infinite Being and that doctrine is only a manner of moving away from the Divine within ourselves. The intention of his journey is to make it the reader's own inner journey. This thought has been the underlying idea of the mise-en-scene of Incipit.

The Commedia has not only served as a philosophical basis for the mise-en-scene, it has also provided the scenic elements. For Incipit, all fragments about sounds, movements, gestures, colour and light were selected and collected in a table. This document proves to be an excellent source for further research on the Commedia's aesthetic journey or for other mises-en-scene. Its sonorous references indicate the significance of liturgical music in Late-Medieval philosophical and musical thought: they can provide useful information for historians and musicologists. The work itself is rich in many historical details. In general, the Commedia is an extensive reflection of Medieval mentality, aesthetics and science, because of its unique presentation in the form of an encyclopedic narrative poem. For its combination of musical references and its profound philosophical concepts it has proven to be an ideal conceptual basis for Incipit. On the other hand, it has also created difficulties for its mise-en-scene due to its great complexity of subjects, metaphors and characters, causing a fragile balance between a strict selection of the Commedia's material and the intention of doing justice to the original work. In order to transmit to the audience what Dante wished to express, it was essential to comprehend his philosophy and metaphysics and to centre the mise-enscene around them.

\section{The musical-theatrical mise-en-scene}

The field of Contemporary Music Theatre is a genre-between-genres where musical thought determines the theatrical process and music is combined with other disciplines. For our research, the music theatre work Incipit was created and performed by the same person. This facilitated a greater control over the work process and the result. Sound was combined with acting and corporal expression. In Inferno the interaction between voice and body was explored in such manner that the body did not only influence the voice but also the use of the voice was visualized through the body, inspiring and starting off choreographic movements.

Incipit was principally based on the sonorous references in Dante's Commedia. The soundtrack determined the timing and duration of the three parts of Inferno, Purgatory and Paradise. The live performance added sonorous-visual elements to the soundtrack so that a theatrical "polyphony" was created, to use a term of Heiner Goebbels. Just like in a polyphonic composition for various voices, a theatrical work can also be thought of as polyphonic if the elements are combined in a musical 
way, either reinforcing or contrasting each other. Since the soundtrack is a recording, the actor does not have total control over the performance. In Inferno this expresses a constant harassment and manipulation of the protagonist. In Purgatory it reflects the fact that the protagonist is not alone anymore and forms part of a community. In Paradise it results into three-voice polyphony, where the performer is actually singing with herself recorded twice. This symbolizes Divinity, being one and many at the same time. It also reflects the fact that the ego is not so important anymore.

Incipit is an internal journey. The performer represents humanity in all its forms of being. It allows for an imaginary space where the spectator can make his own internal journey. Incipit takes the sonorous level as a departure point for a journey through Dante's Afterworld within oneself. Dante's metaphysics are the underlying concept of Incipit. Inferno is a place of desolate loneliness combined with mental and physical torture, a place from which there is no escape because it is the soul itself that cannot come out of its distorted perspective. Purgatory might perfectly be the same place but in a more dignified position and without the tortures of Inferno. The soul is ready to be purified but has to struggle with the temptations within itself in order to be free. Incipit's Paradise is, unlike Dante's Paradise, a place where dark and light come together, where there is silence and empty space. Dante makes clear that the Paradise he visits is only a Divine adaptation of the immaterial Paradise to his mortal senses. It is this concept that has been assimilated into Incipit. Unlike Dante's blinding light, Incipit's Divine representation takes on a serene, dream-like form, where there is a tension between presence and absence. While Dante's Commedia is externalized, Incipit is an internalized form of his Hereafter.

In this mise-en-scene, Historically Informed Performance of Medieval music has provided a unique creative method and perspective. Not only has it determined the sounds and music, but it has also influenced various choices in the creative process, such as the choice of leaving the texts in their original Florentine language, giving priority to the sonorous narrative or focussing on Dante's possible intention with his Commedia. The Anti-Music of Inferno was a composition of mostly natural noises. The music in Purgatory was decided to keep mainly monophonic, except in more celebratory cases such as the Te Lucis Ante or Alleluia. The Divine music in the Terrestrial Paradise and the immaterial Paradise was polyphonically interpreted, which respects the Medieval musical possibilities and still expresses a more Divine type of music than monophony. The noises and chants optimally fulfilled their original function through a musical-theatrical mise-en-scene: the Anti-Music of Inferno expressed chaos, ugliness and lack of divinity, the chants in Purgatory commented on the sin they were coupled with, and the polyphonic chant settings in Paradise were an aesthetic celebration of Divinity. 


\section{The interaction between HIP and Music Theatre}

Returning to our research question, how did the work methods of Historically Informed Performance practice contribute to the creation of Incipit? The departure point of the creative process was the historically informed research and performance of the sounds and chants that Dante mentions in his Commedia. They formed the centre of Incipit's creation, based on the premise that Incipit was to be a historically informed sonorous journey through Dante's Hereafter. The sonorous references of the Commedia thus influenced the entire form of the work. All references to sound, movement, gesture, colour and light were combined in a table and were principally thought to form one great composed theatrical score, but in the rehearsals it soon became clear that many movements or gestures illustrated the sounds and did not add anything new to the scene. Therefore, the sonorous references were remained intact as much as possible whereas the other references were only loosely applied to the mise-en-scene.

First, the texts and music were rehearsed and recorded for the soundtrack of Incipit. Once the rehearsals in the theatre started, a major part of the sounds was already fixed and thus the other elements were adapted to them, of course still with the possibility of minor adaptations in the soundtrack. The chronological order of the Commedia's sonorous references had been maintained, which was a major determinant in the final mise-en-scene. It dictated the exact duration of the three parts of the work. The creative process thus was dictated by this specific methodology.

The chaotic and cacophonous sounds in Inferno, expressing the disorder and mental torture of this place, provided the most flexibility in timing and sonorous material at the moment of composing the soundtrack. The nature of their sounds, very different from those of Purgatory and Paradise, resulted into a mise-en-scene that reacted to these torturous sounds of discord in a more performance-like mise-en-scene. Each of the chants in Purgatory, commenting on a sin or expressing a praise to Divinity, had such a specific function that it was necessary for the performer's dramatical actions to display their purpose. If the action had not expressed that part of the narrative, these chants would have been meaningless and could have easily been experienced as tedious. The performance of the chants thus explicitly determined the mise-en-scene of Purgatory. The chants in Paradise, expressing a Divine festive representation, have a very specific aesthetics. The range of their three voices must be within the performer's vocal range and thus the lowest voice was mostly sung in the chest voice while the other two were sung in mixed and head voice. Their sound in general is light with little accent on the chest voice. There is no rhythmic strong beat nor different instrumentation. It only involves the voice, with generally the same sound colour, flow and character. In this sense, 
the music of Paradise determines its sonorous space. The visual elements can relate to it either through contrast or reinforcement. While the soundscape throughout Incipit is a more literal interpretation of the text, the mise-en-scene tends to be a metaphoric one. These two levels interact and bring the work to a more abstract level where Dante's philosophy behind his work can be expressed.

The fact that chants from a Medieval literary narrative are performed in a historically informed manner contributes both to historical knowledge of Medieval mentality and to musicological knowledge of the role of music in Medieval thought. Performing these chants brings Dante's narrative to life from a fresh perspective. The combination of two disciplines that are normally not seen together, Early Music and Contemporary Music Theatre, provides us with different theoreticalpractical insights of creative processes and musical-theatrical languages. The chants through their use in a theatrical mise-en-scene are taken outside of their ecclesiastical context and are thus opened to a wider audience. Although it was expected that they would lose some of their significance, their dramatization actually gave them back their original meaning.

As we have seen, Historically Informed Performance and Experimental Music Theatre thus interact and influence each other in various ways. Music theatre takes Early Music out of its context toward a broader audience. In the case of Incipit, it has also restored the original function of the chants. Moreover, it can give fresh insights about the role of music in Medieval mentality through a dramatical reading of Dante's Commedia. Historically Informed Performance influences music theatre in its approach, centring the creative process around the historical music trying to maintain its works as intact as possible, which in its turn influences the structure of the mise-en-scene. Medieval chant has some specific characteristics which create a homogeneous soundscape for the work and thus determine its sonorous space. Finally, there is a historical motivation underlying the use of Early Music that may extend to other elements of the mise-en-scene, and in the case of Incipit, even to the subject choice.

Throughout this thesis we have demonstrated possibilities that open the way for the application of the methodology of Historically Informed Performance on Experimental Music Theatre, as well as the opportunity to bring Early Music to a nonspecialist audience through a theatrical setting. The route we have followed through Dante's ideas has not come to an end at this point; it is the beginning of a journey that is an invitation to further exploration in this fascinating combination of research areas. 


\section{SUMMARY OF THE THESIS}

The PhD thesis INCIPIT: The search for a multidisciplinary language at the crossroads of Antiquity and Contemporaneity focusses on the influence of the methodology of Historically Informed Performance practice on the creation of a Contemporary Music Theatre performance. The framework and creative basis for their connection is the Divina Commedia of Dante Alighieri (1265-1321). In music theatre it is not only about music as one of the scenic elements; musical thinking structures the entire theatrical process. It is a genre-between-genre, where various art disciplines interact. Historically Informed Performance practice is a characteristic musical approach of the Early Music movement. It includes study of historical documents and objects in order to obtain a more profound understanding of the music and a performance practice which is based upon this comprehension. In our thesis, Historically Informed Performance practice has been connected with Contemporary Music Theatre through a mise-en-scene of Dante's Commedia, principally based upon its sonorous non-musical and musical references. Also references of movement, gesture, colour and light were taken into account for the mise-en-scene, but always in relation to the sonorous references. In this way, the mise-en-scene is a sonorous journey through Dante's Afterworld as he might have imagined it, but also a contemporary visual and dramatical journey.

This research has been done through artistic practice: the creation and performance of a contemporary music theatre work called Incipit. It is based upon thorough knowledge of the Commedia and, through its methodology of Historically Informed Performance Practice, it has mostly made used of $14^{\text {th }}$ century musical sources. An audio file was created as a sonorous element for Incipit, based on previously existing sounds and recording of songs and texts. The performance was recorded in video format. The research question was:

How do the work methods taken from Historically Informed Performance practice contribute to the creation of a contemporary music theatre performance in a mise-en-scene of the Divina Commedia?

For this practice-based research not only historical-musical knowledge was necessary but also literary knowledge of Dante's Commedia and its underlying meanings. Theoretical knowledge thus was an important basis for the practice. However, the practice itself also provided information for the theory. For the composition of three-voice "simple polyphony" according to the rules for polyphonic improvisation around 1300, theoretical knowledge was essential, but their practice led to historical-musical insights of its performance and its rules for intervallic and rhythmic matters. The practice provided a new perspective on Dante's narrative from a sonorous point of view. 
Finally, the practice combined two disciplines, Early Music and Contemporary Music Theatre, which are not commonly combined, and it provides us with new theoretical insights of creative processes and musical-theatrical languages.

The thesis is subdivided into six chapters. The first three are the theoretical chapters about the research areas. Chapter 4 is also a theoretical chapter but analyses the musical references of the Commedia, essential to the sonorous part of Incipit. The remaining two chapters are focussed on the creative process. Chapter 1 is about Early Music and Historically Informed Performance Practice. It first explains the development of the Early Music movement and its journey from the concept of "authenticity" to that of "historically informed performance". It then discusses a similar but inherently different movement within the Church, which is important for our understanding of the difference between Late-Medieval and $20^{\text {th }}$ century chants. It then continues with the historicalmusical issues for the sounds in the Commedia, such as the secular and ecclesiastical performance practices, the theory of the Harmony of the Spheres, Pythagorean tuning system and its consequences, the Church modes, voice and instruments in the Late Middle Ages, and musical notation and its relationship with Medieval performance practice.

Chapter 2 is about the Commedia, as Dante called the work himself, from the perspective of Literature Studies. First, it discusses the context in which it was created. Then, it gives an overview of the structure of Dante's Afterworld according to his chronological journey. Subsequently it discusses the interpretations of his narrative that have been the inspiration for Incipit, and finally a section is dedicated to Dante's Metaphysics.

Chapter 3 is about Contemporary Music Theatre. It discusses its predecessors and different forms throughout the $20^{\text {th }}$ century. Since this type of music theatre is a genre-between-genres, it encompasses an extended field of differentiated artistic initiatives and is open to the combination of various art disciplines, always from a musical point of view. Its borders are not always clearly definable and it overlaps with other multidisciplinary fields such as dance theatre or performance.

Chapter 4 describes the musical references in the Commedia. It is a critical survey of their literal and symbolical significance within Dante's narrative. Although Inferno, realm of Anti-Music, apparently only contains noises, there are several parodic referrals to music. Purgatory, where music is a means for purgation, is the canticle which is most specific in its description of actual chants and the way they are sung by the souls. In Paradise reigns superhuman music, therefore it contains 
numerous musical references, but very few of them are specific and indicate an existing chant: they are above human music.

Chapters 5 and 6 show different aspects of the creative process. Chapter 5 is about the historical musical sources and their transcription, while chapter 6 is about the creative process of composing and recording the soundtrack, and about the rehearsals. Chapter 5 also discusses the choice of chants for Paradise in the music theatre work Incipit and the composition of additional voices for the chants in Paradise according to the rules around 1300. Chapter 6 first treats the underlying concepts of Incipit and its references in the artistic world. Then it describes the creative process in two steps: the first part of composing, rehearsing and recording the soundtrack, and the second part of the physical rehearsals in the theatre, resulting into the final mise-en-scene of Incipit. 


\section{RESUMEN DE LA TESIS}

La tesis doctoral INCIPIT: La búsqueda de un lenguaje multidisciplinario en el punto de encuentro entre la antigüedad y contemporaneidad trata sobre la influencia de la metodología de la práctica de interpretación históricamente informada en la creación de una puesta en escena de Teatro Musical Contemporáneo. El marco y la base creativa para su combinación es la Divina Comedia de Dante Alighieri (1265 - 1321). El teatro musical no se centra solamente en la música como uno de los elementos escénicos; el pensamiento musical estructura todo el proceso teatral. Es un género-entregéneros donde interactúan varias disciplinas artísticas. La interpretación históricamente informada es una manera de abordar la música que caracterizan los intérpretes especializados en la Música Antigua. Incluye el estudio de documentos y objetos históricos con el fin de llegar a una comprensión más profunda de la música antigua y una práctica interpretativa que se basa en este entendimiento. En esta tesis, se ha relacionado la interpretación históricamente informada con el teatro musical contemporáneo a través de una puesta en escena de la Comedia de Dante basada principalmente en sus referencias sonoras, tanto musicales como no musicales. Además se tomaron en cuenta las referencias de movimiento, gesto, color y luz para la puesta en escena pero siempre en relación con las referencias sonoras. De esta forma, la puesta en escena se ha convertido en un viaje sonoro a través del Más Allá de Dante como él mismo podría haberlo imaginado, pero también siendo un viaje visualmente y dramáticamente de carácter contemporáneo.

Esta investigación se ha realizado a través de la práctica artística: la creación e interpretación de una obra de teatro musical contemporáneo llamada Incipit. Se basa en un conocimiento profundo de la Comedia y, a través de la metodología de la práctica interpretativa históricamente informada, se ha hecho principalmente uso de fuentes musicales del siglo XIV. Un archivo de audio fue creado como elemento sonoro para Incipit, compuesto de sonidos previamente existentes y la grabación de cantos y textos. La actuación fue grabada en formato de vídeo. La pregunta de investigación fue:

¿Cómo contribuyen los métodos de trabajo tomados de la práctica interpretativa históricamente informada a la creación de una actuación de teatro musical contemporáneo en una puesta en escena de la Divina Comedia?

Para esta investigación basada en la práctica, no sólo fue necesario el conocimiento históricomusical, sino también el conocimiento literario de la Comedia de Dante y sus significados subyacentes. Por lo tanto el conocimiento teórico ha constituido una base importante para la práctica. Sin embargo, la práctica en sí también proporciona información para la teoría. En cuanto a 
la composición de "polifonía sencilla" a tres voces, de acuerdo con las reglas para la improvisación polifónica de principios del siglo XIV, ha sido esencial recurrir a un gran conocimiento teórico, pero su práctica interpretativa dio lugar a ideas histórico-musicales de su interpretación y sus normas acerca de cuestiones de intervalos y ritmos musicales. La práctica proporciona, desde un punto de vista sonoro, una nueva perspectiva de la narrativa de Dante. Por último, la interpretación junta dos disciplinas que no han sido combinadas frecuentemente: la Música Antigua y el Teatro Musical Contemporáneo, proporcionándonos nuevos conocimientos teóricos de los procesos creativos y los lenguajes musical-teatrales.

La tesis se divide en seis capítulos. Los tres primeros son capítulos teóricos sobre las áreas de investigación. El capítulo 4 es también un capítulo teórico pero analiza sobre todo las referencias musicales en la Comedia, esenciales para la parte sonora de Incipit. Los dos capítulos restantes se centran en el proceso creativo. El capítulo 1 trata sobre Música Antigua y la práctica interpretativa históricamente informada. Primeramente explica el desarrollo del Movimiento de Música Antigua y su viaje del concepto de la "autenticidad" a la de "interpretación históricamente informada". A continuación se describe un desarrollo similar pero intrínsecamente diferente en la Iglesia que es importante para poder comprender la diferencia entre cantos medievales tardíos y los del siglo XX. El capítulo continúa con los asuntos musicales históricos para los sonidos en la Commedia, tales como las prácticas interpretativas profanas y eclesiásticas, la teoría de la armonía de las esferas, el sistema de temperamento pitagórico y sus consecuencias, los modos eclesiásticos, la voz y los instrumentos en la Edad Media, la notación musical y su relación con la práctica interpretativa medieval.

El capítulo 2 enfoca al Teatro Musical Contemporáneo. El capítulo trata sobre los predecesores de este género y sus diferentes formas a lo largo del siglo XX. Dado que este tipo de teatro musical es un género-entre-géneros, el Teatro Musical Contemporáneo abarca un campo extenso de iniciativas artísticas diferenciadas y está abierto a la combinación de diversas disciplinas, siempre desde un punto de vista musical. Sus fronteras no siempre son claramente discernibles y se superponen con otros campos multidisciplinarios como el teatro de danza o la performance.

El capítulo 3 se centra en la Comedia, el título que puso Dante a su obra, desde la perspectiva de los estudios literarios. En primer lugar se analiza el contexto en el que fue creado. A continuación se ofrece una visión general de la estructura del Más Allá de Dante según su recorrido cronológico. Posteriormente se analizan las interpretaciones de su narrativa que han sido la fuente de inspiración para Incipit y, finalmente, una parte está dedicada a la Metafísica de Dante. 
El capítulo 4 describe las referencias musicales en la Comedia. Se trata de un estudio crítico de sus significados literales y simbólicos dentro de la narrativa de Dante. Aunque el Infierno es el reino de la Anti-Música y aparentemente sólo contiene ruidos, hay sin embargo varias referencias paródicas a la música. El Purgatorio, donde la música es un medio de purificación, es el cántico más específico en la descripción de cantos reales y la forma en que las almas las cantan. En el Paraíso reina la música sobrehumana, por lo tanto contiene numerosas referencias musicales pero muy pocas son específicas indicando un canto litúrgico ya que están por encima de la música humana.

Los capítulos 5 y 6 muestran diferentes aspectos del proceso creativo. El capítulo 5 trata sobre las fuentes musicales históricas y sus transcripciones, mientras que el capítulo 6 se centra en el proceso creativo de la composición, la grabación de la banda sonora y los ensayos. El capítulo 5 también argumenta la elección de los cantos del Paraíso para la obra de teatro musical Incipit y la composición de voces adicionales de acuerdo con las reglas en torno a 1300. El capítulo 6 primero se centra en los conceptos fundamentales de Incipit y sus referencias del mundo artístico. Luego describe el proceso de creación en dos etapas: la primera parte sobre composición, ensayos y grabación de la banda sonora, y la segunda parte sobre los ensayos en el teatro, resultando en la puesta en escena definitiva de Incipit. 


\section{RESUM DE LA TESI}

La tesi doctoral INCIPIT: La recerca d'un llenguatge multidisciplinari en el punt de trobada entre l'antiguitat $i$ contemporaneïtat tracta sobre la influència de la metodologia de la pràctica d'interpretació històricament informada en la creació d'una posada en escena de Teatre Musical Contemporani. El marc i la base creativa per la seua combinació és la Divina Comèdia de Dante Alighieri (1265-1321). El teatre musical no se centra només en la música com un dels elements escènics; el pensament musical estructura tot el procés teatral. És un gènere-entre-gèneres on interactuen diverses disciplines artístiques. La interpretació històricament informada és una manera d'abordar la música que caracteritzen els intèrprets especialitzats en la Música Antiga. Inclou l'estudi de documents i objectes històrics per tal d'arribar a una comprensió més profunda de la música antiga i una pràctica interpretativa que es basa en aquest endement. En aquesta tesi, s'ha relacionat la interpretació històricament informada amb el teatre musical contemporani a través d'una posada en escena de la Comèdia de Dante basada principalment en les seues referències sonores, tant musicals com no musicals. A més es van prendre en compte les referències de moviment, gest, color i llum per a la posada en escena però sempre en relació amb les referències sonores. D'aquesta manera, la posada en escena s'ha convertit en un viatge sonor a través del Més Enllà de Dante com ell mateix podria haver-ho imaginat, però també sent un viatge visualment $\mathrm{i}$ dramàticament de caràcter contemporani.

Aquesta investigació s'ha realitzat a través de la pràctica artística: la creació i interpretació d'una obra de teatre musical contemporani anomenada Incipit. Es basa en un coneixement profund de la Comèdia i, a través de la metodologia de la pràctica interpretativa històricament informada, s'ha fet principalment ús de fonts musicals del segle XIV. Un arxiu d'àudio va ser creat com a element sonor per a Incipit, compost de sons prèviament existents i de la gravació de cants i textos. L'actuació va ser gravada en format de vídeo. La pregunta d'investigació va ser:

Com contribueixen els mètodes de treball presos de la pràctica interpretativa històricament informada a la creació d'una actuació de teatre musical contemporani en una posada en escena de la Divina Comèdia?

Per a aquesta investigació basada en la pràctica, no només va ser necessari el coneixement històricmusical, sinó també el coneixement literari de la Comèdia de Dante i els seus significats subjacents. Per tant el coneixement teòric ha constituït una base important per a la pràctica. No obstant això, la pràctica en si també proporciona informació per a la teoria. Pel que fa a la composició de "polifonia 
senzilla" a tres veus, d'acord amb les regles per a la improvisació polifònica de principis del segle $\mathrm{XIV}$, ha sigut essencial recórrer a un gran coneixement teòric, però la seua pràctica interpretativa va donar lloc a idees historicomusicals de la seua interpretació i les seues normes sobre qüestions d'intervals i ritmes musicals. La pràctica proporciona, des d'un punt de vista sonor, una nova perspectiva de la narrativa de Dante. Finalment, la interpretació junta dues disciplines que no han estat combinades freqüentment: la Música Antiga i el Teatre Musical Contemporani, proporcionantnos nous coneixements teòrics dels processos creatius i els llenguatges musical-teatrals.

La tesi es divideix en sis capítols. Els tres primers són capítols teòrics sobre les àrees d'investigació. El capítol 4 és també un capítol teòric però analitza sobretot les referències musicals en la Comèdia, essencials per a la part sonora de Incipit. Els dos capítols restants es centren en el procés creatiu. El capítol 1 tracta sobre Música Antiga i la pràctica interpretativa històricament informada.

Primerament explica el desenvolupament del Moviment de Música Antiga i el seu viatge del concepte de la "autenticitat" a la de la "interpretació històricament informada". A continuació es descriu un desenvolupament similar però intrínsecament diferent en l'Església que és important per a poder comprendre la diferència entre cants medievals tardans i els del segle XX. El capítol continua amb els assumptes musicals històrics per als sons en la Commedia, com ara les pràctiques interpretatives profanes i eclesiàstiques, la teoria de l'harmonia de les esferes, el sistema de temperament pitagòric i les seues conseqüències, les maneres eclesiàstics, la veu i els instruments a l'Edat Mitjana, la notació musical i la seua relació amb la pràctica interpretativa medieval.

El capítol 2 se centra en la Comèdia, el títol que va posar Dante a la seua obra, des de la perspectiva dels estudis literaris. En primer lloc s'analitza el context en què va ser creat. A continuació s'ofereix una visió general de l'estructura del Més Enllà de Dante segons el seu recorregut cronològic. Posteriorment s'analitzen les interpretacions de la seua narrativa que han sigut la font d'inspiració per a Incipit i, finalment, una part està dedicada a la Metafísica de Dante.

El capítol 3 enfoca al Teatre Musical Contemporani. El capítol tracta sobre els predecessors d'aquest gènere i les seues diferents formes al llarg del segle XX. Atès que aquest tipus de teatre musical és un gènere-entre-gèneres, el Teatre Musical Contemporani abasta un camp extens d'iniciatives artístiques diferenciades i està obert a la combinació de diverses disciplines, sempre des d'un punt de vista musical. Les seues fronteres no sempre són clarament discernibles i es superposen amb altres camps multidisciplinaris com el teatre de dansa o la performance. 
El capítol 4 descriu les referències musicals a la Comèdia. Es tracta d'un estudi crític dels seus significats literals i simbòlics dins de la narrativa de Dante. Tot i que l'Infern és el regne de l'AntiMúsica i aparentment només conté sorolls, hi ha no obstant diverses referències paròdiques a la música. El Purgatori, on la música és un mitjà de purificació, és el càntic més específic en la descripció de cants reals i la forma en què les ànimes les canten. Al Paradís regna la música sobrehumana, per tant conté nombroses referències musicals però molt poques són específiques indicant un cant litúrgic ja que estan per sobre de la música humana.

Els capítols 5 i 6 mostren diferents aspectes del procés creatiu. El capítol 5 tracta sobre les fonts musicals històriques i les seues transcripcions, mentre que el capítol 6 se centra en el procés creatiu de la composició, la gravació de la banda sonora i els assajos. El capítol 5 també argumenta l'elecció dels cants del Paradís per a l'obra de teatre musical Incipit i la composició de veus addicionals d'acord amb les regles al voltant de 1300. El capítol 6 primerament se centra en els conceptes fonamentals d'Incipit i les seues referències del món artístic. Després descriu el procés de creació en dues etapes: la primera part sobre composició, assajos i enregistrament de la banda sonora, i la segona part sobre els assajos al teatre, resultant en la posada en escena definitiva d'Incipit. 


\section{ACKNOWLEDGEMENTS}

There are a number of people I would like to express my gratitude to. I would wish to thank my thesis supervisor Martina Botella Mestres for her interest since I began my thesis in the Master programme and for her clear structural views. Additionally, I would like to thank her for her presence and advice during the rehearsals, for her feedback and her contribution in practical matters around the rehearsals and performances. I am also grateful for the helpful advices by co-supervisor Carlos David Perales and his straightforward approach. I would like to thank Falk Hübner for his enthusiasm, his very helpful advices and way of approaching such a project, his listening ear and humane attitude. He is a great music theatre professional and scholar and a source of inspiration. I would also like to thank Niels Berentsen for sharing his knowledge and teaching method on improvised Medieval organum and Isaac Alonso de Molina for sharing knowledge, documents and thoughts on the Late-Medieval performance practice.

For the realization of Incipit, I am highly grateful for the collaboration of light designer José Martín Márquez de Torres. I would like to thank him for all the artistry, time and energy he has dedicated to this project. I would also like to express my gratitude to Vicente Garzón Orts, who not only recorded the sound of the performances but also gave me the opportunity to try out the music theatre work with a headset microphone and who helped with many practical issues. I wish to thank Jacobo Pallarés and Maribel Bayona of the theatre "Espai Inestable" for allowing me to rehearse freely in the theatre for various weeks. It has been the ideal space for Incipit.

I would like to give all my thanks to Joachim Margot, who has helped me in so many ways that it is almost impossible to enumerate them. He has been my motivating force, my first text corrector, my eyes in the rehearsals of Incipit as if they were my own. He has been my most critical reader and audience, my moral and practical support, my video man and editor, my listener and a great advisor. There are not enough ways to thank him for being at my side for all this time. I also wish to thank my wonderful parents for their moral support and joyfulness whenever I needed it. 


\section{CURRICULUM VITAE}

Lobke Sprenkeling was born in 1979 in Holland. At the age of 15 she won the first prize in the category of wind instruments at the Competition for Young Musicians of Leiden, and she became semi-finalist in the international youth contest of SONBU Holland. She obtained the Bachelor Degree of Music at the Royal Conservatory in The Hague in 2001, having studied the recorder with Jeannette van Wingerden and Sébastien Marq. In the same year, she was selected to participate in the project and national tour of the Baroque Orchestra of Ambronay, France. In 2003, she obtained the Master of Arts Degree at the Conservatory of Utrecht after recorder studies with Heiko ter Schegget. Simultaneously, she obtained the Master of Arts in Experimental Music Theatre at the Royal Conservatory in The Hague. She received a scholarship from the national Prince Bernhard Culture Fund to study Medieval music during a year with Pedro Memelsdorff at the Escola Superior de Música de Catalunya (ESMUC) in Barcelona. In 2012 she obtained her Master of Advanced Studies at the Universidad Politécnica de Valencia, with her research "Dutch Music Theatre, a meeting point between the Performing Arts".

As a recorder player she performed with the French baroque orchestra Les Talens Lyriques under direction of Christophe Rousset, in a co-production with the Dutch Opera, interpreting two operas of Händel in Amsterdam, Paris and Montpellier. In 2008 she played in the Orquestra de la Comunitat Valenciana at the Palau de les Arts in Valencia, under the direction of Eduardo López Banzo, in a production of Händel's opera "Orlando". She has collaborated among others with Capella dels Ministrers, La Academia de los Nocturnos, Capella Saetabis, Orfeón de la Universitat de València, Estampida Real, and Música Trobada. She performs as a soloist with the Orquesta Sinfónica de Albacete in 2015 and 2016. She is the recorder teacher at the Conservatorio Profesional de Valencia and has been a teacher in various Summer Courses. She was the wind instrument coach at the Conservatorio Superior de Música de Albacete in the 2015 Baroque orchestra project "Music and Dance at Versailles".

As a singer, she has studied with various teachers, such as Lennaert Roos, Astrid Kroon and Beatriz Lafont, and has collaborated with the early music ensemble La Academia de los Nocturnos, while also singing jazz and pop ballad style with other groups. In 2009-2010 she enrolled in a school of (popular) musical, with singing classes, acting classes, and dance classes (modern and lyrical jazz as well as ballet classes). She has been taking ballet classes for over 15 years and has been taking 
contemporary dance classes. She has been a student for two years in Tai Chi Yang style with empty hand, sword and stick, and three years in Tai Chi Chen style with empty hand and fan, and now trains in Pilates and Yoga. She was accepted in the artist database of Cirque du Soleil after her personal casting as a recorder player and singer. Over the years she has been involved in various small-scale music theatre projects. 


\section{LIST OF FIGURES}

\section{CHAPTER 1}

Fig.1. In 1843 Mendelssohn directed works of various earlier composers $\quad$ p.16

Fig. 2. Academy of Ancient Music, $1793 \quad$ p.16

Fig. 3. Dolmetsch family and assistants, 1932 p.17

Fig. 4. Neumes, part of excerpt (c.1000) from St. Gallen, Cod. Sang. $390 / 391$ p.23

Fig. 5. The Divine Office or Canonical Hours. p.37

Fig. 6. A resolution that sounds natural to us. p.44

Fig. 7. Medieval resolutions with the heightened $b$ in Pythagorean tuning. p.44

Fig. 8. Ut queant laxis. $\quad$ p.46

$\begin{array}{ll}\text { Fig. } 9 \text { The Guidonian hand. } & \text { p.47 }\end{array}$

Fig. 10. An example of Medieval square notation. p.53

Fig. 11. An overview of various neumes. $\quad$ p.57

Fig. 12 Fragment from Gaudete et exsulate, Saint-Maur-des-Fossés (12th century) p.60

Fig. 13. The rhythmic modes. p.64

\section{CHAPTER 2}

Fig. 14. The first performance of Wagner's Rheingold in $1876 \quad$ p.66

Fig. 15. Leitmotive associated with the hero Siegfried in Wagner's opera. p.66

$\begin{array}{ll}\text { Fig. 16. Appia's design } & \text { p. } 67\end{array}$

Fig. 17. Another of Appia's design for his rhythmic spaces $\quad$ p.67

Fig.18 Study of a bow shot: sequence presented by Meyerhold's students p.68

$\begin{array}{ll}\text { Fig.19. Meyerhold: Le cocu magnifique (1928) p.68 } & \text { p }\end{array}$

Fig. 20. Kandinsky: Dance Curves (with Gret Palucca, 1926) p.69

$\begin{array}{lr}\text { Fig 21. Stravinsky conducting in } 1929 & \text { p.70 }\end{array}$

Fig. 22. A German poster for Brecht's Dreigroschenoper from $1928 \quad$ p.72 
$\begin{array}{ll}\text { Fig.23. Floorplan of the happening in } 1952 & \text { p.73 }\end{array}$

Fig. 24. Kaprow: 18 Happenings in Six Parts (1959), p.74

Fig.25. Fluxus manifest written in 1963 by George Maciunas p.76

Fig.26. George Brecht: Solo for Violin Polishing (1964) p.76

$\begin{array}{ll}\text { Fig.27. Chris Burden: Trans-fixed (1974) p.77 } & \text { p. }\end{array}$

$\begin{array}{ll}\text { Fig.28. Chris Burden: Shoot (1971) p.77 } & \text { p.7 }\end{array}$

Fig. 29. 38 Objects from Marina Abramovic's "Rhythm-0" (1974) p.78

Fig. 30. Marina Abramovic after her "Rhythm-0" (1974) p.78

Fig.31. Laurie Anderson: Duet on Ice (1975) p.78

Fig.32. Debut performance of Mauricio Kagel's "Staatstheater" (1971) p.81

Fig.33. John Cage: Musicircus (1967) p.81

Fig. 34. Stockhausen: Licht (1988) in Scala, Milan $\quad$ p.81

Fig. 35. Hauser Orkater: Zie de Mannen Vallen ("See the men fall", 1979) p.84

Fig. 36 Paul Koek: Machine Agricole (2011) p.90

$\begin{array}{lr}\text { Fig. } 37 \text { Paul Koek: Machine Agricole (2011) p.90 } & \text { p. }\end{array}$

Fig. 38. Alain Platel: Pitié! (2008) p.90

\section{CHAPTER 3}

Fig. 39. Ptolemaic Model (Petrus Apianus: Cosmographia, 1539) p p.106

Fig. 40. Dante's Inferno p.108

Fig. 41. Dante's Purgatory p p.118

Fig. 42. Dante's Paradise p.123

\section{CHAPTER 5}

$\begin{array}{ll}\text { Fig. 43. Ligatures } & \text { p.237 }\end{array}$

Fig. 44 The current version of In exitu israel p.238

Fig. 45. In exitu israel in the sixth book of Jacques de Liège's Speculum Musicae $\quad$ p.238

Fig. 46. Two versions of In exitu israel in the same book p.238 
Fig. 47. In exitu israel as it appears in the Tractatus de intonatione tonorum

Fig. 48. Miserere 1300s, fragment from Stiftsbibliothek codex 61189 sbe-0611_049r $\quad$ p.239

Fig. 49. Twelfth-century antiphoner from Klosterneuburg, Austria, AT5000-1010_86r p.240

Fig. 50. Twelfth-century antiphoner from Klosterneuburg, Austria, AT5000-1013_100r p.240

Fig. 51. Transcription of the Miserere from the 14th-century Einsiedeln antiphoner $\quad$ p.240

Fig. 52. The incipit Salve Regina from the sixth book of Speculum Musicae Liber $\quad$ p.242

Fig. 53. The incipit Salve Regina in the same book p.242

Fig.54. Fragment of Salve Regina in the Salzinnes Antiphonal of $1555 \quad$ p.243

Fig. 55. Salve Regina, 12th century manuscript, Klosterneuburg, Austria p.243

Fig. 56. Transcription of the Salve Regina based on the different sources $\quad$ p.244

Fig. 57. Te lucis ante, 14th century Antiphonarium Benedictinum of St. Lambrecht $\quad$ p.246

Fig. 58. Transcription of the first Te lucis ante from the Antiphonarium Benedictinum $\quad$ p.247

$\begin{array}{ll}\text { Fig. 59. Transcription of the second Te lucis ante } & \text { p.247 }\end{array}$

Fig. 60. Transcription of Incipit of Te DeumFig. 60. Transcription of Incipit of Te Deum p. 249

Fig. 61. Incipit of Te Deum (Einsiedeln, Switzerland) ～p.249

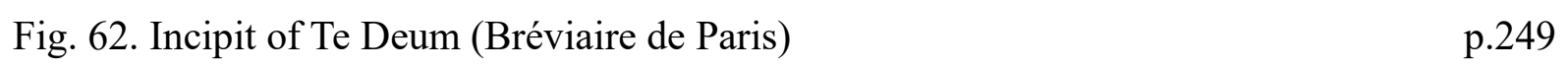

Fig. 63. First part of Te Deum in the Salzinner Antiphonal p.249

$\begin{array}{ll}\text { Fig. 64a. Partial transcription of Te Deum } & \text { p.250 }\end{array}$

$\begin{array}{ll}\text { Fig. 64b. Te Deum a } 2 & \text { p.251 }\end{array}$

Fig. 65. Beati pauperes spiritu, Benediktinerstift St. Lambrecht (1400) p.253

Fig. 66. Beati pauperes spiritu, Einsiedeln (prior to 1314) p.253

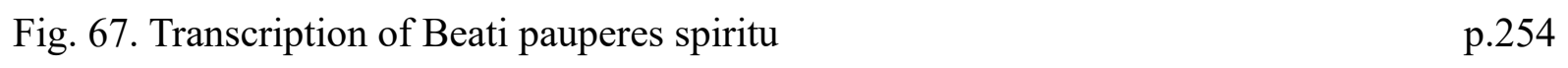

Fig. 68. Beati misericordes, Benediktinerstift St. Lambrecht (1400) p.254

Fig. 69. Beati misericordes, 14th-century, Einsiedeln (Switzerland) p.255

Fig. 70. Gaudeate et exultate, 1101-1125 (France) p.255

$\begin{array}{ll}\text { Fig. 71. Transcription of Beati misericordes } & \text { p.255 }\end{array}$

$\begin{array}{ll}\text { Fig. 72. Transcription of Gaudete } & \text { p.256 }\end{array}$

$\begin{array}{ll}\text { Fig. 73. Transcription of Agnus Dei } & \text { p.256 }\end{array}$ 
Fig. 74. Beati pacifici, early 12th century, St-Maur-F (France)

Fig. 75. Transcription of Beati pacifici

Fig. 76. Beati qui lugent (first page), Benediktinerstift St. Lambrecht, (1400)

p. 258

Fig. 77. Beati qui lugent (second page), Benediktinerstift St. Lambrecht, (1400)

p.258

Fig. 78. Beati qui lugent, Antiphonarium pro Ecclesia Einsidlensi (prior to 1314)

p. 258

Fig. 79. Transcription of Beati qui lugent

p.259

Fig. 80. Adhaesit pavimento anima mea and its first four verses

p.259

Fig. 81. Gloria, Antiphonarium Benedictinum, Sankt Lambrecht, Austria (1400)

p. 260

Fig. 82. Gloria, Antiphonarium pro Ecclesia Einsidlensi, Switzerland (14th century)

p. 260

Fig. 83. Transcription of Gloria in excelsis

p.261

Fig. 84. Beati qui esuriunt et sitiunt, Einsiedeln, Switzerland (prior to 1314)

p.261

Fig. 85. Transcription of Beati qui sitiunt

p. 262

Fig. 86. Domine labia mea, Antiphonarium Benedictinum, Austria (1400)

p.262

Fig. 87. Domine labia mea, Einsiedeln, Switzerland (14th century)

p. 262

Fig. 88. Transcription of Domine labia mea

Fig. 89. Beati qui esuriunt

Fig. 90. Incipit of Summae Deus, St. Maur-des-Fosses (12th century, France) p.264

Fig. 91. Beati mundo corde, 1400, Benediktinerstift St. Lambrecht (Austria) p.264

Fig. 92. Beati mundo corde, Einsiedeln, Switzerland (prior to 1314) p.264

Fig. 93. Transcription of Beati mundo corde p.265

Fig. 94. Venite benedicti Patris mei, Antiphonarium (ca.1300), Freiburg p.266

Fig. 95. Venite benedicti Patris mei, Einsiedeln, Switzerland (14th century) p.266

Fig. 96.Venite benedicti Patris mei, Antiphonarium Benedictinum, Austria (1400) p.266

Fig. 97. Transcription of Venite benedicti Patris mei p.266

Fig. 98. Bonum est confiteri, Einsiedeln, Switzerland (14th century)

Fig. 99. Bonum est confiteri, Antiphonarium Benedictinum Pars aestiva, Austria (1400) p.267

Fig. 100. Transcription of Bonum confiteri est p. 268

Fig. 101. Beati quorum...tecta sunt peccata p. 268 
Fig. 102. Hosanna, Antiphonarium pro Ecclesia Einsidlensi, Switzerland (14th century) p.269

Fig. 103. Asperges me, Graduale Fratrum Minorum, Italy (14th century) ～p.270

Fig. 104. Ave Maria, Antiphonarium Benedictinum Pars aestiva, Austria (1400) ～ p.271

$\begin{array}{ll}\text { Fig. 105. Transcription of Ave Maria } & \text { p.271 }\end{array}$

$\begin{array}{ll}\text { Fig. 106. Sanctus, 15th century, Italy } & \text { p.272 }\end{array}$

$\begin{array}{ll}\text { Fig. 107. Transcription and organum for Sanctus } & \text { p.273 }\end{array}$

Fig. 108. Transcription and organum for Gloria $\quad$ p.274

Fig. 109. Alleluia x, Antiphonarium, Couvent des Cordeliers, Fribourg p p.275

Fig. 110. Transcription and organum for Alleluia $x \quad$ p.276

$\begin{array}{ll}\text { Fig. 111. Victimae Paschali Laudes } & \text { p.277 }\end{array}$

Fig. 112 Transcription and organum for Victimae paschali laudes $\quad$ p.278

Fig. 113. First part of transcription and organum for Te Deum $\quad$ p.279

Fig. 114. Continuation of transcription and organum for Te Deum $\quad$ p.280

$\begin{array}{ll}\text { Fig. 115. Sperent in te } & \text { p.281 }\end{array}$

Fig. 116. First part of transcription and organum for Sperent in te $\quad$ p.282

Fig. 117. Continuation of transcription and organum for Sperent in te p.283

Fig. 118. Last part of Sperent in te, which was not performed $\quad$ p.284

Fig. 119. Gloria Patri et Filio, Einsiedeln, Switzerland (14th century) p.284

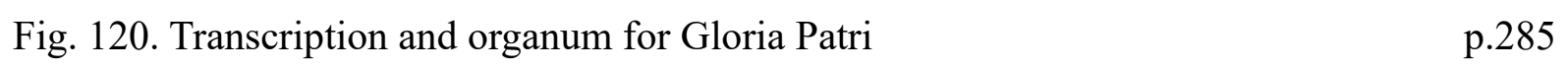

\section{CHAPTER 6}

Fig. 121. Meredith Monk: Solo from Education of the Girlchild (1972). The old woman.p.290

Fig. 122. Meredith Monk: Solo from Education of the Girlchild (1972). The girlchild. p.290

Fig. 123. Meredith Monk: Turtle Dreams (1980) p p.291

Fig. 124. Meredith Monk: Turtle Dreams (1980) p p.291

Fig. 125. The well in the form of an inverted tower in the Quinta da Regaleira p.291

Fig. 126. Meredith Monk: Songs of Ascension (2008) in Ann Hamilton's tower ․ p p $\quad$ p.291

Fig. 127. Laurie Anderson: O Superman (1981) p p.292 


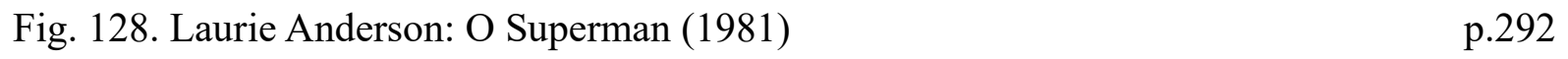

Fig. 129. Pamela Z: Baggage Allowance (2010) p.293

Fig. 130. Pamela Z: Baggage Allowance (2010) p.293

Fig. 131. Cathy Berberian: Stripsody (1966) p.293

Fig. 132. Georges Aperghis: Récitations (1977-78), nº 11 (detail) p p.294

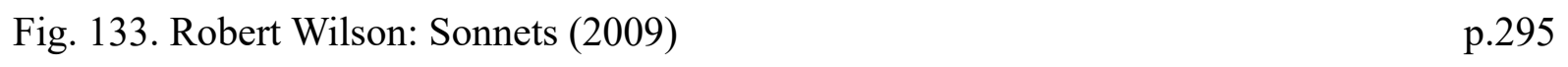

Fig. 134. Robert Wilson: Sonnets (2009) p p.296

Fig. 135. Robert Wilson: Sonnets (2009) p p.296

Fig. 136. Robert Wilson: Claude Debussy's Pelléas et Mélisande (2011) p.296

Fig. 137. Tomaž Pandur: La Divina Commedia - Inferno (2001). The bodies in the water.p.297

Fig. 138. Tomaž Pandur: La Divina Commedia - Inferno (2001). The ladders. p.297

Fig. 139. The Ring (2001): an image of the cursed video tape p.297

Fig. 140. The girl's spirit climbs out of the TV in front of her victim. p.297

$\begin{array}{ll}\text { Fig. 141. The Ring } 2 \text { (2005) p.298 } & \text { p }\end{array}$

Fig. 142. The Ring 2 (2005): the view of the interior of the well from the bottom p.298

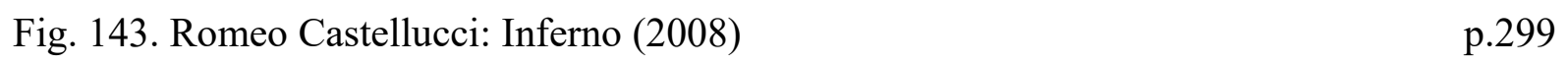

Fig. 144. Romeo Castellucci: Inferno (2008) p p.299

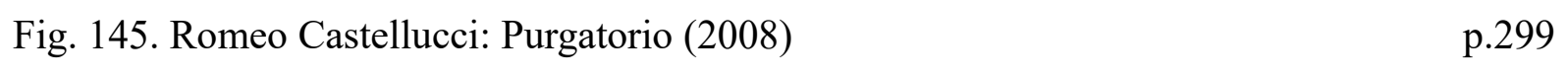

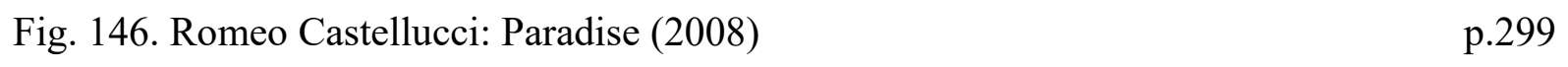

Fig. 147. Romeo Castellucci's Tragedia Endogonidia (L.\#09 London) p.299

Fig. 148. Romeo Castellucci's Tragedia Endogonidia (L.\#09 London) p.299

Fig. 149. Romeo Castellucci's Tragedia Endogonidia (L.\#09 London) p.300

Fig. 150. Romeo Castellucci's Tragedia Endogonidia (L.\#09 London) p.300

Fig. 151. Dir. Cathie Boyd: Optical Identity by Theatre Cryptic and T'ang Quartet (2007)p.300

Fig. 152. Optical Identity (2007) p.300

Fig. 153. Beckett: Act without words (1957) p.301

Fig. 154. Beckett: Happy Days (1961) p.301

Fig. 155. Beckett: Play (1964) p.301 
Fig 156. Beckett: Come and Go (1966) p.301

Fig. 157. Le Roy: Self Unfinished (1998) p p.303

Fig. 158. Le Roy: Self Unfinished (1998) p p.303

Fig. 159. Le Roy: Low Pieces (2010) p p.303

Fig. 160. Le Roy: Low Pieces (2010) p p.303

Fig. 161. Sasha Waltz: Körper (2000) p.303

Fig. 162. Sasha Waltz: Körper (2000) p.303

Fig. 163. Anne Teresa de Keersmaeker: Piano Music (Fase, 1982) p.304

Fig. 164. Anne Teresa de Keersmaeker: Come Out (Fase, 1982) p.304

Fig. 165. Hibernia: Multitudo languentium (2010) p.305

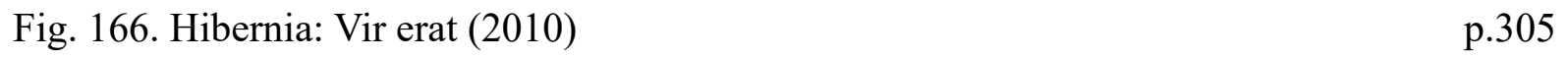

Fig. 167. Purcell's The Indian Queen (2012), B'Rock, dir. Jan Decorte p.306

Fig. 168. Arthur (2014). B'Rock, et. al. Dir. Paul Koek p p.306

$\begin{array}{ll}\text { Fig. 169. Working on the beast sounds in Audacity } & \text { p.309 }\end{array}$

Fig. 170. A first sketch for Inferno's composition and timing of the soundtrack p.310

Fig. 171. First half of the final soundtrack of Inferno p.314

Fig. 172. Second half of the final soundtrack of Inferno p.314

Fig. 173. The trope in Beati pacifici p.319

Fig. 174. First half of the final soundtrack of Purgatory p.322

Fig. 175. Second half of the final soundtrack of Purgatory $\quad$ p.322

Fig. 176. Final soundtrack of Paradise p.324

Fig. 177. Changing in between the three parts was difficult due to the headset microphone p.326

Fig. 178. Visibility of the radio transmitter p.326

$\begin{array}{ll}\text { Fig. 179. The faceless body carressing her hair } & \text { p.327 }\end{array}$

$\begin{array}{ll}\text { Fig. 180. Rehearsing the beginning of Inferno } & \text { p.328 }\end{array}$

$\begin{array}{ll}\text { Fig. 181. The Sour Rain } & \text { p.330 }\end{array}$

$\begin{array}{ll}\text { Fig. 182. The Fight } & \text { p.330 }\end{array}$

$\begin{array}{ll}\text { Fig. 183. The Crucifixion } & \text { p.332 }\end{array}$ 
Fig. 184. The Fall

Fig. 185. Rehearsing the scene of the flame

Fig. 186. Decay

Fig. 187. Final Posture of Inferno

Fig. 188. The boat scene at the beginning of Purgatory

Fig. 189. Waiting and singing in Ante-Purgatory

Fig. 190. The Crucifixion movement

Fig. 191. The folded posture

Fig. 192. The Beast Within p.338

Fig. 193. Pride p.339

Fig. 194. Doing her penance p.339

Fig. 195. Envy p.339

Fig. 196. Wrath p.340

Fig. 197. Submission to God p.340

Fig. 198. The running slothful soul p.340

Fig. 199. The avaricious soul p.340

Fig. 200. Gluttony p.341

Fig. 201. The end of lust p.342

Fig. 202. Penance of the avaricious p.343

Fig. 203. Gloria in Excelsis Deo p.343

Fig. 204. The crossing of the fire p.344

Fig. 205. Hosanna p.345

Fig. 206. Asperges me p.345

Fig. 207. Setting up the lights p.347

Fig. 208. Rehearsal of the hand movements for Sanctus p.348

Fig. 209. Sanctus

p.348

Fig. 210. The final gesture p.348

Fig. 211. Rehearsal of the circular spinning movement p.349 
Fig. 212. The type of lights used for the diagonal light of Victimae and side light for Gloria and Gloria Patri

Fig. 213. Gloria

Fig. 214. Victimae Paschali Laudes p.350

Fig. 215. The backlighting p.350

Fig. 216. Alleluia $\mathrm{x}$ p.351

Fig. 217. Moving out of the light p.351

Fig. 218. Rehearsing arm movements for Te Deum p.351

Fig. 219. Rehearsing arm movements p.351

Fig. 220. Rehearsal with the shadow pattern on the floor p.351

Fig. 221. Gloria Patri et Filio p.352

Fig. 222. Leaving slowly the beam p.352

Fig. 223. Hosanna p.353 


\section{BIBLIOGRAPHY}

\section{Early Music}

Adkins, C. "Monochord." Grove Music Online. Oxford Music Online. Oxford University Press, http://www.oxfordmusiconline.com/subscriber/article/grove/music/18973

Aubert, E., "Locating the Sound of the Medieval Voice - an Analytical Framework", In Search of the Medieval Voice: Expressions of Identity in the Middle Ages, ed. Bleach, L; Närä, K.; Prosser, S.

(Newcastle, 2009)

Berentsen, N., "From Treatise to Classroom: Teaching Fifteenth-Century Improvised Counterpoint", Journal of the Alamire Foundation 6/2 - 2014, p.221-242

Burstyn, S., "Contrapuntal texture in non-learned medieval polyphony”, ed. Meyer, C., Polyphonies de tradition orale: histoire et traditions vivantes (Paris: Éditions Creaphis, 1994), p. 160-169

Gutton, J.-P., Bruits et sons dans notre histoire (Paris, 2000)

Haar, J. "Music of the spheres." Grove Music Online. Oxford Music Online. Oxford University Press, http://www.oxfordmusiconline.com/subscriber/article/grove/music/1944

Haskell, Harry. "Early music." Grove Music Online. Oxford Music Online. Oxford University

Press.Web. http://www.oxfordmusiconline.com/subscriber/article/grove/music/46003 [Accessed 03 Jan 2015].

Haynes, B., The End of Early Music: A Period Performer's History of Music for the Twenty-First Century. (USA: Oxford University Press, 2007)

Herlinger, J. "Marchetto da Padova." Grove Music Online. Oxford Music Online. Oxford University Press, http://www.oxfordmusiconline.com/subscriber/article/grove/music/17738

Hiley, D. "Quilisma." Grove Music Online. Oxford Music Online. Oxford University Press, http://www.oxfordmusiconline.com/subscriber/article/grove/music/22699

Hiley, D. "Oriscus." Grove Music Online. Oxford Music Online. Oxford University Press, http://www.oxfordmusiconline.com/subscriber/article/grove/music/20467

Hiley, D. "Plica." Grove Music Online. Oxford Music Online. Oxford University Press, http://www.oxfordmusiconline.com/subscriber/article/grove/music/21942

Kenneth Levy, et al. "Plainchant." Grove Music Online. Oxford Music Online. Oxford University Press, http://www.oxfordmusiconline.com/subscriber/article/grove/music/40099pg5 [accessed 29-11, 2014]

Kivy, P.. Authenticities (Ithaca: Cornell University Press, 1995) 
Lindley, M. "Pythagorean intonation." Grove Music Online. Oxford Music Online. Oxford University Press, http://www.oxfordmusiconline.com/subscriber/article/grove/music/22604

Mayer Brown, H. et al. "Performing practice." Grove Music Online. Oxford Music Online. Oxford University Press, http://www.oxfordmusiconline.com/subscriber/article/grove/music/40272pg1.

McGee, T. J. The Sound of Medieval Song. Ornamentation and vocal style according to the treatises (Oxford, 1998)

Pérès, M., Les Voix du Plain-chant (Paris, 2001)

Philip, R. Early Recordings and Musical Style (Cambridge, 1991)

Sherman, B.D.,"Authenticity in Musical Performance" from The Encyclopedia of Aesthetics, ed.

Michael J. Kelly (New York, 1998)

Sherman, B.D., Inside Early Music: Conversations with Performers (Oxford, 1997)

Summerly, J. "Vocal Performance before c. 1430", The Cambridge History of Musical Performance, ed. Lawson, C. and Stowell, R. (Cambridge, 2012)

Taruskin, R., "Performance Practice", The Oxford History of Western Music, Vol. 2 (Oxford, 2005)

Taruskin, Text and Act (New York, 1995)

Van Deusen, N., The Cultural Context of Medieval Music, p.105-107

Walker, P., On Identifying and Performing the Chants in Dante's Divine Comedy

(http://www.worldofdante.org/comedy/dante/musicEssay) [Accessed 28-4 2014]

Wilson, D.F., Music of the Middle Ages - Style and Structure (New York, 1990)

\section{Dante}

Baranski, Z., "The Epistle to Can Grande”, Ed. Minnis, A. and Johnson, I., The Cambridge History of Literary Criticism (Cambridge University Press, 1996), p.583-589

Baranski, Z. "Experimentation and (self-)exegesis", ed. Minnis, A. and Johnson I., The Cambridge History of Literary Criticism Volume 2: The Middle Ages (Cambridge University Press, 2005), p. 559582 .

Botterill, S., "The Trecento commentaries on Dante's Commedia", Ed. Minnis, A. and Johnson, I., The Cambridge History of Literary Criticism (Cambridge, 1996), p.590-611

Dante Alighieri, Il Convivio, translation in English by T. Kline, http://www.poetryintranslation.com/PITBR/Italian/ConvivioII.htm

Dante, Vita Nova, online available at http://etcweb.princeton.edu/dante/pdp/vnuova.html, Testo critico della Società Dantesca Italiana; Florence: Società Dantesca Italiana, 1960. Ed. by Michele Barbi. 
Translation in English by Mark Musa.

Dante Alighieri, Convivio (II, i, 3-41), Edizione Nazionale (Florence, 1995), online available at http://etcweb.princeton.edu/dante/pdp/convivio.html, with translation of Lansing, R.: Dante's "Il Convivio" (New York: Garland, 1990).

Dante, De vulgari eloquentia, online available at http://etcweb.princeton.edu/dante/pdp/vulgari.html, Testo critico della Società Dantesca Italiana (Florence, 1960). Ed. by Pio Rajna. Translation by Steven Botterill.

Dante Alighieri, Epistle to Cangrande, Ed. Ermenegildo Pistelli, Testo critico della Societa' Dantesca Italiana (Florence, 1960).

Frisardi, Andrew, “The Commedia as Cosmos”, Temenos Academy Review 14 (2011), p.49-79

Gragnolati, M., Experiencing the Afterlife: Soul and Body in Dante and Medieval Culture (Indiana: University of Notre Dame, 2005)

Lansing, R.H. and Barolini, T., "Devils", The Dante Encyclopedia (New York and London, 2000)

Moevs, C., The Metaphysics of Dante's Comedy (New York, 2005)

Pertile, L., "Dante”, Ed. P. Brand and L. Pertile, The Cambridge History of Italian Literature, $2^{\text {nd }}$

Edition (Cambridge, 1999), p. 37-69

Raffa, G.P., Danteworlds, http://danteworlds.laits.utexas.edu/

Raffa, G.P., The Complete Danteworlds (University of Chicago Press, 2009)

Mazzotta, G., "Dante in Translation”, Yale Online lectures (2008), http://oyc.yale.edu/italian-languageand-literature/ital-310

\section{Music and Dante}

Bent, M. "Songs without music in Dante's De vulgari eloquentia: cantio and related terms", in "Et facciam dolçi canti". Studi in onore di Agostino Ziino in occasione del suo $65^{\circ}$ compleanno. ed. Bianca Maria Antolini, Teresa M. Gialdroni, Annunziato Pugliese (Lucca: LIM- Libreria Italiana Musicale, 2004), vol. I, pp. 161-181.

Ciabattoni, F., Dante's Journey to Polyphony (Toronto, 2010)

Ciabattoni, F., "Musical Ways around Ineffability (Paradiso 10-15)”, Dante Studies, CXXXI, 2013 Mahrt, W.P. "Dante's musical progress through the Commedia", in The echo of music. Essays in honor of Marie Louise Göllner, ed. Sullivan, B (Detroit, 2004)

Stillman, M., "The Music of Dante's Purgatorio", in Hortulus: the Online Graduate Journal of Medieval Studies Vol.1, No.1 (2005) 


\section{Dante and mise-en-scene}

Braida, A. and Calè, L., Dante on View (Ashgate: Aldershot, 2007)

\section{Middle Ages}

Eco, U. Art and Beauty in the Middle Ages (Yale University Press, 1986)

Van Deusen, N., "They All Read the Same Books": A Book-Bag from Antiquity", The Cultural Context of Medieval Music, p.105-122

\section{Music theatre and other theatrical forms}

Botella Mestres, M., De la escultura al teatro, del teatro a la escultura: influencias y confluencias (Valencia, 2005)

Coppens, E. De balans tussen vorm en inhoud, Master thesis at University of Amsterdam, 1998

Coussens, E., "Tweestromenland tussen repertoire en creatie: muziektheater vanuit de blik van de regisseur", Courant 2009/89, pp. 23-32

Hübner, F., Shifting Identities: the Musician as Theatrical Performer, $\mathrm{PhD}$ thesis at University of Leiden, 2013

Rebstock, M. and Roesner, D., Composed Theatre: Aesthetics, Practices, Processes (Intellect Ldt: Bristol, 2012)

Roesner, D., Musicality in Theatre: Music as Model, Method and Metaphor in Theatre-Making (Ashgate: Surrey, 2014)

Salzman, E. and Desi, T., The New Music Theater: Seeing the Voice, Hearing the Body (Oxford University Press: New York, 2008)

Sanchez, J.A., Dramaturgias de la imagen (Universidad de Castilla-La Mancha, Cuenca, 1999) Sanchez, J. A., "Nuevos espacios para el arte", Practica artistica y politicas culturales. Algunas propuestas desde la universidad. (Universidad de Murcia, 2003)

\section{Miscellaneous}

Cobussen, M., “The Trojan Horse. Epistemological Explorations Concerning Practice Based Research." Dutch Journal of Music Theory 12/1 (2007): pp. 18-33 
Hawking, S. and Mlodinow, L., The Grand Design (New York, 2010)

Held, K., Treffpunkt Platon (Stuttgard, 1990)

Östersjö, S., SHUT UP 'N' PLAY! Negotiating the Musical Work, PhD Thesis at Lund University, 2008

Perales, C.D., Electroacústica: la expresión del gesto sonoro, PhD Thesis at Universitat Politècnica de València, 2011 


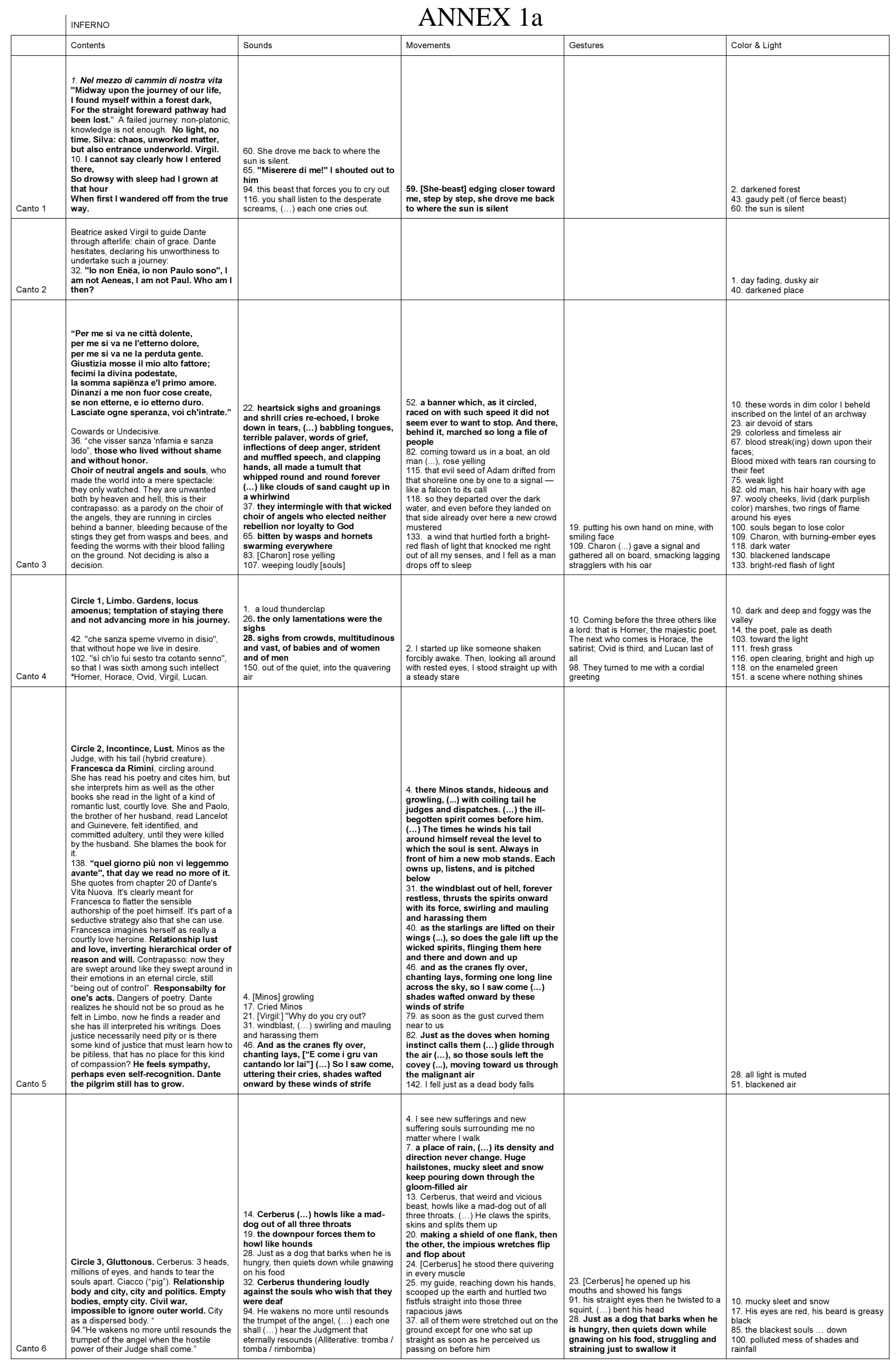




\begin{tabular}{|c|c|c|c|c|c|}
\hline Canto 7 & 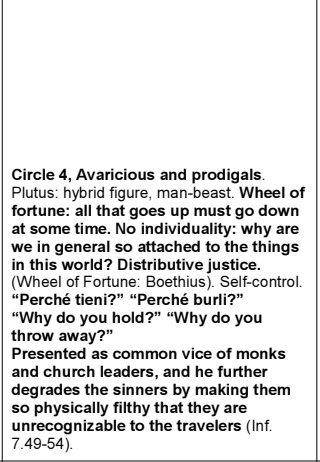 & 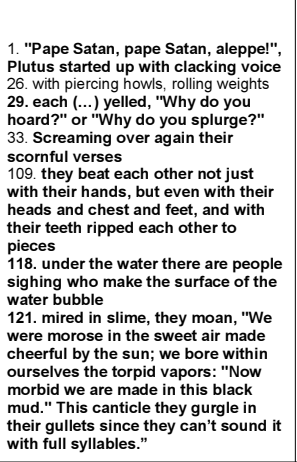 & 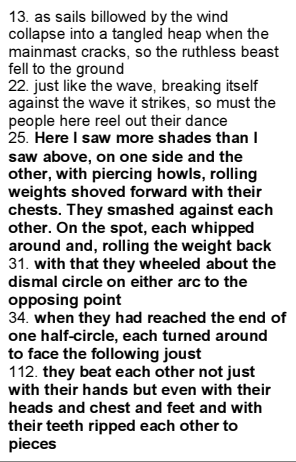 & $\begin{array}{l}\text { 111. people smeared with mud, all } \\
\text { naked, their faces lined with rage }\end{array}$ & $\begin{array}{l}\text { 103. the water was far darker than black } \\
\text { dye, murky waves } \\
\text { 106. gray slopes }\end{array}$ \\
\hline Canto 8 & 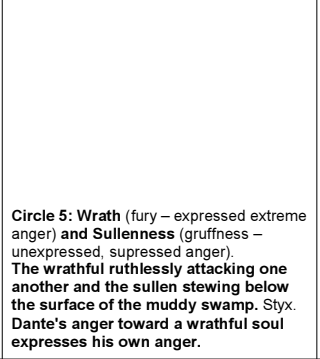 & 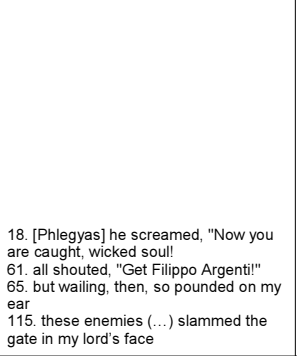 & 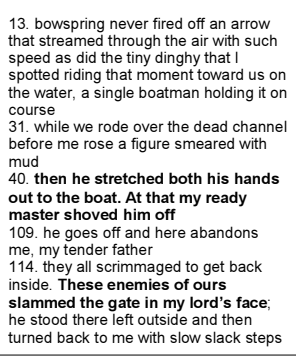 & 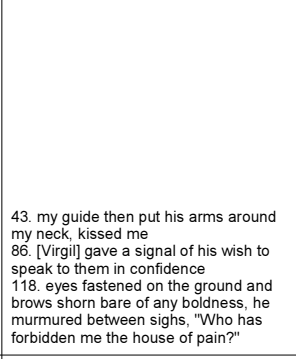 & 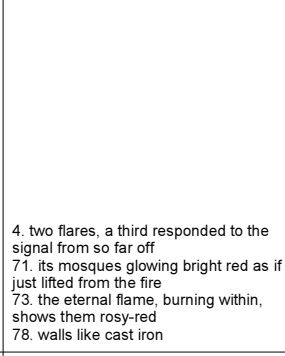 \\
\hline Canto 9 & 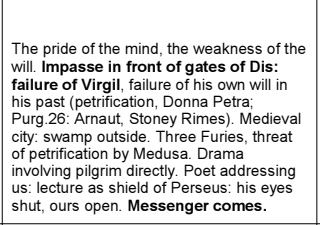 & 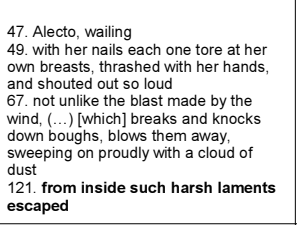 & 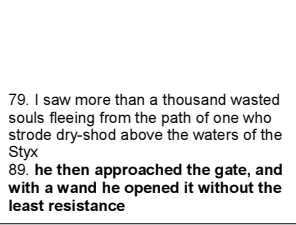 & $\begin{array}{l}\text { 49. with her nails each one tore at her } \\
\text { ow breasts, thrashed with her hands } \\
\text { 82. often he brushed the foul air from } \\
\text { his face, rhythmically moving his left } \\
\text { hand out in tront, and only with that } \\
\text { bother appeared weary. Easily l knew } \\
\text { that he was sent from heaven, and I } \\
\text { turned to my master, but he signaled } \\
\text { that I stay still and bow down there to } \\
\text { him }\end{array}$ & 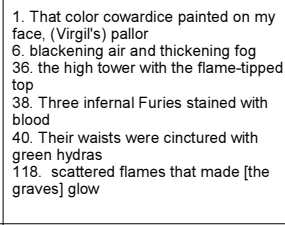 \\
\hline Canto 10 & 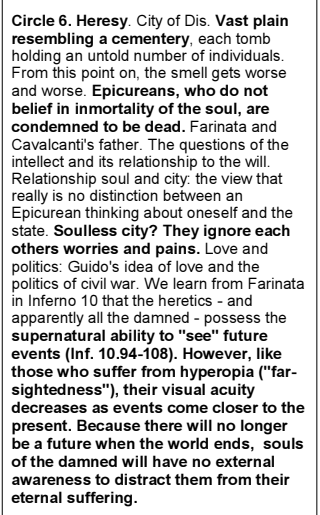 & 67. Suddenly he stood and cried out & 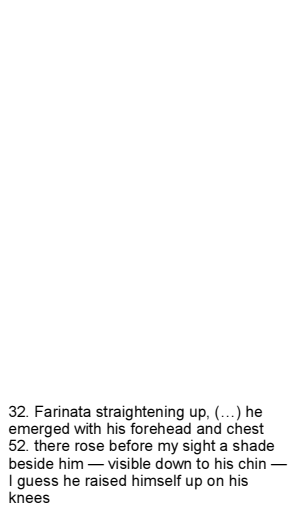 & 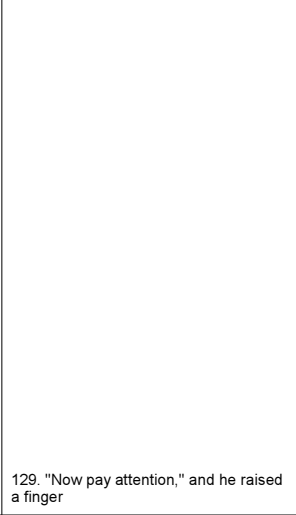 & \\
\hline Canto 11 & 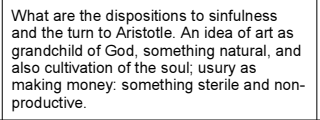 & & & & 73. red-hot city \\
\hline Canto 12 & $\begin{array}{l}\text { Circle 7. Violence. Hybrid figures: } \\
\text { Minotaur, Centaurs. River of boiling blood. } \\
\text { Dual impulses: beastly and humanly. } \\
\text { Tyrans, tyranny of f fixed way of teaching: } \\
\text { teaching must give freedom to move to } \\
\text { any direction. Violence against others. }\end{array}$ & $\begin{array}{l}\text { 88. a spirit came from singing alleluiai to } \\
\text { commmission me } \\
101 \text { the bubling crimson river where } \\
\text { boiling souls raised their piercing cries }\end{array}$ & 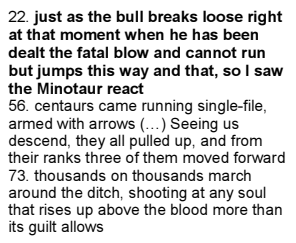 & & 46. river of blood boiling \\
\hline Canto 13 & 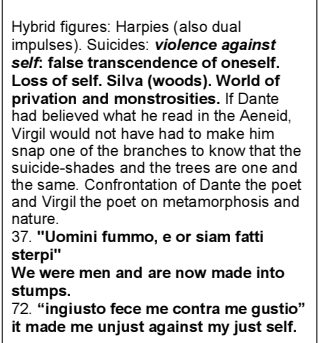 & 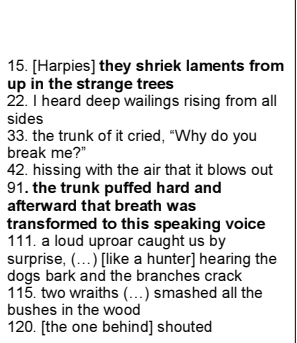 & 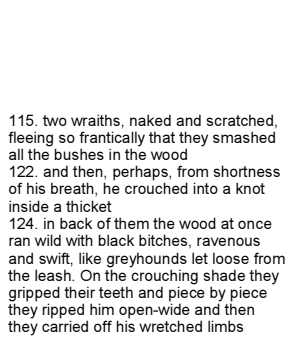 & $\begin{array}{l}\text { 130. immediately my escort took my } \\
\text { hand and led me forward to the bush }\end{array}$ & $\begin{array}{l}\text { 4. No leaves of green but of a blackish } \\
\text { color } \\
\text { 34. in thad darkened with its blood } \\
\text { 124. black bitches }\end{array}$ \\
\hline
\end{tabular}




\begin{tabular}{|c|c|c|c|c|c|}
\hline Canto 14 & 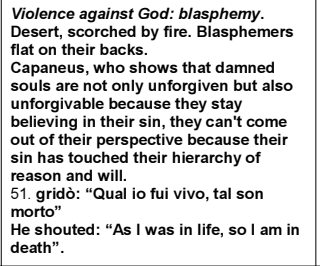 & 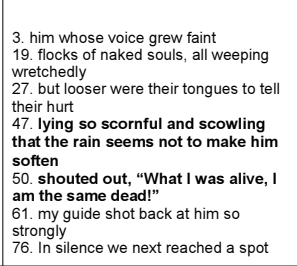 & 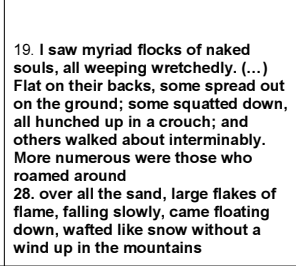 & $\begin{array}{l}\text { 40. Restlessly the dance of wretched } \\
\text { hands went on and on, on this side } \\
\text { and on that, beating off the freshly } \\
\text { falling flames }\end{array}$ & $\begin{array}{l}\text { 28. large flakes of flame, falling (...) like } \\
\text { snow } \\
\text { 77. narrow brook whose redness makes } \\
\text { me still shudder with fear }\end{array}$ \\
\hline Canto 15 & 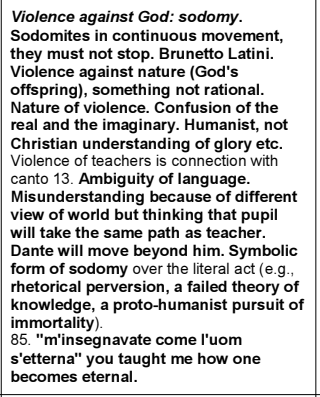 & & & $\begin{array}{l}\text { 23. one who grasped me by the hem } \\
\text { 25. he stretched out his arm to me } \\
\text { 29 bending down my face to be with } \\
\text { his, I asked him, "Ser Brunetto, are } \\
\text { you here?" }\end{array}$ & $\begin{array}{l}\text { 2. the river's smoke throws up a shadon } \\
\text { which screnens the banks and water } \\
\text { trom the fire } \\
\text { 25. his burnt-out features (Brunetto) }\end{array}$ \\
\hline Canto 16 & $\begin{array}{l}\text { Geryon, symbol of fraud (a creature } \\
\text { with h humuman honests face, reptilian } \\
\text { body, and scorion's tail), as a server. } \\
\text { Downward spiral. }\end{array}$ & 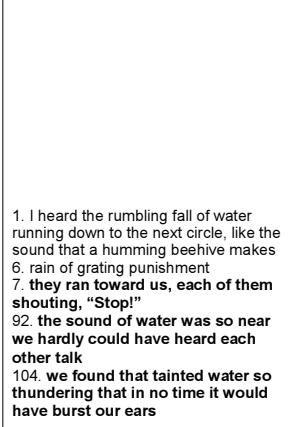 & 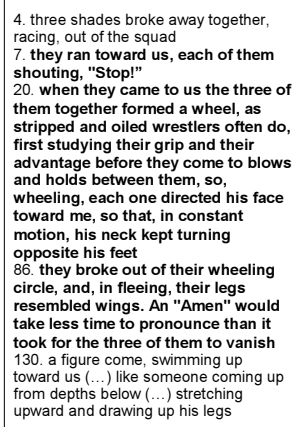 & & $\begin{array}{l}\text { 103. tainted water } \\
\text { 130. thick and darkened air }\end{array}$ \\
\hline Canto 17 & 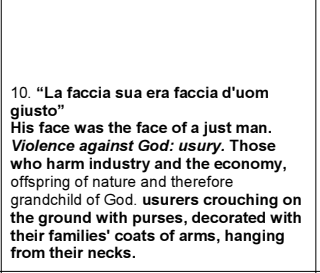 & 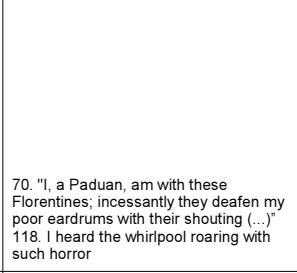 & 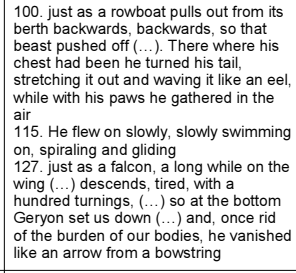 & 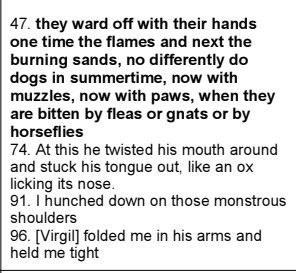 & 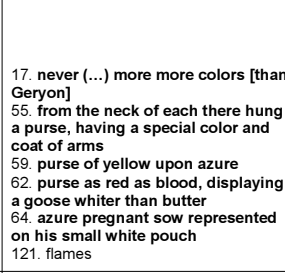 \\
\hline Canto 18 & 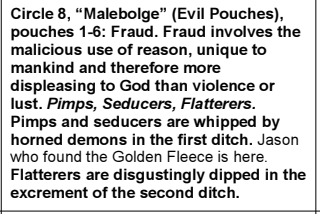 & $\begin{array}{l}\text { 35. horned devils with their huge long } \\
\text { whips cruelly lashing those sinners from } \\
\text { behind } \\
\text { 103. we heard people (..) whining } \\
\text { and snorting gruffly from their } \\
\text { snouts and whacking themselves } \\
\text { with flat open palms }\end{array}$ & 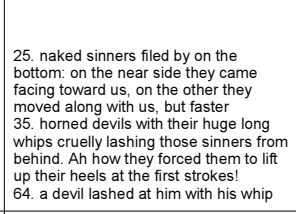 & 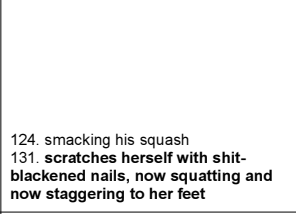 & $\begin{array}{l}\text { 1. Malabolge, all made of stone the } \\
\text { color of iron ore } \\
\text { 106. The bank were coated with a } \\
\text { slimin mold } \\
\text { 113. poople plunged in excrement, as if } \\
\text { it had boen dumped from men's latrines }\end{array}$ \\
\hline Canto 19 & 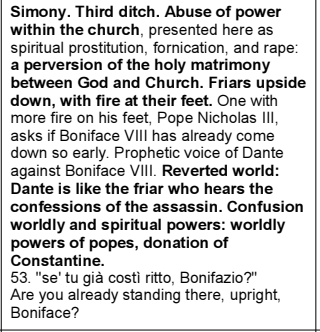 & 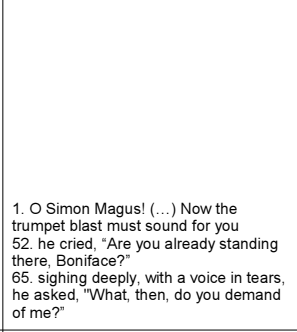 & 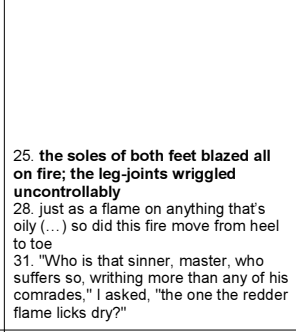 & $\begin{array}{l}\text { 124. he took me within both his arms } \\
\text { and, when he held me wholy to his } \\
\text { breast, climbed up the path }\end{array}$ & $\begin{array}{l}\text { 14. livid rockface } \\
\text { 28. flame, fire [on feet] } \\
\text { 33. the one the redder flame licks dry }\end{array}$ \\
\hline Canto 20 & 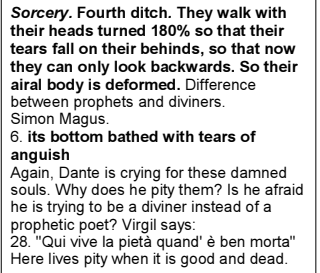 & 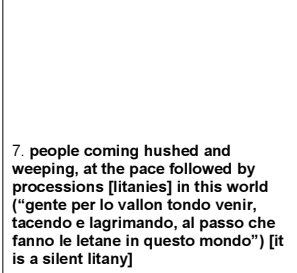 & 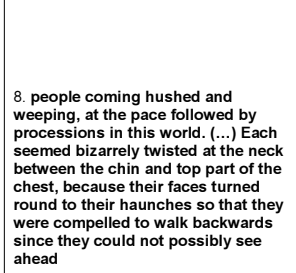 & & 107. brown shoulders \\
\hline
\end{tabular}




\begin{tabular}{|c|c|c|c|c|c|}
\hline Canto 21 & 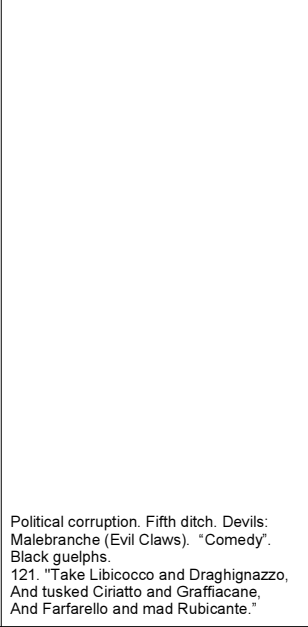 & 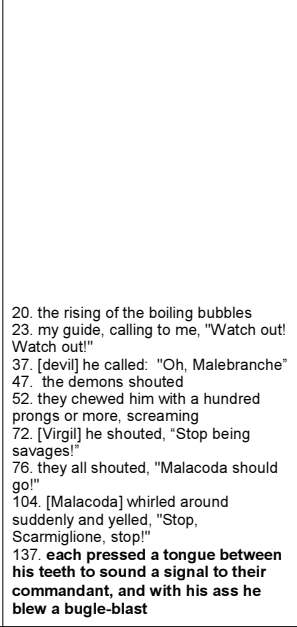 & 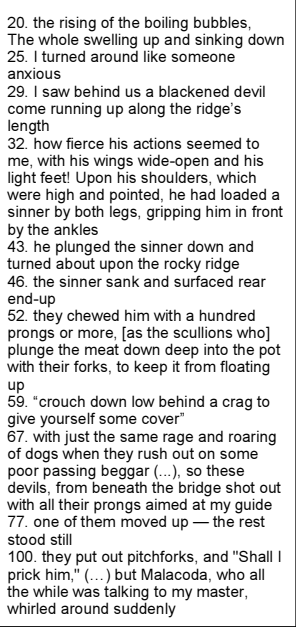 & $\begin{array}{l}\text { 130. they grind their teeth } \\
\text { 131. they threaten harm with their } \\
\text { fierce looks }\end{array}$ & $\begin{array}{l}\text { 4. another gap of Malebolge (...) } \\
\text { awesomely dark } \\
\text { 17. a thick and sticky pitch which glue- } \\
\text { coated the banks ove every side } \\
\text { 29. blackened devil }\end{array}$ \\
\hline Canto 22 & 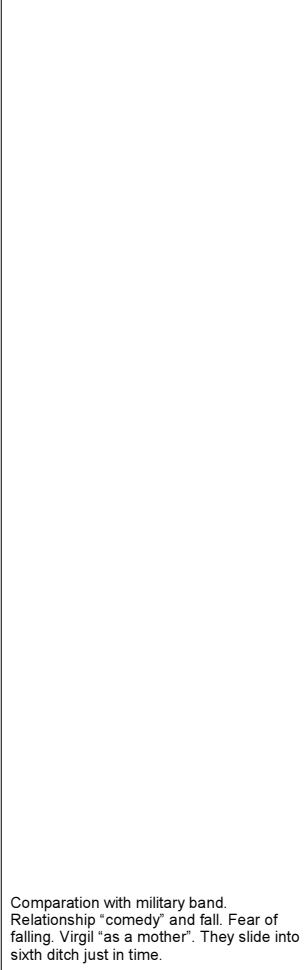 & 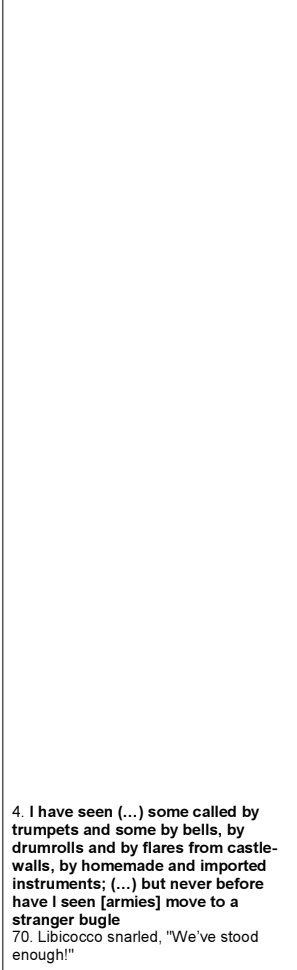 & 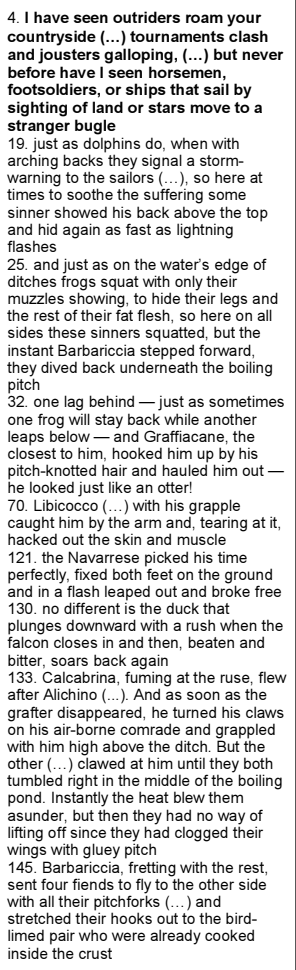 & 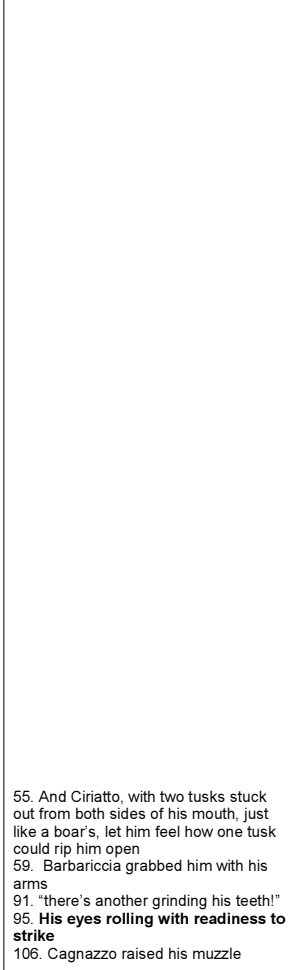 & \\
\hline Canto 23 & $\begin{array}{l}\text { Hypocrisy. Sixth ditch. The bright } \\
\text { golden cloaks of Dante's hypocrites } \\
\text { conceal heavy lead on the inside. The } \\
\text { devils lied to Dante and Virgil, resonates } \\
\text { with hypocrisy. Caiaphas lies on the } \\
\text { ground, crucified, trampled by these } \\
\text { heavy souls. }\end{array}$ & $\begin{array}{l}\text { 112. breathing hard into his beard with } \\
\text { sighs }\end{array}$ & 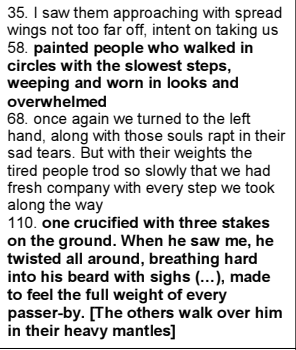 & 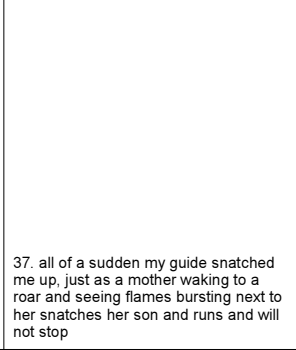 & 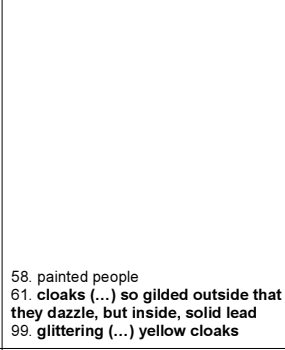 \\
\hline Canto 24 & $\begin{array}{l}\text { Circle 8, pouches 7-10: More Fraud. } \\
\text { Theft. Endless cycle of phoenix-like } \\
\text { proces by snakes: thereare robbed of } \\
\text { their "lives" over and over again. of }\end{array}$ & $\begin{array}{l}\text { 65. arose a voice that seemed } \\
\text { incapable of forming words } \\
69 \text {. whouever spoke appeared to be } \\
\text { moved to anger } \\
\text { 117. sighing as htares }\end{array}$ & 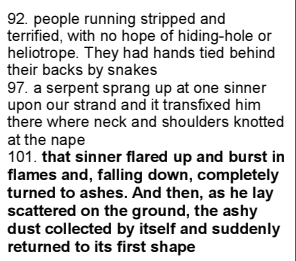 & $\begin{array}{l}\text { 22. [Virgill he opened wide his arms } \\
\text { (.), then he took hold of me, (...) lifting } \\
\text { me toward the dome of one huge } \\
\text { boulder } \\
\text { 32. we could hardly - he, light, and I, } \\
\text { with help - handhold by handhold, } \\
\text { scale the jutting rocks } \\
\text { 112. As one who falls in a fitit, (...) he } \\
\text { lifts himself up, and looks around, } \\
\text { (...) sighing as he stares }\end{array}$ & 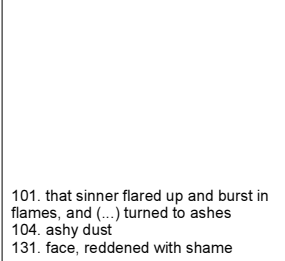 \\
\hline
\end{tabular}




\begin{tabular}{|c|c|c|c|c|c|}
\hline Canto 25 & 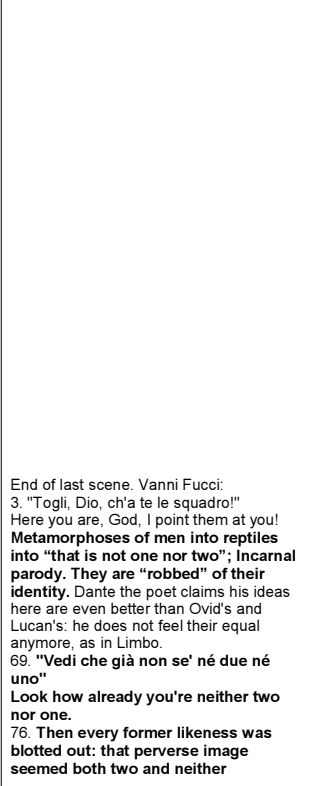 & $\begin{array}{l}\text { 2. cried, "Take that, God, I screwed } \\
\text { them againstyoul", } \\
\text { 18. [Centautr shouting, "Where, where } \\
\text { is that bititer beast?"? } \\
\text { 37. [three spirits] they shouted up, "Who } \\
\text { are ouu? } \\
\text { 67. each crying out, "O Agnello, how } \\
\text { you changel Look! already you are } \\
\text { neither two nor one." } \\
\text { 136. the soul that had been turned } \\
\text { into a beast, hissing, filied off along } \\
\text { the gully, fast, and after him the other } \\
\text { speaking sputters }\end{array}$ & 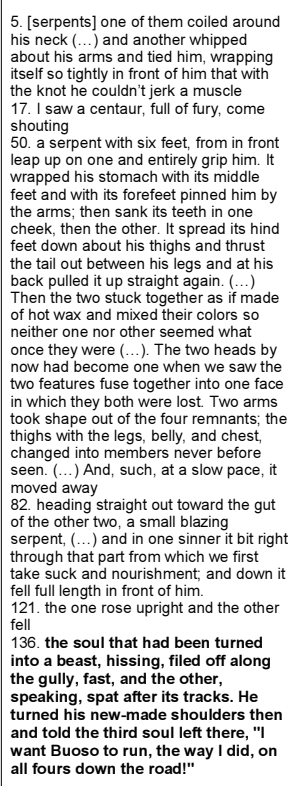 & 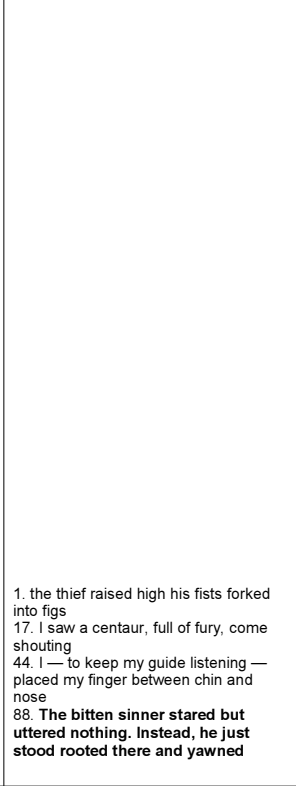 & 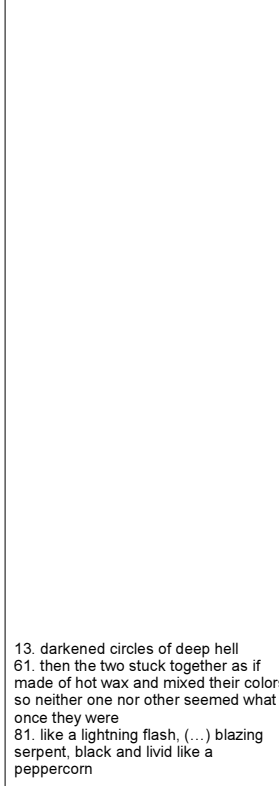 \\
\hline Canto 26 & 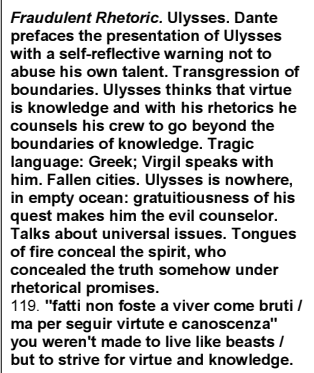 & 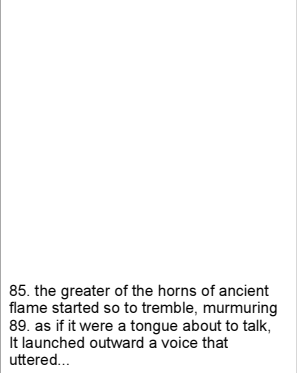 & 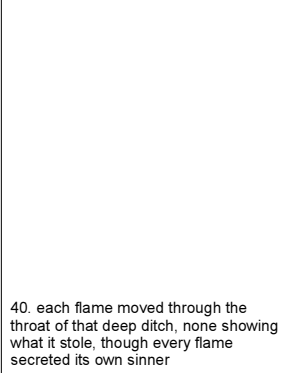 & & $\begin{array}{l}\text { 27. [like) firefilies, glittering below } \\
\text { 31. so many flames }\end{array}$ \\
\hline Canto 27 & 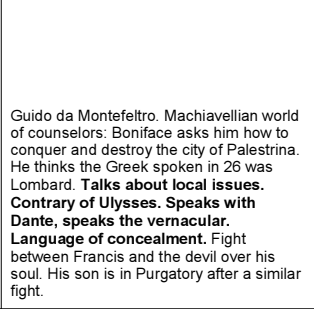 & 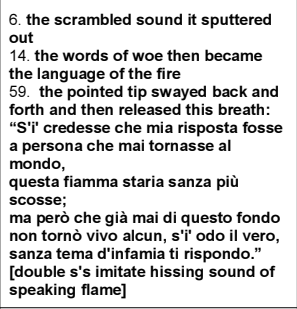 & & & \\
\hline Canto 28 & 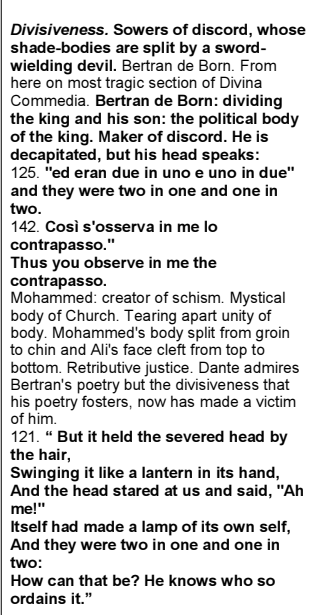 & $\begin{array}{l}\text { 96. shouting, "Here's the one, but he } \\
\text { doesn't talkk } \\
\text { 106. cried out }\end{array}$ & $\begin{array}{l}\text { 61. With one foot lifted in the air to go } \\
\text { (...) then set the foot back on the ground } \\
\text { and left } \\
\text { 110. the sinner (...) curried away like } \\
\text { one gone mad with grief }\end{array}$ & 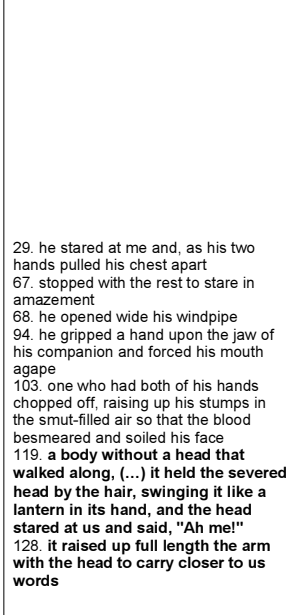 & 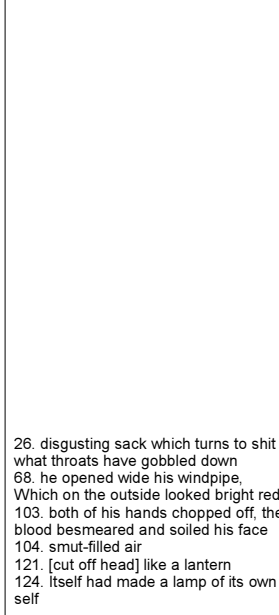 \\
\hline
\end{tabular}




\begin{tabular}{|c|c|c|c|c|c|}
\hline Canto 29 & 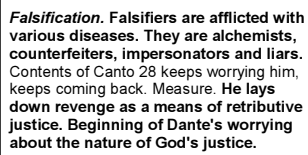 & $\begin{array}{l}\text { 43. I was assaulted by weird volleying } \\
\text { cries }\end{array}$ & $\begin{array}{l}\text { 67. some lay on their stomachs, } \\
\text { some on the shoulders of another } \\
\text { sinner, some hauled themselves on } \\
\text { hands and knees along the careworn } \\
\text { roadway }\end{array}$ & $\begin{array}{l}\text { 79. these two scratch themselves } \\
\text { with nails over and over }\end{array}$ & \\
\hline Canto 30 & 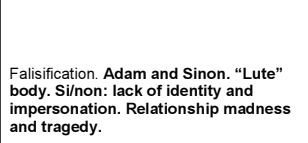 & $\begin{array}{l}\text { 26. [two shades] biting and running } \\
\text { 49. one sinner there shaped like a } \\
\text { lute } \\
\text { 103. The paunch lof the lute-like } \\
\text { figure Master Adam] reverberated } \\
\text { like arum, and Master adam } \\
\text { smashed him in the face }\end{array}$ & $\begin{array}{l}\text { 26. the two shadows I saw, stripped } \\
\text { and pallid, biting and running in the } \\
\text { selfsame way a hog behaves when } \\
\text { let out of the sty. One came straight } \\
\text { at Capocchio and sank his tusks into } \\
\text { his scruff and, dragging him, scraped } \\
\text { his stomach against the stony floor }\end{array}$ & $\begin{array}{l}\text { 102. punched his fist at Adam's } \\
\text { streteched-out paunch } \\
\text { tof and Master Adam smashed him in } \\
\text { the face }\end{array}$ & $\begin{array}{l}\text { 25. two shades I saw, stripped and } \\
\text { pallid }\end{array}$ \\
\hline Canto 31 & 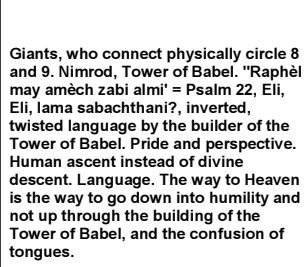 & 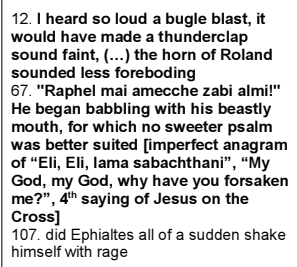 & & 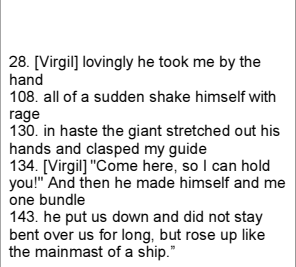 & $\begin{array}{l}\text { 2. it made the blood rush to both my } \\
\text { cheeks } \\
\text { 10. Iess than night and less than day } \\
\text { 37. thick dark atmosphere }\end{array}$ \\
\hline Canto 32 & 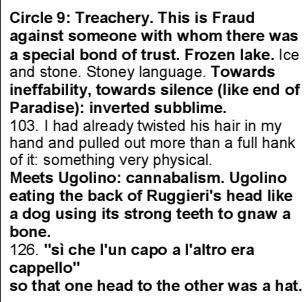 & 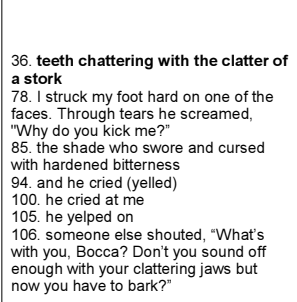 & $\begin{array}{l}\text { 77. moving among the heads, I struck } \\
\text { my foot hard on one of the faces }\end{array}$ & 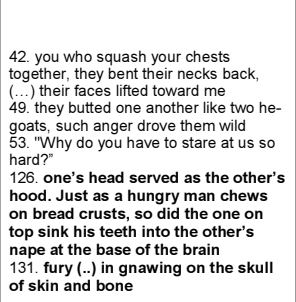 & 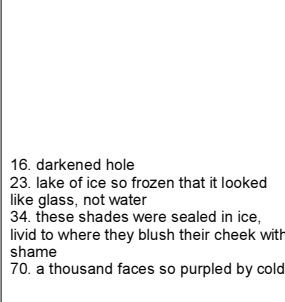 \\
\hline Canto 33 & 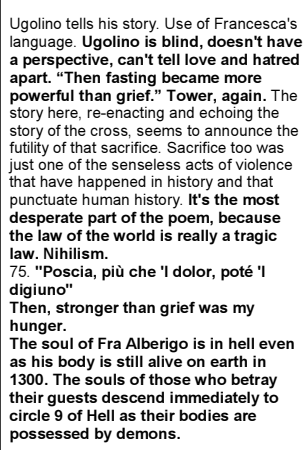 & 109. one ( $(\ldots)$ cried out to us & & 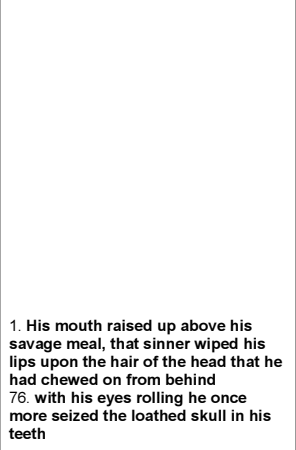 & 97. tears, like a mask of crystal \\
\hline Canto 34 & 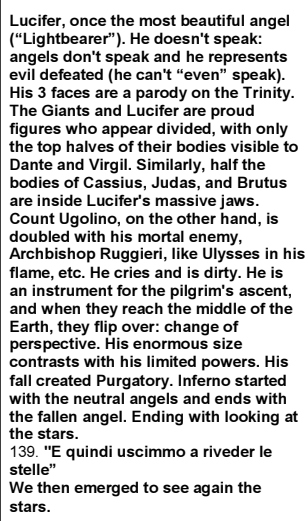 & 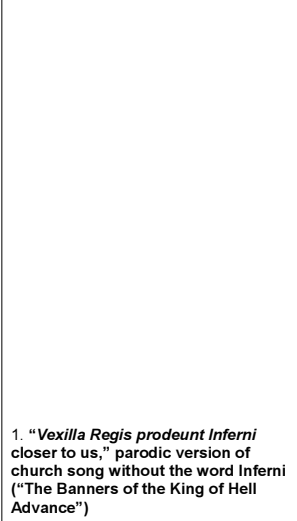 & 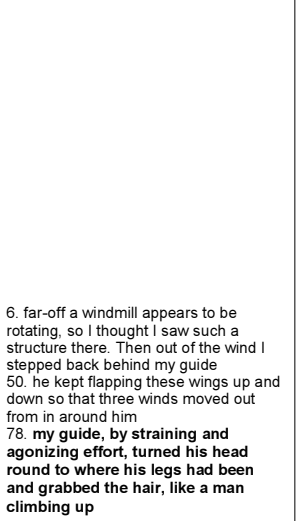 & 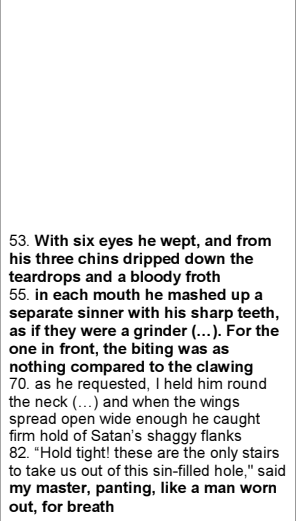 & 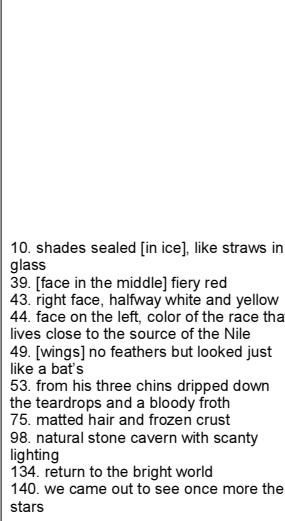 \\
\hline
\end{tabular}




\begin{tabular}{|c|c|c|c|}
\hline 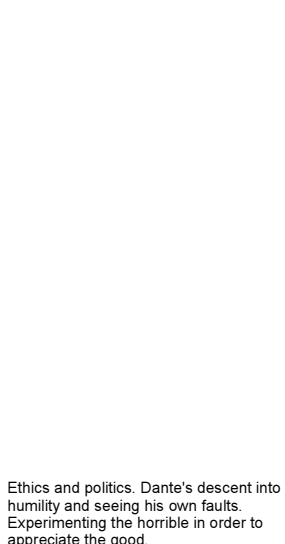 & 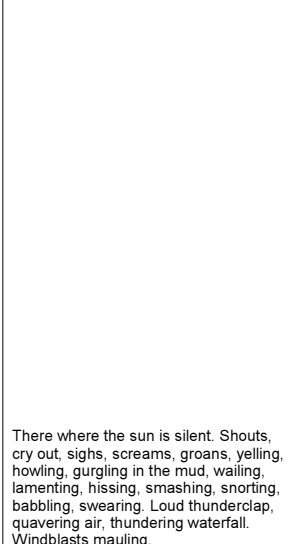 & 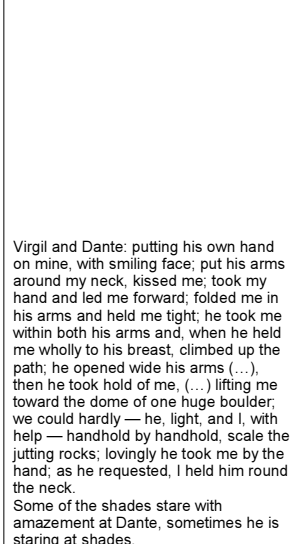 & 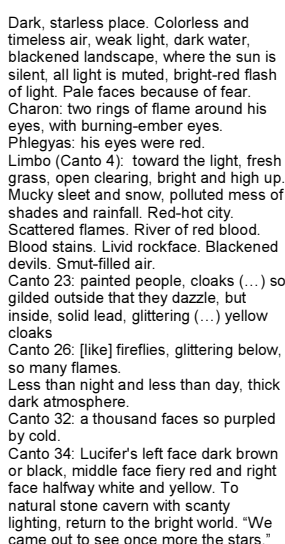 \\
\hline
\end{tabular}


ANNEX 1b

\begin{tabular}{|c|c|c|c|c|c|}
\hline & \multicolumn{5}{|l|}{ PURGATORIO } \\
\hline & Contents & Sounds & Movements & \begin{tabular}{|l|} 
Gestures \\
\end{tabular} & Color \& Light \\
\hline Canto 1 & 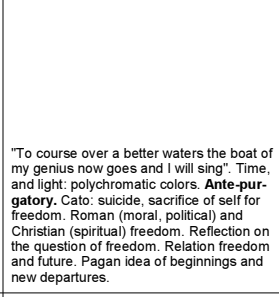 & $\begin{array}{l}\text { 4. and I shall sing this second kingdom where the } \\
\text { unana spirt purtifs itsel, becoming fit to mount } \\
\text { up into heaven }\end{array}$ & & 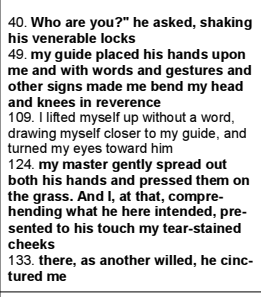 & 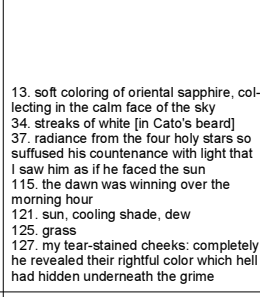 \\
\hline Canto 2 & 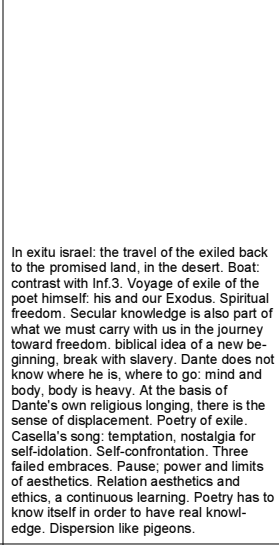 & 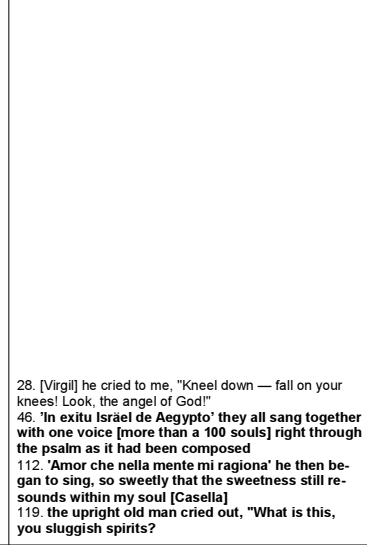 & 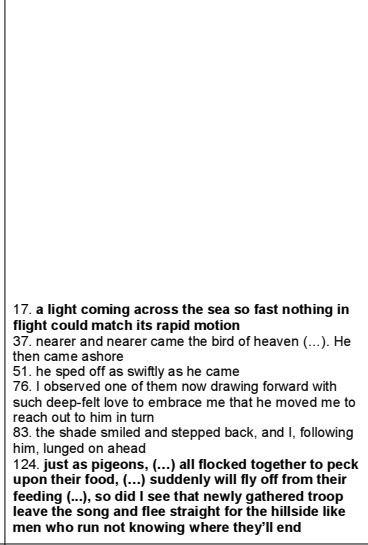 & 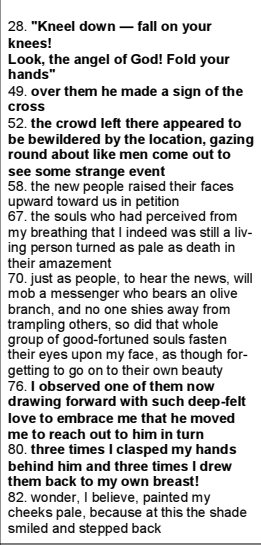 & 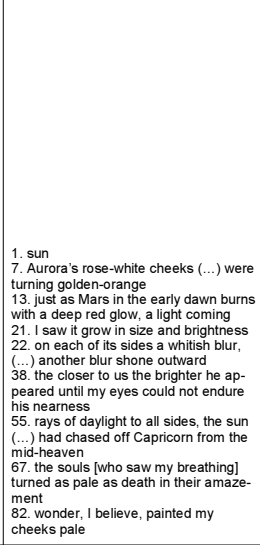 \\
\hline Canto 3 & 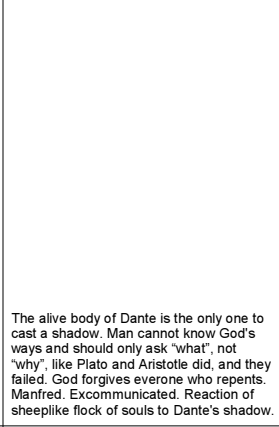 & & 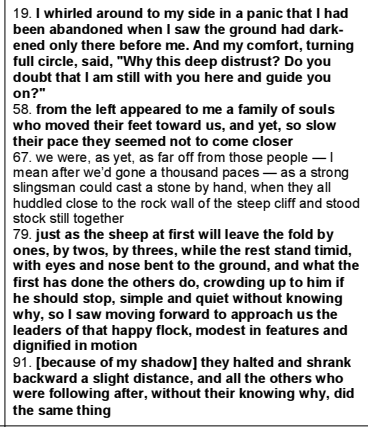 & 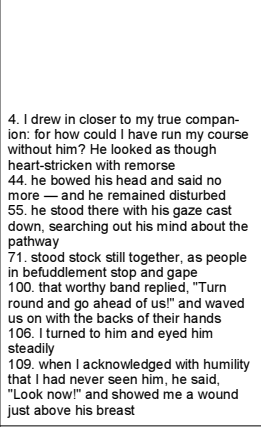 & 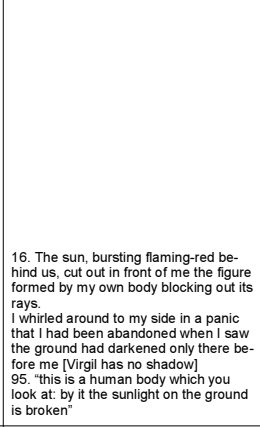 \\
\hline Canto 4 & 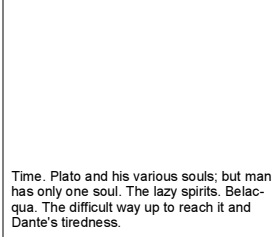 & 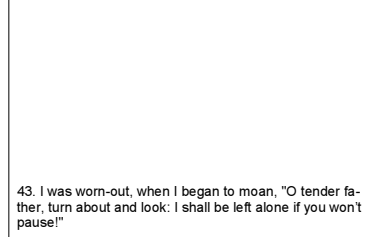 & & 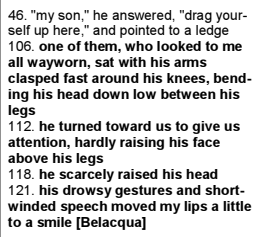 & $\begin{array}{l}\text { 15. the sun had climbed fify full degrees } \\
\text { 位 was } 3 \text { hours later than dawn, past } \\
9.00 \text { a a.m.] }\end{array}$ \\
\hline Canto 5 & 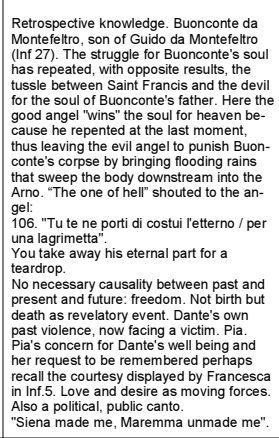 & 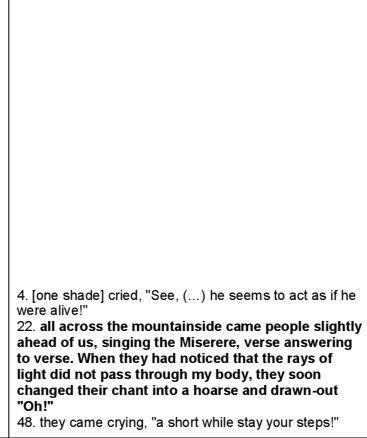 & 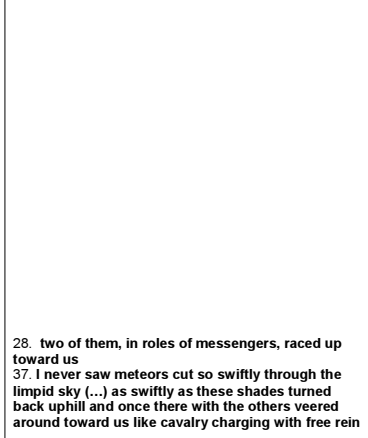 & $\begin{array}{l}\text { 3. one enehind me pointing his finger } \\
\text { 8. Is saw those shadeds stare at me in } \\
\text { wonder, only at me and at the broken } \\
\text { light }\end{array}$ & $\begin{array}{l}\text { 8. And saw those shades stare at me } \\
\text { in wondereronly at me and at he broken } \\
\text { inght shadoow] }\end{array}$ \\
\hline Canto 6 & 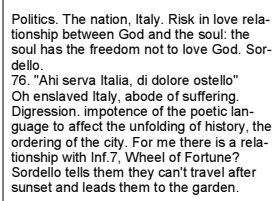 & $\begin{array}{l}\text { 74. "And cried, "O Mantuan, I am Sordello from your } \\
\text { own cityy" }\end{array}$ & 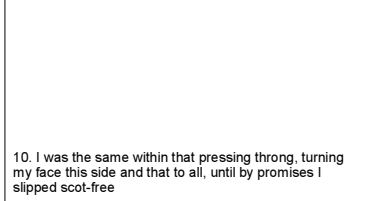 & 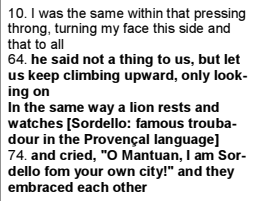 & 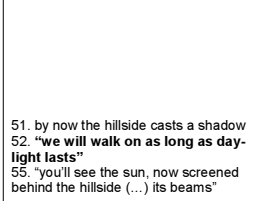 \\
\hline
\end{tabular}




\begin{tabular}{|c|c|c|c|c|c|}
\hline Canto 7 & 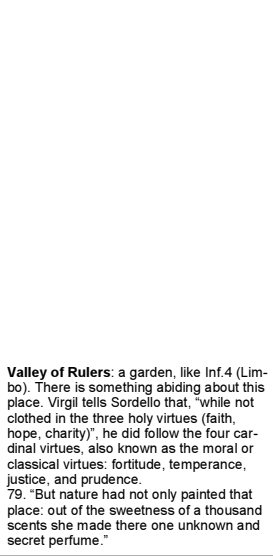 & 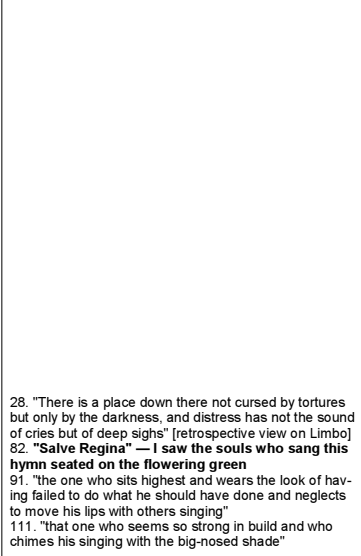 & & 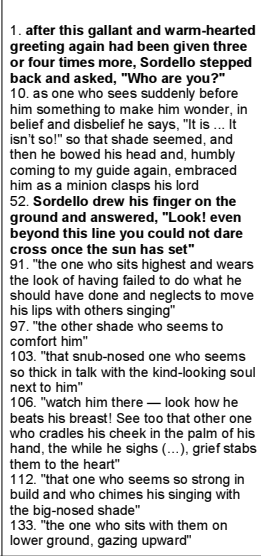 & 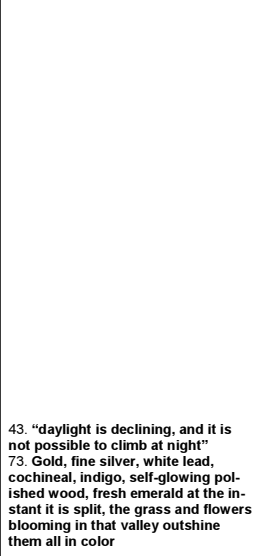 \\
\hline Canto 8 & 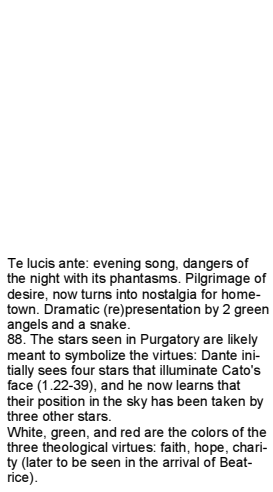 & 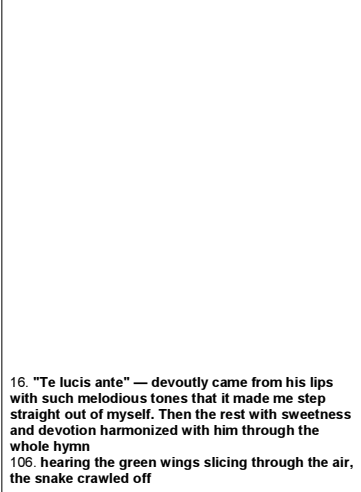 & 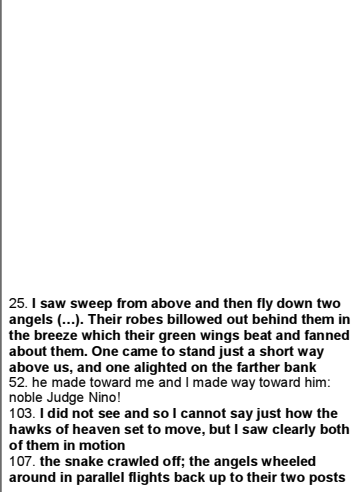 & 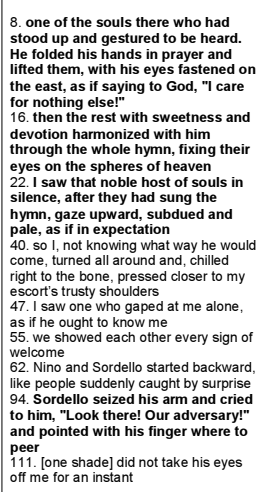 & 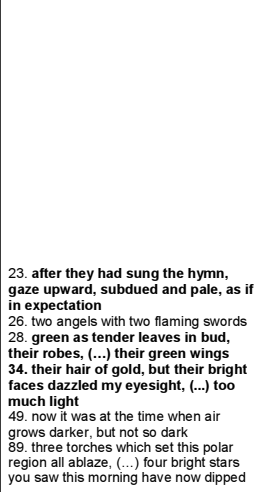 \\
\hline Canto 9 & 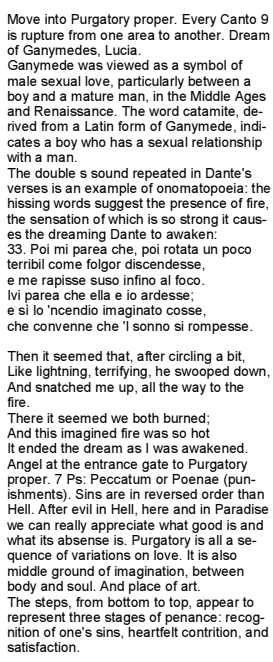 & 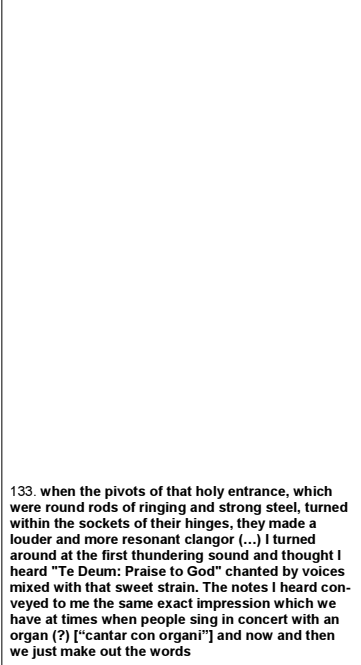 & 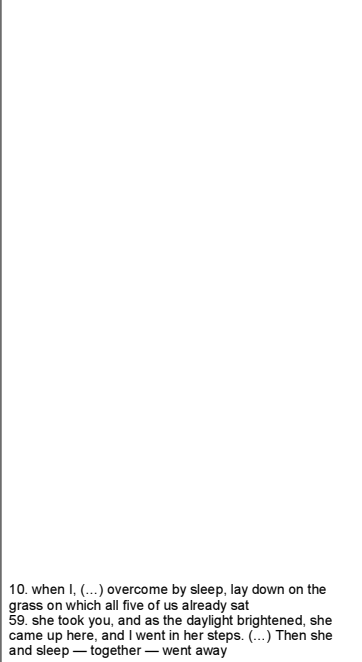 & 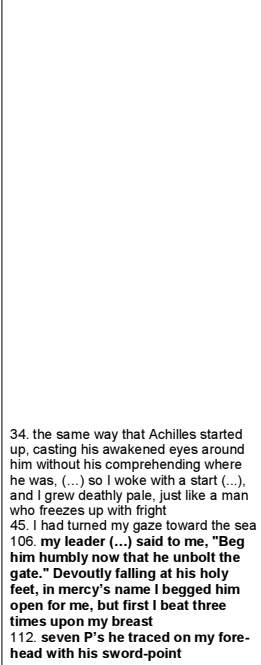 & 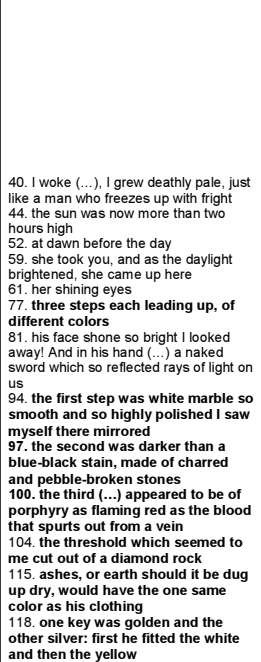 \\
\hline Canto 10 & 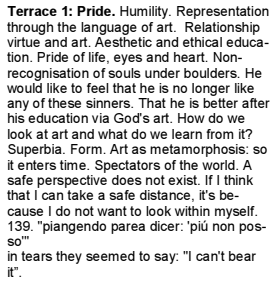 & 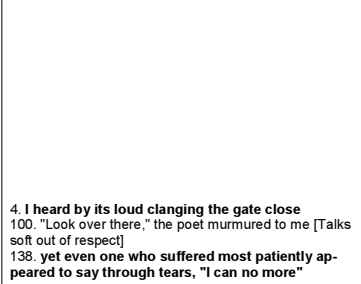 & 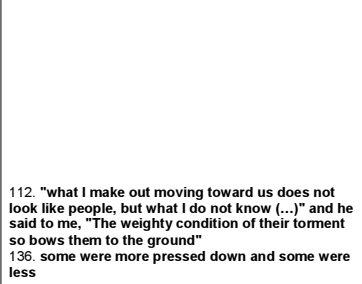 & 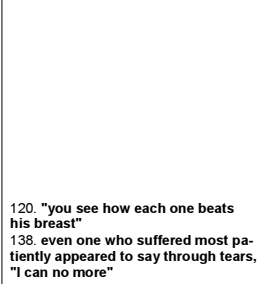 & 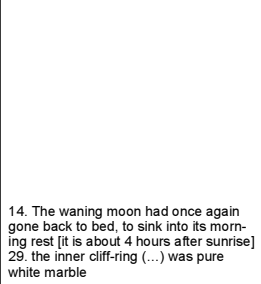 \\
\hline
\end{tabular}




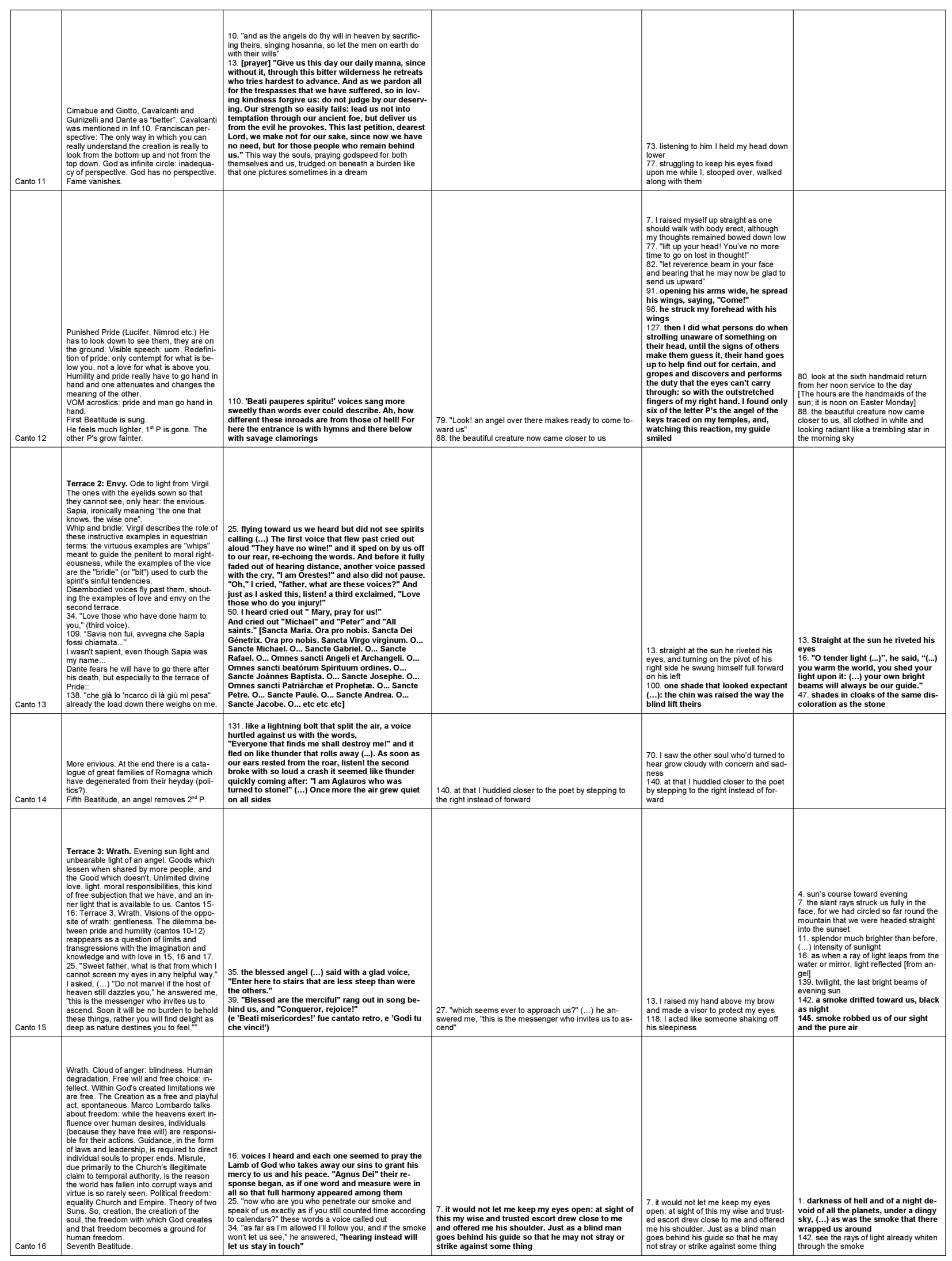




\begin{tabular}{|c|c|c|c|c|c|}
\hline Canto 17 & 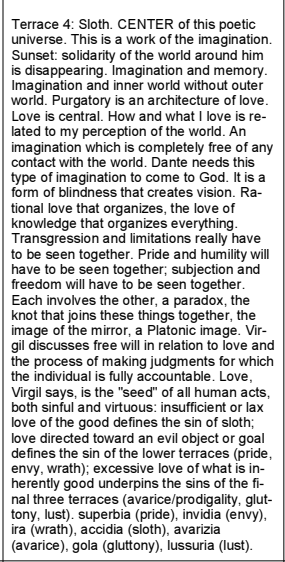 & & & & 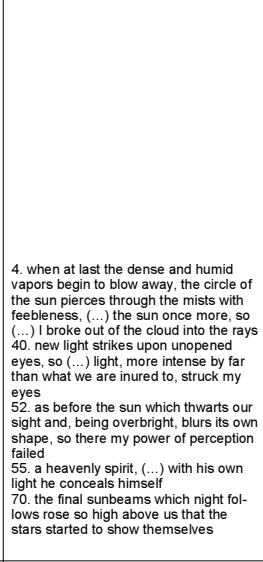 \\
\hline Canto 18 & 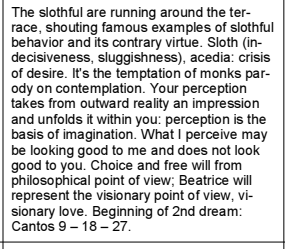 & 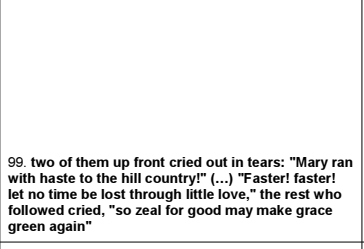 & 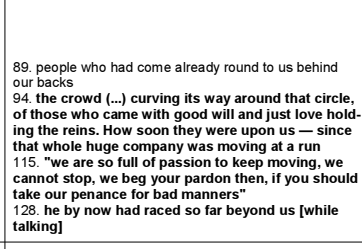 & & 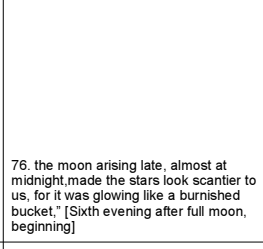 \\
\hline Canto 19 & 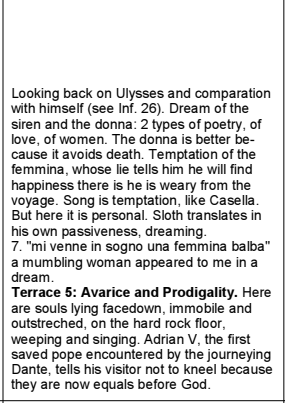 & 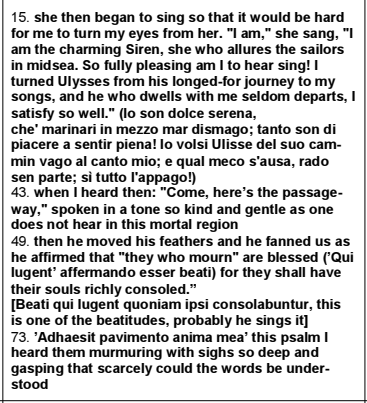 & 49. he moved his feathers and he fanned us & 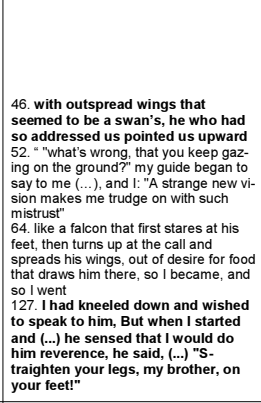 & 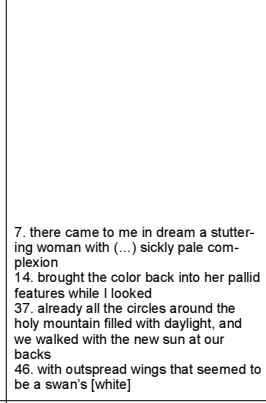 \\
\hline Canto 20 & 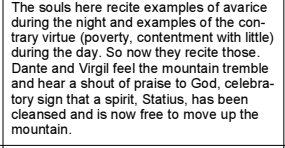 & 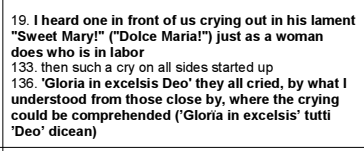 & & & \\
\hline Canto 21 & 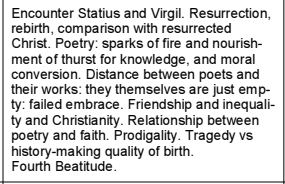 & & 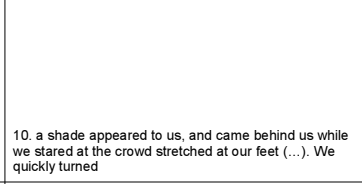 & 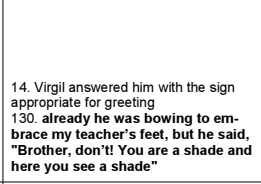 & \\
\hline Canto 22 & 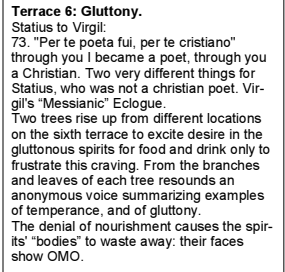 & 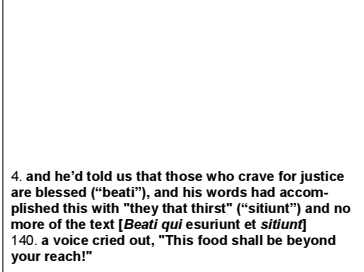 & 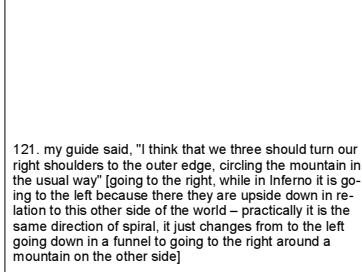 & 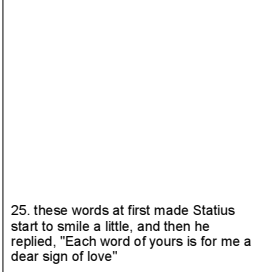 & $\begin{array}{l}\text { 137. clear sparkiling water fell from the } \\
\text { hinht rock and spread itself among the } \\
\text { leaves above }\end{array}$ \\
\hline Canto 23 & 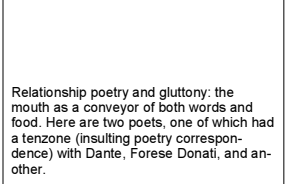 & 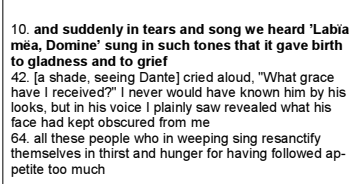 & 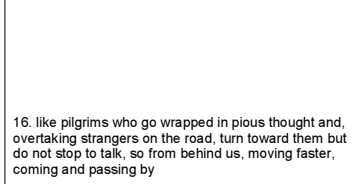 & 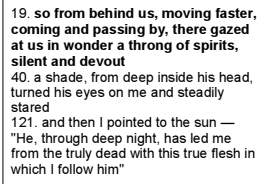 & 50. The dry scabs discoloring my skin" \\
\hline
\end{tabular}




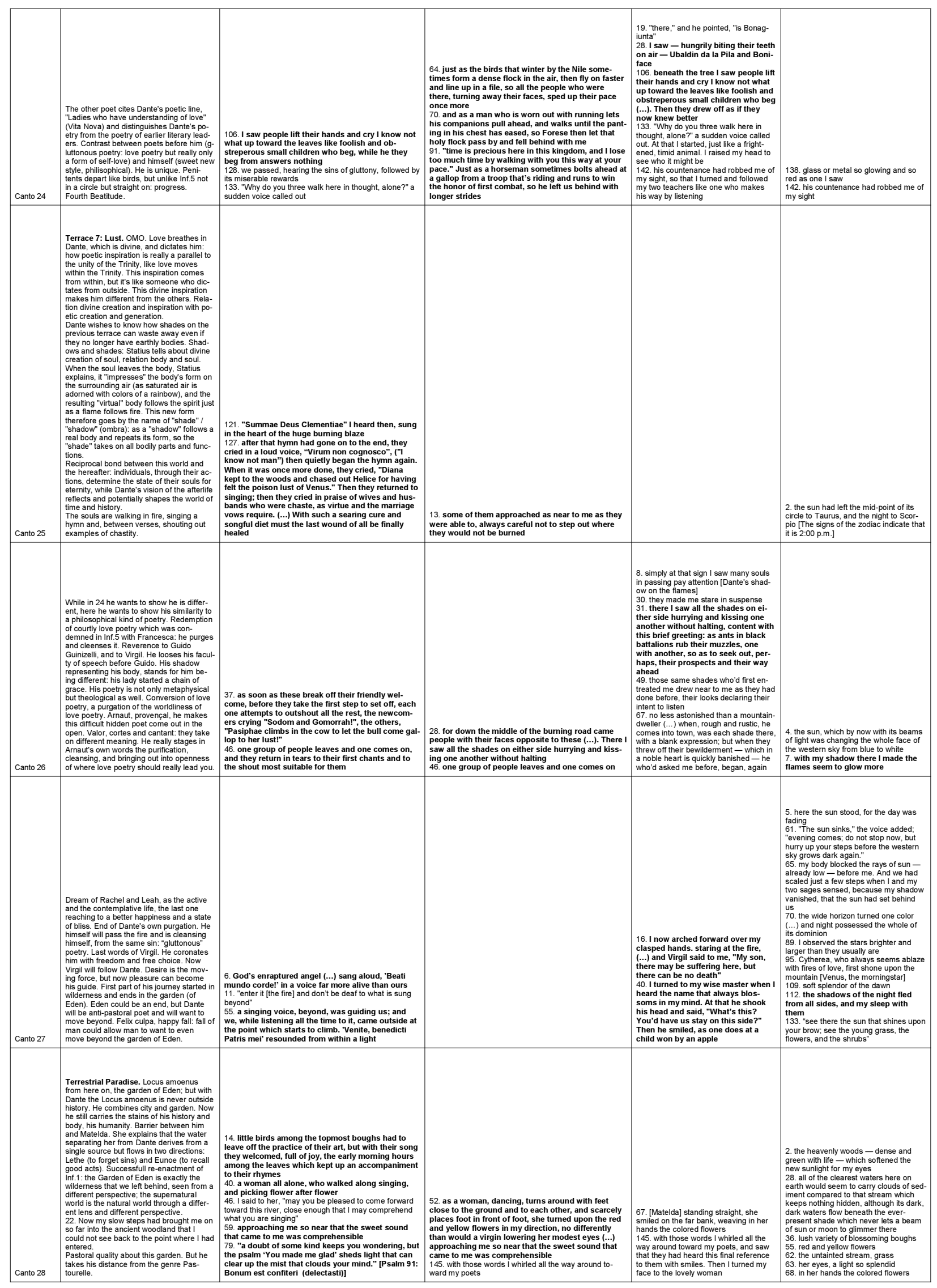




\begin{tabular}{|c|c|c|c|c|c|}
\hline Canto 29 & 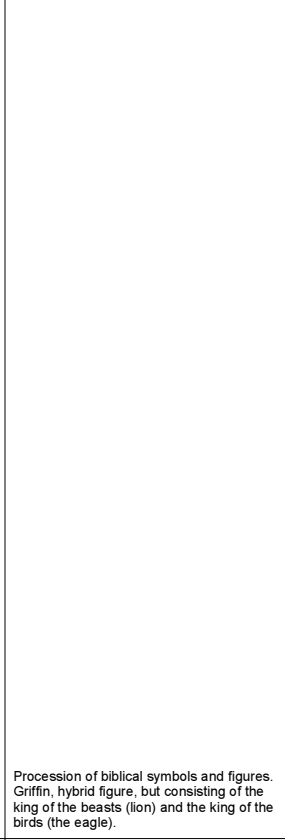 & 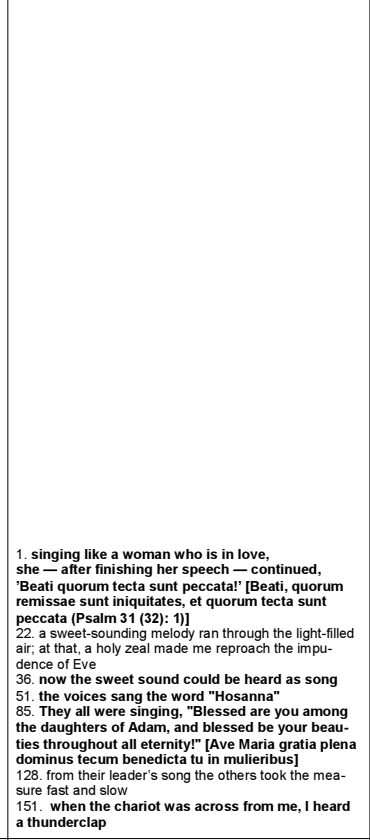 & 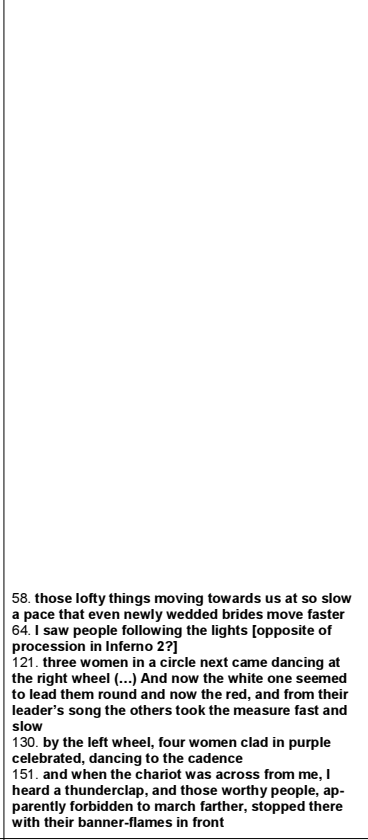 & & 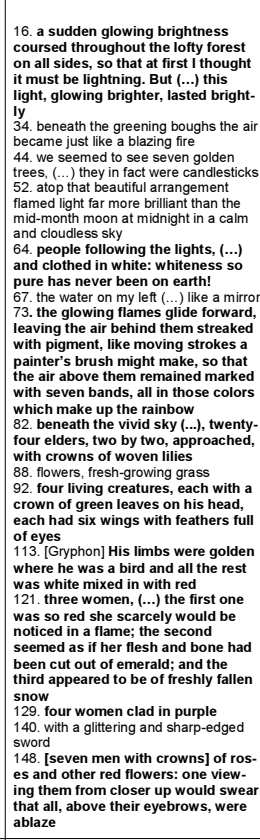 \\
\hline Canto 30 & 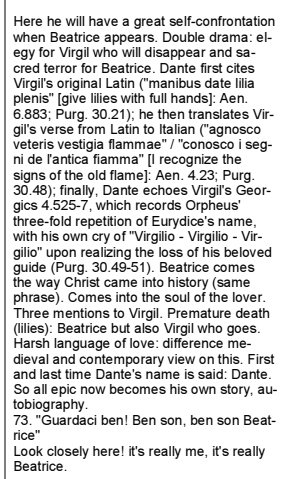 & 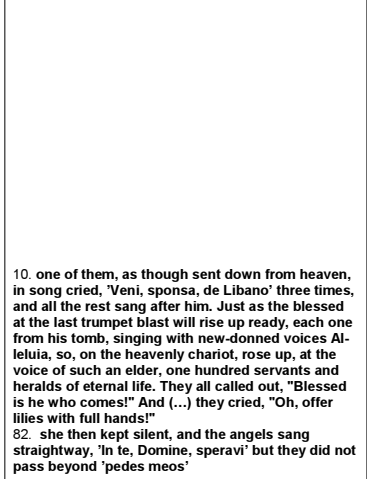 & 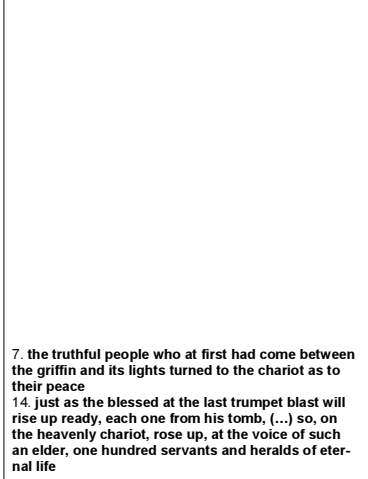 & $\begin{array}{l}\text { 20. tossing flowers up and all } \\
\text { around, they cried, "Oh, offer lilies } \\
\text { with full hands!" }\end{array}$ & 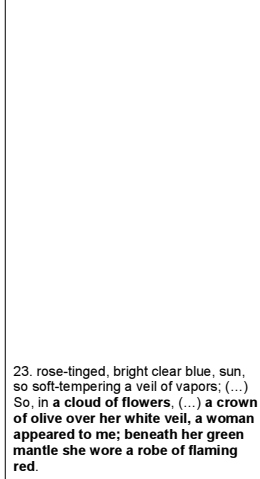 \\
\hline Canto 31 & 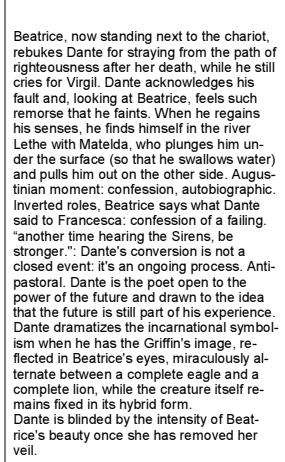 & 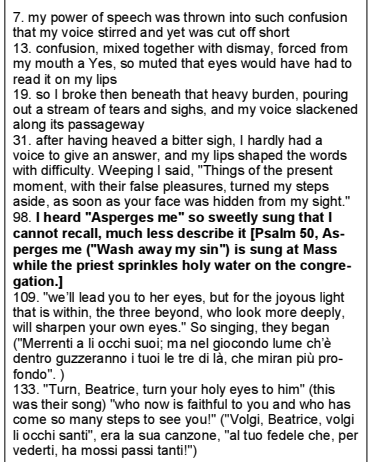 & 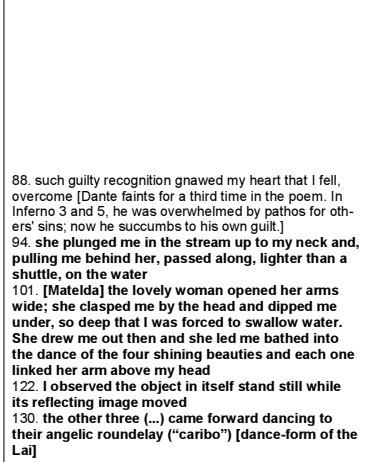 & 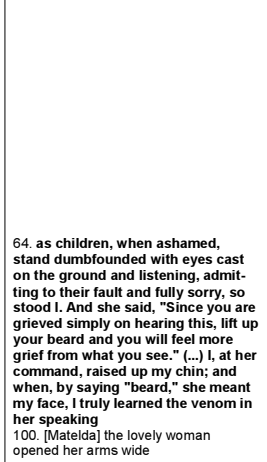 & 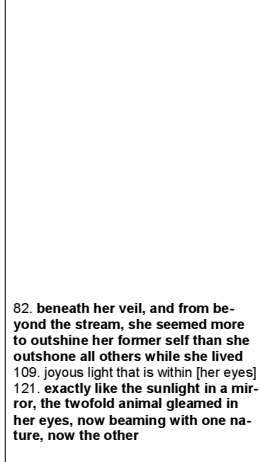 \\
\hline Canto 32 & $\begin{array}{l}\text { Chariot (allegory of medieval Christian his- } \\
\text { tory) }\end{array}$ & 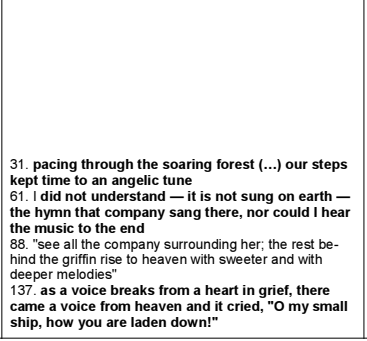 & 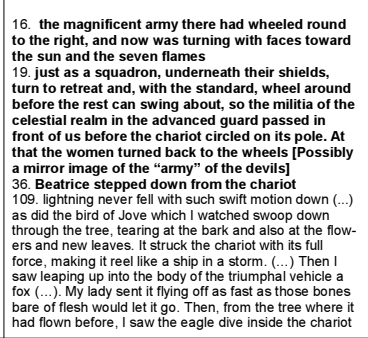 & 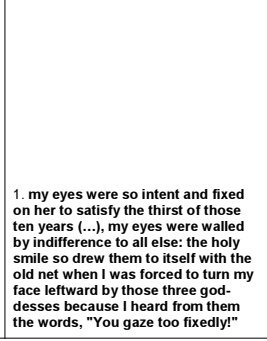 & 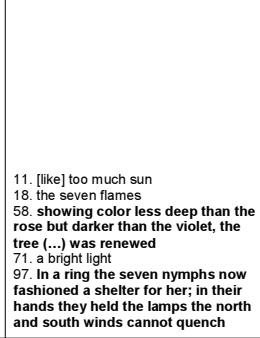 \\
\hline
\end{tabular}




\begin{tabular}{|c|c|c|c|c|}
\hline Canto 33 & 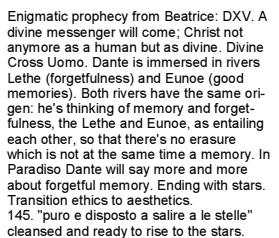 & 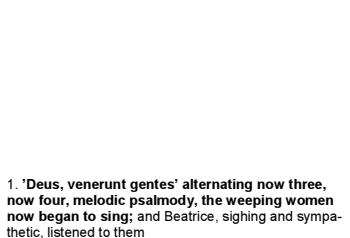 & 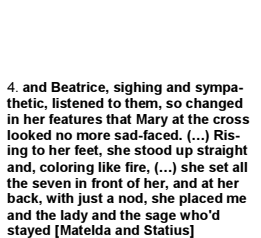 & 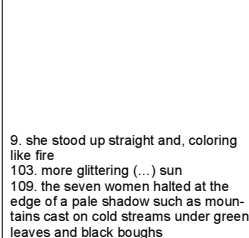 \\
\hline
\end{tabular}

\section{The
when
som
the
tall
h
nut
L}

The souls in Purgatory cry out or call out their surprise
when they see Dante has a shadow and so he is alive. Some also call out devoutly phasases they have to say. In
their purgation they normally do this in ters heir purgatition they normally do this in tears. The angels
takl with alad voice, one that is not heard among
humans: "spoken in a tone so kind and gentle as one does not hear in this mortal region"
Liturgical song is a means of purgation. The song of
Casella and the song of the siren are the only secular songs and they are both depicted as seductive, somethin that distracts from the way to God.
In the Terrenial Paradise the chants are sung by heavenly
spirits.

While Dante and Virgil were moving downwards in a

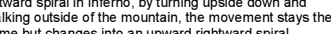
The souls stare in amazement at Dante when they see he is still alive because
his breathing and his shadow. There are many gestures of courtesy
here: the difference with Inferno is great Dante and Virgil are still very lovingly to ach other, but here Virgil does not ne
be as protective as in Inferno, and Dante - as he evolves in his own purgation and weighs less with each erraces - becomes gradually $\mathrm{moc}$
independent towards the Terrenial Independent towards the Terrenial
Paracisese. His gestures with Beatrice are
different, it is dificiult for him not to stare

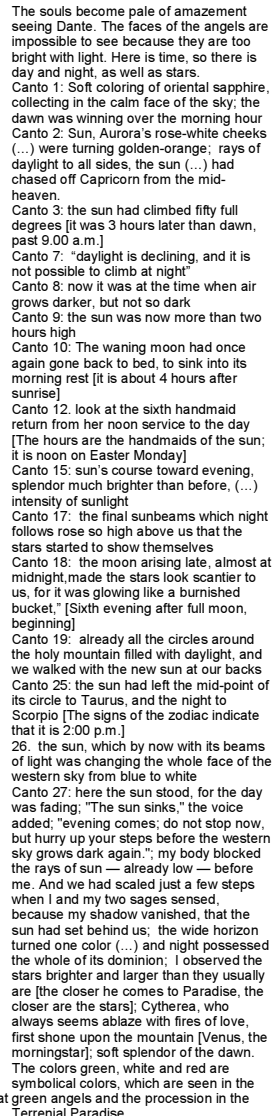




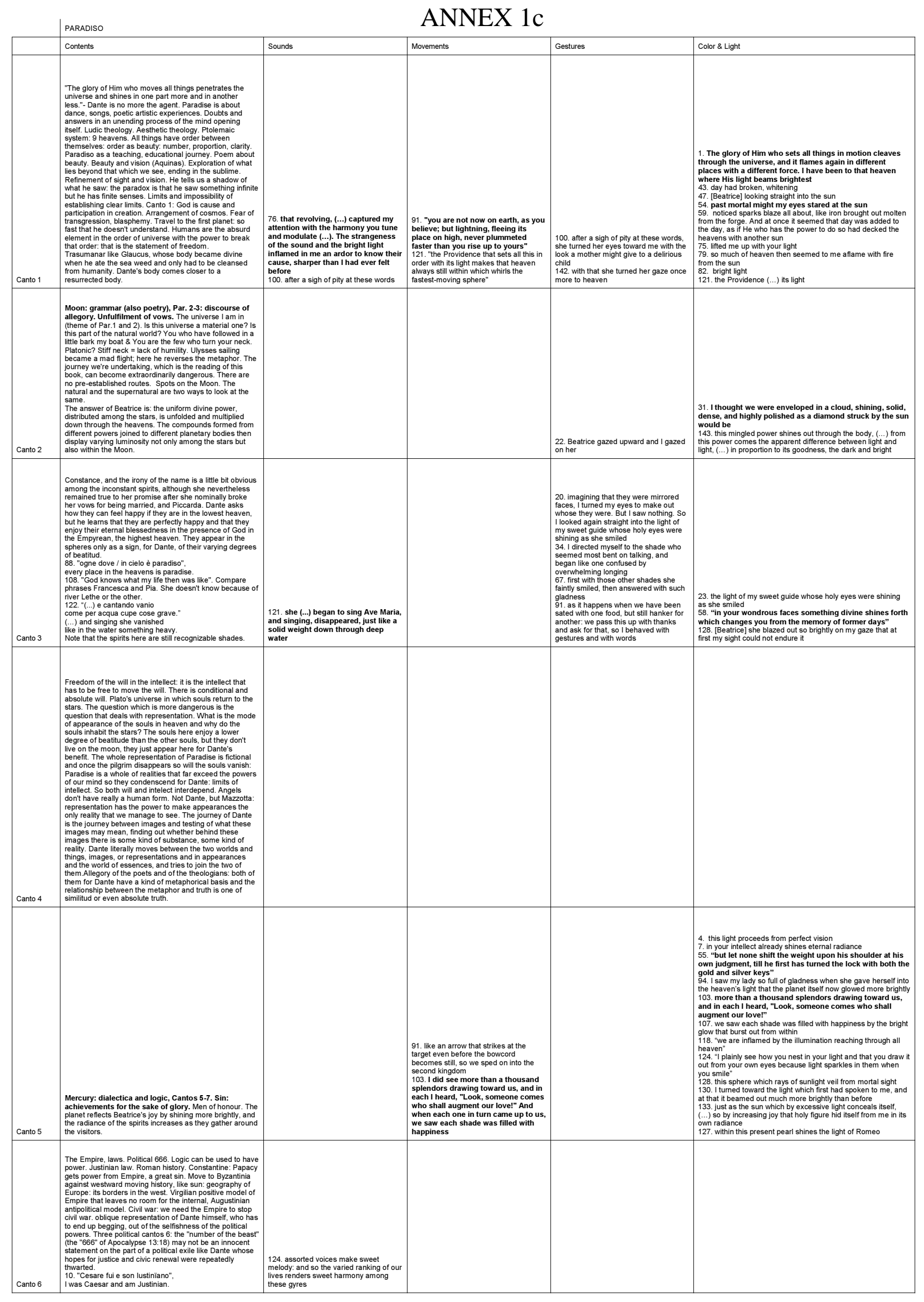




\begin{tabular}{|c|c|c|c|c|c|}
\hline Canto 7 & 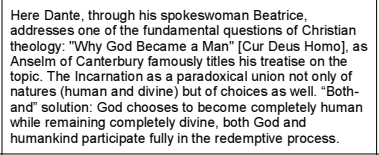 & 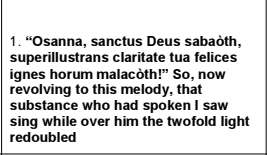 & 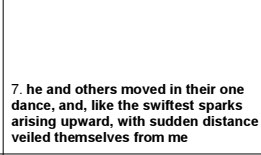 & & $\begin{array}{l}\text { 6. over him the twofold light redoubled } \\
\text { 17. [Beatrice] beaming a smile on me }\end{array}$ \\
\hline Canto 8 & 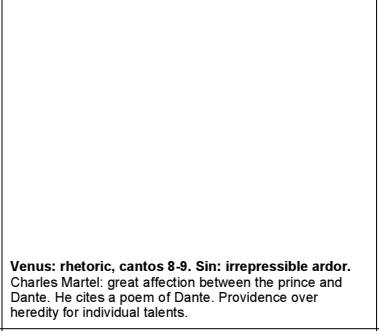 & 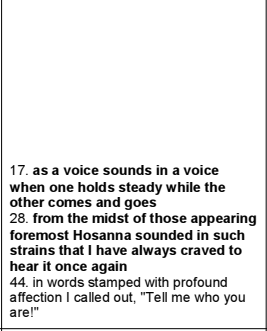 & 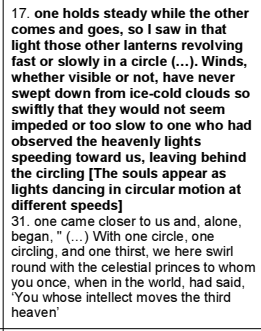 & & 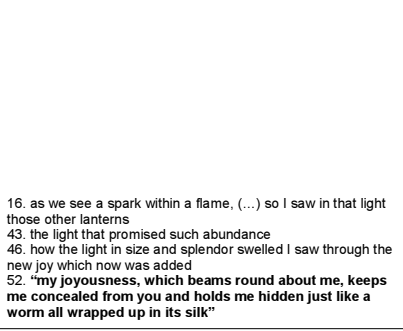 \\
\hline Canto 9 & 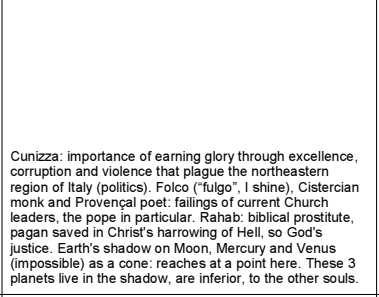 & 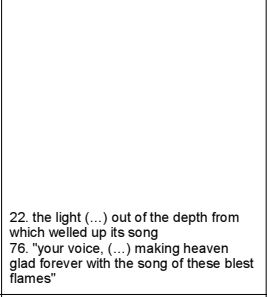 & $\begin{array}{l}\text { 13. another of those splendors came } \\
\text { toward meil } \\
\text { o5 whe whing where she took up the } \\
\text { place she'd lift behind }\end{array}$ & 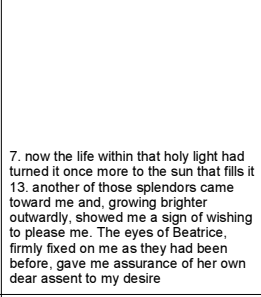 & 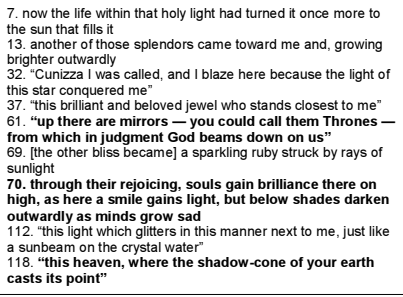 \\
\hline Canto 10 & 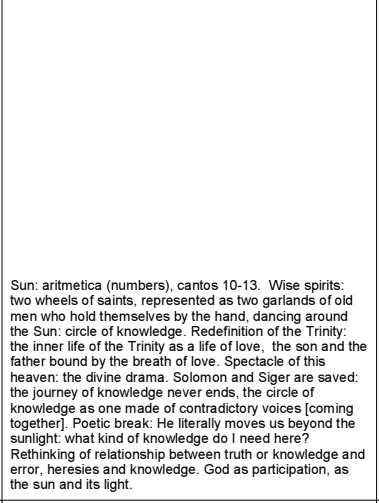 & 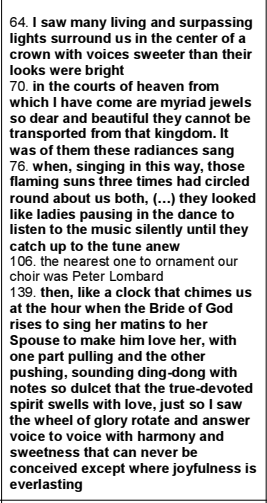 & 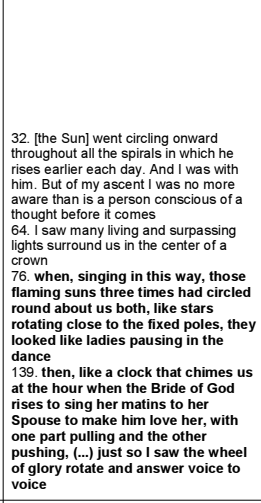 & & 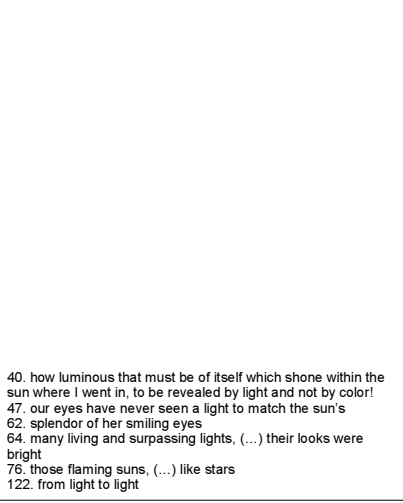 \\
\hline Canto 11 & 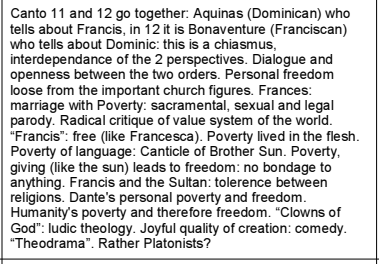 & & 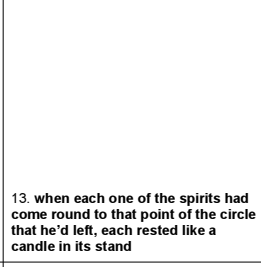 & & 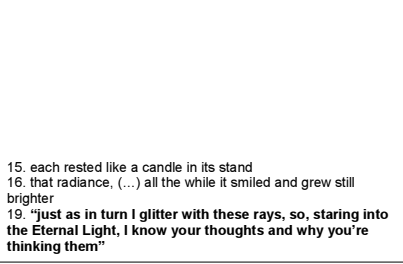 \\
\hline Canto 12 & 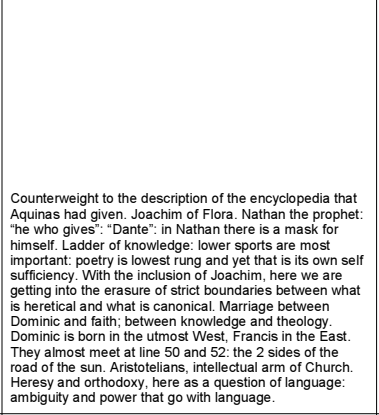 & 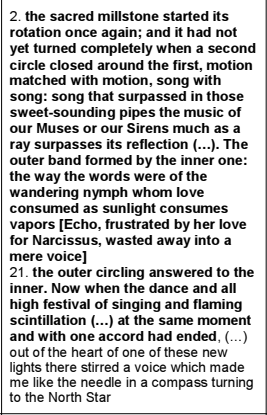 & 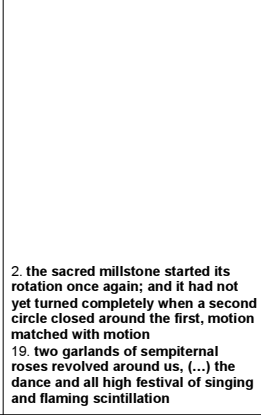 & & 33. flaming scintillation of light with light \\
\hline Canto 13 & $\begin{array}{l}\text { Description of double circle, each of } 12 \text { lights, dancing, } \\
\text { Solomonn saved beccuuse he was the wisest man on earth, } \\
\text { despite his lechery. }\end{array}$ & 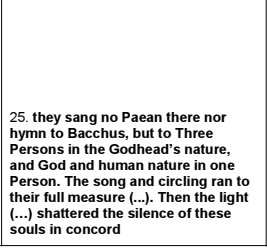 & 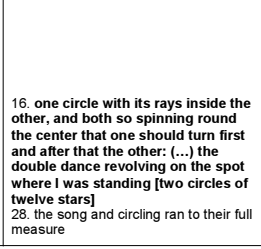 & & 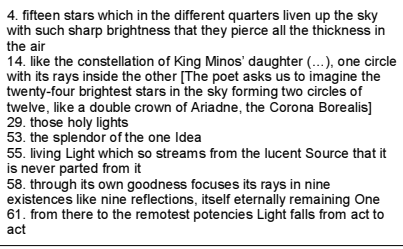 \\
\hline
\end{tabular}




\begin{tabular}{|c|c|c|c|c|c|}
\hline Canto 14 & 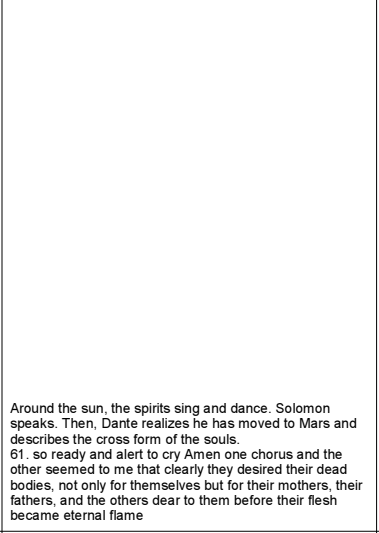 & 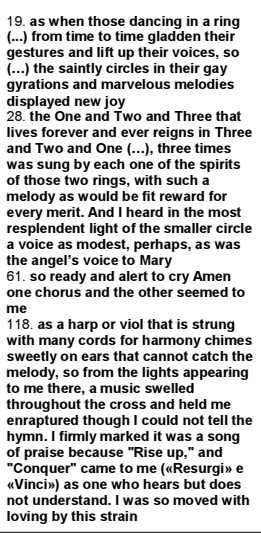 & 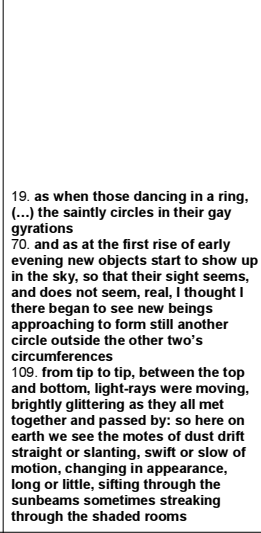 & & 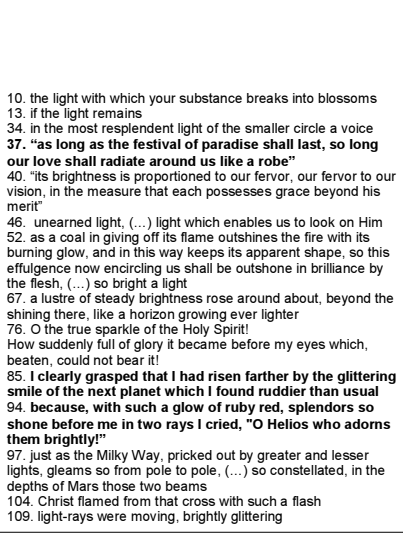 \\
\hline Canto 15 & 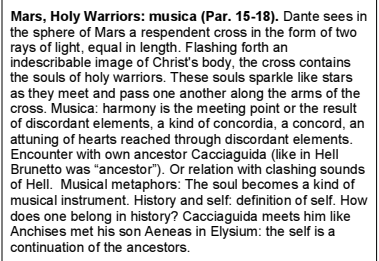 & 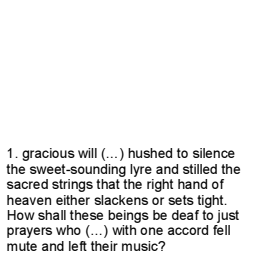 & 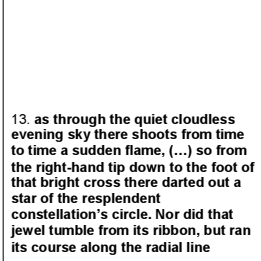 & $\begin{array}{l}\text { 70. It turned to Beatrice, and before I } \\
\text { spoke she heard me, and she smiled } \\
\text { me her assent }\end{array}$ & 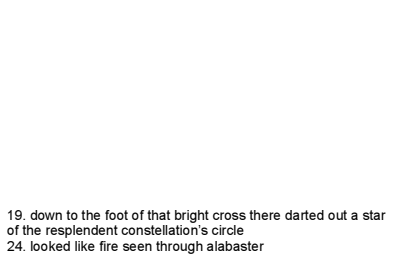 \\
\hline Canto 16 & 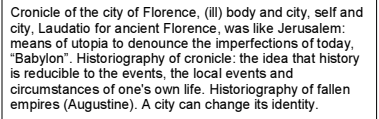 & $\begin{array}{l}\text { 32. with a swetere and a soffer voice, } \\
\text { but not in todays idiom, he said }\end{array}$ & & & $\begin{array}{l}\text { 28. as at the breathing of the winds a coal quickens into flame, } \\
\text { so did Is see that ight glow brighter }\end{array}$ \\
\hline Canto 17 & 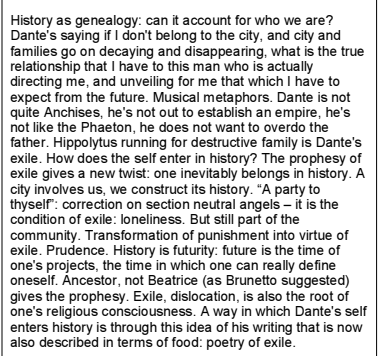 & 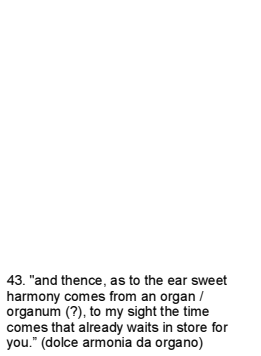 & & & 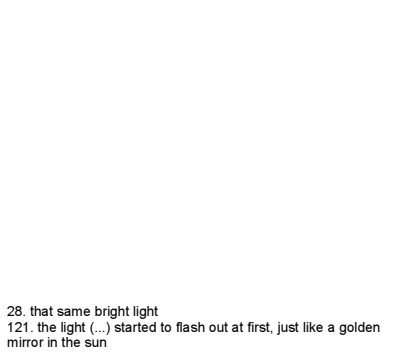 \\
\hline Canto 18 & 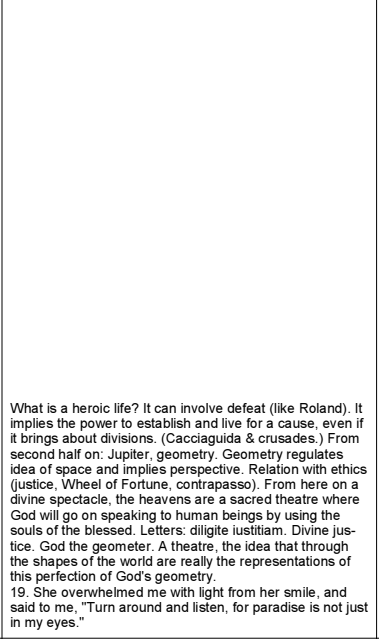 & 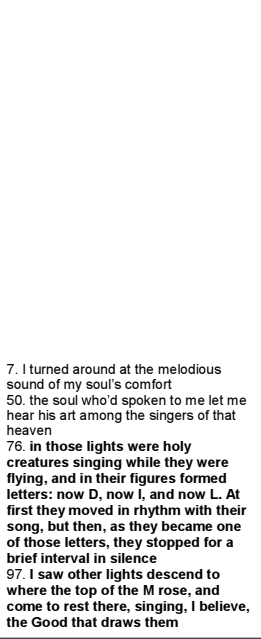 & 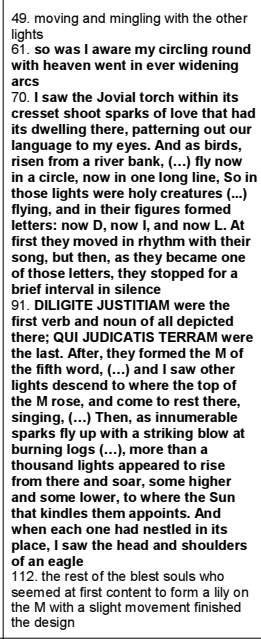 & & 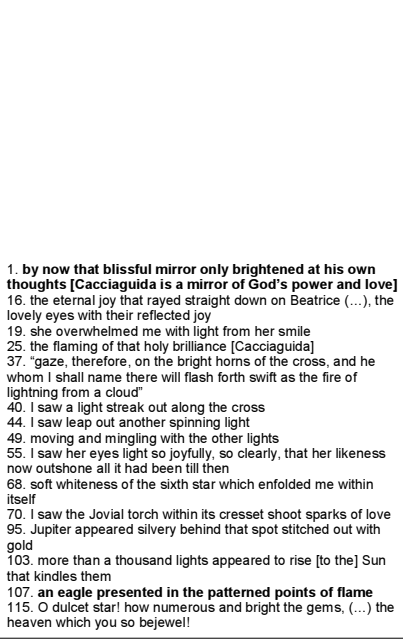 \\
\hline Canto 19 & 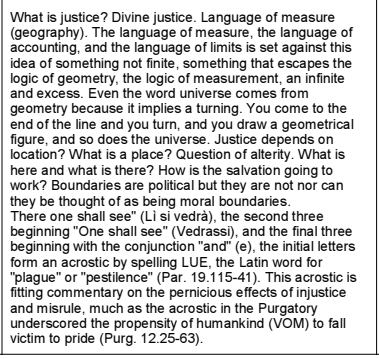 & 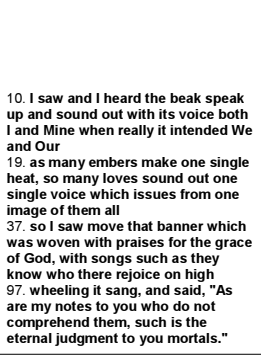 & 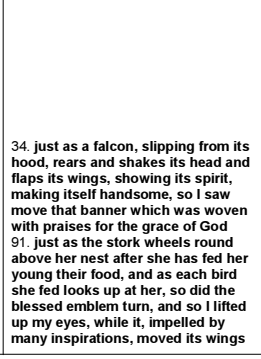 & & 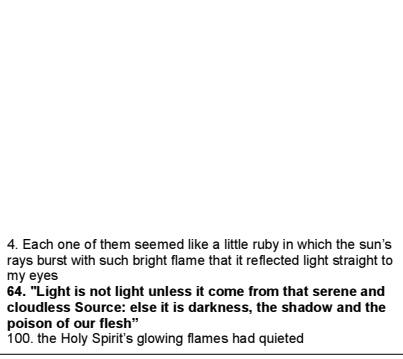 \\
\hline
\end{tabular}




\begin{tabular}{|c|c|c|c|c|c|}
\hline Canto 20 & 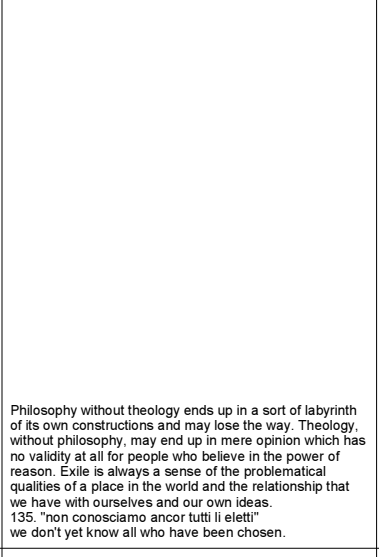 & 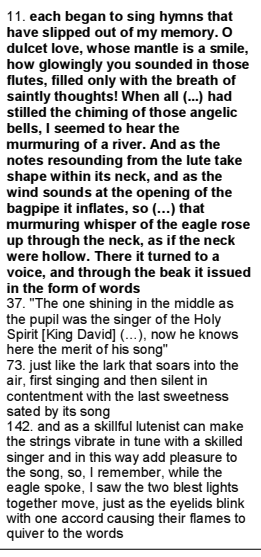 & 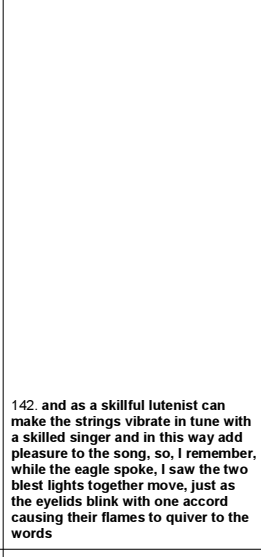 & & 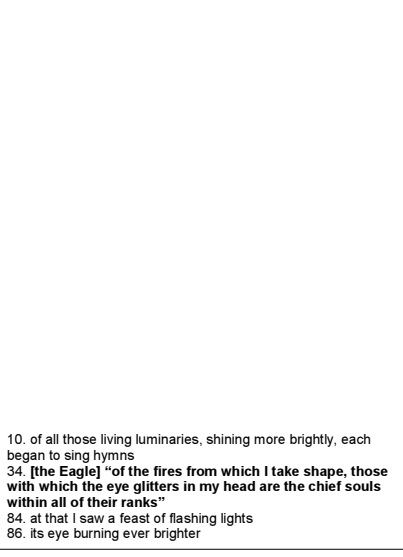 \\
\hline Canto 21 & 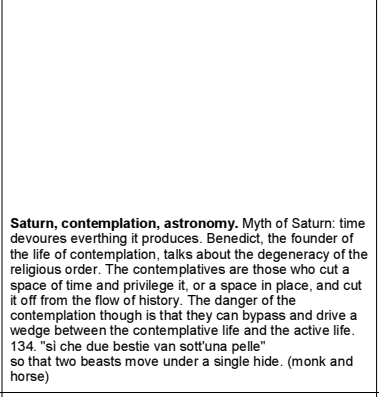 & 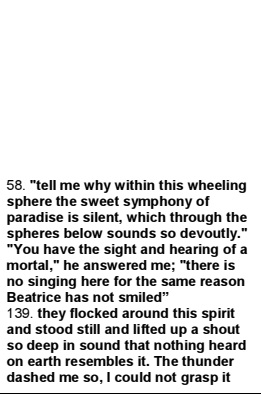 & 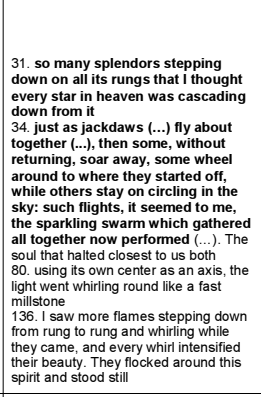 & $\begin{array}{l}\text { 1. by now my eyes fixed once more on } \\
\text { the face of my own lady }\end{array}$ & 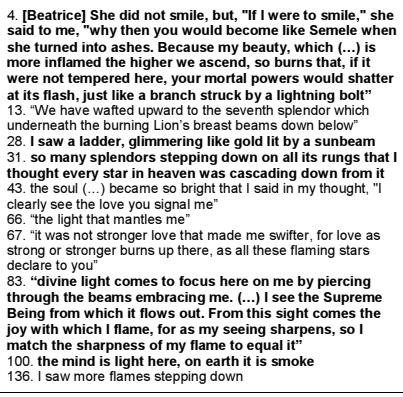 \\
\hline Canto 22 & 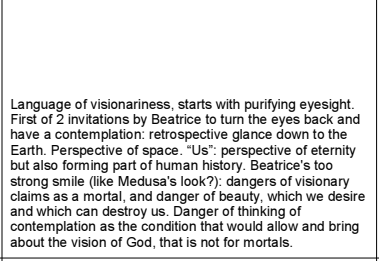 & 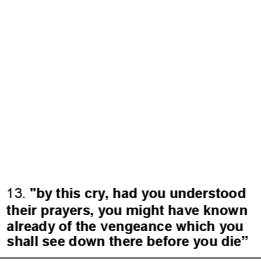 & 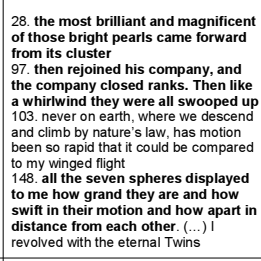 & 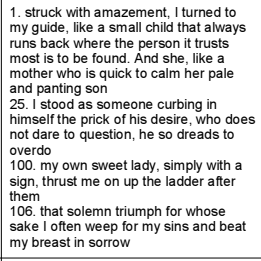 & 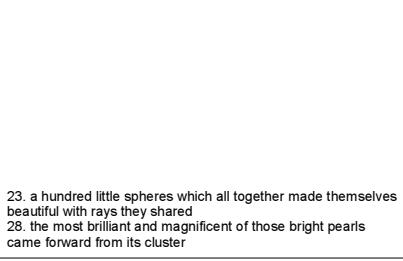 \\
\hline Canto 23 & 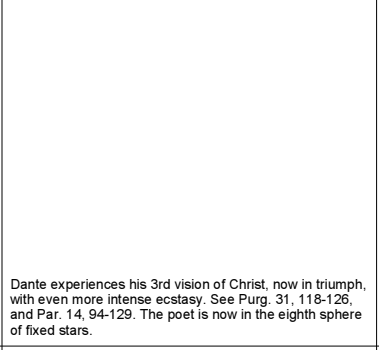 & 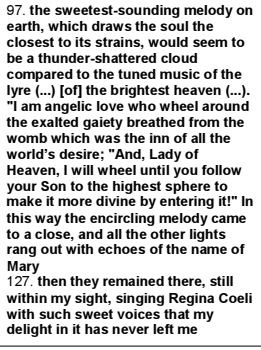 & 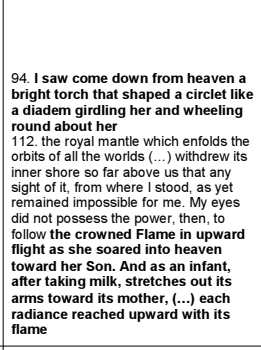 & 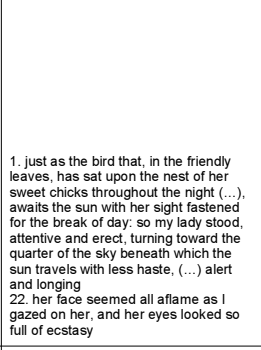 & 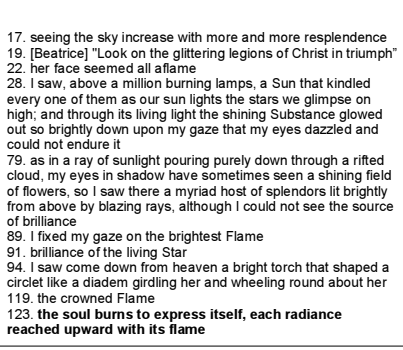 \\
\hline Canto 24 & 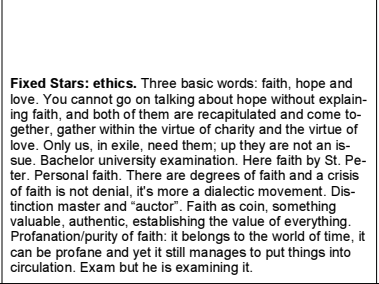 & 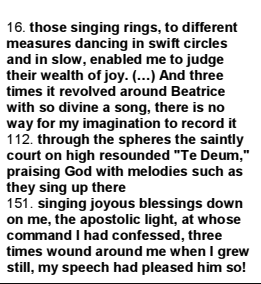 & 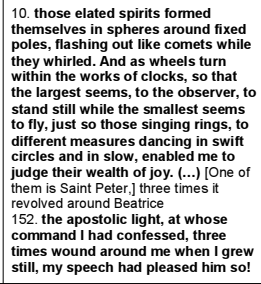 & 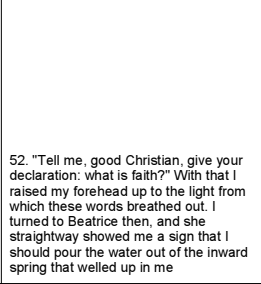 & 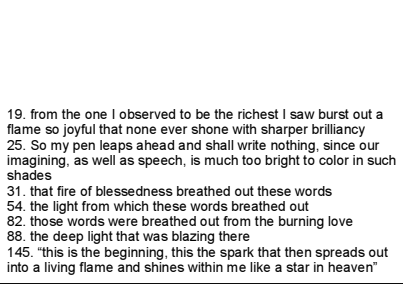 \\
\hline
\end{tabular}




\begin{tabular}{|c|c|c|c|c|c|}
\hline Canto 25 & 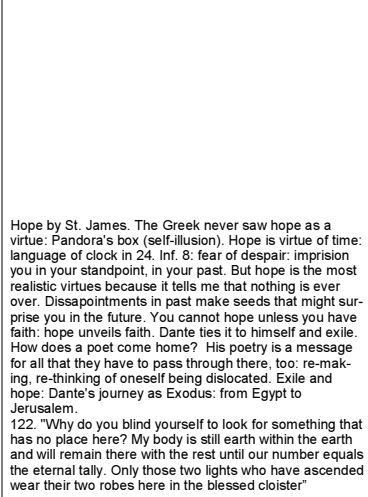 & 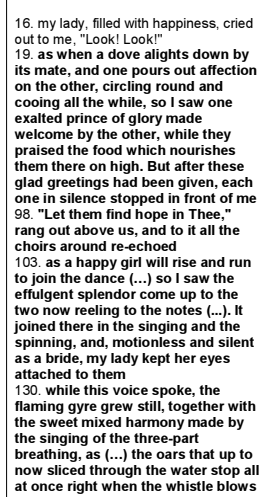 & 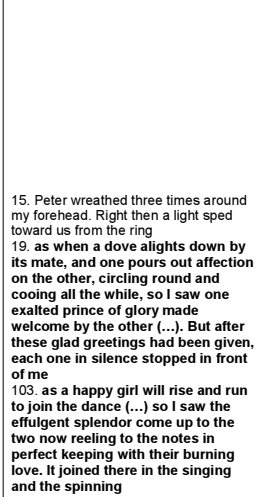 & 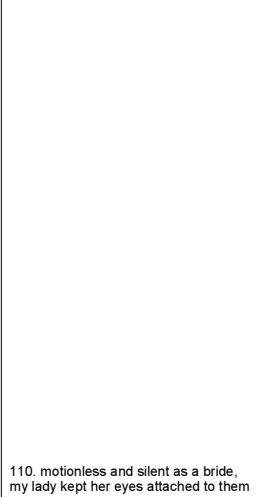 & 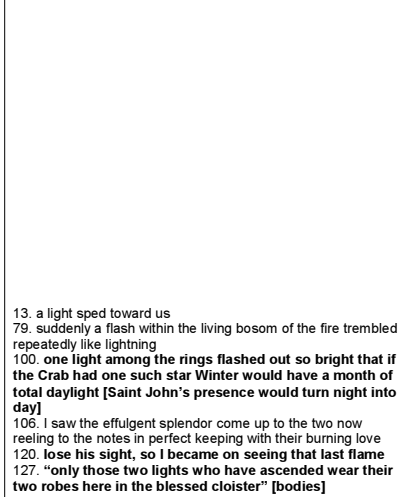 \\
\hline Canto 26 & 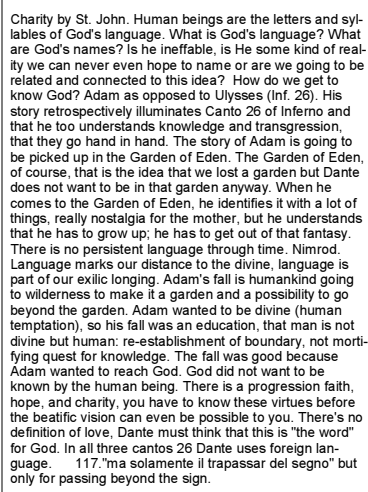 & 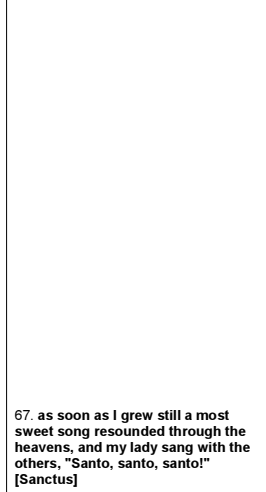 & 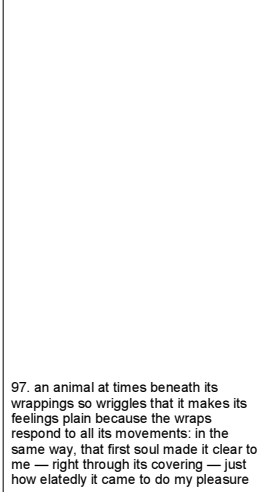 & 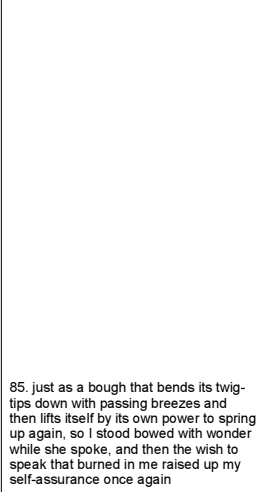 & 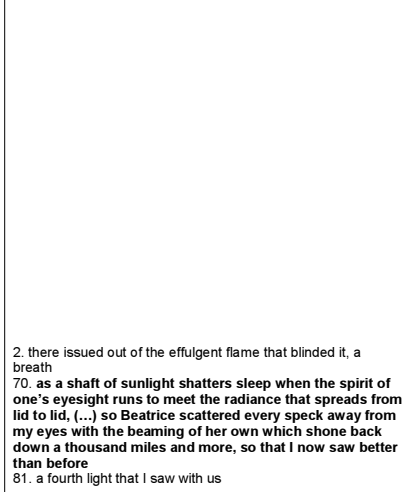 \\
\hline Canto 27 & 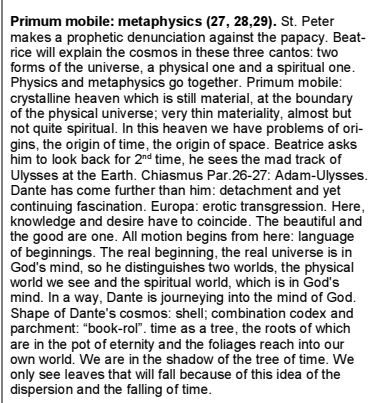 & 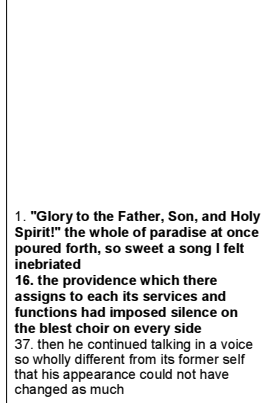 & 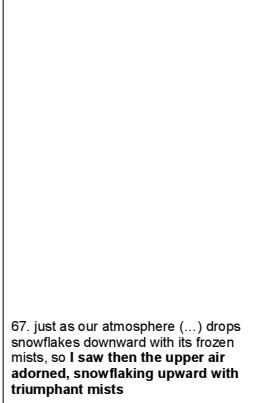 & 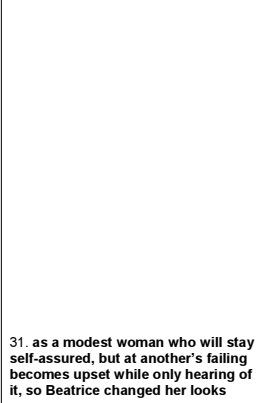 & 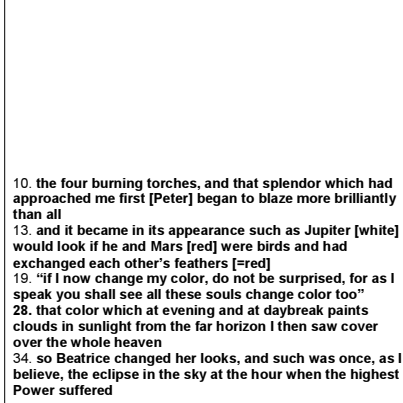 \\
\hline Canto 28 & 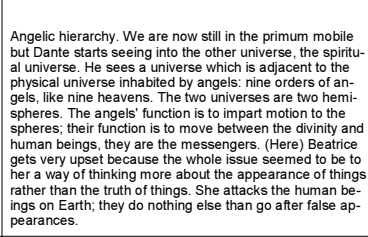 & 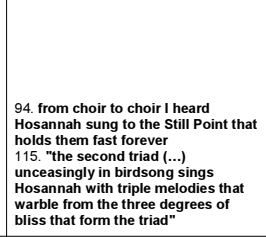 & 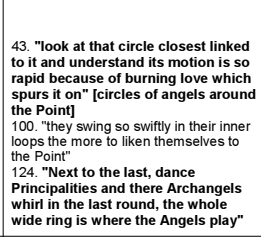 & 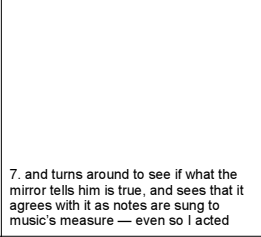 & 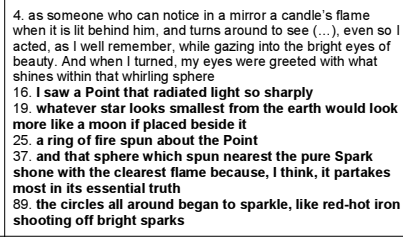 \\
\hline Canto 29 & 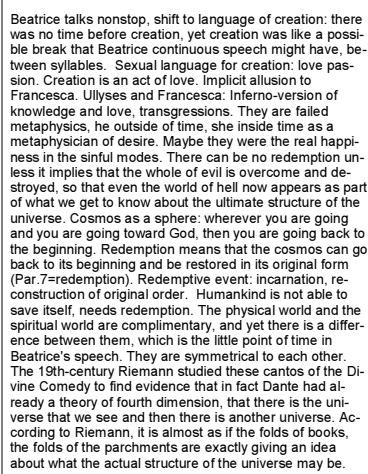 & & & & 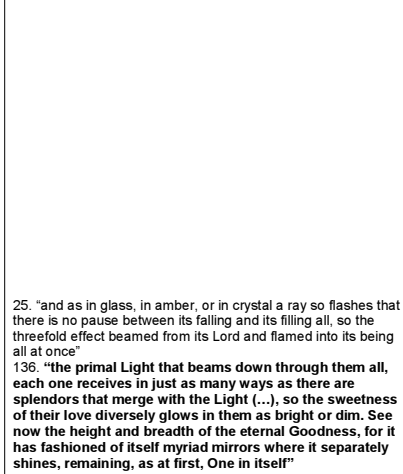 \\
\hline
\end{tabular}




\begin{tabular}{|c|c|c|c|c|c|}
\hline Canto 30 & 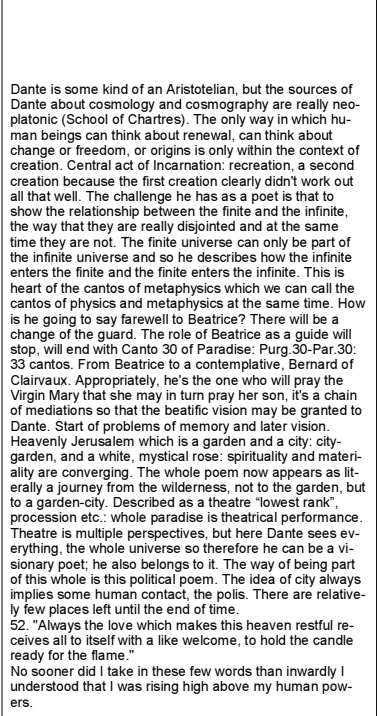 & 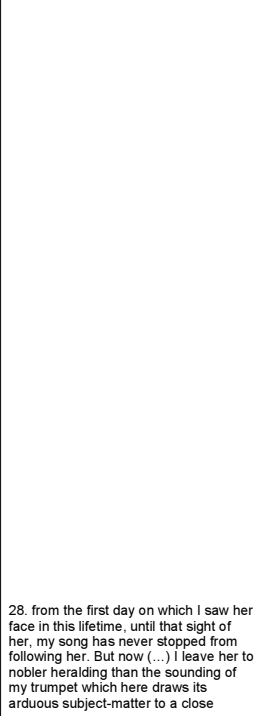 & 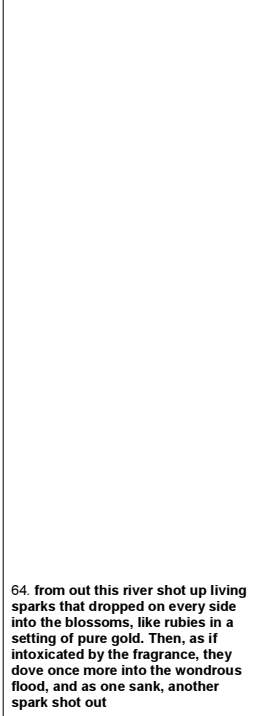 & $\begin{array}{l}\text { 37. with gesture and voice of an } \\
\text { accomplised leader she began again, } \\
\text { "Out from the largest bod we have } \\
\text { cotem to this heaven of pure light" }\end{array}$ & 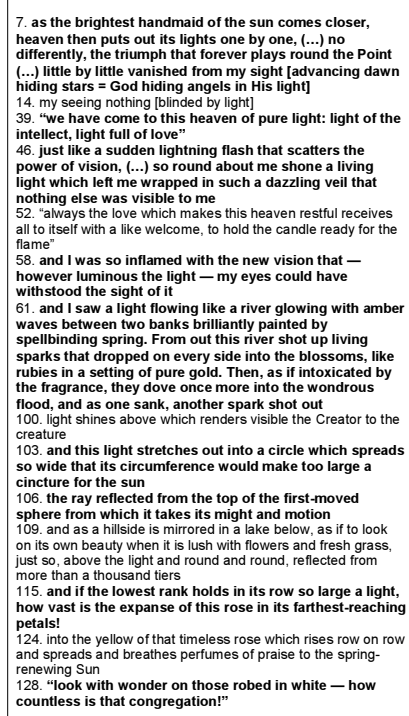 \\
\hline Canto 31 & 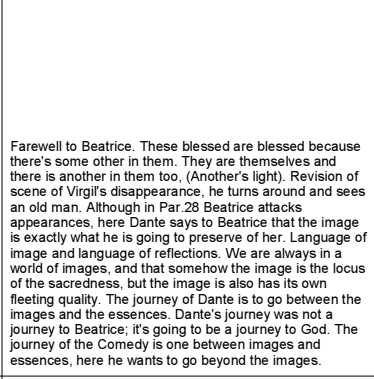 & 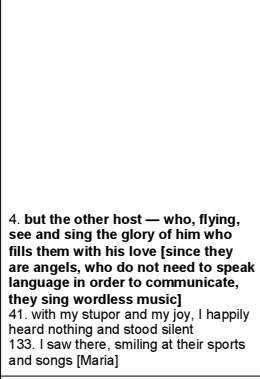 & 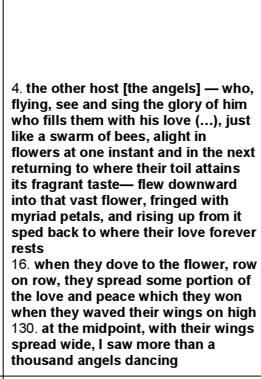 & 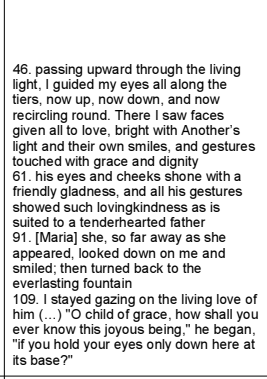 & 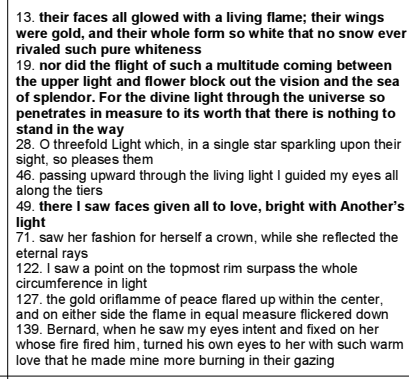 \\
\hline Canto 32 & 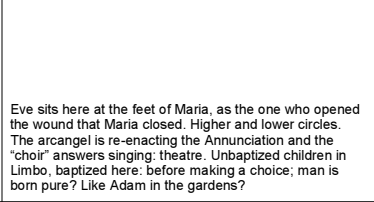 & 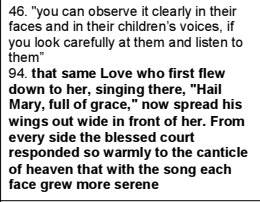 & 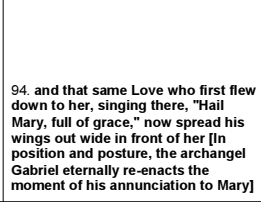 & & $\begin{array}{l}\text { 85. "look now upon the face most like to christ because its } \\
\text { brighthess } \\
\text { to sal alone possesses the power to prepare you }\end{array}$ \\
\hline Canto 33 & 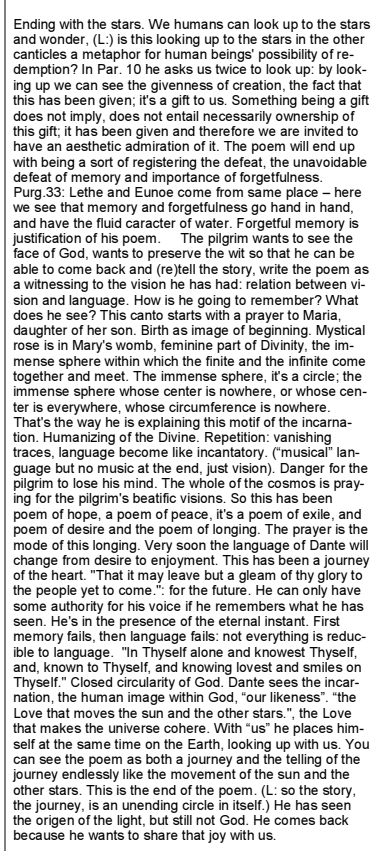 & & & 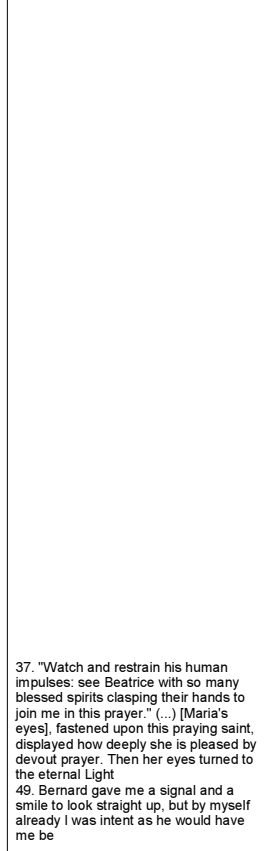 & 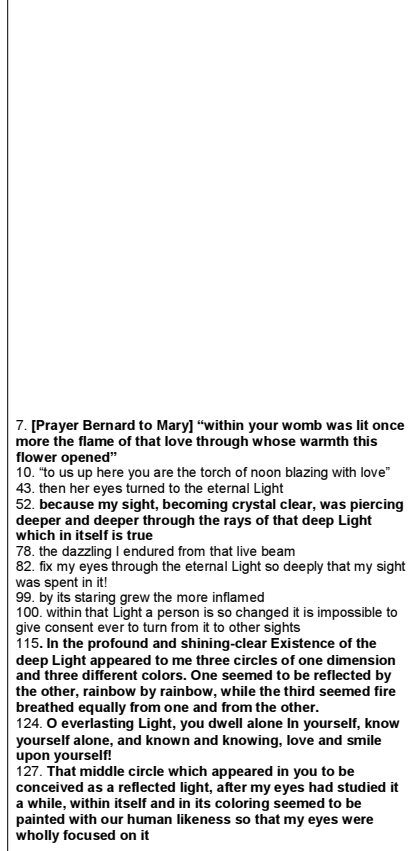 \\
\hline
\end{tabular}




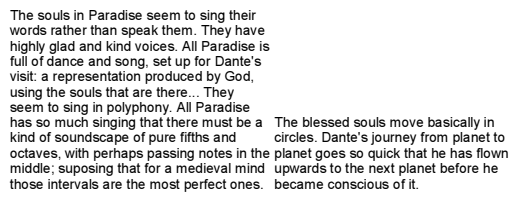

Beatrice's revolving gestures are smiling
with beaming light rtom her eves,

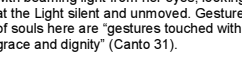

The principal element of Paradise is (divine) light "Light is not
ight unlessit t come trom that serere eand cloudless source: else darkness, the shadow and the poison of our flessh" "Cantio i 19).

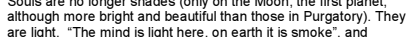

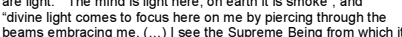

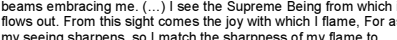

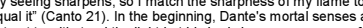

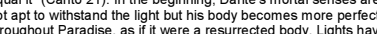

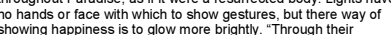

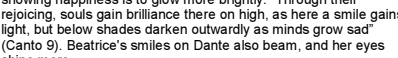

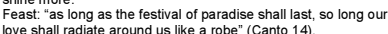
The primallight that beame down thro canthem teeves in iust as many ways as there are splendorors that merge the 政 ctaves, with pert
middeles suposing

The final experience is not tone of sound or movement, but one of The final experience is
light, color and image. 
ANNEX 2a

\begin{tabular}{|c|c|c|c|}
\hline IDEAS & SOUND & MOVEMENT / GESTURE & COLOR / LIGHT \\
\hline \multirow[t]{3}{*}{ Wilderness. } & $\begin{array}{l}\text { Nel mezzo del cammin di nostra vita } \\
\text { mi ritrovai per una selva oscura, } \\
\text { ché la diritta via era smarrita.' } \\
\text { (...) lo non so ben ridir com'i' v'intrai, } \\
\text { tant'era pien di sonno a quel punto } \\
\text { che la verace via abbandonai. } \\
\end{array}$ & & \\
\hline & $\begin{array}{l}\text { "Miserere di me! Miserere, miserere di me! } \\
\text { Miserere, miserere di me!" }\end{array}$ & Driven back by beast. & Fading day, dusky air. \\
\hline & $\begin{array}{l}\text { Per me si va ne città dolente, } \\
\text { per me si va ne l'etterno dolore, } \\
\text { per me si va ne la perduta gente. (...) } \\
\text { Lasciate ogne speranza, voi ch'intrate. }\end{array}$ & & \\
\hline \multirow[t]{2}{*}{ No man's land. } & $\begin{array}{l}\text { Heartsick sighs, groanings, shrill cries re- } \\
\text { echoed, babbling tongues, terrible palaver, } \\
\text { words of grief, inflections of deep anger, } \\
\text { strident and muffled speech, and clapping } \\
\text { hands, = tumult whipping round and round. } \\
\text { Swarming wasps and hornets. Loud weeping. }\end{array}$ & $\begin{array}{l}\text { Circling banner, racing on. Behind it, very } \\
\text { long file of people marching. }\end{array}$ & Blood running down bodies. \\
\hline & Loud thunderclap. & & Bright red flash of light. \\
\hline Limbo, locus amoenus, gardens. & $\begin{array}{l}\text { Sighs = lamentations. By vast crowds of babies, } \\
\text { women and men. Quiet air. }\end{array}$ & & Open clearing, fresh green grass. \\
\hline Air. & Like the "lai" of the cranes they cry. & $\begin{array}{l}\text { Bird-people swirled and mauled by wind. } \\
\text { Like starlings forming one long line in the } \\
\text { sky. }\end{array}$ & Dark air, nothing shines. \\
\hline \multirow[t]{5}{*}{ City? } & $\begin{array}{l}\text { Cerberus howls like a mad-dog out of all three } \\
\text { throats. Thundering loudly against the souls } \\
\text { who wish that they were deaf. }\end{array}$ & $\begin{array}{l}\text { Making a shield of one flank, then the } \\
\text { other, they flip and flop about. }\end{array}$ & $\begin{array}{l}\text { Huge hailstones, mucky sleet and } \\
\text { snow keep pouring down through the } \\
\text { gloom-filled air. Polluted mess of } \\
\text { shades and rainfall. }\end{array}$ \\
\hline & $\begin{array}{l}\text { Pape Satan, pape Satan, aleppe!, Plutus starts } \\
\text { up with clacking voice. } \\
\text { Souls move weights with piercing howls. } \\
\text { Each yells, "Perché tieni?" "Perché burli?", } \\
\text { screaming over again their verses. } \\
\end{array}$ & $\begin{array}{l}\text { In a circled ditch, groups of shades shove } \\
\text { rolling weights forward with their chests } \\
\text { and smash against each other at the } \\
\text { other half of the circle. On the spot, each } \\
\text { whips around and rolls the weight back. } \\
\end{array}$ & \\
\hline & Beating and tearing sound of all the body. & $\begin{array}{l}\text { They beat each other with their hands, } \\
\text { heads, chest, feet; and with their teeth rip } \\
\text { each other to pieces. }\end{array}$ & $\begin{array}{l}\text { In dark mud, people smeared with } \\
\text { mud, their faces lined with rage. }\end{array}$ \\
\hline & $\begin{array}{l}\text { Gurgled in mud by souls under surface: } \\
\text { "Tristi fummo } \\
\text { ne l'aere dolce che dal sol s'allegra, } \\
\text { portando dentro accidioso fummo: } \\
\text { Or ci attristiam ne la belletta negra". }\end{array}$ & & \\
\hline & Pleghyas screams, "Or se' giunta, anima fella!" & Phlegyas comes with high speed. & With red eyes. \\
\hline \multirow[t]{2}{*}{$\begin{array}{l}\text { Gates of city of Dis. Monsters and fallen } \\
\text { angels above it. }\end{array}$} & Slamming door in face. & & $\begin{array}{l}2 \text { lights and a 3rd responding to the } \\
\text { signal from far off. }\end{array}$ \\
\hline & & $\begin{array}{l}\text { Divine messenger walking on water; } \\
\text { fleeing spirits from Hell. Rhythmically } \\
\text { moving left hand out in front to brush foul } \\
\text { air away. We bow down. He opens gate } \\
\text { with a wand. }\end{array}$ & \\
\hline \multirow[t]{3}{*}{ Cementery. } & $\begin{array}{l}\text { Harsh laments in graves. } \\
\text { "Chi fuor li maggior tui?" disdainful. }\end{array}$ & One with look of contempt. & $\begin{array}{l}\text { Scattered flames that make the } \\
\text { graves glow. Red-hot city. }\end{array}$ \\
\hline & “Mio figlio ov'è? e perché non è teco?" & $\begin{array}{l}\text { Shorter one gazing all around us and then } \\
\text { tearful. }\end{array}$ & \\
\hline & Bubbling river of boiling blood, piercing cries. & $\begin{array}{l}\text { Minotaur like a bull jumping this way and } \\
\text { that after fatal blow. Thousands of } \\
\text { centaurs shooting at souls if they come } \\
\text { too far out of boiling blood. }\end{array}$ & Boiling blood. \\
\hline \multirow[t]{3}{*}{ Dead and dark forest. } & $\begin{array}{l}\text { Harpies shriek laments from up in the strange } \\
\text { trees. Deep wailings rising from all sides. }\end{array}$ & Dogs running behind 2 souls. & Dead and dark forest. \\
\hline & $\begin{array}{l}\text { Snapping a shoot off, and trunk cries: "Perché } \\
\text { mi schiante? Perché mi scerpi?" Puffs hard. }\end{array}$ & & Tree darkened with its blood. \\
\hline & $\begin{array}{l}\text { Breath transformed to voice: "Uomini fummo, e } \\
\text { or siam fatti sterpi" }\end{array}$ & & \\
\hline \multirow[t]{7}{*}{ Desert, scorched by fire. } & Many souls weeping wretchedly. & $\begin{array}{l}\text { Most walking about interminably, others } \\
\text { flat on their backs, spread out on the } \\
\text { ground; some squatted down, hunched } \\
\text { up in a crouch. } \\
\text { Restlessly the (popular) dance of } \\
\text { wretched hands goes on and on, on this } \\
\text { side and on that, beating off the freshly } \\
\text { falling flames. }\end{array}$ & Large flakes of flame "snowing" down. \\
\hline & $\begin{array}{l}\text { scornful and scowling, shouting: } \\
\text { "Qual io fui vivo, tal son morto!" }\end{array}$ & & \\
\hline & $\begin{array}{l}\text { Rumbling fall of water running down like the } \\
\text { sound of a humming beehive. }\end{array}$ & & $\begin{array}{l}\text { The river's smoke throws up a } \\
\text { shadow which screens the banks and } \\
\text { water from the fire. }\end{array}$ \\
\hline & each of them shouting: "Sòstati tu!" & $\begin{array}{l}\text { Three shades brake away together, } \\
\text { racing, out of the squad under the rain of } \\
\text { fire. Come running to us. }\end{array}$ & \\
\hline & "fa che di noi a la gente favelle" & $\begin{array}{l}\text { They form a wheel holding each other like } \\
\text { wrestlers before coming to holds between } \\
\text { them. Wheeling, each one directs his face } \\
\text { toward us, so that, in constant motion, his } \\
\text { neck keeps turning opposite his feet. }\end{array}$ & \\
\hline & $\begin{array}{l}\text { So loud thundering sound of falling water that it } \\
\text { almost hurts. }\end{array}$ & $\begin{array}{l}\text { They break out of their wheeling circle } \\
\text { and run back. }\end{array}$ & \\
\hline & & $\begin{array}{l}\text { A reptile with human honest face and } \\
\text { scorpion tail comes swimming up toward } \\
\text { us through the air. }\end{array}$ & $\begin{array}{l}\text { Richly colored animal. Thick and } \\
\text { darkened air. }\end{array}$ \\
\hline
\end{tabular}




\begin{tabular}{|c|c|c|c|}
\hline Malebolge (ditches). & $\begin{array}{l}\text { Whipping sound. } \\
\text { "Via, ruffian! qui non son femmine da conio!" }\end{array}$ & $\begin{array}{l}\text { Horned devils whip souls from behind. } \\
\text { Souls lift their heels, "dance". }\end{array}$ & $\begin{array}{l}\text { Purple-brown colored walls. Slimy } \\
\text { mold. }\end{array}$ \\
\hline & $\begin{array}{l}\text { Whining, snorting gruffly, whacking themselves } \\
\text { with flat open palms. } \\
\text { Smacking their squash, scratching themselves. }\end{array}$ & $\begin{array}{l}\text { Smacking their squash, scratching } \\
\text { themselves. } \\
\text { Now squatting and now staggering to their } \\
\text { feet. }\end{array}$ & Pool of excrement. \\
\hline & & $\begin{array}{l}\text { Friars upside down, with fire at their feet. } \\
\text { The leg-joints wriggle uncontrollably. }\end{array}$ & Feet on fire. \\
\hline & Silent litany. & $\begin{array}{l}\text { People coming hushed and weeping, as } \\
\text { slow as llitanies. } \\
\text { Necks } 180^{\circ} \text { twisted: crying on their buts } \\
\text { and walking backwards. }\end{array}$ & \\
\hline & "Qui vive la pietà quand' è ben morta" & & \\
\hline & $\begin{array}{l}\text { The rising of the boiling bubbles. } \\
\text { Shouting devils. }\end{array}$ & & Black, thick and sticky pitch. \\
\hline & $\begin{array}{l}\text { Each (devil) presses a tongue between his } \\
\text { teeth to sound a signal to their commandant, } \\
\text { and with his ass he blows a bugle-blast. }\end{array}$ & $\begin{array}{l}\text { Kind of bizarre "military group" moving to } \\
\text { "bugle-blast". }\end{array}$ & \\
\hline & $\begin{array}{l}\text { Weeping. } \\
\text { Walking over one crucified to floor, breathing } \\
\text { hard into his beard with sighs. }\end{array}$ & $\begin{array}{l}\text { Walking very slowly because of weight in } \\
\text { circles, looking tired and overwhelmed. } \\
\text { Weeping. }\end{array}$ & $\begin{array}{l}\text { People in dazzling guilded cloaks with } \\
\text { lead inside. }\end{array}$ \\
\hline & $\begin{array}{l}\text { An angry voice that seems incapable of forming } \\
\text { words. }\end{array}$ & $\begin{array}{l}\text { People running with their hands tied to } \\
\text { their backs with snakes. }\end{array}$ & $\begin{array}{l}\text { Phoenix-like process of one soul: } \\
\text { burning into ashes and revolving. }\end{array}$ \\
\hline & “Togli, Dio, ch'a te le squadro!" & Gesture of thumb between fingers to God. & \\
\hline & “Vedi che già non se' né due né uno." & Metamorphosis human - reptile. & $\begin{array}{l}\text { They stick like wax together so they } \\
\text { are "nor one nor two". }\end{array}$ \\
\hline & & & So many flames walking, like fireflies. \\
\hline & $\begin{array}{l}\text { The flame murmers and then, shaking the tip } \\
\text { this way and that, it launches outward a voice. It } \\
\text { sputters out a scrambled sound. }\end{array}$ & $\begin{array}{l}\text { The flame trembles, murmuring. The } \\
\text { pointed tip sways back and forth. }\end{array}$ & \\
\hline & \begin{tabular}{|l|} 
"S'i' credesse che mia risposta fosse \\
a persona che mai tornasse al mondo, \\
questa fiamma staria sanza più scosse."
\end{tabular} & & \\
\hline & Weird volleying cries. & $\begin{array}{l}\text { Some lying on their stomachs, some on } \\
\text { the shoulders of another, some haul } \\
\text { themselves on hands and knees along } \\
\text { the roadway. } \\
\text { Some scratch themselves with nails over } \\
\text { and over. }\end{array}$ & \\
\hline & & $\begin{array}{l}\text { Two pallid shades are biting and running. } \\
\text { One putting teeth in another, dragging } \\
\text { him, scraping his stomach against the } \\
\text { stony floor. }\end{array}$ & \\
\hline & $\begin{array}{l}\text { One is shaped like a lute. When another } \\
\text { punches him in the stomach, he sounds like a } \\
\text { drum. }\end{array}$ & He smashes the other in the face. & Steaming feverish shades. \\
\hline \multirow[t]{5}{*}{ Giants like towers (of Babel). } & A tremendously loud bugle blast. & & Thick dark atmosphere. \\
\hline & $\begin{array}{l}\text { "Raphel mai amecche zabi almi!" the giant } \\
\text { begins babbling with his beastly mouth, for } \\
\text { which no sweeter psalm is better suited } \\
\text { [imperfect anagram of "Eli, Eli, lama } \\
\text { sabachthani", "My God, my God, why have you } \\
\text { forsaken me?", 4th saying of Jesus on the } \\
\text { Cross]. }\end{array}$ & & $\begin{array}{l}\text { Less than night and less than day. } \\
\text { Thick dark atmosphere. }\end{array}$ \\
\hline & Teeth chattering with the clatter of a stork. & & $\begin{array}{l}\text { Darkened hole. } \\
\text { Lake of ice so frozen that it looked like } \\
\text { glass, not water. } \\
\text { A thousand shades are sealed in ice, } \\
\text { purpled by cold. }\end{array}$ \\
\hline & $\begin{array}{l}\text { Through tears he screams: "Perché mi peste? } \\
\text { perché mi moleste?" }\end{array}$ & I strike my foot hard on one of the faces. & \\
\hline & & $\begin{array}{l}\text { Two heads butt one another like two he- } \\
\text { goats with anger. }\end{array}$ & Tears, like a mask of crystal. \\
\hline \multirow[t]{2}{*}{$\begin{array}{l}\text { "sì che l'un capo a l'altro era cappello" } \\
\text { so that one head to the other was a hat. }\end{array}$} & $\begin{array}{l}\text { "Poscia, più che 'I dolor, poté 'I digiuno" } \\
\text { "Then, stronger than grief was my hunger." }\end{array}$ & $\begin{array}{l}\text { The one on top is gnawing on the other's } \\
\text { nape at the base of the brain with fury. }\end{array}$ & \\
\hline & & $\begin{array}{l}\text { With his eyes rolling he continues biting } \\
\text { the skull of the other. }\end{array}$ & \\
\hline \multirow[t]{3}{*}{$\begin{array}{l}\text { Traitor's soul here, while a demon } \\
\text { already inhabits his still alive body. }\end{array}$} & $\begin{array}{l}\text { "Oh! or se' tu ancor morto?" } \\
\text { "Tosto che l'anima trade } \\
\text { come fec'ío, il corpo suo l'è tolto } \\
\text { da un demonio, (che poscia il governa } \\
\text { mentre che 'I tempo suo tutto sia vòlto)." }\end{array}$ & & \\
\hline & & & $\begin{array}{l}\text { Shades sealed [in ice], like straws in } \\
\text { glass. }\end{array}$ \\
\hline & $\begin{array}{l}\text { "Vexilla Regis prodeunt Inferni closer to us," } \\
\text { parodic version of church song without the word } \\
\text { Inferni ("The Banners of the King of Hell } \\
\text { Advance"). (SPOKEN, NOT SUNG) }\end{array}$ & $\begin{array}{l}\text { Lucifer flaps his bat wings up and down } \\
\text { which causes three winds. He has three } \\
\text { heads and is crying, while chewing on } \\
\text { three shades. Half bodies. }\end{array}$ & $\begin{array}{l}\text { Teardrops and a bloody froth from his } \\
\text { eyes. Right face beige, middle face } \\
\text { fiery red, left face black. Matted hair } \\
\text { and frozen crust. }\end{array}$ \\
\hline \multicolumn{4}{|l|}{ World upside down. } \\
\hline & E quindi uscimmo a riveder le stelle. & & $\begin{array}{l}\text { Natural stone cavern with scanty } \\
\text { lighting. Return to the bright world. }\end{array}$ \\
\hline
\end{tabular}


ANNEX 2b

\begin{tabular}{|c|c|c|c|}
\hline IDEAS & SOUND & MOVEMENT / GESTURE & COLOR / LIGHT \\
\hline \multirow[t]{2}{*}{$\begin{array}{l}\text { Time: a clock during all Purgatory. } \\
\text { Light. Shadow. }\end{array}$} & $\begin{array}{l}\text { Per correr miglior acque alza le vele } \\
\text { omai la navicella del mio ingegno, } \\
\text { che lascia dietro a sé mar sì crudele; } \\
\text { e canterò di quel secondo regno } \\
\text { dove l'umano spirito si purga } \\
\text { e di salire al ciel diventa degno. } \\
\end{array}$ & Cleansing action from the "stains" of Hell. & $\begin{array}{l}\text { Soft coloring of oriental sapphire in } \\
\text { the sky. Dawn. } 6.00 \text { o'clock? }\end{array}$ \\
\hline & & & $\begin{array}{l}\text { Golden-orange sky. } \\
\text { A light coming across the sea } \\
\text { tremendously rapid. Deep red glow. }\end{array}$ \\
\hline \multirow[t]{5}{*}{$\begin{array}{l}\text { Voyage of exile, spiritual freedom. New } \\
\text { beginning. }\end{array}$} & $\begin{array}{l}\text { 'In exitu Isräel de Aegypto' sung } \\
\text { monophonically by more than a } 100 \text { souls, right } \\
\text { through the psalm as it had been composed. }\end{array}$ & $\begin{array}{l}\text { For angel kneeling down and folding } \\
\text { hands. }\end{array}$ & \\
\hline & & $\begin{array}{l}\text { Angel makes sign of the cross over them. } \\
\text { They are gazing around bewildered by the } \\
\text { location. }\end{array}$ & $\begin{array}{l}\text { The closer to us the brighter the angel } \\
\text { is - too bright. } \\
\text { The souls are pale with amazement at } \\
\text { seeing us breathe. }\end{array}$ \\
\hline & & $\begin{array}{l}\text { The souls want to see us and almost } \\
\text { trample each other, forgetting } \\
\text { themselves. }\end{array}$ & Rays of daylight to all sides. \\
\hline & & $\begin{array}{l}\text { Souls who come towards us, and yet, so } \\
\text { slowly that they seem not to come closer. }\end{array}$ & \\
\hline & & $\begin{array}{l}\text { They act like sheep, following what the } \\
\text { first do. When they see us: they huddle } \\
\text { close and stand still. } \\
\text { The leaders, dignified and moest } \\
\text { approach us. When they see our shadow, } \\
\text { they shrink backwards a bit, and the rest } \\
\text { of the group does the same, like sheep. } \\
\text { They all huddled close to the rock wall of } \\
\text { the steep cliff and stood stock still } \\
\text { together. }\end{array}$ & \\
\hline $\begin{array}{l}\text { Time. Lazy spirits who decided only at } \\
\text { last moment what to believe. } \\
\text { The difficult way up, tiredness. Man } \\
\text { cannot know God's ways and should only } \\
\text { ask "what", not "why". }\end{array}$ & & \begin{tabular}{|l|} 
Sitting with arms clasped fast around \\
knees, bent head down low between legs. \\
Hardly raising face above legs. Drowsy \\
gestures and short-winded speech.
\end{tabular} & It was past 9.00 a.m. \\
\hline $\begin{array}{l}\text { No necessary causality between past and } \\
\text { present and future: freedom. Not birth but } \\
\text { death as revelatory event: it is not where } \\
\text { you were born but what you had done } \\
\text { when you died. }\end{array}$ & $\begin{array}{l}\text { All across the mountainside come people, } \\
\text { singing the Miserere, verse answering to verse. } \\
\text { When they see our shadows, their chant } \\
\text { changes into a hoarse and drawn-out "Oh!" }\end{array}$ & $\begin{array}{l}\text { Two of them, in roles of messengers, } \\
\text { race up toward us, race back to the } \\
\text { others and then everybody comes. }\end{array}$ & \\
\hline \multicolumn{4}{|l|}{$\begin{array}{l}\text { Risk in love relationship between God } \\
\text { and the soul: the soul has the freedom } \\
\text { not to love God. }\end{array}$} \\
\hline $\begin{array}{l}\text { Locus amoenus: much more beautiful } \\
\text { than Limbo. }\end{array}$ & & $\begin{array}{l}\text { One looking on in the same way a lion } \\
\text { rests and watches. }\end{array}$ & $\begin{array}{l}\text { Gold, fine silver, white lead, cochineal, } \\
\text { indigo, self-glowing polished wood, } \\
\text { fresh emerald at the instant it is split, } \\
\text { the grass and flowers blooming in that } \\
\text { valley outshine them all in color. }\end{array}$ \\
\hline \multirow[t]{8}{*}{$\begin{array}{l}\text { Here one can only walk by daylight. } \\
\text { "the dark of night: } \\
\text { That blinds the will with inability." }\end{array}$} & $\begin{array}{l}\text { "Vedi? sola questa riga } \\
\text { non varcheresti dopo 'I sol partito: } \\
\text { non però ch'altra cosa desse briga, } \\
\text { che la notturna tenebra, ad ir suso; } \\
\text { quella col nonpoder la voglia intriga." } \\
\text { "Look! even beyond this line you could not dare } \\
\text { cross once the sun has set". }\end{array}$ & drew his finger on the ground & \\
\hline & Salve Regina sung by (at least) $3-5$ souls of 9 . & $\begin{array}{l}\text { One sits highest and neglects to move his } \\
\text { lips with others singing. } \\
\text { Another shade seems to comfort him. } \\
\text { There is a snub-nosed one "thick in talk" } \\
\text { with the kind-looking soul next to him. } \\
\text { Another one beats his breast. And } \\
\text { another one cradles his cheek in the palm } \\
\text { of his hand, the while he sighs, grief stabs } \\
\text { them to the heart. } \\
\text { There is one strong in build who chimes } \\
\text { his singing with the big-nosed shade. } \\
\text { And there is one who sits with them on } \\
\text { lower ground, gazing upward. }\end{array}$ & \\
\hline & & $\begin{array}{l}\text { One of the souls stands up and gestures } \\
\text { to be heard. He folds his hands in prayer } \\
\text { and lifts them, with his eyes fastened on } \\
\text { the east, as if saying to God, "I care for } \\
\text { nothing else!" }\end{array}$ & \\
\hline & $\begin{array}{l}\text { "Te lucis ante" he devoutly sings beautifully. } \\
\text { Then the others with sweetness and devotion } \\
\text { harmonize with him through the whole hymn. }\end{array}$ & $\begin{array}{l}\text { All are looking to the heavens while they } \\
\text { sing. They they keep gazing upward in } \\
\text { silence, subdued and pale, as if in } \\
\text { expectation. }\end{array}$ & \\
\hline & & $\begin{array}{l}\text { Two angels sweep from above and fly } \\
\text { down. }\end{array}$ & $\begin{array}{l}\text { They have flaming swords, their robes } \\
\text { and wings are green. Their hair is } \\
\text { gold, their faces are too bright to be } \\
\text { able to look at them. }\end{array}$ \\
\hline & A snake appears. " "Vedi là 'I nostro avversaro!" & $\begin{array}{l}\text { Seizes arm of another, points finger to } \\
\text { snake. }\end{array}$ & \\
\hline & Sound of green wings slicing through the air. & Snake crawls off. & \\
\hline & & $\begin{array}{l}\text { The angels wheel around in parallel flights } \\
\text { back up to their two posts. }\end{array}$ & \\
\hline
\end{tabular}




\begin{tabular}{|c|c|c|c|}
\hline \multirow[t]{4}{*}{$\begin{array}{l}\text { The gate to Inferno being now the gate to } \\
\text { Purgatory Proper: another perspective, } \\
\text { same world. }\end{array}$} & & & $\begin{array}{l}\text { The sun is now more than two hours } \\
\text { high. } \\
\text { About eight o'clock in the morning. } \\
\text { Angel with too bright face and sword, } \\
\text { wearing robe with color of ashes. }\end{array}$ \\
\hline & & $\begin{array}{l}\text { Devoutly falling at angel's feet, begging } \\
\text { him open the gate, but first beating three } \\
\text { times upon own breast. }\end{array}$ & $\begin{array}{l}\text { Three steps of different colors: white } \\
\text { mirroring marble (recognition of one's } \\
\text { sins), black made of charred and } \\
\text { pebble-broken stones (heartfelt } \\
\text { contrition), blood-red (satisfaction). } \\
\text { Threshold is diamond. }\end{array}$ \\
\hline & & & $\begin{array}{l}\text { The first key was silver and the } \\
\text { second gold. }\end{array}$ \\
\hline & $\begin{array}{l}\text { When the pivots of the gate turned a very loud } \\
\text { and very resonant clangor of the pivots of the } \\
\text { gate when it closes behind us. } \\
\text { "Te Deum: Praise to God" seems to be chanted } \\
\text { by voices mixed with that strain. } \\
\text { It sounds like "cantar con organi" and now and } \\
\text { then we just make out the words. }\end{array}$ & & \\
\hline $\begin{array}{l}\text { Pride (Superbia) vs. humility. } \\
\text { Representation through the language of } \\
\text { art. } \\
\text { Relationship virtue and art = Aesthetic } \\
\text { and ethical education. How do we look at } \\
\text { art and what do we learn from it? Form. } \\
\text { Art gives metamorphosis: that is how it } \\
\text { enters time. } \\
\text { Spectators of the world. A safe } \\
\text { perspective does not exist. If I think that I } \\
\text { can take a safe distance, it's because I } \\
\text { do not want to look within myself. }\end{array}$ & The gate closes with loud clanging. & $\begin{array}{l}\text { Souls carrying boulders. } \\
\text { Some are more pressed down and some } \\
\text { were less. } \\
\text { Each one beats his chest, in tears they } \\
\text { seem to say: } \\
\text { 'piú non posso'. }\end{array}$ & $\begin{array}{l}\text { It is about } 4 \text { hours after sunrise, about } \\
10.00 \text { o'clock. } \\
\text { Inner ring of pure white marble. }\end{array}$ \\
\hline $\begin{array}{l}\text { Franciscan perspective: The only way in } \\
\text { which you can really understand the } \\
\text { creation is really to look from the bottom } \\
\text { up and not from the top down. }\end{array}$ & $\begin{array}{l}\text { "O Padre nostro, che ne' cieli stai, } \\
\text { Dà oggi a noi la cotidiana manna, } \\
\text { sanza la qual per questo aspro diserto } \\
\text { a retro va chi più di gir s'affanna. } \\
\text { E come noi lo mal ch'avem sofferto } \\
\text { perdoniamo a ciascuno, e tu perdona } \\
\text { benigno, e non guardar lo nostro merto. } \\
\text { Nostra virtù che di legger s'adona, } \\
\text { non spermentar con l'antico avversaro, } \\
\text { ma libera da lui che sì la sprona." }\end{array}$ & & \\
\hline $\begin{array}{l}\text { Punished Pride (Lucifer, Nimrod etc.) We } \\
\text { have to look down to see them, they are } \\
\text { on the ground. } \\
\text { Redefinition of pride: only contempt for } \\
\text { what is below you, not a love for what is } \\
\text { above you. Humility and pride really have } \\
\text { to go hand in hand and one attenuates } \\
\text { and changes the meaning of the other. } \\
\text { Man and pride go hand in hand. }\end{array}$ & Beati pauperes spiritu!' sung sweetly by voices. & $\begin{array}{l}\text { An angel stands at the next gate, his } \\
\text { arms wide, he spreads his wings, saying, } \\
\text { "Venite". }\end{array}$ & $\begin{array}{l}\text { It is noon. } 12.00 \text { o'clock. } \\
\text { The angel is dressed in white and is } \\
\text { very radiant. }\end{array}$ \\
\hline \multirow[t]{4}{*}{$\begin{array}{l}\text { Envy. The ones with the eyelids sown so } \\
\text { that they cannot see, only hear. } \\
\text { Disembodied voices fly past them, } \\
\text { shouting the examples of love and envy. }\end{array}$} & $\begin{array}{l}\text { Flying disembodied voices toward us. } \\
\text { The first voice that flew past cried out aloud } \\
\text { "Vinum non habent" and it sped on by us off to } \\
\text { our rear, re-echoing the words. And before it } \\
\text { fully faded out of hearing distance, another } \\
\text { voice passed with the cry, "I' sono Oreste" and } \\
\text { also did not pause. A third exclaimed, "Amate } \\
\text { da cui male aveste". }\end{array}$ & Some raise the chin to give attention. & $\begin{array}{l}\text { Shades in cloaks of the same } \\
\text { discoloration as the stone. }\end{array}$ \\
\hline & $\begin{array}{l}\text { I heard cried out "Maria òra per noi". [Sancta } \\
\text { Maria. Ora pro nobis]. } \\
\text { And cried out "Michael" and "Peter" and "All } \\
\text { saints.". [Sancta Dei Génetrix. Ora pro nobis. } \\
\text { Sancta Virgo virginum. O... Sancte Michael. } \\
\text { O... Sancte Gabriel. O... Sancte Rafael. O... } \\
\text { Omnes sancti Angeli et Archangeli. O... } \\
\text { Omnes sancti beatórum Spírituum ordines. } \\
\text { O... Sancte Joánnes Baptista. O... Sancte } \\
\text { Josephe. O... Omnes sancti Patriárchæ et } \\
\text { Prophetæ. O... Sancte Petre. O... Sancte } \\
\text { Paule. O... Sancte Andrea. O... Sancte Jacobe. } \\
\text { O... etc]. }\end{array}$ & & \\
\hline & $\begin{array}{l}\text { Like a lightning bolt, a voice hurtles against us: } \\
\text { "Anciderammi qualunque m'apprende" and it } \\
\text { flees on like thunder that rolls away. Quickly } \\
\text { after, the second breaks with a crash as loud as } \\
\text { thunder: "lo sono Aglauro che divenni sasso". } \\
\text { Then silence. }\end{array}$ & & $\begin{array}{l}\text { Twilight, the last bright beams of } \\
\text { evening sun. } \\
\text { Unbearable brightness of angel } \\
\text { waiting at next gate. }\end{array}$ \\
\hline & $\begin{array}{l}\text { "Beati misericordes!" rings out in song behind } \\
\text { us, and "Godi tu che vinci!" }\end{array}$ & & \\
\hline
\end{tabular}




\begin{tabular}{|c|c|c|c|}
\hline $\begin{array}{l}\text { Wrath (anger). } \\
\text { Goods which lessen when shared by } \\
\text { more people, and the Good which } \\
\text { doesn't. Unlimited divine love, light. An } \\
\text { inner light that is available to us. } \\
\text { Visions of the opposite of wrath: } \\
\text { gentleness. } \\
\text { Pride vs. humility reappears as a } \\
\text { question of limits and transgressions. } \\
\text { Human degradation. Free will and free } \\
\text { choice: intellect. Within God's created } \\
\text { limitations we are free: our free } \\
\text { subjection. } \\
\text { Individuals (because they have free will) } \\
\text { are responsible for their actions: moral } \\
\text { responsabilities. Guidance, in the form of } \\
\text { laws and leadership, is required to direct } \\
\text { individual souls to proper ends. Misrule is } \\
\text { the reason the world has fallen into } \\
\text { corrupt ways. Political freedom: equality } \\
\text { Church and Empire. } \\
\text { So, creation, the creation of the soul, the } \\
\text { freedom with which God creates and that } \\
\text { freedom becomes a ground for human } \\
\text { freedom. }\end{array}$ & $\begin{array}{l}\text { Voices of souls sing "Agnus Dei", perfectly } \\
\text { monophonically. }\end{array}$ & & $\begin{array}{l}\text { A smoke drifts toward us, black as } \\
\text { night. We go into it and we cannot see } \\
\text { anything. Cloud of anger: blindness. }\end{array}$ \\
\hline $\begin{array}{l}\text { Center of this poetic universe. Love. How } \\
\text { and what I love is related to my } \\
\text { perception of the world. } \\
\text { Mirror: limits and transgression, pride } \\
\text { and humility, go together, paradox. } \\
\text { Free will in relation to love: Love is the } \\
\text { "seed" of all human acts, both sinful and } \\
\text { virtuous (too much, too little, wrong) } \\
\text { Rational love organizes. }\end{array}$ & & & $\begin{array}{l}\text { We break out of the cloud into the } \\
\text { sunrays, which is intense after } \\
\text { blindness. Too bright angel. } \\
\text { Final sunbeams, the stars start to } \\
\text { show themselves. } \\
\text { The (half) moon arising late, almost at } \\
\text { midnight, makes the stars look } \\
\text { scantier to us, because it is glowing } \\
\text { strongly. }\end{array}$ \\
\hline \multirow[t]{3}{*}{$\begin{array}{l}\text { Sloth (indecisiveness, sluggishness), } \\
\text { acedia: crisis of desire. } \\
\text { What I perceive may be looking good to } \\
\text { me and does not look good to you. } \\
\text { Choice and free will from philosophical } \\
\text { point of view. }\end{array}$} & $\begin{array}{l}\text { The slothful are shouting famous examples of } \\
\text { slothful behavior and its contrary virtue. }\end{array}$ & $\begin{array}{l}\text { The slothful are running around the } \\
\text { terrace. }\end{array}$ & \\
\hline & $\begin{array}{l}\text { Two of them up front cry out in tears: "Maria } \\
\text { corse con fretta a la montagna". "Ratto, ratto, } \\
\text { che 'I tempo non si perda per poco amor" the } \\
\text { rest who followed cries. }\end{array}$ & $\begin{array}{l}\text { The whole huge company is running } \\
\text { toward us. }\end{array}$ & \\
\hline & $\begin{array}{l}\text { "Noi siam di voglia a muoverci sì pieni, che } \\
\text { restar non potem; però perdona, se villania } \\
\text { nostra giustizia tieni." He by now has raced so } \\
\text { far beyond us while talking that we stop being } \\
\text { able to understand his words. }\end{array}$ & & \\
\hline \multirow[t]{2}{*}{$\begin{array}{l}\text { Avarice and Prodigality. Here are souls } \\
\text { lying facedown, immobile and } \\
\text { outstreched, on the hard rock floor, } \\
\text { weeping and singing. }\end{array}$} & $\begin{array}{l}\text { "Venite; qui si varca" says an angel with an } \\
\text { unhumanly gentle voice. } \\
\text { "Beati qui lugent quoniam ipsi consolabuntur" } \\
\text { he "affirm" (sings). }\end{array}$ & The angel moves his feathers. & \\
\hline & $\begin{array}{l}\text { "Adhaesit pavimento anima mea" murmured } \\
\text { with sighs so deep and gasping that scarcely } \\
\text { can the words be understood. }\end{array}$ & & \\
\hline $\begin{array}{l}\text { Resurrection, rebirth, comparison with } \\
\text { resurrected Christ. }\end{array}$ & $\begin{array}{l}\text { One cries "Dolce Maria!" as a woman in labour. } \\
\text { Then such a cry on all sides starts up, 'Gloria in } \\
\text { excelsis Deo'! } \\
\text { "O frati miei, Dio vi dea pace". }\end{array}$ & $\begin{array}{l}\text { The mountain trembles. } \\
\text { The soul arises and walks toward Heaven } \\
\text { freely. }\end{array}$ & \\
\hline \multirow[t]{2}{*}{$\begin{array}{l}\text { Gluttony. } \\
\text { Two trees rise up from different locations } \\
\text { on the sixth terrace to excite desire in the } \\
\text { gluttonous spirits for food and drink only } \\
\text { to frustrate this craving. From the } \\
\text { branches and leaves of each tree } \\
\text { resounds an anonymous voice } \\
\text { summarizing examples of temperance, } \\
\text { and of gluttony. } \\
\text { The denial of nourishment causes the } \\
\text { spirits' "bodies" to waste away: their } \\
\text { faces show OMO. }\end{array}$} & $\begin{array}{l}\text { "Beati qui ... sitiunt" } \\
\text { Clear sparkling water falls over the trees. } \\
\text { "Labïa mëa, Domine" sung in tears, in such } \\
\text { tones that it gives birth to gladness and to grief. }\end{array}$ & $\begin{array}{l}\text { From behind us, moving faster, coming } \\
\text { and passing by, there gazes at us in } \\
\text { wonder a throng of spirits, silent and } \\
\text { devout. } \\
\text { Hungrily biting their teeth on air. } \\
\text { They all turn away their faces and speed } \\
\text { up their pace once more. }\end{array}$ & Dry scabs discoloring their skin. \\
\hline & & $\begin{array}{l}\text { Beneath the tree people lift their hands } \\
\text { and cry something up toward the leaves } \\
\text { like foolish and obstreperous small } \\
\text { children who beg. Then they draw off as if } \\
\text { they now know better. }\end{array}$ & Too bright angel. \\
\hline \multirow[t]{2}{*}{$\begin{array}{l}\text { Lust. The souls are walking in fire, } \\
\text { singing a hymn and, between verses, } \\
\text { shouting out examples of chastity. }\end{array}$} & $\begin{array}{l}\text { "Summae Deus Clementiae" sung within the } \\
\text { huge burning blaze. After finishing it, they cry in } \\
\text { a loud voice, "Virum non cognosco", then } \\
\text { quietly sing the hymn again. When it is once } \\
\text { more done, they cry, "Al bosco } \\
\text { Si tenne Diana, ed Elice caccionne } \\
\text { che di Venere avea sentito il tossco" Then they } \\
\text { sing again; then they cry in praise of wives and } \\
\text { husbands who are chaste, as virtue and the } \\
\text { marriage vows require. }\end{array}$ & $\begin{array}{l}\text { Some of them approach as near to us as } \\
\text { they can, always careful not to step out } \\
\text { where they would not be burned. }\end{array}$ & $\begin{array}{l}\text { It is } 14.00 \text { o'clock. } \\
\text { Our shadow makes the fire glow } \\
\text { more. }\end{array}$ \\
\hline & & $\begin{array}{l}\text { Down the middle of the burning road } \\
\text { come people with their faces opposite to } \\
\text { these. All the shades on either side are } \\
\text { hurrying and kissing one another without } \\
\text { halting, content with this brief greeting. }\end{array}$ & \\
\hline
\end{tabular}




\begin{tabular}{|c|c|c|c|}
\hline & $\begin{array}{l}\text { As soon as they break off their friendly } \\
\text { welcome, before they set off, each one } \\
\text { attempts to outshout all the rest, the } \\
\text { newcomers crying "Sodom and Gomorrah!", the } \\
\text { others, "Pasiphae climbs in the cow to let the } \\
\text { bull come gallop to her lust!" } \\
\text { They return in tears to their first chants. }\end{array}$ & $\begin{array}{l}\text { One group of people leaves and one } \\
\text { comes on. }\end{array}$ & \\
\hline $\begin{array}{l}\text { First part of our journey started in } \\
\text { wilderness and now ends in the garden } \\
\text { (of Eden), but we will go beyond: Felix } \\
\text { culpa, happy fall: fall of man could allow } \\
\text { man to want to even move beyond the } \\
\text { garden of Eden. }\end{array}$ & $\begin{array}{l}\text { An angel sings aloud, 'Beati mundo corde!' in a } \\
\text { voice far more alive than ours. }\end{array}$ & & \\
\hline $\begin{array}{l}\text { We have to cross the fire and follow the } \\
\text { singing. }\end{array}$ & $\begin{array}{l}\text { A singing voice, beyond, is guiding us; and we } \\
\text { come outside. 'Venite, benedicti Patris mei' } \\
\text { resounds from within a light. }\end{array}$ & & $\begin{array}{l}\text { After sleep, soft splendor of the dawn. } \\
\text { Young grass and flowers. }\end{array}$ \\
\hline \multirow[t]{15}{*}{$\begin{array}{l}\text { Locus amoenus, but never outside } \\
\text { history. } \\
\text { Successfull re-enactment of Inf.1: the } \\
\text { Garden of Eden is exactly the wilderness } \\
\text { that we left behind, seen from a different } \\
\text { perspective; the supernatural world is the } \\
\text { natural world through a different lens and } \\
\text { different perspective. }\end{array}$} & $\begin{array}{l}\text { "Già m'avean trasportato i lenti passi } \\
\text { dentro a la selva antica tanto, ch'io } \\
\text { non potea rivedere ond'io mi 'ntrassi” } \\
\text { Little birds sing accompanied by the sound of } \\
\text { the leaves. }\end{array}$ & & $\begin{array}{l}\text { The heavenly woods are dense and } \\
\text { green with life. } \\
\text { The water stream shows the clearest } \\
\text { and darkest water ever (profound?). }\end{array}$ \\
\hline & $\begin{array}{l}\text { approaching me so near that the sweet sound } \\
\text { that came to me was comprehensible. }\end{array}$ & $\begin{array}{l}\text { A woman all alone, who walked along } \\
\text { singing, and picking flower after flower. } \\
\text { Dancing, she turns around with feet close } \\
\text { to the ground and to each other, and } \\
\text { scarcely places foot in front of foot, she } \\
\text { turns upon the red and yellow flowers in } \\
\text { my direction, lowering her eyes. }\end{array}$ & Red and yellow flowers. \\
\hline & "Bonum est confiteri" (delectasti) & & \\
\hline & $\begin{array}{l}\text { "On this side it flows down with the power } \\
\text { To wipe away the memory of sin, } \\
\text { On that side to bring all good deeds to mind. } \\
\text { It is called Lethe here, Eunoè there; } \\
\text { And its waters will not work unless they first } \\
\text { Be tasted on one side and then the other" }\end{array}$ & & \\
\hline & $\begin{array}{l}\text { Singing like a woman who is in love, } \\
\text { she continues, 'Beati quorum tecta sunt } \\
\text { peccata!' [Beati, quorum remissae sunt } \\
\text { iniquitates, et quorum tecta sunt peccata } \\
\text { (Psalm } 31 \text { (32): 1)] }\end{array}$ & & $\begin{array}{l}\text { A sudden glowing brightness that } \\
\text { lasted courses throughout the forest } \\
\text { on all sides. }\end{array}$ \\
\hline & $\begin{array}{l}\text { A sweet-sounding melody runs through the } \\
\text { light-filled air, until it can be heard as song: with } \\
\text { the word "Hosanna." (to the son of David) }\end{array}$ & $\begin{array}{l}\text { The procession moves very slowly } \\
\text { towards us. }\end{array}$ & $\begin{array}{l}\text { Seven golden candlesticks. } \\
\text { People following the lights [opposite of } \\
\text { procession in Inferno } 2 \text { ?] } \\
\text { and clothed in the purest white. } \\
\text { The candles leave a rainbow-coloured } \\
\text { path in the air. } \\
\text { Twenty-four elders, two by two, with } \\
\text { crowns of woven lilies. }\end{array}$ \\
\hline & $\begin{array}{l}\text { They sing "Ave Maria gratia plena dominus } \\
\text { tecum benedicta tu in mulieribus" }\end{array}$ & & $\begin{array}{l}\text { Four creatures, each with a crown of } \\
\text { green leaves on his head, each had } \\
\text { six wings with feathers full of eyes. } \\
\text { The Gryphon's limbs are golden } \\
\text { where he is a bird and all the rest is } \\
\text { white mixed in with red. }\end{array}$ \\
\hline & $\begin{array}{l}\text { Sometimes the white one leads, sometimes the } \\
\text { red, and the leader gives the others the } \\
\text { measure and song. }\end{array}$ & $\begin{array}{l}\text { Three women in a circle are dancing at } \\
\text { the right wheel of the chariot. }\end{array}$ & $\begin{array}{l}\text { the first one is flaming red; } \\
\text { the second has the color of emerald; } \\
\text { and the third is white like snow. }\end{array}$ \\
\hline & & $\begin{array}{l}\text { Four women dance to the cadence at the } \\
\text { left wheel. }\end{array}$ & They are dressed in purple. \\
\hline & & & $\begin{array}{l}\text { Seven men with crowns of roses and } \\
\text { other red flowers. }\end{array}$ \\
\hline & $\begin{array}{l}\text { When the chariot is across from us, a } \\
\text { thunderclap sounds. }\end{array}$ & $\begin{array}{l}\text { Apparently forbidden to march farther, } \\
\text { they stop there with their banner-flames in } \\
\text { front. }\end{array}$ & \\
\hline & & They turn to the chariot as to their peace. & \\
\hline & $\begin{array}{l}\text { One of them, as though sent down from } \\
\text { heaven, in song cries, 'Veni, sponsa, de Libano' } \\
\text { three times, and all the rest sings after him. } \\
\text { Then they all call out, "Benedictus qui venis!" }\end{array}$ & & \\
\hline & $\begin{array}{l}\text { The angels sing straightway, "In te, Domine, } \\
\text { speravi" but until 'pedes meos'. }\end{array}$ & & \\
\hline & $\begin{array}{l}\text { They sing "Asperges me" after the washing in } \\
\text { an unearthy sweet manner, difficult to recall. }\end{array}$ & $\begin{array}{l}\text { The woman plunges me in the stream up } \\
\text { to my neck and, pulling me behind her, } \\
\text { passes along, lighter than a shuttle, on } \\
\text { the water. }\end{array}$ & \\
\hline $\begin{array}{l}\text { Memory and forgetfulness, Lethe and } \\
\text { Eunoe entailing each other, so that } \\
\text { there's no erasure which is not at the } \\
\text { same time a memory. }\end{array}$ & & $\begin{array}{l}\text { The woman opens her arms wide; she } \\
\text { clasps me by the head and dips me } \\
\text { under, so deep that I swallow water. She } \\
\text { draws me out then and she leads me } \\
\text { bathed into the dance of the four women } \\
\text { and each one links her arm above my } \\
\text { head. }\end{array}$ & \\
\hline
\end{tabular}




\begin{tabular}{|l|l|l|l|}
\hline & & & \\
& & $\begin{array}{l}\text { The magnificent army has wheeled round } \\
\text { to the right, and now is turning with faces } \\
\text { toward the sun and the seven flames. } \\
\text { Just as a squadron turn to retreat and, } \\
\text { with the standard, wheel around before } \\
\text { the rest can swing about, so the militia of } \\
\text { the celestial realm in the advanced guard } \\
\text { passes in front of us before the chariot } \\
\text { circles on its pole. At that the women turn } \\
\text { back to the wheels. . Possibly a mirror } \\
\text { image of the "army" of the devils]. }\end{array}$ & \\
\hline & $\begin{array}{l}\text { Pacing through the forest our steps keep time } \\
\text { to an angelic tune. } \\
\text { (L: compare "to a stranger bugle" of Inferno) }\end{array}$ & & \\
\hline & $\begin{array}{l}\text { They sing a hymn that Dante did not } \\
\text { understand nor heard until the end. }\end{array}$ & \\
\hline & $\begin{array}{l}\text { "lo ritornai da la santissima onda } \\
\text { rifatto si come piante novelle } \\
\text { rinovellate di novella fronda, } \\
\text { puro e disposto a salire a le stelle." }\end{array}$ & \\
\hline
\end{tabular}


ANNEX 2c

\begin{tabular}{|c|c|c|c|}
\hline IDEAS & SOUND & MOVEMENT / GESTURE & COLOR / LIGHT \\
\hline God is cause and participation in creation. & $\begin{array}{l}\text { "La gloria di colui che tutto move } \\
\text { per l'universo penetra, e risplende } \\
\text { in una parte più e meno altrove." }\end{array}$ & & \\
\hline $\begin{array}{l}\text { Travel to the first planet: so fast that he doesn't } \\
\text { understand. } \\
\text { Moon: grammar (also poetry). Discourse of } \\
\text { allegory. Unfulfilment of vows. } \\
\text { The universe I am in. Is this universe a material } \\
\text { one? Is this part of the natural world? }\end{array}$ & Strangeness of sound of revolving (planet). & & $\begin{array}{l}\text { Day has broken, whitening. We can } \\
\text { stare into the sun now (trasumanar) } \\
\text { and see it blazing sparks. Then it } \\
\text { becomes much lighter. }\end{array}$ \\
\hline $\begin{array}{l}\text { How can they feel happy if they are in the lowest } \\
\text { heaven? but these souls are perfectly happy and } \\
\text { enjoy their eternal blessedness in the presence } \\
\text { of God in the Empyrean, the highest heaven. } \\
\text { They appear in the spheres only as a sign, for us, } \\
\text { of their varying degrees of beatitud. }\end{array}$ & $\begin{array}{l}\text { "ogne dove } \\
\text { In cielo è paradiso" } \\
\text { She begins to sing Ave Maria, and singing, } \\
\text { disappears, just like a solid weight down } \\
\text { through deep water. }\end{array}$ & & $\begin{array}{l}\text { The souls are still shades here, but } \\
\text { like mirrored faces, and more } \\
\text { beautiful than they were on Earth. }\end{array}$ \\
\hline $\begin{array}{l}\text { Mercury: dialectica and logic. Sin: achievements } \\
\text { for the sake of glory. Men of honour. } \\
\text { Logic can be used to have power. }\end{array}$ & $\begin{array}{l}\text { More than a thousand splendors drawing } \\
\text { toward us, and in each I heard, } \\
\text { "Look, someone comes who shall augment our } \\
\text { love!" } \\
\text { "We are inflamed by the illumination reaching } \\
\text { through all heaven". }\end{array}$ & & $\begin{array}{l}\text { More than a thousand splendors } \\
\text { drawing toward us, and in each I } \\
\text { heard, } \\
\text { "Look, someone comes who shall } \\
\text { augment our love!" } \\
\text { And when each one in turn came up } \\
\text { to us, we saw each shade was filled } \\
\text { with happiness by the bright glow that } \\
\text { burst out from within. } \\
\text { "We are inflamed by the illumination } \\
\text { reaching through all heaven". } \\
\text { By increasing joy that holy figure hid } \\
\text { itself from me in its own radiance. }\end{array}$ \\
\hline & $\begin{array}{l}\text { From the midst of those appearing in the front a } \\
\text { beautiful Hosanna sounds. }\end{array}$ & & \\
\hline $\begin{array}{l}\text { Importance of earning glory through excellence, } \\
\text { corruption and violence that plague the state } \\
\text { (politics). } \\
\text { Earth's shadow on Moon, Mercury and Venus as } \\
\text { a cone: reaches at a point here. These } 3 \text { planets } \\
\text { live in the shadow, are inferior, to the other souls. }\end{array}$ & & & \\
\hline \multirow[t]{2}{*}{$\begin{array}{l}\text { Sun: aritmetica (numbers). Wise spirits: two } \\
\text { wheels of saints, represented as two garlands of } \\
\text { old men who hold themselves by the hand, } \\
\text { dancing around the Sun: circle of knowledge. } \\
\text { Redefinition of the Trinity: the inner life of the } \\
\text { Trinity as a life of love, the son and the father } \\
\text { bound by the breath of love. } \\
\text { We literally move beyond the sunlight: what kind } \\
\text { of knowledge do I need here? Rethinking of } \\
\text { relationship between truth or knowledge and } \\
\text { error. }\end{array}$} & & & $\begin{array}{l}\text { Very luminous light. The lights here } \\
\text { are reavealed by light and not by } \\
\text { color, so bright are they. } \\
\text { Many lights surround us in the center } \\
\text { of a crown. }\end{array}$ \\
\hline & $\begin{array}{l}\text { The lights sing of myriad jewels in the higher } \\
\text { heavens (God, Maria, angels...) }\end{array}$ & $\begin{array}{l}\text { When, singing in this way, those lights } \\
\text { three times have circled round about us, } \\
\text { they look like ladies pausing in the dance } \\
\text { to listen to the music silently until they } \\
\text { catch up to the tune anew. }\end{array}$ & \\
\hline Tolerence between religions. & $\begin{array}{l}\text { The wheel rotates and answers voice to voice } \\
\text { with harmony and inmense sweetness. }\end{array}$ & $\begin{array}{l}\text { When each light has come round to that } \\
\text { point of the circle that he'd left, each rests } \\
\text { there. }\end{array}$ & \\
\hline Heresy and orthodoxy. & $\begin{array}{l}\text {...song with song: song that surpasses the } \\
\text { music that we know. The outer band echoes the } \\
\text { inner one. }\end{array}$ & $\begin{array}{l}\text { The circle starts its rotation once again; } \\
\text { and it has not yet turned completely when } \\
\text { a second circle closes around the first }(2 \\
\text { circles around us), motion matched with } \\
\text { motion... }\end{array}$ & \\
\hline
\end{tabular}




\begin{tabular}{|c|c|c|c|}
\hline $\begin{array}{l}\text { History as genealogy: can it account for who we } \\
\text { are? If I don't belong to the city, and city and } \\
\text { families go on decaying and disappearing, what } \\
\text { is the true relationship that I have to my } \\
\text { ancestors? } \\
\text { How does the self enter in history? One inevitably } \\
\text { belongs in history. A city involves us, we } \\
\text { construct its history. } \\
\text { Loneliness is the condition of exile. But still part } \\
\text { of the community. Transformation of punishment } \\
\text { into virtue of exile. } \\
\text { History is futurity: future is the time of one's } \\
\text { projects, the time in which one can really define } \\
\text { oneself. Exile, dislocation, is also the root of } \\
\text { one's religious consciousness. }\end{array}$ & & & $\begin{array}{l}\text { A light starts to flash out, just like a } \\
\text { golden mirror in the sun. }\end{array}$ \\
\hline $\begin{array}{l}\text { What is a heroic life? It can involve defeat (like } \\
\text { Roland). It implies the power to establish and live } \\
\text { for a cause, even if it brings about divisions } \\
\text { (crusades). } \\
\text { Jupiter, geometry. Geometry regulates idea of } \\
\text { space and implies perspective. Relation with } \\
\text { ethics (justice, Wheel of Fortune, contrapasso). } \\
\text { From here on a divine spectacle, the heavens } \\
\text { are a sacred theatre where God will go on } \\
\text { speaking to human beings by using the souls of } \\
\text { the blessed. Letters: diligite iustitiam. Divine } \\
\text { justice. God the geometer. A theatre, the idea } \\
\text { that through the shapes of the world are really } \\
\text { the representations of this perfection of God's } \\
\text { geometry. }\end{array}$ & & $\begin{array}{l}\text { The lights are patterning out words. Like } \\
\text { birds fly now in a circle, now in one long } \\
\text { line, so in those lights are creatures } \\
\text { singing while they are flying, and in their } \\
\text { figures form letters: now D, now I, and } \\
\text { now L. At first they move in rhythm with } \\
\text { their song, but then, as they become one } \\
\text { of those letters, they stop for a brief } \\
\text { interval in silence. } \\
\text { DILIGITE JUSTITIAM } \\
\text { QUI JUDICATIS TERRAM }\end{array}$ & \\
\hline $\begin{array}{l}\text { What is justice? Divine justice. Language of } \\
\text { measure (geography). The language of measure, } \\
\text { the language of accounting, and the language of } \\
\text { limits is set against this idea of something not } \\
\text { finite, something that escapes the logic of } \\
\text { geometry, the logic of measurement, an infinite } \\
\text { and excess. Even the word universe comes from } \\
\text { geometry because it implies a turning. You come } \\
\text { to the end of the line and you turn, and you draw } \\
\text { a geometrical figure, and so does the universe. } \\
\text { Justice depends on location? What is a place? } \\
\text { Question of alterity. What is here and what is } \\
\text { there? How is the salvation going to work? } \\
\text { Boundaries are political but they are not nor can } \\
\text { they be thought of as being moral boundaries. }\end{array}$ & $\begin{array}{l}\text { The beak sounds out with its voice both I and } \\
\text { Mine when really it intended We and Our. } \\
\text { As many embers make one single heat, so } \\
\text { many loves sound out one single voice. } \\
\text { Woven with praises for the grace of God, with } \\
\text { heavenly songs. } \\
\text { "Lume non è, se non vien dal sereno } \\
\text { che non si turba mai; anzi è tenèbra } \\
\text { od ombra de la carne o suo veleno." } \\
\text { ["Light is not light unless it come from that } \\
\text { serene and cloudless Source: else it is } \\
\text { darkness, the shadow and the poison of our } \\
\text { flesh".] }\end{array}$ & $\begin{array}{l}\text { The rest of the souls who formed first a } \\
\text { lily on the M finish the design with a slight } \\
\text { movement. } \\
\text { Just as a falcon, slipping from its hood, } \\
\text { rears and shakes its head and flaps its } \\
\text { wings, showing its spirit, making itself } \\
\text { handsome, so that banner is moving, } \\
\text { woven with praises for the grace of God, } \\
\text { with heavenly songs. }\end{array}$ & \\
\hline & $\begin{array}{l}\text { Wheeling it sang (something difficult to } \\
\text { understand for a medieval ear, without words?), } \\
\text { and said, } \\
\text { "Quali } \\
\text { son le mie note a te, che non le 'ntendi, } \\
\text { tal è i giudicio etterno a voi mortali" } \\
\text { "As are my notes to you who do not } \\
\text { comprehend them, such is the eternal judgment } \\
\text { to you mortals." }\end{array}$ & $\begin{array}{l}\text { Just as the stork wheels round above her } \\
\text { nest, so did this emblem turn, and so it } \\
\text { moved its wings. }\end{array}$ & \\
\hline $\begin{array}{l}\text { Philosophy without theology ends up in a sort of } \\
\text { labyrinth of its own constructions and may lose } \\
\text { the way. Theology, without philosophy, may end } \\
\text { up in mere opinion which has no validity at all for } \\
\text { people who believe in the power of reason. Exile } \\
\text { is always a sense of the problematical qualities of } \\
\text { a place in the world and the relationship that we } \\
\text { have with ourselves and our own ideas. }\end{array}$ & $\begin{array}{l}\text { Each living luminary began to sing hymns that } \\
\text { have slipped out of Dante's memory. When all } \\
\text { silence, the murmuring of a river sounds. That } \\
\text { murmuring whisper of the eagle rises up } \\
\text { through the neck, as if the neck were hollow. } \\
\text { There it turns to a voice, and through the beak it } \\
\text { issues in the form of words. }\end{array}$ & & \\
\hline $\begin{array}{l}\text { Saturn, contemplation, astronomy. } \\
\text { The degeneracy of the religious order. The } \\
\text { contemplatives are those who cut a space of } \\
\text { time and privilege it, or a space in place, and cut } \\
\text { it off from the flow of history. The danger of the } \\
\text { contemplation though is that they can bypass } \\
\text { and drive a wedge between the contemplative life } \\
\text { and the active life. }\end{array}$ & & $\begin{array}{l}\text { So many splendors stepping down on all } \\
\text { its rungs that it seems every star in } \\
\text { heaven is cascading down from it. } \\
\text { They fly about together, then some soar } \\
\text { away, some wheel around to where they } \\
\text { started off, while others stay on circling in } \\
\text { the sky. }\end{array}$ & $\begin{array}{l}\text { A ladder, glimmering like gold lit by a } \\
\text { sunbeam. }\end{array}$ \\
\hline & $\begin{array}{l}\text { Here there is silence. } \\
\text { "Tu hai l'udir mortal si come il viso" "onde qui } \\
\text { non si canta" } \\
\text { "You have the sight and hearing of a mortal," he } \\
\text { answered me; "there is no singing here. }\end{array}$ & & \\
\hline
\end{tabular}




\begin{tabular}{|c|c|c|c|}
\hline $\begin{array}{l}\text { Danger of thinking of contemplation as the } \\
\text { condition that would allow and bring about the } \\
\text { vision of God, that is not for mortals. }\end{array}$ & $\begin{array}{l}\text { They flock and stand still, and lift up a shout so } \\
\text { deep in sound that nothing heard on earth } \\
\text { resembles it, like an ungraspable thunder. }\end{array}$ & $\begin{array}{l}\text { More flames are stepping down from rung } \\
\text { to rung and whirling while they come, and } \\
\text { every whirl intensifies their beauty. They } \\
\text { flock and stand still, and lift up a shout so } \\
\text { deep in sound that nothing heard on earth } \\
\text { resembles it. }\end{array}$ & \\
\hline & & $\begin{array}{l}\text { Then like a whirlwind they are all swoopec } \\
\text { up. }\end{array}$ & \\
\hline & $\begin{array}{l}\text { Then they remain there (up there, they have } \\
\text { gone up), still within sight, singing Regina Coeli } \\
\text { with sweet voices. }\end{array}$ & & $\begin{array}{l}\text { Winged flight to next sphere. } \\
\text { All the seven spheres displayed, } \\
\text { grand and swift in their motion and } \\
\text { apart in distance from each other. } \\
\text { And, above a million burning lights, a } \\
\text { Sun that lights them; and through its } \\
\text { living light the shining Substance } \\
\text { glows out so brightly that it is } \\
\text { unbearable to keep looking at. }\end{array}$ \\
\hline $\begin{array}{l}\text { Fixed Stars: ethics. Three basic words: faith, } \\
\text { hope and love. You cannot talk about hope } \\
\text { without explaining faith, and both of them are } \\
\text { recapitulated and gathered within the virtue of } \\
\text { charity and the virtue of love. Only us, in exile, } \\
\text { need them; up they are not an issue. }\end{array}$ & $\begin{array}{l}\text { Singing rings, to different measures dancing in } \\
\text { swift and in slow circles. } \\
\text { Through the spheres the saintly court on high } \\
\text { resounds "Te Deum," praising God with } \\
\text { melodies such as they sing up there. }\end{array}$ & $\begin{array}{l}\text { The lights form themselves in spheres } \\
\text { around fixed poles, flashing out like } \\
\text { comets while they whirl. } \\
\text { To different measures dancing in swift } \\
\text { and in slow circles. }\end{array}$ & \\
\hline \multirow[t]{3}{*}{ 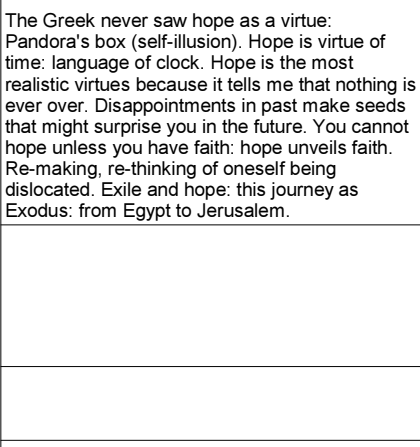 } & $\begin{array}{l}\text { They praise the food which nourishes them } \\
\text { there on high (God?). But after these glad } \\
\text { greetings each one in silence stops in front of } \\
\text { us. }\end{array}$ & $\begin{array}{l}\text { As when a dove flies down to its mate, } \\
\text { and they show their affection, circling } \\
\text { round and cooing all the while, so one } \\
\text { exalted soul is made welcome by the } \\
\text { other, while they praise the food which } \\
\text { nourishes them there on high (God?). But } \\
\text { after these glad greetings each one in } \\
\text { silence stops in front of us. }\end{array}$ & \\
\hline & $\begin{array}{l}\text { Let them find hope in Thee, rings out above us, } \\
\text { and to it all the choirs around re-echo. }\end{array}$ & $\begin{array}{l}\text { As a happy girl will rise and run to join the } \\
\text { dance, so an effulgent splendor comes up } \\
\text { to the two now reeling to the notes in } \\
\text { perfect keeping with their burning love. It } \\
\text { joins there in the singing and the spinning }\end{array}$ & $\begin{array}{l}\text { With loss of sight on seeing that last } \\
\text { flame. }\end{array}$ \\
\hline & $\begin{array}{l}\text { The flaming circling grows still, together with the } \\
\text { sweet mixed harmony made by the singing of } \\
\text { the three-part breathing. }\end{array}$ & & \\
\hline \multirow[t]{2}{*}{ 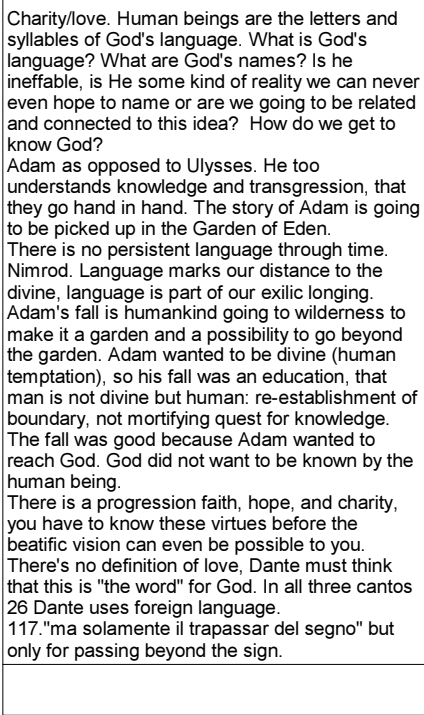 } & & & \\
\hline & $\begin{array}{l}\text { A most sweet song resounds through the } \\
\text { heavens, "Santo, santo, santo!" [Sanctus] }\end{array}$ & & \\
\hline \multirow[t]{3}{*}{ 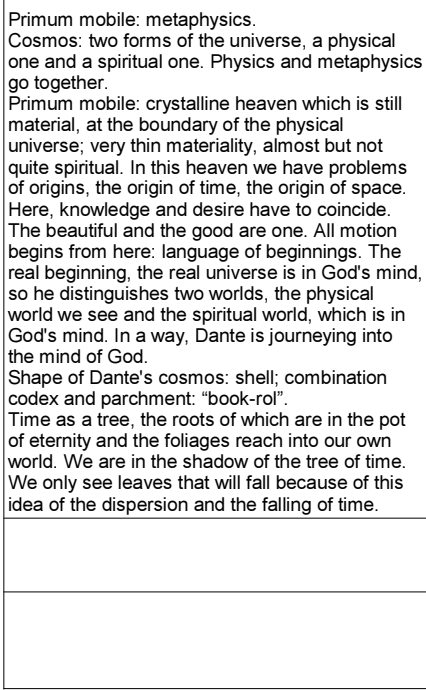 } & & & \\
\hline & $\begin{array}{l}\text { Glory to the Father, Son, and Holy Spiritl the } \\
\text { whole of paradise at once pours forth, so sweet } \\
\text { a song. }\end{array}$ & & \\
\hline & $\begin{array}{l}\text { God imposes silence on the blest choir on } \\
\text { every side. }\end{array}$ & & $\begin{array}{l}\text { That color which at evening and at } \\
\text { daybreak paints clouds in sunlight } \\
\text { from the far horizon now covers over } \\
\text { the whole heaven. }\end{array}$ \\
\hline
\end{tabular}




\begin{tabular}{|c|c|c|c|}
\hline & & $\begin{array}{l}\text { Just as our atmosphere drops snowflakes } \\
\text { downward with its frozen mists, so here } \\
\text { are lights snowflaking upward with } \\
\text { triumphant mists. }\end{array}$ & \\
\hline $\begin{array}{l}\text { Angelic hierarchy. We are now still in the primum } \\
\text { mobilie but we start seeing into the other } \\
\text { universe, the spiritual universe. Dante sees a } \\
\text { universe which is adjacent to the physical } \\
\text { universe inhabited by angels . nine orders of } \\
\text { angels, like nine heavens. The two universes are } \\
\text { two hemispheres. The angels' tunction is to } \\
\text { impart motion to the spheres; their function is to } \\
\text { move between the divinity and human beings, } \\
\text { they are the messengers. } \\
\text { The human beings on Earth; they go after false } \\
\text { appearances. }\end{array}$ & $\begin{array}{l}\text { From choir to choir they sing Hosannah to the } \\
\text { Still Point. The second triad unceasingly in } \\
\text { birdsong sings Hosannah with triple melodies. }\end{array}$ & A ring of fire spins about the Point. & $\begin{array}{l}\text { There is a Point that radiates light so } \\
\text { sharply } \\
\text { A singularity. Infinitely small. } \\
\text { And that sphere which spins nearest } \\
\text { the Point shines with the clearest } \\
\text { flame because it partakes most in its } \\
\text { essential truth. } \\
\text { The circles all around begin to } \\
\text { sparkle, like red-hot iron shooting off } \\
\text { bright sparks. }\end{array}$ \\
\hline 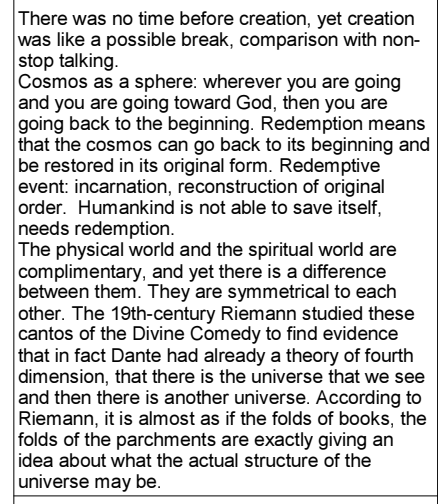 & & & \\
\hline $\begin{array}{l}\text { Dante is some kind of an Aristotelian, but the } \\
\text { sources of Dante about cosmology and } \\
\text { cosmography are really neo-platonic (School of } \\
\text { Chartres.). } \\
\text { The only way in which human beings can think } \\
\text { about renewal, can think about change or } \\
\text { freedom, or origins is only within the context of } \\
\text { creation. Central act of Incarnation rereceation, a } \\
\text { second creation because the first creation clearly } \\
\text { didn't' work out all that well. } \\
\text { Relationship between the finite and the infinite, } \\
\text { they are really disiointed and at the same time } \\
\text { they are not. The finite universe can only be part } \\
\text { of the infinite universe and so he describes how } \\
\text { the infinite enters the finite and the finite enters } \\
\text { the infinite. This is heart of the cantos of } \\
\text { metaphysics which we can call the cantos of } \\
\text { physics and metaphysics at the same time. }\end{array}$ & & & \\
\hline \multirow[t]{3}{*}{$\begin{array}{l}\text { Start of problems of memory and later vision. } \\
\text { Heavenly Jerusalem which is a garden and a } \\
\text { city: city-garden, and a white, mystical rose: } \\
\text { spirituality and materiality are converging. The } \\
\text { whole poem now aappears as literally a journey } \\
\text { from the wilderness, not to the garden, but to a } \\
\text { garden-city. Described as a theatre "lowest rank", } \\
\text { procession etc.: whole paradise is theatrical } \\
\text { performance. } \\
\text { pheatre is multiple perspectives, but here Dante } \\
\text { shees everything, the whole universe so therefore } \\
\text { he can be a visionary poet; he also belongs to it. } \\
\text { The way of being part of this whole is this political } \\
\text { poem. The idea of city always implies some } \\
\text { human contact, the polis. }\end{array}$} & & & \\
\hline & & & $\begin{array}{l}\text { God is hiding the angels, the circles } \\
\text { that turn around him, in His light. } \\
\text { We are blinded by that light. } \\
\text { Like a sudden lightning flash, so } \\
\text { around us shines a living light and } \\
\text { nothing else is visible. } \\
\text { Then it changes into a light flowing } \\
\text { like a river glowing with amber waves } \\
\text { between two banks full of "spring". } \\
\text { From out this river shoot up piing } \\
\text { sparks that drop on every side into the } \\
\text { golden blossoms. Thent,hey dive } \\
\text { once more into the flood, and as one } \\
\text { sinks, another spark shoots out. }\end{array}$ \\
\hline & & & $\begin{array}{l}\text { And this light stretches out into a } \\
\text { circle which spreads so wide that its } \\
\text { circumference would make too large a } \\
\text { cincture for the sun. }\end{array}$ \\
\hline $\begin{array}{l}\text { We are back to timelessness. } \\
\text { These blessed are blessed because there's } \\
\text { some other in them. They are themselves and } \\
\text { there is another in them too, (Another's light). } \\
\text { Language of image and language of reflections. } \\
\text { We are always in a world of images, and that } \\
\text { somehow the image is the locus of the } \\
\text { sacredness, but the image also has its own } \\
\text { fleeting quality. This journey is to go between the } \\
\text { images and the essences. A journey to God, } \\
\text { here we go beyond the images. }\end{array}$ & $\begin{array}{l}\text { The angels sing the glory of God (they do not } \\
\text { use language so it is song without words). }\end{array}$ & $\begin{array}{l}\text { The angels, who see and sing, flying, the } \\
\text { glory of God, fly downward into that vast } \\
\text { flower, and rising up from it speed back to } \\
\text { God, just like a swarm of bees, between } \\
\text { flowers and their beehive. }\end{array}$ & $\begin{array}{l}\text { And as a hillside is mirrored in a lake } \\
\text { below, just so, above the light and } \\
\text { round and round, reflected from more } \\
\text { than a thousand tiers. } \\
\text { And if the lowest rank holds in its row } \\
\text { so large a light, how vast is the } \\
\text { expanse of this rose in its farthest- } \\
\text { reaching petals! } \\
\text { reauntless souls dressed in white } \\
\text { Cobes. }\end{array}$ \\
\hline
\end{tabular}




\begin{tabular}{|c|c|c|c|}
\hline & & & $\begin{array}{l}\text { The angels' faces all glow with a living } \\
\text { flame; their wings are gold, and their } \\
\text { whole form whiter than slow. the r } \\
\text { When they dive to the flower, row on } \\
\text { row, they spread some portion of their } \\
\text { love and peace. } \\
\text { The flight of such a multitude does not } \\
\text { block out the vision and the sea of } \\
\text { splendor, because the divine light } \\
\text { through the universe so penertates in } \\
\text { measure to its worth that there is } \\
\text { nothing to stand in the way. }\end{array}$ \\
\hline & & $\begin{array}{l}\text { Faces given all to love, bright with } \\
\text { Another's light and their own smiles, and } \\
\text { gestures touched with grace and dignity. }\end{array}$ & \\
\hline & $\begin{array}{l}\text { Angels singing. } \\
\text { Children's voices. }\end{array}$ & $\begin{array}{l}\text { At the midpoint, with their wings spread } \\
\text { wide, there are more than a thousand } \\
\text { angels dancing. }\end{array}$ & \\
\hline & $\begin{array}{l}\begin{array}{l}\text { From every side the souls respond warmly to } \\
\text { the canticle of heaven (Seculora? Amen?) }\end{array} \\
\end{array}$ & $\begin{array}{l}\text { Each face grows more serene with that } \\
\text { respond. }\end{array}$ & \\
\hline 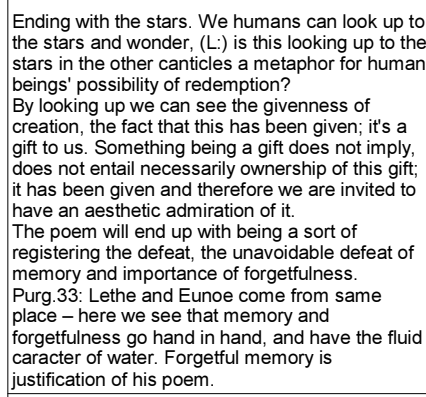 & & & \\
\hline $\begin{array}{l}\text { The pilgrim wants to see the face of God, wants } \\
\text { to preserve the wit so that he can be able to } \\
\text { come back and (re)tell the story, write the poem } \\
\text { as a witnessing to the vision he has had: relation } \\
\text { between vision and language. How is he going to } \\
\text { remember? What does he see? }\end{array}$ & & & \\
\hline $\begin{array}{l}\text { This canto starts with a prayer to Maria, daughter } \\
\text { of her son. Birth as image of beginning. Mystical } \\
\text { rose is in Mary's womb feminine part of Divinity, } \\
\text { the immense sphere within which the finite and } \\
\text { the infinite come together and meet. }\end{array}$ & Prayer to Maria? Or we skip it? & & \\
\hline \multirow[t]{2}{*}{$\begin{array}{l}\text { The immense sphere, it's a circle; the immense } \\
\text { sphere whose center is nowhere, or whose } \\
\text { center is everywhere, whose circumference is } \\
\text { nowhere. That's the way he is explaining this } \\
\text { motif of the incarnation. Humanizing of the } \\
\text { Divine. }\end{array}$} & & & \\
\hline & $\begin{array}{l}\text { Repeetition: vanishing traces, language become } \\
\text { like incantatory. ("musical" language but no } \\
\text { music at the end, just vision). }\end{array}$ & & \\
\hline 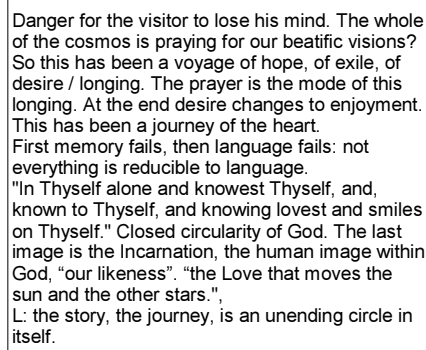 & & & \\
\hline $\begin{array}{l}\text { "Within that Light a person is so changed it is } \\
\text { impossible to give consent ever to turn from it to } \\
\text { other sights." }\end{array}$ & & & $\begin{array}{l}\text { Sight becoming crystal clear, piercing } \\
\text { deeper and deeerer through the rays } \\
\text { of that deep Light which in itself is } \\
\text { true. }\end{array}$ \\
\hline $\begin{array}{l}\text { O everlasting Light, you dwell alone In yourself, } \\
\text { know yourself alone, and known and knowing, } \\
\text { love and smile upon yourself! }\end{array}$ & $\begin{array}{l}\text { A l'alta fantasia qui mancò possa; } \\
\text { ma già volgeva ail mio disio e 'l velle, } \\
\text { si come rota ch'igualimmente è mossa, } \\
\text { 'ramor che move il sole e l'altre stelle. } \\
\text { Here powers failed my high magination } \\
\text { But by now my desire and will were turned, } \\
\text { Like a balanced wheel rotated evenly, } \\
\text { By the Love that moves the sun and the other } \\
\text { stars. }\end{array}$ & & $\begin{array}{l}\text { In the profound and shining-clear } \\
\text { Existence of the deep Light appear } \\
\text { three circles of one dimension and } \\
\text { three different colors. One seems to } \\
\text { be reflected by the other, rainbow by } \\
\text { rainbow, while the third seems fire } \\
\text { breathed equally from one and from } \\
\text { the other. } \\
\text { That middle circle, within itself and in } \\
\text { its coloring seems to be painted with } \\
\text { our human likeness. }\end{array}$ \\
\hline
\end{tabular}



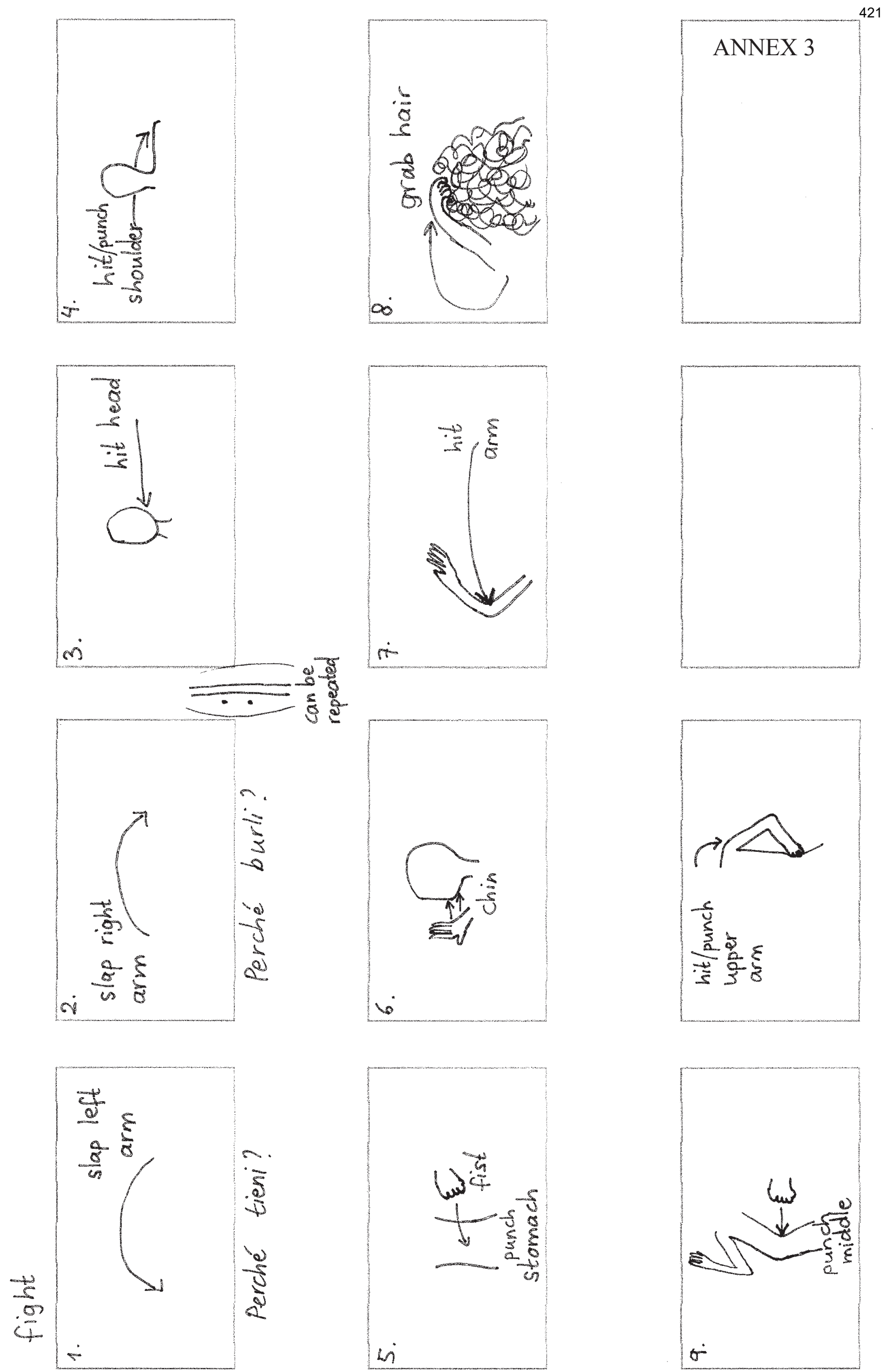

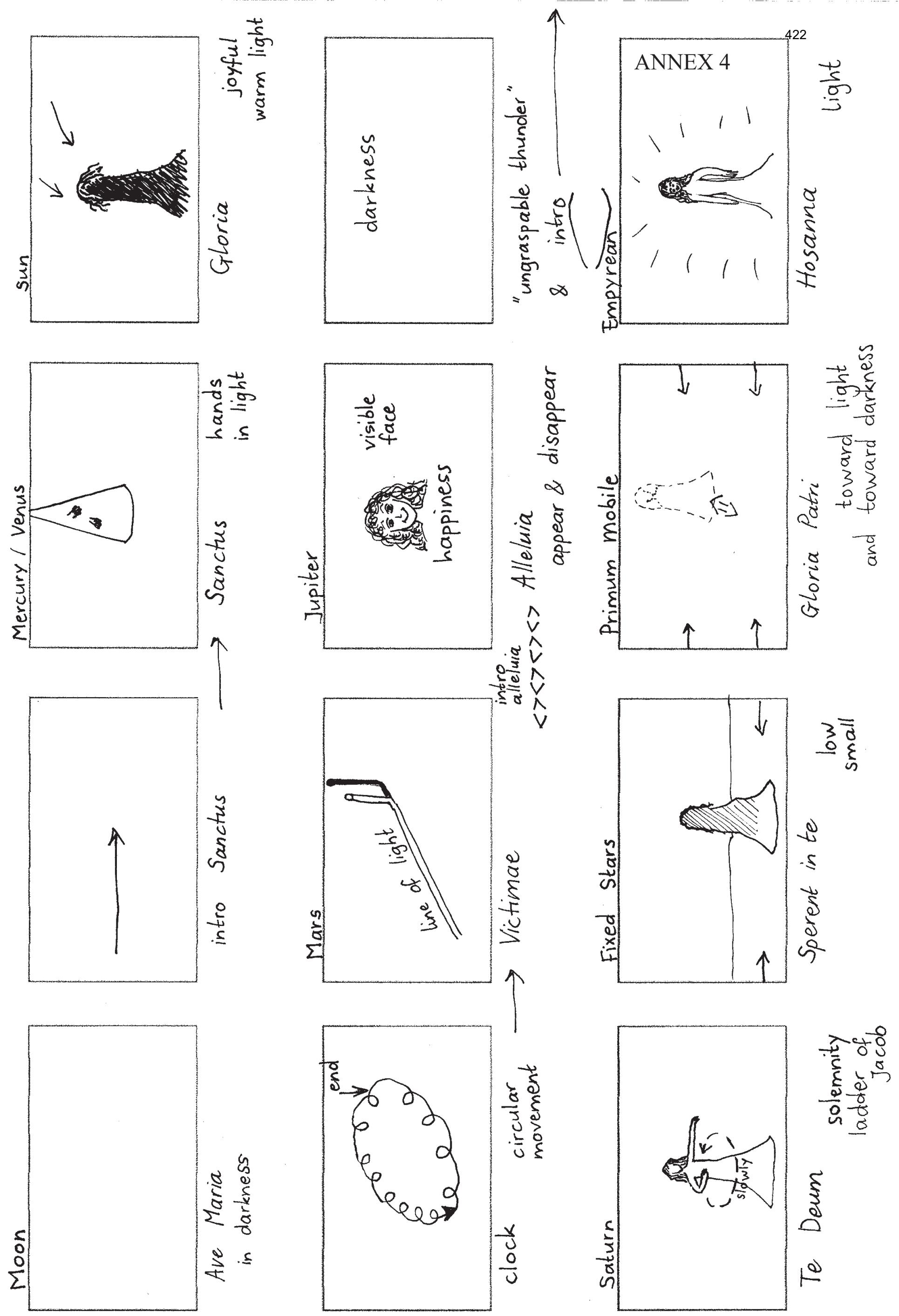


\title{
ANNEX 5a
}

\section{TECHNICAL NEEDS}

\section{Work: INCIPIT \\ by Lobke Sprenkeling}

\author{
Stage \\ Width: $11 \mathrm{~m}$ \\ Entry Width: $8 \mathrm{~m}$ \\ Background: $5 \mathrm{~m}$ \\ Height until rods: $5 \mathrm{~m}$ \\ Border entry height: $4 \mathrm{~m}$ \\ Black floor.
}

\section{Black chamber and machinery}

Complete. Backdrop, four horizontal curtains and eight vertical black curtains for lateral capacity.

\section{Sound}

Equipment P.A. Front (1000-2000 W).

Background monitors left and right (500-600 W).

Professional double CD reader with self-hold option (single). Soundboard (16/4/2).

Intercom with two points (control, left shoulder).

Cabling.

\section{Projection}

Video projector 2,000 lumens for projection on background from room or cabin. VGA input.

IT support for video playback (company).

Cabling.

\section{Lighting}

Regulation: 24 channels 2 KW. Spotlights 7 PC $1 \mathrm{KW}$ visor.

1 PC $2 \mathrm{KW}$ with visor.

3 Scraps $15-40^{\circ} 1$ iris.

8 Scraps $225-50^{\circ}$ gobo holder.

6 PAR 64 \# 2 (CP 61).

3 asymmetric Panoramas 1KW. All spotlights with filter holder.

Digital and programmable table with monitor lighting. Preferably LT series.

Cabling.

4 electrified rods on stage.

5 electrified spotlight plugs in the frontal room or bridge.

10 spotlight plugs on the floor (there are 2).

Four bases for spotlights.

3 blocks to [3-2-1] 1.7-1.5-0.3m spotlights. Small guarding foot lights.

Ladder for spotlights.

Note: The sound and lighting tables must be near each other, if possible in the same space, 
outside of enclosed cabs in order to allow monitoring the work

\section{Installation}

Installation: 4 Removal: $1 \mathrm{~h}$

Duration of the work: $1 \mathrm{~h} 5 \mathrm{mn}$

\section{Crew}

1 lighting / audiovisual technician

1 engineer.

\section{Others}

Camerino conditioned for 1 person.

Mineral water for technicians, assistants and actors.

Elaborated by nestea42@gmail.com 1.0 


\section{NECESIDADES TÉCNICAS}

\section{Obras INGIPIT \\ de Lobke Sprenkeling}

\section{Escenario}

Anchura: 11m

Anchura de boca: $8 \mathrm{~m}$

Fondo: 5m

Altura a varas: $5 \mathrm{~m}$

Altura a bambalinón de boca: $4 \mathrm{~m}$

Suelo negro

\section{Cámara negra y maquinaria}

Completa. Telón de fondo, cuatro bambalinas y ocho patas para aforo lateral.

\section{Sonide}

Equipo de P.A. frontal (1000-2000 W).

Monitores en fondo a derecha e izquierda (500-600 W).

Doble lector de CD profesional con opción de autoparada (single).

Mesa de sonido (16/4/2).

Intercom con dos puntos (control, hombro izquierdo).

Cableado.

\section{Proyección}

Proyector de vídeo de 2.000 lúmenes para proyección sobre fondo desde sala o cabina. Entrada VGA.

Soporte informático para reproducir vídeo (compañía).

Cableado.

\section{Iluminación.}

Regulación: 24 canales de $2 \mathrm{KW}$.

Focos: 7 PC $1 \mathrm{KW}$ con visera.

$1 \mathrm{PC} 2 \mathrm{KW}$ con visera.

3 recortes 15-40으 con 1 iris.

8 recortes $25-50$ 으 con 2 portagobos.

6 PAR 64 no 2 (CP 61).

3 Panoramas asimétricos $1 \mathrm{KW}$.

Todos los focos con portafiltros. 
Mesa de iluminación digital y programable, con monitor.

Preferiblemente series de LT.

Cableado.

4 varas electrificadas en escenario.

5 envíos electrificados en sala o puente frontal.

10 envíos en suelo ( 2 en sala).

4 peanas para foco.

3 calles para [3-2-1] focos a 1.7-1.5-0.3m.

Guardias para paso.

Escalera para enfoque.

Nota: las mesas de sonido e iluminación han de estar una cerca de la otra, a ser posible en la sala, fuera de cabinas cerradas para permitir el seguimiento de la obra

\section{Montaje}

Montaje: $4 \mathrm{~h}$

Desmontaje: $1 \mathrm{~h}$

Duración de la obra: $1 \mathrm{~h} 5 \mathrm{mn}$

\section{Personal}

1 técnico de iluminación/audiovisual.

1 maquinista.

\section{Otros}

Camerino acondicionado para 1 persona.

Agua mineral para técnicos, ayudantes y actores. 
ANNEX 6

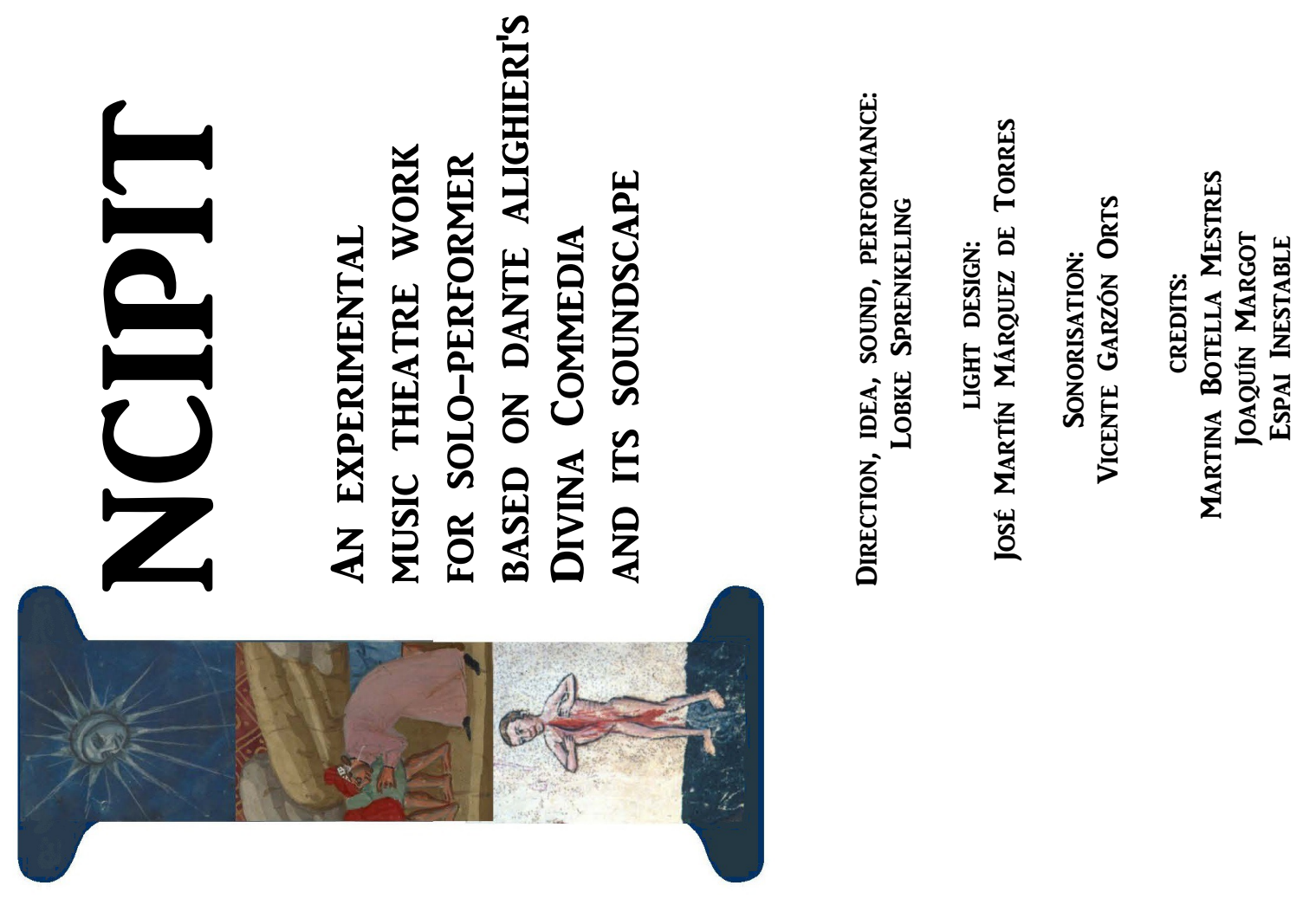




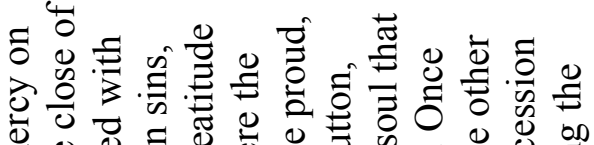

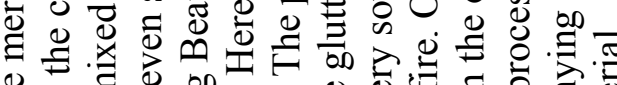

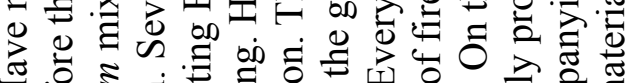

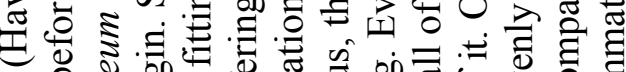

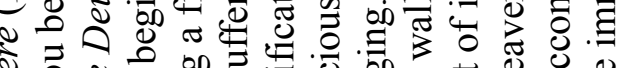
के

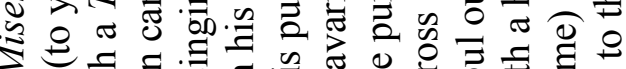
$\sum_{0}$

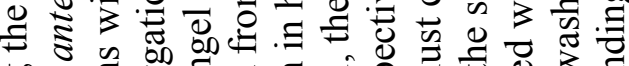

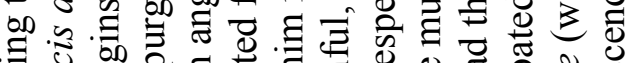

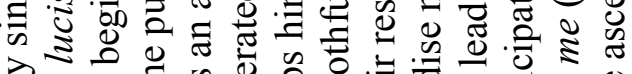

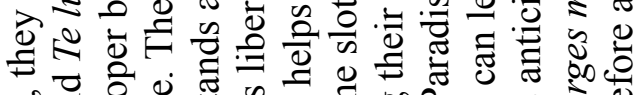

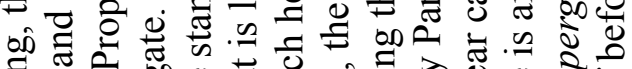

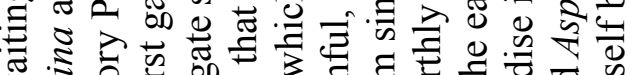

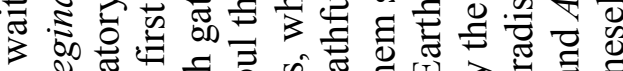

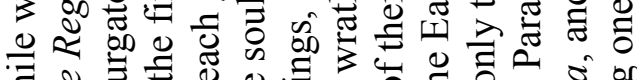

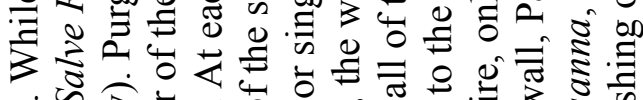

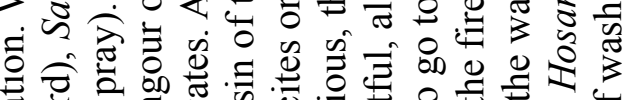

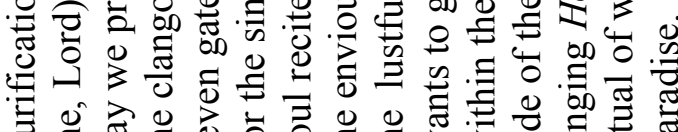

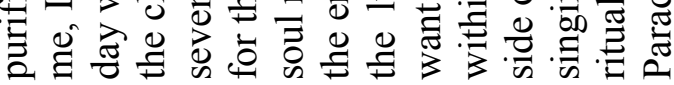

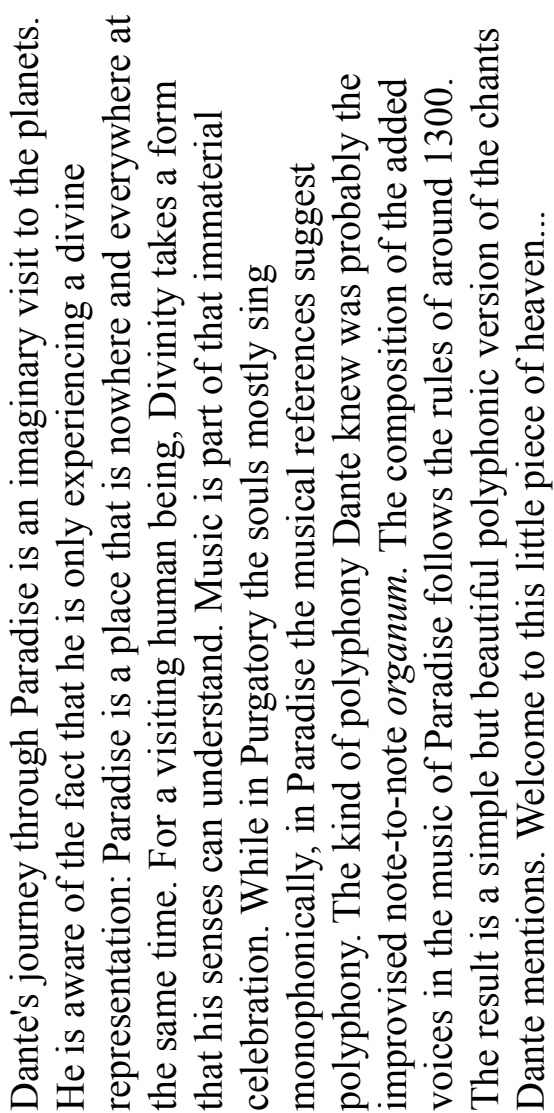

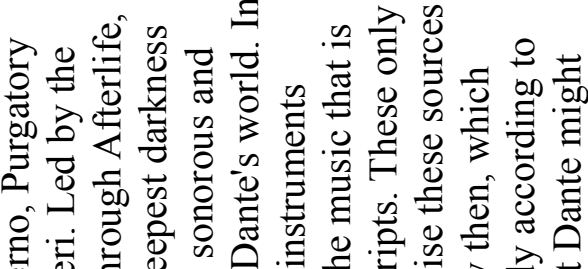

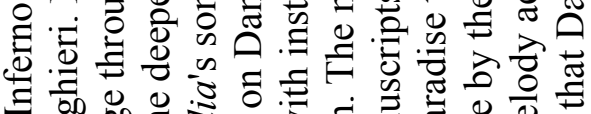
尊品过

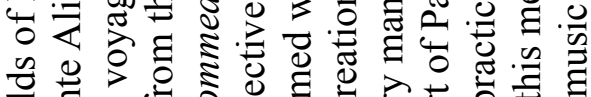

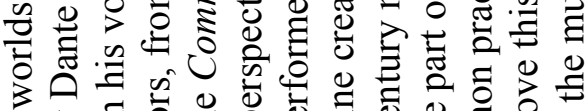

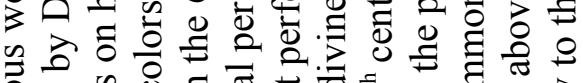

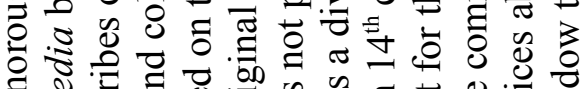

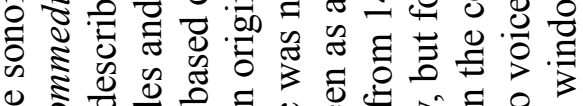

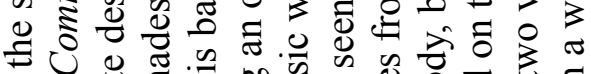

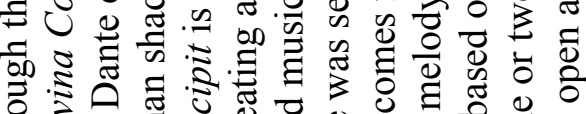

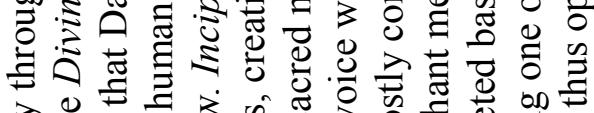
屯.

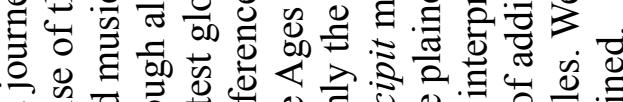
은

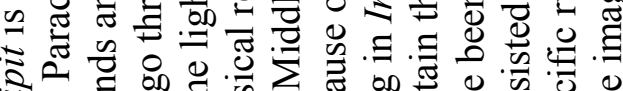

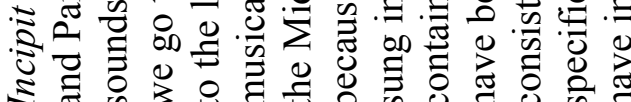

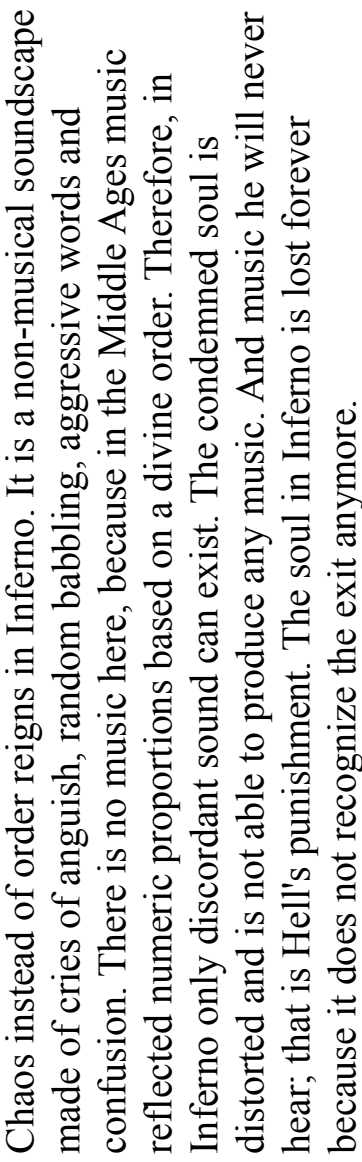

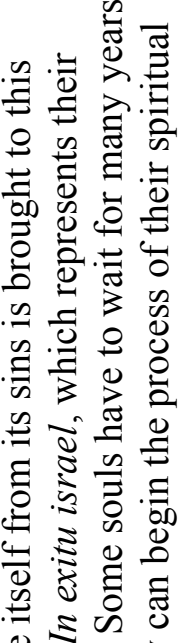

का

昆 율 足 $气$ 灵芆施

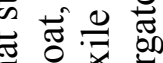
每

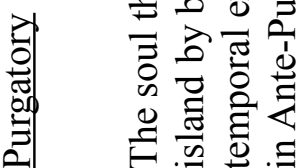




\begin{abstract}
ANNEX 7
In this annex we will give an overview of the final mise-en-scene. Not only the technical details are discussed but also the meaning or origin of each element. The details on lighting are added in blue, the ones on audiovisual elements are written in green. The lighting was done by light designer José Martín Márquez de Torres, who has provided us with the more technical details on lighting, both in this annex and in annex 5.
\end{abstract}

INFERNO (23:20 $\mathrm{min})$

Projection of the following three texts (with Adobe Caslon as its font):

\title{
INCIPIT
}

INFERNO

\section{Nel mezzo del cammin di nostra vita \\ mi ritrovai per una selva oscura \\ ché la diritta via era smarrita. ${ }^{1}$}

Darkness. A smoke machine has filled the whole with a thin smoke. Fade-in of sound of beasts: the three beasts blocking Dante's way and probably symbolizing sins. The performer is naked up from the knees and wears black textile knee protectors. The black knee socks cover these protectors, thus blackening the lower legs and the knees, intended to reinforce the sensation of her body being buried until her knees in the ground or her lower legs being stuck to the ground. The performer is sitting on her knees in "child's pose"" with her arms crossed at the height of their elbows (cowering position), placed under the neck, and touching each other at the back of the neck; as if the protagonist is embracing her neck. This way, the left arm and hand are on the right side, while the right arm and hand are on the left, which creates an ambivalent body which is not sure to be facing up or down. This is reinforced by the fact that her hair is flung over her face and covers it during the entire Inferno. Her hands symbolize Evil while her body is their victim. She is in a beast-like state, which is accentuated by the fact that her face is always covered by her hair.

1 "Halfway through the journey we are living / I found myself deep in a darkened forest, / for I had lost all trace of the straight path." Inferno 1.1-3

2 Term used in yoga to describe the following position: https://en.wikipedia.org/wiki/B $\% \mathrm{C} 4 \% 811 \% \mathrm{C} 4 \% 81$ sana 


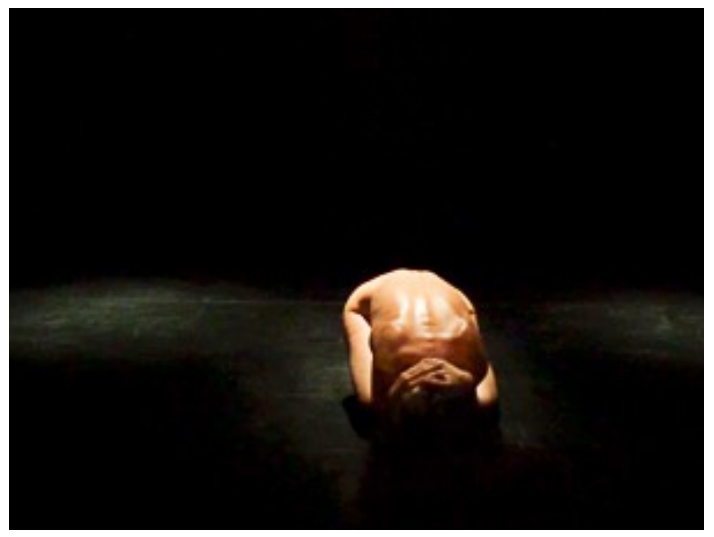

Fig. A01. Beginning posture of the performer

Lights: Fade-in. Overhead light 117, Steel blue.

The left hand starts to move, the right one also, in a slow but animal-like manner. Both hands explore the neck and shoulders and come back subsequently to the neck. When the left hand covers the right hand, just as in the initial position, the right hand with difficulty breaks loose from its grip and begins to caress the hair. The other does the same. They begin the pull the hair. The right arm is withdrawn to the body's right side and continues to caress and pull the air from the right side, followed by the left arm. They begin pulling her head up by the hair. The body comes up as well until the performer is upright on her knees, with her hair covering her face. Fade-out of beast sound.

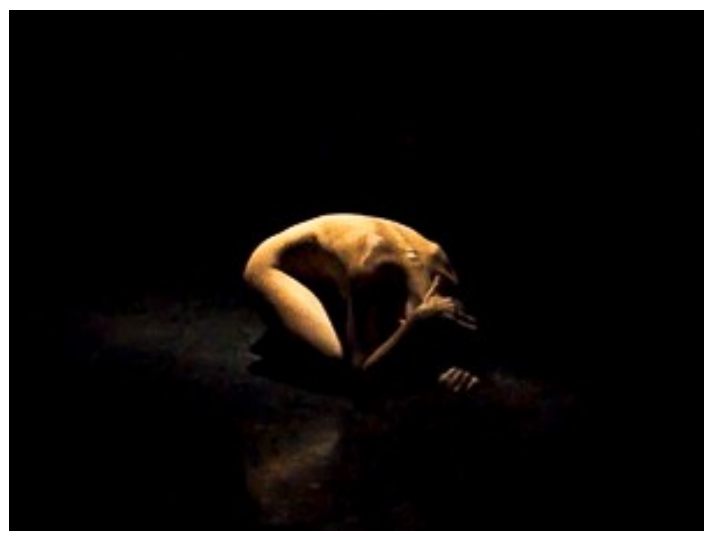

Fig. A02. The hands stroke the hair and begin to pull the performer upward

Lights: growing frontal low 035 (alt 136 alto 036) when the following words are whispered, while the performer continues caressing her hair.

Minute 2.05: 
"Per me si va ne la città dolente,

per me si va ne l'etterno dolore,

per me si va tra la perduta gente. (...)

Giustizia mosse il mio alto fattore:

fecemi la divina podestate,

la somma sapienza e 'l primo amore.

Dinanzi a me non fuor cose create

se non etterne, e io etterno duro.

Lasciate ogne speranza, voi ch'intrate. ${ }^{3}$

These words are the words written on the entrance gate of Inferno.

Minute 2.58: Fade-in of cacophonous sound of people crying, clapping, screaming, babbling,

shouting. They are the sounds of the Neutral Souls, who cannot enter Heaven nor Hell, and must run around forever bitten by wasps. The performer continues caressing her hair, which slowly becomes faster during this scene. She begins to babble in jabber-talk as well: she tries to communicate but her speech is incomprehensible, while her hands keep on caressing her hair over her face. There is a crescendo in her sounds followed a decrescendo as if she has given up the fight due to exhaustion. However, the movement of her hands becomes increasingly faster, especially when the voices cease and the wasp sound grows in crescendo towards a thunderclap (minute 4.26), introducing a silence directly after it.

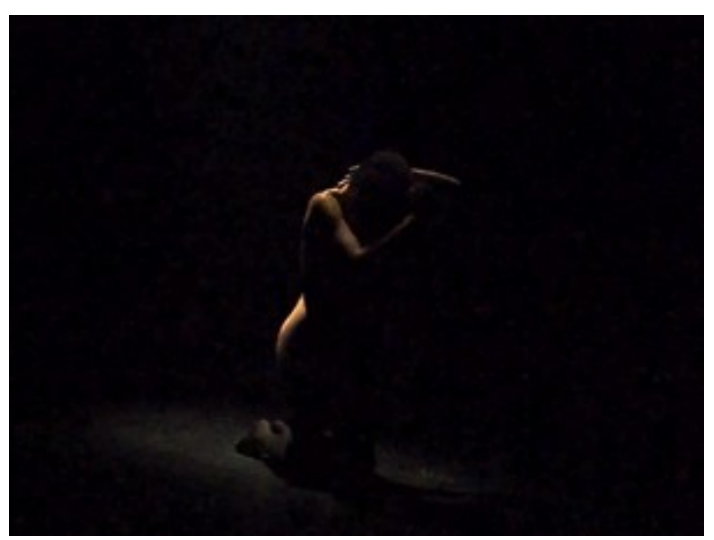

Fig. A03. The upright performer

continuing to caress her hair during the

first scenes

3 Through Me Pass into the Painful City, / Through Me Pass into Eternal Grief, / Through Me Pass among the Lost People. / Justice Moved My Master-Builder: / Heavenly Power First Fashioned Me / With Highest Wisdom and with Primal Love. / Before Me Nothing Was Created That / Was Not Eternal, and I Last Eternally. / All Hope Abandon, You Who Enter Here. (Inferno 1-9) 
The thunderclap is a reference to the thunderclap that wakens Dante up in Limbo after he fainted watching the neutral souls. ${ }^{4}$ In Incipit, it introduces a scene consisting of a polyphony of recorded and live sighs, a sound Dante's souls in Limbo make. ${ }^{5}$ The performer's sighs provoke bodily movement in abdomen and shoulders and this movement is consciously extended toward shoulders and neck, converting it in a dance-like movement. The body and sighs express relief but also melancholy without hope. The recorded sighs change gradually into the sound of a strong wind and her body begins to swing. The strong wind refers to Dante's lustful souls who are swung around by it and whose cries are indirectly compared to the $\operatorname{lais}^{6}$ of the cranes. ${ }^{7}$

\section{Minute 5.35:}

Light: the counter-light Steel blue is augmented.

The performer's body moves as if controlled by the wind. The sound of cranes make her arms go up in the air, associating her bodily movement to a bird, just as Dante does in his text.

\section{Minute 6.18}

Cerberus howls over the fading-out sound of the wind and cranes. Immediately the performer covers her ears, her mouth wide open under her hair, her body lowered and in tension. It is followed by the sound of rain, representing the sour, mucky rain falling on the gluttonous bodies. ${ }^{8}$ She is back in her starting posture (child's pose) but this time placing her hands on the ground. Her back is moving in "spasms" as if the rain hurt her skin, referring to the souls in Dante's Inferno, who flip constantly over because of the pain. The muscles and bones of her back are visible. Her movements become stronger and her lower arms hit the ground, which adds to the sound.

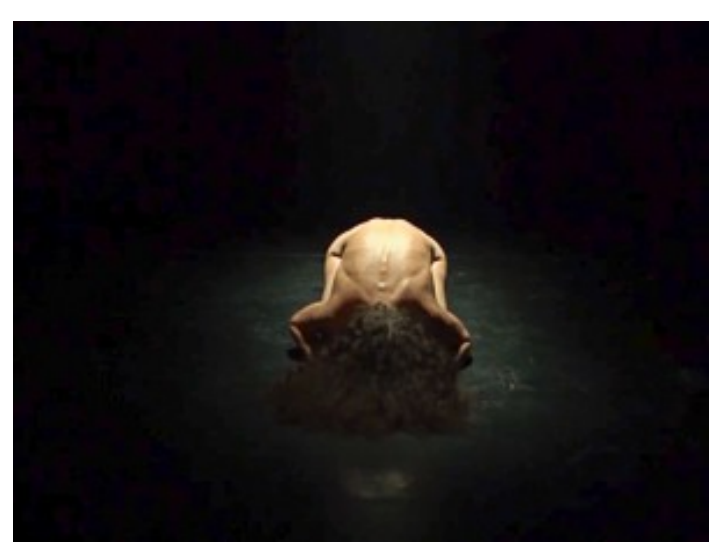

Fig. A04. The gluttonous body under the rain

4 Transition Inferno 3 to 4.

5 Inferno 3

6 Poetical genre, roundelay in English.

7 Inferno 5.46-48

8 Inferno 6.19-21

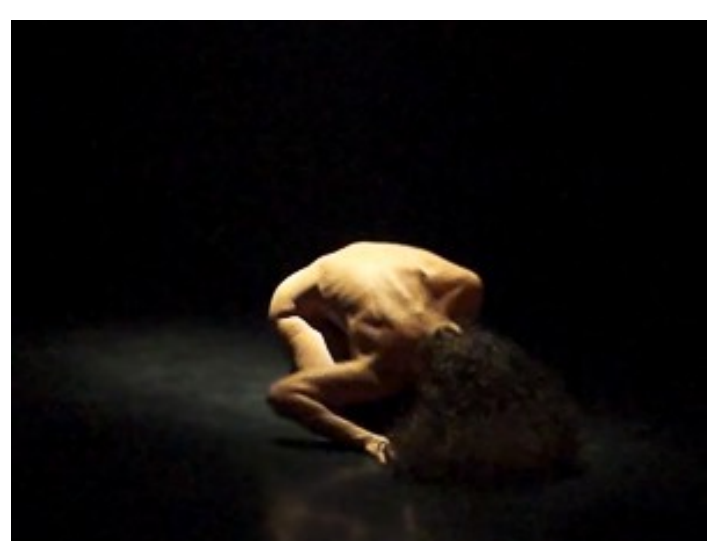

Fig. A05. Spasms of the back 
Minute 7.36:

Plutus' clacking phrase sounds: "Pape satan, pape satan, aleppe!". ${ }^{9}$ She is still moving in the same way as before, thus connecting physically the previous sound with this one. Out of this movement flows the next one, when Plutus does not clack anymore. The performer comes slightly up and looks to her left, and says with soft but angry voice: "Perché tieni?" Then she turns to her right, and answers with “Perché burli?”. In Dante's Inferno, these phrases are shouted by avaricious and prodigals to each other: "Why do you hold?" "Why do you splurge?". ${ }^{10}$ In Incipit, the scene has obtained a schizophrenic character: again, it is the own body that is not a unity, just as in the beginning of Incipit. The performer turns to her left again and repeats the first question, this time with somewhat louder and more menacing voice. She does the same with "Perché burli?" to her right. This is repeated a number of times, in crescendo, louder and more angry, shouting. She begins to accompany her questions by hitting her other arm. It ends up in a fight with herself. At this moment the recorded sounds of fights in mud enter. These are derived from Dante's scene of the wrathful fighting at the surface of the muddy river and the sullen gurgling at the bottom of the same river. ${ }^{11}$ While the recorded voices enter, "gurgling their hymn", and the volume of the fight sounds is lowered, her fight is in slow-motion, until the gurgling ends and the fight sounds becomes louder again.

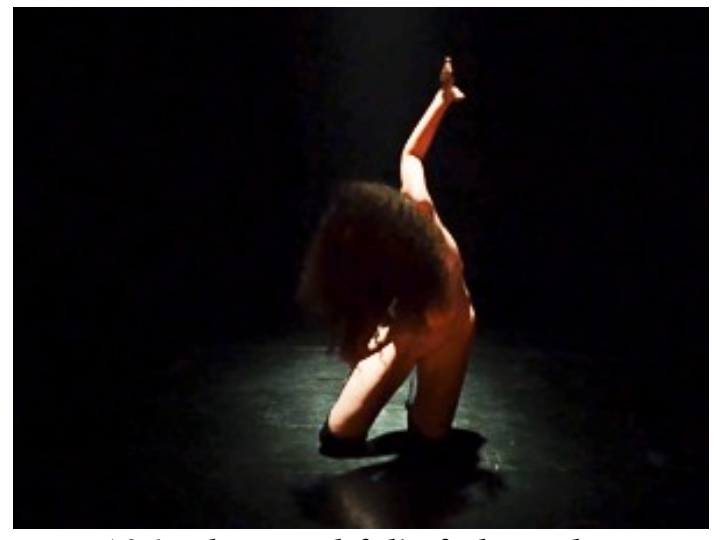

Fig. A06. The wrathful's fight with herself

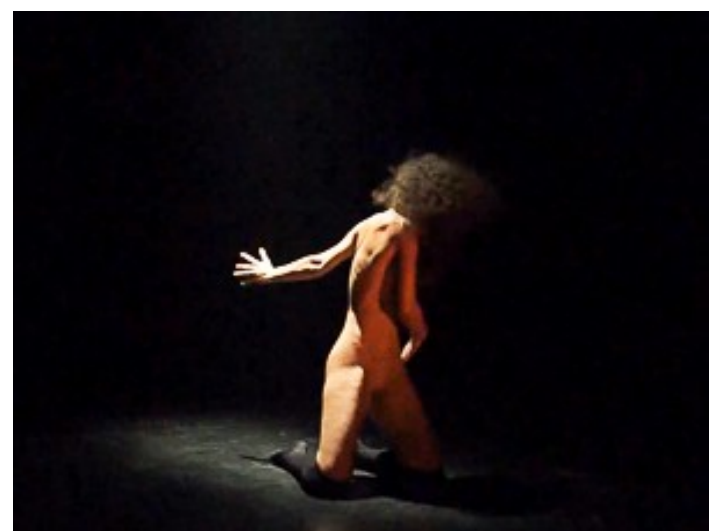

Fig. A07. Another image of the fight

The recorded phrase "Or se giunta, anima fella!" sounds while she keeps on fighting with herself. ${ }^{12}$ At the end of this phrase, when she punches herself in her stomach, she stops and cringes, puts both hands on her tummy and starts crying softly “Mio figlio, ov 'e?", repeating this phrase and directing

9 Inferno 7.1; Plutus is the god of wealth, in Dante's narrative reduced to a pathetic powerless creature. His expression is a mixture of imagination and etymological identifiable words. It means, more or less, "father satan, help!"

10 Inferno 7.30

11 Inferno 7.109-139

12 This phrase is shouted by Phlegyas in Dante's narrative, Inferno 8.18 
her towards the audience, as if she were searching for her son there or asking them for help. The sound of fire is on the background. The sounds are based on Dante's scene of the heretics who are in deep mass graves, surrounded by flames. There are two characters and one of the two asks for his son. ${ }^{13}$ When this changes into the sound of boiling blood and piercing cries (minute 10.15), she continues repeating the same phrase, but lifting her arms higher, spreading her hands, contracting her abdominals, opening her mouth and interrupting her breathing, as someone who is in a substance that is far too hot, burning her. The burning blood refers to Dante's circle of tyrants, standing in the blood and uttering terrible cries. ${ }^{14}$

Minute 10.42:

The performer is paralysed and holds her arms in the way of strange branches. She represents one of the tree-souls in Dante's dead forest of suicidal souls, which are bitten by the Harpies sitting on them. ${ }^{15}$

\section{Light: growing PAR counter-light_1 on 117}

She sways lightly back and forth and lowers her head a bit. She reacts to the shrieking sounds of the Harpies by trembling. A snap sounds and her left wrist is lowered abrupt, as if it is the breaking branch. She puffs: "Perché mi schiante? Perché mi scerpi?"16 During the sound of the running and barking dogs followed by an anguished cry of a man and sounds of him being eating by them ${ }^{17}$, she cringes and makes fast, nervous gestures of trying to protect her body by trying to cover it with her body. She begins to cry with agony (minute 12.14), still cringed, and then starts brushing off her lower arms rhythmically while the crying sounds and the desert-flame sounds enter, which are based upon the sounds Dante hears in the sand plain next to the forest. ${ }^{18}$

\section{Minute 12.58:}

A running sound enters. ${ }^{19}$ She rises up a bit and stops her crying a bit while starts calling "Sóstati tu!". Her "looking" is changing direction from her left to her right while she repeats the same petition, which is gradually more desperate. When the running ceases to be audible, she cries again. Her arm movements become larger (entire arm instead of lower arm) and therefore slower. In its rhythm, she shouts with an accentuated, angry, disdainful and scornful voice: "Qual io fui vivo, tal

13 He is the father of the poet Guido Cavalcante, who was banished from Florence by then partly being Dante's fault. Inferno 10.60

14 Inferno $12.100-102$

15 Inferno 13

16 Inferno13.31-35. Dante breaks off a shoot from a tree, who puffs and utters - among others - these two phrases.

17 Inferno 13.124-129

18 Inferno 14

19 In Dante's narrative, there are three souls which come running to him, shouting "Sóstati tu!" ("Stop!"). They make a circle and speak to him in that way. In Incipit, the sounds have been interpreted in another way, separating the running (sound of outsider) from "Sóstati tu! (the protagonist). 
son morto!" (minute 13.33). This is the phrase said by Dante's Capaneus, which shows that the souls are so captured in their own perspectives that they cannot be saved anymore, even if they were offered the opportunity. ${ }^{20}$ The recorded cries are heard while she sobs softly continuing to sway her arms. The sound of a waterfall enters and she becomes silent while enlarging her swaying movement, making it more fluent. The waterfall is the blood red stream that leads Dante to the edge of circle 7 , where the stream is a deafening waterfall falling into circle $8 .^{21}$

\section{Minute 14.17:}

Whips sound, referring to the first pitch of Dante's eighth circle where horned devils whip the seducers and pimps. ${ }^{22}$ The performer interrupts her swaying movement, moaning and reacting physically to each "hit". Then the recorded sound changes into scratching, snoring and whacking, which is the sound of the flatterers dipped in excrement. ${ }^{23}$ The performer keeps on reacting in the same way as to the whips, but now she really hits her body, and at the same time has a reaction of pain and surprise, as if her hands did not form a part of her being. She hits on her back and the sounds turn into silence (min. 14.49). Her hands intertwine behind her back and pull her arms together, so that from the front the arms are not seen and her body obtains again the ambivalence of being the front or the back. This is a silent litany without moving from her spot; she is lifting up her knees and lower legs and making sound by dropping them on the floor. It expresses Dante's silent litany of the sorcerers and foretellers, who now walk backwards with their heads turned 180 degrees and their tears falling on their buttocks. ${ }^{24}$

Min. 15.30:

The recorded sound of the devils is a free interpretation of Dante's comical scene of the devils who have funny names and argue. The performer loosens her arms and begins to move head, rib cage, hips, arms, fingers in a comical way, according to the rhythm of the speech, sometimes fluid, sometimes in staccato, and in circular directions. At the end of the last devil's speech, a fart sound is expressed in her body posture, and she shakes her head on the sound of the raspberry. This is derived from the phrase "with his ass he blew a bugle-blast" 25 after which another one makes a raspberry to him. Both in the Commedia and Incipit, the "bugle-blast" forms a signal for the strangest march Dante has ever witnessed. ${ }^{26}$

20 Inferno 14.51

21 Inferno 16.103-105

22 Inferno 18.35-39

23 Inferno 18.112-132

24 Inferno 20.7-24

25 "ed elli avea del cul fatto trombetta", Inferno 21.139

26 Inferno 22.10-12 
Light: PAR counter-light_2 on 117 grows until the scene of the "crucifixion".

When the recorded "military" sound enters, the performer begins to "march" (without moving any part of her legs) with her arms and torso in a vigorous staccato movement. This marching is arrhythmical, out of measure, as well as the recorded music. Her arms gradually open during the "march", until they are completely horizontal and her fists open.

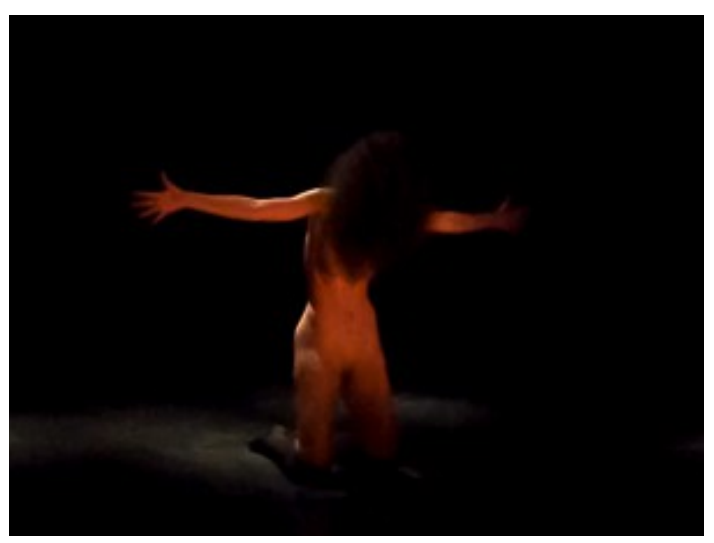

Fig. A08. The scene of the crucifixion

Min. 16.46:

Scene of crucifixion, inspired by the figure of Caiaphas in Dante's ditch of hypocrites. He is lying crucified on the floor while they, in heavy cloaks of gold, trample him in their slow march. ${ }^{27}$ Dante describes him as breathing in his beard with heavy sighs, therefore the performer also breathes with heavy sighs and contracts frequently her abdominals or her chest, as if she were lying on the floor and trampled, in a posture of a crucifixion. There is a fade-in of an angry voice and of the sound of snakes. This is Dante's ditch of thieves, who are now repeatedly robbed of their conscience and their identity. ${ }^{28}$ The performer wriggles with her arms as if she is fixed and tries to get loose. Then she slowly closes her right hand and sticks up her middle finger, while bursting out, cursing God:

“Togli, Dio, ch'a te le squadro!" In Dante's version, this is the soul with snakes crawling all over him, being reduced to ashes by the bite of a snake, after which he resurrects alive and stares and sighs. It happens over and over again to this soul, just like the life cycle of the Phoenix. He curses God, sticking his thumb between his index finger and middle finger. ${ }^{29}$ The hissing becomes stronger and she falls flat forward, hitting the floor hard with her open arms, which makes a loud clap, as if the snakes have attacked her. The arms are withdrawn slowly towards the body, only touching the floor with the fingertips.

29 This gesture was called fare le fige and was just as insulting as sticking up the middle finger nowadays. Inferno 24.97-120 and 25.1-3. 


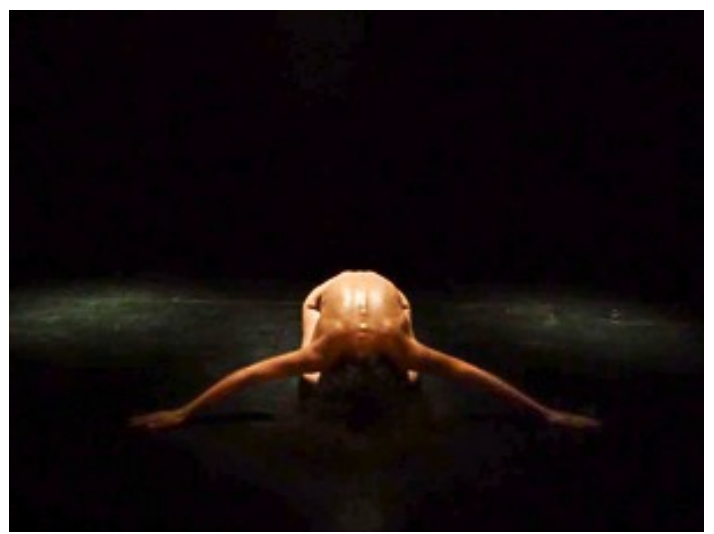

Fig. A09. Just after the moment the performer has fallen forward, she begins to withdraw her arms

The performer rounds her back, shows her neck, and caresses her hair, ordering it. The hissing sound of flames has substituted the snakes. It reflects Dante's ditch of the fraudulent rhetoricians in circle 8 . They are inside flames, moving around through the ditch. When they speak, the flame sputters and then throws out the sound. ${ }^{30}$ She puts her hands on the floor and begins to speak, emphasizing the $\mathrm{s}$ and $\mathrm{f}$ which imitate the sound of a flame, with a lingering, high voice with twang ${ }^{31}$ :

"S'i credesse che mia risposta fosse

a persona che mai tornasse al mondo, questa fiamma staria sanza più scosse." 32

During these words, the movement of the neck is accentuated by her posture. She hisses a few times.

Min. 18.33:

Feverish sounds, based on Dante's ditch of the falsifiers and counterfeiters, whose body is now cankered. ${ }^{33}$ The performer is still in the same posture with a round back and her hiss changes into cough, which makes the back move. Then, the recorded sound shows a sonorous punch like a drum, a hit, and two men arguing. This is derived from the scene between Master Adam and Sinon. Master Adam has a lute-like body and speaks ill of Sinon, who punches him in the stomach that actually

30 Inferno 26.31-48

31 A vocal technique that is more metallic-sounding by narrowing slightly the aryepiglottic sphincter, a circular band of muscle that encircles the larynx.

32 "If I thought that my answer was to someone / who might one day return up to the world, / this flame would never cease its flickering." It is the onomatopoeic speech of Guido da Montefeltro. His premeditated character was translated to a sly voice colour.

33 Inferno 30 
sounds like a drum, a comical musical metaphor of Dante. Master Adam then hits Sinon and they begin to argue with each other. ${ }^{34}$ The performer lifts up her head a bit, listening, supporting herself by pushing with her hands on the ground, but they do not hold her. A compound movement of three variously ordered positions is initiated: on both forearms, on one forearm, or higher up with both hands on the ground. This creates percussion sounds. It is a movement in crescendo.

Min. 19.20:

A bugle sounds and the performer babbles, with a voice imitating a giant's (widening the throat): "Raphel mai amecche zabi almi", while the movement continues in crescendo. They are the bugle and words of the giant Nimrod, who is uttering an imperfect anagram of "Eli, Eli, lema sabachtani?" (“My God, my God, why have you left me?", one of the sayings on the Cross). He is not able to communicate himself anymore, not even to God, and neither is the performer able to do so. The recorded sound changes into clattering of teeth, the sound the souls make in the lowest circle of Hell, where they are stuck in a frozen lake and at best only their heads stand out. ${ }^{35}$ The performer's movement of the collapsing body continues and she cries out in a high, whining, furious voice: "Perché mi peste? Perché mi moleste?" The movement continues. The words are said by one of souls that Dante by accident kicks in the face when he walks over the frozen lake. ${ }^{36}$

Min. 20.14:

Smacking sounds. In Dante's narrative, they belong to Lucifer, an enormous three-headed helpless, dirty and tearful creature that cannot talk, only chew on three sinners with his three mouths and claw one of them. He is stuck to his middle in the centre of the Earth, symbolizing defeated Evil. ${ }^{37}$ However, for the souls themselves it is Evil that will always keep them imprisoned. The performer's falling movements transition into one of a breaking body. The left arm is moved under, passing the neck to her right side. The hand is open and claw-like, the arm shakes. The other arm resists but then also passes to the other side.

34 Inferno 30.49-57 and 91-129

35 Inferno 32.34-36

36 Inferno $32.79 ; 32.81$.

37 Inferno 34 


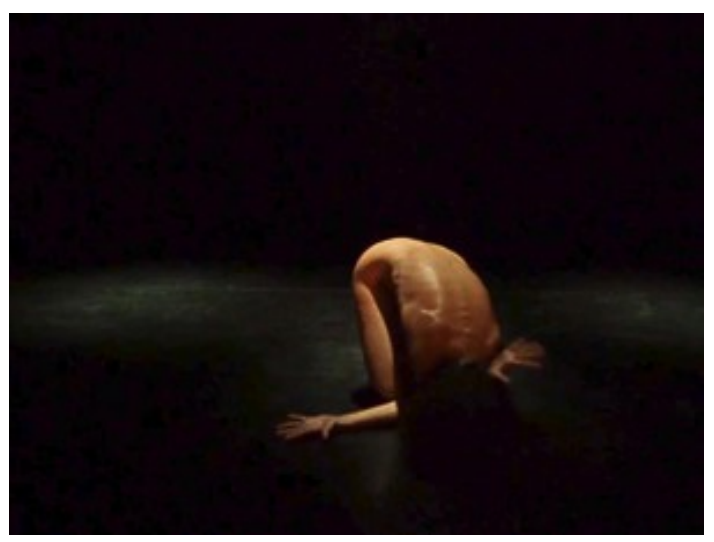

Fig. A10. The breaking body

The performer is returning to her original posture when the hands fold around her neck again. Her body resists but the hands hold her neck in a firm grip. The following words sound:

"Vexilla regis prodeunt Inferni,

fulget crucis mysterium,

quo carne carnis conditor

suspensus est patibulo." ${ }^{38}$

This text is a liturgical parody of Lucifer. In Dante's text, only the first phrase is said by Virgil:

'Vexilla regis prodeunt inferni' verso di noi ("'The Banners of the King of Hell issue forth' closer to us").

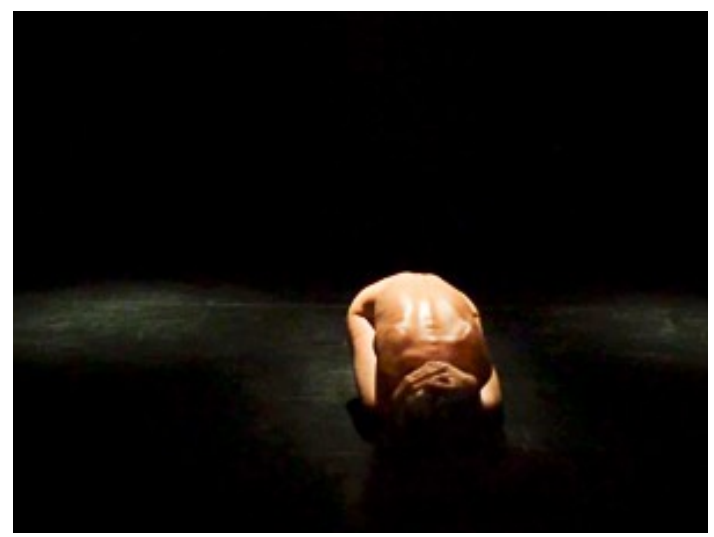

Fig. A11. Final posture of Inferno

Light: black-out

Projection of following texts:

38 "The banners of the king of Hell issue forth, / the mystery of the cross does gleam, / where the creator of flesh, in the fesh, / by the cross-bar is hung." Taking away the words "of Hell” it is a Latin hymn from the $6^{\text {th }}$ century. 
E quindi uscimmo a riveder le stelle. ${ }^{39}$

\section{PURGATORIO}

canterò di quel secondo regno

dove l'umano spirito si purga

e di salire al ciel diventa degno. ${ }^{40}$

There is a cave sound in the dark and during the projections while performer changes outfit behind the scene. This cave sound is based on the scene in which Dante and Virgil climb out on the Souther Hemisphere into a cave, which they have to climb in order to reach the shore of the mount of Purgatory. ${ }^{41}$

39 "From there we came out to see once more the stars." Inferno 34.139

40 "I shall sing this second kingdom where / the human spirit purifies itself, / becoming fit to mount up into heaven." Purgatory 1.4-6

41 Inferno 34.126-139 


\section{PURGATORY (27.57 min)}

The light accentuates the separation of the different sins in sections, by using a blinding flash and short darkness before augmenting the light for the following scene. Blackout before performer comes on stage with a chair so that she can place it and take her posture.

\section{Light: Counter-light 204.}

The performer has the same posture as Inferno's first and last posture, but now dressed in lightcoloured knickers and an old top, thus being the middle ground in between nude flesh and being completely dressed. There is a calm sea sound. She is swaying from side to side as if she were on a boat. In Dante's Purgatory, the souls are brought by a boat and sing monophonically In exitu israel. ${ }^{42}$ This psalm is about exile and symbolizes the exile of humankind from Paradise. The recorded chant is sung by others and she drops one of her arms. Contrary to Inferno, she is not alone anymore, but forms part of a large group of souls who also will have to purge themselves. It is a reign of hope and community. She begins to sing sleepily with the choir while trying to sit straight, supporting herself first with her other arm on her leg and then with both. She rubs her face while singing.

Light: PAR frontal 007 growing until she is blinded when she lifts up her head.

She tries to block the light with her left hand. She looking to her sides. Then she looks ahead, making a sunscreen of her hand. Apparently the coast is still not visible, she expresses tired frustration and leans back. She begins to "fall asleep" again, with her body falling to her right. The singing stops. Then, her body makes the move as if the boat hits shore and she wakes up again.

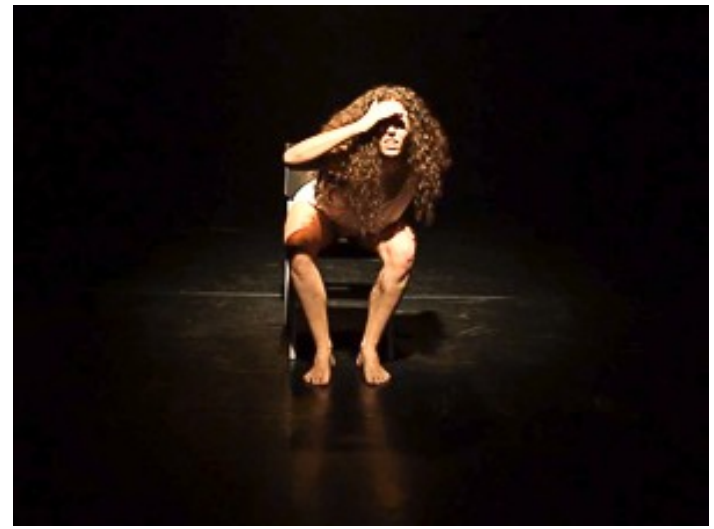

Fig. A12. The protagonist looking for land

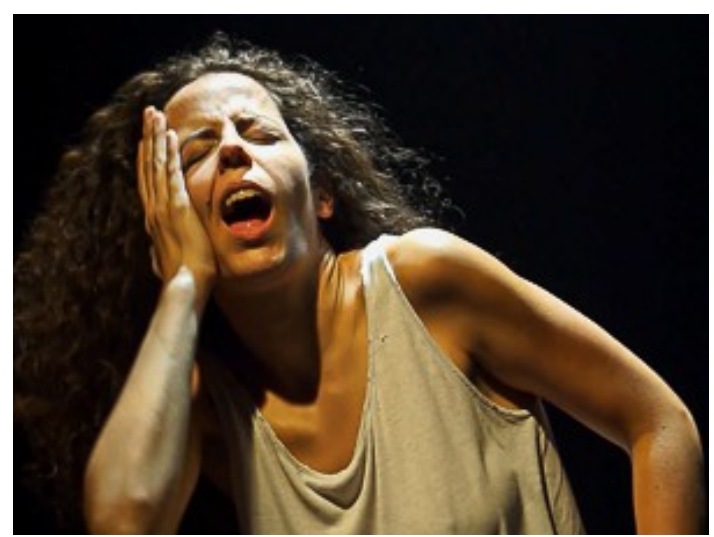

Fig. A13. Waking up on the shore

42 Purgatory 2.45-48. 
Light: Pc counter-light 204 y frontal PAR/Pc more open (general stage light).

The performer wakes up again because of this. The Miserere is sung (min. 22.55) and she sings with it, yawning and stretching, rubbing her face. She opens her eyes again, blinking, and then discovers the audience with a shock, looking at it. The recorded Miserere and the live one end in a long "oh". In Dante's version, "all across the mountainside came people slightly ahead of us, singing the Miserere, verse answering to verse." ${ }^{\prime 3}$ The Miserere is a plead for mercy on God's side ("Have pity on me") and an expression of one's recognition of a sinful state and readiness to purify oneself from them.

When she recovers from her surprise, she says partially timidly, "innocent", a bit sulky and fed-up, while tracing a line on the floor with her finger: "Vedi? sola questa riga non varcheresti dopo '1 sol partito". This is the phrase Sordello says in Dante's Purgatory, in order to show Dante and Virgil that they cannot travel at night. ${ }^{44}$ In Incipit it is as if the protagonist were explaining the "rules" but at the same time hints at not being allowed to travel further at all. The phrase has been expressed in clear gestures, in the end she looks to her left, up high, as to indicate the sun. She sighs and looks a bit sad or fed up with boredom: the souls have to wait here in Ante-Purgatory for many years before they can finally begin their purification.

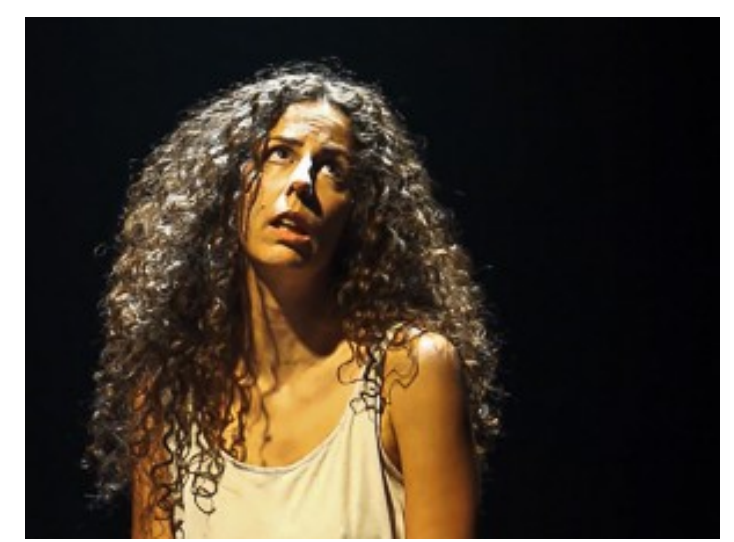

Fig. A14. Being stuck in Ante-Purgatory

43 "per la costa di traverso / venivan genti innanzi a noi un poco, / cantando 'Miserere' a verso a verso." Purgatory 5.22-24. Although they sing it answering verse to verse, in Incipit it is shortened to only one verse. The souls in Dante's Purgatory are shocked about Dante's shadow, which shows that he is alive. In Incipit, it is the audience itself that shocks the protagonist.

44 Purgatory 7.52-53 
Min. 23.36:

She begins to sing the Salve Regina together with the recorded choir, looking up as if she were pleading Divinity. ${ }^{45}$ In the second stanza, her look is lowering, first in front of her. On the words "et spes", she leans on her legs, and looks down on her hands. On the words "ad te clamamus" her foot starts tapping on the ground and she leans backward. On "filii eve" she lays her elbow on the back of the chair and leans even more backwards. She yawns and rubs her face. These are all an expression of her boredom. She begins to fall a bit to her right. Just when she falls asleep with her head falling to the side, she wakes up, looks at the entire audience with a shock, looks up to her left up high (where she indicated the sun) and stands up rapidly. The audience is always the witness. She puts her hair in order, joins the palms of hands, lifts herself up for a moment on her toes, and takes on a fake smile. This scene, including the Te lucis ante, is loosely based upon Dante's scene where one stands up: "He folded his hands in prayer and lifted them, with his eyes fastened on the east, as if saying to God, 'I care for nothing else!"'46

Min. 25.03:

A church bell sounds. She sings Te lucis ante together with the church bell sounds, with a fake but hopeful smile. The recorded two-voice choir joins her. Also this is according Dante's text: “ "To You before the light is done" - devoutly came from his lips with such melodious tones that it made me step straight out of myself. Then the rest with sweetness and devotion harmonized with him through the whole hymn, fixing their eyes on the spheres of heaven." ${ }^{47}$

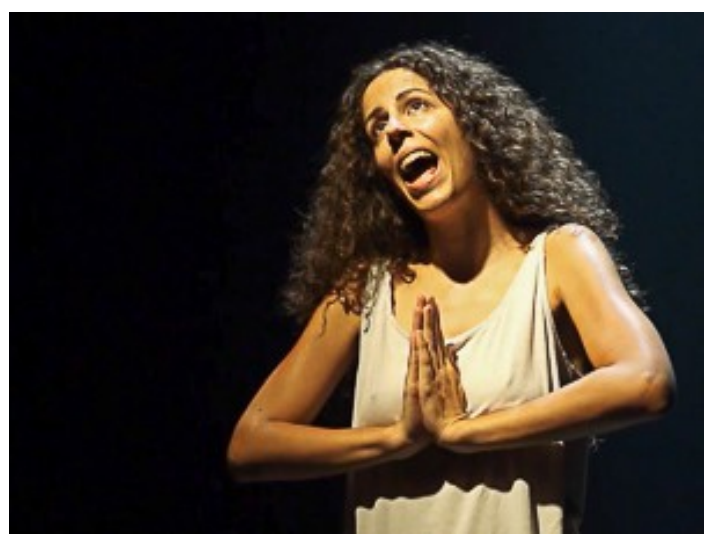

Fig. A15. Singing Te Lucis Ante

45 Purgatory 7.82. In Incipit, the sung text is only a part of Salve Regina: "Salve, Regina, Mater misericordiae, vita dulcedo, et spes nostra, salve. Ad te clamamus, exsules filii Hevae, ad te suspiramus, gementes et flentes, in hac lacrimarum valle." ("Hail, Queen, Mother of mercy, our life, our sweetness and our hope, hail. To thee we cry out, exiled children of Eve; to thee we sigh, mourning and weeping in this valley of tears."

46 "Ella giunse e levò ambo le palme, / ficcando li occhi verso l'orïente, / come dicesse a Dio: 'D'altro non calme'." Purgatory 8.10-12

47 “'Te lucis ante' sì devotamente / le uscìo di bocca e con sì dolci note, / che fece me a me uscir di mente; / e l'altre poi dolcemente e devote / seguitar lei per tutto l'inno intero, / avendo li occhi a le superne rote." Purgatory 8.13-18 
She looks expectantly up while freezing her posture during a moment, but then lets go of her posture with a disappointed sigh. She sits again on the chair and folds her upper body over her legs, with her arms holding each other at the elbow. This posture will be the repeated posture between the terraces: it marks the transitions and is a way of ceasing to be present in this transition. There is a sound of two keys turned in a key hole, based on Dante's text: "One key was golden and the other silver: first he [the angel] fitted the white and then the yellow and so unlocked the gate (...)". ${ }^{48}$

\section{Min. 26.15:}

The Te Deum sounds above the stretched sound of the gate's clangour. Also this is directly taken from Dante's text: “And when the pivots of that holy entrance, which were round rods of ringing and strong steel, turned within the sockets of their hinges, hey made a louder and more resonant clangour (...) I turned around at the first thundering sound and thought I heard 'Te Deum: Praise to God' chanted by voices mixed with that sweet strain." ${ }^{49}$ The performer is coming up very slowly, with her hair hanging over her face, her hands moving towards the knees. There is one moment in which she sits straight up, but with her hair entirely covering her face, reminiscent of the Infernal creature.

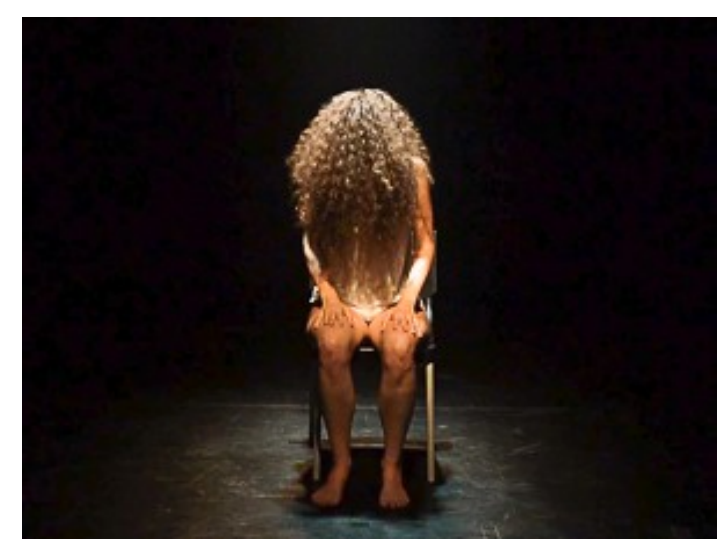

Fig. A16. Beast versus Human

Min. 26.40:

We are on the terrace of Pride. The performer moves her hair backwards. She puts her hair in order. She looks at one person in the audience (right) and reacts: "puh!" disdainfully and laughs about that person. She leans backwards, crosses her legs, looks at another person (left) disdainfully, rolls her eyes and shakes her head saying “ay...”. She examines her nails with an self-satisfied smile, while

48 "L'una era d'oro e l'altra era d'argento; / pria con la bianca e poscia con la gialla / fece a la porta sì, ch'i' fu' contento." Purgatory 9.118-120

49 "E quando fuor ne' cardini distorti / li spigoli di quella regge sacra, / che di metallo son sonanti e forti, / non rugghiò sì né si mostrò sì acra (...) / Io mi rivolsi attento al primo tuono, / e 'Te Deum laudamus' mi parea / udire in voce mista al dolce suono.”, Purgatory 9.133-141 
turning her body slightly to her left (right for the audience), and caresses her hair. She looks at another person (left) from his head to his feet, sniffing with a small laughter, sighing and looking the other way: it is not worth her time being with such people.

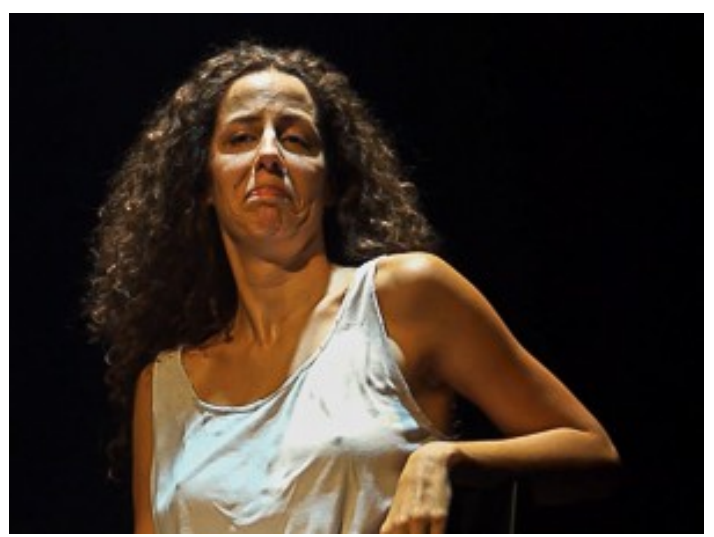

Fig. A17. The proud soul

Min. 27.13:

The recorded $O$ Padre Nostro begins to sound. In Dante's Purgatory, the proud souls have to carry heavy rocks that push them down and they murmur an alternative version of the Pater Noster. ${ }^{50}$ She startles a bit and realises she has to be purging. She stands up, goes to the left side of the chair, slides her hair to one side as if it were important for her to be pretty when she is purging, and lifts up the chair with great difficulty, until loading it on her back. She "walks" without moving from her spot, while murmuring the Padre Nostro, moaning. As this scene shows, the performer can get up from her chair, but the movement is still on a limited surface. She pauses a moment, looks at the audience and looses herself in her pride again. She realises her fault with a shock, nods vigorously as to motivate herself, and then utters the Padre Nostro again, this time louder.

50 This is what has been selected from the prayer for Incipit: ""O Padre nostro, che ne' cieli stai, (...) Dà oggi a noi la cotidiana manna, / sanza la qual per questo aspro diserto / a retro va chi più di gir s'affanna. / E come noi lo mal ch'avem sofferto / perdoniamo a ciascuno, e tu perdona / benigno, e non guardar lo nostro merto. / Nostra virtù che di legger s'adona, / non spermentar con l'antico avversaro, / ma libera da lui che sì la sprona. (...)" (“Our Father, who art in heaven, (...) Give us this day our daily manna, since / without it, through this bitter wilderness / he retreats who tries hardest to advance. / And as we pardon all for the trespasses / that we have suffered, so in loving kindness / forgive us: do not judge by our deserving. / Our strength so easily fails: lead us not / into temptation through our ancient foe, / but deliver us from the evil he provokes. (...)") Purgatory 21.1-24 


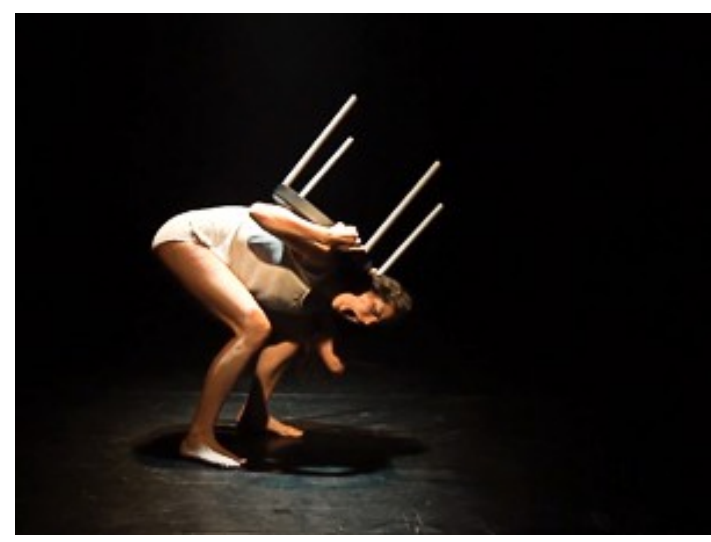

Fig. A18. The penitence of the proud soul

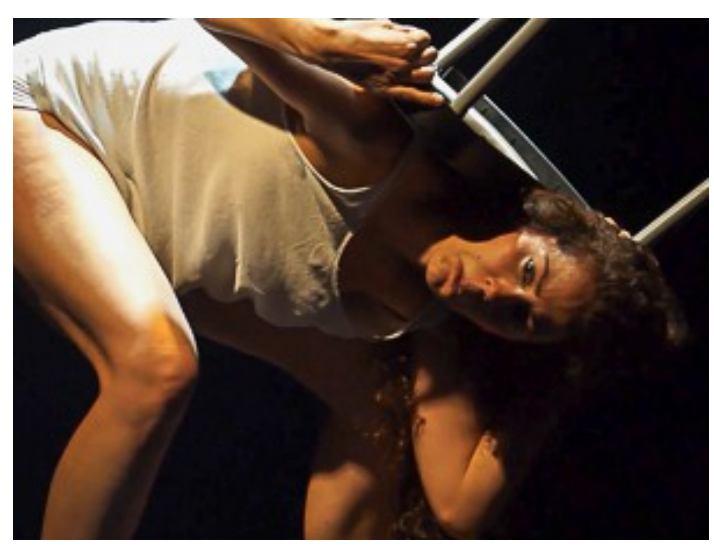

Fig. A19. Pride rears its head

When the voices cease to recite the Padre Nostro, she still continues. Then the Beatitude Beati pauperes spiritu sounds, an angel is singing about the blessed that are free from pride by being “poor in spirit". In Dante's version, it is sung at the gate ${ }^{51}$, while in Incipit it liberates the protagonist from her sin. She stops, puts down the chair with difficulty, pulls it to the exact centre and take a seat on it. She shows happiness, relief and peace. She opens her arms which is reminiscent of the Crucifixion, and slowly closes them while she closes her eyes and folds her upper body slowly forward: she has found inner peace. This movement is performed in between each scene of a different sin.

Min. 29.08:

Closing gate. The terrace of the envious.

Light: flash with the end of the gate. Add to the counter-light 204 the light PAR 117. Light lower and fade-in.

The performer sits up straight and rapidly pulls her hair back. She looks rapidly from one side of the audience to the other, to and fro. Then she sees something in the audience (right), freezes with her mouth half open, points and sighs at it with an expression of liking it very much. She withdraws her arm, makes faces. Looking at the other side (left), she sees another thing she likes very much but this time reacts with pity, frustrated that she cannot possess it. She again makes faces. Then, looking at the right part of the audience, direct reacts with great frustration, making fists and moving them up and down, as a little child that cannot have what it wants. 


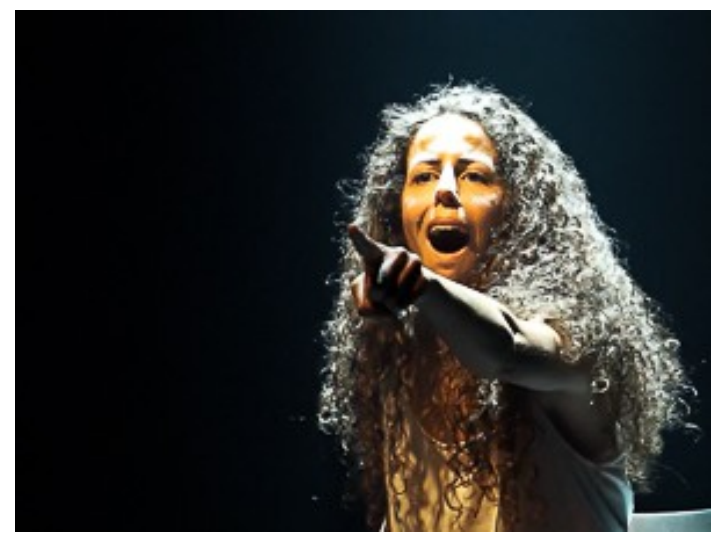

Fig. A20. Something she would like to have herself

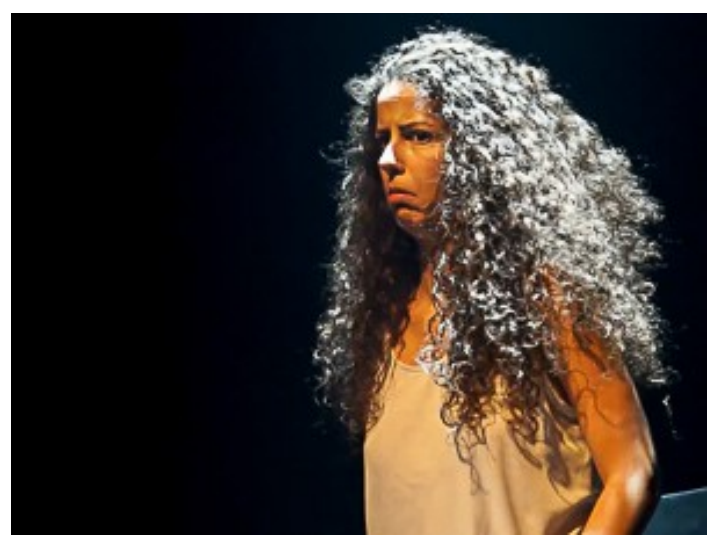

Fig. A21. Envy

However, she is interrupted by the "hurtling voices" that are examples of selflessness. ${ }^{52}$ She freezes, looks startled in front of her, and begins to nod, accepting that she needs to purge this sin. She takes an imaginary needle from under her, and begins to "sew" her eyes, while singing together with the choir "ora(te) pro nobis" in the Litany of All Saints. ${ }^{53}$ She makes three stitches in each eyelid and expresses the pain while trying to sing as well as possible. In Dante's Purgatory, it was a Divine hand that sewed their eyelids: they are already sitting with sewn eyelids against the rocks. ${ }^{54}$ After the sewing, still singing, she holds on to the chair with her hands, like a blind person, lifting up her chin and moving her head around as to distinguish sounds. Two voices sound as examples of envy and she looks around while shaking her head as to express she rejects envy. ${ }^{55}$

52 Purgatory 13.25-33. Dante writes about two "hurtling" voices giving examples of empathy. Mary said Vinum non habent ("they have no wine") at the marriage feast in Cana, after which Jesus changed the water into wine (John 2:1-11). The words Io sono Oreste are the words spoken by Pylades, friend of Orestes, in order to save Orestes' life by dying in his place.

53 "E poi che fummo un poco più avanti, / udia gridar: 'Maria òra per noi': / gridar 'Michele' e 'Pietro' e 'Tutti santi'." ("And when we went straight forward a short space, I heard cried out " Mary, pray for us!": cried out "Michael" and "Peter" and "All saints.") Purgatory 13.49-51. In Incipit, only a selection of the Litany of Saints is sung.

54 Purgatory $13.58-72$

55 The first voice says: "Anciderammi qualunque m’apprende!" (“Everyone that finds me shall destroy me!") It is the voice of Cain, saying these words to God after killing his own brother Abel (Genesis 4:14). The second voice says "Io sono Aglauro che divenni sasso!" (“I am Aglauros who was turned to stone!") Aglauros, daughter of King Cecrops of Athens, envied her sister Herse because Mercury loved her; the god turned Aglauros into stone (Metamorphoses II, 737-832). Purgatory 14.133 and 139 


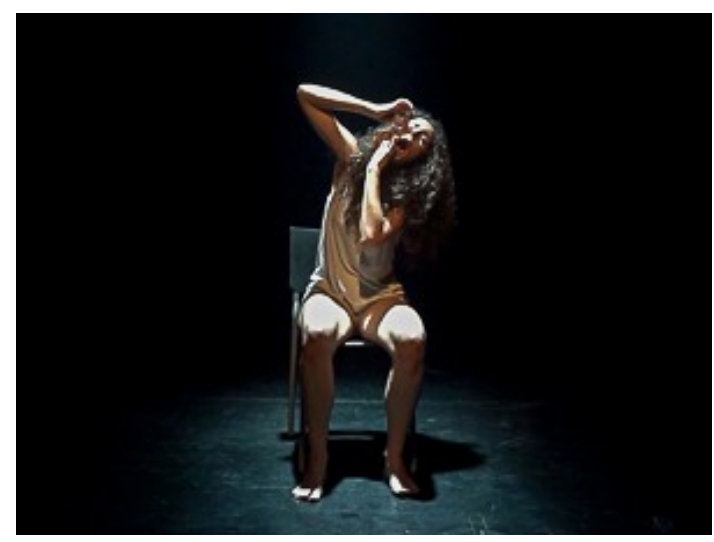

Fig. A22. Sewing her own eyes

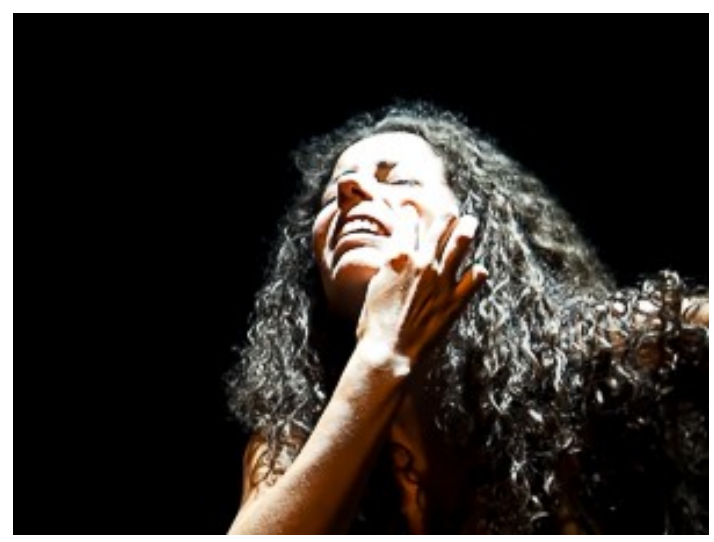

Fig. A23. Singing the Litany

She freezes when the Beatitude Beati misericordes sounds. This is the angelic songs about the blessed ones that are merciful. ${ }^{56}$ Her eyes open: she can see again, but this time without being envious of others. She smiles full of happiness. Then she repeats the movement of the "Crucifixion" and her torso folds over her legs.

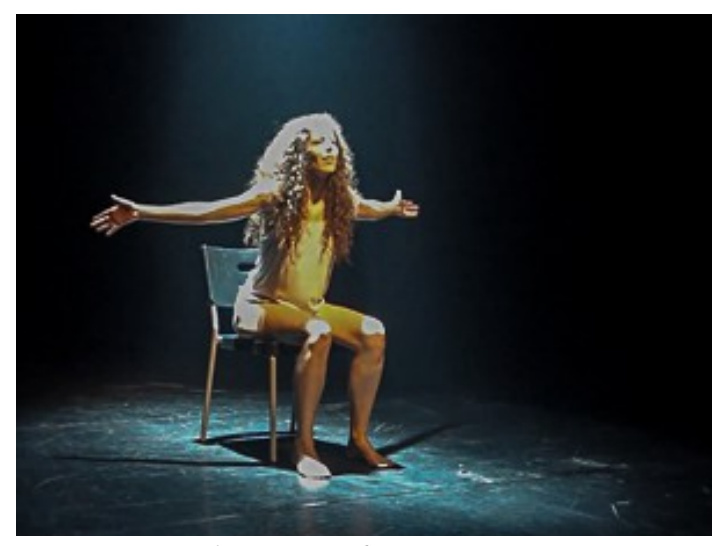

Fig. A24. The Crucifixion movement

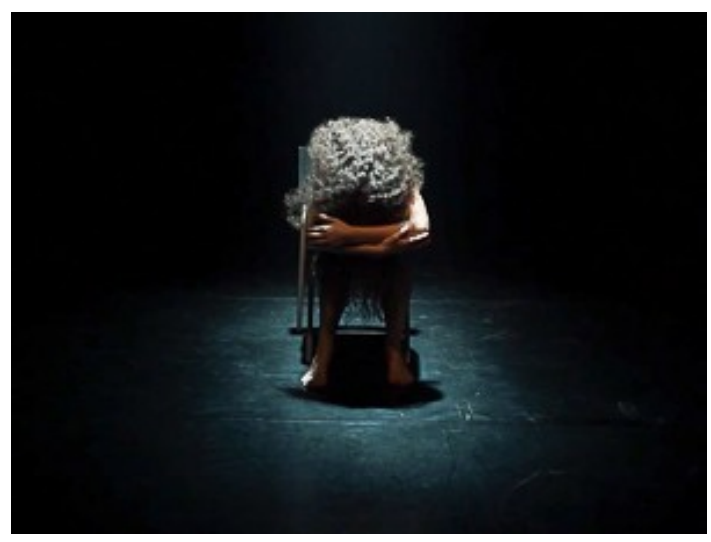

Fig. A25. The folded position

Min. 31.29:

We are at the terrace of the wrathful.

Light: Flash at the end of the gate. Add to frontal light the limelight in 035 .

The performer sits up straight very quickly when fade-in of light is still not completed. When the light is faded in, she is watching the audience menacingly. She "opens" her physical position: she places her feet more wide apart and separates her elbows from her body. Her lower jaw is positioned forward during this entire scene. She frowns and expresses a growing anger towards the audience (left), with a direct look, her eyes open, shoulders up, closed fists, a provoking expression which seems to say “wanna fight?". She begins to move as if she is preparing for boxing. When looking to the audience on the right, she stops one moment, but she seems to express "what are you looking at" and immediately her anger and fighting attitude augment. 


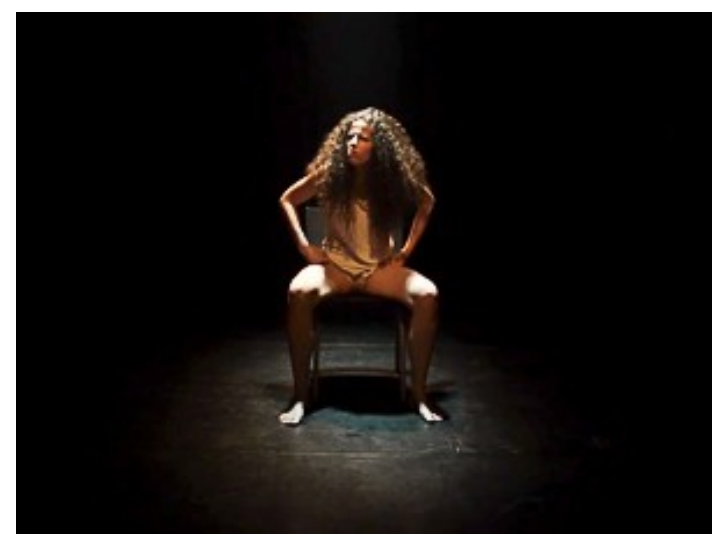

Fig. A26. The wrathful soul

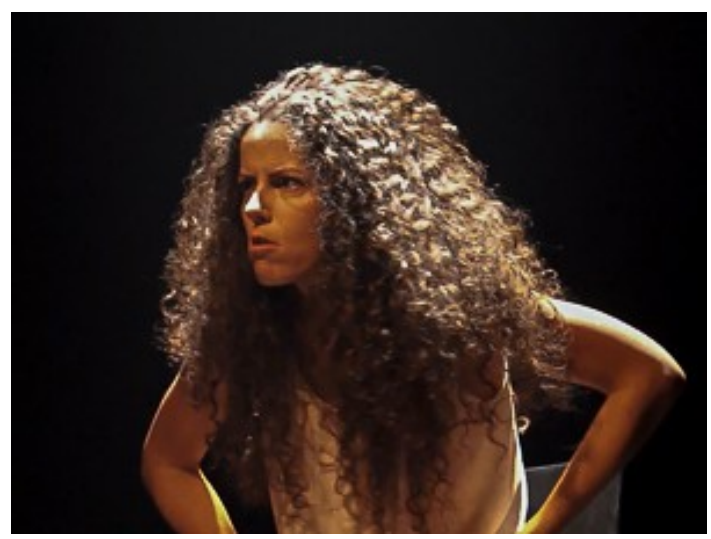

Fig. A27. Wanna fight?

Then, suddenly, Agnus Dei sounds, a chant she has to sing too in order to purify herself. It is the chant of Dante's wrathful because it is the ultimate example of pacifism: the Lamb of God, Christ. ${ }^{57}$ It is a plea to Christ for peace: "dona nobis pacem" ("give us peace"), perhaps especially for inner peace. Her facial expression changes completely: to a very submissive one to Divinity above her. She opens her fists and places her hands on her knees.

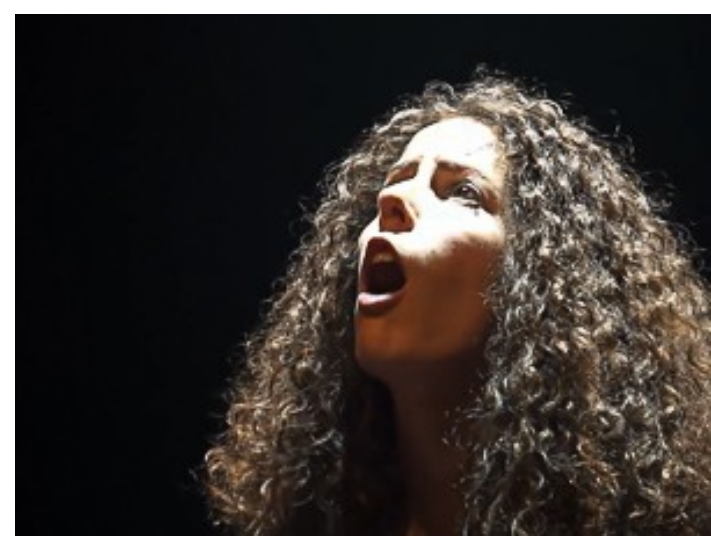

Fig. A28. Devotion

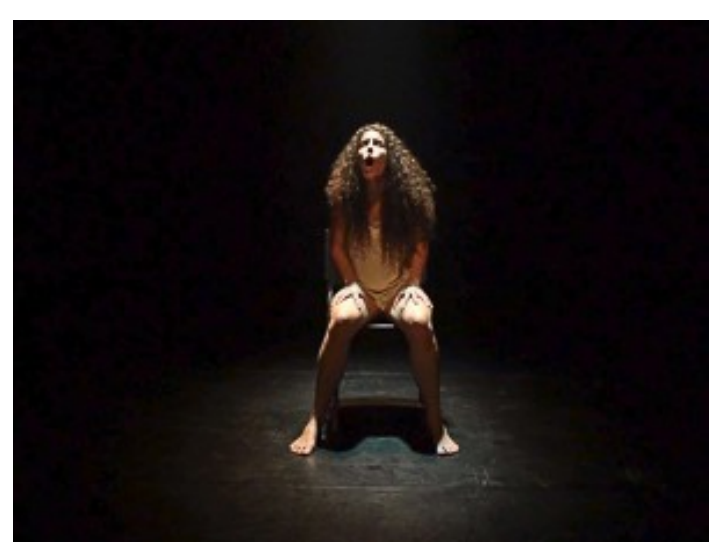

Fig. A29. Asking for inner peace

She begins to sing along and even tries to be "presentable" for God, taking away hair out of her face and ordering it next to her face. Halfway the second phrase, she begins to make fists again and her look is drawn to the audience on the right. Her face begins to express a growing anger while she keeps on singing. At the beginning of the third phrase, she shakes her head and closes her eyes tightly, trying to control her anger and turn to God again. She looks up again, submissively and asking for God's help in her look. Her knees close a bit. But then, in the fourth phrase, her anger overcomes her again, looking at someone in the audience on the left. She closes her fists and anger 
spreads through her posture and face. However, she manages to control it quicker this time, directing herself towards God, opening the palms of her hands upward for a moment, before placing them on her knees. When she finishes singing, she keeps looking up to God, with a submissive and supplicatory look, as to reinforce the sung prayer for peace, with a somewhat shaking underlip. Beati Pacifici is sung by an angel (min. 33.23), which means "Blessed are the peaceful" 58 and her look is slowly directed in front of her, with a grateful smiling look filled with wonder and emotion. She relaxes, exhales and smiles, while her arms are opened for the "Crucifixion" movement until she is completely folded over her knees.

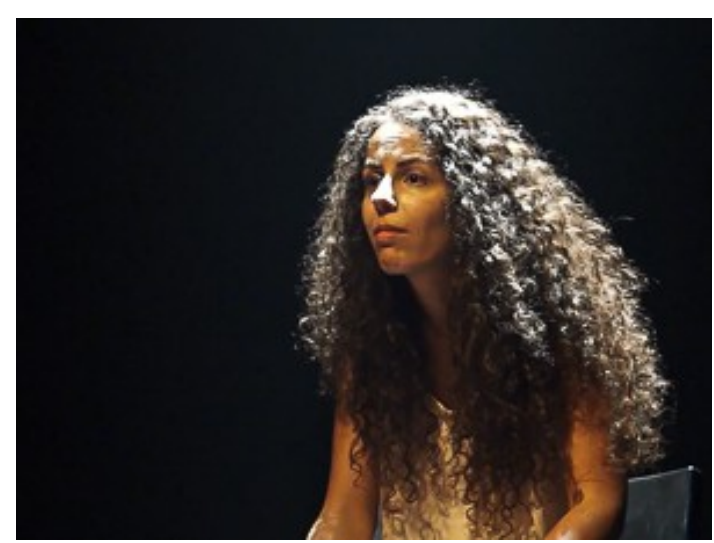

Fig. A30. Liberation

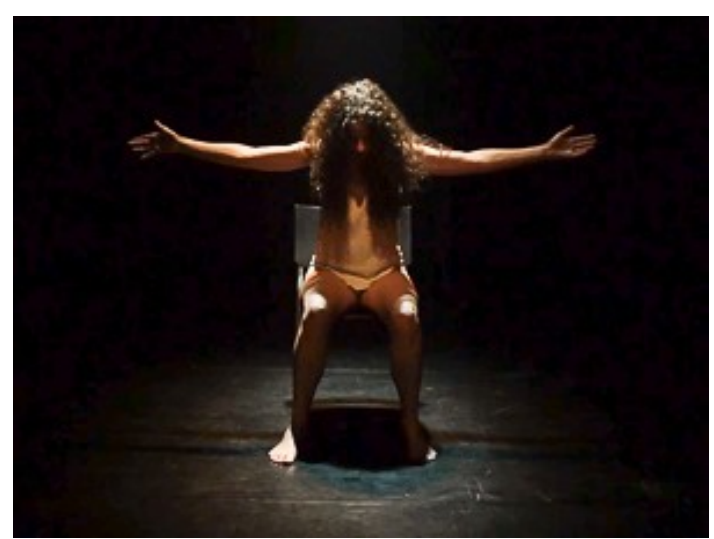

Fig. A31. The Crucifixion movement

Min. 34.00:

The gate closes. We have arrived at the terrace of the slothful.

Light: Flash at the end of the gate sound. General stage light.

The performer lifts her upper body a bit up, leans to one side, and takes away her hair from her face.

She has a very tired and lazy attitude. She rubs her face while leaning on her knee with her elbow.

She sits up straight, but immediately rests her left elbow on the back of the chair and leans back.

She yawns extensively, sighs, yawns again, munches, and is just falling asleep when sounds of running people appear. They wake her up and she realizes, still sleepy, that she should be running too. The slothful run as a remedy for their inactive attitude, in order to obtain zeal. She moves her fists up and down as to motivate herself, which is the beginning of a running arm movement. She stands up and jogs via the right side of the chair to just behind the chair. She holds the chair and runs on the same spot, with her legs en dehors so that her knees are lifted to her diagonal rather than in front, as if she had tibia vara (bow legs). She breathes heavily.

58 Purgatory 17.67-69. It is the troped version (see chapter 4 and 6), with Dante's additive text "che son sanz'ira mala!" ("those free of wicked wrath!") in the middle. 


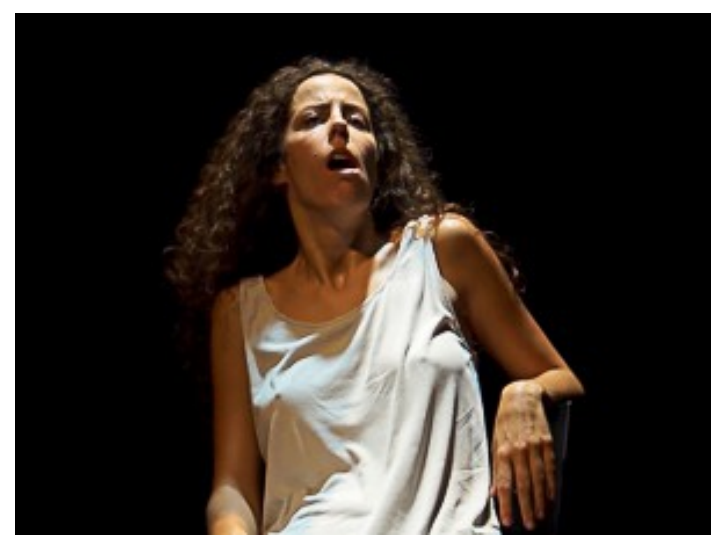

Fig. A32. The slothful soul

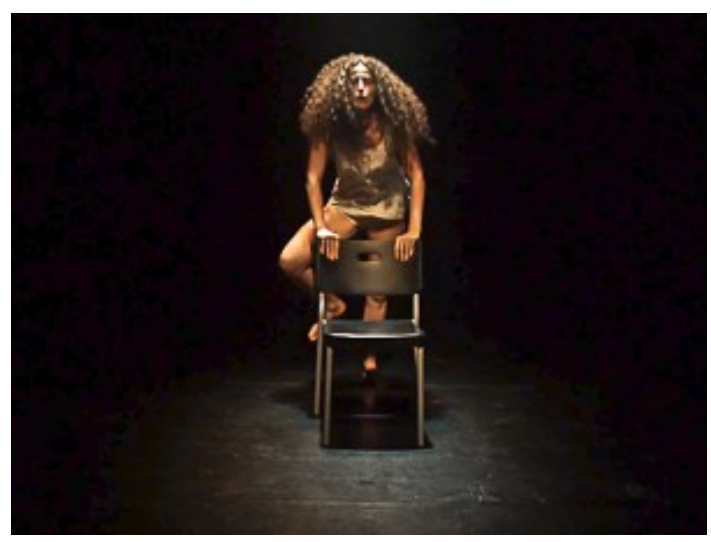

Fig. A33. Running as purification

She cries out "Maria corse con fretta a la montagna!" 59 She begins to lean more on the back of the chair and her running slows down. She stops one moment, but then realizes she should keep on running and does so. With all her possible zeal she cries out: "Ratto, ratto, che 'l tempo non si perda per poco amor!"60, accompanying her running with an motivating movement in the air with her fist. She becomes very tired, slowing down her running while panting opening her mouth even wider and exhaling on "pfff". She stops and leans on the back of the chair with her lower arms, puffing and collapsing her upper body for a moment on the back of the chair. But she realizes she should not and her own motivation moves her into almost immediate running again. She runs enthusiastically and cries out fervently: "Noi siam di voglia a muoverci sì pieni, che restar non potem; però perdona, se villania nostra giustizia tieni!"'61 while breathing heavily and making the same gesture with her fist. She nods after speaking and keeps on running with conviction, smiling with her mouth open and breathing heavily, but this time not stopping. Her face shows her determination. Then, the Beatitude Beati qui lugent is sung by an angel. ${ }^{62}$ She shows surprise while continuing to run. She lets go of the chair and while slowing down her running, she jogs back to the front of the chair. She sits down, still breathing heavily but slower, with open mouth. She looks to one side of the audience and then the other side, and relief appears on her face while she looks smilingly in front. She opens her arms for the "Crucifixion" movement and the folding over.

59 "Mary ran with haste to the hill country!" Purgatory 18.100. Mary ran to visit Elizabeth after learning of her cousin's pregnancy (Luke 1:38-40).

60 "Faster! faster! let no time be lost through little love!" Purgatory 18.103-104

61 "We are so full of passion to keep moving, we cannot stop, we beg your pardon, then, if you should take our penance for bad manners." Purgatory 18.115-117

62 "Blessed are those who mourn". Purgatory 19.49-51. They mourn because now they are aware of having shown lax love. (see chapter 4). 


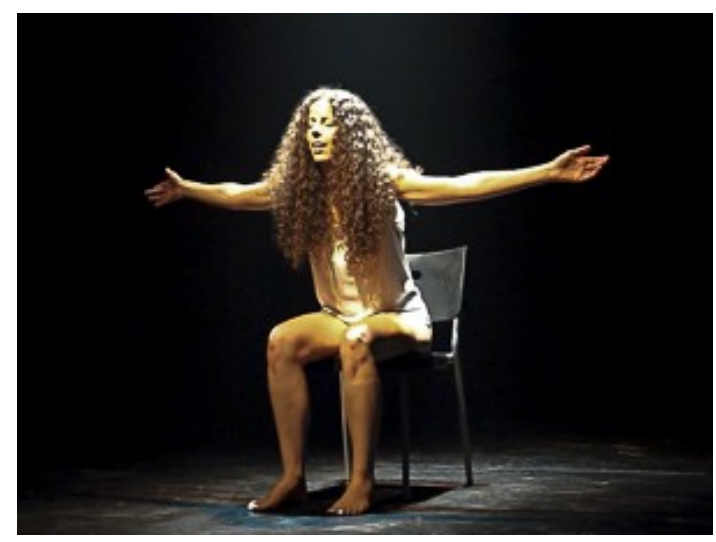

Fig. A34. The Crucifixion movement

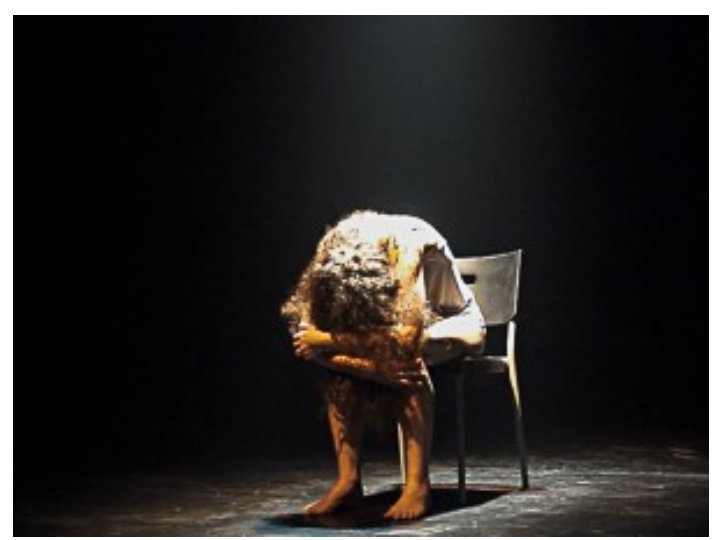

Fig. A35. The folded posture

Min. 36.28:

We are on the terrace of the avaricious. ${ }^{63}$

Light: Flash at the end of the gate sound. Add to the counter-light 204 the PAR 117 in distinct percentages (making more blue).

The performer comes up abruptly and slowly brushes some hair out of her face on one side and then on the other, while keeping her neck short and her shoulders high. Then her eye falls on a point close to her and she lengthens her neck for a moment to see what it is, takes hastily between her left fingers that what she has seen, looks at it approvingly with a smile and uttering "hmmm...", taking it close to her. Then she sees another thing on her right side, which she also shoves toward her with her right hand and observes with admiration. She shoves another thing with her left hand towards her, quicker this time. The movement is repeated various times, gradually faster, while she is trying to hold the imaginary bundle together. She holds the bundle with two hands, notices the audience with wide-open eyes and a distrustful look. She turns toward her right with the entire bundle, out of the centre of the light, while shortening her neck, looking over her shoulder to the audience as if to say: "This is MINE".

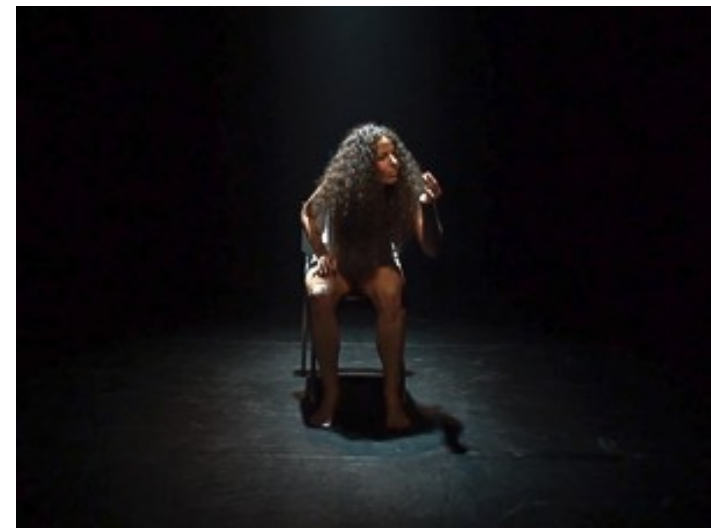

Fig. A36. The avaricious soul

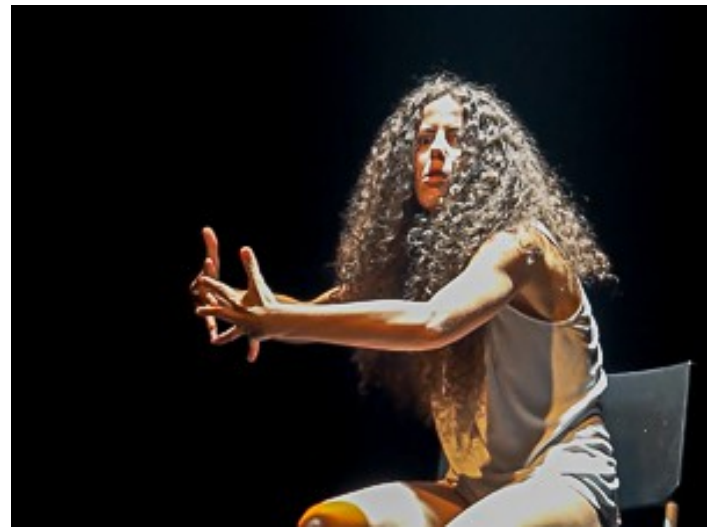

Fig. A37. "My treasure"

63 Although supposedly it is the terrace of the prodigals as well, Dante's Purgatory focuses especially on the avaricious. Only by the fact that the freed soul on this terrace, Statius, was a prodigal (Purgatory 20). 
The sound of a drone (bordone) enters and she is startled. She looks up and immediately opens her arms, in order to drop down her bundle. She quickly stands up and walks with bow legs to the other side of the chair, takes her hair in her right hand, sits on her knees facing the side of the chair, takes her hair in her right hand and drops her face down to the surface of the chair. This refers to Dante's scene where the avaricious lie flat on the ground with their faces down, tied with hands and feet. They can only sing pressed against the ground. ${ }^{64}$ The performer does the same but against the surface of the chair, on her knees, and by her own initiative. She sings along with the recorded version Adhaesit pavimento anima mea, with her mouth on the chair, due to which her singing is altered. This chant is perfectly suitable for the situation of the avaricious: "Adhaesit pavimento anima mea; vivifica me secundum verbum tuum. (...) Dormitavit anima mea prae taedio; confirma me in verbis tuis. (...)" ("My soul has cleaved to the dust; revive me according to your word. (...) My soul has melted away for sorrow; strengthen me according to your word." ${ }^{65}$ During the first verse, her look is directed in front of her, where she left her precious bundle. Her body moves forward so that her mouth also travels forward on the surface of the chair while her right hand, still on the chair hidden by her body and hair, slowly reaches out to it.

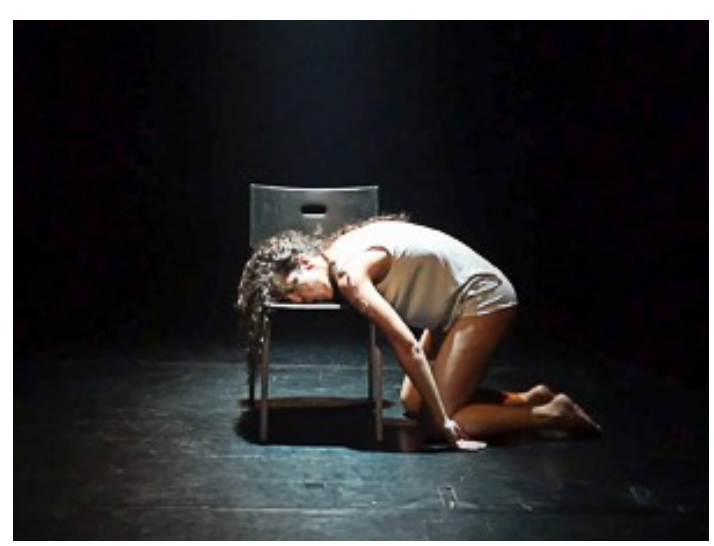

Fig. A38. The avaricious soul singing Adhaesit Pavimento Anima Mea

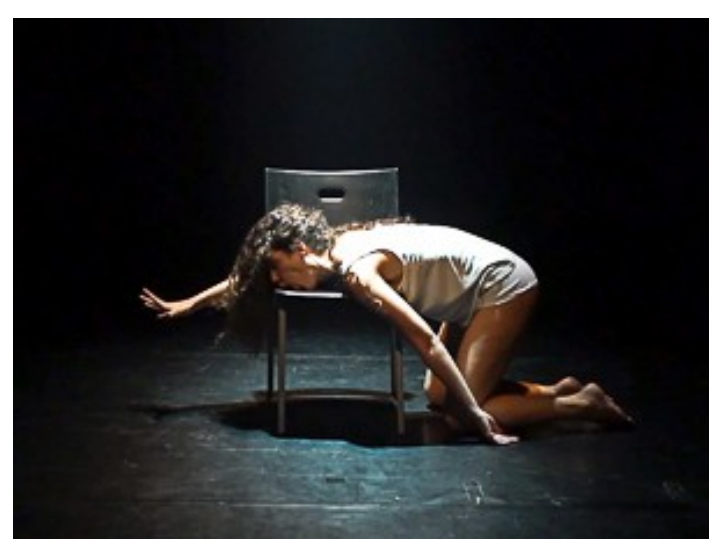

Fig. A39. The temptation

At the beginning of the second verse, she suddenly notices the audience that is watching her, she feels she has been caught in the act, and rapidly withdraws her arm and moves back to the centre of the chair. She sings with her eyes closed, concentrated on not being seduced again by the bundle. When she is just inhaling for a new verse, the phrase "Dolce Maria!" sounds and an earthquake is heard. This is one of the phrases that Statius says in Dante's narrative just before being liberated, which is signalled by the trembling and celebrated by all the souls, singing Gloria in excelsis. ${ }^{66}$ In Incipit, "Dolce Maria!" is an anonymous soul's exclamation at being liberated. The performer lifts

64 Purgatory 19.70-75

65 These are the first and fourth verses of Adhaesit anima mea (Psalm 119).

66 "Dolce Maria": Purgatory 20.20. Trembling and Gloria: Purgatory 20.127-138 
up her head, looks around a bit surprised, then apparently discovers the soul that cried in front of her. She points in that direction and looks at the audience as to tell them it is him. Gloria in excelsis in parallel octaves and fifths is sung in choir on the recording, and she joins them immediately, still on her knees but right up, putting her hands on the chair. She sings it in a pompous way, like singing a type of national hymn.

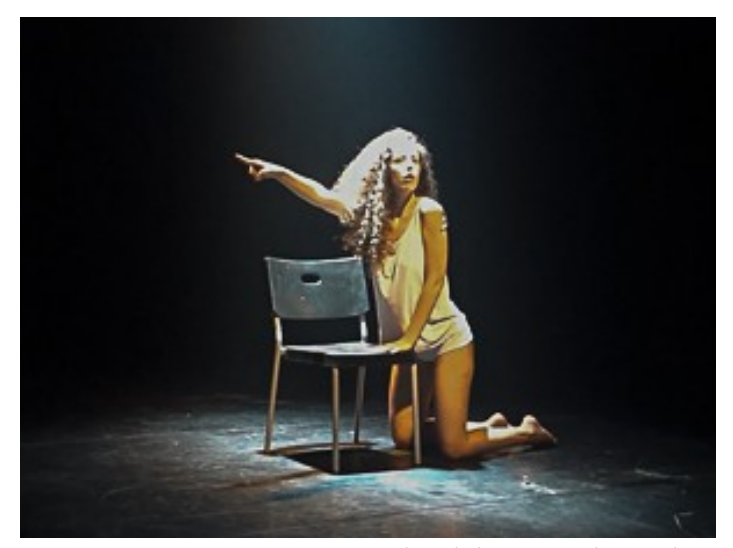

Fig. A40. Pointing at the liberated soul

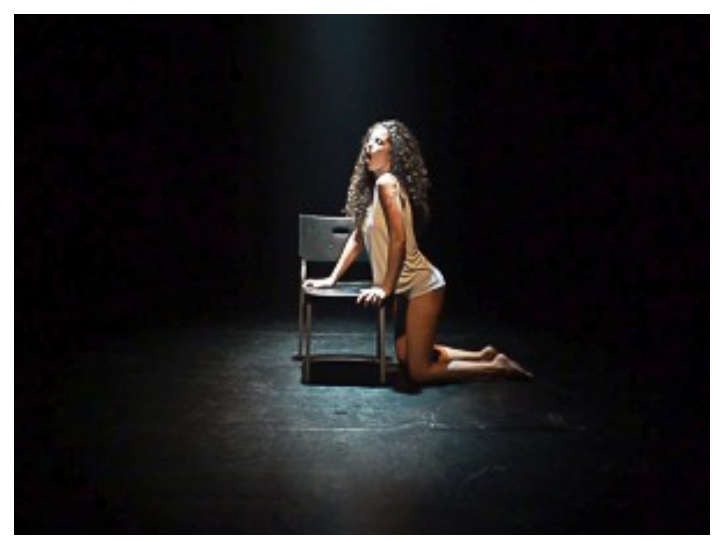

Fig. A41. Singing the Alleluia

After she finishes, she suddenly realizes she has to continue her purification. She takes her hair in her hand again and drops her face again on the chair. This time she sings with her eyes open, looking at the audience from side to side, with an expression of having been reprimanded.

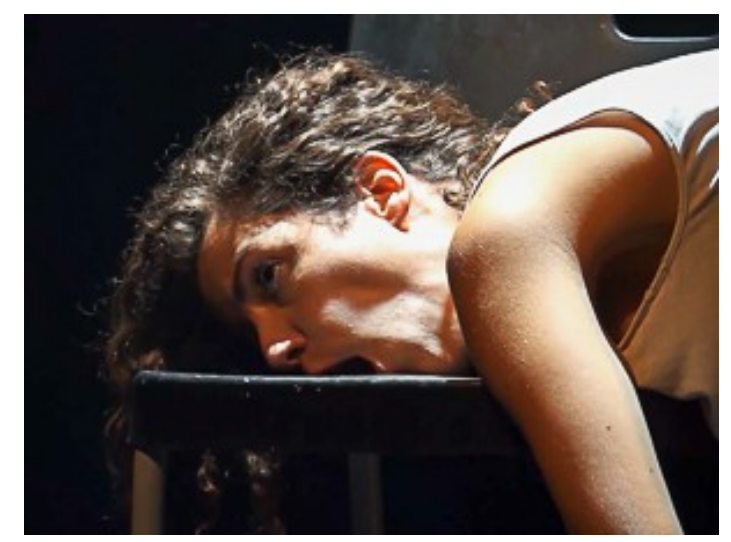

Fig. A42. Doing her penance

The last part she sings concentrating on her purging rather than on the audience. When she is about to continue to a next verse, the Beatitude Beati qui sitiunt liberates her from her penance. ${ }^{67}$ This is partially the Beatitude Beati qui esuriunt et sitiunt ("Blessed are those who hunger and thirst [for justice]"). Thirst for justice implies freeing oneself from the thirst for gold and earthly wealth. The performer freezes for a moment, looks up incredulously, puts her hands on the chair while looking up, standing up and stepping to the front of the chair in order to sit down, still looking up to this 
voice. She then relaxes and smiles, opening her arms for the "Crucifixion" movement towards her folded position.

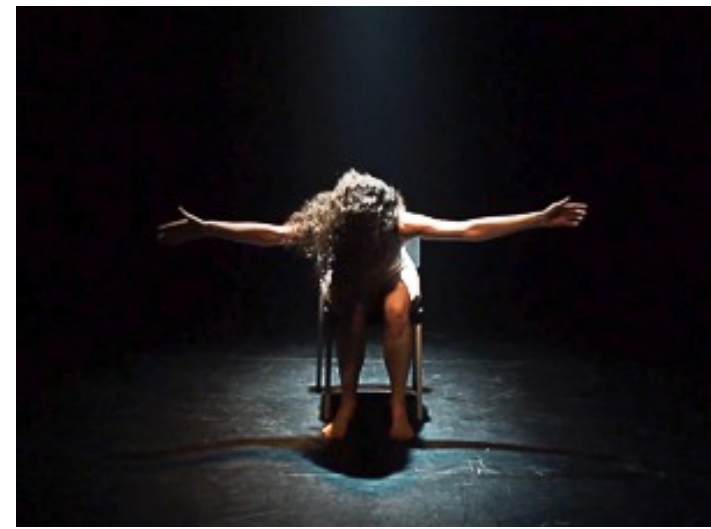

Fig. A43. The Crucifixion movement

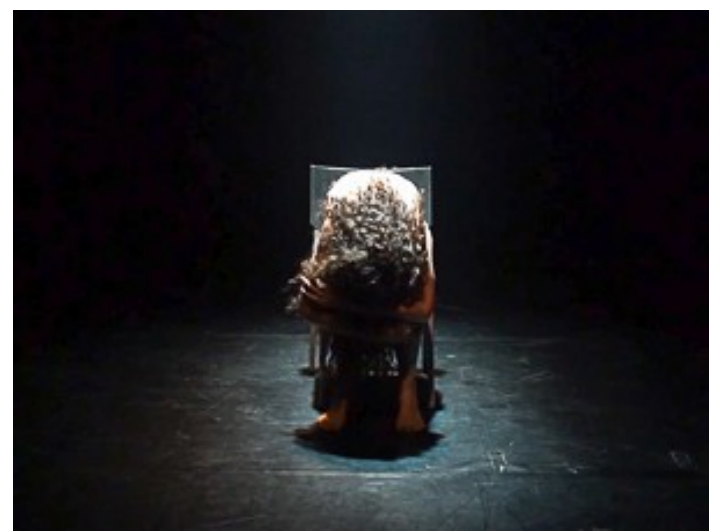

Fig. A44. The folded posture

Min. 39.40:

The gate closes. We have reached the terrace of the gluttonous.

Light: Flash at the end of the gate sound. Warm light emphasized.

The performer moves her hair to the back when she arise. She expresses cheerfulness. She places her legs and arms wider. She rubs her upper legs and grabs something which she eats, which she finds very tasteful. While still chewing, she sees another thing, grabs it and takes a bite from it. She moves along with her chewing movements, expressing deep enjoyment. A third thing is smaller and she puts it in her mouth with the tips of her fingers. With her other hand she scoops something else into her mouth. This gradually becomes faster, while she is still chewing on food. It becomes obsessive-like, breathing rapidly and propping up the things in her mouth even though there is no space for them in there.

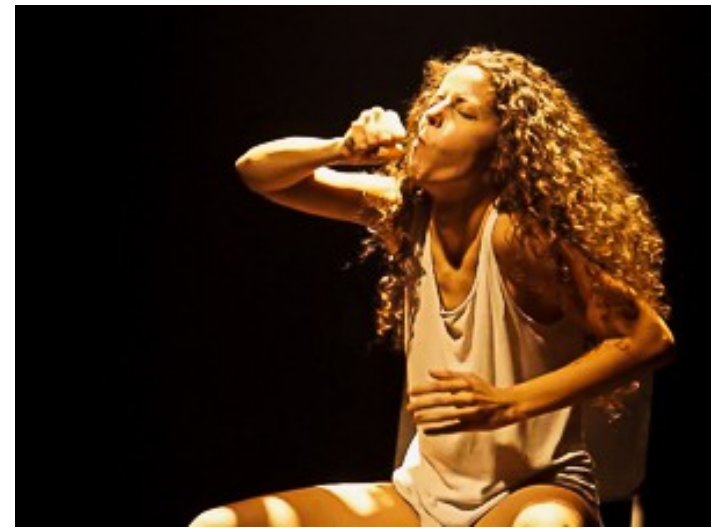

Fig. A45. The glutton

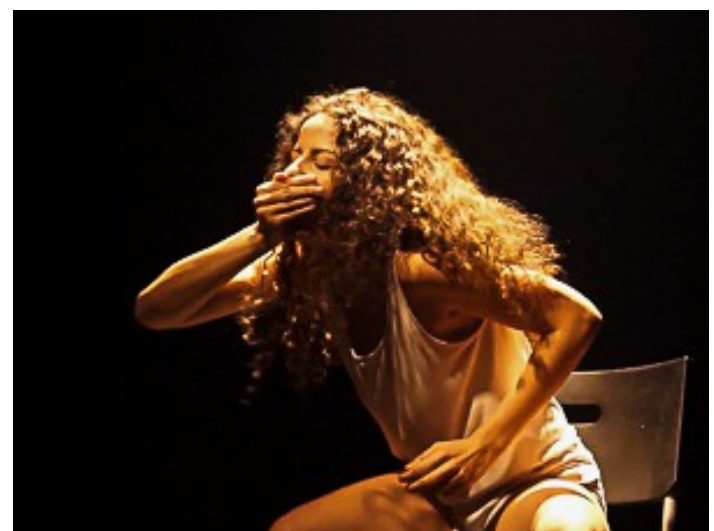

Fig. A46. Guzzling the food 
Then the sound of fresh water enters, she looks up and tries to reach for it, opening her mouth, with her tongue sticking out, and pointing at her mouth from time to time begging for some of that delicious water. This is based on Dante's text "Beneath the tree I saw people lift their hands and cry I know not what up toward the leaves, like foolish and obstreperous small children who beg, while he they beg from answers nothing, but, to make their hankering the keener, holds what they crave aloft and will not hide it." ${ }^{96}$ While she is doing this, Domine labia mea sounds, and she freezes, turning her head slowly in front, with a guilty look on her face. Dante places this chant at the terrace of the gluttonous for its text: "Domine labia mea aperies et os meum adnuntiabit laudem tua" ("Lord, open my lips and my mouth will declare your praise"). ${ }^{69}$ She begins to sing along with them, lowering finally her arms and placing them on her legs. However, around "et os meum" she begins looking up to her other side and licking her lips, clearly having difficulty to control herself. On the last word she already lifts up her hands, moaning in desire and frustration. This time she realizes she wants to stop being a glutton and she lowers her arms. When the song starts again, she eagerly sings along looking upward and nodding, even though she is still fighting against her urge to eat or drink.

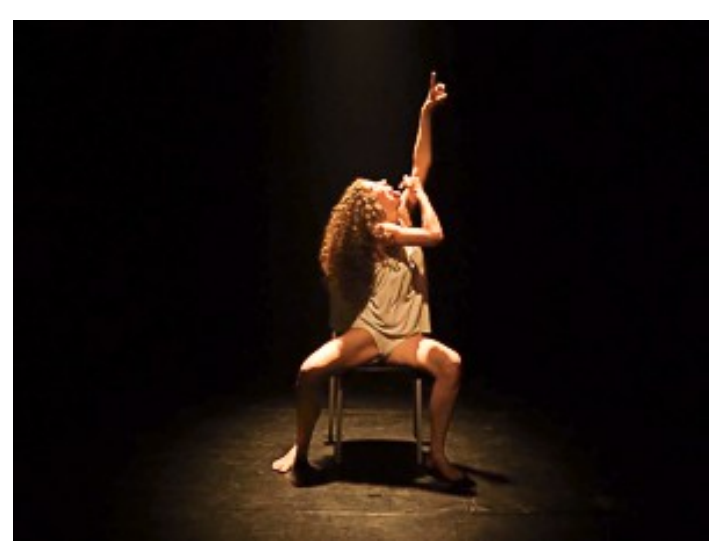

Fig. A47. Begging for some of the tasty water up there

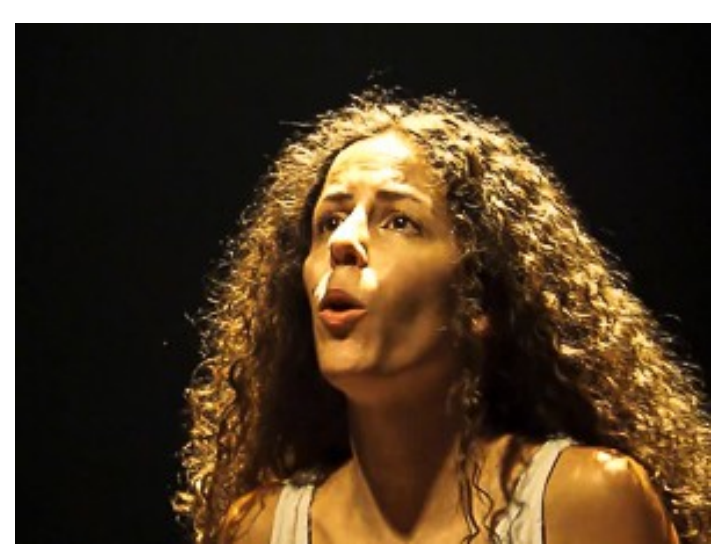

Fig. A48. The inner fight while singing Domine Labia Mea

The Beatitude Beati qui esuriunt sounds and she looks surprised. It is the missing part about "those who hunger" of Beati qui esuriunt et sitiunt. ${ }^{70}$ She looks up to the two places which were a strong source of seduction to her but have ceased to be so, and she smiles happily and serene. She opens her arms for the "Crucifixion" and the folded posture.

68 "Vidi gente sott'esso alzar le mani / e gridar non so che verso le fronde, / quasi bramosi fantolini e vani / che pregano, e 'l pregato non risponde, / ma, per fare esser ben la voglia acuta, / tien alto lor disio e nol nasconde." Purgatory 24.106-111

69 Purgatory 23.10-12

70 Purgatory 24.151-154 


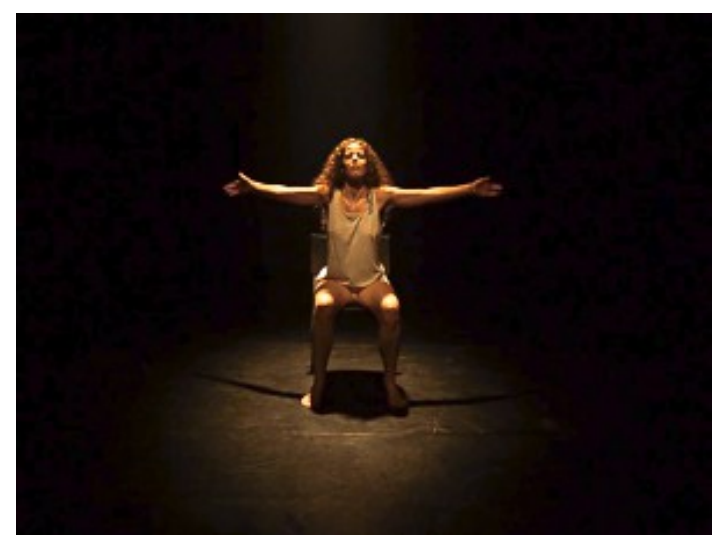

Fig. A49. The Crucifixion movement

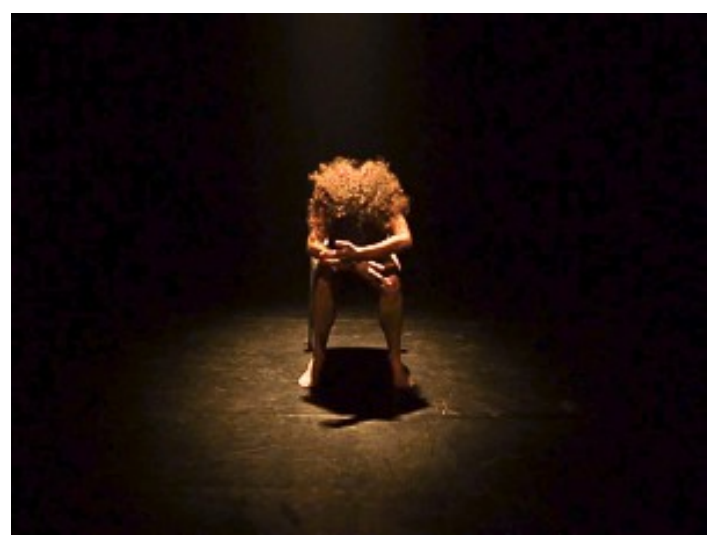

Fig. A50. The folded posture

Min. 42.27:

The gate closes. This is the last terrace, the one of the lustful.

Light: Flash at the end of the gate. Add to the frontal light the limelight in 035, at a lower level than at the terrace of Wrath.

The performer sits up straight, taking her hair out of her face to the side. She leans her head backwards and shakes her hair. She looks in front, discovers the audience, begins to smile seductively and giggles. She is very cheerful. She caresses her upper legs and wriggles her legs, pushing them together into a more "feminine" posture. She lifts up her left hand and waves at someone in the audience wriggling her fingers, accompanied by her small laughs. She blows a hand kiss to the same side and reacts to this in a quasi-timid, laughing way, raising her shoulder. She crosses her legs - her toes are pointed - and caresses her hair and a part of her chest, while biting her underlip and looking to the audience on the other side (left). She bounces her lower leg up and down a few time, lifts up her arm completely and waves to someone in the audience by moving her hand at the wrist and making the same vocal sounds as if she were saying "yoohoo...!" She reacts again by raising her shoulder, biting her underlip and giggling, and also by caressing her lower leg. She wriggles and bites on her index finger while giggling and smiling at that person.

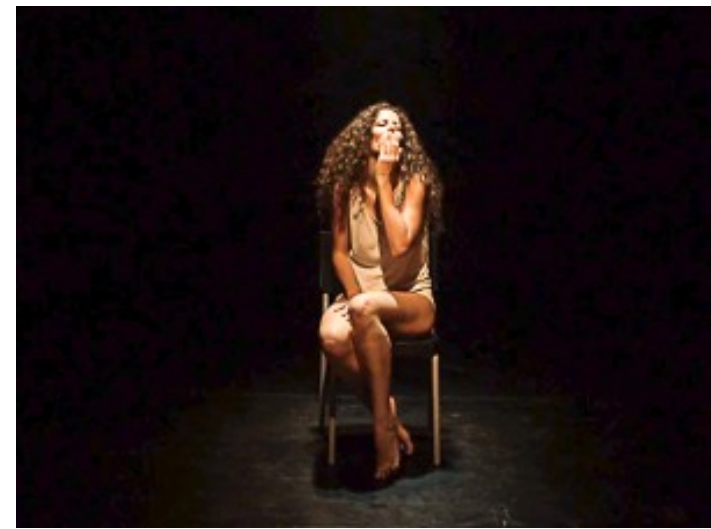

Fig. A51. The lustful soul

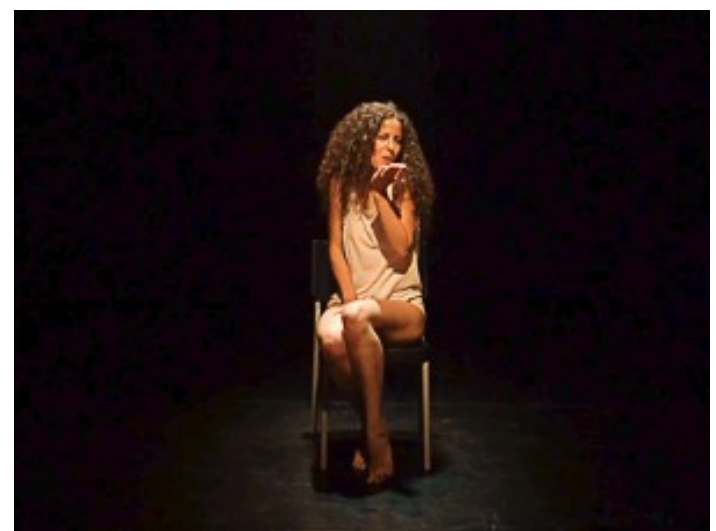

Fig. A52. Blowing a hand-kiss 


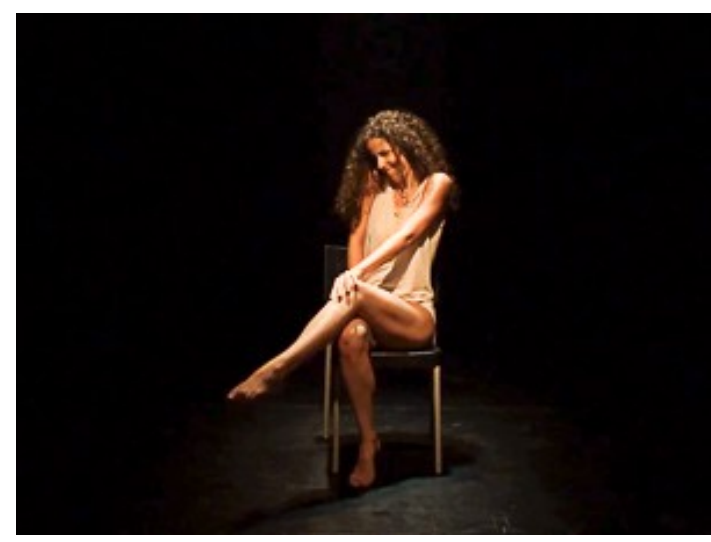

Fig. A53. Lust

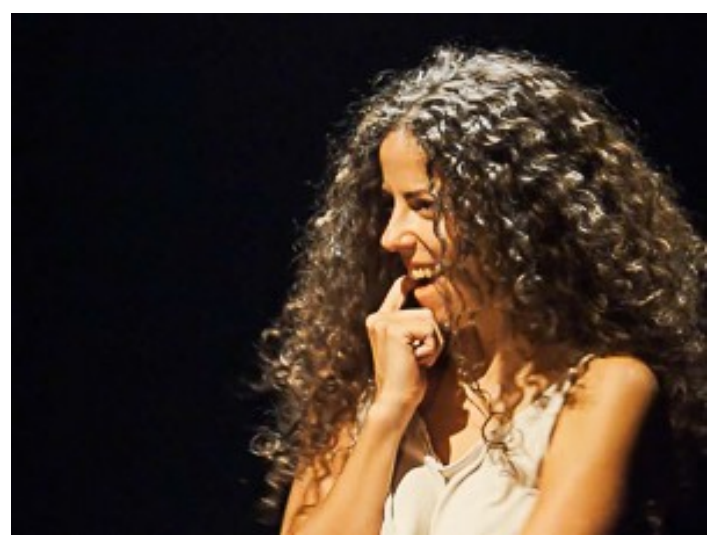

Fig. A54. Seduction

Then the sound of flames enters (min. 43.04) and she reacts directly, expresses a great heat, but without being burned. She opens her mouth a bit, closes her eyes halfway, breathes more intensely, opens her hands next to her body, looks in front, wriggles her body but this time because of the heat. In Dante's text, the lustful have to walk inside of flames. She cries out "Virum non cognosco!"71 together with the recorded choir, and then they all sing the first verse of Summae Deus clementiae. During this verse, she smiles seductively to the audience and starts caressing her legs. When she finishes, she cries out "Pasiphae!" ${ }^{72}$ They all sing the next verse of the chant. The words of this verse are "Lumbos adure congruis tu caritatis ignibus, accincti ut adsint perpetim tuisque prompti adventibus" ("With the proper flames of your charity set our loins on fire so that they may be girt up at all times and ready for your coming"). She now directs herself to God, with all her physical love energy. She turns the palms of her hands up.

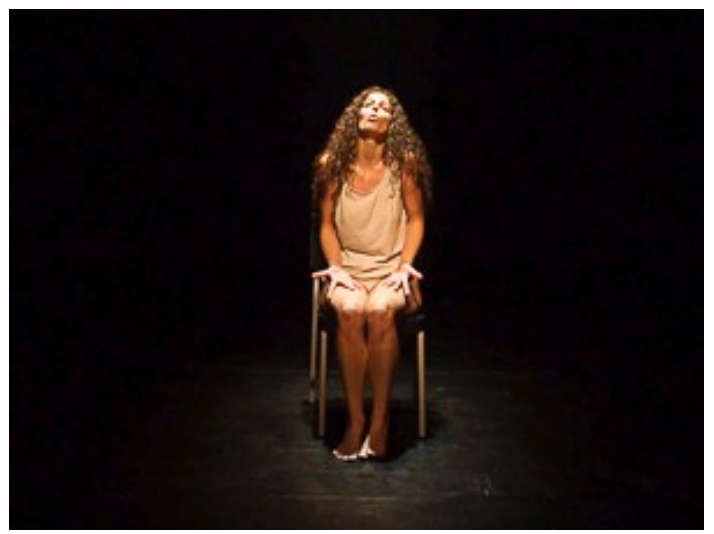

Fig. A55. Giving herself to God

71 "I know not man!". This was Mary's answer to Gabriel (Luke 1: 34). Purgatory 25.128. The original order of the shouts and chants in Dante's text is Summae Deus 1 - "Virum non cognosco" - Summae Deus verse 2 - "Al bosco / si tenne Diana, ed Elice caccionne / che di Venere avea sentito il tòsco" ("Diana kept to the woods and chased out Helice for having felt the poison lust of Venus.") - Summae Deus verse 3 - indi donne gridavano e mariti che fuor casti ("In praise of wives and husbands who were chaste"). Later, when two groups meet each other (Purgatory 26.40)

72 Originally "Pasife" in the phrase "Ne la vacca entra Pasife, perché 'l torello a sua lussuria corra" ("Pasiphae climbs in the cow to let the bull come gallop to her lust"). Pasiphae, wife of King Minos of Crete, had a wooden cow built by Daedalus so that she could make love to a bull whom she felt lust for. From their sexual union the Minotaur was born, who is the guardian in Inferno 12 . Purgatory 26.41 
Then she happily cries out, shaking her head in passion, "Sodom e Gomorrah!" kiss to God and directs her short laugh towards Him. She smiles happily and says to the audience: "Ciao!!" while she waves at the audience in a more standard way. The soundtrack shows the other souls who are still kissing each other affectionately, based on Dante's description of the lustful souls. ${ }^{74}$ Then she looks up again to God and sighs happily: she has directed her physical love toward God and is now in love with him, happy to save her aerial body for him.

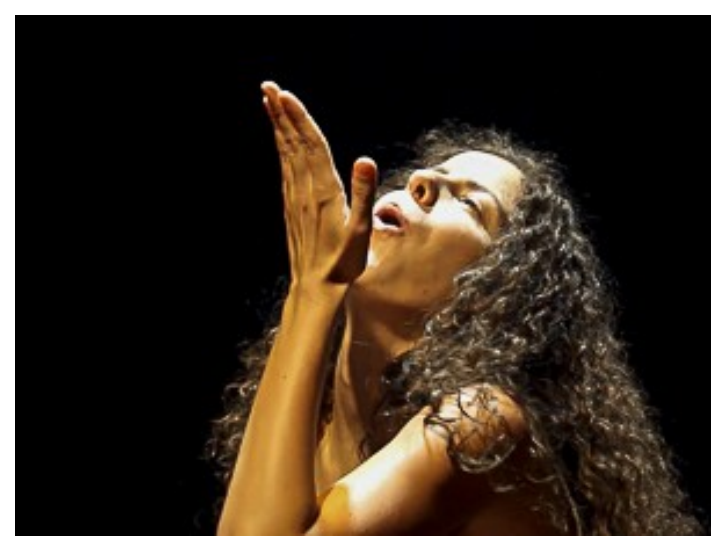

Fig. A56. Blowing a kiss to God

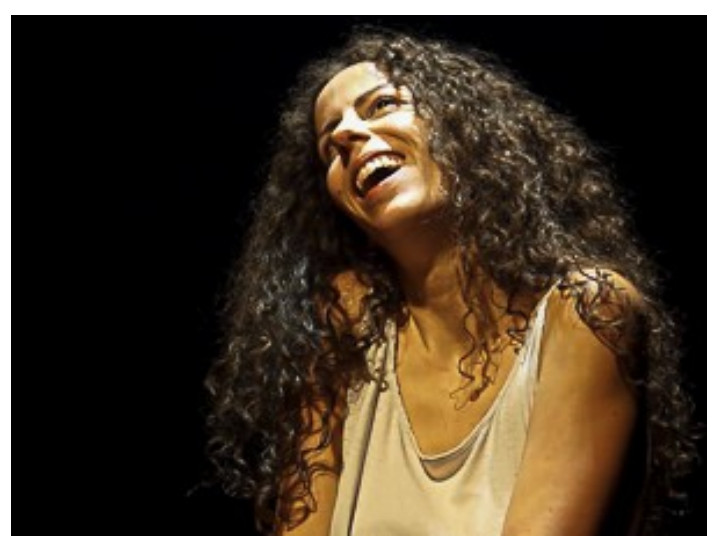

Fig. A57. In love with God

The Beatitude Beati mundo corde sounds sung by an angel (min. 44.26). Its translation is "Blessed are the pure in heart". In Dante's text, all souls have to cross a wall of fire at the end of this terrace in order to reach Purgatory: lust and love (the heart) are intimately connected in his Purgatory. ${ }^{75}$ She smiles relieved and happy and opens her arms for the "Crucifixion" and the folded posture.

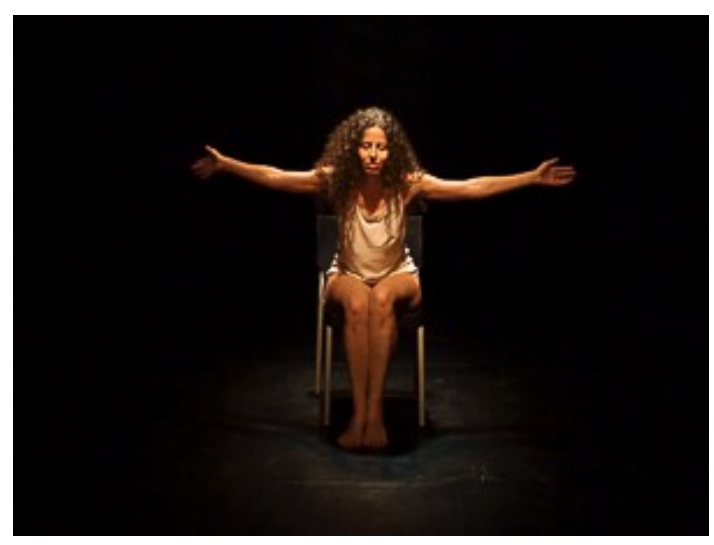

Fig. A58. The Crucifixion movement

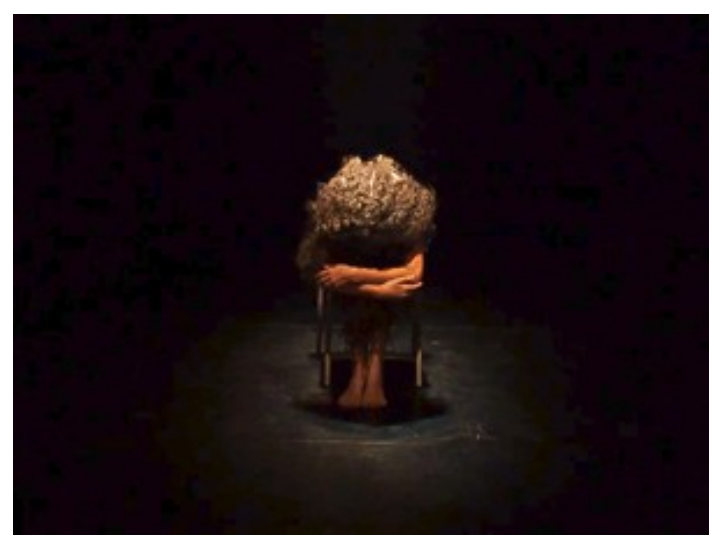

Fig. A59. The folded posture

The fire keeps on sounding and has a crescendo.

73 Sodom and Gomorrah were cities destroyed by God because of their sexual immorality (Genesis 18:16-33, 19:128). Purgatory 26.40

74 Groups of souls who meet with each other: "down the middle of the burning road came people with their faces opposite to these, and they made me stare in suspense. There I saw all the shades on either side hurrying and kissing one another without halting, content with this brief greeting", Purgatory 26.28-33

75 Purgatory 27.8 


\section{Light: general stage light.}

The performer gets up shakily and covers her eyes with her right hand while she stretches her left arm in front of her, as if she is testing if something is ahead of her. This is the moment in which she has to cross the wall of fire. Venite benedicti Patris mei ("Come, you who are blessed of my Father") sounds, sung by an angel, and she searches for its direction. ${ }^{76}$ The angelic voice leads her to the exit of this fire, and she "walks" without getting off her spot, first turning towards her left diagonal, then towards her right diagonal, and in this way keeps on changing slightly her direction from side to side to see if she can find the location of the voice. Despite the fact that she does not move from her place, she has stood up definitively from her chair, which is a move toward physical - and spiritual - freedom.

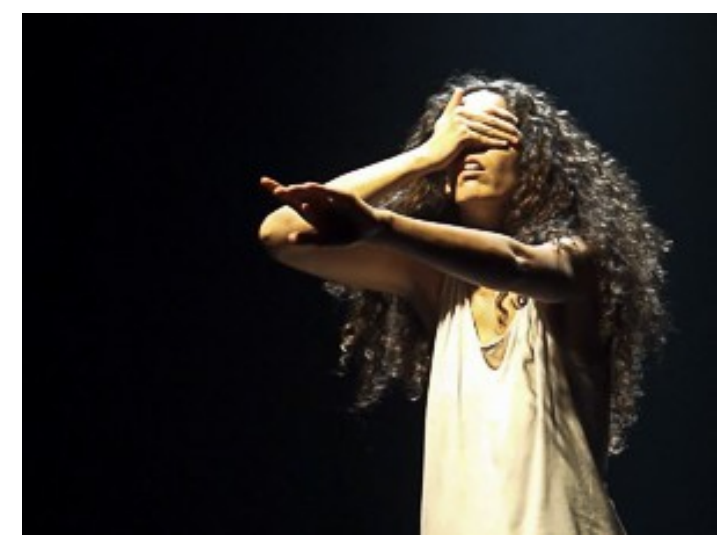

Fig. A60. Searching her way out of the fire

Min. 45.50:

The fire sound changes into one of a forest with birds and the soft humming of a stream: this the Terrestrial Paradise. Dante writes about the "music" of the birds and the trees: "Yet the trees weren't so swayed from standing straight that little birds among the topmost boughs had to leave off the practice of their art, but with their song they welcomed, full of joy, the early morning hours among the leaves which kept up an accompaniment to their rhymes". ${ }^{77}$ The performer uncovers her eyes, slowly drops her eyes, looks with happiness and surprise around her and begins to sing the second verse of Bonum confiteri est: "Quia delectasti”, gradually starting to move her body like a child who is happy, swinging her arms around her. The text she sings is "quia delectasti me Domine in factura tua et in operibus manuum tuarum exultabo" ("for you make me glad by your deeds, O Lord; I sing for joy at the works of your hands.") In Dante's text, this is Matelda singing, who represents human

76 These words of Jesus shall be spoken on the last day according to Matthew 25:34. In the fire, they lead those with a good heart out of the wall of fire.

77 Purgatory 28.13-18 
innocence $^{78}$, but in Incipit it is the very soul who has found her own innocence after her purgation. When she finishes singing, she keeps on swinging her arms around her and is happily looking around.

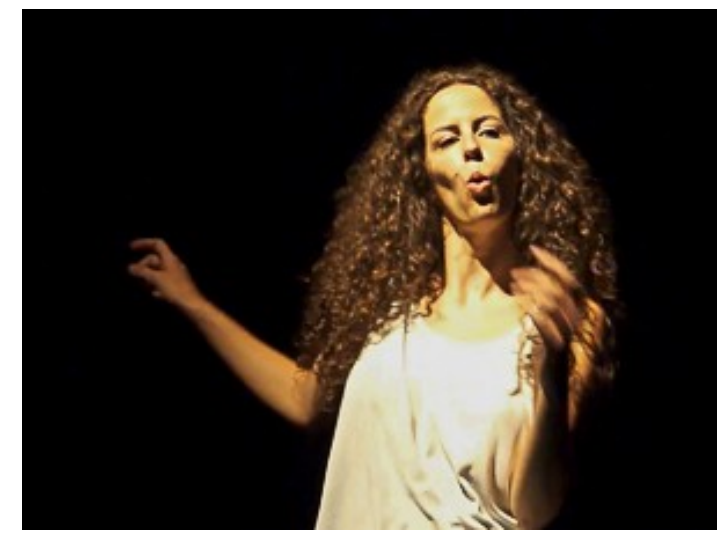

Fig. A61. Happily singing Quia

Delectasti in the Terrestrial Paradise

Then suddenly, a recorded, seemingly close-by voice of a child sings the phrase "Beati quorum tecta sunt peccata!" ("Blessed are they whose sins are covered over!"). This time it is the voice of Matelda. ${ }^{79}$ The protagonist reacts startled by it, looking to her right as if the voice had sounded just next to her ear. She turns to the audience with a surprised look and then smiles timidly while lightly shrugging her shoulders, as to show she is indeed innocent. She keeps on smiling but then looks at her hands in surprise. She slowly looks upward as if aware that she is in the presence of Divinity, and Hosanna sounds (min. 47.01). In the Commedia, Hosanna is the heavenly song that approaches Dante in the Terrestrial Paradise and that is sung by a biblical symbolical procession. ${ }^{80}$ In Incipit, it stands for the Divine that has come to meet the protagonist.

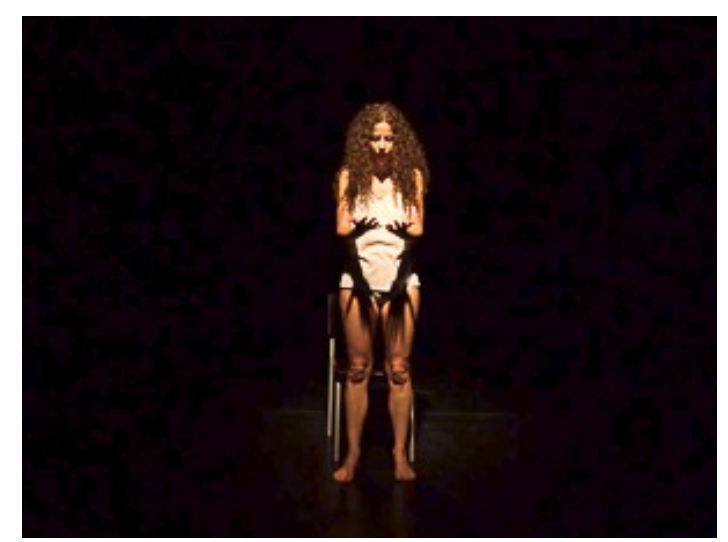

Fig. A62. Looking at her hands

78 In Purgatory 28.79-81 In Dante's text, Matelda refers to this psalm suggesting it was the one she was singing or is about to sing.

79 Purgatory 29.3

80 Purgatory 29.44-154 
Light: highlight the frontal component, thus bordering and focussing the image of the performer. During the Hosanna, she lowers her arms for a second, standing still and looking up with an expression of happiness and adoration, being in the presence of such a miracle. She lifts her arms slowly via her sides, passing for a moment through the "Crucifixion" posture, and then bringing her hands together in front of her in the form of holding a bowl, looking at them. All movement here is ritual-like and slow. During the song, slowly there is a crescendo of the sound of streaming water. She lifts up her hands towards the light, which is a movement that takes until the word "domini".

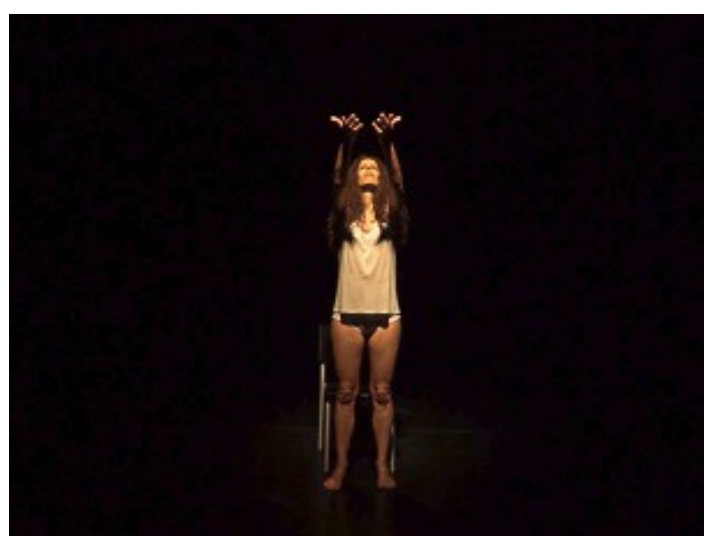

Fig. A63. Lifting up her hands toward Divinity

Together with the next phrase of the music, beginning with "Rex", she lowers her hands slowly, this time until the ground, as if she places a bowl on the floor. Then she places her fingers on the ground next to her knees and puts herself on her knees. She takes her hair back, out of her face, and begins to wash her hands in the imaginary bowl in front of her, in the white light. ${ }^{81}$ After that she washes her lower arms, accompanied by the sound of the water stream. Asperges me sounds (min. 48.08), which means "sprinkle me", ${ }^{82}$ It is normally sung at baptism. The performer looks up for a moment, she "takes some water" in her hands and throws it in her face, covered by the white light. Then she repeats this action, throwing it over her head and "washing" her hair by caressing it. The third time she throws it over her face, the fourth and last time over her head and then slowly lowers her arms, until her hands are on her knees.

81 In Dante's narrative, he is first washed in the river Lethe (oblivion of guilty memories of sin) and then Eunoe (the recollection of good deeds). Purgatory 31.

82 Purgatory 31.98 


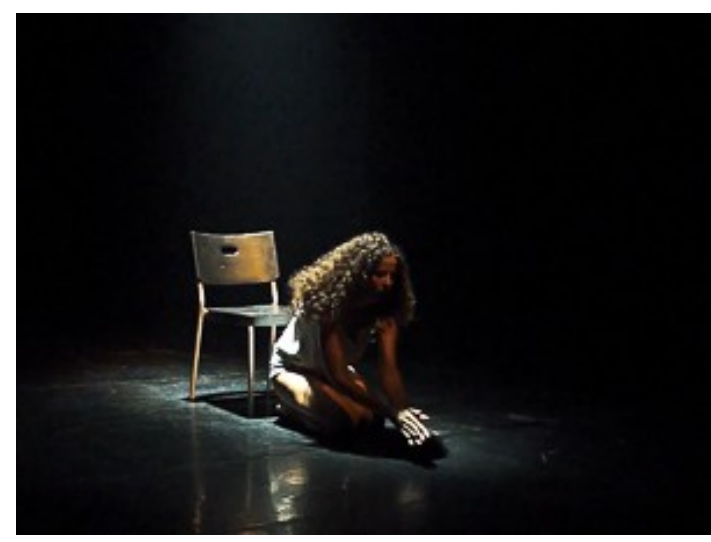

Fig. A64. Washing her hands

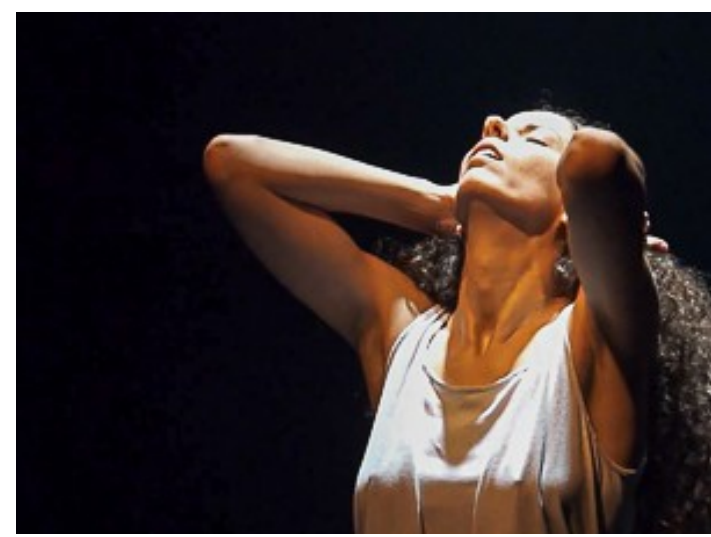

Fig. A66. Washing her face and hair

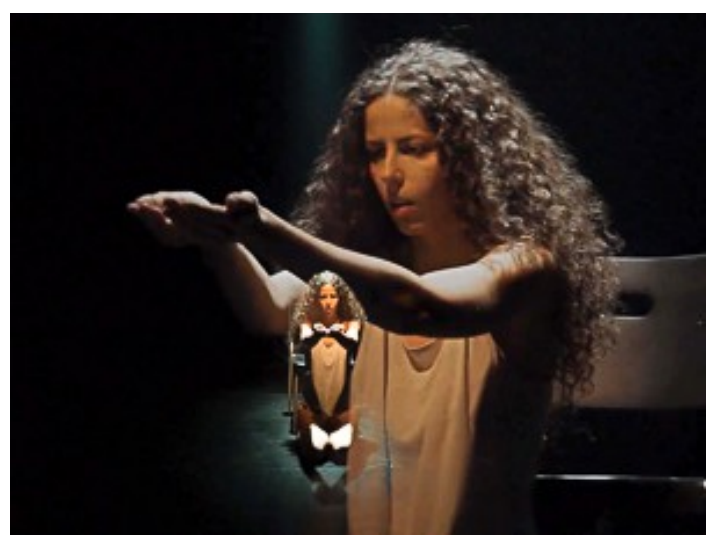

Fig. A65. The ritual

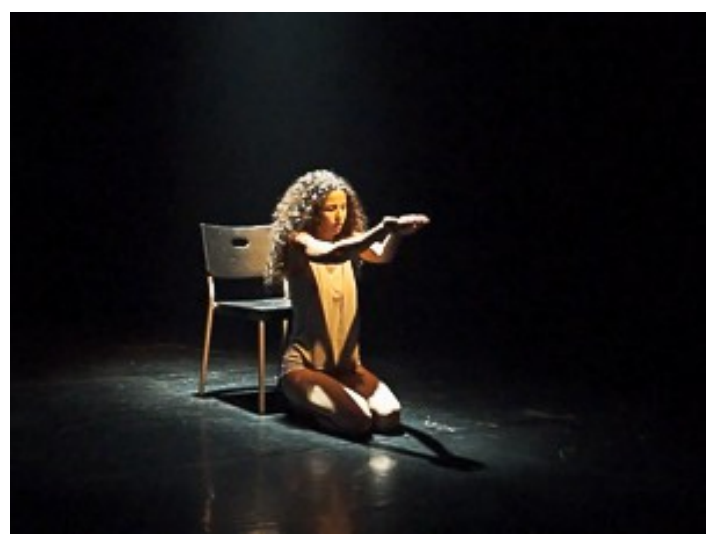

Fig. A67. The Purification

The song ends, she smiles serenely, and moves her face down. This "inward" posture takes about 15 seconds before there is a black-out. In the dark, the performer gets up and leaves with the chair. Then there are three projected texts:

puro e disposto a salire a le stelle. ${ }^{83}$

\section{PARADISO}

La gloria di colui che tutto move per l'universo penetra, e risplende in una parte più e meno altrove. ${ }^{84}$

83 "pure and prepared to leap up to the stars." Purgatory 33.145

84 "The glory of Him who sets all things in motion / cleaves through the universe, and it flames again / in different places with a different force." Paradise 1.1-3 


\section{PARADISE (14.34 $\mathrm{min}$.)}

Light: in opposition to the "cold" Inferno in Steel Blue, Paradise is warm, from 007 and 104 to 135. In relation to the scarceness of effects in the previous parts, Paradise represents the variety of states of blessedness. Timing delimits the episodes. Highlighting of cross-fade.

After the projection, Black-out.

A "strange revolving" sound introduces the ambiance of Paradise. ${ }^{85}$ There is joyful laughter of two female voices. ${ }^{86}$ The protagonist, still not physically on the stage, sings Ave Maria in the dark (min. 49.49). This is based upon Dante's character Piccarda, who sings this chant while she disappears "just like a solid weight down through deep water". ${ }^{87}$ After this, the laughing continues a short while, reflecting the gentle happiness here: "Ogni dove in cielo è paradiso" ("Everywhere in heaven is paradise"). ${ }^{88}$ Then recorded bell-like notes sound ${ }^{89}$, first the beginning of the melody of the next chant, then its repetition with a second added voice. These are the introduction for the Sanctus. Light: at the sounds of the bells, a subtle "screen" of 15\% of light at the front of the stage is created in order to break the darkness, which gives an alienating effect.

Accompanied by the bell-like sounds, still in the dark, the protagonist enters and walks slowly at the back of the stage, dressed completely in black, on the rhythm of the notes. Only her hands and head are not dressed. Therefore, she is scarcely visible: her body "disappears" against the black background. When the second voice is added, she walks slowly towards the front of the stage. The chants in Paradise are all sung live by the performer (except the Ave Maria) in combination with the two other recorded voices of a three-voice organum setting of chants.

Mercury and Venus (min 51.46).

Light: narrow overhead light 007 in the centre: fade-in after beginning of the Sanctus.

The performer sings the Sanctus. She does not enter the light but only comes to its border. One hand enters the overhead light and makes aesthetic movements. The other hand joins that hand, and the two are moved together musically: it is a dance of hands on the Sanctus. Dante is his Paradise refers to a kind of alternative version of the Sanctus sung by Justinian. ${ }^{90}$ In Venus the souls sing the word

85 Dante wrote of "la novità del suono" ("the strangeness of the sound").

86 In Dante's text, they are not literally laughing, but they are described as very happy and smiling souls. Paradise 3.

87 " e cantando vanio / come per acqua cupa cosa grave", Paradise 3.123

88 Paradise 7.1

89 These sounds derive from tapping against a crystal glass. They were composed with the idea of a "natural" sound reminiscent of a music box.

90 "Osanna, sanctus Deus sabaòth, / superillustrans claritate tua / felices ignes horum malacòth!" ("Hosanna to the holy Lord of Hosts, relighting by your brightness from above the blissful burning fires of these kingdoms!"), 
"hosanna" hands, washed and purified at the end of Purgatory, are now representing innocence. The physical decrescendo lies in the fact that at the end of Sanctus only one hand dances in the light before also leaving the light spot. After the Sanctus we hear the strange sound of the revolving planets again.

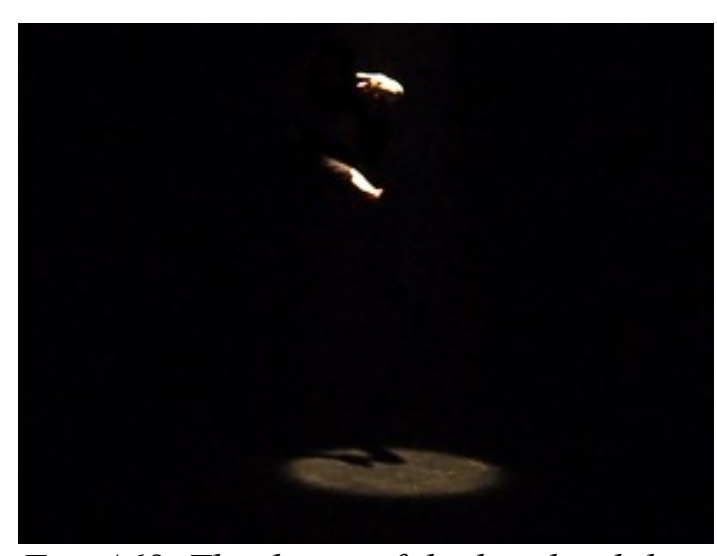

Fig. A68. The dance of the hands while Sanctus is sung

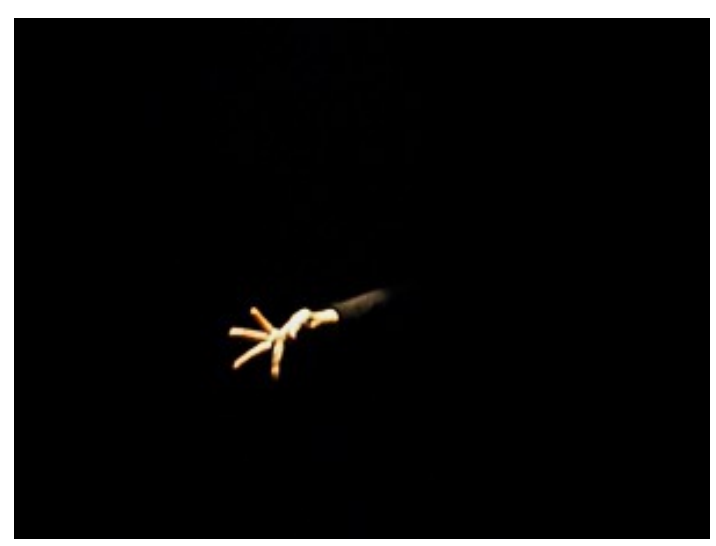

Fig. A69. The last gesture before disappearing from the light

\section{Sun.}

Light: fade-in of counter-light $1 \mathrm{~K}$ on 104.

In the warm-coloured counter-light, only the performer's back and hair are lighted, thus we see her figure but her front is dark. She stands still in the middle while singing the repeated Gloria (min. 52.56). This Gloria is based upon the melody of the festive Gloria in Purgatory, when one of the souls was liberated. Dante in his sphere of the Sun gives various non-specific musical references and also speaks of an echo-like response from the outer circle of dancing wise men around the sun to the inner circle. ${ }^{93}$

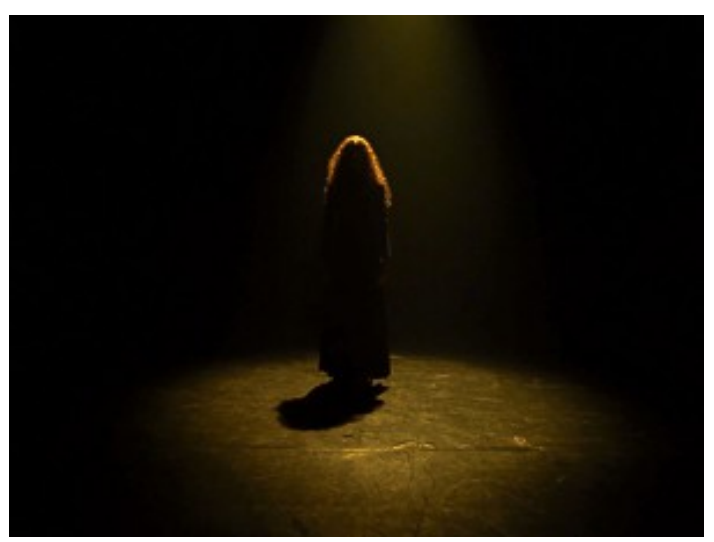

Fig. A70. The backlit soul singing Gloria

91 “e dentro a quei che più innanzi appariro / sonava 'Osanna' sì, che unque poi / di rïudir non fui sanza disiro." (“And from the midst of those appearing foremost, Hosanna sounded in such strains that I have always craved to hear it once again") Paradise 8.28-31

92 Therefore it was decided to sing one entire Sanctus representing both planets.

93 Paradise 10.60, 10.70-81, 10.139-148, 12.4-15, 13.25-30. See chapter 4 and 6. 
When she finishes, the sound of an old clock enters (min. 53.56), referring to Dante's image of the dancing circles around the sun as a clock. ${ }^{94}$

Light: Overhead light on 156.

The performer begins to turn around, moving towards the edge of the circle, just like the souls dancing around the sun. She holds her arms diagonally downwards, as if she were a figure in a music box. The sound of rubbed glass adds to the ticking sound of the clock $^{95}$, while she spins around moving along the edge of the light-bundle. She makes two circles and finishes at the right side of the stage in the back. She is out of the light.

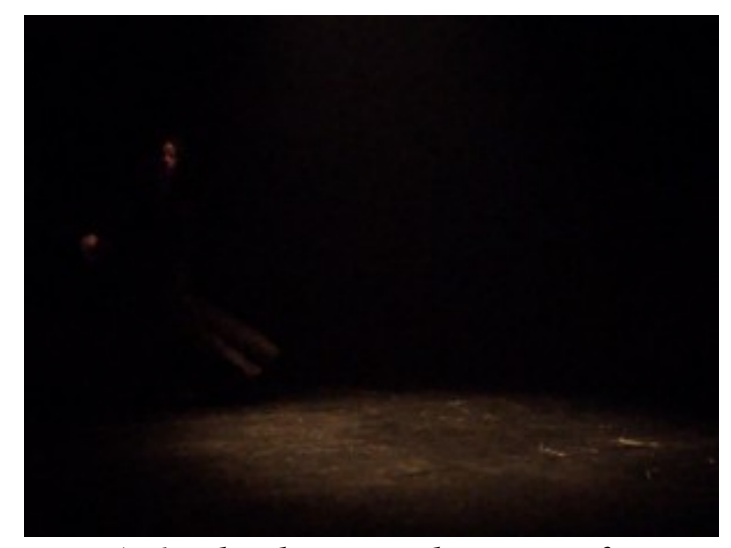

Fig. A71. The dance at the circumference of the light

Light: fade-in diagonal rear "street" on 134 alt 156.

The performer is standing in front of the warmly coloured light during its fade-in. Four louder ticks introduce Victimae paschali laudes (min. 54.32). During this chant the performer slowly advances. This way there is gradually more light; her shadow on the floor and wall, which was first enormous, shrinks with each step, until it is about her own height and she stands in front of it. The chant itself is about the fight between life and death when Christ died and now reigns alive. ${ }^{96}$ It is represented by the performer who "conquers" her own shadow. This is Mars, the sphere of the Holy Warriors: the light is dark orange toward red. The line represents one of the arms of the cross in Dante's Paradise.

94 "Indi, come orologio che ne chiami / ne l'ora che la sposa di Dio surge / a mattinar lo sposo perché l'ami, / che l'una parte e l'altra tira e urge, / tin tin sonando con sì dolce nota, / che 'l ben disposto spirto d'amor turge; / così vid' io la gloriosa rota / muoversi e render voce a voce in tempra / e in dolcezza ch'esser non pò nota / se non colà dove gioir s'insempra." ("Then, like a clock that chimes us at the hour when the Bride of God rises to sing her matins to her Spouse to make him love her, with one part pulling and the other pushing, sounding ding-dong with notes so dulcet that the true-devoted spirit swells with love, just so I saw the wheel of glory rotate and answer voice to voice with harmony and sweetness that can never be conceived except where joyfulness is everlasting.") Paradise $10.139-148$

95 Another natural yet mysterious sound

96 It is probably not the original chant Dante was thinking of, but a similar sequence (probably Concinat orbis cunctus, see chapter 4), because of the two words he mentions, Resurgi and Vinci. 


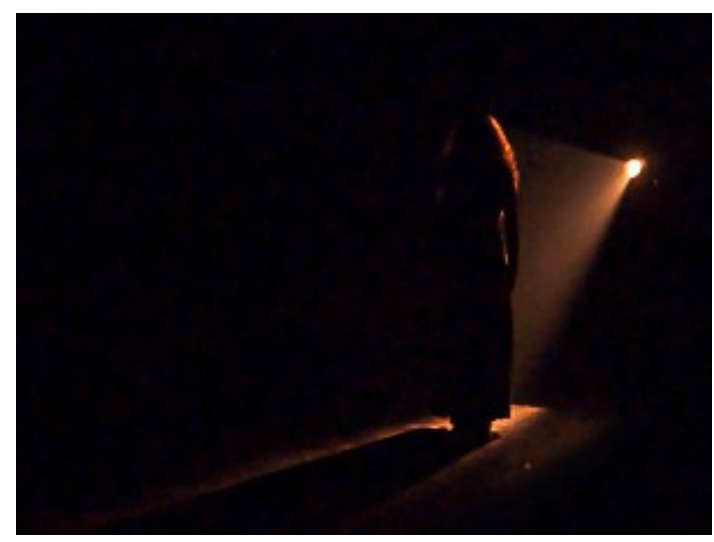

Fig. A72. The soul and her shadow in Victimae Paschali Laudes

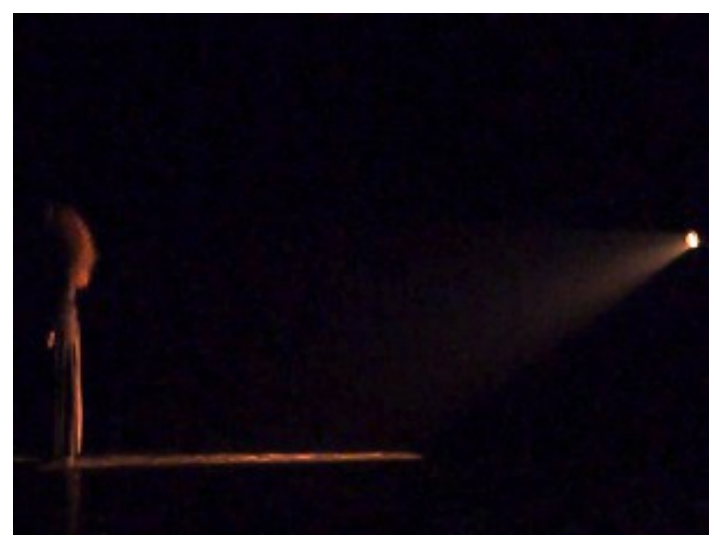

Fig. A73. The red light of Mars

Jupiter.

Four fragments of the Alleluia sound. ${ }^{97}$ With each fragment she turns in the dark, while moving through space. She stands still in the short silences between them.

Light: side "street" on 007 at the height of her face.

While she sings the Alleluia (min. 56.05), she enters the light, steps in front of it, goes back in the light, goes behind the light, etc. The light focusses on her face only. It expresses the tension between physical presence and absense, between materiality and immateriality. At the end she steps behind the light: she vanishes.

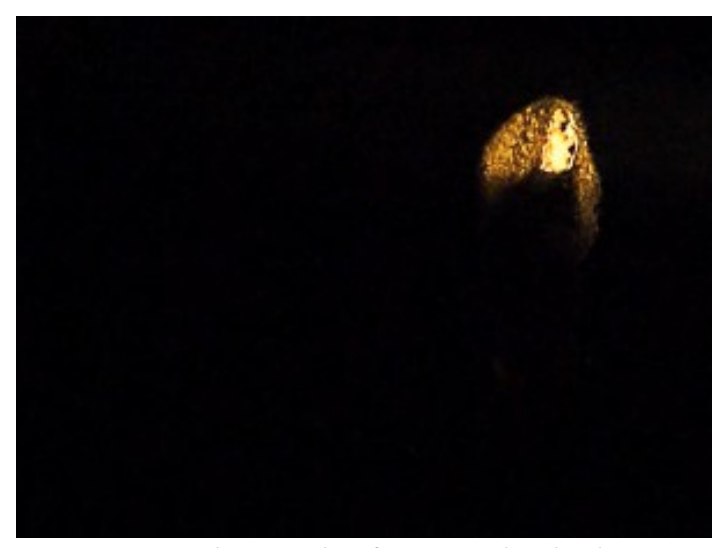

Fig. A74. The soul's face in the light

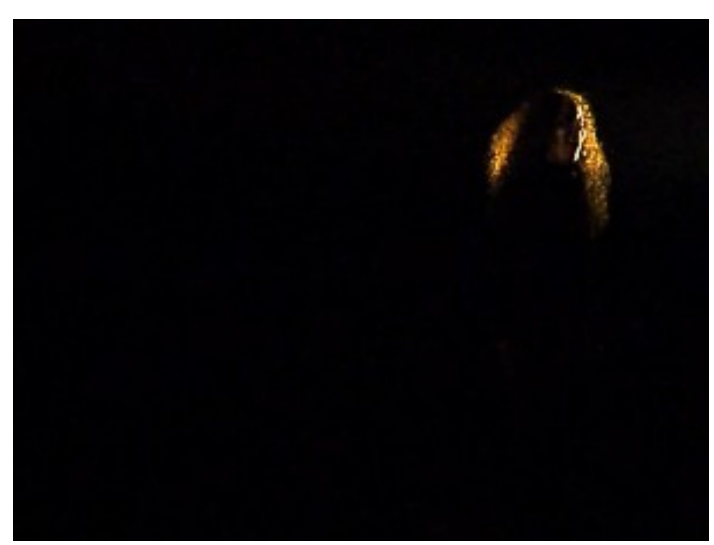

Fig. A75. Vanishing

Light : Black-out.

A very low trembling sounds: it is the ungraspable shout of the souls in Dante's Saturn. ${ }^{98}$ A sound

97 In Dante's narrative, Virgil says to one of the guardians in Hell that Beatrice "came from singing alleluia" ("Tal si partì da cantare alleluia", Inferno 12.88). Singing alleluia seems to be representative for all Paradise.

98 "Dintorno a questa vennero e fermarsi, / e fero un grido di sì alto suono, / che non potrebbe qui assomigliarsi; / né io lo 'ntesi, sì mi vinse il tuono." ("They flocked around this spirit and stood still / and lifted up a shout so deep in sound / that nothing heard on earth resembles it; / the thunder dashed me so, I could not grasp it."). Paradise 21.139142. 
has a crescendo and decrescendo. It is the paulstretched clangour of the gate, accompanying the Te Deum at the entrance gate to Purgatory Proper.

Saturn.

Light: Cut of $50^{\circ}$ with a gobo projecting a maze-like pattern on 007.

The stretched clangour converts into the Te Deum (min. 57.19). The performer stands in the middle of the maze-like pattern, spinning slowly around with arms in ballet positions (she begins in a fourth position). The Te Deum is one of the most solemn praises to Divinity. ${ }^{99}$ The labyrinth-like shadow on the floor symbolizes the mystery of Divinity. She continues turning while singing, her arms flowing through different positions. She begins to move in a spiral, leaving the centre gradually.

At the end, she moves at the edge of the patterned light and ends on its frontal-right edge. She lowers down on one knee under her wide dress, which covers her feet. The fact that her feet are not visible reinforces the sensation that she is not earthly anymore.

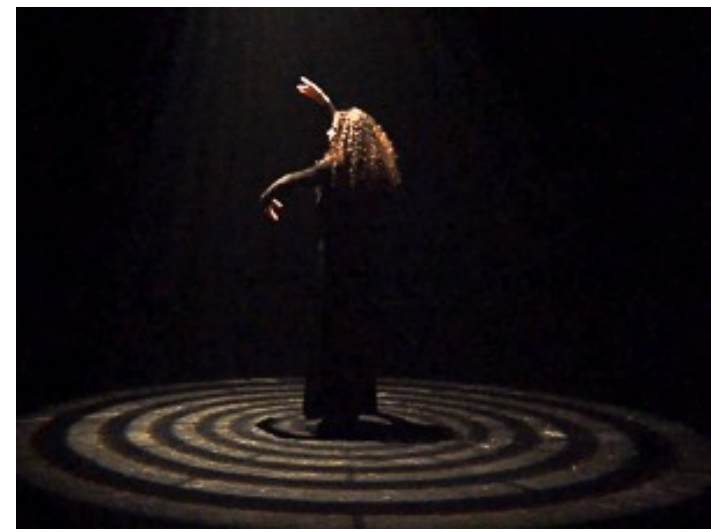

Fig. A76. The soul in the enigmatic circle during the Te Deum

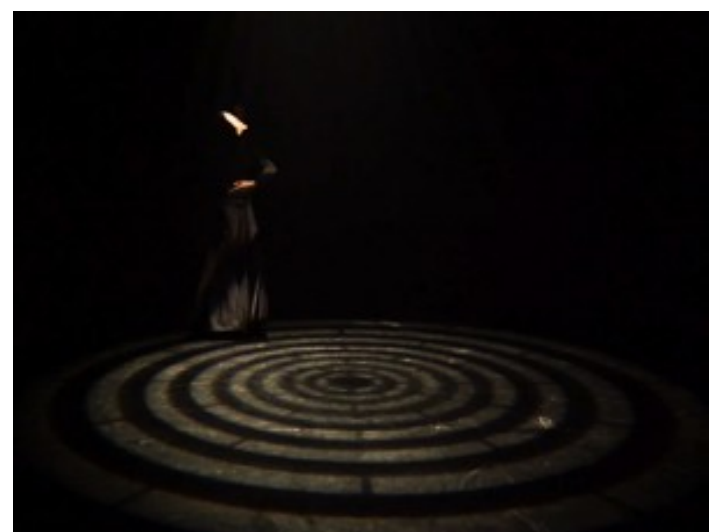

Fig. A77. Spiral movement outward

\section{Fixed Stars.}

Light: Transition supported by the movement from one effect to the other. Cut of $50^{\circ}$ focal at the performer in her lowered posture on 007.

The performer sings Sperent in $t e^{100}$ (min. 59.10) after a recorded introduction of one of the voices

99 "Te Deum laudamus: / te Dominum confitemur / Te aeternum Patrem, / omnis terra veneratur. / Tibi omnes angeli, / tibi caeli et universae potestates: / tibi cherubim et seraphim, / incessabili voce proclamant: / Sanctus, Sanctus, Sanctus / Dominus Deus Sabaoth. (...)" ("We praise thee, O God : / we acknowledge thee to be the Lord. / All the earth doth worship thee : / the Father everlasting. / To thee all Angels cry aloud : / the Heavens, and all the Powers therein. / To thee Cherubim and Seraphim : / continually do cry, / Holy, Holy, Holy : / Lord God of Hosts")

100 "Sperent in te omnes qui noverunt nomen tuum, Domine, / quoniam non derelinquis quaerentes te. / Psallite Domino qui habitat in Sion (...)" ("Let them trust in thee all who know thy name: for thou dost not forsake them that seek thee, O Lord. Sing ye to the Lord, who dwelleth in Sion (...)") Paradise 25.97-99 
before. It is a chant of Divine mercy to humanity and of praise to God, which is the reason the protagonist has lowered down on her knees. She sings the lower voice of the three with her chest voice. Just as she has lowered her body, she has also lowered her voice.

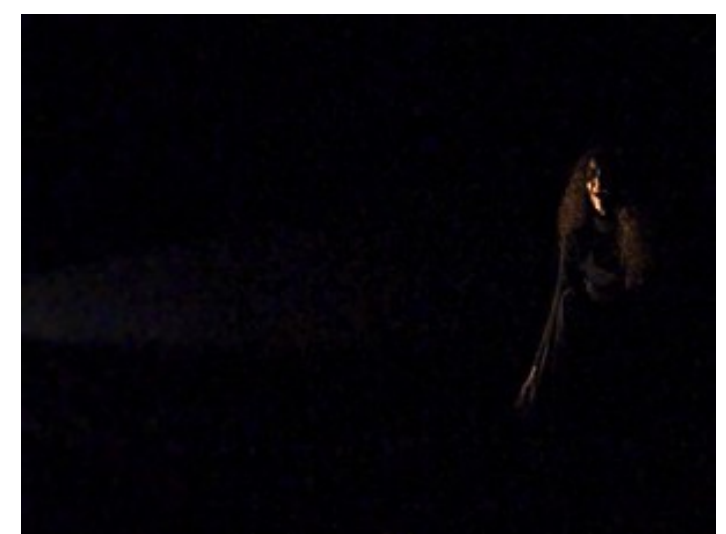

Fig. A78. The low position in the chant Sperent In Te

She stands up while little bells sound and rubbed glass at different pitches, which reinforce - just like earlier - the dream-like sensation of Incipit's Incipit. In the dark, she moves slowly to the centre. Her movement is stylized and geometrical, aesthetically devised just as all other elements in this Divine representation. She begins to sing Gloria Patri ${ }^{101}$ (min.1.01.14).

\section{Primum Mobile.}

Light: Cut of $50^{\circ}$ light beam in the sideways curtain on 007.

The Gloria Patri is sung repeated. The performer moves toward the light beam during the first time, being in the light at the end of the first, and then moves slowly backwards, "disappearing" out of the light. This is again illustrating the tension between physical presence and absence: it is only an illusion, a Divine adaptation to the capacity of human senses to perceive the Divine.

101 “'Al Padre, al Figlio, a lo Spirito Santo', / cominciò, 'gloria!', tutto 'l paradiso, / sì che m'inebrïava il dolce canto." ("“"Glory to the Father, Son, and Holy Spirit!" / the whole of paradise at once poured forth, / so sweet a song I felt inebriated.") Paradise 27.1-3 


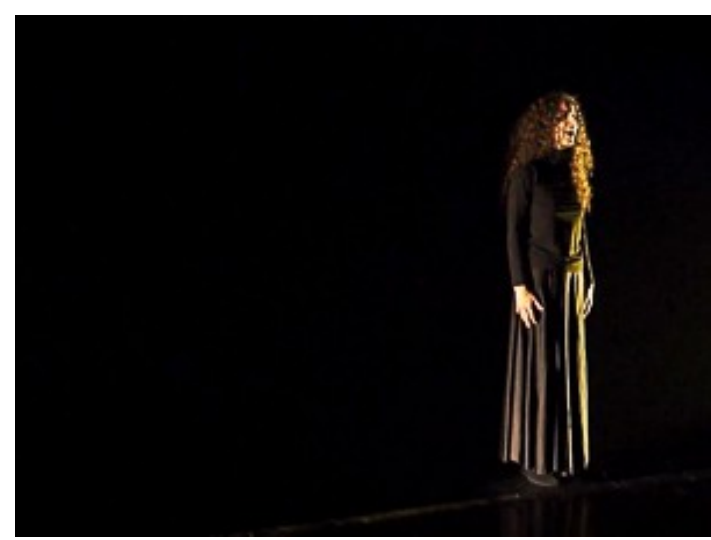

Fig. A79. The soul in the thin line of light during Gloria Patri et Filio

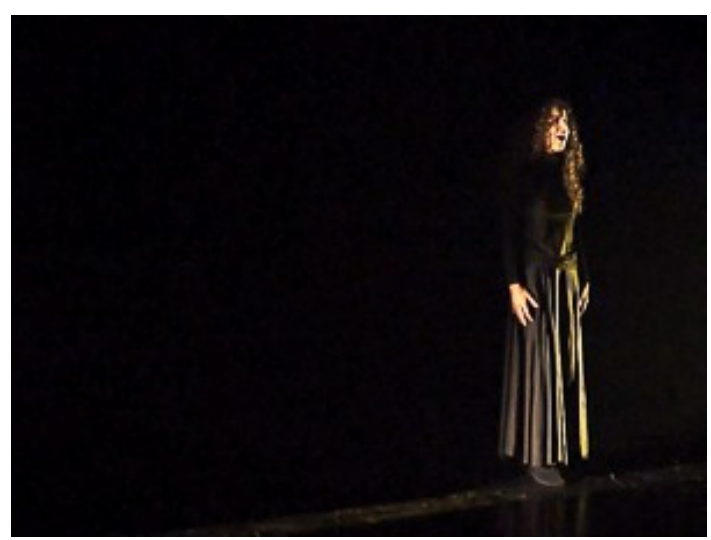

Fig. A80. Slowly vanishing from the light

\section{Empyrean.}

Counter-light $2 \mathrm{~K}$ on 104 and small overhead light in the centre.

Children's laughter sounds and four bells, while the light fades in. Dante speaks of children's voices in the Empyrean. ${ }^{102}$ The performer stands in the middle of the small beam within a larger beam, as if she were floating. This is the scene with the most light of all Incipit, most according to Dante's description of Paradise, full of Divine light. ${ }^{103}$ The performer smiles, full of Divine happiness, and sings Hosanna (min. 1.02.37) twice. ${ }^{104}$ She ends in a unison with them, musically relatively simple and small. Incipit's Paradise is unlike Dante's image: it is an inner Paradise, a little music box filled with magic.

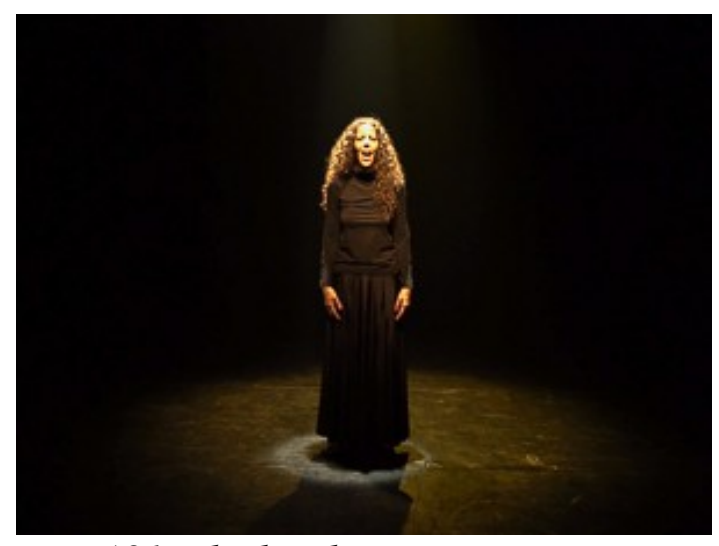

Fig. A81. The bright Hosanna

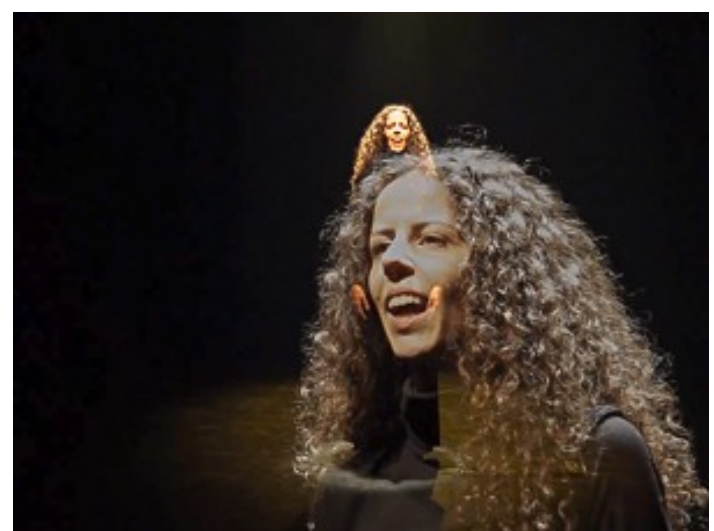

Fig. A82. Expression of happiness

102 "Ben te ne puoi accorger per li volti / e anche per le voci püerili, / se tu li guardi bene e se li ascolti." ("You can observe it clearly in their faces and in their children's voices, if you look carefully at them and listen to them.") Paradise 32.47

103 In Dante's Paradise, Divinity is described as a Point of immense light within a circle of angels.

104 "Io sentiva osannar di coro in coro / al punto fisso che li tiene a li ubi, / e terrà sempre, ne' quai sempre fuoro. (...) / perpetüalemente 'Osanna' sberna / con tre melode, che suonano in tree / ordini di letizia onde s'interna." ("From choir to choir I heard Hosannah sung to the Still Point that holds them fast forever to that one spot where they have always been. (...) unceasingly in birdsong sings Hosannah with triple melodies that warble from the three degrees of bliss that form the triad.") Paradise 28.94-120 
Light: Black-out. Stage light for applause.

\section{Projection of text:}

l'amor che move il sole e l'altre stelle. ${ }^{105}$ 